Universidad deValladolid

PROGRAMA DE DOCTORADO EN INGENIERÍA INDUSTRIAL

TESIS DOCTORAL:

\title{
TÉCNICAS DE EVALUACIÓN, SIMULACIÓN Y MEJORA DEL ESTADO LÍMITE DE SERVICIO RESPECTO A VIBRACIONES EN ESTRUCTURAS PEATONALES
}

Presentada por Norberto Ibán Lorenzana para optar al grado de Doctor por la Universidad de Valladolid

Dirigida por:

Dr. Antolín Lorenzana Ibán Profesor Titular en la Escuela de Ingenierías Industriales de la Universidad de Valladolid Dr. Iván Muñoz Díaz Profesor Titular en la Escuela Técnica Superior de Ingenieros de Caminos, Canales y Puertos de la Universidad Politécnica de Madrid 

Esta Tesis Doctoral es presentada en la Escuela de Ingenierías Industriales de la Universidad de Valladolid, estando compuesto el tribunal por:

Presidente

D.

Secretario

D.

Vocal

Obteniendo la calificación de:

Valladolid, a de de 201 

Parce que nous sommes des ingénieurs, croit-on donc que sa beauté ne nous préoccupe pas dans nos constructions et qu'en même temps que nous faisons solide et durable nous ne nous efforçons pas de faire élégant?

¿Acaso puede uno pensar que, porque somos ingenieros, la belleza no nos preocupa o que no intentamos construir estructuras, a la vez que sólidas y duraderas, hermosas?

Alexandre Gustave Eiffel 

A mi esposa Marta y a mi hija Paola, ese `algo bueno’ que tengo todos los días aunque no todos los días sean buenos 



\section{AGRADECIMIENTOS}

Me siento afortunado porque sé que esta Tesis existe gracias a las personas que me rodean, así que a ellas mi más sincero agradecimiento.

Especial reconocimiento merece la persona que me ha brindado su apoyo, tiempo, esfuerzo, paciencia y su extraordinario conocimiento y saber hacer, ya sea en el ámbito profesional, científico o personal, el profesor Antolín Lorenzana cuya orientación ha sido clave para la consecución de esta Tesis entre otros logros.

Quisiera hacer extensiva mi gratitud a los compañeros con los que he formado equipo estos años de trabajo, Carlos Casado, Javier, Sebas, Pablo, Ali, Carlos Lavín, Melania, Mariano, Álvaro, Iván y Soria de los que he aprendido infinidad de cosas de diferentes ámbitos técnicos y sin los que no hubiese podido realizar esta Tesis.

Agradecer también al centro donde trabajo, CARTIF, por fomentar la dedicación a la investigación, por las ayudas económicas y las herramientas necesarias de las que he dispuesto en el desarrollo de mi Tesis, con la que espero el centro pueda verse reforzado profesionalmente en un futuro no muy lejano.

Agradecer en general el esfuerzo, el trabajo, el cariño y mil cosas más de mi abuela Fe, de mis tíos Laura y Antolín y por encima de todo de mi madre Angelina, quienes en conjunto, me han dotado de valores y oportunidades para poder estar culminando con este trabajo mi formación universitaria.

Agradecer también a mis amigos, los Fulan@s de siempre, los que están ahí año tras año, con los que conecto para desconectar y de quienes también he aprendido mucho.

Y por supuesto, mil gracias a mi esposa, Marta y a mi hija Paola, a quienes dedico este trabajo por el simple hecho de que me hacen muy feliz.

A todos ellos, muchas gracias. 



\section{PREÁMBULO}

De acuerdo con la normativa vigente de presentación y defensa de la tesis doctoral en la Universidad de Valladolid (BOCYL de 15 de junio de 2016, reglamento de régimen interno de la Escuela de Doctorado del 29 de Abril de 2014 y Real Decreto 99/2011, BOE del 28 de Enero de 2011)), esta Tesis Doctoral se presenta como compendio de publicaciones. Además de incluir los artículos publicados, en el apartado de méritos, también se incluyen otros trabajos realizados en el marco de esta línea de investigación (ANEXO II).

Los artículos incluidos en este documento son:

a) CUANTIFICACIÓN DE LA PERCEPCIÓN DE LA VIBRACIÓN EN PASARELAS PEATONALES Istrate, M., Lorenzana, A., Ibán, N., y Vasallo, A. DYNA 87(4): 467-473. 2012/07 Engineering, Multidisciplinary Factor de impacto 0.237. Rank Q4. DOI: http://dx.doi.org/10.6036/4510

\section{Dyna}

ISSN: 0012-7361

FEDERACION ASOCIACIONES INGENIEROS INDUSTRIALES ESPANA ALAMEDA DE MAZARREDO,BILBAO,SPAIN 69-48009 SPAIN

\begin{tabular}{|c|c|c|c|c|}
\hline \multirow{3}{*}{$\begin{array}{l}\text { Titles } \\
\text { ISO: Dyna }\end{array}$} & \multirow{3}{*}{$\begin{array}{l}\text { JCR } \\
\text { Year - }\end{array}$} & \\
\hline & & \multicolumn{3}{|c|}{ ENGINEERING, MULTIDISCIPLINARY } \\
\hline & & Rank & Quartile & JIF Percentile \\
\hline JCR Abbrev: DYNA-BILBAC & 2017 & $76 / 86$ & Q4 & 12.209 \\
\hline \multirow{4}{*}{$\begin{array}{l}\text { Categories } \\
\text { ENGINEERING, } \\
\text { MULTIDISCIPLINARY - }\end{array}$} & 2016 & $70 / 85$ & Q4 & 18.235 \\
\hline & 2015 & $77 / 85$ & Q4 & 10.000 \\
\hline & 2014 & $84 / 85$ & Q4 & 1.765 \\
\hline & 2013 & $82 / 87$ & Q4 & 6.322 \\
\hline \multirow{2}{*}{$\begin{array}{l}\text { Languages } \\
\text { Spanish }\end{array}$} & 2012 & $81 / 90$ & Q4 & 10.556 \\
\hline & 2011 & $84 / 90$ & Q4 & 7.222 \\
\hline 6 Issues/Year: & 2010 & $76 / 87$ & Q4 & 13.218 \\
\hline
\end{tabular}

\section{Key Indicators}

\begin{tabular}{|c|c|c|c|c|c|c|c|c|c|c|c|c|c|}
\hline Year & $\begin{array}{r}\text { Total } \\
\text { Cites - } \\
\text { Graph }\end{array}$ & $\begin{array}{c}\text { Journal } \\
\text { Impact } \\
\text { Factor } \\
\text { Graph }\end{array}$ & $\begin{array}{l}\text { Impact } \\
\text { Factor } \\
\text { Without } \\
\text { Journal } \\
\text { Self } \\
\text { Cites }\end{array}$ & $\begin{array}{c}5 \text { Year } \\
\text { Impact } \\
\text { Factor } \\
\text { Graph }\end{array}$ & $\begin{array}{l}\text { Immediacy } \\
\text { Index } \\
\text { Graph }\end{array}$ & $\begin{array}{l}\text { Citable } \\
\text { Items } \\
\text { Graph }\end{array}$ & $\begin{array}{l}\text { Cited } \\
\text { Half- } \\
\text { Life } \\
\text { Graph }\end{array}$ & 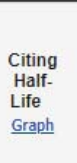 & $\begin{array}{c}\text { Eigenfacto } \\
\text { Score } \\
\text { Graph }\end{array}$ & $\begin{array}{c}\begin{array}{c}\text { Article } \\
\text { Influence } \\
\text { Score }\end{array} \\
\text { Graph }\end{array}$ & $\begin{array}{c}\% \\
\text { Articles } \\
\text { in Citable } \\
\text { Items } \\
\text { Graph }\end{array}$ & $\begin{array}{l}\text { Normalized } \\
\text { Eigenfacto } \\
\text { Graph }\end{array}$ & $\begin{array}{c}\text { Average } \\
\text { JIF } \\
\text { Percentile } \\
\text { Graph }\end{array}$ \\
\hline & & & Graph & & & & & & & & & & \\
\hline 2017 & 139 & 0.500 & 0.384 & 0.288 & 0.105 & 76 & 3.6 & 7.9 & $0.00 \ldots$ & 0.040 & 100.00 & $0.01 \ldots$ & 12.209 \\
\hline 2016 & 128 & 0.541 & 0.423 & 0.319 & 0.127 & 55 & 2.9 & 8.7 & $0.00 \ldots$ & 0.055 & 100.00 & $0.02 \ldots$ & 18.235 \\
\hline 2015 & 88 & 0.302 & 0.232 & 0.234 & 0.100 & 50 & Not ... & 8.0 & $0.00 \ldots$ & 0.038 & 100.00 & $0.01 \ldots$ & 10.000 \\
\hline 2014 & 65 & 0.179 & 0.116 & 0.167 & 0.031 & 65 & Not. & 89 & 0.00 & 0.032 & 10000 & 0.01 & 1765 \\
\hline 2012 & 64 & 0.237 & 0.149 & 0.160 & 0.049 & 61 & Not. & 7.2 & 0.00 & 0.030 & 98.36 & Not. & 10.556 \\
\hline 2013 & 54 & 0.200 & 0.108 & 0.143 & 0.039 & 51 & Not $\ldots$ & 8.0 & $0.00 \ldots$ & 0.028 & 100.00 & $0.01 \ldots$ & 6.322 \\
\hline 2011 & 50 & 0.171 & 0.059 & Not ... & 0.034 & 59 & Not ... & 8.3 & $0.00 \ldots$ & Not ... & 100.00 & Not ... & 7.222 \\
\hline 2010 & 38 & 0.144 & 0.050 & Not $\ldots$ & 0.036 & 55 & Not ... & 7.2 & $0.00 \ldots$ & Not $\ldots$ & 100.00 & Not. & 13.218 \\
\hline
\end{tabular}

b) VIBRATION MONITORING OF A STEEL-PLATED STRESS-RIBBON FOOTBRIDGE: UNCERTAINTIES IN THE MODAL ESTIMATION

Soria, J.M., Díaz, I.M., García-Palacios, J., and Ibán, N.

JOURNAL OF BRIDGE ENGINEERING 21(8): C5015002. 2016/01

Engineering, Civil

Factor de impacto 1.476. Rank Q2

DOI: 10.1061/(ASCE) BE.1943-5592.0000830

\section{JCR Impact Factor}

\begin{tabular}{|c|c|c|c|c|c|}
\hline \multicolumn{2}{|c|}{ 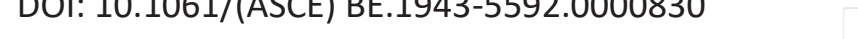 } & \multirow{2}{*}{$\begin{array}{c}\text { JCR } \\
\text { Year - }\end{array}$} & \multicolumn{3}{|c|}{ ENGINEERING, CIVIL } \\
\hline & & & Rank & Quartile & JIF Percentile \\
\hline & ISO: J. Bridge Eng. & 2017 & $64 / 128$ & Q2 & 50.391 \\
\hline & JCR Abbrev: J BRIDGE ENG & 2016 & $57 / 125$ & Q2 & 54.800 \\
\hline & & 2015 & $60 / 126$ & Q2 & 52.778 \\
\hline & Categories & 2014 & $54 / 125$ & Q2 & 57.200 \\
\hline Journal of Bridge Engineering & ENGINEERING, CIVIL -S & 2013 & $66 / 124$ & Q3 & 47.177 \\
\hline & & 2012 & $61 / 122$ & Q2 & 50.410 \\
\hline ISSN: 1084-0702 & Languages & 2011 & $65 / 118$ & Q3 & 45.339 \\
\hline ASCE-AMER SOC CIVIL ENGINEERS & English & 2010 & $34 / 115$ & Q2 & 70.870 \\
\hline 1801 ALEXANDER BELL DR,RESTON,USAVA 20191-4400 & & 2009 & 70/106 & Q3 & 34.434 \\
\hline USA & 12 Issues/Year; & 2008 & $69 / 91$ & Q4 & 24.725 \\
\hline
\end{tabular}




\begin{tabular}{|c|c|c|c|c|c|c|c|c|c|c|c|c|c|}
\hline \multicolumn{14}{|c|}{ Key Indicators } \\
\hline \multirow[t]{2}{*}{ Year - } & $\begin{array}{c}\text { Total } \\
\text { Cites } \\
\text { Graph }\end{array}$ & $\begin{array}{c}\text { Journal } \\
\text { Impact } \\
\text { Factor } \\
\text { Graph }\end{array}$ & $\begin{array}{l}\text { Impact } \\
\text { Factor } \\
\text { Without } \\
\text { Journal } \\
\text { Self } \\
\text { Cites }\end{array}$ & $\begin{array}{c}5 \text { Year } \\
\text { Impact } \\
\text { Factor } \\
\text { Graph }\end{array}$ & $\begin{array}{l}\text { Immediacy } \\
\text { Index } \\
\text { Graph }\end{array}$ & $\begin{array}{l}\text { Citable } \\
\text { Items } \\
\text { Graph }\end{array}$ & $\begin{array}{l}\text { Cited } \\
\text { Half- } \\
\text { Life } \\
\text { Graph } \\
\end{array}$ & $\begin{array}{l}\text { Citing } \\
\text { Half- } \\
\text { Life } \\
\text { Graph }\end{array}$ & $\begin{array}{c}\text { Eigenfacto } \\
\text { Score } \\
\text { Graph }\end{array}$ & $\begin{array}{c}\text { Article } \\
\text { Influence } \\
\text { Score } \\
\text { Graph }\end{array}$ & $\begin{array}{c}\% \\
\text { Articles } \\
\text { in Citable } \\
\text { Items } \\
\text { Graph }\end{array}$ & $\begin{array}{c}\text { Normalized } \\
\text { Eigenfacto } \\
\text { Graph }\end{array}$ & $\begin{array}{c}\text { Average } \\
\text { JIF } \\
\text { Percentile } \\
\text { Graph }\end{array}$ \\
\hline & & & Graph & & & & & & & & & & \\
\hline 2017 & 2721 & 1.454 & 1146 & 1881 & 0239 & 176 & 62 & $>100$ & 0.00 & 0.522 & 100.00 & 0.56 & 50.391 \\
\hline 2016 & 2,119 & 1.476 & 1.016 & 1.678 & 0.259 & 197 & 6.4 & 9.9 & 0.00 & 0.464 & 99.49 & 0.43 . & 54.800 \\
\hline 2015 & 1,572 & 1.069 & 0.900 & 1.310 & 0.207 & 116 & 7.1 & 9.9 & $0.00 \ldots$ & 0.466 & 98.28 & $0.42 \ldots$ & 52.778 \\
\hline 2014 & 1,330 & 1.065 & 0.853 & 1.231 & 0.138 & 130 & 7.0 & 9.1 & $0.00 \ldots$ & 0.413 & 100.00 & $0.32 \ldots$ & 57.200 \\
\hline 2013 & 1,161 & 0.927 & 0.750 & 1.172 & 0.252 & 131 & 7.2 & 9.7 & $0.00 \ldots$ & 0.510 & 100.00 & $0.35 \ldots$ & 47.177 \\
\hline 2012 & 894 & 0.793 & 0.621 & 0.956 & 0.119 & 101 & 7.1 & 9.6 & $0.00 \ldots$ & 0.442 & 100.00 & Not... & 50.410 \\
\hline 2011 & 660 & 0.623 & 0.434 & 0.784 & 0.165 & 91 & 6.6 & 9.1 & $0.00 \ldots$ & 0.364 & 100.00 & Not ... & 45.339 \\
\hline 2010 & 669 & 1.009 & 0.761 & Not ... & 0.342 & 73 & 5.5 & 9.1 & $0.00 \ldots$ & Not ... & 100.00 & Not ... & 70.870 \\
\hline 2009 & 461 & 0.460 & 0.380 & Not ... & 0.102 & 49 & 5.5 & 9.7 & $0.00 \ldots$ & Not ... & 100.00 & Not ... & 34.434 \\
\hline 2008 & 375 & 0.438 & 0.320 & Not ... & 0.094 & 64 & 5.1 & 8.7 & $0.00 \ldots$ & Not $\ldots$ & 100.00 & Not ... & 24.725 \\
\hline
\end{tabular}

C) AD-HOC VIBRATION MONITORING SYSTEM FOR A STRESS-RIBBON FOOTBRIDGE: FROM DESIGN TO OPERATION

Ibán, N., Soria, J.M., Magdaleno, A., Casado, C., Díaz, I.M., and Lorenzana, A.

SMART STRUCTURES AND SYSTEMS 22(1): 13-25. 2018/07

Engineering, Civil

JCR Impact Factor

Factor de impacto 2.231. Rank Q1

DOI: 10.12989/sss.2018.22.1.013

Titles

ISO: Smart. Struct. Syst.

\begin{tabular}{l|l} 
JCR & ENGINEERING, CIVIL
\end{tabular}

JCR Abbrev: SMART STRUCT SYST

Categories

ENGINEERING, CIVIL - SCIE;

ENGINEERING, MECHANICAL

SCIE;

INSTRUMENTS \&

Smart Structures and Systems ISSN: 1738-1584

TECHNO-PRESS

INSTRUMENTATION - SCIE:

\begin{tabular}{|cccc|}
\hline Year $~$ & Rank & Quartile & JIF Percentile \\
\hline 2017 & $32 / 128$ & Q1 & 75.391 \\
\hline 2016 & $62 / 125$ & Q2 & 50.800 \\
2015 & $57 / 126$ & Q2 & 55.159 \\
2014 & $37 / 125$ & Q2 & 70.800 \\
2013 & $46 / 124$ & Q2 & 63.306 \\
2012 & $24 / 122$ & Q1 & 80.738 \\
2011 & $28 / 118$ & Q1 & 76.695 \\
2010 & $22 / 115$ & Q1 & 81.304 \\
2009 & $28 / 106$ & Q2 & 74.057 \\
2008 & $22 / 91$ & Q1 & 76.374 \\
2007 & $49 / 89$ & Q3 & 45.506 \\
2006 & $27 / 83$ & Q2 & 68.072 \\
2005 & $80 / 80$ & Q4 & 0.625 \\
\hline
\end{tabular}

SOUTH KOREA

Languages

English

12 Issues/Year,

\section{Key Indicators}

\begin{tabular}{|c|c|c|c|c|c|c|c|c|c|c|c|c|c|}
\hline \multirow[t]{2}{*}{ Year - } & $\begin{array}{l}\text { Total } \\
\text { Cites } \\
\text { Graph }\end{array}$ & $\begin{array}{c}\text { Journal } \\
\text { Impact } \\
\text { Factor } \\
\text { Graph }\end{array}$ & $\begin{array}{l}\text { Impact } \\
\text { Factor } \\
\text { Without } \\
\text { Journal } \\
\text { Self } \\
\text { Cites }\end{array}$ & $\begin{array}{c}5 \text { Year } \\
\text { Impact } \\
\text { Factor } \\
\text { Graph } \\
\end{array}$ & $\begin{array}{l}\text { Immediacy } \\
\text { Index } \\
\text { Graph }\end{array}$ & $\begin{array}{l}\text { Citable } \\
\text { Items } \\
\text { Graph }\end{array}$ & $\begin{array}{l}\text { Cited } \\
\text { Half- } \\
\text { Life } \\
\text { Graph }\end{array}$ & $\begin{array}{l}\text { Citing } \\
\text { Half- } \\
\text { Life } \\
\text { Graph }\end{array}$ & $\begin{array}{l}\text { Eigenfacto } \\
\text { Score } \\
\text { Graph }\end{array}$ & $\begin{array}{l}\text { Article } \\
\text { Influence } \\
\text { Score } \\
\text { Graph }\end{array}$ & $\begin{array}{c}\% \\
\text { Articles } \\
\text { in Citable } \\
\text { Items } \\
\text { Graph }\end{array}$ & $\begin{array}{l}\text { Normalized } \\
\text { Eigenfacto } \\
\text { Graph }\end{array}$ & $\begin{array}{c}\text { Average } \\
\text { JIF } \\
\text { Percentile } \\
\text { Graph }\end{array}$ \\
\hline & & & Graph & & & & & & & & & & \\
\hline 2017 & 1,597 & 2.231 & 1.682 & 2.083 & 1.057 & 123 & 3.3 & 7.0 & $0.00 \ldots$ & 0.415 & 100.00 & $0.34 \ldots$ & 70.829 \\
\hline 2016 & 989 & 1.382 & 1.072 & 1.436 & 0.293 & 123 & 3.9 & 7.4 & $0.00 \ldots$ & 0.288 & 100.00 & $0.21 \ldots$ & 47.296 \\
\hline 2015 & 761 & 1.138 & 0.792 & 1.528 & 0.159 & 145 & 4.1 & 8.3 & $0.00 \ldots$ & 0.341 & 100.00 & $0.21 \ldots$ & 48.229 \\
\hline 2014 & 568 & 1.368 & 1.060 & 1.352 & 0.265 & 117 & 3.9 & 8.1 & $0.00 \ldots$ & 0.298 & 100.00 & $0.15 \ldots$ & 63.000 \\
\hline 2013 & 497 & 1.160 & 0.915 & 1.428 & 0.380 & 71 & 3.5 & 8.3 & $0.00 \ldots$ & 0.359 & 100.00 & $0.18 \ldots$ & 57.695 \\
\hline 2012 & 352 & 1.430 & 1.140 & 1.276 & 0.177 & 62 & 2.9 & 7.8 & $0.00 \ldots$ & 0.314 & 100.00 & Not ... & 73.139 \\
\hline 2011 & 302 & 1.231 & 0.879 & 1.248 & 0.140 & 57 & 3.2 & 7.9 & $0.00 \ldots$ & 0.320 & 100.00 & Not ... & 71.542 \\
\hline 2010 & 235 & 1.316 & 0.778 & 1.292 & 0.281 & 64 & 2.7 & 6.3 & $0.001 \ldots$ & 0.339 & 98.44 & Not ... & 73.686 \\
\hline 2009 & 126 & 1.064 & 0.961 & 0.992 & 0.068 & 44 & 2.3 & 7.7 & $0.00 \ldots$ & 0.398 & 100.00 & Not ... & 67.645 \\
\hline 2008 & 101 & 1.137 & 0.666 & 1.205 & 0.235 & 51 & 2.1 & 7.5 & $0.00 \ldots$ & 0.370 & 98.04 & Not ... & 66.589 \\
\hline 2007 & 25 & 0.478 & 0.413 & 0.500 & 0.074 & 27 & Not ... & 6.7 & $0.00 \ldots$ & 0.192 & 96.30 & Not ... & 40.278 \\
\hline 2006 & 15 & 0.682 & 0.682 & Not ... & 0 & 24 & Not ... & 7.8 & Not ... & Not ... & 100.00 & Not ... & 57.754 \\
\hline 2005 & 1 & Not A... & Not A... & Not ... & 0.045 & 22 & Not ... & 6.4 & Not ... & Not ... & 100.00 & Not ... & 1.330 \\
\hline
\end{tabular}


Las ponencias en congresos científico-técnicos (nacionales e internacionales) son:

a) IMPROVEMENT COMFORTABILITY THROUGH ADDING SOFT RUBBER PAVEMENT ON LIVELY FOOTBRIDGES

Istrate, M., Sebastián, J., Vasallo, A., Casado, C.M., Ibán, N., Lorenzana, A., Poncela,A.V. Proceedings of $4^{\text {th }}$ Internacional Conference of Experimental Vibration Analysis for Civil Engineering Structures, 2011

b) DISCOMFORT EVALUATION ON LIVELY FOOTBRIDGES WITH SOFT-RUBBER PAVEMENT Istrate, M., Ibán, N., Vasallo, A., Lorenzana, A. and Diaz, I. M.

Proceedings of $30^{\text {th }}$ International Modal Analysis Conference, 2012

c) QUANTIFYING DIFFERENCES BETWEEN WALKING LOCOMOTION ON RIGID AND FLEXIBLE PAVEMENTS

Istrate, M., Zivanovic S., Lorenzana A., Ibán, N., Dang H.

Proceedings of XXXI Conference and Exposition on Structural Dynamics, 2013

d) SIMPLIE MECHANICAL MODEL FOR HUMAN-STRUCTURE INTERACTION DURING WALKING ALONG A SLENDER STRUCTURE

Cacho-Pérez, M., Ibán, N., Fernández, J., Lorenzana, A.

Proceedings of $6^{\text {th }}$ Edición World Conference of the International Association for Structural Control and Monitoring, 2014

e) ONE YEAR OF THE STRUCTURAL HEALTH MONITORING OF PEDRO GÓMEZ BOSQUE FOOTBRIDGE

Lorenzana, A., Poncela,A.V., Sebastián, J., Ibán, N., Istrate, M, Vasallo, A, Pereda, J. Diaz, I. M., Casado, C.M., Castaño, J.

Proceedings of $6^{\text {th }}$ Edición World Conference of the International Association for Structural Control and Monitoring, 2014

f) VIBRATION MONITORING OF A STEEL-PLATED STRESS-RIBBON FOOTBRIDGE: EFFECTS OF ENVIRONMENTAL AND OPERATIONAL FACTORS ON MODAL PROPERTIES

Diaz, I. M., Soria, J.M., Ibán, N., Cacho-Pérez, M. and García-Palacios, J.

Proceedings of $6^{\text {th }}$ Edición World Conference of the International Association for Structural Control and Monitoring, 2014

g) FINITE ELEMENT MODEL UPDATING OF A LIVELY FOOTBRIDGE

Ibán, N., Castaño,J., Cara, J., Fernández, J., Cacho-Pérez, M, Lorenzana, A.

Proceedings of $6^{\text {th }}$ International Operational Modal Analysis Conference, 2015

h) DYNAMIC CHARACTERIZATION, MODELLING AND MODEL UPDATING OF A LIVELY FOOTBRIDGE

Ibán, N., Castaño,J., Soria, J.M., Diaz, I.M, Lorenzana, A.

Proceedings of $3^{\text {rd }}$ International Conference on Mechanical Models in Structural Engineering, 2015

i) A PROCEDURE TO TRACK VIBRATION MODES UNDER CHANGING EXTERNAL FACTORS: APPLICATION TO A PEDESTRIAN BRIDGE

Soria, J.M., Diaz, I. M., García-Palacios, J., Ibán, N., Lorenzana, A.

Proceedings of $3^{\text {rd }}$ International Conference on Mechanical Models in Structural Engineering, 2015

j) SERVICEABILITY CONDITIONS OF PEDESTRIAN STRUCTURES USING A SIMPLIFIED MOVING MASS MODEL

Magdaleno, A., Cacho-Pérez, M., Castaño, J., Ibán, N., Diaz, I.M., Lorenzana, A.

Proceedings of $3^{\text {rd }}$ International Conference on Mechanical Models in Structural Engineering, 2015 
k) SIMULATION OF THE RESPONSE OF A LIVELY FOOTBRIDGE UNDER PEDESTRIAN LOADING WITH TWO TUNED MASS DAMPERS FOR ITS TWO FIRST MODES (2.1HZ AND 2.5HZ)

Ibán, N., Castaño, J., Magdaleno, A., Cacho-Pérez, M., Fraile, A., Lorenzana, A. Proceedings of $6^{\text {th }}$ European Conference on Structural Control, 2016

I) OPTIMAL DESIGN AND PRACTICAL IMPLEMENTATION OF EDDY-CURRENT TUNED MASS DAMPERS WITH PERMANENT MAGNETS FOR MULTI-STOREY BUILDINGS

Magdaleno, A., Pereira, E., Castaño, J., Ibán,N., Diaz, I.M., Lorenzana, A. Proceedings of $6^{\text {th }}$ European Conference on Structural Control, 2016

m) A NEW PROCEDURE BASED ON TIME DOMAIN INDICATORS FOR OPTIMAL TMD TUNING ON FOOTBRIDGES

Magdaleno, A., Ibán, N., Cacho-Pérez, M., Cara, J., Diaz, I.M., Lorenzana, A.

Proceedings of $10^{\text {th }}$ European Conference on Structural Dynamics, 2017

n) ADJUSTABLE TMD (IN STIFFNESS AND DAMPING) USING MAGNETS AND COILS

Hernandez, O., Poncela, A.V., López, P., Ibán, N.

Proceedings of $4^{\text {rd }}$ International Conference on Mechanical Models in Structural Engineering, 2017

ñ) OPTIMAL LOCATION OF A TMD ON A LIVELY FOOTBRIDGE

Ibán,N., Magdaleno, A., Cacho-Pérez, M., Diaz, I.M.

Proceedings of $4^{\text {rd }}$ International Conference on Mechanical Models in Structural Engineering, 2017

o) DYNAMIC CHARACTERIZATION AND SERVICEABILITY ASSESSMENT OF A TIMBER FOOTBRIDGE

Magdaleno, A., Ibán,N., Infantino, V., Lorenzana, A.

Proceedings of $1^{\text {st }}$ IConference on Structural Dynamics, 2018

Asimismo se ha solicitado la siguiente Patente Nacional. Número: 201730925. Título: DISPOSITIVO PARA MITIGACIÓN DE OSCILACIONES

Todos estos rendimientos del trabajo de investigación realizado, junto con uno de los informes técnicos relativos a un contrato profesional, se incluyen en el anexo II. Tanto la patente como el informe, por su consideración confidencial, solo se incluyen en el tomo destinado a los evaluadores y al tribunal, no en el que se dejará disponible en el repositorio TESEO.

Por último, se insiste en que el presente documento adopta el formato de Tesis Doctoral como compendio de publicaciones y por lo tanto consiste en una síntesis de los trabajos de investigación publicados en lugar del formato tradicional de documento extenso autocontenido. 



\section{RESUMEN}

El modelado y la simulación de sistemas son de gran utilidad para muchas áreas de conocimiento. Poder simular el comportamiento real de un sistema reporta muchas ventajas a diferentes niveles, por ejemplo, en el de la seguridad y en el económico.

Del mismo modo, en el campo del diseño estructural considerar aspectos sociales y económicos es tan importante como el científico-técnico. Es por ello que la predicción de la respuesta dinámica de ciertas infraestructuras flexibles ante determinadas acciones (no siempre fáciles de caracterizar) presenta una estrecha relación con la mejora sobre su estado de seguridad y de sus condiciones de servicio. Además, a partir de los modelos obtenidos se pueden diseñar atenuadores pasivos para evitar o, en la medida de lo posible, reducir las vibraciones del sistema principal, asegurando, mediante simulación, el correcto futuro funcionamiento estructural.

El uso de modelos discretos y simples ha demostrado ser insuficiente para el adecuado modelado de estructuras esbeltas, ya que no pueden representar algunos efectos relacionados con los modos de vibración cuando éstos están poco espaciados y que frecuentemente ocurren en la práctica bajo la acción de los peatones, por lo que la necesidad de considerar las vibraciones, su cuantificación y control en la fase de diseño es primordial.

Esta tesis aborda una metodología adecuada para afrontar dichas consideraciones sobre una pasarela peatonal concreta, estudiando el problema bajo nuevas estrategias de evaluación que derivan en diferentes posibilidades en función del propósito.

Como ocurre en muchos proyectos de ingeniería, se hace necesario trabajar en equipo y combinar múltiples conocimientos de diversos campos. Cuando además el proyecto es de investigación, esas necesidades son mayores. En el desarrollo de esta tesis doctoral se ha trabajado en modelado mediante elementos finitos, en sensorización e instrumentación, en identificación estructural, en tratamiento de registros temporales, en el calibrado de modelos computacionales para que las simulaciones sean realistas y en el diseño conceptual y mecánico de sistemas pasivos de mitigación de vibraciones, entre otros campos. Algunos de estos trabajos han sido objeto de los artículos y congresos enumerados anteriormente. Complementariamente a lo largo de los siguientes capítulos se ilustrarán, a través del ejemplo concreto de una de las pasarelas peatonales en la que se ha trabajado, los aspectos más interesantes de esta tesis, identificando los enfoques originales y las aportaciones al estado de la técnica. 


\section{ABSTRACT \\ TECHNIQUES FOR EVALUATION, SIMULATION AND IMPROVEMENT OF SERVICEABILITY IN PEDESTRIAN STRUCTURES}

Modeling and system simulation are very useful for many areas of knowledge. Being able to predict the real behavior of a system brings many advantages at different levels, for example, security and economics.

In the same way, in structural design, considering social and economic aspects is as important as the technical ones. That is why the prediction of the dynamic response of certain flexible infrastructures under certain loading conditions (not always easy to characterize) has a close relationship with the improvement on their security status and their serviceability conditions. In addition, passive control devices can be considered in the model to avoid or, as far as possible, reduce the vibrations of the main system, ensuring, through simulation, the correct future structural performance.

The use of simplified models has reveal to be poor for the proper modeling of slender structures, since they can not represent some effects related to the modes of vibration when their frequencies are not spaced apart enough. These cases appear in practice under the action of pedestrians. So, the need to consider a realistic system for modelling and control in the design phase is paramount.

This thesis addresses an adequate methodology for these considerations on a specific pedestrian footbridge, studying the problem under new simulation strategies that result in different possibilities depending on the purpose.

As in many engineering projects, it is necessary to work integrated in a multidisciplinary team and to combine multiple knowledge from different fields. For research projects, those needs are greater. In the development of this doctoral thesis the author has worked in several areas: finite element modeling, sensing and instrumentation, modal identification, signal proccesing, model updating, conceptual and mechanical design of passive vibration mitigation systems, among other fields. Some of these works have been the object of the journal articles and conference papers listed above. In addition, throughout the following chapters, the most interesting aspects of this thesis will be illustrated, through the particular example of one of the pedestrian footbridges in which the author has been worked, identifying the original approaches and the contributions to the state of the art. 
ÍNDICE GENERAL

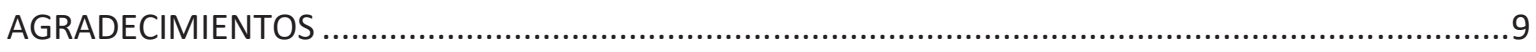

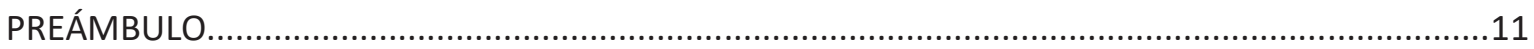

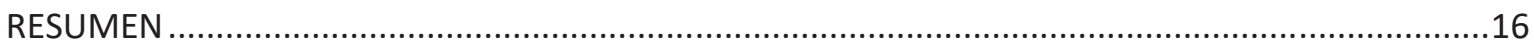

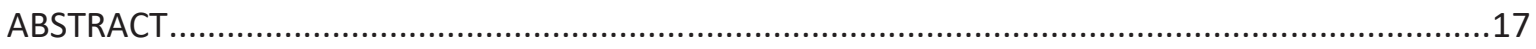

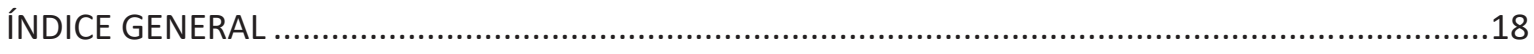

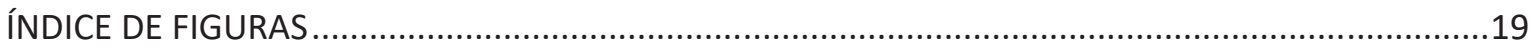

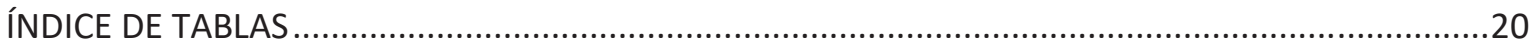

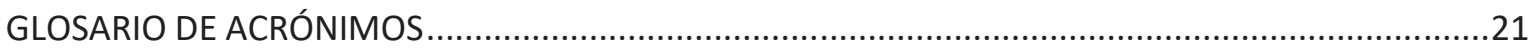

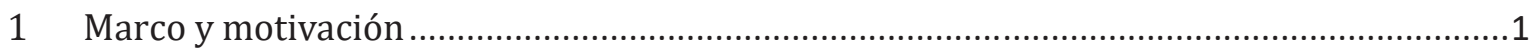

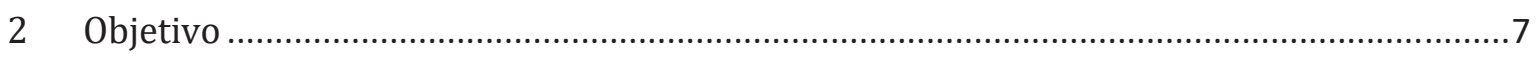

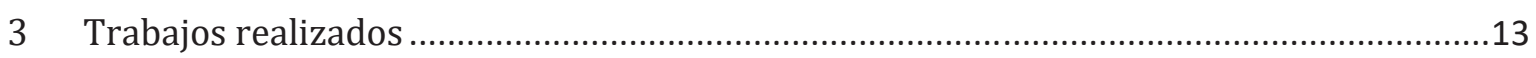

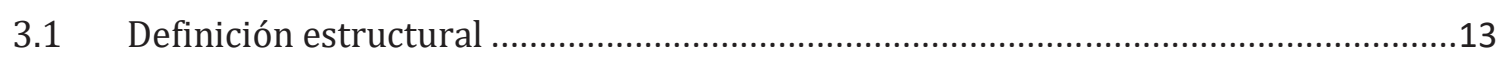

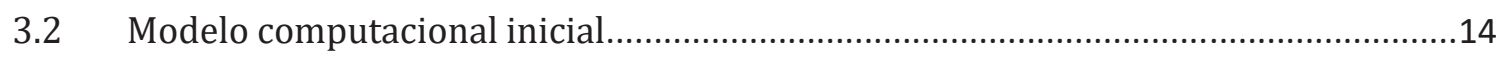

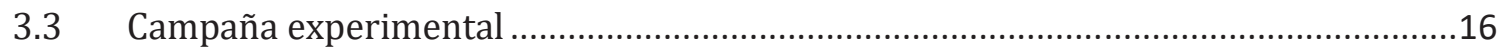

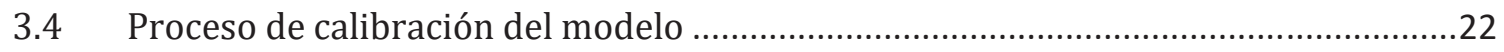

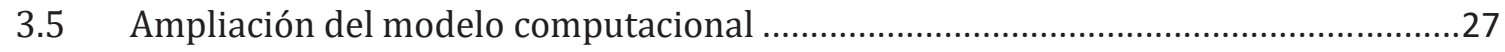

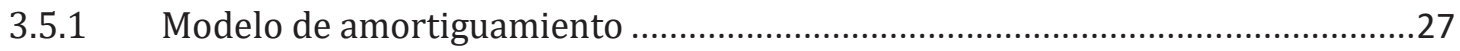

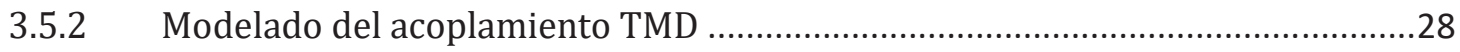

3.5.3 Modelo de interacción peatón-estructura ..........................................................28

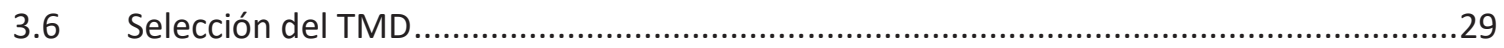

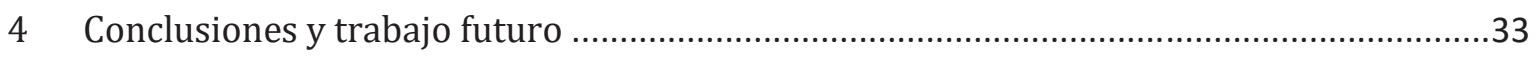

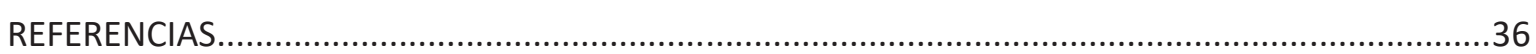

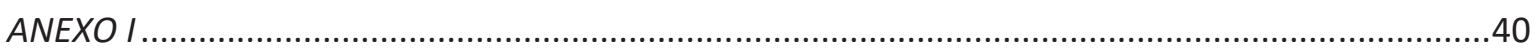

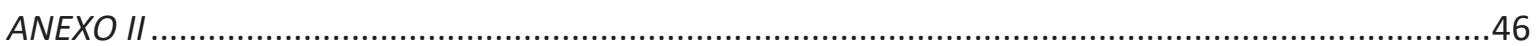




\section{ÍNDICE DE FIGURAS}

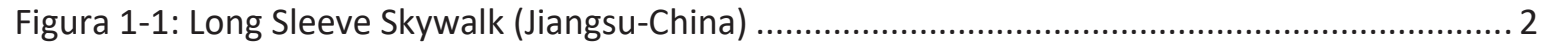

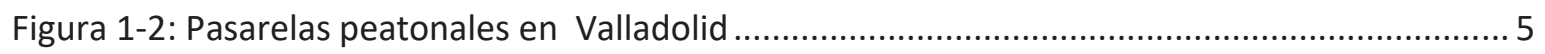

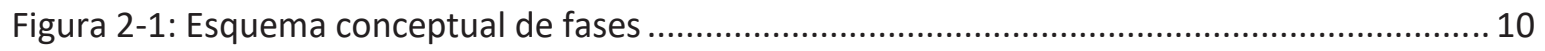

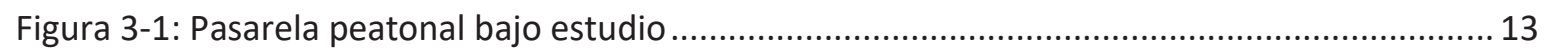

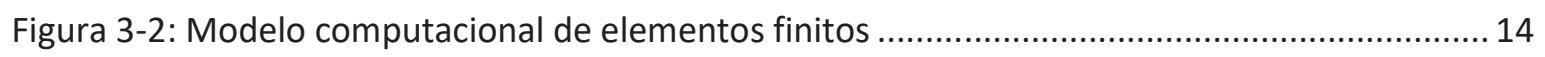

Figura 3-3: Tres primeros modos del modelo inicial de la pasarela ................................................... 15

Figura 3-4: Condiciones de contorno y estado de cargas para análisis estático ................................ 15

Figura 3-5: Distribución de los 4 puntos de medida........................................................................ 17

Figura 3-6: Registros temporales de los 4 canales de medida y sus espectrogramas (Fast Fourier

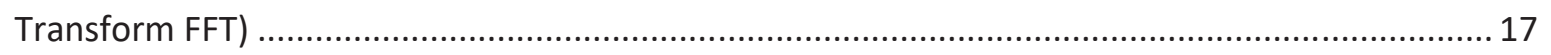

Figura 3-7: Curvas para identificación de parámetros modales................................................... 18

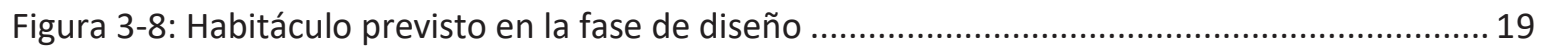

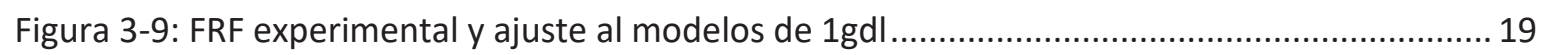

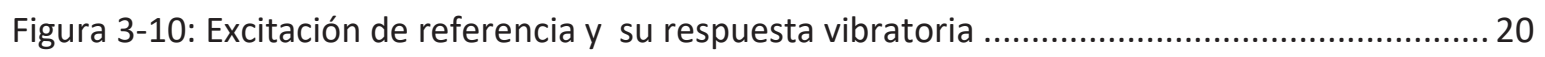

Figura 3-11: Amortiguamiento evaluado mediante ajuste exponencial......................................... 20

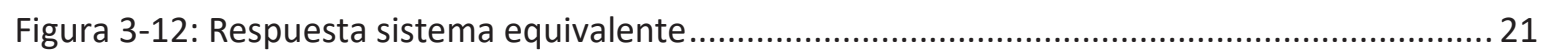

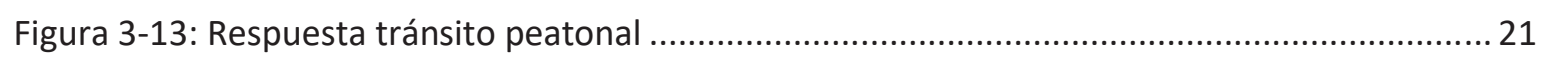

Figura 3-14: detalle constructivo de la unión metálica con el tablero de hormigón ......................... 23

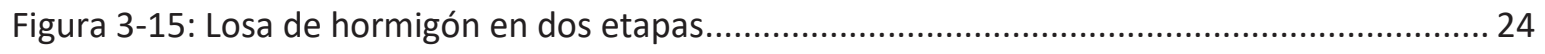

Figura 3-16: sensibilidad de los parámetros globales elegidos ......................................................... 24

Figura 3-17: Tendencia de los porcentajes de cambio de la densidad sobre los 120 elementos

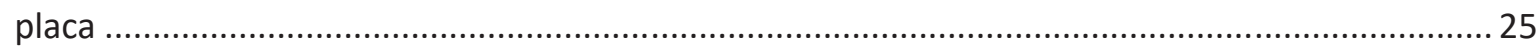

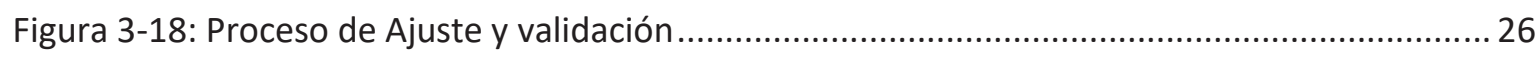

Figura 3-19: Variación del amortiguamiento relativo modal en función de la frecuencia ............... 27

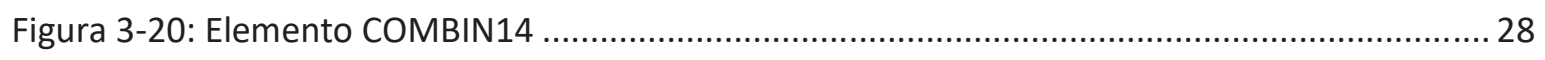

Figura 3-21: Modelo de interacción peatón-estructura propuesto ................................................ 29

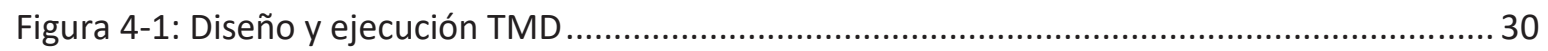

Figura 4-2: Respuestas del punto medio del modelo y del registro real........................................... 32 


\section{ÍNDICE DE TABLAS}

Tabla 1-1: Frecuencias críticas y valores de aceleración máxima de confort .....................................

Tabla 3-1: Tres primeras frecuencias propias del modelo inicial de la pasarela ...............................15

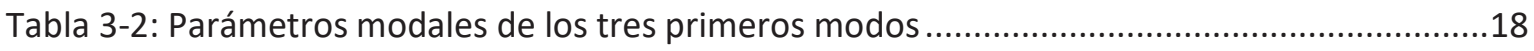

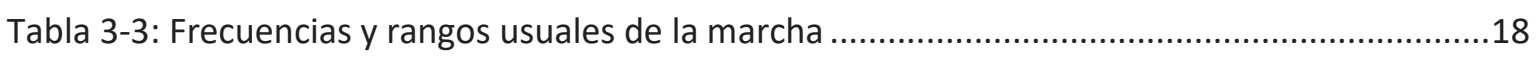

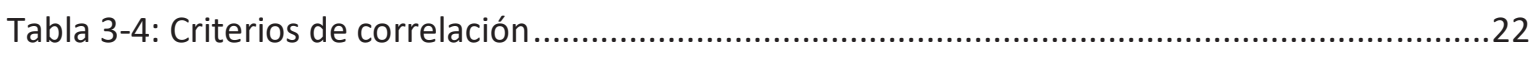

Tabla 3-5: Resultados modales de los ajustes realizados en base a consideraciones lógicas ..........24

Tabla 3-6: Correlaciones MAC sobre los modelos FEM\#0, FEM\#1, y FEM\#2 ……...........................25

Tabla 3-7: Resultados modales de los ajustes realizados en base a modificaciones locales de la

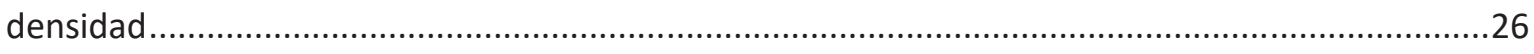

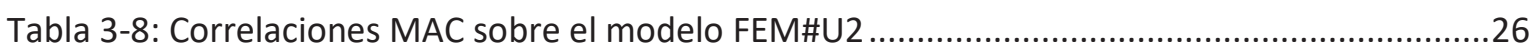




\section{GLOSARIO DE ACRÓNIMOS}

$\begin{array}{ll}\text { CAE } & \text { Computer aided engineering } \\ \text { FEM } & \text { Método de los Elementos Finitos } \\ \text { OMA } & \text { Operacional Modal Analysis (Análisis Modal Operacional) } \\ \text { EMA } & \text { Experimental Modal Analysis (Análisis Modal Experimental) } \\ \text { FRF } & \text { Frequency Response Function (Función de Respuesta en Frecuencia) } \\ \text { GDL } & \text { Grado De Libertad } \\ \text { PEB } & \text { Pasarela estadio Balear } \\ \text { TMD } & \text { Tuned Mass Damper (Amortiguador de Masa Sintonizado) } \\ \text { VDV } & \text { Valor de la dosis de la vibración } \\ \text { RMS } & \text { Valor eficaz o cuadrático también llamado equivalente } \\ \text { MTVV } & \text { Valor máximo de vibración transitoria } \\ \text { a_max } & \text { Aceleraciones máximas }\end{array}$





\section{Marco y motivación}

Hoy en día existen estructuras típicas de proyectos e instalaciones de tipo industrial y de ingeniería civil, tales como chimeneas industriales, torres, edificios altos, puentes, pasarelas o viaductos, que han sido diseñadas y ejecutadas bajo criterios que difieren de los planteamientos actuales. Por otro lado, los nuevos materiales son cada vez más resistentes y permiten el diseño y construcción de estructuras cada vez más ligeras, complejas y ambiciosas, en las cuales los movimientos pueden ser apreciables, caso que se da con bastante asiduidad. Estos aspectos, junto con las actuales demandas sociales relativas a la percepción de seguridad y confort, recogidas en algunos casos en las normativas (Eurocódigos [EN1991-1], ISO [ISO2631,ISO10137], British Standards [BS6472, BS5400],...) y guías (SETRA, Fib, Hivoss,...), suscitan la necesidad de desarrollar una metodología adecuada para el análisis y el diseño asistido por ordenador de estructuras esbeltas, integrando técnicas experimentales que permitan una precisa identificación de los parámetros más relevantes y que definen el comportamiento estructural (estático y dinámico). De esta manera se dispondrá de datos fiables para la calibración y validación de los modelos numéricos empleados en la etapa de diseño y de su posterior simulación estructural.

Desde finales del siglo XIX ingenieros e investigadores han tenido conocimiento de los problemas vibratorios que se presentan en ciertas estructuras (Broughton Suspension Bridge y Angers Bridge) [1]. Uno de los primeros casos de problemas de vibraciones inducidas por personas sucedió en 1831 en Inglaterra cuando 60 soldados marchaban sobre un puente. Este fue el evento que provocó que un considerable número de puentes tuvieran la advertencia de que las tropas deben romper la marcha cuando crucen sobre estos.

Quizá, lo acontecido el 7 de noviembre de 1940 a las 11.00 de la mañana en la localidad de Tacoma (Washington) sobre uno de sus puentes colgantes (1600 metros de longitud) sea el máximo exponente de estos fenómenos. La filmación del colapso estructural del Puente de Tacoma [2] (inaugurado el 1 de julio de 1940) inducido por el viento a causa del fenómeno aerodinámico conocido como flameo aerolástico (flutter) es, aún a día de hoy, uno de esos videos que se enseñan en las escuelas de ingeniería, física o arquitectura y que queda grabado a fuego en la retina de los estudiantes. El hecho es, que un viento que impactaba de manera transversal a 68 kilómetros por hora (intensidad media) provocó una excitación en el puente que hizo que éste se retorciera hasta venirse abajo por completo. Con el conocimiento actual nos podemos permitir el lujo de establecer que el error ingenieril fue obviar el fenómeno del flameo, y más aún sobre este tipo de construcciones tan esbeltas donde la aerodinámica es tan importante. En la época no se pensaba que la aerodinámica de estas construcciones pudiera afectar a su estabilidad estructural pero a raíz de este acontecimiento los túneles de viento fueron una herramienta fundamental para el diseño y la validación de las respuestas de estas construcciones a fin de evitar fenómenos indeseables. 
Era de esperar que con la experiencia adquirida, las normativas existentes en la materia, las validaciones y procedimientos aplicados sobre los diseños modelados, bien con el uso de túneles de viento o, actualmente, mediante el uso de herramientas de simulación computacional, no podamos llegar a visualizar otro episodio de consecuencias tan llamativas como destructivas.

Aun así, nuevas tendencias constructivas, formas estructurales singulares, novedosos materiales y nuevas necesidades de movilidad y funcionalidad afloran y ponen el conocimiento adquirido fuera de la zona de confort en la que se afianzaba.

Desde el punto de vista del diseño estructural, la robustez ha dado paso a estructuras ligeras y vistosas, sobre todo las que favorecen la movilidad de las personas dentro de las ciudades permitiendo su paso sobre vías de tráfico o cuerpos de agua, como es el caso de las pasarelas peatonales. Estas estructuras han visto aumentada su presencia en los últimos años de forma excepcional, convirtiéndolas en muchos casos en símbolos de las propias ciudades y es por ello, y no solo por el ahorro económico, que en multitud de casos se sacrifica la racionalidad estructural por la singularidad y la estética de la construcción.

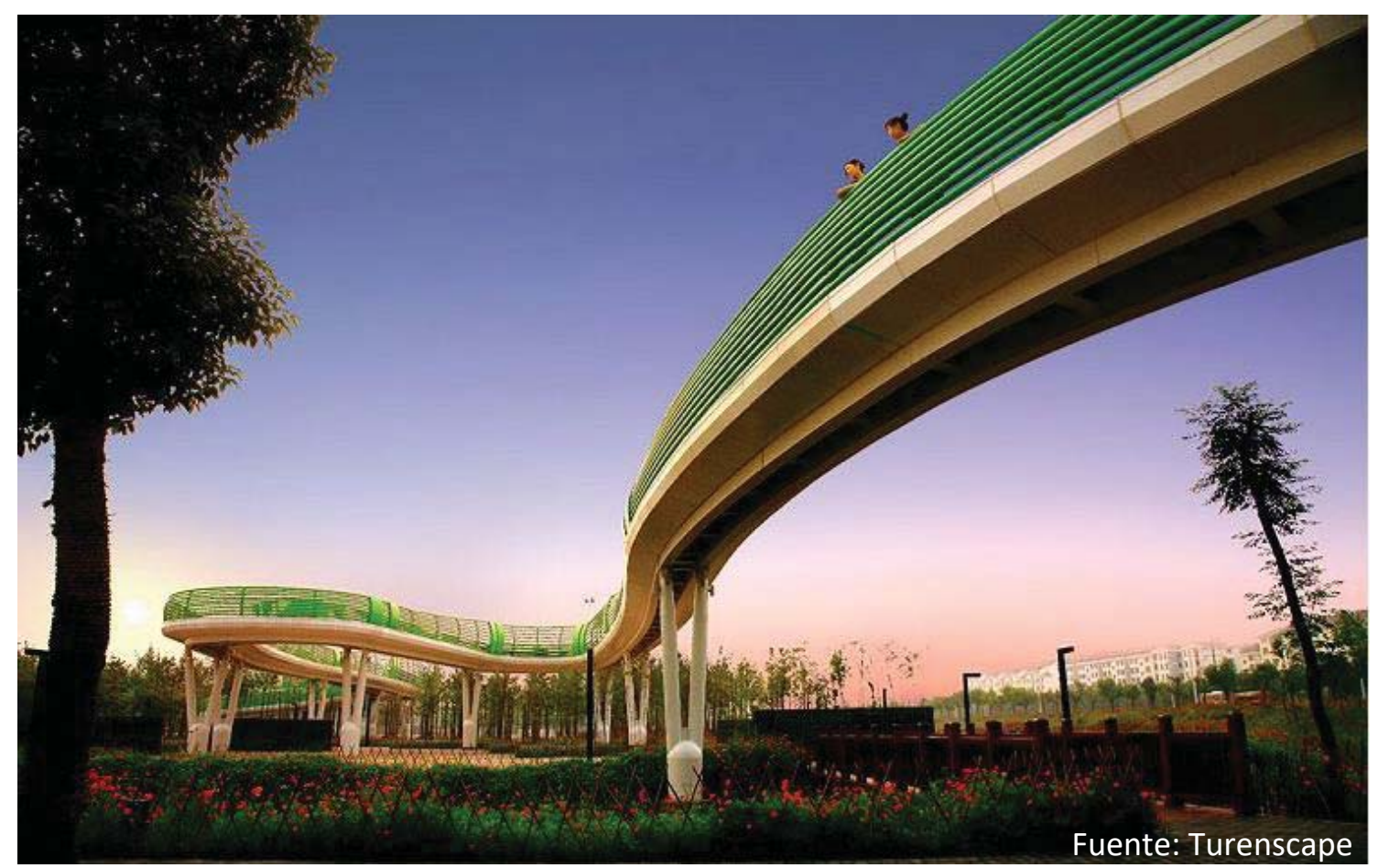

Figura 1-1: Long Sleeve Skywalk (Jiangsu-China)

Los expertos en ingeniería y múltiples investigadores han reconocido la importancia de la vibración inducida en la respuesta dinámica y en el daño, deterioro, fatiga y en general en la vida útil de ciertas estructuras, evidenciando que los métodos actuales de análisis y diseño con frecuencia subestiman los efectos de las cargas dinámicas en estructuras [3], [4].

En general los diseños contemporáneos de pasarelas peatonales se presentan como estructuras esbeltas, ligeras y poco amortiguadas, lo que provoca fenómenos de interacción y acoplamiento, ya que en ocasiones la aparición de modos propios de vibración se presentan dentro de los rangos susceptibles de ser excitados por las cargas de uso una vez puestas en servicio, requiriendo en muchos casos la implementación de sistemas de control [5], [6], [7] del 
movimiento y de disipación de energía cuya efectividad real solo se puede simular computacionalmente disponiendo de herramientas que contemplen el comportamiento dinámico del conjunto interactuando simultáneamente con la excitación (terreno para el caso de cargas sísmicas, fluidos usuarios etc).

Aunque las fuerzas inducidas por los peatones [8], [9], [10], [11] en movimiento suelen ser de baja intensidad, cuando su frecuencia coincide con alguna de las naturales de la pasarela, puede provocar movimientos apreciables que incluso pueden llegar a ser molestos [12] o, en casos concretos, inadecuados o peligrosos desde el punto de vista de la resistencia estructural. Por tanto sería importante poder caracterizar estas acciones para, hasta cierto punto, poderlas reproducir computacionalmente e incorporarlas al modelo tanto de pasarelas peatonales, como es el caso de este trabajo, como de forma más general en forjados de grandes luces, escaleras esbeltas o estadios deportivos.

Afortunadamente, las multitudes no son capaces de coordinar perfectamente sus movimientos por lo que la respuesta de la estructura raramente alcanzan su máximo teórico. Sin embargo pueden darse fenómenos involuntarios de sincronización [13] persona-persona o persona-estructura que invalidan las habituales hipótesis simplificativas, pudiendo llevar a la estructura a sobrecargas no consideradas que comprometan la resistencia estructural, tal como ocurrió en el año 2000 en una pasarela peatonal situada en Londres "Millennium Bridge" [10]. Un flamante diseño realizado en acero sobre el que no se había previsto ni considerado la acción de las componentes laterales de la fuerza ejercida por los transeúntes a su paso y mucho menos los efectos de la sincronización de estas fuerzas laterales y cuya aplicación forzaba a la estructura a responder balanceándose de un lado a otro asustando a los usuarios y forzando a un intervención estructural que limitase sus movimientos, solo tres días después de inaugurarla.

Los antecedentes ponen de manifiesto el problema de las respuestas estructurales por fenómenos de vibraciones inducidas al que la comunidad científica dedica ahora un mayor nivel de atención. A pesar de los grandes avances alcanzados en los diseños, validaciones y en los procesos de estas validaciones, aún aparecen estructuras con características de respuesta dinámica indeseable.

Así el esfuerzo investigador en este tipo de estructuras se centra, actualmente, en poder caracterizar numéricamente el comportamiento real de estructuras esbeltas frente a excitaciones inducidas por sus ocupantes. Estas excitaciones suelen presentarse mediante la acción del viento, por la actividad humana y por sobrecargas. Conocer su respuesta ante ellas, garantizando tanto la integridad estructural como su correcto comportamiento en servicio, es fundamental a fin de evitar problemas como los acontecidos en el "Millennium Bridge" [14] o en otros muchos puentes, pasarelas, forjados en centros comerciales, estadios deportivos, centros de conciertos, etc.

Numerosos trabajos han centrado su esfuerzo en estudiar y caracterizar el movimiento armónico en el transito del peatón y la fuerza de interacción de este con la estructura [15]. Conocidos estos rangos de influencia, las diferentes normativas tratan de evitar construcciones que presenten frecuencias (en cualquier dirección) que puedan resonar con las de las de las acciones humanas. Así las normativas, o más bien recomendaciones, están claramente dirigidas a que los usuarios no perciban la respuesta vibratoria de la estructura, lo que se definiría como el cumplimiento del estado límite de servicio de vibraciones. Además, si para las solicitaciones (fuerzas y frecuencias) a las que se puede presuponer que va a ser sometida la pasarela, no presenta una respuesta vibratoria perceptible por los usuarios, el nivel vibratorio distará mucho 
de entrañar un verdadero riesgo para la estructura (estado límite último). De este modo se puede llegar a concluir que estas estructuras presentan un criterio de diseño y construcción dependiente de los valores que presentan las guías de diseño y que atienden únicamente a la percepción del confort de los transeúntes, medido este confort mediante las aceleraciones dadas por la respuesta vibratoria de la pasarela.

\begin{tabular}{|c|c|c|}
\hline \multirow{2}{*}{ Normativas } & Frecuencias críticas $(\mathrm{Hz})$ & Aceleraciones máximas de confort $\left(\mathrm{m} / \mathrm{s}^{2}\right)$ \\
\cline { 2 - 3 } & Vertical & Vertical \\
\hline DIN102 & $1.6 \div 2.4 \mathrm{y} 3.5 \div 4.5$ & $0.50 .5 \mathrm{Vf}_{\mathrm{v}}$ \\
\hline DIN4150/2 & $1 \div 80$ & (en términos de velocidad) \\
\hline ONT 83 & - & $0.25 \mathrm{f}_{0}^{0,18}$ \\
\hline ISO2631 & $1 \div 5$ & $\leq 0.43$ \\
\hline ENV 1995 & $\approx 2$ & 0.7 \\
\hline BS5400 & $<5$ & $0.50 .5 \mathrm{Vf}$ \\
\hline ISO10137 & $1.7 \div 2.3$ & $60 \mathrm{X}$ \\
\hline EAE2011 & $1.25 \div 4.6$ & (sin especificar) \\
\hline
\end{tabular}

Tabla 1-1: Revisión de criterios de comodidad en distintas normativas.

Ante las pautas marcadas para el diseño, se pueden plantear circunstancias que escapan a estas previsiones de uso o limitaciones y que sí podrían suponer un riesgo para la salud estructural. En los últimos años han surgido diferentes actos vandálicos [16] sobrevenidos sobre estas estructuras de paso, donde un conjunto de individuos se colocan y se agitan al son de la estructura, acoplándose a su movimiento y generando grandes desplazamientos estructurales. Vemos de este modo que no todo está evaluado, y que las guías no solo quedan lejos de predecir la confortabilidad o adecuación que pueda darse bajo el uso normal sino que para usos inesperados no se tienen previsiones de las respuestas.

Otras circunstancias que también sobrepasan a las guías de diseño vienen derivadas por comportamientos vibratorios excesivos, que difieren de lo esperado en los modelos de diseño debido a propiedades locales de difícil incorporación en los modelos de cálculo. Por ejemplo, la existencia de un vano con dos pavimentos distintos, tal como ocurre en la pasarela Pedro Gómez Bosque de Valladolid, donde uno de sus pavimentos es rígido, en la zona del carril bici, y otro flexible, por medio de aglomerado de caucho, en la zona peatonal. Las sensaciones percibidas, a pesar de que el comportamiento estructural es exactamente el mismo, son distintas dependiendo de la zona de tránsito.

A raíz de este último comentario sobre las diferencias bajo distintas zonas de transito se quiere referenciar, junto a la ya comentada pasarela Pedro Gómez Bosque, otras pasarelas de la ciudad de Valladolid por su relevancia en el aprendizaje y estudios realizados sobre ellas así como muestra de la proliferación de estas construcciones en los últimos 15 años. 


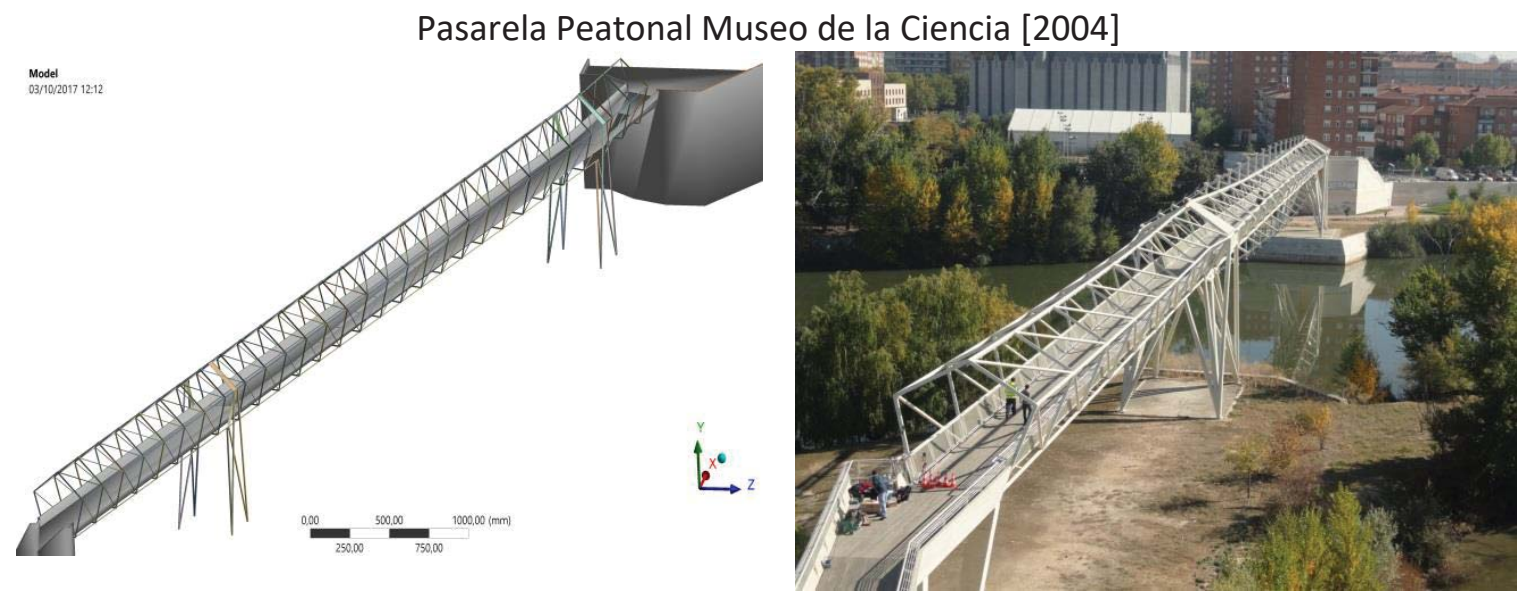

Pasarela Peatonal Pedro Gómez Bosque [2010]
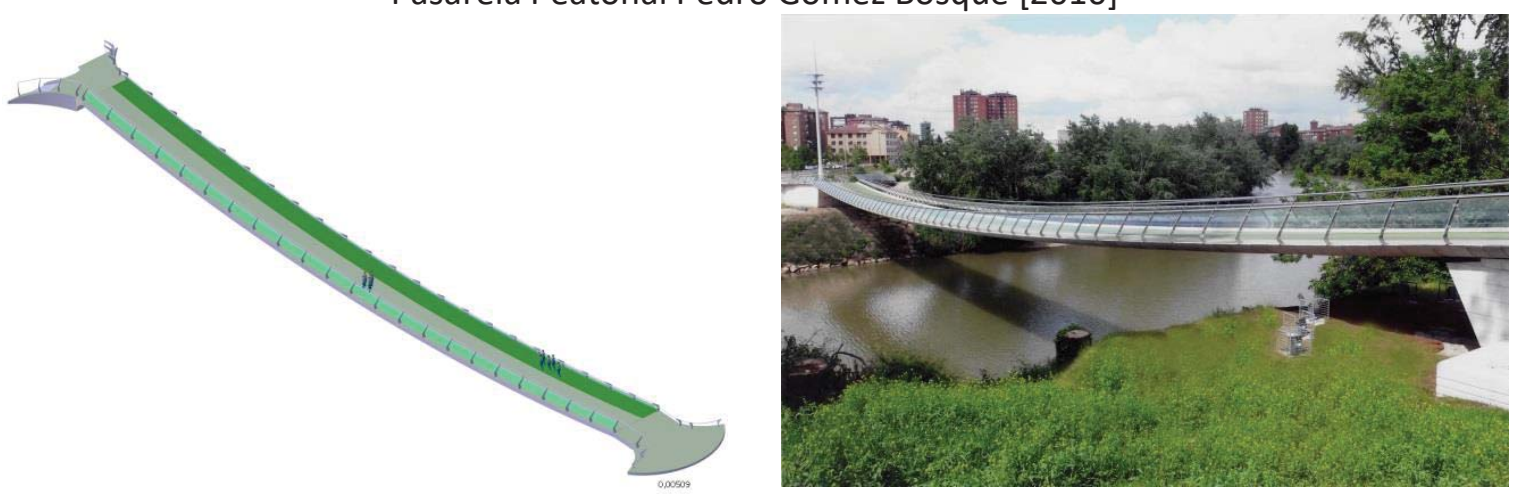

Pasarela Peatonal sobre Vía Padre José Acosta Pasarela Peatonal y Ciclista de Boecillo [2015]

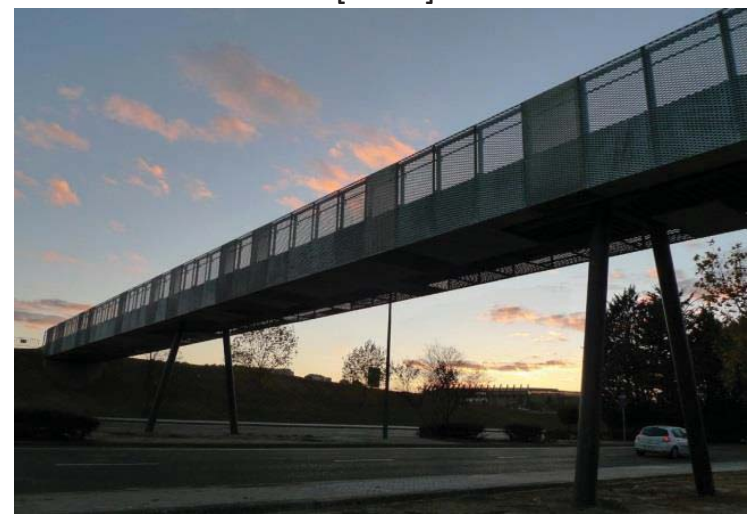

[2018]

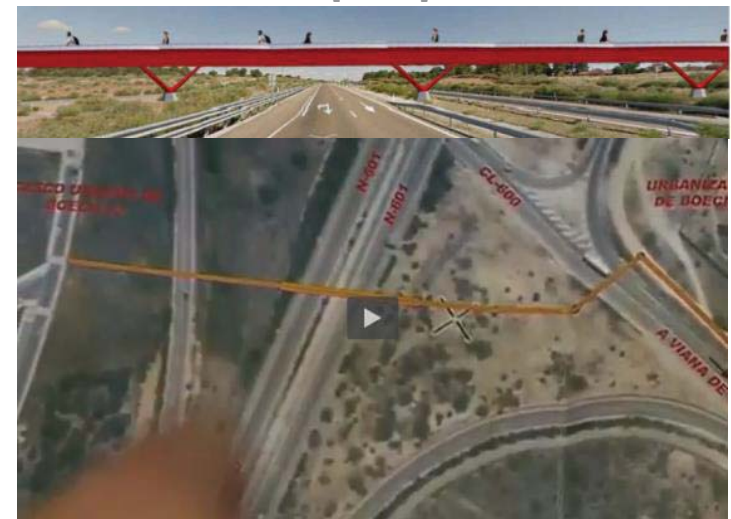

Figura 1-2: Pasarelas peatonales en Valladolid

En este contexto y aunque en el pasado, en el sector de la ingeniería civil, venía siendo habitual el uso de modelos aproximados para estimar la respuesta dinámica de las estructuras de tipo puente, hoy en día es habitual modelar la estructura utilizando las actuales capacidades CAE que se venían usando en el sector aeroespacial.

Mediante el Método de los Elementos Finitos (FEM) se pueden realizar simulaciones [17] del comportamiento estático y dinámico suficientemente precisos, previa calibración del modelo con los que estudiar la respuesta estructural ante las diferentes combinaciones de los escenarios a los que la estructura pueda estar sometida, entendiendo estos escenarios como las múltiples 
posibilidades que se presentan tanto desde el punto de vista en que el peatón transita por la pasarela bajo sus condiciones particulares de masa, velocidad y frecuencia de paso entre otras, como desde el punto de vista en el que se considera el acoplamiento de uno o varios sistemas amortiguador que atenúen la vibración. Presentando de esta forma un problema de interacción y acoplamiento. 


\section{Objetivo}

Esta Tesis está dotada de un contenido fundamentalmente práctico, sirviendo en muchas de sus partes de guía para otros investigadores o ingenieros a los que se les presenten problemas de vibraciones, tanto de pasarelas peatonales, como de forma más general en forjados de grandes luces, escaleras esbeltas, mástiles de aerogeneradores o chimeneas, por citar tan solo algunas tipologías estructurales con las que se ha trabajo.

Con este enfoque, se puede decir que el objetivo de este documento es mostrar diversas capacidades en el ámbito de la dinámica estructural avanzada aplicadas a una pasarela concreta. Por distintas razones se ha seleccionado la Pasarela "Estadio Balear" sobre la la Vía de cintura MA-20 de Manacor (Palma de Mallorca). Entre las referidas capacidades se encuentran el modelado mediante elementos finitos, la identificación modal experimental [18], [19], [20], el calibrado computacional y la incorporación de sistemas pasivos de mitigación de vibraciones [21].

La simulación mediante FEM es una técnica ampliamente utilizada en la actualidad para realizar tanto análisis estáticos como análisis dinámicos sobre estructuras, ya que es preferible realizar simulaciones virtuales a costosos ensayos sobre maquetas en laboratorios. Sin embargo, los resultados obtenidos mediante el empleo de estas técnicas a menudo difieren de los obtenidos mediante técnicas experimentales sobre las propias estructuras proyectadas (existentes).

A diferencia de la industria aeroespacial o automotriz, los diseños de la ingeniería civil presentan, en un altísimo porcentaje, la peculiaridad de ser únicos. Esto implica al diseñador un desconocimiento sobre el futuro funcionamiento estructural, pues intervienen no solo aspectos de diseño sino de ejecución, que queda fuera en muchos casos de su control. Por lo tanto, el beneficio inmediato de calibrar modelos de estructuras civiles existentes, diseñadas y ejecutadas, no es tan obvio como, por ejemplo, si sucede en la industria automovilística, donde lo que se busca es la mejora continua de un mismo producto. En la ingeniería civil el fundamento de este proceso es lograr obtener modelos más fiables y servir de utilidad, quizá, en futuros diseños de estructuras similares y por consiguiente, incrementar el conocimiento a partir de la calibración de los modelos FEM.

A fin de predecir el comportamiento de la estructura se recurre a técnicas basadas en procedimientos numéricos de aproximación, conocido como el "método de los elementos finitos" por el cual se consiguen analizar numerosos problemas de diseño estructural entre los que se incluyen los problemas vibratorios. Conocer dichos métodos y las capacidades para realizar un modelado preciso (calibración de modelos) [22], [23], [24], [25], [26], [27], [28], [29], [30], [31], [32], [33], y que se ajuste a un comportamiento estructural real es esencial para 
contrastar los resultados obtenidos de las respuestas simuladas en función de las diferentes estrategias de análisis. Una de las estrategias estará basada en FRFs (funciones de respuesta de frecuencia) y la otra en registros temporales. La dificultad que entraña las estrategias FRF no es solo debida a que es una tarea tediosa (se deben considerar varias FRF a lo largo de la pasarela), sino también a su limitación, ya que el cruce de peatones es un efecto transitorio y las curvas FRF no incluyen la respuesta transitoria, solo el estacionario bajo carga armónica siendo esto una de las principales deficiencias de los modelos existentes. Tampoco se consideran los cambios en las propiedades dinámicas del sistema debidos a la presencia y tránsito de los peatones.

Con esta perspectiva, se presentará una metodología capaz de verificar las condiciones de servicio de una pasarela peatonal concreta. En el caso de que las vibraciones observadas o previsibles sean inadmisibles, existen distintas posibles actuaciones para intentar mitigarlas. Entre otras, rigidizar o reforzar la estructura, de forma que sus frecuencias fundamentales "no caigan" dentro de los rangos de las frecuencias de excitación, o bien aumentar el amortiguamiento estructural mediante el uso de diferentes disposiciones constructivas y la incorporación de sistemas de disipación de energía de distinta naturaleza.

La primera de las soluciones (rigidizar o reforzar) ha sido y es una de las formas más habituales de reducción o modificación del estado vibratorio, pero tiene como principales desventajas que puede afectar al diseño estético o arquitectónico de la estructura y suponer un incremento significativo de la masa y de los costes finales de la misma. Es por ello que los esfuerzos se enfocan, incluso en la etapa de diseño y dimensionamiento, y no sólo como medidas correctoras, en soluciones más modernas consistentes en el uso de elementos disipadores de energía con el fin de aumentar el amortiguamiento estructural. Nótese que, en general, las pasarelas presentan amortiguamientos bajos (por debajo del $1 \%$ del amortiguamiento crítico) y que este parámetro, fundamental para conocer el comportamiento dinámico, sólo puede ser conocido con precisión tras la ejecución de la estructura. De nuevo se resalta la necesidad de tener capacidad de incorporar adecuadamente estos sistemas de control en el modelo computacional.

Para todo ello se establece un procedimiento que engloba el uso de diferentes técnicas y herramientas computacionales capaces de predecir y verificar en una etapa temprana de diseño que las futuras respuestas estructurales son lo más bajas posibles gracias a la intervención realizada basada en el amortiguamiento adicional a incorporar a la estructura, que puede consistir en los sistemas mecánicos viscosos o friccionales (comúnmente usados en máquinas y mecanismos) o en sistemas inerciales. En el primer caso es necesario anclar los amortiguadores entre dos puntos de la estructura con un desplazamiento relativo significativo, lo cual no suele ser usual. Es más práctico, y lo que se ha hecho en este trabajo, añadir a un solo punto de la estructura un sistema inercial TMD [34], [35], [36], donde la disipación en el amortiguador se consigue gracias al movimiento de la masa móvil del sistema respecto al punto donde dicho sistema se une a la estructura.

El fin es establecer que la intervención realizada no sea únicamente funcional (desde un punto de vista normativo, entiéndase esto como la reducción del nivel vibratorio a límites adecuados) sino que es la mejor opción porque su repercusión sobre la pasarela minimiza la 
repuesta estructural al máximo, gracias a su correcta ubicación [37] y sintonizado, debido a la adecuada selección de los parámetros de diseño [38], [39], [40], [41], contemplando la posibilidad de incorporar más de un dispositivo [42].

Un TMD ${ }^{1}$ es una solución críticamente dependiente de los parámetros modales de la estructura y su trabajo se presenta óptimo cuando están sintonizados adecuadamente a la frecuencia fundamental correspondiente al modo de vibración cuyos desplazamientos se quieren limitar.

Sabiendo además que uno de los principales inconvenientes de los TMDs es el bajo rendimiento que prestan cuando se desvían de la frecuencia para la que fueron sintonizados y las variaciones que las estructuras reales involucran frente a sus modelos, este documento profundiza en la comprensión del problema vibratorio y en cómo la optimización de los diseños de TMDs pudieran no ser tan "óptimos" cuando la intervención se presenta sobre una estructura real, difícilmente simplificable y alejándose así de las hipótesis contempladas en las formulaciones clásicas. De este modo la localización del dispositivo y su correcto sintonizado en esa localización se verán modificados en función del propósito último de la intervención. Es decir, ¿se precisa atenuar la respuesta para un modo y una frecuencia concreta? o ¿se tienen distintos modos y frecuencias en un rango susceptible de ser excitado?, y en caso de estar

${ }^{1}$ En referencia a los sistemas más usuales para corregir el nivel vibratorio de las estructuras, Den Hartog (1956) fue el pionero en el estudio de TMDs obteniendo a raíz de sus investigaciones formulaciones para la determinación de los parámetros óptimos que definen el principio de funcionamiento del TMD. Uno de los primeros investigadores que realizó estudios con amortiguadores sintonizados fue Jones (1967), que presentó un análisis aproximado de la respuesta debida al modo fundamental de una viga simple de un único vano equipada con amortiguadores sintonizados. A principios de los años 80 G.B. Warburton presenta soluciones analíticas de sintonizados óptimos de TMDs para varios tipos de excitaciones y con diferentes objetivos de minimización. Estos primeros resultados fueron obtenidos, sin embargo, para sistemas realmente sencillos compuestos únicamente de un grado de libertad y carentes de amortiguamiento, el único escenario que posee solución analítica. Por esta razón, múltiples estudios en las últimas décadas se han destinado a completar dicho trabajo incluyendo aproximaciones y correlaciones empíricas para estructuras más complejas y con diferentes modelos de amortiguamiento. Al mismo tiempo Özgüvent e Çandir (1986) determinaron los parámetros óptimos de dos amortiguadores de vibraciones dinámicos sintonizados para las dos primeras frecuencias de resonancia de una viga. Ellos estudiaron numéricamente una viga empotrada, encontrando los valores óptimos de las razones de amortiguamiento y de sintonía de los amortiguadores en la primera y segunda frecuencia de la viga. Ya en 1995, Hugo Bachmann fue el precursor del uso de los TMDs en el control de las vibraciones verticales de las pasarelas peatonales y su satisfactorio efecto en la dinámica de la estructura. Así, 15 años más tarde Mustafa Kemal estudio el efecto de estos elementos y de sus parámetros, sobre modelos simples tipo barra, examinando su eficacia ante vibraciones simples y forzadas. Estos modelos podían ser adecuadamente aceptados para las pasarelas peatonales de la época, pero las tendencias constructivas actuales obligan a realizar una severa revisión de esta materia. 
ubicados en esta última cuestión, ¿̇ería un único TMD capaz de corregir esta problemática o por el contrario se necesitará más de uno?, y, si fuesen varios dispositivos, ¿cómo se diseñarían sus parámetros si obviamente uno influiría sobre el otro y sobre la propia estructura?.

Por ello, se hace necesario diseñar y analizar el comportamiento dinámico de la estructura y la influencia cuando sobre ella se acopla uno o varios dispositivos atenuadores de vibraciones que mitiguen las indeseadas vibraciones de la forma más eficiente. En función de la proximidad entre las frecuencias de la estructura y su forma modal, el propósito de la intervención puede ser distinto. En líneas generales podemos establecer que el trabajo consta de las siguientes fases indicadas esquemáticamente en la Figura 2-1:

- Identificación experimental dinámica de la pasarela peatonal (si está construida) o estimación mediante simulación por elementos finitos (en caso contrario).

- Elaboración de un modelo computacional (mediante FEM) con capacidad para incorporar sistemas de mitigación de vibraciones.

- Si se disponed e información experimental, se calibrará el modelo adecuadamente.

- Implementaciones de modelos realistas de carga peatonal

- Propuesta del sistema de mitigación a incorporar

- Proyecto de ejecución y pruebas para la evaluación de la eficiencia real (una vez instalado).

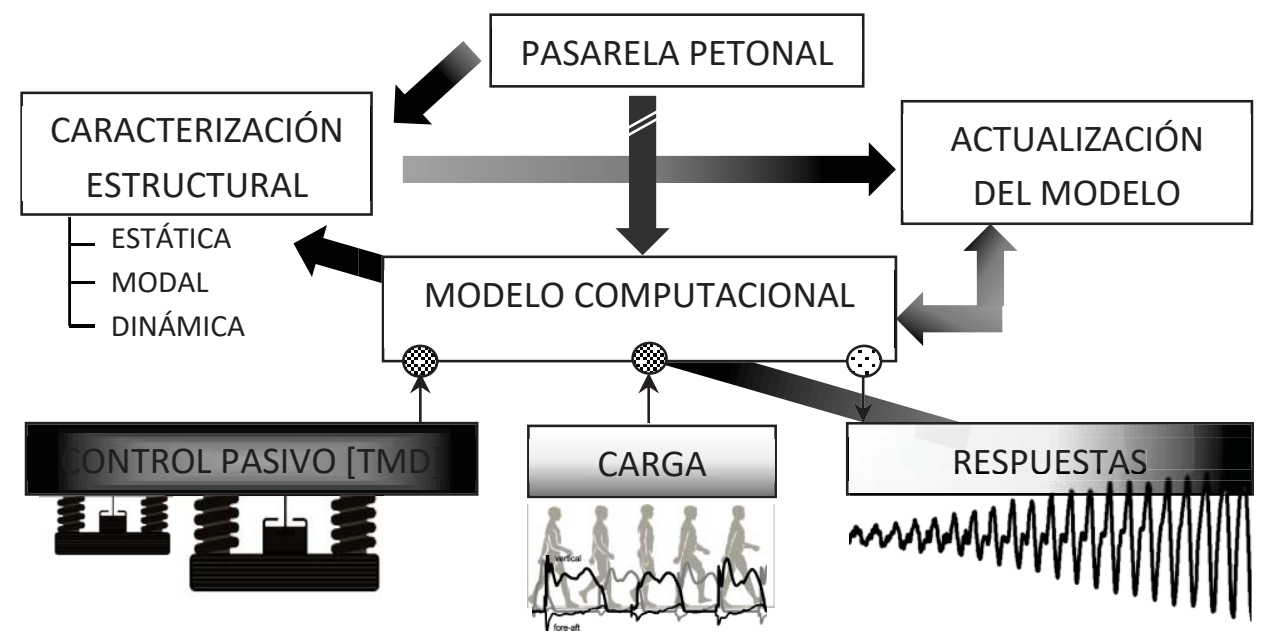

Figura 2-1: Esquema conceptual de fases

Otros muchos ingenieros persiguen actualmente objetivos similares y no solo en los ámbitos académicos. Proyectistas como Faukie (3), Interconstech (4), Sophia-Engineering (5), Massimo Majowiecki (6) o Renato Benedetti (7), incluyen en sus diseños de puentes peatonales estudios sobre vibraciones y, llegado el caso, incorporan sistemas de mitigación de vibraciones.

Existen asimismo empresas dedicadas específicamente a la fabricación e instalación de sistemas de disipación como Maurer, Gerb, Taylordevices o Vicodagruop. Es bastante usual ver a ingenieros de estas empresas en congresos temáticos [43], [44], [45], e incluso publicando en revistas de impacto [46]. 
A pesar de lo comentado en los párrafos anteriores, la mayor parte de los nuevos modelos de cálculo y simulación, prototipos conceptuales innovadores y publicaciones en revistas de impacto provienen del ámbito universitario y de centros tecnológicos. En la temática propia de esta tesis caben destacar, adicionalmente a las referencias incluidas en este documento y en los artículos listados en el anexo II, los trabajos de Nimmem et al [47], RamosMoreno et al. [48], Lai et al. [49], Shahabpoor et al. [50], Toso et al. [51], McDonald et al. [52], Dei et al. [53] o Rai et al. [54] entre otros. 


\section{Trabajos realizados}

\subsection{Definición estructural}

En este trabajo la estructura en cuestión es la denominada PEB pasarela peatonal de acceso al Estadio Balear sobre la Vía de cintura MA-20 de Manacor (Palma de Mallorca) mostrada en la Figura 3-1. Esta pasarela es un enlace urbano a cuyo vano principal de $40 \mathrm{~m}$ de longitud se accede mediante dos rampas circulares. Estructuralmente consta de un tubo primario de acero de sección circular y diámetro $500 \mathrm{~mm}$ sobre el que se montan ménsulas soldadas construidas de perfil HEB 320 cada 3.33 m en la zona recta y cada 15 en las zonas de acceso curvo. El vano central dispone de un arco construido a base de dos tubos de acero de diámetro $500 \mathrm{~mm}$ montados en celosía con 9 montantes de diámetro $200 \mathrm{~mm}$. El tablero montado sobre las ménsulas está construido a base de hormigón armado con chapa colaborante.

En la fase de diseño se advirtió la posibilidad de respuestas inadecuadas ante determinadas acciones peatonales. Tras su visado y ejecución se manifestaron, durante las pruebas de carga, vibraciones excesivas y se optó por incorporar un TMD.
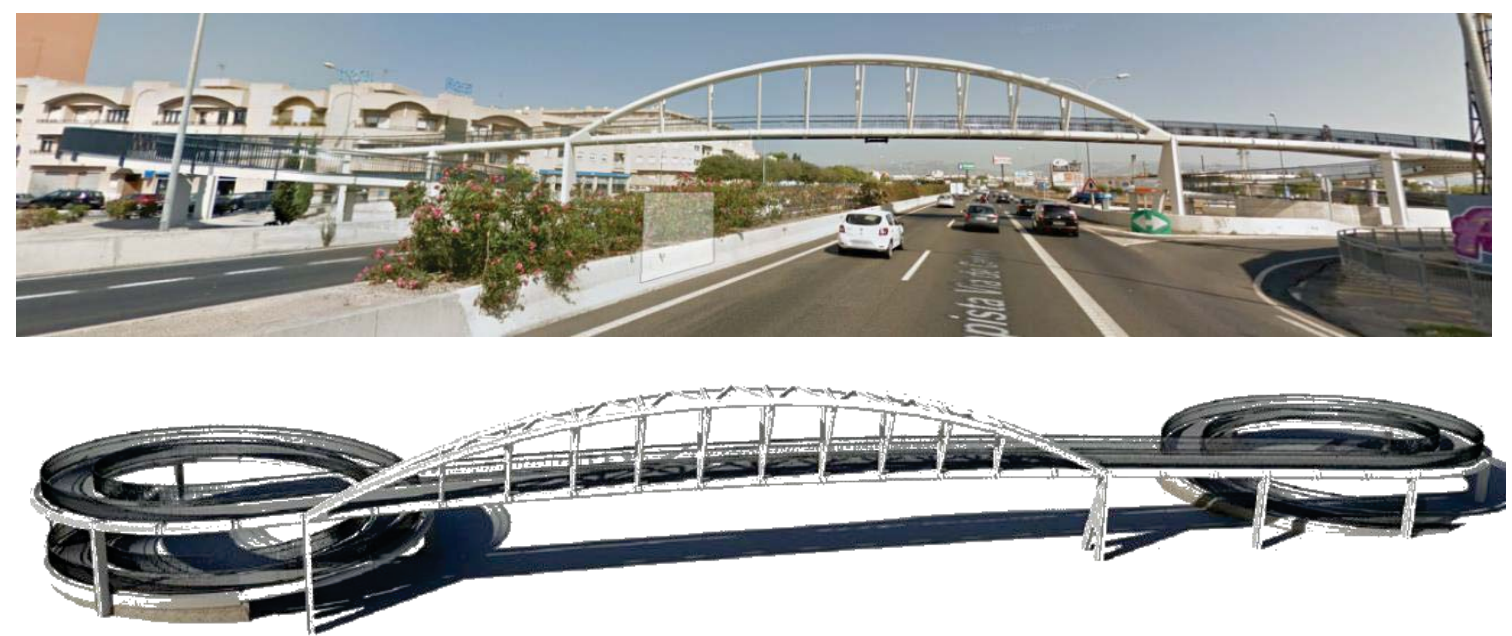

Figura 3-1: Pasarela peatonal bajo estudio 


\subsection{Modelo computacional inicial}

La estructura bajo estudio presenta ciertas características que complican el modelado estructural, entre ellas su esbeltez y ligereza, fuente de la significativa respuesta dinámica. Como primer paso, partiendo del CAD y de análisis previos realizados en SAP 2000, se generó un modelo de elementos finitos de la estructura en cuestión mediante el software comercial ANSYS WORKBENCH. El primer paso para la simulación numérica es tener un modelo geométrico que discretizar. Con el fin de simplificar el modelo, se recurre a elementos unidimensionales (tipo beam) para los perfiles laminados y tubulares y a elementos bidimensionales (tipo shell) para el tablero con sobrada capacidad para simulaciones en régimen elástico lineal como las que se llevarán a cabo. Tras estudios de convergencia realizados se fija una discretización de 620 elementos BEAM188 y 455 elementos SHELL181 suponiendo en su conjunto 2162 nodos y 9144 grados de libertad totales.

El elemento BEAM 188 es un elemento tipo viga (3D) con seis grados de libertad en cada uno de sus nodos y basado en la Teoría de Timoshenko que tiene en cuenta la deformación por cortante, lo cual puede interesar en este caso en el que la longitud de algunas barra de relleno es relativamente corta en relación con su canto. Es decir las secciones de la viga no permanecen perpendiculares al eje neutro de la viga tras la deformación.

El elemento SHELL181 es un elemento tipo placa con cuatro nodos y seis grados de libertad en cada uno de sus nodos basado en la teoría de primer orden o de Reissner-Mindlin en la que también se consideran las deformaciones por cortante..

Se consideraron varios tipos de sección transversal para el esqueleto de acero según las dimensiones comentadas en el anterior punto, pero para el tablero se utilizó un elemento de espesor constante de $200 \mathrm{~mm}$. Aunque los pasamanos de la pasarela se muestran rígidamente unidos al tablero, se ha considerado excluirlos del modelado computacional por su baja y prácticamente nula participación estructural. Sin embargo su masa si ha sido considerada sobre el peso de la tablero.

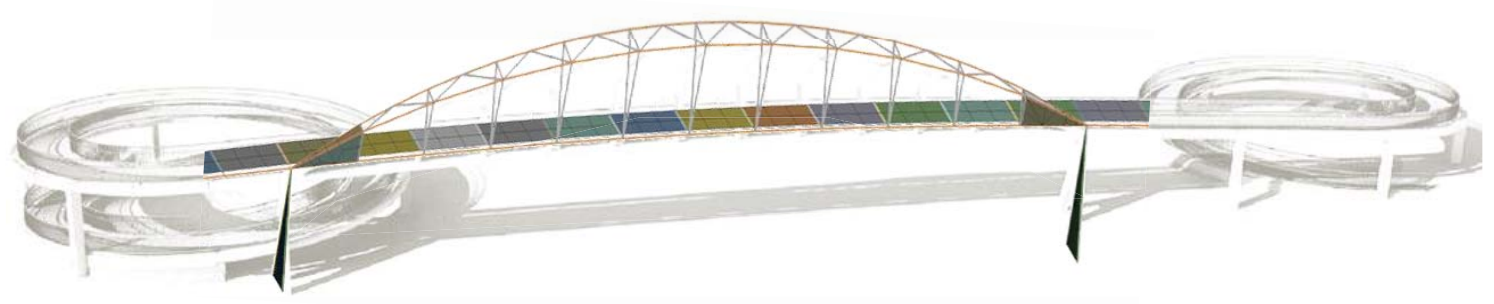

Figura 3-2: Modelo computacional de elementos finitos

Se comienza generando el modelo inicial [FEM\#0]. Se realiza un proceso de convergencia de malla afín de encontrar el equilibrio entre la simplicidad del mallado y la invariabilidad de resultados ante análisis estáticos y modales. Este punto es fundamental, pues la malla será la que determine la agilidad de los análisis transitorios que serán realizados posteriormente. Las condiciones de contorno supuestas, donde la estructura contacta (los 15 puntos que se pueden observar en Figura 3-4) con el suelo son consideradas como empotramientos perfectos y el 
amortiguamiento estructural es estimado en un $0.5 \%$ siendo incorporado al modelo como amortiguamiento proporcional, afectando por igual a todos sus modos.

Tras el análisis modal, se obtienen las frecuencias propias y modos reflejados en la siguiente tabla que se irán analizando en los siguientes apartados.

\begin{tabular}{|c|c|c|}
\hline MODO FEM\#0 & TIPO & FRECUENCIA (Hz) \\
\hline 1 & Torsional Arco (Sim.) & 2.105 \\
\hline 2 & Longitudinal Horizontal (Ant.) & 2.889 \\
\hline 3 & Torsional Arco 2 (Sim.) & 3.153 \\
\hline
\end{tabular}

Tabla 3-1: Tres primeras frecuencias propias del modelo inicial de la pasarela
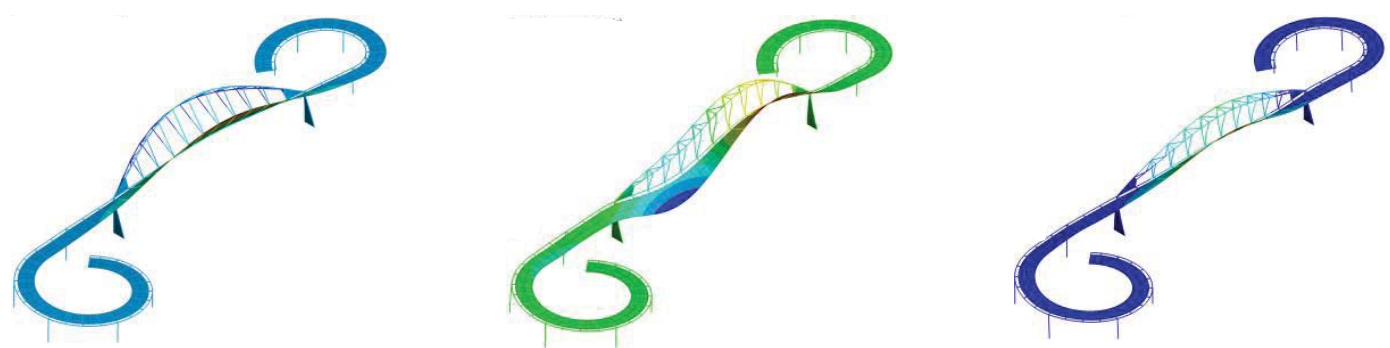

Figura 3-3: Tres primeros modos del modelo inicial de la pasarela

Desde un punto de vista estático hacer notar que la deflexión en el punto medio del vano en el extremo de mayor desplazamiento es de $24.17 \mathrm{~mm}$ bajo una carga como la de la Figura 3-4, estado de cargas al que fue sometida la estructura para su prueba de carga estática en la realidad y que dio como valor de flecha $32 \mathrm{~mm}$. Esta discrepancia evidencia que el modelo no es todo lo bueno que cabría desear.

\section{B: Static Structural \\ Static Structural \\ Time: $1, \mathrm{~s}$ \\ 25/05/2017 14:31 \\ A Fixed Support \\ B Force: $25000 \mathrm{~N}$ \\ C Force 2: $25000 \mathrm{~N}$ \\ D Force 4: $25000 \mathrm{~N}$ \\ E Force 6: $25000 \mathrm{~N}$ \\ F Force 7: $25000 \mathrm{~N}$ \\ G Force 9: $25000 \mathrm{~N}$ \\ H Force 11: $25000 \mathrm{~N}$ \\ I Force 12: $25000 \mathrm{~N}$}

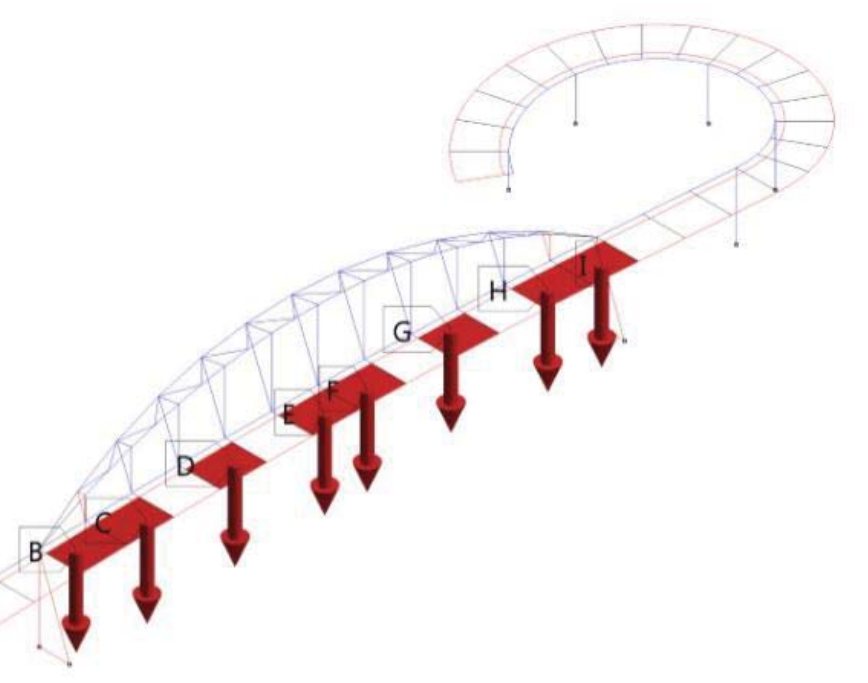

A

Figura 3-4: Condiciones de contorno y estado de cargas para análisis estático 


\subsection{Campaña experimental}

Conocer las características dinámicas de las estructuras se ha convertido en un aspecto importante tras su construcción, especialmente en los nuevos e imponentes diseños de las pasarelas peatonales. Resulta muy complicado contar inicialmente con modelos numéricos fiables que incluyan propiedades dinámicas tan importantes como puede ser el amortiguamiento modal. La identificación de los modelos se consigue mediante el uso de diversas metodologías que extraen los parámetros modales (frecuencias naturales, coeficientes de amortiguamientos, masas modales y formas modales) característicos de la estructura y que son fundamentales para ajustar los modelos de elementos finitos para conseguir simulaciones realistas.

El Análisis Modal Operacional (OMA), y el Análisis Modal Experimental (EMA) son las metodologías más empleadas para la estimación de los parámetros modales de las estructuras. Es importante conocer la variabilidad de la estimación pensado en la regulación (ajuste fino) que deba poseer el diseño mecánico del sistema atenuador de vibraciones. Dicha variabilidad puede venir, por un lado, debido a los diferentes métodos de estimación y elección de los parámetros de búsqueda y por otro lado, debido a los agentes externos como la temperatura o el nivel de ocupación de la estructura. En general estos análisis son realizados sobre registros de aceleraciones en las direcciones y localizaciones más relevantes. En el ANEXO I se resumen algunos de los conceptos básicos respecto a técnicas de identificación.

Para este tipo de análisis es usual emplear redes de sensores (acelerómetros) y en ocasiones se requieren equipos y sistemas poco portables capaces de proporcionar excitación a la estructura, generalmente mediante un vibrador electromagnético denominado "shaker" (para estos trabajos se utilizó un excitador electrodinámico de APS Dynamics modelo 400). El equipo necesario para estos análisis se presenta, en muchas ocasiones, influenciando en ciertos parámetros a las propias estructuras, como puede ser su masa.

En primer lugar se procede con un Análisis Modal Operacional (OMA), registrando síncronamente aceleraciones en 4 puntos durante 20 minutos con una frecuencia de muestreo de $200 \mathrm{~Hz}$. Los sistemas de captación son acelerómetros piezoeléctricos uniaxiales (MMF KS48C con sensibilidad $1000 \mathrm{mV} / \mathrm{g}$ y con rango de frecuencias que van desde $0.1 \mathrm{~Hz}$ hasta 2000-4000 $\mathrm{Hz}$ ) ampliamente utilizados para la realización de este tipo de análisis. Los puntos de registro se muestran en la Figura 3-5, correspondiendo el canal 1 al punto central, el 2 al punto situado 14 $\mathrm{m}$ izquierda y el 3 y el 4 posicionados a $7 \mathrm{~m}$ para cada lado respecto al central. 


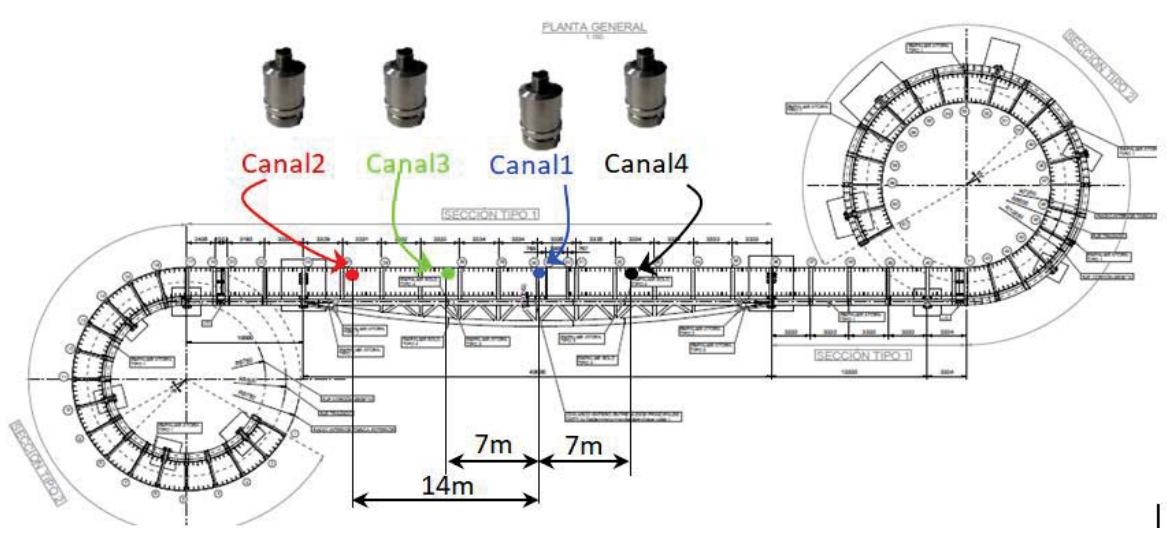

Figura 3-5: Distribución de los 4 puntos de medida

Puesto que el registro de señales es esencialmente la medida y el almacenamiento de algún parámetro físico en un periodo de tiempo, se necesita un aparato que sea capaz de adquirir las señales proporcionadas por los sensores. Es en este punto donde se recurre a los registradores de señales, conocidos también como Data Logger, que miden fenómenos físicos analógicos (generalmente de tipo eléctrico, variaciones de intensidad o de tensión) y los transforman en datos digitales que se almacenan internamente. El equipo empleado fue un HBM MGCPlus y los registros obtenidos se muestran en Figura 3-6 junto a su correspondiente espectrograma.

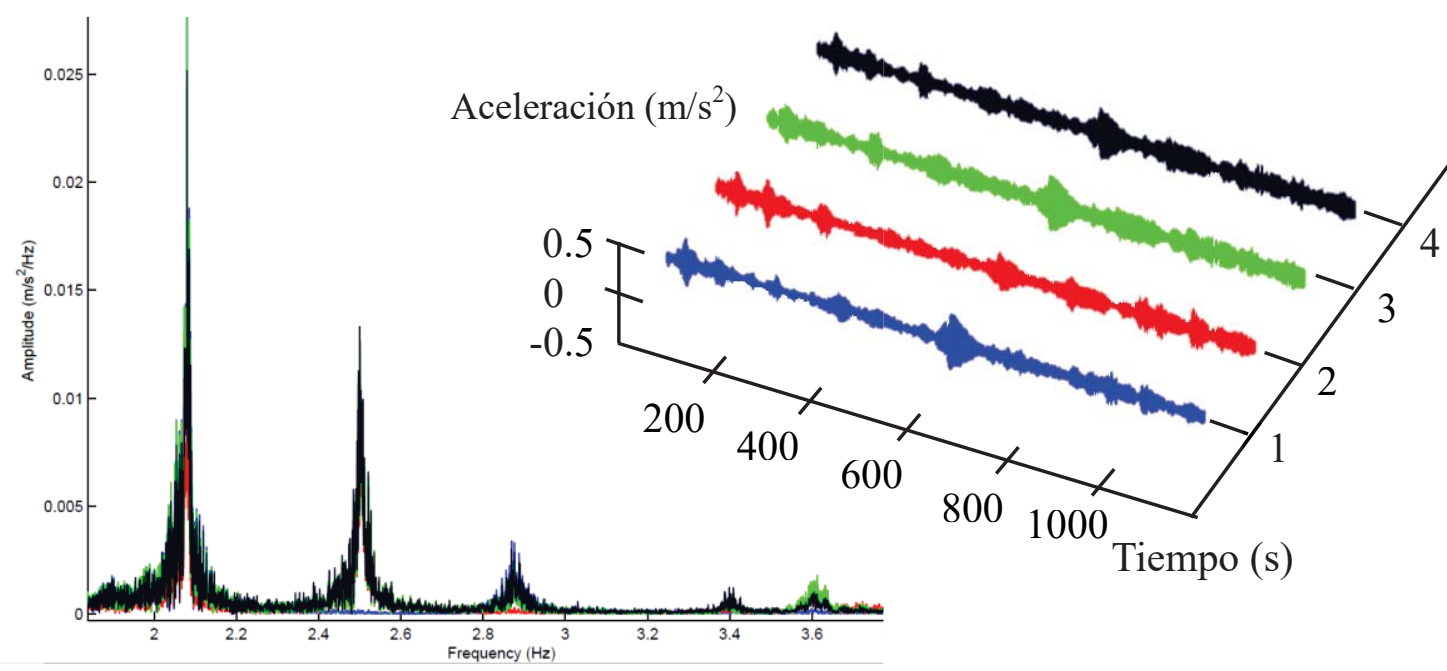

Figura 3-6: Registros temporales de los 4 canales de medida y sus espectrogramas (Fast Fourier Transform FFT)

Mediante el OMA, en el rango evaluado, se identifica los tres modos propios comentados en la Figura 3-3 y sus correspondientes amortiguamientos en base al método SSI, obtenidos por medio del software comercial FEMTools donde la obtención de frecuencias y modos experimentales se realiza a través de la metodología de identificación comentado anteriormente y utilizando además diferentes herramientas de comparación (rutinas de Matlab o softwares como ARTeMIS). 
FEMtools representa diagramas de estabilidad, cuyos resultados, similares a los obtenidos con otras aplicaciones, son los que se muestran en Tabla 3-2: Parámetros modales de los tres primeros modos.

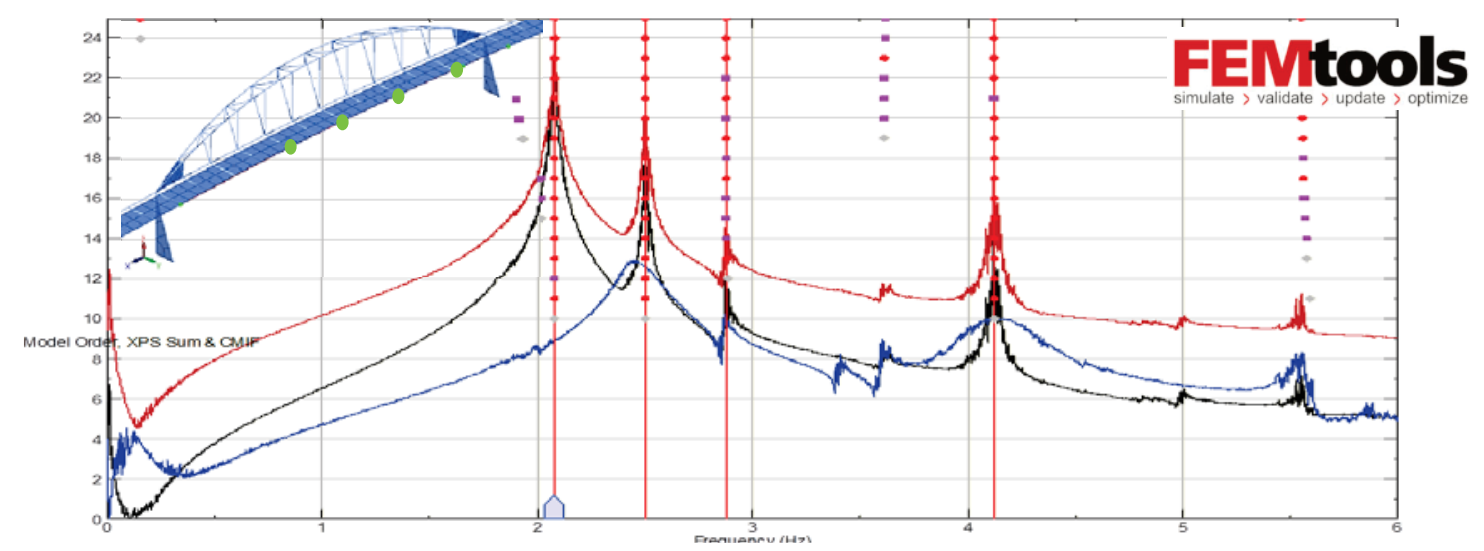

Figura 3-7: Curvas para identificación de parámetros modales

\begin{tabular}{|c|c|c|}
\hline Modo OMA & Frecuencia & Amortiguamiento \\
\hline 1 & $2.081 \mathrm{~Hz}$ & $0.19 \%$ \\
\hline 2 & $2.502 \mathrm{~Hz}$ & $0.24 \%$ \\
\hline 3 & $2.877 \mathrm{~Hz}$ & $0.37 \%$ \\
\hline
\end{tabular}

Tabla 3-2: Parámetros modales de los tres primeros modos

Todos los modos presentan un bajo amortiguamiento y debido a que su frecuencia está en el rango susceptible de ser excitado por los peatones (Tabla 3-3: Frecuencias y rangos usuales de la marcha), se presenta en este caso concreto, el problema a tratar y como plantear la intervención sobre la estructura. Un planteamiento conservador apostaría por un acoplamiento del dispositivo TMD sintonizado para el modo uno, puesto que los datos anteriores revelan que el modo predominante (por su altura de pico) es el de $2.081 \mathrm{~Hz}$, correspondiendo al primer modo de torsión. Pero otras posibilidades, las cuales se pretenden analizar, contemplarían la inclusión de varios TMDs o uno que funcione de la mejor forma posible para varios modos y frecuencias.

Nótese que los tres modos identificados son problemáticos hasta tránsitos a 173 pasos por minuto $(2.88 \mathrm{~Hz})$ (incluyendo andar y correr).

\begin{tabular}{|l|c|c|c|}
\hline \multicolumn{1}{|c|}{ PROMEDIOS } & FRECUENCIAS (Hz) & DESVIACIÓN EST (Hz) & RANGO USUAL (bpm) \\
\hline Andar & 1.88 & 0.29 & {$[95,130]$} \\
\hline Correr Lento & 2.70 & 0.45 & {$[135,189]$} \\
\hline Correr rápido & 3.41 & 0.85 & {$[153,256]$} \\
\hline
\end{tabular}

Tabla 3-3: Frecuencias y rangos usuales de la marcha

En algunos de los trabajos del ANEXO I/ se abordan opciones menos obvias, pero el planteamiento de partida, y el cual sirve como base para el estudio, es el que se ejecutaría desde un punto de vista lógico, es decir, posicionar un TMD en el centro del vano y sintonizado para atacar el modo 1. De hecho, en el proyecto original fue contemplado un habitáculo a tal efecto (ver Figura 3-8). 


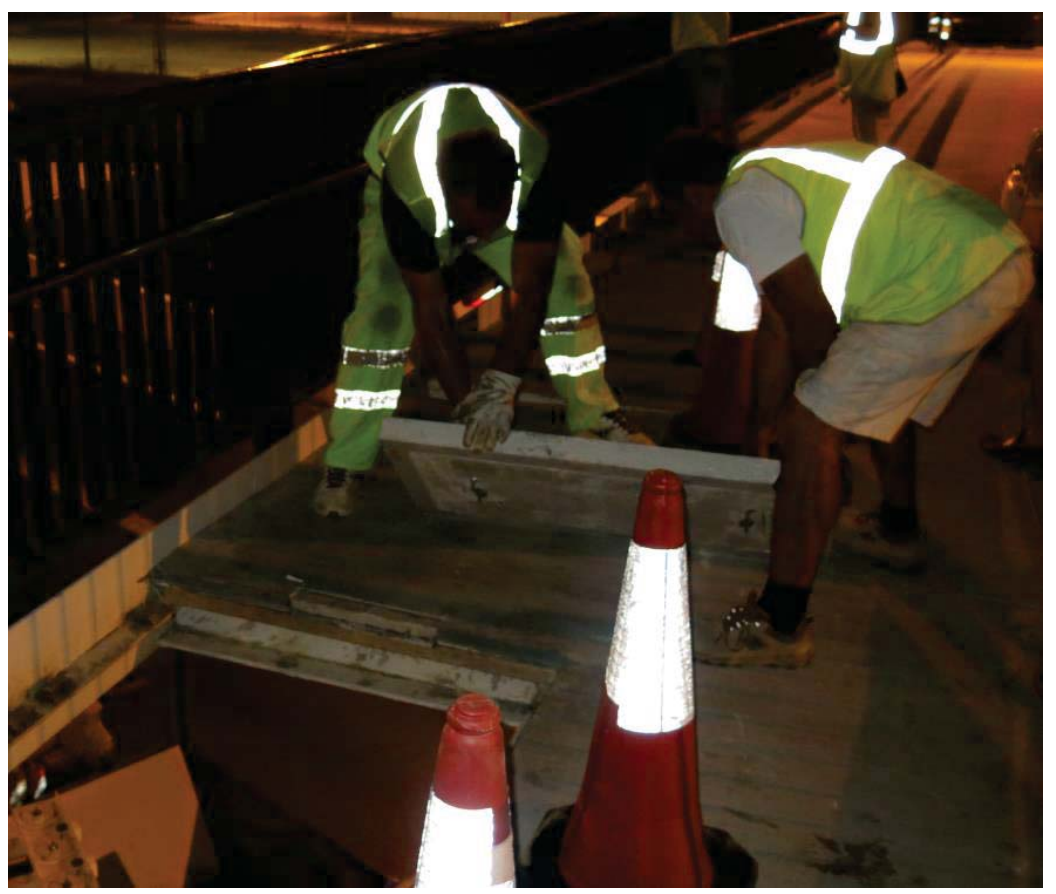

Figura 3-8: Habitáculo previsto en la fase de diseño

Adicionalmente al OMA, es preciso determinar la función de respuesta en frecuencia (FRF) en torno a la frecuencia del modo 1 para determinar con precisión la correspondiente masa modal y su amortiguamiento. Parámetros necesarios para dimensionar el TMD, basándose en las formulaciones clásicas. De este modo se procede a realizar un barrido senoidal durante 150 segundos entre las frecuencias $1.9 \mathrm{~Hz}$ y $2.2 \mathrm{~Hz}$ (mediante el Shaker) y tras post-procesar los registros de la fuerza introducida (entrada) y de las aceleraciones con las que responde la pasarela (salidas) se obtiene la función de respuesta en frecuencia representada por medio de la curva negra de la Figura 3-9.
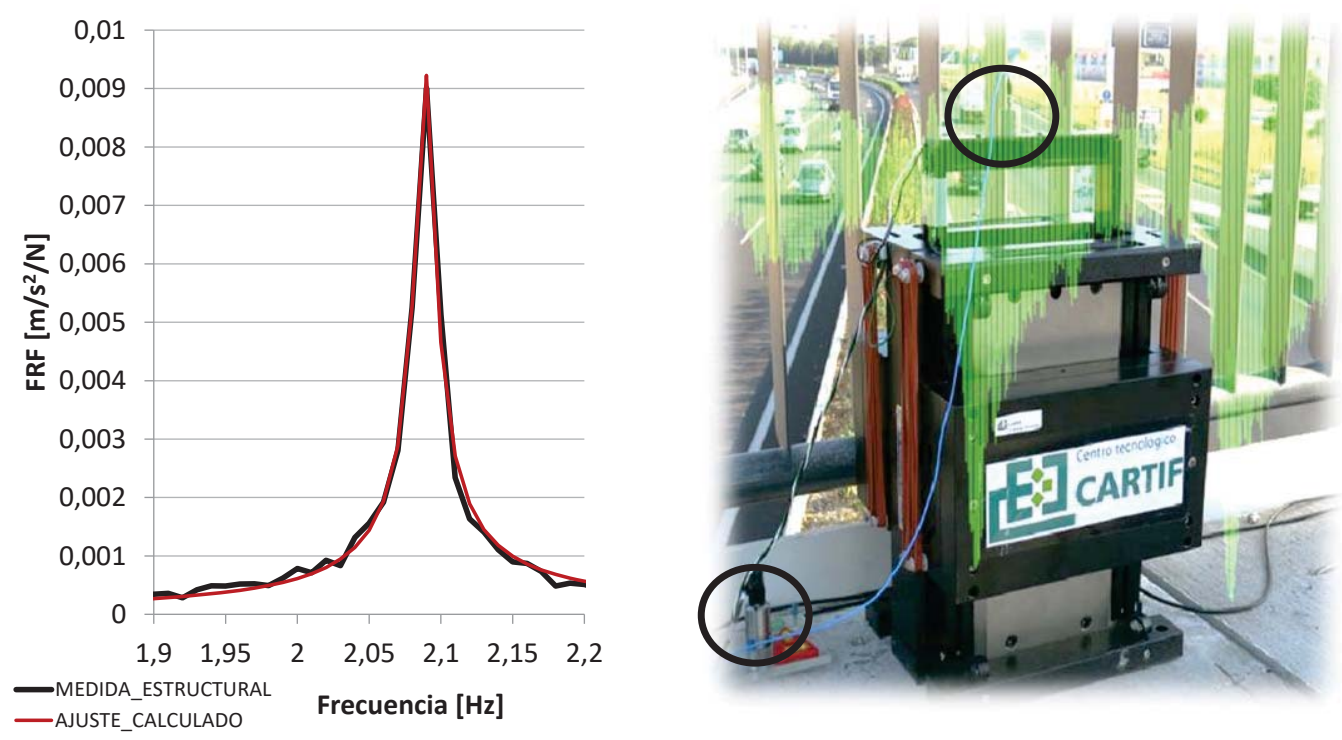

Figura 3-9: FRF experimental y ajuste al modelos de 1gdl

Tras ello se realiza el ajuste del sistema de un grado de libertad de tal manera que ante similar excitación responda de la misma forma (en términos de FRF). Tras los correspondientes 
cálculos se determina que el sistema de un grado de libertad con mejor ajuste corresponde a una frecuencia de $2.089 \mathrm{~Hz}$, una masa de $17300 \mathrm{Kg}$ y un amortiguamiento de $0.31 \%$. La curva en rojo de la Figura 3-9 muestra el ajuste realizado.

Adicionalmente se somete a la pasarela a una excitación tipo con el objetivo de tener una respuesta con la que poder comparar una vez la intervención sea realizada. La excitación tipo y su respuesta son las mostradas en la Figura 3-10, correspondiendo a una fuerza armónica a $2.089 \mathrm{~Hz}$ introducida con el shaker hasta el segundo 32, viéndose hasta ese punto la respuesta forzada y cómo a partir de ese tiempo pasa a una respuesta donde se ve la caída libre.

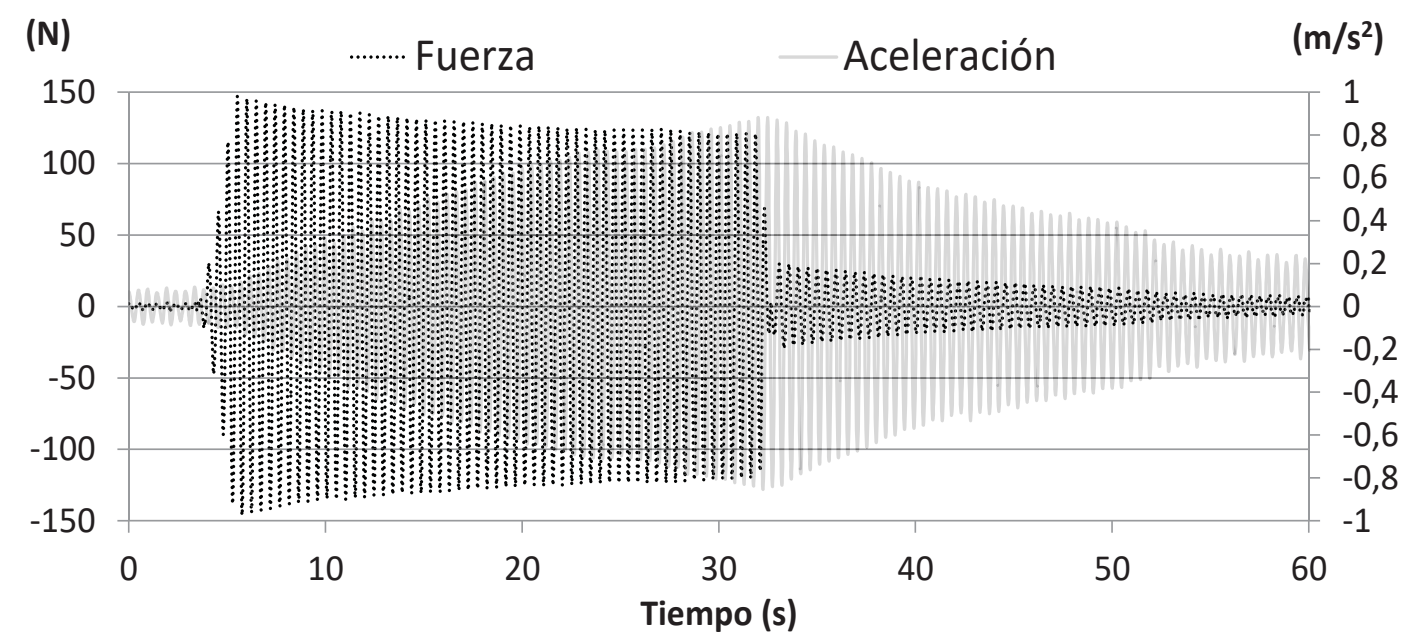

Figura 3-10: Excitación de referencia y su respuesta vibratoria

La estimación del amortiguamiento mediante la técnica de la envolvente exponencial se muestra en la Figura 3-11, siendo el valor estimado en todo el tramo de bajada (del segundo 32 al 65 ) de $0.306 \%$. En el primer tramo (de 32 a 48 ) es de $0.28 \%$ y en el segundo (de 48 a 65 ) de $0.35 \%$. Se comprueba de esta forma la estimación inicial realizada $(0.31 \%)$ a través del ajuste a la FRF.

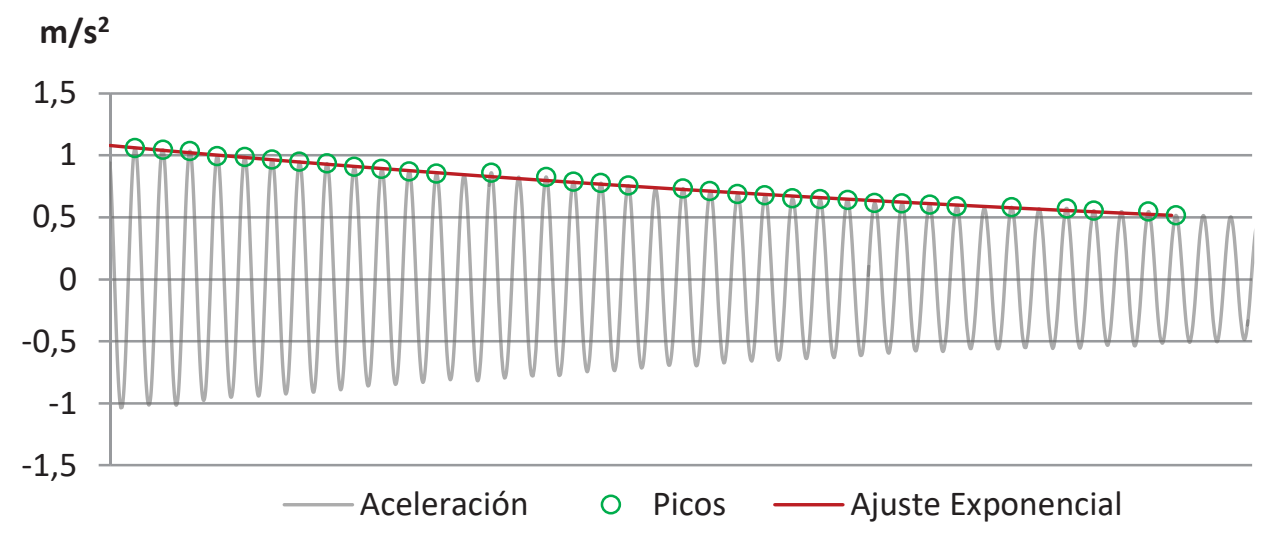

Figura 3-11: Amortiguamiento evaluado mediante ajuste exponencial

Si sobre al modelo equivalente de un grado de libertad $(2.089 \mathrm{~Hz}, 17300 \mathrm{Kg}, 0.31 \%)$ se aplica la fuerza de excitación de referencia registrada (mostrada en linea negra de puntos en la Figura 3-12) se obtiene la respuesta indicada en rojo en la siguiente figura, la cual se asemeja a la respuesta real medida (mostrada en gris, según Figura 3-12) tanto en el tramo de subida (hasta 
el segundo 32) como en el tramo de respuesta libre, confirmando que los parámetros modales son correctos. Similares respuestas se obtendrán mediante el modelo de elementos finitos una vez sea calibrado.

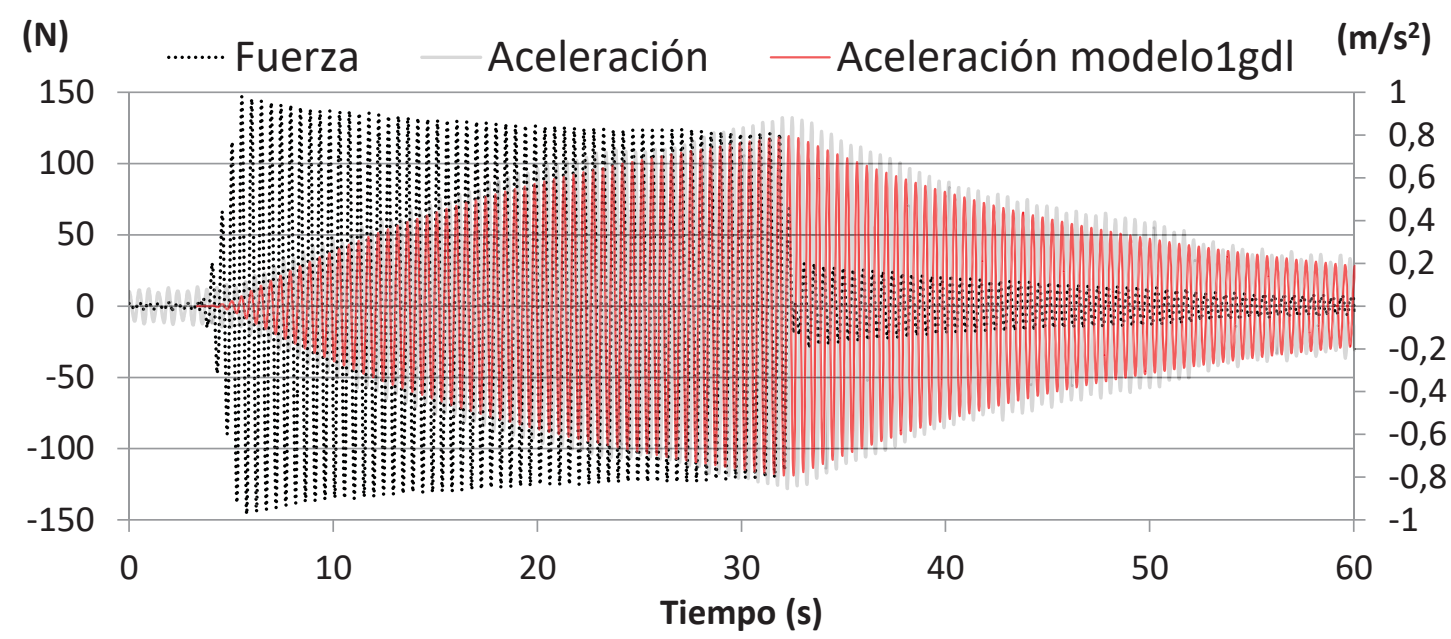

Figura 3-12: Respuesta sistema equivalente

En este punto se está en disposición de usar los parámetros modales adquiridos para definir el TMD. Pero, ¿y qué garantías tenemos de que funcione de la mejor forma posible?, lo cierto es que la experiencia diría que la instalación del TMD en la pasarela sería beneficiosa, es decir, la respuesta vibratoria se vería influenciada de forma favorable aunque posiblemente diferirá de estar optimizado.

Para dar una garantía de funcionamiento adecuado previo a ejecución se debe conocer qué respuesta tendrá el futuro acoplamiento sobre la estructura, para lo cual si el modelo computacional de partida difiere del comportamiento estático y dinámico obtenido de los trabajos de campo se necesitará modificar el modelo de partida [FEM\#0] hasta que su comportamiento se adecue al real.

Hacer notar en este apartado que de forma complementaria a los registros necesarios para los análisis de identificación modal fueron realizados diferentes estudios con diferentes hipótesis de tránsito peatonal. El tránsito más destacado y cuya respuesta registrada es la de la Figura 3-13, caso de un peatón andando a un ritmo coincidente con la frecuencia más desfavorable de la pasarela (125 bpm), servirá de futura comparación para validar el modelo calibrado cuando la carga sea una masa móvil que modeliza el tránsito del peatón.

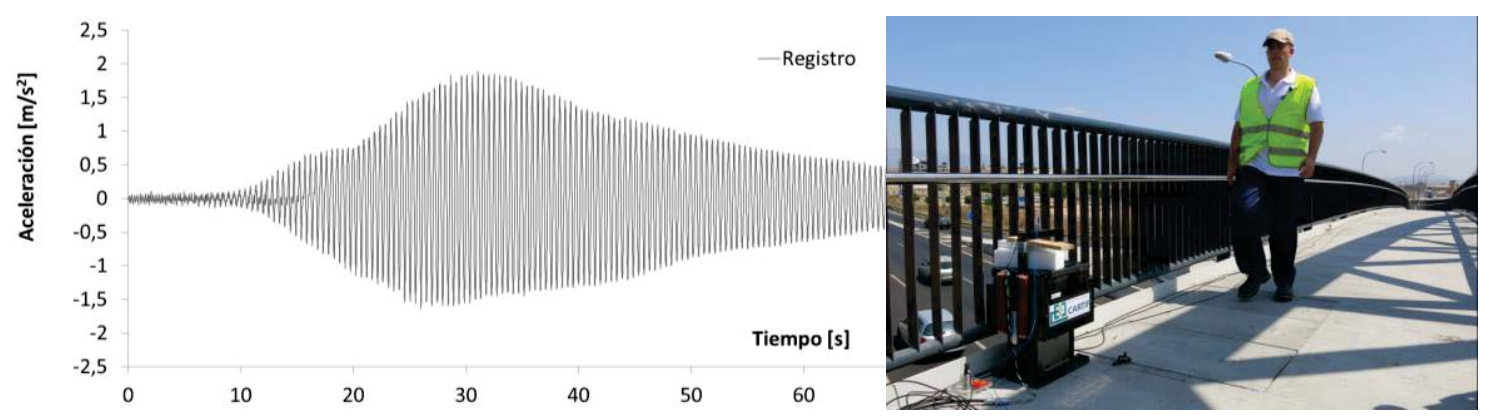

Figura 3-13: Respuesta tránsito peatonal 


\subsection{Proceso de calibración del modelo}

Tradicionalmente, la forma de obtener esos modelos fiables o, mejor dicho, de reducir las discrepancias existentes entre los resultados analíticos y los experimentales era la variación mediante ensayo-error de las idealizaciones mecánicas y de los parámetros del modelo analítico hasta la aproximación de los mismos a un nivel aceptable. El principal problema radicaba en que esta forma de trabajo, en las estructuras más complejas, requería un gasto temporal excesivo e incluso, en algunos casos, no viable. Por todo ello se hizo necesario un método computacional que modifique y actualice aquellos parámetros del modelo analítico que en un primer momento deben ser estimados. Mediante el ajuste o calibración del modelo, denominado comúnmente como Model Updating, se consigue realizar el ajuste de los parámetros de los modelos de elementos finitos de forma que la respuesta computacional se asemeje a la experimental.

Tal como se expuso en el ANEXO I, a partir del OMA realizado mediante el software FEMtools y una vez obtenidos los modos de vibración y las frecuencias naturales asociadas al modelo experimental, se procede a importar a FEMtools el modelo computacional FEM\#0 de Ansys y hacer coincidir los puntos de medición experimentales con los puntos correspondientes en el modelo de elementos finitos. Esta combinación de softwares está motivada por las carencias que cada uno de ellos presenta. Por un lado el modelo computacional integrado en FEMtools, presenta unas prestaciones adecuadas mediante el uso de diferentes algoritmos y diferentes grados de ejecución para el ajuste de funciones de respuesta en frecuencia, aspecto que, a pesar del potencial computacional de ANSYS, no presenta y por el contrario en este último software se puede modelar un análisis transitorio bajo una carga peatonal, simulación para la que no parece estar preparado FEMtools.

Haciendo uso de los algoritmos y de los criterios de correlación con los que cuenta FEMtools, se comparan los resultados experimentales obtenidos de los ensayos sobre las estructuras reales con los obtenidos a partir del modelo de elementos finitos. Se indican brevemente algunos de los métodos que existen para realizar esta correlación teóricoexperimental en la Tabla 3-4, métodos de calibración basados en FRF, iterativos, paramétricos y usando coeficientes de sensibilidad y valores de ponderación (estimación bayesiana). EI procedimiento se puede configurar con diferentes niveles de confianza para los diferentes objetivos (frecuencias naturales, formas de modo, etc).

\begin{tabular}{|c|c|c|}
\hline Modal Assurance Criterion & Coordinate Modal Assurance Criterion & Auto Modal Assurance Criterion \\
\hline \multicolumn{1}{|c|}{ MAC } & \multicolumn{1}{|c|}{ COMAC } & AutoMAC \\
\hline \multicolumn{1}{|c|}{ Formas modales } & \multicolumn{1}{|c|}{ Formas modales } & Formas modales \\
\hline $\begin{array}{l}\text { Relación entre dos modos } \\
\text { para todos los puntos de } \\
\text { medida }\end{array}$ & $\begin{array}{l}\text { correlación existente entre dos } \\
\text { localizaciones de medida para todos } \\
\text { los pares de modos }\end{array}$ & \\
\hline
\end{tabular}
Tabla 3-4: Criterios de correlación

A pesar de que el software puede trabajar de forma autónoma, iterando hasta alcanzar, en la medida de lo posible, los objetivos que se le indican, se recomienda supervisar los valores que van tomando los distintos parámetros con el fin de no perder el sentido físico de los mismos. 
Como se ha indicado en 3.2 el modelo FEM\#0 presenta de partida una diferencia significativa, una flecha del orden de un $25 \%$ menor respecto al valor de deflexión estática experimental; se puede pensar que los valores de flexibilidad o semi-rigidez [ $\mathrm{K}$ ] de las uniones metálicas y el módulo de elasticidad del hormigón $\left[E_{h}\right]$ no estén adecuadamente representados con los valores dados en el modelo de partida. Se podría entender que existe un extra de rigidez y que por ello existe esa minorada deflexión o que el módulo de elasticidad del hormigón fuese demasiado alto, o una combinación de ambas, presentándose así muchas posibilidades de ajuste.

Muchas de estas "sospechas" están basadas en la experiencia de los calculistas y en aspectos propios de la ejecución de las obras, siendo ambos factores importantes con el fin de conseguir los objetivos que se persiguen. Así, por ejemplo, bien por aspectos no considerados o por una ejecución incorrecta, el nudo de la Figura 3-14, sobre el que apoyo el tablero, parece no tener la rigidez que se presuponía en el diseño inicial.
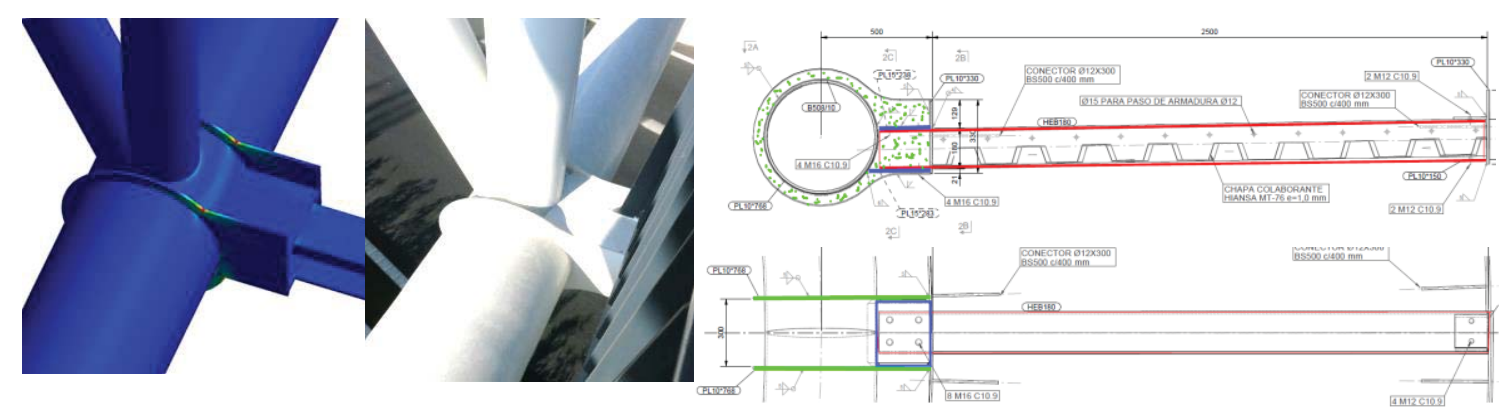

Figura 3-14: detalle constructivo de la unión metálica con el tablero de hormigón

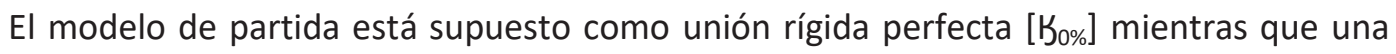
articulación estaría representada por $\mathrm{K}_{100 \%}$. Planteando que la mayor parte de la flexibilidad se concentra en las conexiones entre el cordón inferior del arco y de las vigas transversales que soportan el tablero, parece adecuado definir una unión semirrígida ajustando su valor ${ }^{(*)}$ para coincidir con la deflexión medida, resultando para ello un valor de la rigidez de $83 \%$. Incorporando este efecto sobre el modelo [FEM\#1] la deflexión estática calculada numéricamente es la esperada (objetivo de las modificaciones, $32 \mathrm{~mm}$ ). Pero Esta reducción en la rigidez de las referidas uniones se considera demasiado grande para ser coherente, por lo que otras fuentes de discrepancias deben ser consideradas. De esta forma reducir el módulo de elasticidad de Young usado para simular el hormigón de la tablero $\left[E_{h}\right]$ puede ser un parámetro más a contemplar junto a la [K] configurando así un nuevo modelo [FEM\#2]. Al hacerlo, se pueden encontrar varios pares de valores para $K$ y $E_{h}$, para los que fijando variaciones lógicas de $\mathrm{b}$ entorno al $25 \%$ y buscando el objetivo de que la deflexión sea $32 \mathrm{~mm}$, $\mathrm{b}$ se vea modificado $21 \%$ y $E_{h}$ pase a valer $9.0 * 10^{9} \mathrm{~N} / \mathrm{m}^{2}$. Obsérvese que este valor supone un decremento del $70 \%$ (valor inicial $\mathrm{E}_{\mathrm{h}}=3.0^{*} 10^{10} \mathrm{~N} / \mathrm{m}^{2}$ ). En condiciones nominales no es consistente una reducción tan grande pero puede ser factible si valoramos el procedimiento de construcción, donde el hormigón fue vertido en varias tongadas induciendo juntas de hormigón y reduciendo significativamente la inercia del conjunto.

\footnotetext{
${ }^{(*)}$ Para ello, se realizó un modelado de detalle de una de las uniones, mallando todas las barras mediante elementos shell y comparando los resultados estáticos con respecto a la unión rígida modelada con elementos beam
} 


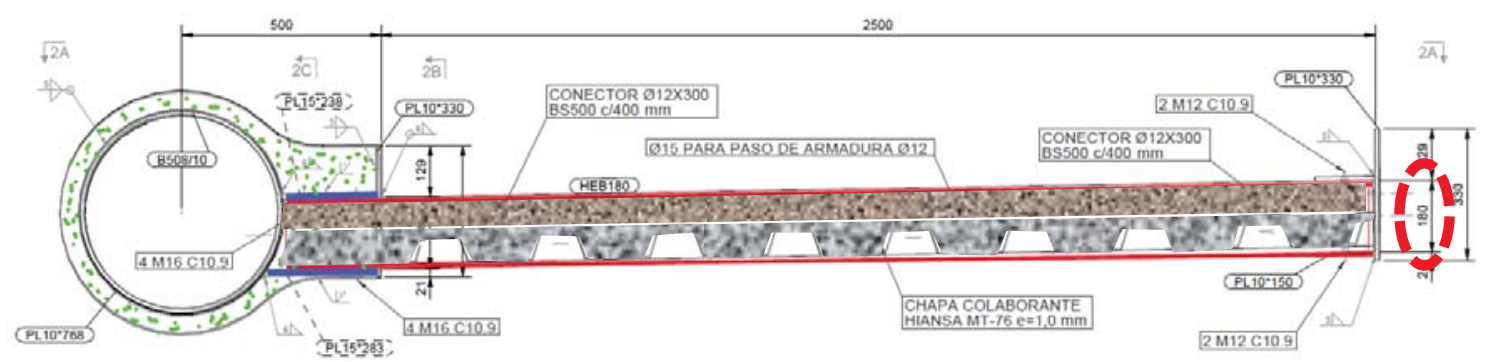

Figura 3-15: Losa de hormigón en dos etapas

Una vez que el modelo coincide de manera razonable con el valor de deflexión estática, se observa de nuevo que hay diferencias en el comportamiento modal. Bajo las anteriores hipótesis, los resultados modales se reflejan en la Tabla 3-5, junto a su diferencias porcentuales respecto a las frecuencias obtenidas del análisis modal.

\begin{tabular}{|c|c|c|c|c|c|c|c|c|c|}
\hline Modo & OMA & \multicolumn{2}{|c|}{ FEM\#0 } & \multicolumn{2}{c|}{ FEM\#1 } & \multicolumn{2}{c|}{ FEM\#2 } & \multicolumn{2}{c|}{ FEM\#U2 } \\
\hline 1 & $2.081 \mathrm{~Hz}$ & $2.105 \mathrm{~Hz}$ & $1.15 \%$ & $1.988 \mathrm{~Hz}$ & $4.46 \%$ & 1.939 & $6.82 \%$ & & \\
\hline 2 & $2.502 \mathrm{~Hz}$ & $2.889 \mathrm{~Hz}$ & $15.5 \%$ & $2.689 \mathrm{~Hz}$ & $7.47 \%$ & 2.583 & $3.23 \%$ & & \\
\hline 3 & $2.877 \mathrm{~Hz}$ & $3.153 \mathrm{~Hz}$ & $9.59 \%$ & $2.939 \mathrm{~Hz}$ & $2.15 \%$ & 2.680 & $6.84 \%$ & & \\
\hline
\end{tabular}
Tabla 3-5: Resultados modales de los ajustes realizados en base a consideraciones lógicas

La actualización manual es importante, ya que permite al analista apreciar el posible efecto que cada parámetro seleccionado puede tener sobre la respuesta estática y modal de la estructura. Este ejercicio es extremadamente importante ya que proporciona una base para juzgar si los resultados obtenidos son razonables. Este ejercicio de ajuste previo con modificaciones puramente manuales sobre los valores globales seleccionados permite observar la dificultad que entraña encontrar qué valores modificar y cúanto deben ser modificados respetando la lógica. Siguiendo un objetivo puramente estático se ha logrado ajustar el modelo, pero desde un punto de vista modal el ajuste realizado no solo es pobre sino que es imposible bajo estas premisas, es decir, puede ocurrir, como es el caso, que para ajustar el modo uno las modificaciones en los parámetros sean contrarias a las necesidades para ajustar el modo dos.

Mediante FEMtools se puede conocer, a través de un análisis de sensibilidad, si los parámetros seleccionados son dignos de cambiar o no y en qué sentido. A este respecto, en el caso que nos ocupa, las posibles modificaciones de los valores seleccionados varían según se indica en la Figura 3-16.

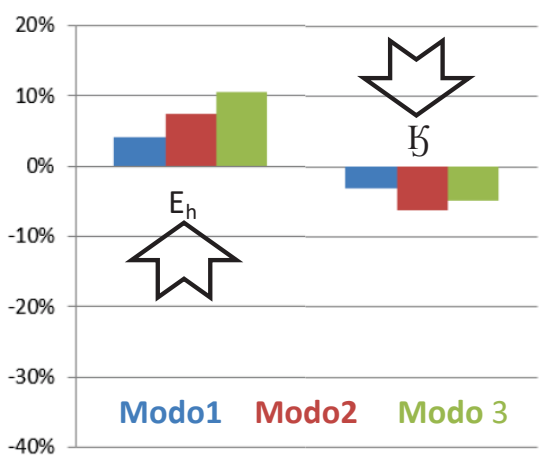

Figura 3-16: sensibilidad de los parámetros globales elegidos 
Además, a menos que los valores iniciales sean dados de forma razonable los parámetros de actualización seleccionados pueden presentar dificultades para mejorar la correlación entre lo experimental y lo numérico.

En este punto, y para realizar un ejercicio de calibrado automático es necesario elegir parámetros adicionales para su modificación. Se recomienda actuar sobre los parámetros con más indeterminación. En esta etapa se elige la distribución de la masa a lo largo del tablero (incluyendo el entramado de acero, las barras de refuerzo, el hormigón, el pavimento y los pasamanos) como parámetro local para cada uno de los 120 elementos situados en el tramo central. Este procedimiento se realiza de forma automática y haciendo uso de los mecanismos y de los criterios de correlación como pueda ser el MAC (modal assurance criterion). A este respecto y para los modelos evaluados hasta el momento, con modificaciones sobre ciertos parámetros globales, se muestra en la Tabla 3-6 los MAC para los dos primeros modos.

\begin{tabular}{|c|c|c|r|c|r|c|r|r|l|}
\hline Modo & OMA & FEM\#0 & MAC & FEM\#1 & MAC & FEM\#2 & MAC & \multicolumn{2}{|c|}{ FEM\#U2 } \\
\hline 1 & $2.081 \mathrm{~Hz}$ & $2.105 \mathrm{~Hz}$ & 99.1 & $1.988 \mathrm{~Hz}$ & 99.4 & 1.939 & 99.3 & & \\
\hline 2 & $2.502 \mathrm{~Hz}$ & $2.889 \mathrm{~Hz}$ & 98.7 & $2.689 \mathrm{~Hz}$ & 99.1 & 2.583 & 99.3 & & \\
\hline
\end{tabular}

Tabla 3-6: Correlaciones MAC sobre los modelos FEM\#0, FEM\#1, y FEM\#2

Aunque los valores MAC están prácticamente ajustados (100\%) y las formas modales son las que deben, ya hemos visto que la discrepancia en las frecuencias hace necesario realizar una comparativa en este sentido, de forma que se pueda evaluar la mejora en la respuesta del modelo.

La densidad inicial de los elementos placa fue de $2300 \mathrm{~kg} / \mathrm{m}^{3}$ y los valores finales después del calibrado modal automático muestran variaciones, de los 120 elementos contemplados, que van desde aumentos de densidad del $50 \%$ hasta diminuciones del $75 \%$, cubriendo todo el rango. Los valores que presentan una mayor variación se localizan en la zona central del vano, y los resultados parecen muy bajos para cualquier losa de hormigón armado. Este resultado, junto con la bajada del módulo de elasticidad obtenida en el modelo FEM\#2, de la sección anterior (70\% de reducción), sugiere que si se hubiera reducido el espesor del tablero, ambos parámetros $\left(E_{h}\right.$ y $\left.\rho_{h}\right)$ no habrían cambiado mucho. El efecto estructural podría ser similar a reducir el espesor del elemento Shell utilizado para modelar el hormigón.

Para los valores referidos, la respuesta modal se presenta en la Tabla 3-7. La tendencia es retirar la masa del medio y añadirla cerca de los soportes en el tramo central. Esta tendencia coincide con la realidad, ya que el tablero presenta en la parte central del vano un espacio libre (no hormigonado) contemplado para la posible instalación de un TMD (ver Figura 3-8).

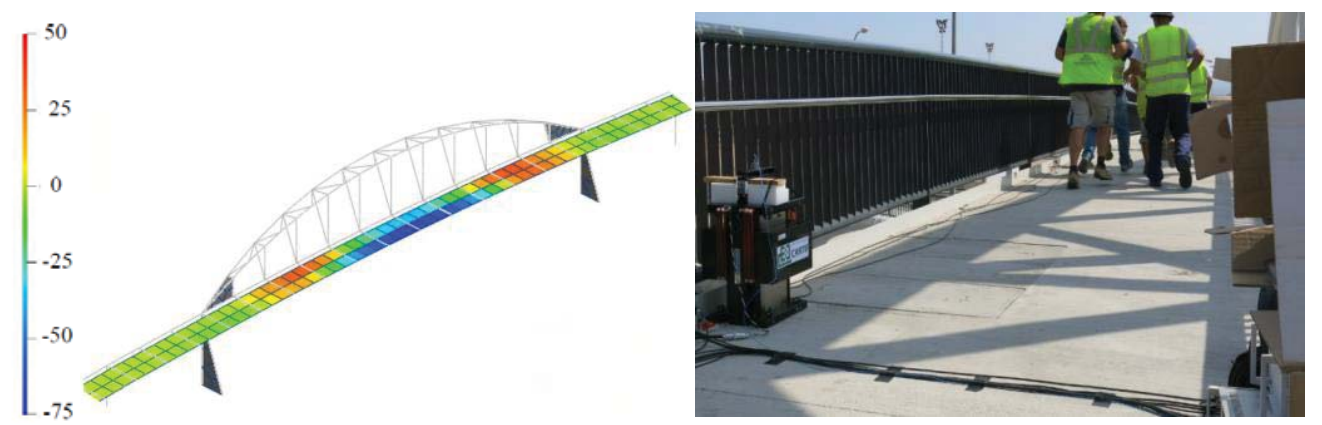

Figura 3-17: Tendencia de los porcentajes de cambio de la densidad sobre los 120 elementos placa 


\begin{tabular}{|c|c|c|c|c|c|c|c|c|c|}
\hline Modo & OMA & \multicolumn{2}{|c|}{ FEM\#0 } & \multicolumn{2}{c|}{ FEM\#1 } & \multicolumn{2}{c|}{ FEM\#2 } & \multicolumn{2}{c|}{ FEM\#U2 } \\
\hline 1 & $2.081 \mathrm{~Hz}$ & $2.105 \mathrm{~Hz}$ & $1.15 \%$ & $1.988 \mathrm{~Hz}$ & $4.46 \%$ & 1.939 & $6.82 \%$ & 2.0809 & $0.004 \%$ \\
\hline 2 & $2.502 \mathrm{~Hz}$ & $2.889 \mathrm{~Hz}$ & $15.5 \%$ & $2.689 \mathrm{~Hz}$ & $7.47 \%$ & 2.583 & $3.23 \%$ & 2.5022 & $0.007 \%$ \\
\hline 3 & $2.877 \mathrm{~Hz}$ & $3.153 \mathrm{~Hz}$ & $9.59 \%$ & $2.939 \mathrm{~Hz}$ & $2.15 \%$ & 2.680 & $6.84 \%$ & 2.680 & $6.8 \%$ \\
\hline
\end{tabular}

Tabla 3-7: Resultados modales de los ajustes realizados en base a modificaciones locales de la densidad

\begin{tabular}{|c|c|c|r|c|r|r|r|r|r|}
\hline Modo & OMA & FEM\#0 & MAC & FEM\#1 & MAC & FEM\#2 & MAC & FEM\#U2 & MAC \\
\hline 1 & $2.081 \mathrm{~Hz}$ & $2.105 \mathrm{~Hz}$ & 99.1 & $1.988 \mathrm{~Hz}$ & 99.4 & 1.939 & 99.3 & 2.0809 & 99.4 \\
\hline 2 & $2.502 \mathrm{~Hz}$ & $2.889 \mathrm{~Hz}$ & 98.7 & $2.689 \mathrm{~Hz}$ & 99.1 & 2.583 & 99.3 & 2.5022 & 99.6 \\
\hline
\end{tabular}

Tabla 3-8: Correlaciones MAC sobre el modelo FEM\#U2

A continuación se representa mediante la Figura 3-18 el proceso descrito en este apartado acompañado de los resultados obtenidos para los dos primeros modos, así como las validaciones pertinentes que corroboran en términos estáticos y dinámicos, bien mediante estudios de respuesta transitoria y mediante la función de respuesta en frecuencia, la validez del proceso de actualización.

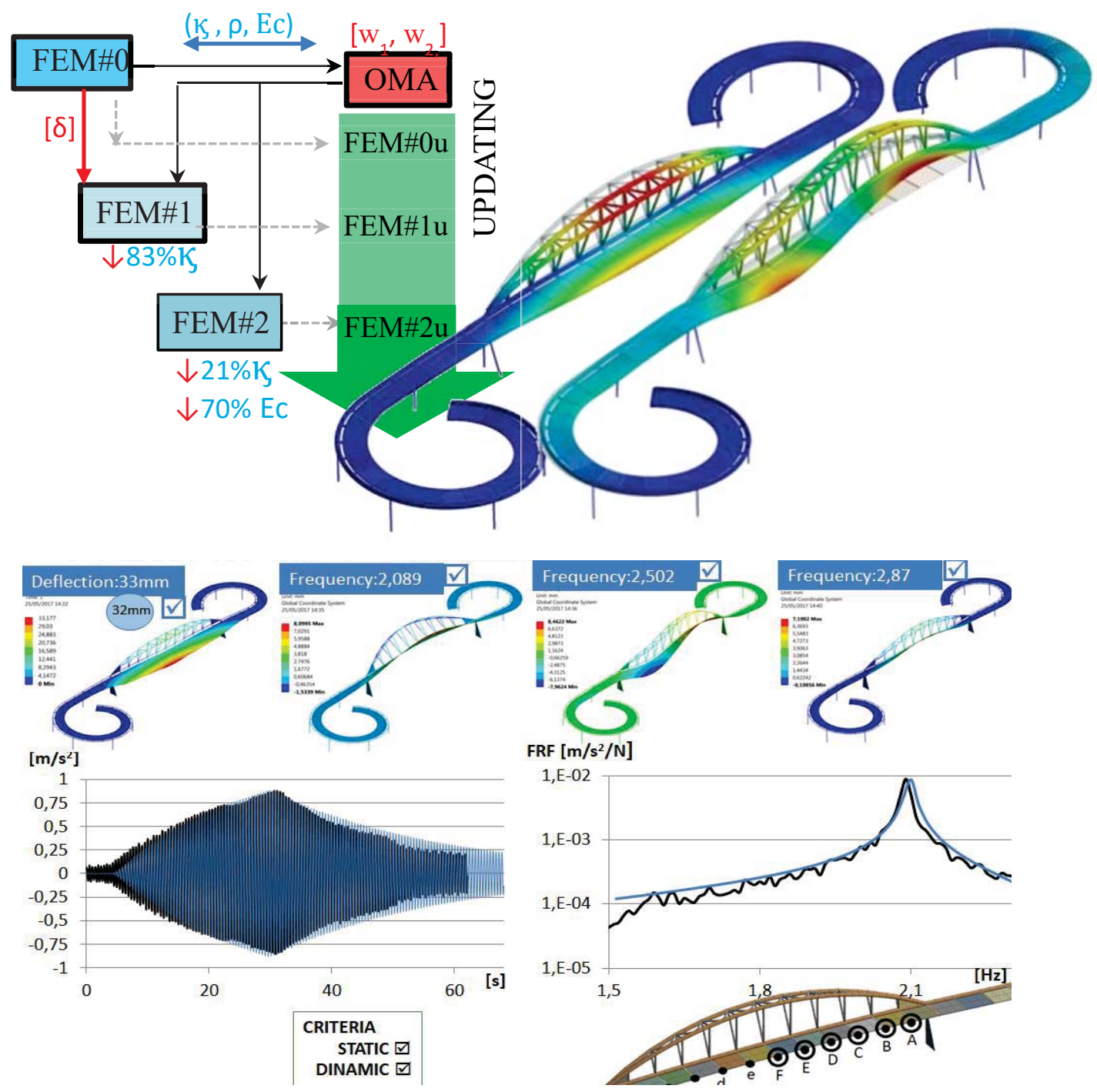

Figura 3-18: Proceso de Ajuste y validación 


\subsection{Ampliación del modelo computacional}

El desarrollo del modelo de elementos finitos de la pasarela se generó mediante ANSYS WORKBENCH. Las ecuaciones pueden expresarse de forma compacta como se ilustra en la (1, empleando para ello las matrices masa $(\mathbb{M})$, amortiguamiento $(\mathbb{C})$ y rigidez $(\mathbb{K})$. El vector $\mathrm{q}$ contiene los grados de libertad asociados a los nodos resultantes de discretizar la estructura en elementos finitos.

$$
\mathbb{M} \ddot{q}+\mathbb{C} \dot{q}+\mathbb{K} q=F
$$

En este punto se contemplan aquellos aspectos relevantes referentes a consideraciones sobre el amortiguamiento estructural e implementaciones de acoplamiento para los diferentes TMDs así como de la carga móvil estimada para representar la carga transitoria del peatón mediante el uso del lenguaje de programación conocido como APDL (ansys parametric design language).

\subsubsection{Modelo de amortiguamiento}

En los estudios de dinámica estructural el amortiguamiento es un factor esencial y como tal debe ser contemplado. Concretamente para los diferentes análisis realizados sobre el modelo calibrado, el amortiguamiento ha sido contemplado en el modelo de elementos finitos como amortiguamiento de Rayleigh, es decir, como un amortiguamiento proporcional a la masa y a la rigidez de la estructura y el cual está ligado a la matriz de amortiguamiento modal (contemplado en una primera aproximación) mediante un par de coeficientes $\mathrm{a}_{0} \mathrm{y} \mathrm{a}_{1}$. El primero establece el coeficiente de amortiguamiento proporcional a la masa, mientras que el segundo se relaciona con la rigidez.

Para sistemas de varios grados de libertad, como el que nos ocupa, la relación de amortiguamiento es:

$$
C=\mathrm{a}_{0} \mathrm{~m}+\mathrm{a}_{1} \mathrm{k}
$$

Siendo el coeficiente de amortiguamiento relativo del n-ésimo modo:

$$
\xi_{n}=\frac{a_{0}}{2 \omega_{n}}+\frac{a_{1} \omega_{n}}{2}
$$

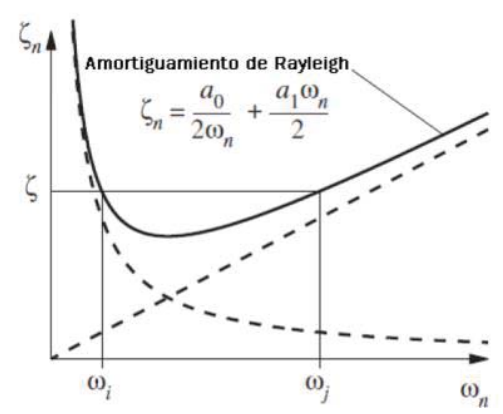

Figura 3-19: Variación del amortiguamiento relativo modal en función de la frecuencia 
Los coeficientes $a_{0}$ y $a_{1}$ se pueden calcular a partir de los coeficientes de amortiguamiento relativo de dos modos, lo que se expresa de forma matricial en la siguiente ecuación:

$$
\frac{1}{2}\left[\begin{array}{ll}
1 / \omega_{i} & \omega_{i} \\
1 / \omega_{j} & \omega_{j}
\end{array}\right]\left[\begin{array}{l}
\mathrm{a}_{0} \\
\mathrm{a}_{1}
\end{array}\right]=\left[\begin{array}{l}
\xi_{\mathrm{i}} \\
\xi_{\mathrm{j}}
\end{array}\right]
$$

Resolviendo el sistema anterior se obtienen ambos coeficientes. Bajo el supuesto de que los modos tienen distintos coeficiente de amortiguamiento, en concordancia con los datos experimentales $\xi_{1}=0.31 \%$ y $\xi_{2}=0.75 \%, \mathrm{a}_{0}$ y a $\mathrm{a}_{1}$ toman los siguientes valores:

$$
\begin{gathered}
\mathrm{a}_{0}=\xi_{1} \frac{2 \omega_{1} \omega_{2}}{\omega_{1}+\omega_{2}}=0.0446 \\
\mathrm{a}_{1}=\xi_{2} \frac{2}{\omega_{1}+\omega_{2}}=0.000496
\end{gathered}
$$

\subsubsection{Modelado del acoplamiento TMD}

Para modelar el acoplamiento del TMD se utilizó el elemento COMBIN14 y MASS21 de ANSYS. El elemento COMBIN14 tiene capacidad longitudinal en aplicaciones de una, dos o tres dimensiones. La opción longitudinal de resorte-amortiguador es un elemento uniaxial de tracción/compresión con hasta tres grados de libertad: translaciones en las direcciones nodales $x, y, z$. No se considera flexión o torsión.

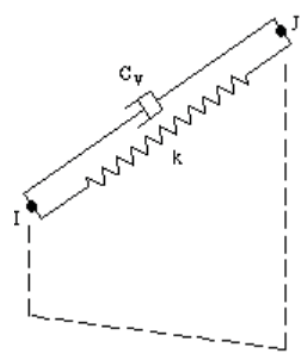

Figura 3-20: Elemento COMBIN14

En el modelo se aplicó un conjunto muelle-amortiguador de tracción/compresión en el eje vertical. Los extremos se fijan en función del caso de análisis, así por ejemplo, cuando se conecta el TMD en la posición central del vano los extremos del elemento muelle se definen entre el nodo correspondiente a esa ubicación y el definido por la propia masa del TMD, modelada con el elemento MASS21.

\subsubsection{Modelo de interacción peatón-estructura}

Un peatón al caminar por una estructura interactúa de forma dinámica con el sistema sobre el que circula y dicha interacción afecta a ambos. Una de las principales deficiencias que suelen presentar los modelos existentes es la no consideración de las modificaciones que el 
modelo presenta intrínsecamente en las propiedades dinámicas de la estructura por la presencia del peatón. Seguidamente se presenta un modelo discreto, consistente en una masa puntual $\left(M_{e q}\right)$ con un único grado de libertad ligada elásticamente a la estructura mediante un resorte $\left(k_{e q}\right)$ y un amortiguador $\left(c_{e q}\right)$ desplazándose el conjunto a velocidad constante sobre la superficie de paso, interactuando dinámicamente con el sistema estructural e influyendo de este modo sobre las propiedades dinámicas de la pasarela y considerando así los efectos transitorios, siendo validados con los resultados experimentales previamente obtenidos.

Destacar que la principal diferencia existente entre la idea de una masa móvil con velocidad (propuesta en el modelo de interacción peatón-estructura) y la dada por una carga constante móvil es que la carga aplicada sobre la estructura debido a la masa suspendida es variable con el tiempo y la ubicación. La Figura 3-21 muestra el modelo adoptado haciendo uso de los diferentes elementos de la biblioteca de ANSYS así como de su forma de contacto. Hablamos así, nuevamente de un elemento MASS21 y COMBIN14 para definir la parte mecánica del peatón e introducimos el modelo de contacto mediante los elementos CONTA175 y TARGET170, cuya combinación representa un contacto deslizante entre un nodo y una superficie tal como vemos en la Figura 3-21. Notar que el elemento TARGE170 está asociado a una superficie y no tiene en cuenta la sección.

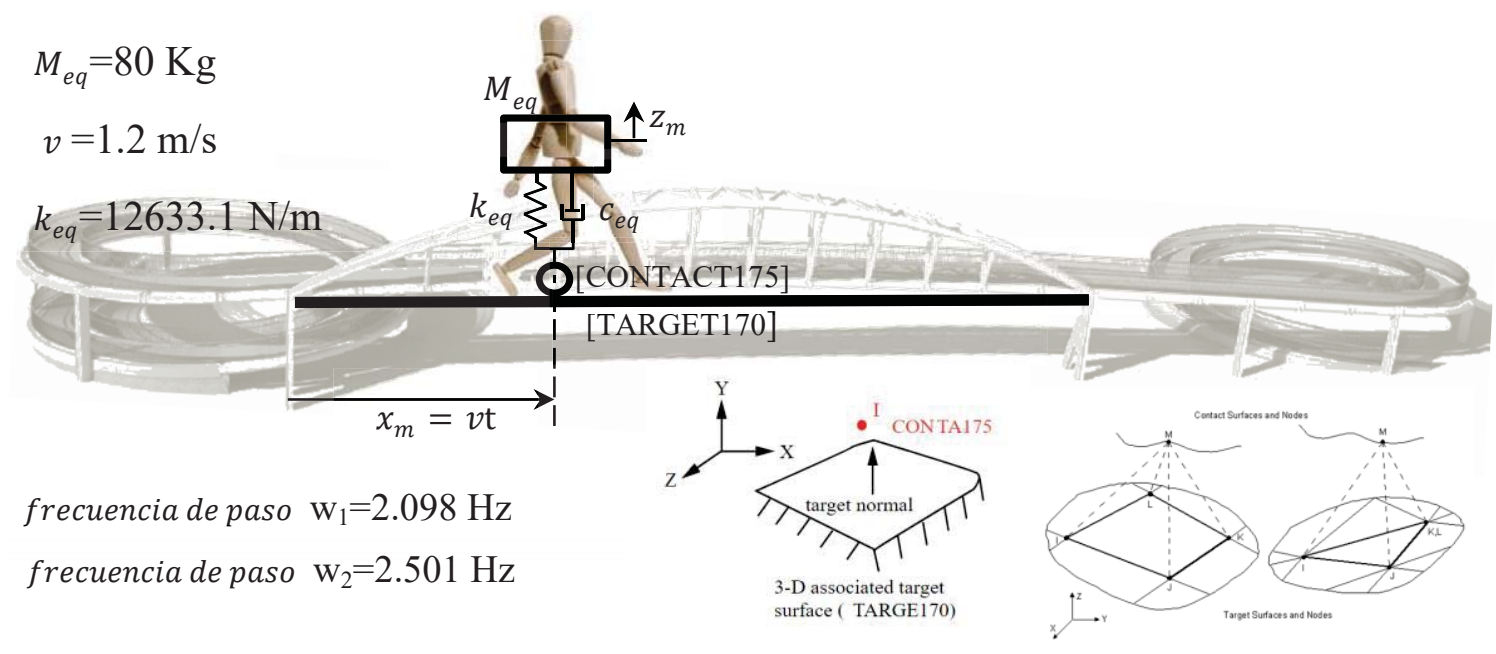

Figura 3-21: Modelo de interacción peatón-estructura propuesto

El modelo de fuerza puntual propuesto, es el dado por la guía de diseño estructural Sétra ( iError! No se encuentra el origen de la referencia.).

$$
F(t)=M_{e q} g\left(1+0.4 \sin \left(2 \pi w_{1} t\right)+\sum_{j=2}^{3} 0.1 \sin \left(2 \pi j w_{1} t-\frac{\pi}{2}\right)\right)
$$

\subsection{Selección del TMD}

En la actualidad existe una gran diversidad de sistemas que permiten reducir las vibraciones en las estructuras, causadas por diferentes tipos de excitación dinámica tales como sismos, viento, impactos, fuerzas ocasionadas por los usuarios de las estructuras, entre otros. En función del tipo de excitación dinámica y la dirección de las vibraciones se debe de determinar 
cuál es el sistema más adecuado y económico que logre reducir las respuestas dinámicas de las estructuras de manera eficiente. En el caso de excitaciones debidas al tránsito humano, la vía más económica de reacondicionar la estructura es mediante TMDs. Se trata de un sistema oscilatorio secundario, habitualmente compuesto por masas conectadas a la estructura principal a través de elementos con cierta rigidez como muelles, amortiguadores viscosos o visco elásticos. Deben ser sintonizados a la frecuencia del modo de la estructura cuya contribución se desea reducir. Las localizaciones más eficientes suelen ser donde tiene ocurrencia la máxima amplitud modal. El objetivo de su instalación es que al actuar la fuente de excitación, parte de la energía se transfiere al TMD donde se disipa, reduciéndose las oscilaciones indeseables. Su rendimiento en resonancia es elevado, pero se reduce notoriamente en el resto de las situaciones, en parte debido a las simplificaciones contempladas. Como ventajas fundamentales de estos elementos cabe destacar que no necesitan estar conectados entre dos puntos con movimiento relativo, requieren de poco mantenimiento y las modificaciones que debe sufrir la estructura principal para albergarlos son mínimas.La clásica elección de los parámetros que definen el TMD, dada su masa móvil, parten de los propios parámetros modales (vistos en el apartado 3.3) que se quiera mitigar. Su adecuada ubicación dentro de la pasarela es objeto de este trabajo. Sobre la pasarela en estudio, como se ha comentado anteriormente, la localización (aproximadamente el centro del vano) estaba definida por el espacio previsto para la posible instalación de unos de estos sistemas. Tras simulaciones previas y de acuerdo con la constructora se definió que la masa móvil serían $1000 \mathrm{~kg}$. Mediante formulaciones clásicas (Den Hartog [ ]), se determina que la frecuencia debe ser de $1.97 \mathrm{~Hz}$ y su amortiguamiento de $14.6 \%$ y se materializa el correspondiente diseño mecánico adaptado al hueco existente en el tablero. En la Figura 3-22 se muestran diversas instantáneas durante su instalación.

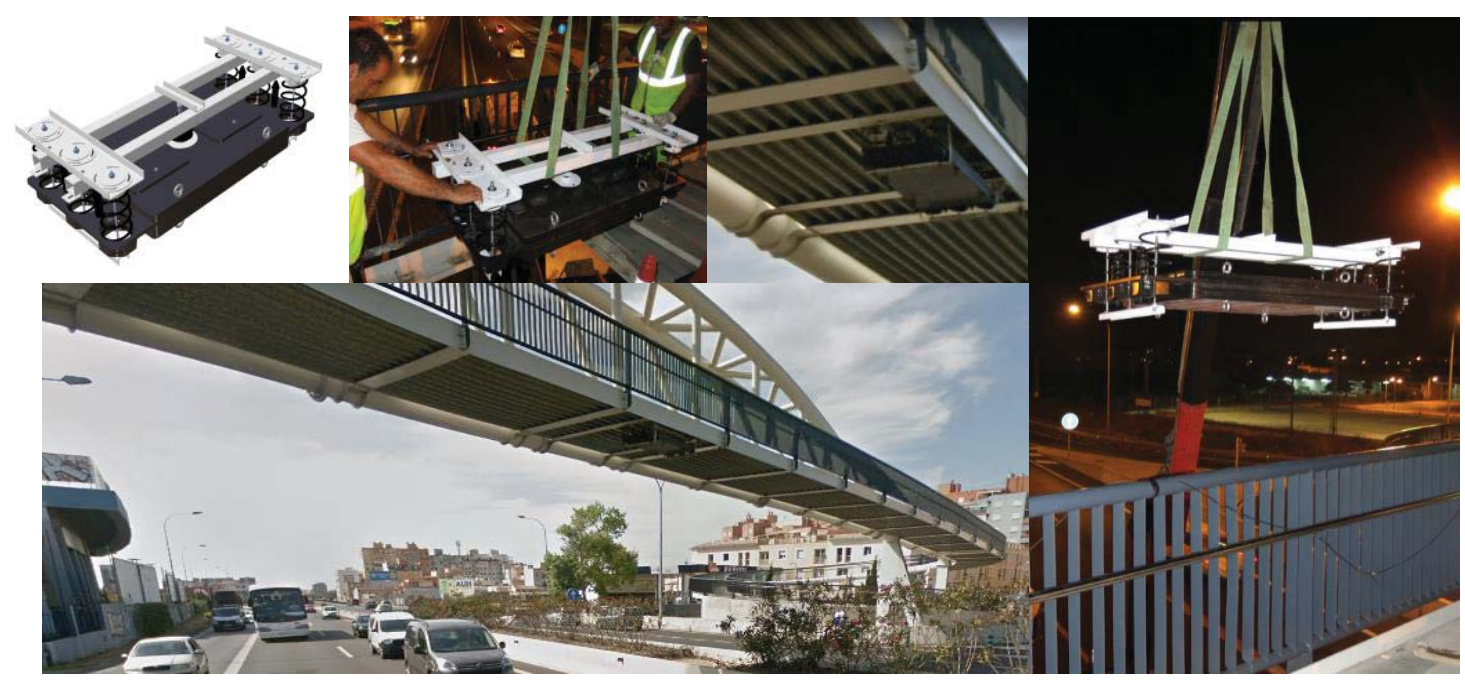

Figura 3-22: Diseño y ejecución TMD

Notar que las formulaciones tradicionales para el sintonizado de un TMD están basadas en múltiples simplificaciones.

Entre ellas, se supone que su ubicación dentro de la estructura es conocida, que la estructura a la que se acopla responde bien, en esa ubicación y en la cercanía del modo que se quiere mitigar, a un sistema de un grado de libertad $(*)$, que la carga va a ser armónica, etc. 
Como las condiciones reales pueden verse alejadas de estas hipótesis, la posibilidad de mejora en la instalación de un dispositivo TMD sobre una estructura real no solo es susceptible de estudio sino de mejora. Ahora bien, la resolución del problema ya no estaría basada en formulaciones simples sino en el análisis de las respuestas temporales dadas sobre un modelo realista estructural (3D) y aunque podría ser factible aplicar los métodos numéricos, el coste computacional para su resolución sería excesivo, ya que no solo se tendría que tantear las múltiples ubicaciones dentro de la estructura sino los diferentes parámetros del TMD. Por ello y a fín de reducir el gasto temporal en resolución, para explorar este enfoque se modela una estructura 2D equivalente compuesta de 12 elementos finitos tipo barra basados en la teoría clásica de flexión de vigas de Euler-Bernoulli.

Bajo estas hipótesis el modelo equivalente propuesto presenta modos verticales similares al modelo 3D pudiendo ser utilizado para encontrar los valores óptimos de los parámetros de diseño del TMD. Estos valores nos aportarán una información muy útil para reducir el campo de búsqueda o de optimización dentro de nuestro modelo 3D.

Entendida esta metodología se implementan algoritmos de optimización mediante formulaciones en espacio de estados logrando cálculos muy rápidos tanto en el dominio de la frecuencia (FRFs) como en el temporal.

El cálculo completo se lleva a cabo en entorno Matlab utilizando las funciones estándar: $\mathrm{SYS}=\mathrm{sS}(\mathrm{A}, \mathrm{B}, \mathrm{C}, \mathrm{D})$ para crear el modelo de espacio de estado, G=tf (SYS) para obtener la función de transferencia del modelo y $M A G=$ bode $(G, W)$ para calcular su diagrama de Bode (FRFs).Los resultados se irán viendo en los siguientes apartados a la par que se analizan las diferentes respuestas obtenidas tanto para estrategias basadas en funciones de respuesta en frecuencia como estrategias basadas en registros temporales (mucho más realistas pues contemplan fenómenos transitorios sobre el modelo actualizado de la estructura).Los resultados de estos estudios se presentan en el ANEXO II.

Tras todo el trabajo realizado sobre el modelo 2D simplificado se hacen estudios similares sobre el modelo 3D calibrado. En este caso los cálculos, mediante ANSYS, son mucho más lentos y por ello se comprueban solo ciertos escenarios, aquellos identificados como más idóneos en el estudio previo. En el ANEXO I/ se muestra la metodología y los resultados obtenidos. Es de destacar que los resultados difieren de los obtenidos en el modelo simplificado, precisamente por las simplificaciones adoptadas. En la estructura bajo estudio son importantes los efectos tridimensionales. Así, las respuestas cuando el mismo peatón transita a la misma frecuencia de paso son distintas si transita por la zona interior cercana al arco o si lo hace por la exterior, efectos que en el modelo 2D no se pueden estudiar. Cuando se tratan de comparar los resultados del tránsito simulado con los registros experimentales es usual obtener mayores respuestas por simulación (ver Figura 3-23). 


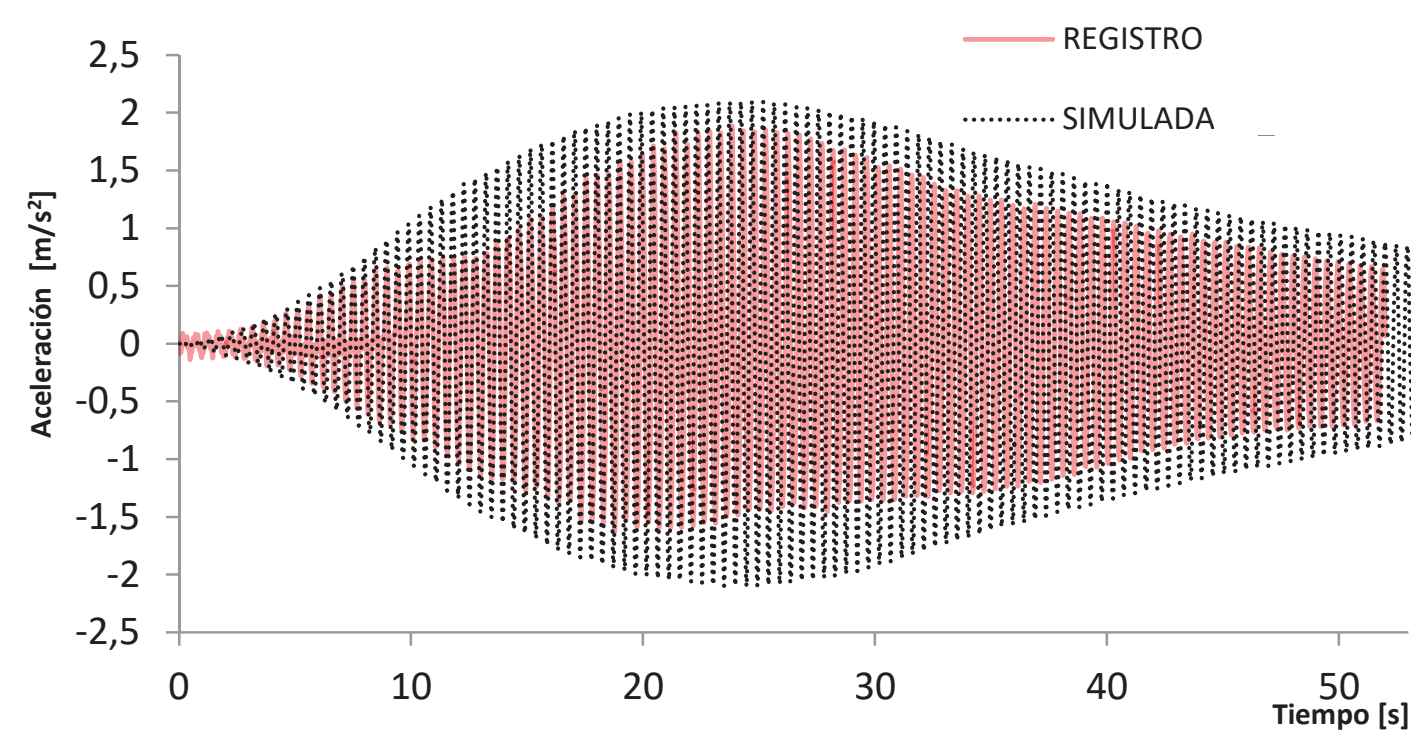

Figura 3-23: Respuestas del punto medio del modelo y del registro real

En este sentido y a modo de justificar esta circunstancia, se debe hacer notar que raramente puede una persona establecer una frecuencia de paso prefijada sin desviarse de ella y mucho menos con el ritmo asumido desde el primer momento. En este sentido no es de extrañar que por simulación, la excitación sea numéricamente perfecta y como consecuencia pueda resonar mejor, obteniéndose una mayor amplitud en términos de aceleraciones. 


\section{Conclusiones y trabajo futuro}

La primera conclusión es que los objetivos a los que se hacía referencia en el apartado 2 han sido logrados. Se ha puesto de manifiesto que nuevos elementos constructivos pueden albergar incertidumbres de comportamiento durante su uso y ante las que se han de contemplar medidas y consideraciones para el adecuado control estructural. La forma de avanzar en el desarrollo de estas competencias es vincular las pruebas modales y el análisis FEM con la calibración de los modelos de las estructuras y extraer unas directrices generales de diseño.

Un procedimiento para la toma de medidas experimentales y la calibración de los modelos de elementos finitos es descrito en este trabajo así como el estudio y las propuestas de los dispositivos de mitigación sobre ese modelo numérico calibrado, prestando especial atención a su localización dentro de la estructura.

De forma general puede decirse que el uso de modelos con elementos $2 \mathrm{D}$ ha resultado de gran utilidad para estudiar en profundidad la parametrización que involucra el diseño óptimo de un TMD pudiendo ser extrapolados a modelos de elementos 3D, lo que permite abordar el problema con un bajo coste computacional, gracias a que se pueden acotar así los rangos de variabilidad de diseño.

El proceso de validación y calibración ha permitido dar fiabilidad al modelo FEM adoptado, utilizando datos experimentales. El procedimiento se ha aplicado con éxito a una pasarela particular con varias frecuencias problemáticas.

La aplicación ciega de los procedimientos de calibración automática incorporados en un software desarrollado a propósito puede producir fácilmente resultados sin sentido en el caso de las aplicaciones de ingeniería civil. A menos que los parámetros iniciales de entrada estén lo suficientemente cerca de los valores finales, es posible que el software de calibración no encuentre una buena solución lógica. Además, si solo se utilizan frecuencias naturales para la calibración, pueden predecirse valores poco realistas para los parámetros seleccionados.

La diferencia entre las frecuencias computacionales naturales y los resultados experimentales se redujo a través de los progresivos modelos de calibración. Sin embargo, los valores MAC no mejoraron significativamente (ya eran lo suficientemente buenos).

El problema de ingeniería para mitigar las vibraciones de estructuras esbeltas bajo cargas transitorias no es simple. El problema de encontrar el mejor número de TMDs, su ubicación y ajuste se puede abordar mediante formulaciones y simulaciones en el dominio de la frecuencia o en el dominio del tiempo. 
Siendo conscientes de la profundizad alcanzada para la realización de este documento, y de la multitud de posibles escenarios a evaluar, donde otros TMDs fueran considerados en otras localizaciones y contemplando además la posibilidad de combinar varios de ellos, los análisis realizados y los valores que de ellos se desprenden para los diferentes tránsitos indican varias cosas a tener en cuenta para las estrategias evaluadas.

Por un lado, la valoración de la calibración del TMD puede analizarse no solo mediante diferentes indicadores sino mediante diferentes estrategias. Ante ello, este trabajo muestra cómo en función de estas elecciones los resultados con los que se valora la adecuación del dispositivo mitigador pueden ser bien diferentes.

Estos resultados ponen de manifiesto la necesidad de realizar estudios transitorios que aseguren la respuesta dinámica del problema, a pesar del coste computacional que requiere. Otras posibilidades de análisis basadas en simplificaciones pueden resultar poco útiles si las condiciones del problema son tales que desvirtúan la realidad del escenario.

En una etapa temprana de diseño, la valoración de la respuesta de una pasarela peatonal ante el tránsito de un peatón en perfecta resonancia puede, perfectamente, caracterizar la sensibilidad de esta estructura. Sobre una pasarela peatonal estas cargas están determinadas por el flujo de los peatones, por lo tanto sería más realista diseñar estas estructuras teniendo en cuenta el efecto producido por grupos de personas que transitan por ella. Si el modelo computacional es válido para simular y obtener resultados para un peatón, debería ser válido para simular condiciones de flujo realistas.

Seguidamente son propuestas a continuación distintas líneas de desarrollo que complementarían el trabajo:

I. Desde un punto de vista técnico se podría utilizar diferentes parámetros para ubicar y optimizar el diseño de uno o varios TMDs. Así nuevas estrategias de análisis con un punto de vista basado en conceptos de energía podrían determinar parámetros de diseño así como ubicaciones que difieran de lo establecido en base a las estrategias empleadas en esta Tesis.

II. Por otro lado, ampliar el estudio a otras tipologías estructurales como forjados de grandes luces, estadios deportivos, escaleras... beneficiaría el conocimiento sobre comportamientos adecuados bajo condiciones que se alejan de situaciones de utilidad pero que podrían darse por diferentes motivos en estos sistemas estructurales y sirviendo de este modo, ya en la fase de diseño, ser contempladas en su análisis.

III. En línea con los procesos de calibración, sería muy interesante analizar las diferencias en cuanto a las técnicas matemáticas existentes y que incertidumbre presentan para de una forma general calibrar los modelos de forma robusta, evitando así incidir en la fiabilidad de las estimaciones por la acción de decisiones propias del ingeniero.

IV. Desde una vertiente experimental, adquirir diferentes respuestas en función de niveles ocupacionales así como de tránsitos peatonales a distintos ritmos y direcciones que sirvan de comparación frente a los valores arrojados por las simulaciones computacionales. 
V. Actualmente el conocimiento sobre el estado de las infraestructuras en tiempo real es uno de los puntos de mayor interés ingenieril. Implementar sistemas de monitorización que controlen de forma activa la variación no solo de los parámetros propios del dispositivo atenuador a las circunstancias dadas (nivel de ocupación, peso puntual de las personas, velocidad del tránsito,...) sino que esté implementando además un sistema mecánico que adapte la localización del TMD a la localización más favorable en tiempo real sería algo totalmente novedoso en el ámbito del control estructural aunque totalmente inviable a día de hoy desde el punto de vista práctico.

También le gustaría al autor comentar brevemente de qué manera las técnicas o conocimientos recopilados en este documento podrían ser usados

Este trabajo junto a los que puedan derivarse de él permiten demostrar el impacto de la instalación de TMDs sobre estructuras cada vez más ligeras y esbeltas, en cuanto a atenuar vibraciones. De ello se puede desprender que nuevas estructuras podrían reducir el gasto de materiales de una forma considerable. Siendo esto de gran importancia desde un punto de vista medio-ambiental.

Se ha adquirido experiencia en el ensayo, modelado y calibrado de estructuras construidas con materiales tradicionales (acero y hormigón), evidenciando en muchos casos ciertas dificultades. Teniendo en cuenta los nuevos materiales de construcción (composites) y las nuevas tecnologías de ejecución podría ser todo un acto de fe confiar en los resultados iniciales de simulaciones dinámicas de estos nuevos escenarios. La caracterización tensodeformacional de estos materiales ya es de por si todo un trabajo investigador, imaginemos ahora la dificultad de caracterizarlos modalmente para por ejemplo diseñar una pasarela peatonal. Por ello los procesos de calibrado toman especial relevancia en estas complejas estructuras, las cuales aún no presentan grandes vanos por verse limitados en términos vibracionales. Intervenir en los procesos de diseño considerando a los TMDs como parte del diseño amplificaría las posibilidades de estos materiales para su uso en estructuras civiles. 


\section{REFERENCIAS}

BIBLIOGRAFÍA:

[1] Skempton, A. W.; Chrimes (2002). A biographical dictionary of civil engineers in Great Britain and Ireland. M. Thomas Telford.

[2] Plaut, R. H. (2008). Snap loads and torsional oscillations of the original Tacoma Narrows bridge. Journal of Sound and Vibration, 309(3-5), 613-636.

[3] Bachmann et al. (1995). Vibration problems in structures. Practical guidelines. Birkhäuser.

[4] Tilly, G.P. et al. (1984). Dynamic behaviour of footbridges. Int. Ass. Bridge Structural. Engineering., 194, 259-67.

[5] Housner, G. W., Bergman, L. A., Caughey, T. K., Chassiakos, A. G., Claus, R. O., Masri, S. F., ... Yao, J. T. P. (1997). Structural control: Past, present, and future. Journal of Engineering Mechanics, 127, 887-971.

[6] J.J. CONNOR (2003). Introduction to Structural Motion Control. Prentice Hall Pearson Education, 217-285.

[7] Symans, M. D., \& Constantinou, M. C. (1999). Semi-active control systems for seismic protection of structures: A state-of-the-art review. Engineering Structures, 21(6), 469-487.

[8] Smith, J. W., Kappos, A. J. (2002). Human-induced vibrations en Dynamic loading and design of structrures. Spon Press.

[9] Ebrahimpour A, Sack RL. (2005). A review of vibration serviceability criteria for floor structures. Computers and Structures, 83, 2488-2494.

[10] Pascal Charles, W. H. (2006). Footbridges: Assessment of vibrational behaviour of footbridges under pedestrian loading. SÉTRA: service d'Études techniques des routes et autoroutes. Technical Guide.

[11] Feldmann, M. (2008). Human induced vibrations of steel structures. Design of footbridges guidelines, Research Fund for Coal and Steel (RFCS), Technical Guide.

[12] Zivanović, S. Pavic, A. (2005). Vibration Serviceability of Footbridges a Under HumanInduced excitation: a literature review. Journal of Sound and Vibration, 279, 1-74.

[13] Tommaso Morbiato, Renato Vitaliani, Anna Saetta. (2011). Numerical analysis of a synchronization phenomenon: Pedestrian-structure interaction. Journal of Sound and Vibration, 326, 1-49

[14] Dallard, P., Fitzpatrick, T., Flint, A., Low, A., Ridsdill Smith, R., Willford, M., and Roche, M. (2001). London Millennium Bridge: Pedestrian-Induced Lateral Vibration. Journal Bridge Engineering, 6(6), 412-417.

[15] Daniel, S., Marigold and Aftab, E. Patla. (2005). Adapting locomotion to different surface compliances: neuromuscular responses and changes in movement dynamics. Journal Neurophysiol 94, 1733-1750.

[16] Elsa, C. Cunha, A. Moutinho, C. (2011). Vandal Loads and Induced Vibrations on a Footbridge. Journal of bridhe engineering, 16(3).

[17] ANSYS v5.2 Users Manual, ANSYS, 1995

[18] Ewins, D.J. (1992). Modal Testing: Theory and Practice. Taunton: Research Studies Press Ltd.

[19] He, J., Fu, Z.F. (2001). Modal analysis. Oxford: Butterworth-Heinemann. 
[20] Heylen, W., Lammens, S., Sas, P. (1998). Modal Analysis: Theory and Practice. Leuven: KU

[21] J. S. Sanz. (2012). Análisis del estado límite de servicio y control de vibraciones en pasarelas peatonales, Ph.D. Dissertation, Escuela de Ingenierías Industriales, Universidad de Valladolid.

[22] Li W.M., Hong J.Z.(2001). New iterative method for model updating based on model reduction. Mechanical Systems and Signal Processing, 25(1), 180-192.

[23] Mottershead J. E., Friswell M. I. (1993). Model updating in structural dynamics: a survey. Journal of Sound and Vibration, 167(2), 347-375.

[24] Ribeiro, D., Calçada, R., Delgado, R., Brehm, M., Zabel, V. (2012). Finite element model updating of a bowstring-arch railway bridge based on experimental modal parameters. Engineering Structures, 40, 413-435.

[25] Brownjohn J.M.W., Xia P.Q., Hao H., Xia Y. (2001). Civil structure condition assessment by FE model updating: Methodology and case studies. Finite Elements in Analysis and Design, 37, 761-775.

[26] Zivanovic' S., Pavic A., Reynolds P. (2006). Modal testing and finite element model tuning of a lively footbridge structure. Engineering Structures, 28(6), 857-868.

[27] Zivanovic, S., Pavic, A. And Reynolds, P. (2007). Finite element modelling and updating of a lively footbridge: the complete process. Journal of Sound and Vibration, 301, 126-145

[28] Dynamic Design Solution. (2008). Femtools Model Updating. Theoretical Manual.

[29] Turek, M., Ventura, C. \& Dasconte, E. (2010). Model updating of the Ironworkers Memorial Second Narrows Bridge, Vancouver, Canada. IMAC. Jacksonville, Florida.

[30] Kim G.H., Park Y.S. (2004). An improved updating parameter selection method and finite element model update using multiobjective optimisation technique. Journal of Bridge Engineering, 16(3), 375-382.

[31] Pavic, A., Hartely, M. J. \& Waldron, P. (1998). Updating of the Analytical Models of Two Footbridges Based on Modal Testing of Full-Scale Structures. ISMA23.

[32] Teughels A, Maeck J, De Roeck G. (2002). Damage assessment by FE modal updating using damage functions. Computers and Structures, 80(25), 1869-1879.

[33] Zapico, J.L., González, M.P., Friswell, M.I., Taylor, A.J. and Crewe, A.J. (2003). Finite element model updating of a small scale bridge. Journal of Sound and Vibration, 268, 9931012.

[34] Den Hartog J P. (1956). Mechanical Vibrations, 4th edition, mcgraw-Hill, New York.

[35] Miranda, J. C. (2005). On tuned mass dampers for reducing the seismic response of structures. Earthquake Engineering and Structural Dynamics, 34(7), 847-865.

[36] Abé, M., \& Igusa, T. (1995). Tuned mass dampers for structures with closely spaced natural frequencies. Earthquake Engineering \& Structural Dynamics, 24(2), 247-261.

[37] Krenk, S., Brønden, A., \& Kristensen, A. (2005). Placement and tuning of resonance dampers on footbridges. Infootbridge 2005: 2nd International Conference ( Abstract Book and CD ROM). Venice: University IUAV, Italy.

[38] Sadek, F., Mohraz, B., Taylor, A. W., \& Chung, R. M. (1997). A method of estimating the parameters of tuned mass dampers for seismic applications. Earthquake Engineering and Structural Dynamics, 26(6), 617-635.

[39] Frahm, H. (1911). Device for damping vibrations of bodies. Google Patents, Retrieved from www.scopus.com 
[40] Warburton, G. B. (1982). Optimum absorber parameters for various combinations of response and excitation parameters. Earthquake Engineering \& Structural Dynamics, 10(3), 381-401.

[41] Yamaguchi, H., \& Harnpornchai, N. (1993). Fundamental characteristics of multiple tuned mass dampers for suppressing harmonically forced oscillations. Earthquake Engineering \& Structural Dynamics, 22(1), 51-62.

[42] Daniel Y., Lavan O., Levy R. (2012). Multiple-tuned mass dampers for multimodal control of pedestrian bridges Journal of Structural Engineering, 138 (9), 1173-1178.

[43] Weber, F., Distl, H., Spensberger, S., Benicke, O., Huber, P., Braun, C. (2017). New RealTime Controlled Semi-Active Tuned Mass Damper for Human, Vortex and Wind Excitations. Conference 6. Footbridge 8.9.2017 TU-Berlín.

[44] Sahnaci, C., Kasperki, M. (2017). A full probabilistic model for loads induced by walking. Conference 6. Footbridge 8.9.2017 TU-Berlín.

[45] Sahnaci, C., Meinhardt, C., Krampe, T. (2017). Performance of mtmd systems based on realistic load contributions due to walking. Conference 6. Footbridge 8.9.2017 TU-BERLIN.

[46] Weber F. 2013 Dynamic characteristics of controlled mr-stmds of wolgograd bridge. Smart Materials and Structures 22(16)

[47] Van Nimmen, K., Lombaert, G., De Roeck, G., and Van den Broeck, P. (2014). Vibration serviceability of footbridges: Evaluation of the current codes of practice. Engineering. Structures, 59, 448-461.

[48] Ramos-Moreno, C.(2015). Design of cable-stayed footbridges under serviceability loads. Phd thesis. Imperial College London.

[49] Lai, E., Gentile, C., \& Mulas, M.G.(2017). Experimental and numerical serviceability assessment of a steel suspension footbridge. Journal of Constructional Steel Research, $132,16-28$.

[50] Shahabpoor, E., Pavic, A., Racic, V. And Zivanovic, S. (2017).Effect of group walking traffic ondynamic properties of pedestrian structures. Journal of Sound and Vibration, 387,207225.

[51] Toso, M., Gomes, H., Silva, F., Pimenter, R. (2016). Experimentally fitted biodynamic models for pedestrian-structure interaction in walking sitations. Mechanical Systems and Signal Processing, 72(72), 590-606.

[52] Mcdonald, M.G., Zivanovic, S. (2017). Measuring ground reaction force and quantifying variability in jumping and bobbing action. ASCE Journal of Structural Engineering, 143(2).

[53] Dey, P., Sychterz, A., Narasimhan, S. And Walbridges, S. (2016). Performance of pedestrian-load models through experimental studies on lightweight aluminum bridges. Journal of Bridge Engineering, 21(8),C4015005.

[54] Rai, E., Gentile, C., Mulas, M.G. (2017). Experimental and numerical serviceability assessment of a Steel suspension footbridge. Journal of Constructional Steel Research, $132,16-28$. 
WEBGRAFÍA:

(1) https://www.turenscape.com/

consultado en oct'2016

(2) https://www.sharcnet.ca/Software/Ansys/17.0/en-us/help/wb_dm/agpbook.html consultado en ene'2017

(3) http://www.faukie.com/en/

consultado en ene'2017

(4) http://www.interconstech.com/

consultado en feb'2017

(5) http://www.sophia-engineering.nl/

consultado en nov'2017

(6) http://www.majowiecki.com/

consultado en nov'2017

(7) https://www.benedettiarchitects.com/

consultado en mar'2018 


\section{ANEXO I}

\section{Análisis Modal Experimental}

En el análisis modal experimental (EMA-Experimental Modal Analysis) los parámetros modales se obtienen de las funciones de respuesta en frecuencia (FRFs), que relacionan la salida (respuesta) con la entrada (excitación).

La definición de función de respuesta en frecuencia indica la relación entre la señal de salida y la señal de entrada en el dominio de las frecuencias. Si definimos $F(f)$ como el espectro en frecuencia de la señal de entrada y $X(f)$ como el espectro en frecuencia de la señal de salida, entonces $\mathrm{H}(\mathrm{f})$ puede escribirse como:

$$
H(f)=\frac{X(f)}{F(f)}
$$

Al evaluar dicha función se corre el riesgo de que $F(f)$ sea cero para algunos términos. En la práctica existen formas alternativas de calcular $\mathrm{H}(\mathrm{f})$, utilizando las potencias espectrales:

$$
\begin{aligned}
& H_{1}(f)=\frac{X(f)}{F(f)} \frac{F^{*}(f)}{F^{*}(f)}=\frac{G_{X F}}{G_{F F}} \\
& H_{2}(f)=\frac{X(f)}{F(f)} \frac{X^{*}(f)}{X^{*}(f)}=\frac{G_{X X}}{G_{F X}}
\end{aligned}
$$

El principal motivo para estimar las FRFs con las ecuaciones anteriores, es la disminución del ruido en las señales de entrada y salida al promediar. En realidad, la función de respuesta en frecuencia se estima mediante valores promedio de las potencias espectrales

$$
\begin{array}{ll}
\hat{G}_{F F}=\frac{1}{N_{a}} \sum_{n=1}^{N_{a}}\left(G_{F F}\right)_{n} & \hat{G}_{F F}=\frac{1}{N_{a}} \sum_{n=1}^{N_{a}}\left(G_{F X}\right)_{n} \\
\hat{G}_{F F}=\frac{1}{N_{a}} \sum_{n=1}^{N_{a}}\left(G_{X X}\right)_{n} & \hat{G}_{F F}=\frac{1}{N_{a}} \sum_{n=1}^{N_{a}}\left(G_{X F}\right)_{n}
\end{array}
$$

Donde $\mathrm{N}_{\mathrm{a}}$ es el número promedio que se repite el ensayo, lo que permite extraer una aproximación por mínimos cuadrados de $\mathrm{H}(\mathrm{f})$.

Puesto que las funciones de respuesta en frecuencia se obtienen mediante una aproximación de mínimos cuadrados, se puede definir un coeficiente de correlación, que suele denominarse función de coherencia. Ésta permite dar una medida del error de la aproximación y se define como:

$$
\gamma^{2}=\frac{\left|\widehat{G}_{F X}\right|^{2}}{\widehat{G}_{F F} \widehat{G}_{X X}}=\frac{H_{1}(f)}{H_{2}(f)}
$$


La función de coherencia toma valores entre 0 y 1 . Un valor de 1 , indica una relación completamente lineal entre las señales de entrada y las señales de salida. Si, por el contrario, el valor es menor que 1, puede buscarse la razón en los siguientes fenómenos:

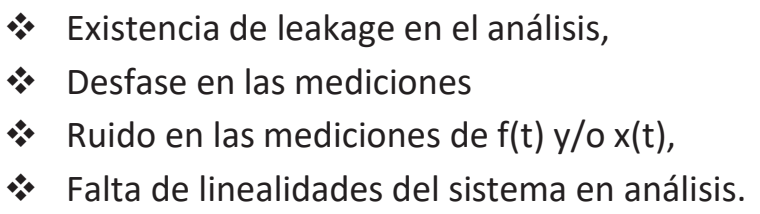

\section{Análisis Modal Operacional}

El análisis modal operacional (OMA-Operacional Modal Análisis) es el procedimiento más actual y fue desarrollado principalmente por la comunidad de ingenieros civiles. Trata de dar solución a las dificultades que plantea, en numerosas ocasiones, inducir una excitación artificial y controlada sobre estructuras de grandes dimensiones como requeriría un EMA. Así el análisis modal operacional se basa en la medida de la respuesta de la estructura en base a una excitación natural, definiendo modalmente la estructura bajo sus condiciones de operación. Este procedimiento no mide las fuerzas de entrada al sistema, por tanto este análisis no deriva en las medidas de las funciones de respuesta en frecuencia (FRF) del sistema, pero relaciona la respuesta medida por un sensor cualquiera con uno de referencia, para, en función de los múltiples procedimientos (Peak Picking-PP, Descomposición en el dominio de la frecuencia-FDD, Identificación de Subespacios Estocásticos-SSI, entre otros) identificar ciertos parámetros modales (frecuencia natural, coeficientes de amortiguamiento y formas modales) con mayor 0 menor precisión según la tipología que presente la estructura.

\begin{tabular}{|l|l|l|}
\hline \multicolumn{1}{|c|}{ PP } & \multicolumn{1}{|c|}{ FDD } & \multicolumn{1}{|c|}{ SSI } \\
\hline Simple-método de campo & Simple- pero mejora a PP & Avanzado \\
\hline $\begin{array}{l}\text { Funciona bien cuando los modos } \\
\text { están separados y cuando los } \\
\text { amortiguamientos son muy } \\
\text { pequeños }\end{array}$ & $\begin{array}{l}\text { Funciona bien aun cuando los } \\
\text { modos están muy juntos }\end{array}$ \\
\hline Identifica deformaciones modales & $\begin{array}{l}\text { Identifica modos de vibración } \\
\text { (próximos) y coeficientes de } \\
\text { amortiguamiento }\end{array}$ & $\begin{array}{l}\text { Identifica frecuencias que } \\
\text { escaparían en otros métodos } \\
\text { además de los modos y de los } \\
\text { coeficientes de amortiguamiento }\end{array}$ \\
\hline Literatura: Brownjohn [2003] & Literatura: Brincker [2001] & Literatura: De Roeck[1999] \\
\hline
\end{tabular}

Breve presentación de algunos de los procedimiento de identificación

Puesto que en un OMA la fuerza de excitación es desconocida, el concepto de función de transferencia es inaplicable y, por tanto, no puede calcularse la representación gráfica de la FRF. Es por ello que debe introducirse el concepto de función de densidad espectral de potencia o PSD. En el dominio del tiempo, un proceso estocástico queda caracterizado si se conoce la función de medias $\mu x(t)$ y la función de autocorrelación $\operatorname{Rx}(\tau)$. Dicho proceso estocástico se define en el domino de la frecuencia mediante la función de densidad espectral (también conocida como función espectral de potencia), que es la transformada de Fourier de $\operatorname{Rx}(\tau)$.

$$
\begin{gathered}
S_{x}(\omega)=\frac{1}{2 \pi} \int_{-\infty}^{\infty} R_{x}(\tau) e^{-i \omega \tau} d \tau \\
R_{x}(\tau)=\int_{-\infty}^{\infty} S_{x}(\omega) e^{i \omega \tau} d \omega
\end{gathered}
$$


Como la función de autocorrelación caracteriza al proceso estocástico en el dominio del tiempo, la función de densidad espectral caracteriza al proceso en el dominio de la frecuencia. Suprimiendo las frecuencias negativas, la función de densidad espectral puede escribirse como:

$$
G_{X}(\omega)=2 S_{X}(\omega) \quad \omega \geq 0
$$

En la gran mayoría de los análisis modales, los datos obtenidos de los ensayos están almacenados en tantas señales como sensores activos haya conectados. En tal caso, es necesario introducir un nuevo concepto: función de densidad espectral cruzada o XPSD. El software de CAE empleado en este trabajo (FEMTools) permite el análisis de varias señales al mismo tiempo, ya que cuenta con dicha función implementada. Definiendo $X(t)$ e $Y(t)$ como dos procesos estocásticos estacionarios, la función de correlación cruzada es:

$$
\begin{aligned}
& R_{X Y}(\tau)=E[X(t) Y(t+\tau)] \\
& R_{Y X}(\tau)=E[X(t+\tau) Y(t)]
\end{aligned}
$$

La función de densidad espectral cruzada se define como la transformada de Fourier de la función de correlación cruzada. Por tanto, las dos funciones de densidad espectral cruzada se presentan como:

$$
\begin{aligned}
& S_{X Y}(\omega)=\frac{1}{2 \pi} \int_{-\infty}^{\infty} R_{X Y}(\tau) e^{-i \omega \tau} d \tau \\
& S_{Y X}(\omega)=\frac{1}{2 \pi} \int_{-\infty}^{\infty} R_{Y X}(\tau) e^{-i \omega \tau} d \tau
\end{aligned}
$$

Como ya se ha mencionado, las FRF son propias de los EMA, necesitándose para la aplicación de los OMA las PSD. La relación entre la salida y la entrada de la PSD y la descomposición modal de la FRF son respectivamente:

$$
\begin{aligned}
G_{Y Y}(j \omega) & =H^{*}(j \omega) G_{X X}(j \omega) H^{T}(j \omega) \\
H(j \omega) & =\sum_{r=1}^{N}\left(\frac{R_{r}}{j \omega-\lambda_{r}}+\frac{R_{r}^{*}}{j \omega-\lambda_{r}^{*}}\right)
\end{aligned}
$$

Asumiendo que todas las entradas carecen de correlación, la matriz de salida de la PSD puede escribirse según:

$$
G_{Y Y}(j \omega)=\sum_{r=1}^{N}\left(\frac{A_{r}}{j \omega-\lambda_{r}}+\frac{A_{r}^{*}}{j \omega-\lambda_{r}^{*}}+\frac{B_{r}}{j \omega-\left(-\lambda_{r}\right)}+\frac{B_{r}^{*}}{j \omega-\left(-\lambda_{r}^{*}\right)}\right)
$$

Este modelo modal cuenta con $\lambda, \lambda^{*},-\lambda,-\lambda^{*}$ como polos, de los cuales dos son estables $\left(\lambda, \lambda^{*}\right)$ y dos son inestables $\left(-\lambda,-\lambda^{*}\right)$. La PSD positiva (sólo tiene en cuenta las frecuencias positivas) está definida por la transformada de Fourier de las funciones de correlación, pudiéndose escribir como

$$
G_{Y Y}^{+}(j \omega)=\sum_{r=1}^{N}\left(\frac{A_{r}}{j \omega-\lambda_{r}}+\frac{A_{r}^{*}}{j \omega-\lambda_{r}^{*}}\right)
$$

Comparando la descomposición modal de la FRF con esta última ecuación puede observarse que ambas presentan el mismo formato, por lo que, para los EMA la FRF y la PSD son la misma representación. Para los OMA, la PSD hace las funciones de FRF, ya que como anteriormente se ha indicado, la PSD caracteriza al proceso estocástico en el dominio del tiempo, pudiéndose aplicar las mismas técnicas de identificación de parámetros modales a través de las FRF. 
La Complex Mode Indicator Function o CMIF, es un algoritmo empleado para la identificación de frecuencias modales, particularmente cuando éstas se encuentran estrechamente espaciadas. Este algoritmo está basado en el Teorema de la Expansión, que asume que, para cada frecuencia, la dimensión larga de la matriz de la FRF se obtiene como el sumatorio de los vectores modales.

Empleando una descomposición en valores singulares para comparar el sumatorio lineal de los vectores modales (dimensión larga de la matriz FRF) y las diversas referencias (dimensión corta de la matriz FRF), se extrae una gráfica que identifica el número de vectores modales dominantes participando en cada frecuencia. Si se estima la CMIF mediante una descomposición en valores singulares, los vectores singulares son unitarios y sus valores son una medida de la fuerza o predominancia de cada modo en cada frecuencia.

La CMIF se define como el conjunto de valores propios de la matriz normal de la FRF o la XPSD. Dicha matriz normal se obtiene premultiplicando a la matriz FRF (o XPSD en su defecto) sus matrices Hermitianas, $[\mathrm{H}(\omega)]^{\mathrm{H}}[\mathrm{H}(\omega)]^{\mathrm{H}}$. La CMIF es la representación gráfica de dichos valores propios en función de la frecuencia y en escala logarítmica. Los picos detectados en la gráfica de la CMIF, indican la existencia de modos, y las frecuencias correspondientes a cada pico, ofrecen una estimación de las frecuencias naturales amortiguadas de cada modo. Puede programarse un detector automático capaz de identificar así la existencia de modos. El vector singular correspondiente a cada pico detectado, es equivalente al factor de participación modal.

El algoritmo base representa las frecuencias de resonancia mediante polinomios racionales. Las funciones de respuesta en frecuencia, así como la transmisibilidad, pueden definirse en forma de fracción racional, es decir, la razón de dos polinomios, en la que los órdenes del denominador y del numerador son independientes. La función de transmisibilidad puede representarse según:

$$
T_{i j}^{k}(\omega)=\frac{H_{i k}(\omega)}{H_{i j}(\omega)}=\frac{X_{i k}(\omega)}{X_{j k}(\omega)}=\frac{\sum_{p=1}^{n} a_{p} s^{p}}{\sum_{p=1}^{m} c_{p} s^{p}}
$$

Los ceros del numerador son precisamente las frecuencias de la FRF de la fila i y columna $k$, mientras que los ceros del polinomio del denominador corresponden a las frecuencias de resonancia de FRF de la fila j y la columna $k$. A tenor de lo expuesto anteriormente, las funciones de transmisibilidad sólo muestran información acerca de las frecuencias modales. Tratando de ajustar las curvas de las funciones de transmisibilidad a la ecuación de medida del error de la aproximación vista en el apartado 7.1 y mediante la resolución de las raíces de ambos polinomios, pueden determinarse las frecuencias de resonancia del sistema para una determinada excitación.

Para determinar las frecuencias de la FRF de la fila j y la columna $\mathrm{k}$ con mayor exactitud, el algoritmo base emplea la suma de todas las funciones de transmisibilidad cuyos denominadores cuentan con respuesta en $\mathrm{j}$.

$$
T_{j}^{k}(\omega)=\sum_{p=1, p \neq j}^{N} T_{p j}^{k}=\sum_{p=1, p \neq j}^{N} \frac{X_{p k}(\omega) X_{j k}^{*}(\omega)}{X_{j k}(\omega) X_{j k}^{*}(\omega)}
$$

Donde $\mathrm{N}$ es el número de respuestas medidas. Las funciones de transmisibilidad reducen el ruido presente en las señales, y por tanto, incrementan la precisión con que se extraen las frecuencias detectadas. La función resultante $\left(T_{j}^{K}(\omega)\right)$ contiene solo los picos de las frecuencias de resonancia en la fila j y columna $k$ de la FRF. Por tanto, si se ajusta la curva de la ecuación 
$\mathrm{T}_{j}{ }^{K}(\omega)$ a una forma de fracción racional y se resuelven las raíces del denominador, pueden identificarse las frecuencias de la fila j y columna $k$ de la FRF. En el siguiente apartado se verá en la figura 7.3 la como el algoritmo basado en funciones de transmisibilidad es capaz de identificar las frecuencias para un caso en particular.

Como ya se vio, el método de mínimos cuadrados consiste en asignar valores iniciales a las variables desconocidas, e ir utilizando los datos conocidos de frecuencias naturales, fácilmente identificables en los diagramas de estabilidad. Los diagramas de estabilidad son herramientas que ayudan a obtener los polos y las frecuencias naturales reales y se obtienen al ir repitiendo el análisis modal incrementando el orden del sistema (número de polos asumidos). Para cada análisis incremental se estiman los polos donde los resultados son presentados gráficamente en el diagrama de estabilidad en cuyo eje vertical se encuentra el orden y en el eje horizontal se representa la frecuencia natural del polo estimado. En general, los polos reales aparecen en la misma frecuencia en el diagrama, independientemente del orden del sistema. En cambio, la frecuencia de los polos computacionales (no reales, modelan ruido), varían al aumentar el orden del sistema. 


\section{ANEXO II}

Publicaciones 46

1. Cuantificación de la percepción de la vibración en pasarelas peatonales 47

2. Vibration monitoring of a steel-plated stress-ribbon footbridge: uncertainties in the modal estimationmodal estimation 55

3. Ad-hoc vibration monitoring system for a stress-ribbon footbridge: from design to operation.

Artículos publicados en congresos. 83

IMPROVEMENT COMFORTABILITY THROUGH ADDING SOFT RUBBER PAVEMENT ON LIVELY FOOTBRIDGES .83

DISCOMFORT EVALUATION ON LIVELY FOOTBRIDGES WITH SOFT-RUBBER PAVEMENT 93 QUANTIFYING DIFFERENCES BETWEEN WALKING LOCOMOTION ON RIGID AND FLEXIBLE PAVEMENTS

SIMPLIE MECHANICAL MODEL FOR HUMAN-STRUCTURE INTERACTION DURING WALKING ALONG A SLENDER STRUCTURE

ONE YEAR OF THE STRUCTURAL HEALTH MONITORING OF PEDRO GÓMEZ BOSQUE FOOTBRIDGE129 VIBRATION MONITORING OF A STEEL-PLATED STRESS-RIBBON FOOTBRIDGE: EFFECTS OF ENVIRONMENTAL AND OPERATIONAL FACTORS ON MODAL PROPERTIES

FINITE ELEMENT MODEL UPDATING OF A LIVELY FOOTBRIDGE

DYNAMIC CHARACTERIZATION, MODELLING AND MODEL UPDATING OF A LIVELY FOOTBRIDGE163 A PROCEDURE TO TRACK VIBRATION MODES UNDER CHANGING EXTERNAL FACTORS:

SERVICEABILITY CONDITIONS OF PEDESTRIAN STRUCTURES USING A SIMPLIFIED MOVING MASS MODEL

SIMULATION OF THE RESPONSE OF A LIVELY FOOTBRIDGE UNDER PEDESTRIAN LOADING WITH TWO TUNED MASS DAMPERS FOR ITS TWO FIRST MODES (2.1HZ AND 2.5HZ)

OPTIMAL DESIGN AND PRACTICAL IMPLEMENTATION OF EDDY-CURRENT TUNED MASS

DAMPERS WITH PERMANENT MAGNETS FOR MULTI-STOREY BUILDINGS.

A NEW PROCEDURE BASED ON TIME DOMAIN INDICATORS FOR OPTIMAL TMD TUNING ON FOOTBRIDGES

ADJUSTABLE TMD (IN STIFFNESS AND DAMPING) USING MAGNETS AND COILS 245

OPTIMAL LOCATION OF A TMD ON A LIVELY FOOTBRIDGE

DYNAMIC CHARACTERIZATION AND SERVICEABILITY ASSESSMENT OF A TIMBER FOOTBRIDGE..269

Informe .

Patente 


\section{CUANTIFICACIÓN DE LA PERCEPCIÓN DE LA VIBRACIÓN EN PASARELAS PEATONALES}

Istrate, M., Lorenzana, A., Ibán, N., y Vasallo, A.

DYNA 87(4): 467-473. 2012/07

Engineering, Multidisciplinary

\begin{tabular}{|c|c|c|c|c|c|}
\hline \multirow[t]{2}{*}{ Factor de impacto 0.237. Rank Q4. } & \multirow{3}{*}{$\begin{array}{l}\text { Titles } \\
\text { ISO: Dyna } \\
\text { JCR Abbrev: DYNA-BILBAl }\end{array}$} & \multirow{2}{*}{$\begin{array}{l}\text { JCR } \\
\text { Year - }\end{array}$} & \multicolumn{3}{|c|}{ ENGINEERING, MULTIDISCIPLINARY } \\
\hline & & & Rank & Quartile & JIF Percentile \\
\hline \multirow{4}{*}{ DOI: http://dx.doi.org/10.6036/4510 } & & 2017 & $76 / 86$ & Q4 & 12.209 \\
\hline & Categories & 2016 & $70 / 85$ & Q4 & 18.235 \\
\hline & ENGINEERING, & 2015 & $77 / 85$ & Q4 & 10.000 \\
\hline & MULTIDISCIPLINARY - & 2014 & $84 / 85$ & Q4 & 1.765 \\
\hline \multirow{3}{*}{ Dyna } & Languages & 2013 & $82 / 87$ & Q4 & 6.322 \\
\hline & Spanish & 2012 & $81 / 90$ & Q4 & 10.556 \\
\hline & & 2011 & $84 / 90$ & Q4 & 7.222 \\
\hline DNE & 6 Issues/Year; & 2010 & $76 / 87$ & Q4 & 13.218 \\
\hline
\end{tabular}
ALAMEDA DE MAZARREDO, BILBAO,SPAIN $69-48009$

SPAIN

\begin{tabular}{|c|c|c|c|c|c|c|c|c|c|c|c|c|c|}
\hline \multicolumn{14}{|c|}{ Key Indicators } \\
\hline \multirow[t]{2}{*}{ Year } & $\begin{array}{r}\text { Total } \\
\text { Cites - } \\
\text { Graph }\end{array}$ & $\begin{array}{c}\text { Journal } \\
\text { Impact } \\
\text { Factor } \\
\text { Graph }\end{array}$ & $\begin{array}{l}\text { Impact } \\
\text { Factor } \\
\text { Without } \\
\text { Journal } \\
\text { Self } \\
\text { Cites }\end{array}$ & $\begin{array}{c}5 \text { Year } \\
\text { Impact } \\
\text { Factor } \\
\text { Graph } \\
\end{array}$ & $\begin{array}{l}\text { Immediacy } \\
\text { Index } \\
\text { Graph }\end{array}$ & $\begin{array}{l}\text { Citable } \\
\text { Items } \\
\text { Graph }\end{array}$ & $\begin{array}{l}\text { Cited } \\
\text { Half- } \\
\text { Life } \\
\text { Graph } \\
\end{array}$ & $\begin{array}{l}\text { Citing } \\
\text { Half- } \\
\text { Life } \\
\text { Graph }\end{array}$ & $\begin{array}{c}\text { Eigenfacto } \\
\text { Score } \\
\text { Graph }\end{array}$ & $\begin{array}{c}\text { Article } \\
\text { Influence } \\
\text { Score } \\
\text { Graph }\end{array}$ & $\begin{array}{c}\% \\
\text { Articles } \\
\text { in Citable } \\
\text { Items } \\
\text { Graph }\end{array}$ & $\begin{array}{c}\text { Normalized } \\
\text { Eigenfacto } \\
\text { Graph }\end{array}$ & $\begin{array}{c}\text { Average } \\
\text { JIF } \\
\text { Percentile } \\
\text { Graph }\end{array}$ \\
\hline & & & Graph & & & & & & & & & & \\
\hline 2017 & 139 & 0.500 & 0.384 & 0.288 & 0.105 & 76 & 3.6 & 7.9 & $0.00 \ldots$ & 0.040 & 100.00 & $0.01 \ldots$ & 12.209 \\
\hline 2016 & 128 & 0.541 & 0.423 & 0.319 & 0.127 & 55 & 2.9 & 8.7 & $0.00 \ldots$ & 0.055 & 100.00 & $0.02 \ldots$ & 18.235 \\
\hline 2015 & 88 & 0.302 & 0.232 & 0.234 & 0.100 & 50 & Not ... & 8.0 & $0.00 \ldots$ & 0.038 & 100.00 & $0.01 \ldots$ & 10.000 \\
\hline 2014 & 65 & 0.179 & 0116 & 0167 & 0031 & 65 & Not_. & 89 & 0.00 & 0.032 & 10000 & 0.01 & 1765 \\
\hline 2012 & 64 & 0.237 & 0.149 & 0.160 & 0.049 & 61 & Not. & 7.2 & 0.00 & 0.030 & 98.36 & Not. & 10.556 \\
\hline 2013 & 54 & 0.200 & 0.108 & 0.143 & 0.039 & 51 & Not ... & 8.0 & $0.00 \ldots$ & 0.028 & 100.00 & $0.01 \ldots$ & 6.322 \\
\hline 2011 & 50 & 0.171 & 0.059 & Not ... & 0.034 & 59 & Not ... & 8.3 & $0.00 \ldots$ & Not ... & 100.00 & Not ... & 7.222 \\
\hline 2010 & 38 & 0.144 & 0.050 & Not $\ldots$ & 0.036 & 55 & Not $\ldots$ & 7.2 & $0.00 \ldots$ & Not ... & 100.00 & Not ... & 13.218 \\
\hline
\end{tabular}

\begin{tabular}{c|c|c|c|} 
Aportaciones: & Experimentación & Procesado & Edición \\
\hline \multirow{2}{*}{} & Instrumentación & Matlab & Tablas \\
Registros & Excel & Gráficas \\
& Tests & Sigview & Imágenes \\
\cline { 2 - 4 } & \multicolumn{2}{|c}{}
\end{tabular}




\section{Cuantificación de la percepción de la vibración en pasarelas peatonales}

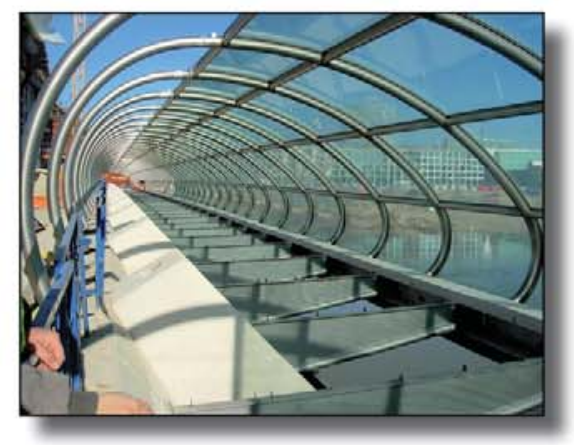

\author{
Melania Vasilica Istrate \\ Antolin Lorenzana lban \\ Norberto Ibán Lorenzana \\ Ali Vasallo Belver \\ Ingeniero Industrial \\ Dr. Ingeniero Industrial \\ Ingeniero Técnico Industria \\ Dr. Ingeniero Industrial
}

Centro Tecnológico CARTIF. División de Ingeniería Mecánica. Parque Tecnológico de Boecillo, parcela 205-47151 Valladolid. Tfno: +34983546504. melisł@cartif.es UNIVERSIDAD DE VALLADOLID. ITAP. Paseo del Cauce, 59 - 47011 Valladolid. Tfno: +34 983 423313. ali@eii.uva.es

\section{QUANTIFYING FOOTBRIDGES SERVICEABILITY}

\section{ABSTRACT}

- Modern pedestrian bridges are very often slender and very flexible structures, where the first natural frequencies of vibration may fall close to dominant frequencies of the dynamic excitation due to walking or running. Aesthetic, technical and technological developments lead to ever more slender, flexible and low damped footbridges and, as a consequence, they can vibrate significantly even under a single person.

Some codes and guidelines establish acceptable values in terms of acceleration functions. In many of these codes, dynamic problems are addressed by defining limits for the natural frequencies of the structures or for the accelerations associated with pedestrian-induced vibrations. Such approaches are usually conservative and fail to deal with all the parameters relevant to human sensitivity to vibrations, which is highly subjective. This, together with the fact that the natural frequencies and accelerations calculated by analytical or numerical methods are subject to uncertainties, may hinder pedestrian bridge design.

In general, the individual judgement whether vibrations are disturbing or not are based on psychological parameters and can lead to different limits, as certain persons can perceive vibrations without being discomforted by them. Some of these parameters are difficult to quantify or are highly subjective. They include the number of simullaneous users, frequency of use, pedestrians' activity, flexibility of the pavement, time of exposure, if vibration is expected or not, etc. In this work the vibration perception is addressed and certain applied approaches are presented.

- Key Words: pedestrian bridges, vibration, perception, discomfort, serviceability.

\section{RESUMEN}

Desde el punto de vista del diseño estructural la tendencia actual -en lo que a pasarelas peatonales se refiere- es hacia estructuras ligeras y vistosas que en ocasiones tienen modos propios de vibración dentro del rango susceptible de ser excitado por los viandantes. Aunque las fuerzas inducidas por los peatones en movimiento son de baja intensidad. cuando su frecuencia coincide con alguna de las naturales de la pasarela, pueden provocar movimientos significativos cuando ésta es ligera y poco amortiguada. Este comportamiento dinámico es apreciado por los distintos usuarios y puede provocar cierta incomodidad.

En algunas normativas, recomendaciones y guias de diseño se dan pautas para estimar esta incomodidad mediante distintos indicadores, si bien su utilidad es limitada al depender de distintos factores, algunos dificilmente cuantificables y otros incluso subjetivos. Por tanto, es difícil estimar la adecuación en servicio en las etapas de diseño y cálculo por simulación, $y$, en ocasiones, tras la construcción de la pasarela, podrian ser necesarias intervenciones para limitar los movimientos que experimenta ante cargas normales de uso. Entre los factores que deben ser tenidos en cuenta se tiene el número de usuarios, su actividad (parados, andar, correr...) y el ritmo de la misma, la flexibilidad del pavimento, el tipo de barandillas y 
la visibilidad a través de ellas, la altura sobre el suelo, la previsión del movimiento esperado por el usuario, etc.

En este trabajo se presenta una revisión del estado actual del arte y se lleva a cabo una valoración y comparación critica de las diversas metodologías y criterios, mostrando los resultados obtenidos para ciertos estudios aplicados a casos concretos.

Palabras Clave: pasarelas peatonales, vibración, percepción, disconfort, aptitud en servicio.

\section{INTRODUCCIÓN}

Es conocido que las pasarelas peatonales esbeltas son propensas a vibrar de forma apreciable en condiciones de servicio, es decir, cuando son transitadas por los viandantes En la actualidad este comportamiento se ha acentuado por dos razones principalmente. Por una parte, el desarrollo de los materiales de construcción con mayor resistencia especifica, que lleva a que la masa modal de la estructura sea baja, siendo su relación con la masa de los viandantes cada vez menor. Por otra, la tendencia en los países desarrollados hacia ciudades más accesibles, lo que demanda pasos sobre carreteras y ríos que sean no solo funcionales, sino también atractivos. Esto lleva a concepciones estructurales singulares donde en ocasiones lo que prima es la estética en detrimento de la racionalidad ya que a menudo [1] se pasan por alto ciertos principios clásicos del diseño resistente. En la Tabla 1 se clasifican y enumeran, entre otros, distintos factores que pueden intervenir en la percepción de movimientos y oscilaciones en este tipo de estructuras.

Este trabajo se centra en el estudio de varios indicadores propuestos por las distintas guias de diseño para cuantificar la adecuación al servicio de las pasarelas peatonales. En este sentido se realiza - a través de un caso práctico - una valoración critica y una discusión de potenciales factores que deben ser tenidos en cuenta, evidenciando la necesidad de completar los criterios de lasnormativas actuales. Una versión extendida de esta introducción, junto con la presentación de los antecedentes y un resumen de las principales normativas aplicables a pasarelas se pueden consultar en este enlace: http://www. revistadyna.com/dyna/documentos/pdfs/ adic/4510 2.pdf

En la Tabla 2 se resumen las indicaciones más relevantes de algunas de las normas y guias de diseño. Siguiendo el eurocódigo [2], si la pasarela no tiene frecuencias naturales menores de $5 \mathrm{~Hz}$ en la dirección vertical, se puede considerar que es adecuada al uso y no son necesarias comprobaciones

\begin{tabular}{|c|l|}
\hline Factores fisicos & $\begin{array}{l}\text { - Caracteristicas estructurales, (estáticas y dinámicas como rigidez, } \\
\text { frecuencias propias, modos, amortiguamientos y masas modales) } \\
\text { - Número de usuarios y actividad de los mismos (andar, correr, ...) } \\
\text { - Tipo de pavimento }\end{array}$ \\
\hline \multirow{3}{*}{ Factores fisiológicos del viandante } & $\begin{array}{l}\text { - Biomecánica y Biometría (sexo, constitución, peso, ritmo, características } \\
\text { conductuales, sensibilidad sensorial, ...) } \\
\text { - Postura, tipo de calzado, si va cargado o no,... } \\
\text { - Tiempo de exposición }\end{array}$ \\
\hline Factores psicológicos & $\begin{array}{l}\text { - Estado de ánimo } \\
\text { - Movimiento esperado o no } \\
\text { - Comentarios de otros usuarios } \\
\text { - Indicios visuales (transparencia y altura de las barandillas y vallas de } \\
\text { protección, altura sobre el suelo, cercanía de otras construcciones, ...) } \\
\text { - Preocupación por la integridad estructural }\end{array}$ \\
\hline
\end{tabular}

Tabla 1: Factores que pueden afedar a la percepción de la incomodidad

\begin{tabular}{|l|c|c|c|c|}
\hline \multirow{2}{*}{ Normativas } & \multicolumn{2}{|c|}{ Frecuencias criticas (Hz) } & \multicolumn{2}{c|}{ Aceleraciones máximas de confort (m/s') } \\
\cline { 2 - 5 } & Vertical & Lateral & Vertical & Lateral \\
\hline IS0 10137 [4] & $1.7 \div 2.3$ & & $60 \mathrm{X}$ umbral vertical & $30 \mathrm{X}$ umbral horizontal \\
\hline Eurocódigo (ENV1995) [2] & $<5$ & $<2.5$ & 0.7 & 0.2 \\
\hline EAE 2011(España) [5] & $1.6 \div 2.4$ & \multirow{2}{*}{$0.6 \div 1.2$} & $\min \left(0.5 \sqrt{ } f_{v}, 0.7\right)$ & $0.2(0.4)$ \\
& $3.5 \div 4.5$ & & $0.5 \sqrt{f_{v}}$ & \\
\hline BS 5400 (Reino Unido) [6] & $<5$ & & $0.5,1.0,2.5$ & $0.15,0.3,0.8$ \\
\hline SETRA (Francia) [7] & $1.0 \div 5.0$ & & & \\
\hline
\end{tabular}

Tabh 2: Frecuencies ufiticas y vadores de acelercción mizxima de confort 
adicionales. En direcciones transversales o torsionales, el rango a evitar está por debajo de $2.5 \mathrm{~Hz}$. Es difícil, con diseños resistentes racionales, no tener ninguna frecuencia natural significativa en los rangos indicados [3]. En este caso, hay que garantizar que las aceleraciones máximas en condiciones normales de uso no superan ciertos valores límite. Dicho eurocódigo establece $0.7 \mathrm{~m} / \mathrm{s}^{2}$ para vibraciones verticales y $0.2 \mathrm{~m} / \mathrm{s}^{2}$ para las laterales. Estos límites, en algunas normativas, se imponen en función de $f$, siendo $f$ la frecuencia natural de la estructura en dirección vertical más susceptible de ser excitada por los viandantes (andando o corriendo)

En España, las referencias normativas más relevantes se recogen en las recomendaciones RPX-1995 [8] y en las recientes instrucciones EAE-11 [5] y LAP-11 [9]. En la primera se establece como aceleración vertical máxima el valor de $0.5 \sqrt{ } f_{v} \mathrm{~m} / \mathrm{s}^{2}$. Para las frecuencias habituales en puentes multiuso se suelen clasificar las vibraciones como ligeramente perceptibles por debajo de $0.034 \mathrm{~m} / \mathrm{s}^{2}$, hasta $0.1 \mathrm{~m} / \mathrm{s}^{2}$ como claramente perceptibles, hasta $0.55 \mathrm{~m} / \mathrm{s}^{2}$ como molestas y hasta $1.8 \mathrm{~m} / \mathrm{s}^{2}$ como intolerables. Valores superiores deberian evitarse. La Instrucción de Acero Estructural EAE-11 se limita a indicar que se deben evitar frecuencias verticales en los rangos $(1.6 \mathrm{~Hz}, 2.4 \mathrm{~Hz})$ y $(3.5 \mathrm{~Hz}, 4.5 \mathrm{~Hz})$ y que, en caso de no ser posible, no se superen los $0.5 \bullet \sqrt{ } f$ olos $0.7 \mathrm{~m} / \mathrm{s}^{2}$ cuando sea transitada por un único peatón andando o corriendo. En la dirección horizontal el rango de frecuencias a evitar es $0.6 \mathrm{~Hz} \div 1.2 \mathrm{~Hz}$ y que no se superen $\operatorname{los} 0.2 \mathrm{~m} / \mathrm{s}^{2}$ o, excepcionalmente, $\operatorname{los} 0.4 \mathrm{~m} / \mathrm{s}^{2}$. La Instrucción IAP-11 sobre acciones a considerar en el proyecto de puentes de carretera, en su apartado 7.2 .2 relativo a pasarelas peatonales, añade valores de referencia de aceleraciones verticales para el confort de los peatones, siendo el confort máximo por debajo de $0.5 \mathrm{~m} / \mathrm{s}^{2}$, medio hasta $1.0 \mathrm{~m} / \mathrm{s}^{2}$ y minimo hasta $2.5 \mathrm{~m} / \mathrm{s}^{2}$. Por encima lo clasifica como "no aceptable". En la dirección horizontal los valores indicados son $0.10,0.30 \mathrm{y} 0.80 \mathrm{~m} / \mathrm{s}^{2}$, respectivamente

En la guia francesa SETRA [7], enfocada especificamente hacia pasarelas ligeras, se definen 4 rangos de frecuencias según el riesgo asumible y se establecen tres niveles de confort en función de las aceleraciones máximas, si bien la adecuación al uso de la pasarela depende del tráfico peatonal esperado. Para movimientos verticales, el confort es máximo por debajo de $0.5 \mathrm{~m} / \mathrm{s}^{2}$, medio entre $0.5 \mathrm{y} 1.0 \mathrm{~m} / \mathrm{s}^{2}$ y minimo entre 1.0 y $2.5 \mathrm{~m} / \mathrm{s}^{2}$. Por encima de 2.5 se considera inaceptable. Para movimientos laterales los limites son $0.15,0.30$ y 0.80 respectivamente. Los rangos según las frecuencias en la dirección vertical son: poco riesgo entre 2.6 y $5.0 \mathrm{~Hz}$, riesgo medio entre 1.0 y 1.7 y entre 2.1 y $2.6 \mathrm{~Hz}$ y alto riesgo entre 1.7 y $2.1 \mathrm{~Hz}$. En la dirección lateral son: bajo entre 1.3 y $2.5 \mathrm{~Hz}$, medio entre 0.3 y 0.5 y entre 1.1 y 1.3 y alto entre 0.5 y $1.1 \mathrm{~Hz}$.

Estas aceleraciones son dificiles de estimar en etapas de diseño. A la dificultad de estimar las excitaciones se añade la usual complejidad estructural y la dificil estimación de las propiedades dinámicas de los materiales en servicio, incluyendo cimentaciones, condiciones de apoyo, efecto de las barandillas, del pavimento, de la existencia de bancos, farolas, etc. Aun asi, muchas de estas normativas indican métodos aproximados para estimar estas aceleraciones. Pero tras la aplicación de distintos métodos a una misma pasarela se pueden obtener, según se muestra en el trabajo de Pavic [10], resultados que difieren entre sí en factores mayores de 4 , lo que en cierto modo da una idea de su escasa utilidad.

Más allá de estos métodos aproximados podría intentarse una simulación mediante métodos numéricos como el Método de los Elementos Finitos. Aunque la capacidad de cálculo computacional es alta, para la resolución del problema dinámico se necesitan datos que no siempre son fáciles de estimar en la etapa de diseño. Algunos de estos parámetros son críticos, como el amortiguamiento estructural, pudiendo resultar que a pesar de que las simulaciones numéricas hayan sido satisfactorias, tras la construcción, la estructura presente valores ligeramente distintos de esos parámetros y aparezcan problemas funcionales que demanden rediseño o medidas correctoras.

Además, hay que tener en cuenta que puede haber comportamientos de interacción [11] y propiedades locales que no pueden ser incorporadas en el modelo de forma sencilla. Asi, pudiera ocurrir que una determinada pasarela tenga carriles con pavimentos distintos, uno rigido y otro flexible. A pesar de que el comportamiento estructural es exactamente el mismo, las sensaciones percibidas por un viandante son distintas dependiendo de si está en la zona de pavimento rigido o en la de flexible.

\section{EVALUACIÓN DEL CONFORT EN PASARELAS}

Dado su interés social y comercial, son numerosos los trabajos de investigación en los que se proponen, más allá de las normativas, métodos para determinar el confort (o su inversa, la incomodidad) de determinados medios de transporte incluyendo aquellos donde está permitido que los viajeros permanezcan de pie. Tras estos estudios se pueden obtener conclusiones sobre la influencia en el confort de distintos factores como las irregularidades de la carretera o de la vía, el sistema de suspensión del vehículo, el régimen del motor, la postura o puntos de apoyo, etc. Estas conclusiones pueden interesar tanto a los responsables de las vias y carreteras como a los fabricantes de los vehículos, además de a los usuarios finales. Con intenciones similares comienzan a aparecer estudios aplicados a forjados de grandes luces [1215] y a pasarelas peatonales [16-18], sistemas estructurales ambos propensos a desarrollar vibraciones perceptibles bajo cargas de servicio.

Respecto a las pasarelas, cabe destacar los trabajos de Hawryszkow [17], quien desarrolla distintos experimentos con 100 usuarios de distinta constitución transitando a distintos ritmos (andar, correr lento y correr rápido a las frecuencias promedio indicadas en la Tabla 3 , junto con su desviación estándar) sobre distintas tipologías de pasarelas ligeras, de entre 25 y $90 \mathrm{~m}$ de luz, de las normalmente 
construidas en entornos urbanos europeos. Las pasarelas se clasificaron en 4 grupos en función de la estimación de la actividad de los usuarios (porcentaje esperado de personas paradas, andando, corriendo lento o corriendo rápido). En el grupo 1, propio de entornos turísticos, se considera que el $30 \%$ de los ocupantes están parados y el $70 \%$ andando. En el grupo 2, propio de zonas verdes, se toma el $10 \%$ parado, el $85 \%$ andando y el $5 \%$ corriendo lento. En el grupo 3, relativo a lugares de paso sobre carreteras o pequeños ríos en zonas urbanas, todos los usuarios se suponen andando y en el grupo 4 , asociado con zonas deportivas, los porcentajes considerados son $30 \%$ andando, $60 \%$ corriendo lento y $10 \%$ corriendo rápido.

En todos estos escenarios y con distintas ocupaciones, se hicieron ensayos para relacionar la percepción de comodidad (mediante encuesta) de dichos usuarios con la aceleración máxima en el centro del vano de cada pasarela (medida mediante el correspondiente acelerómetro). Los resultados se muestran en la Tabla 4, donde se dan tres valores de aceleración $\left(\mathrm{a}_{\min }, \mathrm{a}_{\text {med }}, \mathrm{a}_{\max }\right)$ en base a los cuales se obtienen 4 clasificaciones. Por debajo de $a_{\min }$ el movimiento no es causa de incomodidad. Entre $\mathrm{a}_{\text {min }} \mathrm{y}_{\text {med }}$ ("normal") la percepción del movimiento no es causa de inseguridad, pero comienza a llamar la atención, entre $\mathrm{a}_{\text {med }}$ y $\mathrm{a}_{\max }$ ("incómoda") algunos usuarios se preocuparían y serían reticentes a volver a cruzar por la pasarela y por encima de $\mathrm{a}_{\max }$ la pasarela se podría calificar de no apta para el uso peatonal. Los tres valores indicados se interpretan según la Tabla 5 , en función de las reacciones de los usuarios que están andando o parados en el centro del vano.

\section{CASO PRÁCTICO}

A modo de referencia numérica, se indican seguidamente los valores obtenidos experimentalmente en una pasarela metálica, de $51 \mathrm{~m}$ de vano y $18 \mathrm{Tn}$ de masa modal en el primer modo de flexión, con apreciable comportamiento vibratorio, cuando es transitada por 1,4 y 15 viandantes, distribuidos aleatoriamente, simulando condiciones normales de uso (casos a, cy d). La pasarela tiene varias frecuencias naturales en rangos susceptibles de ser excitados por los distintos viandantes, destacando la primera de flexión a $3.5 \mathrm{~Hz}$, excitable andando a 105 pasos por minuto o corriendo a $210 \mathrm{ppm}$. Por ello se ha considerado representativo mostrar también la respuesta del centro del vano cuando un único viandante camina a $105 \mathrm{ppm}$ (caso b). En la Fig. (1) se presentan las aceleraciones, para cada caso, durante dos segundos cualesquiera (de los 245 s registrados) y en la Fig. (2) se muestran los correspondientes indicadores, junto con los límites establecidos según la norma ISO 2631 [19].

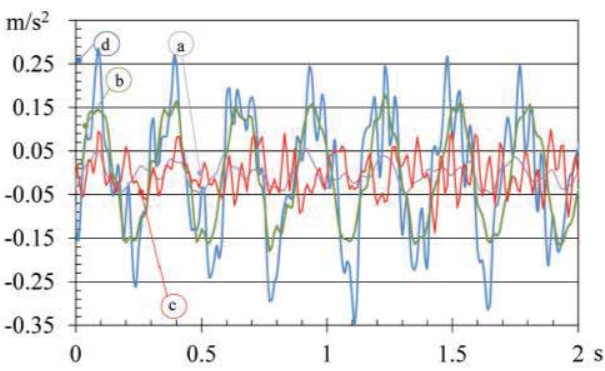

Fig. 1: Registros de aceleración en el centro del vano en los disfintos casos de uso

\begin{tabular}{|c|c|c|c|}
\hline & Frecuencia promedio $(\mathrm{Hz})$ & Desviación estándar $(\mathrm{Hz})$ & $\begin{array}{c}\text { Rango usual }(90 \%) \\
\text { (pasos por minuto) }\end{array}$ \\
\hline Andar & 1.88 & 0.18 & {$[95,130]$} \\
\hline Correr lento & 2.70 & 0.27 & {$[135,189]$} \\
\hline Correr rápido & 3.41 & 0.52 & {$[153,256]$} \\
\hline
\end{tabular}

Tabla 3: Frecuencias y rongos usuales de la locomoción humana

\begin{tabular}{|l|l|c|c|c|}
\hline & \multicolumn{4}{|c|}{ Uso de la pasarela (\%parado, \%andando, \%corriendo lento, \%corriendo rápido) } \\
\hline & $\begin{array}{c}1: \text { Entorno turistico } \\
(30 / 70 / 0 / 0)\end{array}$ & $\begin{array}{c}2: \text { Zonas verdes } \\
(10 / 85 / 5 / 0)\end{array}$ & $\begin{array}{c}3: \text { Pasos urbanos } \\
(0 / 100 / 0 / 0)\end{array}$ & $\begin{array}{c}4: \text { Zonas deportivas } \\
(0 / 30 / 60 / 10)\end{array}$ \\
\hline$\left(\mathrm{a}_{\min } / \mathrm{a}_{\operatorname{med}} / \mathrm{a}_{\max }\right)$ & $(0.50 / 1.01 / 1.78)$ & $(0.67 / 1.31 / 2.18)$ & $(0.70 / 1.40 / 2.30)$ & $(1.39 / 2.50 / 4.75)$ \\
\hline
\end{tabular}

Tobla 4: Límites de aceleroción $\left(\mathrm{m} / \mathrm{s}^{2}\right)$ según el uso

\begin{tabular}{|l|c|c|}
\hline & Usuarios andando & Usuarios parados \\
\hline$a_{\min }$ & \begin{tabular}{c} 
Perceptible, pero no desvia la atención \\
\hline$a_{\operatorname{med}}$
\end{tabular} & $\begin{array}{c}\text { La lectura o el uso de móviles se hace difícil. } \\
\text { Tendencia a asirse en las baran falsos pasos }\end{array}$ \\
\hline$a_{\max }$ & $\begin{array}{c}\text { Sensación de peligro de caerse. Tendencia a pararse y asirse a las } \\
\text { barandillas. }\end{array}$ & \begin{tabular}{c} 
Inestabilidad y sensación de inseguridad. \\
\hline
\end{tabular} \\
\hline
\end{tabular}

Tabla 5: Efectos del movimiento de la pasarela sobre los usuarios 

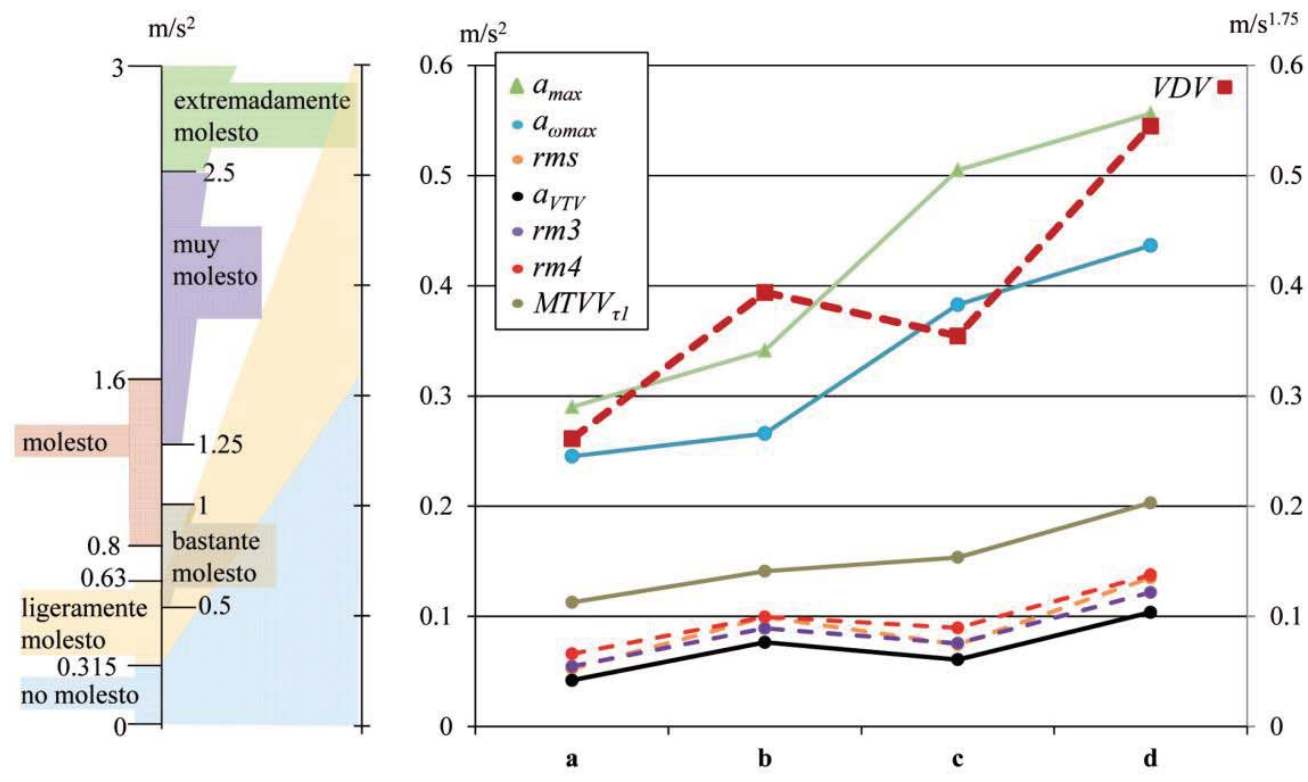

Fig. 2: Límites según ISO 2631 y valor de los indicadores para las distintas condiciones de uso

Además del acelerómetro empleado para el registro en centro del vano, uno de los viandantes (Fig. 3, izda.), de $75 \mathrm{~kg}$, iba equipado con otros 3 acelerómetros situados en su puntera $(\mathrm{P})$, talón $(\mathrm{T})$ y cadera $(\mathrm{C})$, como se muestra simbólicamente en la Fig. (3) junto con el sistema de ejes usado.
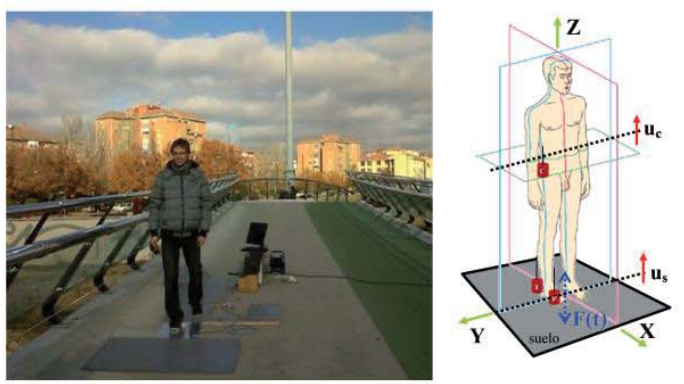

Fig. 3: Instrumentación y ensayo con viandante sensorizado (izda.) y sistema de referencia para los acelerómetros (dcha.)

En la Fig. (4) se muestran los registros en P, T y C correspondientes a un paso representativo. También se incluyen en la misma figura las fuerzas (en relación a su peso) ejercidas por el viandante sobre la pasarela, tanto en la dirección vertical $\mathbf{Z}$ como frontal $\mathbf{X}$ y lateral $\mathbf{Y}$ [18]. En la Tabla 6 se presentan el valor máximo y promedio $\mathrm{rms}$ (durante 60s) de las aceleraciones registradas en $\mathrm{P}, \mathrm{T}$ y $\mathrm{C}$.

\begin{tabular}{|c|c|c|}
\hline & $\begin{array}{c}\mathrm{rms} \\
\left(\mathrm{m} / \mathrm{s}^{2}\right)\end{array}$ & $\begin{array}{c}a_{\max } \\
\left(\mathrm{m} / \mathrm{s}^{2}\right)\end{array}$ \\
\hline Puntera $(\mathrm{P})$ & 11.31 & 82.14 \\
\hline Talón $(\mathrm{T})$ & 9.56 & 68.36 \\
\hline Cadera $(\mathrm{C})$ & 3.23 & 14.33 \\
\hline
\end{tabular}

Tabla 6: Valores promedio y máximo de las aceleraciones durante un paso

Del análisis de los datos de la Fig. (2) y Tabla 6 se puede concluir que incluso siendo las aceleraciones de las distintas partes del cuerpo 1 o 2 órdenes de magnitud superiores a las que experimenta la estructura, los viandantes aprecian el movimiento de ésta incluso bajo condiciones normales de uso. Nótese que con esta diferencia de magnitudes, los valores de los distintos indicadores aplicados a los registros de $\mathrm{P}$, T y $\mathrm{C}$ no revelarían diferencias significativas entre los distintos casos de uso (a, b, c y d). Además, la incomodidad apreciada por los autores es proporcional a los indicadores obtenidos de los registros en el centro del vano (y no, en principio, en las distintas partes del cuerpo), lo que en cierto modo valida la metodología promulgada por las normativas y guías de diseño.

Analizando los distintos indicadores mostrados en la Fig. (2) se pueden extraer diversas conclusiones. En primer lugar se tiene que todos los indicadores crecen a medida que aumenta el número de viandantes (casos a, c y d) si bien no en proporción lineal, debido a que no se sincronizan entre ellos ni con el movimiento de la pasarela. 


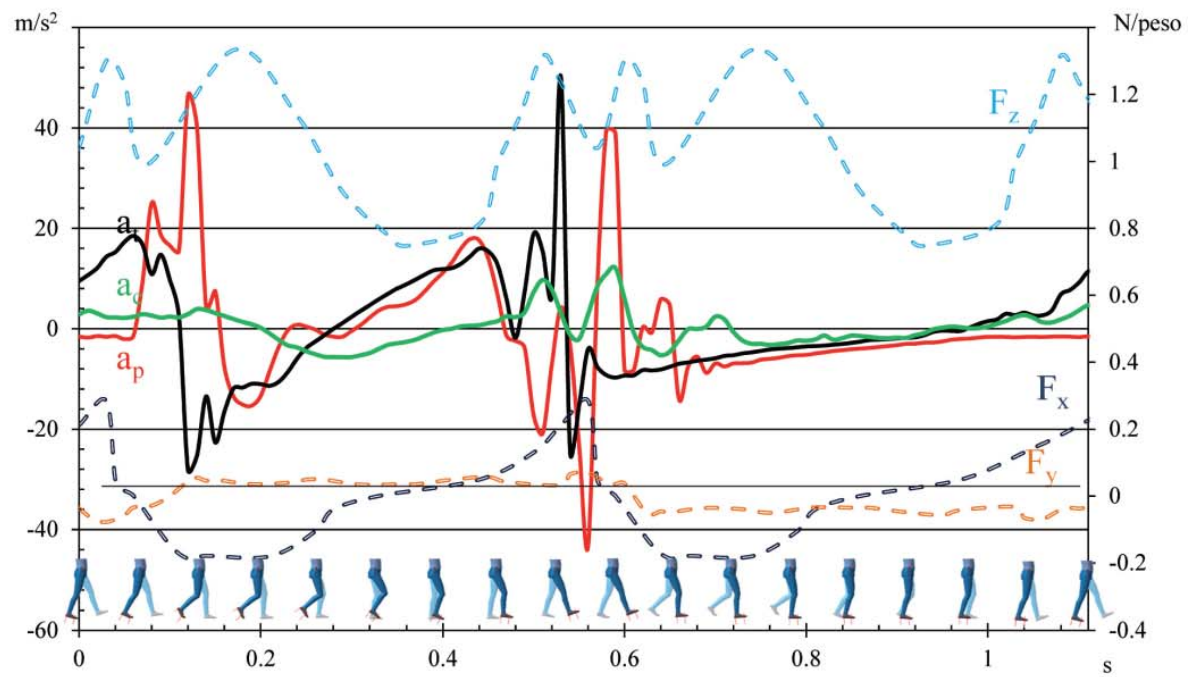

Fig. 4: Aceleraciones y fuerzas durante un paso completo

Por otra parte, cuando la frecuencia de paso coincide con la natural de la estructura, los efectos son significativamente mayores y todos los indicadores en el caso b son mayores que en el caso a. Aunque las aceleraciones máximas (y el $\left.M T V V_{\tau}\right)$ para el caso $\mathbf{c}$ son mayores que para el caso $\mathbf{b}$, los promedios potenciales $(r m \lambda, \lambda=2,3,4)$ son menores y el $V D V$ también (ya que $V D V=T^{1 / 4} \bullet r m 4$ ). En este caso, según qué indicador se use, podría concluirse que el movimiento que se induce en el caso b es menos incómodo (o más) que el inducido en c. La apreciación subjetiva de los autores es que $\mathbf{c}$ no es tan incómodo como b, dando más importancia a los indicadores promediados (y $V D V$ ) que a los valores pico $\left(\mathrm{y} M T V V_{\tau}\right)$. Por último, destacar que para los anchos de ventanas considerados $(0.5,1$ y $2 \mathrm{~s}) M T V V_{\tau}$ no cambia de tendencia y solo para anchos mayores (del orden de 10s) comienza a tomar valores menores de $M T V V_{\tau}$ el caso c que el b.

Con los valores obtenidos, y haciendo uso de los distintos criterios de confortabilidad comentados en este trabajo, se concluye que según la norma ISO10137 se supera el límite de confort $\left(\mathrm{a}_{\max }>0.3 \mathrm{~m} / \mathrm{s}^{2}\right.$, considerando la frecuencia predominante de $3.5 \mathrm{~Hz}$ ) en los casos b, c y d. Según la norma ISO2631 ninguno de los casos llega a ser molesto, ya que en todos $a_{V T V}$ es menor de $0.315 \mathrm{~m} / \mathrm{s}^{2}$. Sin embargo, como en todos los casos $M T V V_{\tau}$ es mayor que $1.5 a_{V T V}$ sería recomendable no comparar en términos de $a_{V T V}$ sino de $M T V V_{\tau}$. Respecto a $V D V$, considerando el mismo nivel de vibración durante $8 \mathrm{~h}$ (en vez de los 245 s considerados) se tendrían valores de $0.86,1.30,1.17$ y 1.79 , todos ellos molestos para trabajos sedentarios pero muy por debajo de $\operatorname{los} 8.5 \mathrm{~m} / \mathrm{s}^{1.75}$, considerado el límite a partir del cual debieran tomarse medidas.
Respecto a las indicaciones de las normas y guías enumeradas en el apartado 2 tenemos que en ningún caso se superan los $0.86 \mathrm{~m} / \mathrm{s}^{2}$ recomendados en RPX o BS, ni tampoco los $0.7 \mathrm{~m} / \mathrm{s}^{2}$ indicados en los eurocódigos y en la EAE-11. Según SETRA, la pasarela bajo estudio es de "poco riesgo" al tener la primera frecuencia propia por encima de $2.6 \mathrm{~Hz}$ y para los casos de uso a y b su nivel de confort es máximo (por debajo de $0.5 \mathrm{~m} / \mathrm{s}^{2}$ ) y para los casos c y d es medio (entre $0.5 \mathrm{y} 1 \mathrm{~m} / \mathrm{s}^{2}$ ). Similares conclusiones se obtendrían de la aplicación de la IAP-11, mientras que según ISO 2631 tendríamos que los casos a y b son "no molestos" y los c y d "ligeramente molestos".

Según la metodología propuesta por Hawryszkow y esbozada en el apartado 4, se tiene que si se clasifica como del tipo 2, en ningún caso su movimiento es causa de incomodidad, aunque si se clasificara como del tipo 1 podría considerarse como incómoda (pero no insegura) en los casos de uso c y d.

\section{CONCLUSIONES}

La cuantificación de la incomodidad en pasarelas peatonales es compleja y no hay consenso en la comunidad científica sobre las magnitudes que intervienen, dónde medirlas ni en qué casos de uso (número y actividad de los viandantes). A pesar de ello, los distintos indicadores disponibles, basados en las aceleraciones del centro del vano, permiten comparar entre sí distintos casos de uso y correlacionar los valores obtenidos con los baremos preestablecidos.

Dada la diversidad de indicadores y baremos, ocurre que una misma pasarela puede ser clasificada como "cómoda" 
- "incómoda" según cuales se usen. Con los estudios realizados se pone de manifiesto que los indicadores sugeridos en las actuales normativas y guias de diseño deben ser completados, no solo para tener en cuenta factores cuantificables como la fase o la flexibilidad del pavimento, sino también para incluir, en la medida de las posibilidades, alguno de los aspectos subjetivos de los comentados en este trabajo

El desarrollo de nuevas metodologias de caracterización dinámica de pasarelas, que incorporen aspectos de percepción como los tratados en este trabajo, será de gran utilidad no sólo en las etapas finales de evaluación (para cada procedimiento de ensayo que se pueda definir) sino también en las etapas de concepción estructural y dimensionamiento resistente, con potenciales consecuencias durante la vida útil de la pasarela.

\section{AGRADECIMENTOS}

Los contenidos de esta comunicación han sido parcialmente obtenidos en el marco del proyecto de investigación BIA2011-28493-C02-02 titulado "Técnicas experimentales y numéricas para la valoración del comportamiento vibratorio de pasarelas peatonales", financiado por el Ministerio de Ciencia e Innovación.

\section{BIBLIOGRAFIA}

[1] Flaga A, Pantak M. "Vibration comfort criteria for pedestrians on footbridges". En: 3th International Conference Footbridge (Porto 16-19 July 2008), 2008.

[2] European Standard Norme Basis of structural design. Annex A2. Application for bridges. EN 1990-A2. Brussels: European Committee for Standardization, 2005.

[3] Ruiwamba J; Tanner P; Bellod JL; et al. "Towards a consistent design method: A proposal for a new steel and composite bridge design code for Spain". Nordic Steel Construction Conference "95. 1995. Vol. 1-2 p.337-344

[4] International Standards Organization. Bases for design of structure, serviceability of buildings and pedestrian walkways against vibration. ISO 10137:2004. Geneva, 2005.

[5] Ministerio de Fomento. Instrucción de acero estructural (EAE). Real Decreto 751/2011. Madrid: BOE (Boletin Oficial del Estado) Reino de España, 2011.

[6] BS5400. Steel, concrete and composite bridges. Part3. Code of practice for design of steel bridges. BS5400. BS5400. 1982.

[7] SETRA. Technical guide Footbridge: Assesment of vibration behavior of footbridges under pedestrian loading, Bagneux: Setra, 2006.

[8] Ministerio de Obras Públicas, Transporte y Medio Ambiente. Recomendaciones para el proyecto de puentes mixtos para carreteras. RPX. España: Ministerio de Obras Públicas, Transporte y Medio Ambiente, Octubre 1995.
[9] Ministerio de Fomento. Instrucción sobre las acciones a considerar en el proyecto de puentes de carretera (IAP-11). Orden FOM/2842/2011. Madrid, 2011.

[10] Pavic A et al. "Vertical crowd dynamic action on footbridges: review of design guidelines and their application". En: 4th International Conference Footbridge, (Wroclow 6-8 July 2011), 2011.

[11] Zivanovic S, PavicA, Reynolds P. "Vibration serviceability of footbridges under human-induced excitation: a literature review". Journal of sound and vibration. 2005. Vol.279-1 2 p.1-74. http://dx.doi.org/10.1016/j.jsv.2004.01.019

[12] Smith AL, Hicks S, Devine P. Design of floors for vibration: a new approach. SCI Publication ISBN 10:1-85942-1768, 2007. 354p. ISBN 13:978-1-85942-176-5

[13] Feldmann M, Heinemeyer Ch. "A new approach fort the assessment of human induced vibration of slabs". Bauingenieur. 2010. Vol.85 p.36-44

[14] Maier C., "A probabilistic approach to prognosticate pedestrian induced vibrations of long-span floor systems" Bauingenieur, 2010. Vol.85 p.241-248

[15] Jun C, Xiongxiong S, 2010, "Investigation of as-built vibration serviceability of long-span floor by field measurement under human-induced excitation". En: 2nd Asia-Pacific young researchers and graduates symposium. Advance in Structural Engineering (Hangzhou - China, 2010), 2010. P.19

[16] Casado C, Sebastián J, Muñoz I, et al. "Control de vibraciones en pasarelas peatonales". DYNA Ingenieria e Industria. Julio 2011. Vol.86-3 p.318-327

[17] Hawryszkow P. "Analysis of dynamical sensitivity and comfort of footbridges". En: 4th International Conference Footbridge, (Wroclow 6-8 July 2011), 2011.

[18] Racic V, Pavic A, Brownjohn JMW. "Experimental identification and analytical modelling of human walking forces: Literature review". Journal of Sound And Vibration. 2009. Vol.326-1-2 p.1-49 http://dx.doi.org/10.1016/j.jsv.2009.04.020

[19] Evaluation of human exposure to whole-body vibration. International Standards Organisation, ISO 2631-1. Geneva 1997. 
2. VIBRATION MONITORING OF A STEEL-PLATED STRESS-RIBBON FOOTBRIDGE: UNCERTAINTIES IN THE MODAL ESTIMATION

Soria, J.M., Díaz, I.M., García-Palacios, J., and Ibán, N.

JOURNAL OF BRIDGE ENGINEERING 21(8): C5015002. 2016/01

Engineering, Civil

Factor de impacto 1.476. Rank Q2

DOI: 10.1061/(ASCE) BE.1943-5592.0000830

ISO: J. Bridge Eng. JCR Abbrev: J BRIDGE ENG

JCR Impact Factor

\begin{tabular}{|c|c|c|c|c|c|}
\hline DUI: 10.10 & & & & & \\
\hline & ISO: J. Bridge Eng. & 2016 & $57 / 125$ & Q2 & 54.800 \\
\hline & JCR Abbrev: J BRIDGE ENG & 2015 & $60 / 126$ & Q2 & 52.778 \\
\hline & & 2014 & $54 / 125$ & Q2 & 57.200 \\
\hline & Categories & 2013 & $66 / 124$ & Q3 & 47.177 \\
\hline Iournal of Rridce Encineprina & ENGINEERING, CIVIL - S & 2012 & $61 / 122$ & Q2 & 50.410 \\
\hline journal or Dinge angineering & & 2011 & $65 / 118$ & Q3 & 45.339 \\
\hline ISSN: 1084-0702 & Languages & 2010 & $34 / 115$ & Q2 & 70.870 \\
\hline ASCE-AMER SOC CIVIL ENGINEERS & English & 2009 & $70 / 106$ & Q3 & 34.434 \\
\hline 1801 ALEXANDER BELL DR,RESTON,USAVA 20191-4400 & & 2008 & $69 / 91$ & Q4 & 24.725 \\
\hline USA & 12 issues/Year, & & & & \\
\hline
\end{tabular}

Key Indicators

\begin{tabular}{|c|c|c|c|c|c|c|c|c|c|c|c|c|c|}
\hline \multirow[t]{2}{*}{ Year - } & $\begin{array}{c}\text { Total } \\
\text { Cites } \\
\text { Graph }\end{array}$ & $\begin{array}{c}\text { Journal } \\
\text { Impact } \\
\text { Factor } \\
\text { Graph }\end{array}$ & $\begin{array}{l}\text { Impact } \\
\text { Factor } \\
\text { Without } \\
\text { Journal } \\
\text { Self } \\
\text { Cites }\end{array}$ & $\begin{array}{l}5 \text { Year } \\
\text { Impact } \\
\text { Factor } \\
\text { Graph }\end{array}$ & $\begin{array}{l}\text { Immediacy } \\
\text { Index } \\
\text { Graph }\end{array}$ & $\begin{array}{l}\text { Citable } \\
\text { Items } \\
\text { Graph }\end{array}$ & $\begin{array}{l}\text { Cited } \\
\text { Half- } \\
\text { Life } \\
\text { Graph }\end{array}$ & $\begin{array}{l}\text { Citing } \\
\text { Half- } \\
\text { Life } \\
\text { Graph }\end{array}$ & $\begin{array}{c}\text { Eigenfacto } \\
\text { Score } \\
\text { Graph }\end{array}$ & $\begin{array}{c}\text { Article } \\
\text { Influence } \\
\text { Score } \\
\text { Graph }\end{array}$ & $\begin{array}{c}\% \\
\text { Articles } \\
\text { in Citable } \\
\text { Items } \\
\text { Graph }\end{array}$ & $\begin{array}{c}\text { Normalized } \\
\text { Eigenfacto } \\
\text { Graph }\end{array}$ & $\begin{array}{c}\text { Average } \\
\text { JIF } \\
\text { Percentile } \\
\text { Graph }\end{array}$ \\
\hline & & & Graph & & & & & & & & & & \\
\hline 2017 & 2.721 & 1.454 & 1.146 & 1.881 & 0.239 & 176 & 6.2 & $>10.0$ & 0.00. & 0.522 & 100.00 & 0.56 . & 50.391 \\
\hline 2016 & 2,119 & 1.476 & 1.016 & 1.678 & 0.259 & 197 & 6.4 & 9.9 & 0.00. & 0.464 & 99.49 & 0.43 & 54.800 \\
\hline 2015 & 1,572 & 1.069 & 0.900 & 1.310 & 0.207 & 116 & 7.1 & 9.9 & $0.00 \ldots$ & 0.466 & 98.28 & $0.42 \ldots$ & 52.778 \\
\hline 2014 & 1,330 & 1.065 & 0.853 & 1.231 & 0.138 & 130 & 7.0 & 9.1 & $0.00 \ldots$ & 0.413 & 100.00 & $0.32 \ldots$ & 57.200 \\
\hline 2013 & 1,161 & 0.927 & 0.750 & 1.172 & 0.252 & 131 & 7.2 & 9.7 & $0.00 \ldots$ & 0.510 & 100.00 & $0.35 \ldots$ & 47.177 \\
\hline 2012 & 894 & 0.793 & 0.621 & 0.956 & 0.119 & 101 & 7.1 & 9.6 & $0.00 \ldots$ & 0.442 & 100.00 & Not $\ldots$ & 50.410 \\
\hline 2011 & 660 & 0.623 & 0.434 & 0.784 & 0.165 & 91 & 6.6 & 9.1 & $0.00 \ldots$ & 0.364 & 100.00 & Not $\ldots$ & 45.339 \\
\hline 2010 & 669 & 1.009 & 0.761 & Not ... & 0.342 & 73 & 5.5 & 9.1 & $0.00 \ldots$ & Not ... & 100.00 & Not ... & 70.870 \\
\hline 2009 & 461 & 0.460 & 0.380 & Not $\ldots$ & 0.102 & 49 & 5.5 & 9.7 & $0.00 \ldots$ & Not $\ldots$ & 100.00 & Not $\ldots$ & 34.434 \\
\hline 2008 & 375 & 0.438 & 0.320 & Not ... & 0.094 & 64 & 5.1 & 8.7 & $0.00 \ldots$ & Not ... & 100.00 & Not ... & 24.725 \\
\hline
\end{tabular}

\begin{tabular}{l|l|l|l|} 
Aportaciones: & Experimentación & Procesado & Edición \\
\hline \multirow{2}{*}{} & $\begin{array}{c}\text { Instrumentación } \\
\text { Registros }\end{array}$ & Matlab & Imágenes \\
\cline { 2 - 4 }
\end{tabular}


Case Study

\title{
Vibration Monitoring of a Steel-Plated Stress-Ribbon Footbridge: Uncertainties in the Modal Estimation
}

\author{
José M. Soria ${ }^{1}$; Iván M. Díaz ${ }^{2}$; Jaime H. García-Palacios ${ }^{3}$; and Norberto lbán ${ }^{4}$
}

\begin{abstract}
A low-cost vibration-monitoring system was developed and installed on an urban steel-plated stress-ribbon footbridge. The system continuously measures the acceleration [using 18 triaxial microelectromechanical system (MEMS) accelerometers distributed along the structure), the ambient temperature, and the wind velocity and direction. Automated output-only modal parameter estimation based on the stochastic subspace identification (SSI) was carried out to extract the modal parameters (i.e., the natural frequencies, damping ratios, and modal shapes). Thus, this study analyzed the time evolution of the modal parameters over data monitoring for 1 year. First, for similar environmental/ operational factors, the uncertainties associated with the SSI-based techniques used and to the acceleration records used were studied and quantified. Second, a methodology for tracking the vibration modes was established, because several of them with closely spaced natural frequencies were identified. Third, the modal parameters were correlated against external factors. It has been shown that this stress-ribbon structure is highly sensitive to temperature variations (frequency changes of more than $20 \%$ ) with strongly seasonal and daily trends. Fairly simple dynamic multiple regression models for the lowest persistent vibration modes were derived, and excellent correlations for some of them were obtained. These correlations enable the influence of these uncertainties on modal estimates to be removed, thus facilitating their use as damage-sensitive features. DOI: 10.1061/(ASCE)BE.1943-5592.0000830. ( 2016 American Society of Civil Engineers.
\end{abstract}

Author keywords: Footbridges; Continuous dynamic monitoring; Environmental effects; Operational modal analysis.

\section{Introduction}

The long-term vibration monitoring of civil engineering structures is increasingly used to monitor both structure integrity and vibration serviceability. A number of examples of bridges and footbridges equipped with a monitoring system can be found (Cross et al. 2013; Gomez et al. 2011; Moser and Moaveni 2013; $\mathrm{Hu}$ et al. 2012). In these monitoring systems, the vibrations due to traffic or wind are measured and recorded. These data can be used to continuously extract the modal parameters (natural frequencies, damping ratios, and modal shapes), which may be used to assess structural integrity, because structural damages lead to changes in the modal parameters. Thus, vibration-based structural health monitoring (SHM) systems using automated output-only modal identification [also known as operational modal analysis (OMA)] have been extensively proposed (e.g., Deraemaeker et al. 2008; Magalhães et al. 2012). One of the main problems of these systems is that they have to cope with changing environmental/operational conditions that

${ }^{1} \mathrm{Ph} . \mathrm{D}$. Candidate, E.T.S de Ingenieros de Caminos, Univ. Politécnica de Madrid, c/Prof. Aranguren s/n, 28040 Madrid, Spain. E-mail: jm soria@upm.es

${ }^{2}$ Associate Professor, E.T.S de Ingenieros de Caminos, Univ. Politécnica de Madrid, c/Prof. Aranguren s/n, 28040 Madrid, Spain (corresponding author).E-mail: ivan.munoz@upm.es

${ }^{3}$ Associate Professor, E.T.S de Ingenieros de Caminos, Univ. Politécnica de Madrid, c/Prof. Aranguren s/n, 28040 Madrid, Spain. E-mail: jaime.garcia.palacios@upm.es

${ }^{4}$ Ph.D. Candidate, Cartif Research Center, Boecillo, 47011 Valladolid, Spain. E-mail: noriba@cartif.es

Note. This manuscript was submitted on December 1, 2014; approved on July 14, 2015; published online on January 4, 2016. Discussion period open until June 4, 2016; separate discussions must be submitted for individual papers. This paper is part of the Journal of Bridge Engineering, (C) ASCE, ISSN 1084-0702. often significantly affect the modal estimation. Hence, the removal of these spurious factors on modal estimates becomes crucial in the implementation of a SHM system, which uses modal parameters as damage-sensitive features. These factors may mask meaningful changes for damage detection due to, for instance, extraordinary events such as earthquakes or very dense traffic (Stiros and Moschas 2014), especially in structures, such as bridges, that are always exposed to environmental factors.

The main obstacle for a more widespread adoption of these monitoring systems is the cost associated with their installation. Recently, a successful attempt to reduce the cost of a monitoring system was carried out through the use of low-cost sensors to measure structural vibrations on a footbridge. Thus, a low-cost continuous vibration-monitoring system using small microelectromechanical system (MEMS) accelerometers was developed and installed on Pedro Gómez Bosque (PGB) footbridge (Valladolid, Spain) to track its long-term dynamic performance. The system continuously measures the acceleration (using 18 triaxial MEMS accelerometers distributed along the structure), the ambient temperature, and the wind velocity and direction (de Sebastián et al. 2013). PGB footbridge is a singular steel-plated stress-ribbon footbridge with a single span of $85 \mathrm{~m}$. The dynamic behavior shows several low-frequency vibration modes with closely spaced natural frequencies and low damping ratios.

A procedure for tracking vibration modes was programmed to carry out an automatic modal parameter estimation. This procedure has to cope with vibration modes with closely spaced natural frequencies. In this case, sorting vibration modes using frequency criteria and removing outliers that lay out of intervals of frequency variation might not be adequate (Magalhães et al. 2008a; Moser and Moaveni 2013). This paper describes the detailed procedure carried out to track vibration modes of PGB footbridge over time. The procedure uses three tolerances based on the modal assurance criterion (MAC). This approach enables reliable monitoring of vibration modes that are maintained over time. 
Regarding the use of modal parameter variations as a possible damage detector in structures, it is necessary to observe the modal variations over time that result from the influence of some external agents acting on the undamaged structure (Magalhães et al. 2008a; Koo et al. 2013). It is important to evaluate the magnitude of this modal variation and the main factors that influence the relationship between them. The temperature is usually the most significant environmental factor (Zhou et al. 2011). However, other factors, such as operational or boundary conditions, may significantly affect the modal estimates (Avci 2014; Koo et al. 2013). Several studies have dealt with this problem and included correlation analyses between modal estimates and these external factors (Ni et al. 2005; Liu and DeWolf 2007; Hua et al. 2007; Mosavi et al. 2012; López and Astiz 2014).

Finite-element models are usually updated by using the modal parameters (Cismaşiu et al. 2014; Moaveni and Behmanesh 2012). However, when the modal parameters show significant variability with changing environmental factors, the updated model might not be as accurate as required (Bayraktar et al. 2009). Hence, it is important to estimate uncertainties in the modal parameter identification to establish the degree of confidence of the updated model. This updated model can be useful for guaranteeing a successful structural intervention during structural rehabilitation (Costa et al. 2014; Ivorra et al. 2013). That is, nondestructive tests, such as an OMA, together with calibrated models greatly benefit reliable structural evaluations.

The methods available for performing the identification of modal parameters of dynamic systems based on OMA are usually classified as frequency domain or time domain methods, which have been extensively studied in the literature (MacLamore et al. 1971; Overschee and Moor 1996; Andersen 1997; Jacobsen et al. 2008; Zhang et al. 2010). Formulations that use state-space models, designated as stochastic subspace identification (SSI) methods, constitute the parametric approach that is adopted more commonly for civil engineering applications in the time domain. They are also recommended when there are closely spaced eigenfrequencies (Magalhães et al. 2008b; Magalhães and Cunha 2011). Accordingly, the methods discussed in this paper are based on the SSI techniques.

The paper continues with the description of the structure and its monitoring system. The uncertainties associated with a single timehistory record are discussed in Peered Analysis of One Test. The output-only modal parameter estimation using three SSI-based OMA techniques and different data blocks was carried out. Thus, uncertainties that result from the selection of the SSI technique and the data block were quantified. The results of continuous dynamic analysis are described in the Continuous Dynamic Analysis section. A tracking method for following the evolution of the persistent vibration modes over time is proposed. The influence of the environmenta1/operational factors on the modal estimates was studied, and correlation models were derived to remove the influence of these spurious factors. Finally, some conclusions are drawn, and suggestions for future work are given.

\section{The Footbridge and Its Vibration Monitoring}

\section{Structure Description}

The PGB footbridge, sited in Valladolid, is a slender and lightweight structure that creates a pedestrian link over the Pisuerga River between a sport complex and the city center (see Fig. 1). This bridge, built in 2011, is a singular stress-ribbon footbridge born by a pretensioned catenary-shaped steel band with a single span of $85 \mathrm{~m}$

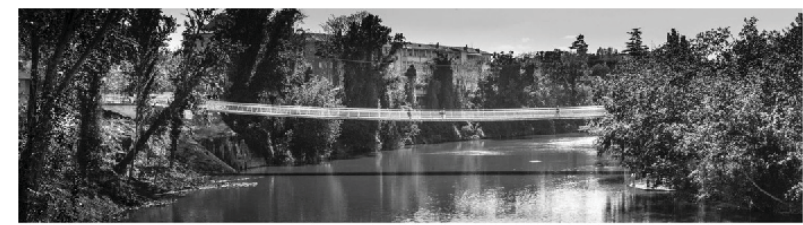

(a)

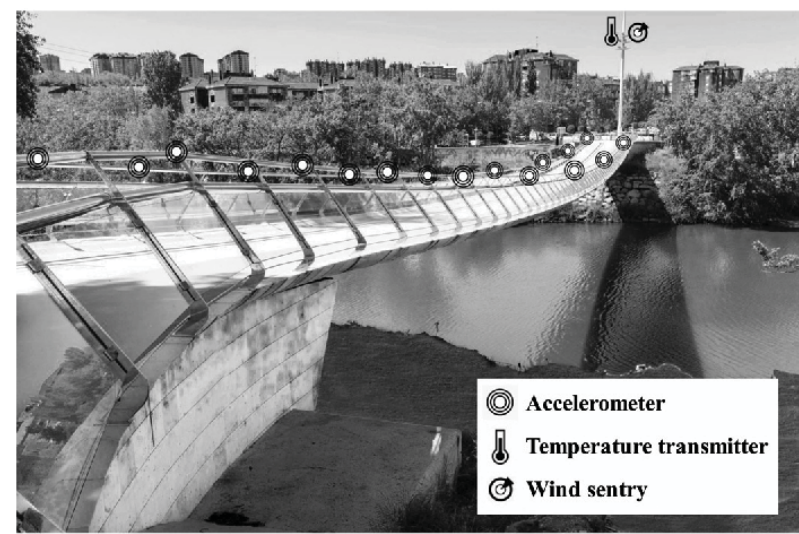

(b)

Fig. 1. PGB footbridge (images courtesy of J. Muñoz-Rojas): (a) landscape view; (b) distribution of sensors

that has a minimal impact on the surroundings. The structure mainly consists of a Corten steel band $94 \mathrm{~m}$ long, $3.6 \mathrm{~m}$ wide, and only 30 $\mathrm{mm}$ thick that is pretensioned and anchored to the two abutments. The complete steel band was fabricated by welding 8-m-long sheets, and a number of 110 precast concrete slabs lay on the steel band (Narros 2011). These slabs do not have bearing capacity; the only structural element is the band. The structure was completed by rubber flooring and a stainless steel glass handrail.

\section{Monitoring System}

A structural vibration-monitoring system was devised to continuously estimate the modal parameters of the structure and to assess their changes under various environmental conditions. Therefore, along with the accelerometers, needed for performing modal analysis, sensors for wind and environmental temperature conditions were installed. The monitoring system comprises 18 triaxial accelerometers (nine at each side of the deck), a temperature sensor, and an anemometer with a vane. Wires and acceleration sensors were installed inside the handrail, so the structure aesthetic was not modified in any way, which introduced the following additional complications: (1) the installation process was laborious, and (2) additional angular transformations are required to obtain the acceleration vector in the structure axes for each accelerometer.

The vibration sensor used for the monitoring system was the low-cost MEMS accelerometer ADXL327 (Analog Devices, Norwood, MA), which measures the static acceleration of gravity. The ADXL 327 is a very small, low-power, three-axis accelerometer with signal conditioning voltage output. The key properties of this sensor are that it has a measurement range of up to $\pm 2.5 \mathrm{~g}$, a sensitivity up to $500 \mathrm{mV} / \mathrm{g}$, and a bandwidth up to $550 \mathrm{~Hz}$. However, this sensor was not designed to transmit a signal over long distances. To overcome this problem, an ad-hoc conditioning circuit was designed to enhance its long-distance performance. First, three capacitors, one to each channel, were placed to fix the frequency 
bandwidth to $100 \mathrm{~Hz}$. Second, because the accelerometer has to be supplied by $3.6 \mathrm{~V}$ to get its maximum nominal sensitivity of 500 $\mathrm{mV} / \mathrm{g}$, the $12-\mathrm{V}$ power supply unit and a $3.6-\mathrm{V}$ voltage regulator were integrated into each circuit board to avoid power losses by the long-distance wires. Third, an operational amplifier was used to reduce significantly the output impedance, which enabled a good signal-to-noise ratio for the acceleration parameter (constant sensitivity and low noise). The achieved signal-to-noise ratio was $25 \mu \mathrm{g} / \sqrt{\mathrm{Hz}}$, which was considered to be enough for monitoring the structural vibrations. Finally, each circuit board with all its components was covered with a plastic coating to protect it from environmental conditions. Then, the accelerometers were ready to be installed inside the tube of the handrail. The sensing system was completed by a temperature sensor (Model T0110 transmitter, Comet, Rožnov pod Radhoštěm, Czech Republic) and a wind sentry (Model 03002L, R. M. Young Company, Traverse City, MI) to measure the speed and direction of the wind. The temperature sensor and wind sentry were installed on the public light tower sited closed to the structure [see Fig. 1(b)].

The monitoring system comprises 57 voltage channels that are processed continuously. The data logger CompactRIO 9076 (National Instruments, Austin, TX), with two NI 9205s with 32 ana$\log$ input channels, is used for real-time data acquisition. The frequency sampling for each channel was chosen to be $200 \mathrm{~Hz}$, enough to identify the modal parameters of the structure and to avoid aliasing problems during postprocessing.

The actual orientation of the accelerometers installed inside the handrail is unknown. However, the Euler angles between the accelerometer coordinate system and the structure coordinate system can be derived while taking into account the following: (1) the longitudinal axis of each accelerometer matches with the longitudinal axis of the footbridge, and (2) the accelerometers can measure acceleration due to gravity. Therefore, the transformation matrix between both coordinate systems can be obtained, and then the acceleration in the global axes can be finally calculated (de Sebastián et al. 2013). Before its final installation, laboratory validation was carried, out and after the installation, an in situ validation was performed by comparing the data against those of conventional piezoelectric accelerometers.

\section{Peered Analysis of One Test}

The uncertainties associated with the modal identification of one test, corresponding to the record measured on January 5, 2013, at 19:16 (60-min test), are analyzed herein. The dynamic behavior of the structure is governed mainly by the vertical response (previous time-history analyses have shown that lateral and longitudinal accelerations are small and negligible, respectively, compared to those of vertical ones), which is why this analysis concentrates on the vertical vibration. The process is as follows. First, signal processing is undertaken before the modal identification is presented. Afterward, identification from the same test $(60 \mathrm{~min})$ is performed by using different OMA techniques. Then, the same technique is applied to different 20-min time windows of the 60-min test.

\section{Data Processing}

The vertical response of the structure in a 1-h test is analyzed (with an initial sampling frequency of $200 \mathrm{~Hz}$ ). The signal is filtered by a low-pass Butterworth filter of order 4 with a cutoff frequency of $5 \mathrm{~Hz}$. A decimation factor of 16 is applied, and a Nyquist frequency of $6.25 \mathrm{~Hz}$ is obtained. As an example, Figs. 2(a and b) show the filtered and decimated responses in time and frequency domain,
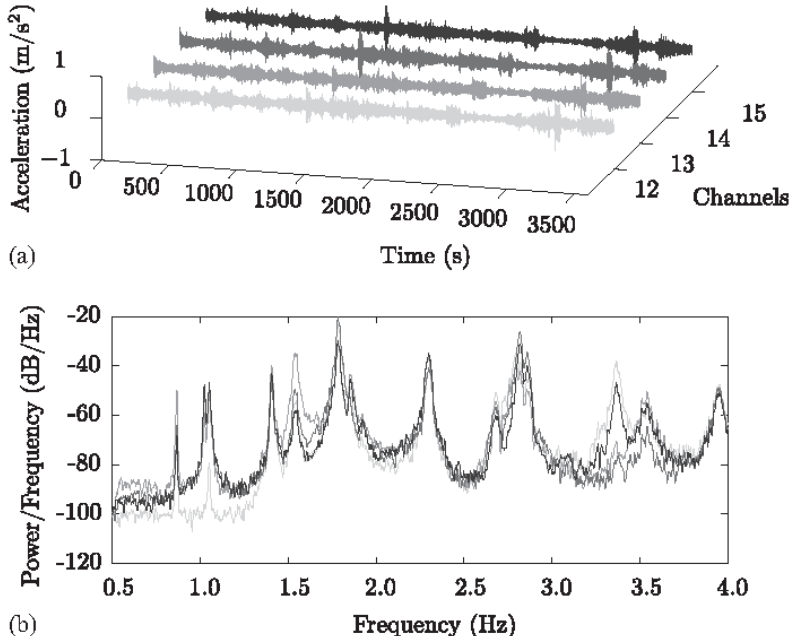

(b)

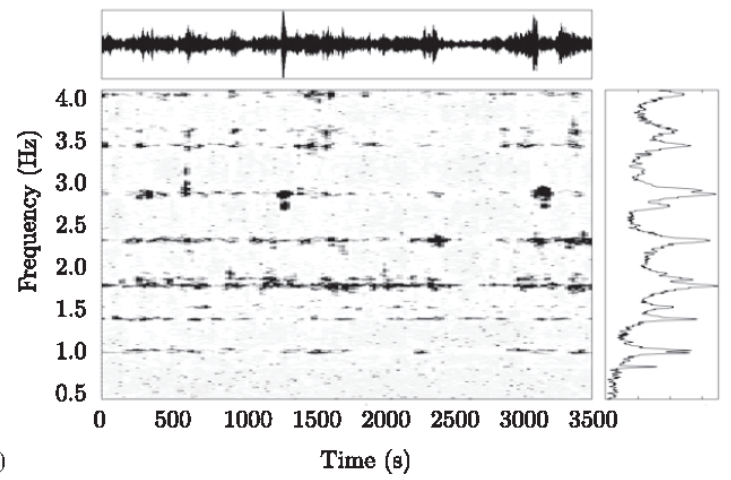

Fig. 2. Processed raw data of four central channels on the upstream side: (a) time domain; (b) frequency domain; (c) spectrogram of channel 15 using the short-time Fourier transform

respectively, corresponding to the four central channels for the upstream side. Fig. 2(c) shows the spectrogram using the short-time Fourier transform for channel 15; up to 10 horizontal alignments below $4 \mathrm{~Hz}$ can be seen.

\section{Operational Modal Analysis Using Three SSI Techniques}

Three different OMA techniques based on the SSI (Overschee and Moor 1996) and programmed in MATLAB 8.3.0.532 are used for the same test. The techniques used are covariance-driven SSI (SSIcov), data-driven SSI (SSI-data), and expectation maximization SSI (SSI-EM). The same criteria for defining a pole of the stabilization diagram as stable are used for the three identification techniques. To define a pole as stable, three requirements against estimates of the previous state-space order must be fulfilled: (1) the frequency must match within $1 \%$ (relative), (2) the damping ratio must match within 5\% (absolute), and (3) the mode shapes must match within $95 \%$, using the MAC for comparing. In addition, modes with identified damping ratios higher than $5 \%$ are also rejected.

The advantages of SSI-cov, programmed in MATLAB, are its conceptual simplicity and its ability to compute the probability density function of the identified system parameters. It selects the average 


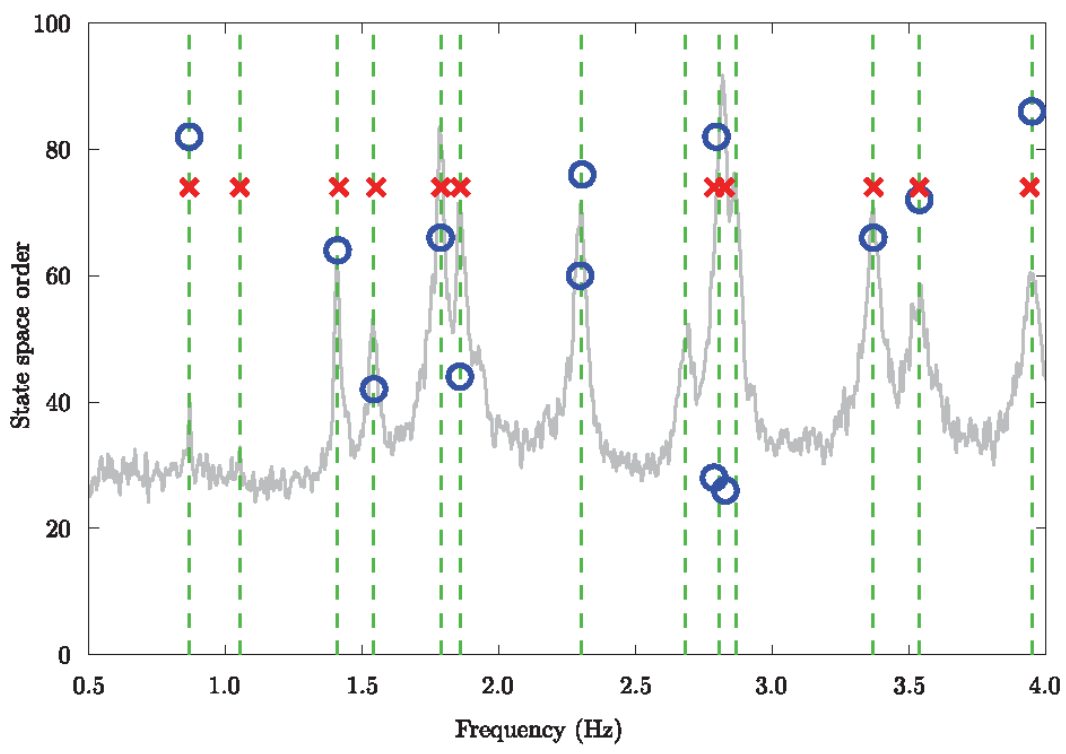

Fig. 3. Selected poles: SSI-cov (dashed lines), SSI-data (circles), and SSI-EM (crosses)

values of the modal parameters for each column (of stable aligned poles) with a minimum number of stable poles (Peeters and De Roeck 1999). SSI-data has been applied by using MACEC [Commercial Toolbox of MATLAB for modal analysis (Reynders et al. 2008)] and has the advantage of providing optimal statistical performance when the weighting matrices are chosen properly. A statistical analysis of the stable poles is used to choose final results (Reynders et al. 2012). SSI-EM is a combination of SSI and the EM algorithm. Using SSI for the initial estimate, the maximum-likelihood estimation requires iterations when using the EM algorithm (Cara et al. 2012). SSI-EM introduces the EM algorithm (McLachlan and Krishnan 2007) to maximize the likelihood function, which optimizes the lack of optimal solution shown by Bauer (2005) and Chiuso and Picci (2004) and improves the SSI results but does not define criteria for choosing the pole in the stabilization diagram. That is, the poles are those obtained by the modal order previously selected by an experienced user. Fig. 3 illustrates the final selected poles for the three techniques and the averaged normalized power spectral density. From the aforementioned characteristics, the recommendations given by Wenzel and Pichler (2005), and the authors' experience, the simultaneous use of several methods is a good way to improve the results and to quantify the estimation uncertainties.

Table 1 shows the estimated natural frequencies and damping ratios. A MAC correlation between the modal shapes estimated by three techniques was carried out. Modes that exhibit a MAC value greater than 0.95 for all of the cross values are shown in bold type. Modes with natural frequencies greater than $4 \mathrm{~Hz}(0.8$ times the cutoff frequency of the filter) are not included. Fig. 4 shows an example of identified modal shapes corresponding to the lowest six modes obtained with SSI-cov.

Table 2 shows a summary of the selected modes, including the mean values, the maximum relative error of the natural frequencies, and the maximum absolute error of the damping ratios. It is well known that damping is estimated with greater variability than natural frequencies (Reynders 2012), so it is better to use absolute errors for damping estimates. The maximum errors obtained were $0.6669 \%$ and $26.67 \%$ for frequencies and damping ratios, respectively. It is worth noting the very low values obtained for the
Table 1. Natural Frequencies and Damping Ratios Identified by the Three SSI Techniques

\begin{tabular}{|c|c|c|c|c|c|c|}
\hline \multirow[b]{2}{*}{ Mode } & \multicolumn{2}{|c|}{ SSI-cov } & \multicolumn{2}{|c|}{ SSI-data } & \multicolumn{2}{|c|}{ SSI-EM } \\
\hline & $f(\mathrm{~Hz})$ & $\zeta(\%)$ & $f(\mathrm{~Hz})$ & $\zeta(\%)$ & $f(\mathrm{~Hz})$ & $\zeta(\%)$ \\
\hline \multirow[t]{2}{*}{1} & 0.8671 & 0.3352 & 0.8670 & 0.1179 & 0.8671 & 0.1006 \\
\hline & 1.0548 & 0.9622 & 1.0508 & 0.6378 & 1.0526 & 0.6807 \\
\hline 2 & 1.4077 & 0.3792 & 1.4089 & 0.4058 & 1.4135 & 0.6459 \\
\hline 3 & 1.5408 & 0.6762 & 1.5418 & 0.6230 & 1.5511 & 0.7600 \\
\hline 4 & 1.7869 & 0.4483 & 1.7864 & 0.3760 & 1.7884 & 0.1983 \\
\hline \multirow[t]{10}{*}{5} & 1.8571 & 0.6381 & 1.8568 & 0.5737 & 1.8590 & 0.3884 \\
\hline & - & - & 2.2977 & 0.3730 & 2.2928 & 0.5868 \\
\hline & 2.3020 & 0.4799 & 2.3041 & 0.4690 & - & - \\
\hline & 2.6819 & 0.3206 & - & - & - & - \\
\hline & - & - & - & - & 2.7838 & 0.6067 \\
\hline & - & - & 2.7949 & 0.4447 & - & - \\
\hline & 2.8051 & 0.5159 & - & - & - & - \\
\hline & - & - & 2.8157 & 0.2338 & 2.8190 & 0.4646 \\
\hline & 2.8682 & 0.3238 & 2.8679 & 0.1601 & - & - \\
\hline & - & - & - & - & 2.8828 & 0.4393 \\
\hline 6 & 3.3674 & 0.4485 & 3.3684 & 0.4092 & 3.3687 & 0.4361 \\
\hline 7 & 3.5375 & 0.8723 & 3.5369 & 0.7968 & 3.5407 & 0.9700 \\
\hline 8 & 3.9487 & 0.5106 & 3.9487 & 0.4873 & 3.9413 & 0.5285 \\
\hline
\end{tabular}

Note: Modes that exhibit a MAC value greater than 0.95 for all of the cross values are shown in bold type. $f=$ natural frequency; $\zeta=$ damping ratio.

damping ratios, although the estimation uncertainty is high, as usual (Moser and Moaveni 2011).

\section{Operational Modal Analysis Using the Same SSI Technique}

To track the modal parameters of a structure, it is recommended to use the minimum test duration that leads to a successful identification. As a rule of thumb, the minimum duration of the measurement should be at least 1,000 cycles of the lowest natural frequency that is expected to be identified (Wenzel and Pichler 2005). This is the minimum duration 


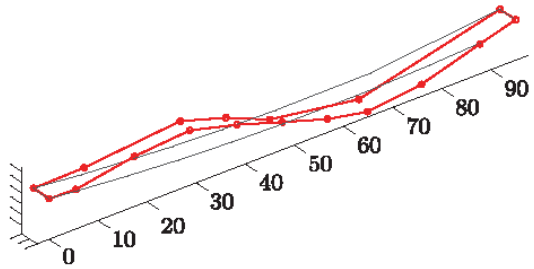

(a)

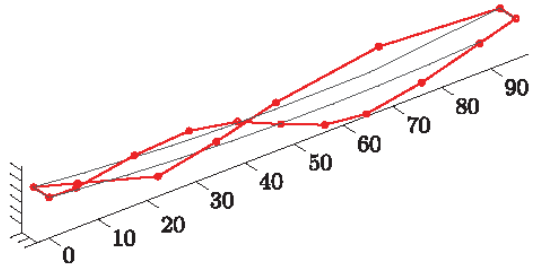

(d)

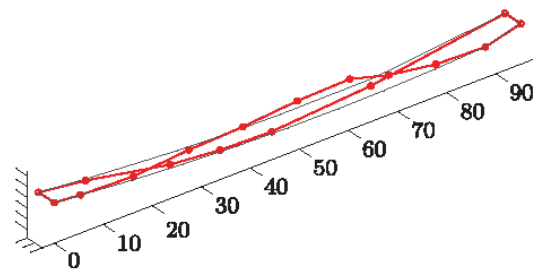

(b)

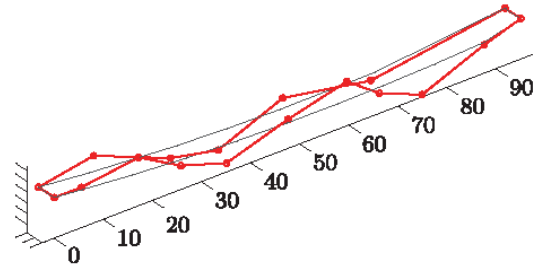

(e)

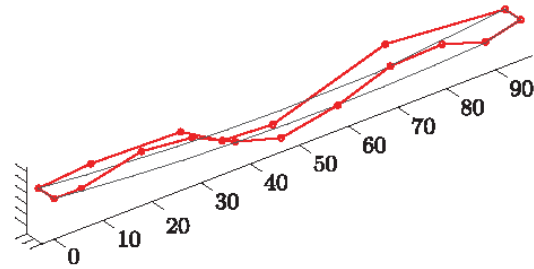

(c)

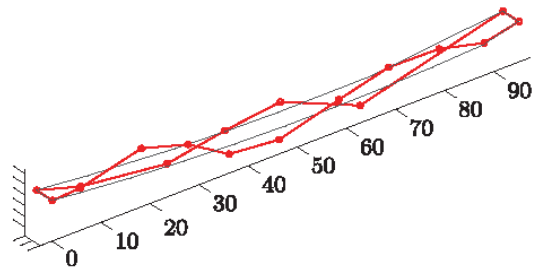

(f)

Fig. 4. First six mode shapes obtained with SSI-cov: (a) $f=0.87 \mathrm{~Hz}$; (b) $f=1.05 \mathrm{~Hz} ;$ (c) $f=1.41 \mathrm{~Hz}$; (d) $f=1.55 \mathrm{~Hz}$; (e) $f=1.79 \mathrm{~Hz} ;$ (f) $f=1.86 \mathrm{~Hz}$

Table 2. Summary of Identified Modes and Statistical Comparison for the Three Techniques

\begin{tabular}{lccccc}
\hline & \multicolumn{2}{c}{ Frequency } & & \multicolumn{2}{c}{ Damping } \\
\cline { 2 - 3 } Mode & $\bar{f}(\mathrm{~Hz})$ & Error $(\%)$ & & $\bar{\zeta}(\%)$ & Error (\%) \\
\hline 1 & 0.8671 & 0.0115 & & 0.2346 & 18.46 \\
2 & 1.4100 & 0.4113 & & 0.4770 & $\mathbf{2 6 . 6 7}$ \\
3 & 1.5446 & $\mathbf{0 . 6 6 6 9}$ & 0.6864 & 13.70 \\
4 & 1.7872 & 0.1119 & & 0.3409 & 25.00 \\
5 & 1.8576 & 0.1184 & & 0.5334 & 24.97 \\
6 & 3.3682 & 0.0386 & & 0.4313 & 3.930 \\
7 & 3.5384 & 0.1074 & & 0.8797 & 17.32 \\
8 & 3.9462 & 0.1875 & & 0.5088 & 4.120 \\
\hline
\end{tabular}

Note: Modes that exhibit a MAC value greater than 0.95 for all of the cross values are shown in bold type. $\bar{f}=$ mean frequency; $\bar{\zeta}=$ mean damping.

usually recommended for noise-contaminated signals and close vibration modes. Therefore, this duration, which corresponds to approximately $20 \mathrm{~min}$, was adopted here to carry out the modal tracking.

Now, three consecutive windows of 20-min data are considered for identifying the modal parameters using only SSI-cov. These results are compared with those obtained by using the 60-min record. Table 3 shows the estimates obtained from the four data blocks. Using the same criteria as in the previous case, modes that exhibit a MAC value greater than 0.95 for all of the cross values are shown in bold type. The average temperatures for each 20 -min time window were $16.42^{\circ} \mathrm{C}, 13.84^{\circ} \mathrm{C}$, and $11.56^{\circ} \mathrm{C}$, respectively, and $13.94^{\circ} \mathrm{C}$ for the 60-min record.

Table 4 presents a summary of the selected modes, including the mean values for the 20 -min tests and the maximum errors compared with the results obtained with the 60-min test. In this case, the maximum errors obtained were $0.2855 \%$ and $61.09 \%$ for frequencies and damping ratios, respectively. The errors in natural frequency estimates using $20 \mathrm{~min}$ compared with that using $60 \mathrm{~min}$ are negligible.

\section{Continuous Dynamic Analysis}

The procedure carried out to track the vibration modes is depicted in Fig. 5. The results obtained from 1 year of continuous dynamic
Table 3. Natural Frequencies and Damping Ratios Identified by SSI-cov and Different Time Blocks

\begin{tabular}{|c|c|c|c|c|c|c|c|c|}
\hline \multirow[b]{2}{*}{ Mode } & \multicolumn{2}{|c|}{$60 \mathrm{~min}$} & \multicolumn{2}{|c|}{ First $20 \mathrm{~min}$} & \multicolumn{2}{|c|}{ Second $20 \mathrm{~min}$} & \multicolumn{2}{|c|}{ Third $20 \mathrm{~min}$} \\
\hline & $f(\mathrm{~Hz})$ & $\zeta(\%)$ & $f(\mathrm{~Hz})$ & $\zeta(\%)$ & $f(\mathrm{~Hz})$ & $\zeta(\%)$ & $f(\mathrm{~Hz})$ & $\zeta(\%)$ \\
\hline - & 0.8671 & 0.3352 & 0.8663 & 0.2526 & - & - & 0.8660 & 1.0824 \\
\hline - & - & - & 1.0251 & 0.3793 & 1.0243 & 0.1433 & 1.0281 & 1.8147 \\
\hline 1 & 1.0548 & 0.9622 & 1.0536 & 0.3755 & 1.0518 & 0.3513 & 1.0535 & 0.4883 \\
\hline 2 & 1.4077 & 0.3792 & 1.4073 & 0.3523 & 1.4059 & 0.5874 & 1.4093 & 0.2594 \\
\hline 3 & 1.5408 & 0.6762 & 1.5408 & 0.5343 & 1.5395 & 0.7945 & 1.5431 & 0.7658 \\
\hline 4 & 1.7869 & 0.4483 & 1.7884 & 0.5036 & 1.7882 & 0.6227 & 1.7833 & 0.4014 \\
\hline 5 & 1.8571 & 0.6381 & 1.8567 & 0.6340 & 1.8574 & 0.6775 & 1.8569 & 0.4995 \\
\hline - & - & - & 1.9260 & 0.3870 & - & - & - & - \\
\hline 6 & 2.3020 & 0.4799 & 2.3022 & 0.4444 & 2.3020 & 0.5353 & 2.3014 & 0.4788 \\
\hline — & 2.6819 & 0.3206 & - & - & 2.6802 & 0.2709 & 2.6836 & 0.2546 \\
\hline - & - & - & - & - & - & - & 2.7306 & 0.4594 \\
\hline - & - & - & - & - & 2.7848 & 0.3825 & - & - \\
\hline 一 & 2.8051 & 0.5159 & 2.8097 & 0.7520 & - & - & 2.8041 & 0.4918 \\
\hline - & - & - & - & - & 2.8147 & 0.1976 & - & - \\
\hline - & 2.8682 & 0.3238 & - & - & - & - & 2.8631 & 0.3248 \\
\hline - & - & - & 2.9171 & 0.2887 & - & - & - & - \\
\hline 7 & 3.3674 & 0.4485 & 3.3680 & 0.4194 & 3.3659 & 0.4449 & 3.3709 & 0.4587 \\
\hline 8 & 3.5375 & 0.8723 & 3.5356 & 0.6417 & 3.5361 & 0.9920 & 3.5343 & 0.8376 \\
\hline 9 & 3.9487 & 0.5106 & 3.9443 & 0.4427 & 3.9458 & 0.5759 & 3.9552 & 0.3504 \\
\hline
\end{tabular}

Note: Modes that exhibit a MAC value greater than 0.95 for all of the cross values are shown in bold type. $f=$ natural frequency; $\zeta=$ damping ratio.

monitoring are described from now on. First, a method to track the evolution of the main vibration modes over time is described. Then, the influence of the environmental/operational factors on the modal estimates is studied, and correlation models are derived to remove the influence of these spurious factors.

\section{Tracking of Modal Properties}

From the acquired data, an automated OMA was implemented by using SSI-cov. The procedure carried out to remove the environmenta1/operational effects is depicted in Fig. 5. The process can be divided into the following steps: 
Table 4. Summary of Identified Mode Frequencies and Statistical Comparison for the 20-min versus 1-h Time Blocks

\begin{tabular}{llccc}
\hline & \multicolumn{4}{c}{ 20-min time windows } \\
\cline { 2 - 5 } Mode & \multicolumn{2}{c}{ Frequency } & \multicolumn{2}{c}{ Damping } \\
\cline { 2 - 5 } & $\bar{f}(\mathrm{~Hz})$ & Error (\%) & $\bar{\zeta}(\%)$ & Error (\%) \\
\hline 1 & 1.0530 & 0.2849 & 0.4050 & $\mathbf{6 1 . 0 9}$ \\
2 & 1.4075 & 0.2416 & 0.3997 & 32.80 \\
3 & 1.5411 & 0.2336 & 0.6982 & 26.02 \\
4 & 1.7866 & $\mathbf{0 . 2 8 5 5}$ & 0.5092 & 22.13 \\
5 & 1.8570 & 0.0377 & 0.6037 & 17.80 \\
6 & 2.3019 & 0.0348 & 0.4862 & 9.090 \\
7 & 3.3683 & 0.1484 & 0.4410 & 3.930 \\
8 & 3.5353 & 0.0905 & 0.8238 & 35.05 \\
9 & 3.9484 & 0.2761 & 0.4563 & 22.55 \\
\hline
\end{tabular}

Note: Modes that exhibit a MAC value greater than 0.95 for all of the cross values are shown in bold type. $\bar{f}=$ mean frequency; $\bar{\zeta}=$ mean damping.
- Take the last $N$ tests ( $N$ is the number of tests). $N$ should be representative of the variability of the modal estimates.

- For each test, the OMA is carried out. Thus, a number of modes for each test is identified and denoted as $r_{i}$ (with $i=1 \ldots N)$.

- The objective is to find modal estimates that correspond to the same persistent mode over time. Each modal shape estimate is compared with all the remaining estimates within the $N$ tests, and counter increases each time that two mode shapes match. The counter indicates the repeatability of a vibration mode. This process is used for all modal shape estimates. To carry out this step, the MAC value is used. That is, a number of

$$
\left[\sum_{i=1}^{N} r_{i}\right]
$$

estimates are compared by using the MAC value. The following three tolerances were defined for this purpose:

- $t o l_{1}$ is a MAC value that enables group estimates corresponding to the same vibration mode. The repeatability is the number of estimates of a group.

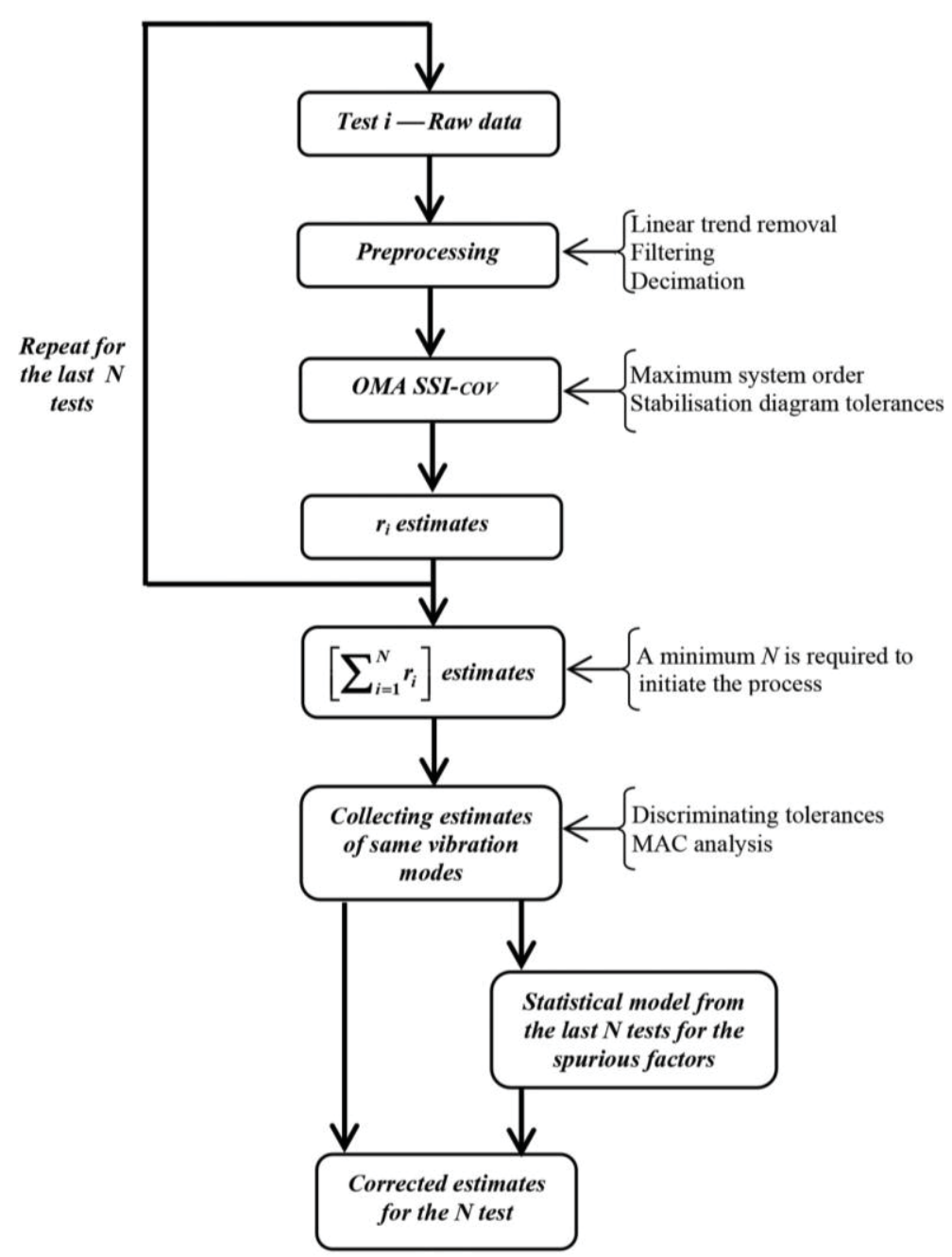

Fig. 5. Tracking procedure for modal parameters 
- $\mathrm{tol}_{2}$ is included to reject groups that are not repeated sufficiently to be considered significant modes. This tolerance is the lower limit of the success ratio (i.e., groups with low repeatability are automatically rejected).

- $t_{0} l_{3}$ is a MAC value included to detect groups of estimates that are actually estimations of the same mode. Then, if more than one group corresponds to the estimation of the same mode, the one with higher repeatability is selected.

- From this procedure, the most significant modes of the dynamic response of the structure are detected for the $N$ tests.

- Variations of these selected modes are statistically studied, and corrected modal parameters are derived.

This tracking method is applied to consecutive time-history records every $20 \mathrm{~min}$ using SSI-cov. During the year 2013, 21,643 tests were taken. The tolerances chosen to carry out the tracking were $t_{0} l_{1}>0.95, \mathrm{tol}_{2} \geq 40 \%$, and $\mathrm{tol}_{3} \leq 0.80$. Up to nine vibration modes below $4 \mathrm{~Hz}$ were tracked. Table 5 shows statistics of the estimation (mean, standard deviation, absolute percentage variation, and their repeatability; success ratios are included in parentheses). Note that the fourth mode at $1.79 \mathrm{~Hz}$ (with a damping ratio of only $0.42 \%$ ) corresponds to the highest success ratio.

It can be seen that the repeatability of modes is much lower than the total number of tests, which is because some of them are performed under very low-vibration conditions, which leads to wrong estimates that, obviously, are not tracked by the method. The pedestrian traffic over the structure during the daytime hours induces the necessary operational energy that allows successful identification. However, the lack of this excitation during the night hides the real structural response inside the signal noise. Fig. 6 shows hourly distribution of successful identifications obtained for the fourth mode selected (see Table 5).

The time variations of the natural frequency estimates over a year for the lowest ninth mode are shown in Fig. 7(a). Fig. 7(b) presents a magnification showing that the tracking method can identify two closely spaced natural frequencies. Although the monitoring has been operating since January 1,2013, up to now, some occasional stops (due to minor technical problems and maintenance) tasks can be seen in the figure.

\section{Effects of External Factors}

Strong seasonal and daily trends with temperature have been identified. Fig. 8 shows the time evolution of the frequency estimates of the fourth mode (in the left axis) and temperature (in the right axis).

Table 5. Summary of Identified Natural Frequencies and Damping Ratios for 1-Year Monitoring and Their Statistics

\begin{tabular}{lcccccccrr}
\hline & \multicolumn{3}{c}{ Frequency } & & \multicolumn{3}{c}{ Damping } & \\
\cline { 2 - 3 } Mode & $\bar{f}(\mathrm{~Hz})$ & SD & $\nu(\%)$ & & $\bar{\zeta}(\%)$ & SD & $\nu(\%)$ & $\begin{array}{l}\text { Repeatability } \\
\text { [number (\%)] }\end{array}$ \\
\hline 1 & 1.0482 & 0.0152 & 14.23 & & 0.3665 & 0.1710 & 147.89 & $9,667(44.7)$ \\
2 & 1.4145 & 0.0107 & 35.26 & & 0.3381 & 0.1513 & 110.74 & $10,619(49.1)$ \\
3 & 1.5440 & 0.0181 & 27.63 & & 0.6498 & 0.2357 & 133.62 & $9,886(45.7)$ \\
$\mathbf{4}$ & $\mathbf{1 . 7 9 3 7}$ & $\mathbf{0 . 0 2 9 1}$ & $\mathbf{2 0 . 2 7}$ & & $\mathbf{0 . 4 1 9 2}$ & $\mathbf{0 . 1 5 0 2}$ & $\mathbf{2 2 1 . 8 8}$ & $\mathbf{1 3 , 8 1 7}(\mathbf{6 3 . 8})$ \\
5 & 1.8594 & 0.0168 & 6.87 & & 0.5718 & 0.1605 & 234.74 & $9,936(45.9)$ \\
6 & 2.3117 & 0.0425 & 15.01 & & 0.3753 & 0.1474 & 128.54 & $8,746(40.4)$ \\
7 & 3.3821 & 0.0549 & 42.95 & & 0.3868 & 0.1191 & 103.96 & $12,210(56.4)$ \\
8 & 3.5512 & 0.0524 & 51.87 & & 0.7226 & 0.1884 & 157.48 & $9,237(42.7)$ \\
9 & 3.9610 & 0.0624 & 8.95 & 0.3853 & 0.1185 & 230.82 & $10,183(57.8)$ \\
\hline
\end{tabular}

Note: Modes that exhibit a MAC value greater than 0.95 for all of the cross values are shown in bold type. $\bar{f}=$ mean frequency; $\mathrm{SD}=$ standard deviation; $\bar{\zeta}=$ mean damping; $\nu=$ corresponding variation.
The seasonal [Fig. 8(a)] and daily [Fig. 8(b)] trends can be seen clearly. Fig. 9 shows the frequency estimates versus temperature for Mode 1 [Fig. 9(a)] and Mode 4 [Fig. 9(b)] of Table 5. It should be noted that the pure vertical response and the thermal behavior (Cacho-Perez et al. 2014) are similar to those of an equivalent suspended cable. Therefore, for these modes (such as Mode 4), increasing temperatures lead to an increase into the ribbon sag, which produces a reduction of band tension and leads to a decrease in the natural frequencies (del Arco et al. 2001). However, Mode 1 [of Table 5 and Fig. 4(b)] does not follow this pattern, because it is a torsional mode.

No other visual evidence of the correlation between the frequency estimates and other factors, different from the temperature, has been found (with neither the wind velocity nor the operational values). Regarding damping ratios, no clear visual dependencies with any external factor have been found.

\section{Statistical Analysis}

A correlation analysis was carried out to study the influence of the external effects on the natural frequencies and damping ratios. The technique used to study the dependence of a dependent variable, $y$, with other independent variables or predictors was multiple linear regression (MLR). The equation of MLR can be written as

$$
y=\mathbf{Z} \boldsymbol{\beta}+\varepsilon=\hat{y}+\varepsilon
$$

where $\mathbf{Z}=\left[1, Z_{1}, \ldots, Z_{k}\right]=$ row vector of $(k+1)$ terms that contain the $k$ predictors; $\boldsymbol{\beta}=\left[\beta_{0}, \beta_{1}, \ldots, \beta_{k}\right]^{\prime}=$ column vector of $(k+1)$ coefficients to be determined that weight the contribution of each predictor; and $\varepsilon=$ residual error. The variable $\hat{y}=\mathbf{Z} \boldsymbol{\beta}$ is the estimate of the statistical model for the dependent variable $y$.

It is important to have an indicator to provide information on the goodness of the regression fitting. The most common indicator is the adjusted coefficient of determination, or adjusted $R^{2}$, because it takes into account the number of observations and predictors included in the model (Cohen et al. 2013). This coefficient represents the proportion of variation of the dependent variable explained by the regression model. The increase in the adjusted $R^{2}$

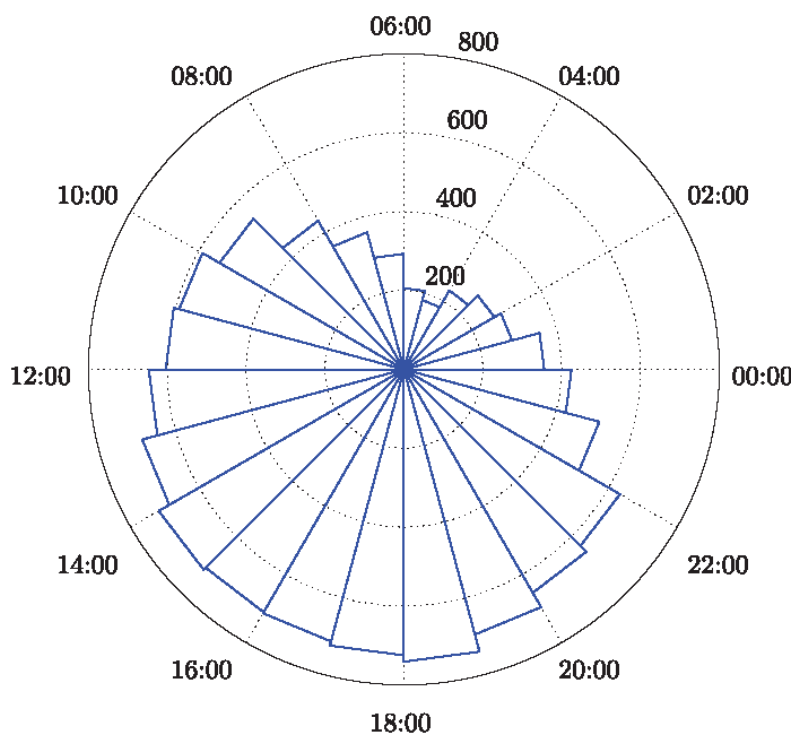

Fig. 6. Distribution per hour of the repeatability for Mode 4 

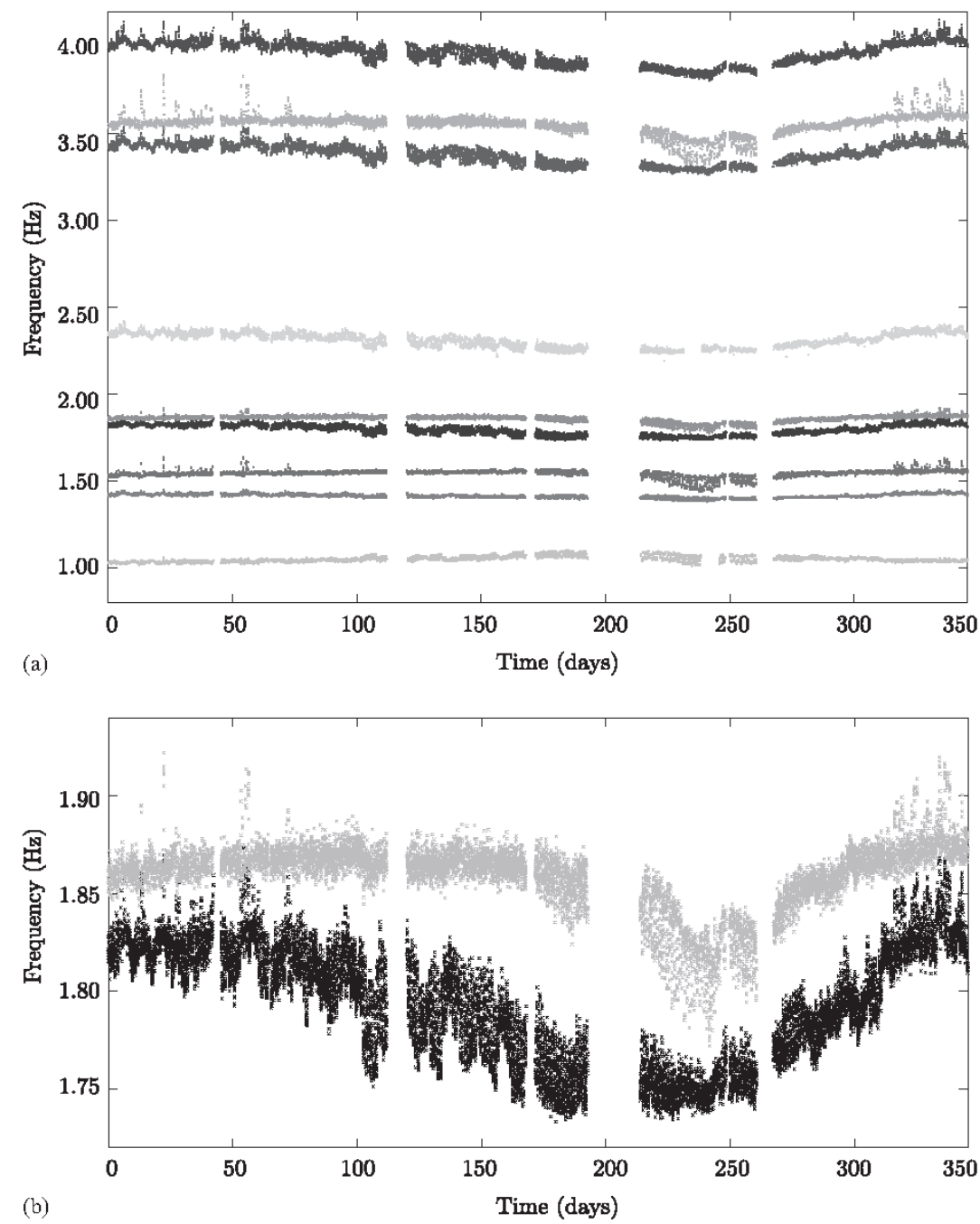

Fig. 7. Tracked frequency estimates for the whole year: (a) complete view; (b) magnified view of the fourth and fifth vibration modes

value by each additional predictor indicates the ratio provided by this predictor.

The independent variables were considered as a function of the ambient temperature, structure acceleration, and wind speed. Thus, the statistical model adopted consists of linearly fitting the independent variables (that might be nonlinear functions of environmental/operational measurements), which are selected according to their statistical relevance. Furthermore, temperature dependence was also explored, not only for this test but also for the temperatures observed in previous tests. That is, a dynamic regression model regarding temperature dependence was adopted.

The estimates were considered as a function of the following variables:

$$
\hat{y}=g\left[T,(\Delta T / \Delta t)_{i}, T_{R_{j}}, a_{\max }, a_{\mathrm{rms}}, V D V, V_{\max }, V_{\mathrm{mms}}\right]
$$

where $\hat{y}=$ modal estimate; $T=$ temperature associated with each test (the mean temperature of the test is taken); $(\Delta T / \Delta t)_{i}=$ gradient of temperature between the current test and the $i$-times former test; $T_{R_{j}}=$ running average temperature using the $j$ previous tests; $a=$ vertical acceleration; and $V=$ wind velocity. The subscripts $\max$ and rms indicate the maximum value and root-mean square, respectively. Thus, $a_{\max }=$ peak acceleration. The variables $a_{\mathrm{mms}}$ ( $\mathrm{rms}$ acceleration) and VDV (vibration dose value) are integrals of the second and the fourth powers of vertical acceleration, respectively. These are measures suitable for assessing the vibration serviceability for pedestrian structures (ISO 10137 2007). Contrary to peak and rms accelerations, VDV accumulates the vibration effects rather than averaging them and increases with duration. according to Eq. (1), Eq. (2) is considered

$$
\hat{y}=\beta_{0}+\sum_{r=1}^{k} \beta_{r} Z_{r}
$$

in which $Z_{r} \in\left[z_{r}, z_{r}^{2}, \ldots, z_{r}^{n}, 1 / z_{r}, 1 / z_{r}^{2}, \ldots, 1 / z_{r}^{n}\right]$, which thus explores nonlinear relationships, and the $z_{r}$ values are the independent variables that appear in Eq. (2); the coefficients $\beta_{r}$ are obtained from the linear least square solutions; and $k$ is the number of predictors for the model.

To extract the corrected estimates and remove the spurious effects, Eq. (3) is rewritten as follows: 

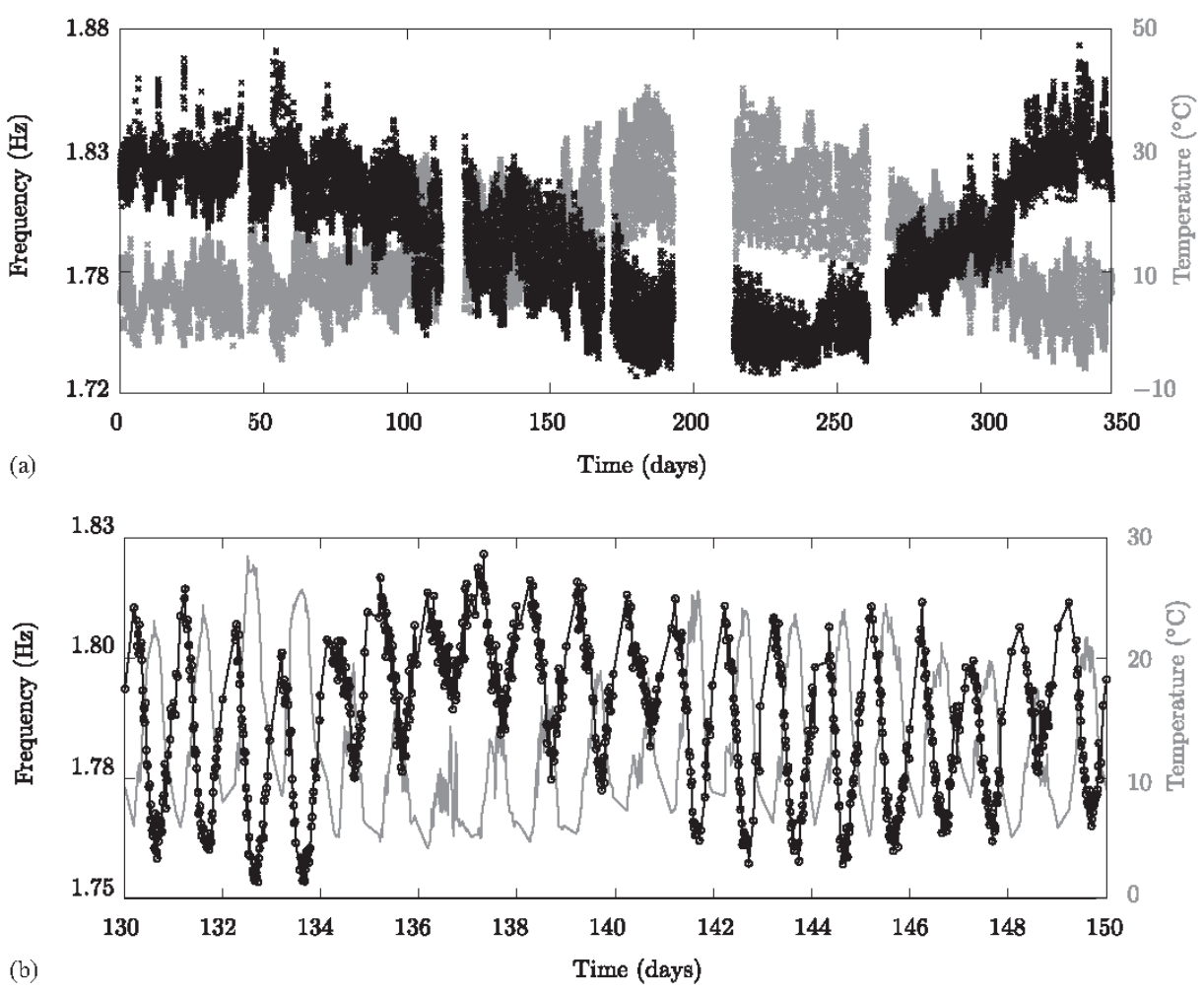

Fig. 8. Frequency estimates and temperature recorded for Mode 4: (a) complete view; (b) magnified view of 20 days

$$
\hat{y}=\underbrace{\left(\beta_{0}+\sum_{r=1}^{k} \beta_{r} \overline{Z_{r}}\right)}_{y^{*}}+\sum_{r=1}^{k} \beta_{r}\left(Z_{r}-\overline{Z_{r}}\right)
$$

where $\overline{Z_{r}}=$ mean value of all the observations of $Z_{r}$; and $y^{*}=$ corrected estimate, defined as

$$
y^{*}=\beta_{0}+\sum_{r=1}^{k} \beta_{r} \overline{Z_{r}}
$$

The MLR method presented here was applied to frequency and damping ratio estimates for all of the tracked modes (of Table 5). It was considered that $i=1,2, \ldots, 30, j=50,100,250,1,000$, 1,500 , and 2,000 [see Eq. (2)], and $n=3$ and $k=4$ [see Eq. (3) and definition of $Z_{r}$ ]. Eventually, 252 candidates for predictors were considered. Thus, Table 6 shows the values of the adjusted $R^{2}$ values for all the natural frequency estimates of the selected modes as the number of predictors increased in the statistical models. The predictors of those models that obtained a value of the adjusted $R^{2}$ greater than 0.80 are also shown in Table 6. The last column of the table shows the maximum adjusted $R^{2}$ and $R_{\max }^{2}$ values obtained for the maximum number of predictors and the $k_{\max }$ value for each model (shown in parentheses). It can be seen that those modes with a higher adjusted $R^{2}$ (Modes 4, 6, 7, and 9), $R_{\max }^{2}>0.90$, have as predictors independent variables related to the temperature. It can also be seen that there are two modes, 1 and 2, with adjusted $R^{2}$ values close to 0.80 , for which serviceability parameters were used as the third and fourth predictors for their respective models (see Table 6).
The frequency distribution for each mode is shown in Fig. 10. There are some modes $(3,5$, and 8$)$ with a frequency that have a very narrow distribution, indicating that (1) they do not change significantly, (2) they do not need any correction, and (3) they might already be used for SHM. Therefore, the variation of these modes cannot be explained, which leads to adjusted $R^{2}$ values lower than the remainders.

Finally, very low values for the adjusted $R^{2}$ value (smaller than 0.20 ) were achieved for damping ratios. Therefore, the results for the damping ratios are not presented here, because there is no clear dependency of damping ratio variations.

\section{Removing External Factors}

As an example, the model obtained for the natural frequency estimate of Mode 4 is expounded in detail. This is the mode with the highest success ratio, and its model achieves the highest adjusted $R^{2}$ value. The model obtained for the statistical frequency is as follows:

$$
\hat{f}=\beta_{0}+\underbrace{\beta_{1} \cdot T+\beta_{2} \cdot(\Delta T / \Delta t)_{19}+\beta_{4} \cdot T^{2}}_{\text {daily }}+\underbrace{\beta_{3} \cdot T_{R_{1,000}}}_{\text {seasonal }}
$$

where $\hat{f}=$ frequency estimate by statistical model. Eq. (6) shows the dependency on temperature and on the temperature gradient with respect to the 19 -times former test $\left(\Delta t_{19}=19 \cdot 20=380 \mathrm{~min}\right)$; the running average temperature used 1,000 previous tests and temperature to the second power. These values provided the higher increment of the adjusted $R^{2}$. Additional predictors introduced only marginal improvements to the correlation. 
To test this statistical model, data from the first 20 days of January 2014 were used as unseen data. Fig. 11 shows the frequency estimates according to the SSI-cov technique and the statistical model [Eq. (6)]. The maximum relative error did not exceeded $1 \%$.
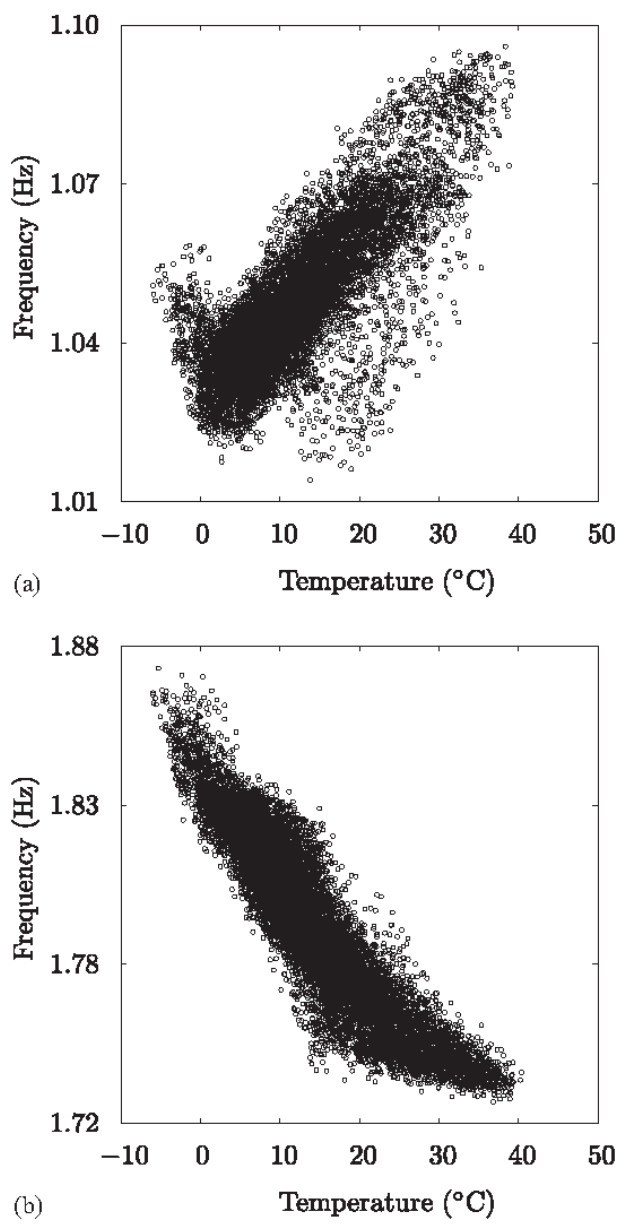

Fig. 9. Frequency estimates versus temperature for (a) Mode 1 and (b) Mode 4
As stated in Eq. (5) and according to Eq. (6), the corrected frequency is as follows:

$$
f^{*}=\beta_{0}+\beta_{1} \cdot \bar{T}+\beta_{2} \cdot(\overline{\Delta T / \Delta t})_{19}+\beta_{3} \cdot \bar{T}_{R_{1,000}}+\beta_{4} \cdot \bar{T}^{2}
$$

Considering Eq. (7), Eq. (6) can be rewritten as

$$
\begin{gathered}
\hat{f}=f^{*}+\beta_{1} \cdot(T-\bar{T})+\beta_{2} \cdot\left[(\Delta T / \Delta t)_{19}-(\overline{\Delta T / \Delta t})_{19}\right]+\cdots \\
\ldots+\beta_{3} \cdot\left(T_{R_{1,000}}-\bar{T}_{R_{1,000}}\right)+\beta_{4} \cdot\left(T^{2}-\bar{T}^{2}\right)
\end{gathered}
$$

Eq. (8) is now rewritten as

$$
\hat{f}=f^{*}+H
$$

where $H=$ sum of all terms that accompany the corrected frequency $f^{*}$ on the right-hand side of Eq. (8). Taking into account that, in this case, the independent variable is the natural frequency estimated by SSI [ $\left.f^{(\mathrm{SSI})}\right]$, Eq. (1) can be expressed as

$$
f^{(\mathrm{SSI})}=\hat{f}+\varepsilon
$$

Replacing Eq. (9) into Eq. (10) leads to

$$
f^{(\mathrm{SSI})}-H=f^{*}+\varepsilon=\hat{f}^{*}
$$

in which $\hat{f}^{*}=$ corrected frequency estimate (i.e., the corrected frequency including the residual error), which is independent of the influence of the considered predictors. Figs. 12(a and b) show $f^{\text {(SSI) }}, \hat{f}^{*}$, and $f^{*}$ for Mode 4 . It can be seen that the variability range decreased from 0.1422 to $0.0446 \mathrm{~Hz}$ (i.e., a $70 \%$ reduction was achieved). Finally, Figs. 12(c and d) show the distribution of the residual errors for the SSI frequency estimate $f^{\text {(SSI) }}$ and the corrected frequency estimate $\hat{f}^{*}$ as well as their fittings to a normal Gaussian distribution. It is worthwhile to remark that the residual error for the corrected estimate fits to a normal Gaussian distribution, which indicates that dependen-

\begin{tabular}{|c|c|c|c|c|c|c|c|c|c|}
\hline \multirow[b]{3}{*}{ Mode } & \multicolumn{9}{|c|}{ Predictors, $k$} \\
\hline & \multicolumn{2}{|c|}{1} & \multicolumn{2}{|c|}{2} & \multicolumn{2}{|c|}{3} & \multicolumn{2}{|c|}{4} & \multirow[b]{2}{*}{$R_{\max }^{2}\left(k_{\max }\right)$} \\
\hline & Number & Variable & Number & Variable & Number & Variable & Number & Variable & \\
\hline 1 & 0.627 & $T$ & 0.761 & $(\Delta T / \Delta t)_{9}$ & 0.777 & $1 / a_{\mathrm{rms}}$ & 0.785 & $T^{2}$ & $0.839(52)$ \\
\hline 2 & 0.616 & $T_{R_{1,000}}$ & 0.651 & $T$ & 0.782 & $T^{2}$ & 0.791 & $1 / a_{\mathrm{rms}}$ & $0.841(45)$ \\
\hline 3 & 0.157 & & 0.222 & & 0.268 & & 0.325 & & $0.440(35)$ \\
\hline 4 & 0.850 & $T$ & 0.921 & $(\Delta T / \Delta t)_{19}$ & 0.942 & $T_{R_{1,00}}$ & 0.955 & $T^{2}$ & $0.967(36)$ \\
\hline 5 & 0.521 & & 0.537 & & 0.553 & & 0.565 & & $0.621(34)$ \\
\hline 6 & 0.874 & $T$ & 0.929 & $(\Delta T / \Delta t)_{18}$ & 0.943 & $T_{R_{1} m}$ & 0.951 & $T^{2}$ & $0.964(56)$ \\
\hline 7 & 0.826 & $T$ & 0.905 & $T_{R_{1,000}}$ & 0.925 & $(\Delta T / \Delta t)_{11}$ & 0.943 & $T^{2}$ & $0.953(38)$ \\
\hline 8 & 0.502 & & 0.546 & & 0.567 & & 0.577 & & $0.653(41)$ \\
\hline 9 & 0.799 & $T_{R_{1000}}$ & 0.886 & $T$ & 0.907 & $T^{2}$ & 0.918 & $(\Delta T / \Delta t)_{10}$ & $0.929(29)$ \\
\hline
\end{tabular}
cies with external agents were successfully eliminated.

\section{Conclusions}

A low-cost vibration-monitoring system based on MEMS accelerometers was successfully installed on a singular stress-ribbon

Table 6. Adjusted $R^{2}$ and Independent Variable for Each Statistical Model According to the Number of Predictors

Note: Modes that exhibit a MAC value greater than 0.95 for all of the cross values are shown in bold type. 


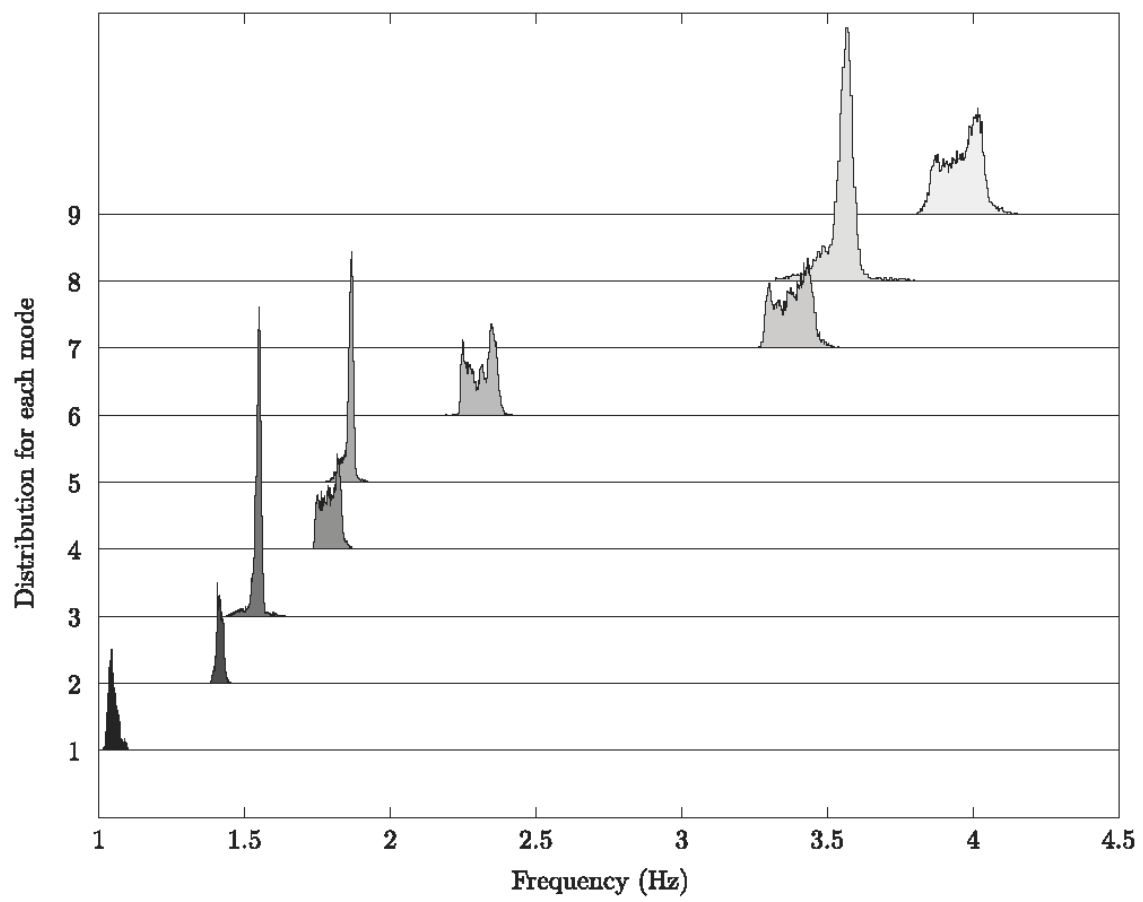

Fig. 10. Overlaid distributions of the identified natural frequencies

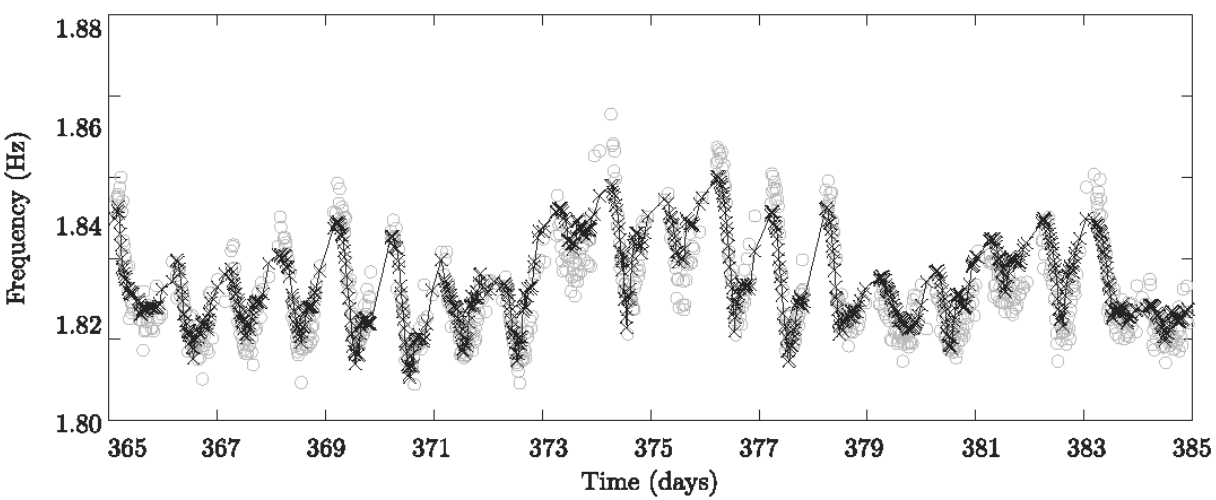

Fig. 11. Validation of the statistical model with "unseen data"; circles indicate SSI estimates, and crosses indicate estimates from the statistical model

footbridge, and it is currently providing live data for its analysis. It has been demonstrated that these low-cost sensors, carefully conditioned, can be a competitive alternative to the traditional ones. Thus, using this innovate system, this study has focused mainly on the time evolution of the modal parameters and their correlation against environmental/operational factors. A simple and efficient method of removing environmental effects was carried out on the basis of dynamic linearized multiple regression. A correction of these modal parameters was proposed in such a way that the corrected frequencies might be used as a potential damage index in a SHM system. It should be noted that the presented methodology for tracking the modal parameters and removing the influence of external factors can be applied to other bridges following the same steps while considering that the predictors may be different.

It was demonstrated that this particular stress-ribbon structure is highly sensitive to temperature variations (frequency changes of more than $20 \%$ ). Although only one ambient temperature sensor was installed, an interesting statistical model for the frequency estimates was derived. This model makes use of not only the temperature but also the gradient of temperature and the running averaged temperature, which explain more than $95 \%$ of the frequency variations over time for two of the vibration modes. A procedure for obtaining the corrected frequency (removing the influence of external factors) has been proposed, and the residual error in this case was shown to be fitted to a narrow normal Gaussian distribution. This feature makes 

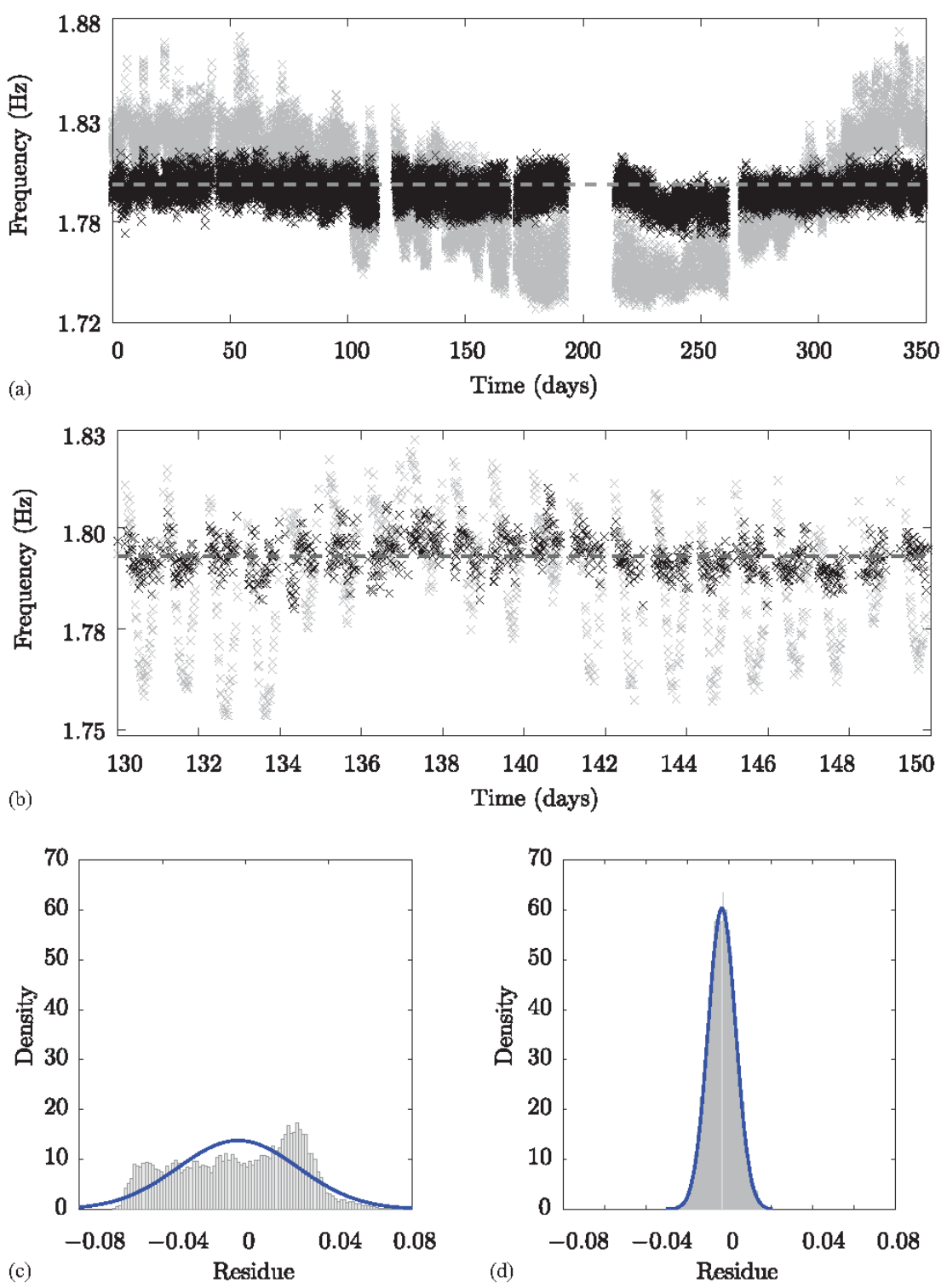

Fig. 12. Removing the external factors for Mode 4: (a) complete view; (b) magnified view of 20 days; (c) residue before correcting; (d) residue after correcting; grey crosses indicate SSI estimates $f^{(\text {SSI })}$; black crosses indicate corrected frequency estimates $\hat{f}^{*}$; and grey dashed lines indicate corrected frequency $f^{*}$

modal estimates more appropriate for use as damage detectors. Furthermore, the uncertainties that result from the estimation process (using different SSI techniques and different data blocks) were studied. The corrected frequency had a closer range of variability than the original one. However, the variability for the corrected frequency had a wider range than the errors quantified from the estimation process.

Future work should consider the development of a finite-element model for this strongly nonlinear structure and its model updating. The results obtained in this paper are essential for the development of a reliable model that might be used with a SHM system. Future work should also consider studying the optimal way to update the statistical models while taking into consideration model accuracy and computational burden, because both of them can be critical for their use in a SHM system.

\section{Acknowledgments}

The authors acknowledge the financial support provided by the Spanish Government Research Program with the Grant BIA201128493 and by the project SETH of INNPACTO Program with reference IPT-2012-0703-380000. The authors also acknowledge the financial support provided by Research Project DPI201347441-P.

\section{References}

Andersen, P. (1997). "Identification of civil engineering structures using vector ARMA models." Ph.D. thesis, Aalborg Univ., Aalborg, Denmark. 
Avci, O. (2014). "Modal parameter variations due to joist bottom chord extension installations on laboratory footbridges." J. Perform. Constr. Facil., 10.1061/(ASCE)CF.1943-5509.0000635, 04014140.

Bauer, D. (2005). "Asymptotic properties of subspace estimators." Automatica, 41(3), 359-376.

Bayraktar, A., Altunişik, A. C., Sevim, B., and Türker, T. (2009). "Modal testing, finite-element model updating, and dynamic analysis of an arch type steel footbridge." J. Perform. Constr. Facil., 10.1061/(ASCE)0887 $-3828(2009) 23: 2(81), 81-89$

Cacho-Perez, M., Frechilla, N., Diaz, I., and Lorenzana, A. (2014). "Simplified mechanical model for a stress-ribbon monitorized footbridge: Analytical and experimental results." Proc., 6th World Conf. on Structural Control and Monitoring, International Center for Numerical Methods in Engineering, Barcelona, Spain, 358-368.

Cara, F. J., Carpio, J., Juan, J., and Alarcón, E. (2012). "An approach to operational modal analysis using the expectation maximization algorithm.” Mech. Syst. Sig. Process., 31, 109-129.

Chiuso, A., and Picci, G. (2004). "The asymptotic variance of subspace estimates." J. Econometrics, 118(1), 257-291.

Cismaşiu, C., Narciso, A. C., and Amarante dos Santos, F. P. P. (2014). "Experimental dynamic characterization and finite-element updating of a footbridge structure." J. Perform. Constr. Facil., 10.1061/(ASCE)CF .1943-5509.0000615, 64014116.

Cohen, J., Cohen, P., West, S. G., and Aiken, L. S. (2013). Applied multiple regression/correlation analysis for the behavioral sciences, Routledge, London.

Costa, B. J. A., Magalhães, F., Cunha, A., and Figueiras, J. (2014). "Modal analysis for the rehabilitation assessment of the Luiz I Bridge." $J$. Bridge Eng., 10.1061/(ASCE)BE.1943-5592.0000632,05014006.

Cross, E., Koo, K., Brownjohn, J., and Worden, K. (2013). "Long-term monitoring and data analysis of the Tamar Bridge." Mech. Syst. Sig. Process., 35(1-2), 16-34.

de Sebastián, J., Escudero, A., Amaz, R., Díaz, I., Poncela, A., and Lorenzana, A. (2013). "A low-cost vibration monitoring system for a stress-ribbon footbridge." Proc., 6th ECCOMAS Conf. on Smart Structures and Materials, SMART2013, Trans Tech Publications, Durnten-Zurich, Switzerland.

del Arco, D. C., Aparicio, A., and Marí, A. (2001). "Preliminary design of prestressed concrete stress ribbon bridge." J. Bridge Eng., 10.1061 /(ASCE) 1084-0702(2001)6:4(234), 234-242.

Deraemaeker, A., Reynders, E., De Roeck, G., and Kullaa, J. (2008). "Vibration-based structural health monitoring using output-only measurements under changing environment." Mech. Syst. Sig. Process., 22(1), 34-56

Gomez, H. C., Fanning, P. J., Feng, M. Q., and Lee, S. (2011). "Testing and long-term monitoring of a curved concrete box girder bridge." Eng. Struct., 33(10), 2861-2869.

Hu, W., Caetano, E., and Cuhna, A. (2012). "Structural health monitoring of a stress-ribbon footbridge." Eng. Struct., 47, 578-593.

Hua, X. G., Ni, Y. Q., Ko, J. M., Asce, F., and Wong, K. Y. (2007). "Modeling of temperature-frequency correlation using combined principal component analysis and support." J. Comput. Civil Eng., 10.1061 /(ASCE)0887-3801(2007) 21:2(122), 122-135.

ISO. (2007). "Bases for design of structures: Serviceability of buildings and walkways against vibrations," ISO 10137, Geneva.

Ivorra, S., Foti, D., Bru, D., Javier, F. B., and Baeza, F. J. (2013). "Dynamic behavior of a pedestrian bridge in Alicante, Spain." J. Perform. Constr. Facil., 10.1061/(ASCE)CF.1943-5509.0000556.

Jacobsen, N., Andersen, P., and Brincker, R. (2008). "Applications of frequency domain curve-fitting in the EFDD technique." Proc., International Modal Analysis Conf., IMAC 26, Curran, Red Hook, NY.

Koo, K. Y., Brownjohn, J. M. W., List, D. I., and Cole, R. (2013). "Structural health monitoring of the Tamar suspension bridge." Struct. Control Health Monit., 20(4), 609-625.

Liu, C., and DeWolf, J. T. (2007) "Effect of temperature on modal variability of a curved concrete bridge under ambient loads." J. Struct. Eng., 10 .1061/(ASCE) 0733-9445(2007)133:12(1742), 1742-1751.
López, J. A., and Astiz, M. A. (2014). "An experimental analysis of the evolution of dynamic parameters of a long-span metal arch bridge." Struct. Eng. Int. 24(1), 8-19.

MacLamore, V., Hart, G., and Stubbs, I. (1971). "Ambient vibration of two suspension bridges.” J. Struct. Div., 97(10), 2567-2582.

Magalhães, F., and Cunha, A. (2011). "Explaining operational modal analysis with data from an arch bridge." Mech. Syst. Sig. Process., 25(5), 1431-1450.

Magalhães, F., Cunha, A., and Caetano, E. (2008a). "Dynamic monitoring of a long span arch bridge." Eng. Struct., 30(11), 3034-3044.

Magalhães, F., Cunha, A., and Caetano, E. (2008b). "Permanent monitoring of 'Infante D. Henrique' bridge based on FDD and SSI-COV methods.' Proc., Int. Conf. on Noise and Vibration Engineering, P. Sas and B. Bergen, eds., Vol. 1, Katholieke Univ. Leuven, Leuven, Belgium, 649 664.

Magalhães, F., Cunha, A., and Caetano, E. (2012). "Vibration based structural health monitoring of an arch bridge: From automated OMA to damage detection." Mech. Syst. Sig. Process., 28, 212-228.

MATLAB 8.3.0.532 (2014). MathWorks, Inc., Natick, MA

McLachlan, G., and Krishnan, T. (2007). The EM algorithm and extensions, John Wiley \& Sons, New York.

Moaveni, B., and Behmanesh, I. (2012). "Effects of changing ambient temperature on finite element model updating of the Dowling Hall Footbridge." Eng. Struct., 43, 58-68.

Mosavi, A. A., Seracino, R., and Rizkalla, S. (2012). "Effect of temperature on daily modal variability of a steel-concrete composite bridge." $J$. Bridge Eng., 10.1061/(ASCE)BE.1943-5592.0000372,979-983.

Moser, P., and Moaveni, B. (2011). "Environmental effects on the identified natural frequencies of the Dowling Hall footbridge." Mech. Syst. Sig. Process., 25(7), 2336-2357.

Moser, P., and Moaveni, B. (2013). "Design and deployment of a continuous monitoring system for the Dowling Hall footbridge." Exp. Tech., $37(1), 15-26$.

Narros, A. (2011). "Pasarela Peatonal 'Pedro Gómez Bosque' sobre el Río Pisuerga en la Ciudad de Valladolid. Un Nuevo Récord de Longitud en Pasarelas Colgadas de Banda Tesa." Rev. Tec. Cemento-Hormigón, 947, 80-86 (in Spanish)

Ni, Y., Hua, X., Fan, K., and Ko, J. (2005). "Correlating modal properties with temperature using long-term monitoring data and support vector machine technique." Eng. Struct., 27(12), 1762-1773.

Overschee, P. V., and Moor, B. D. (1996). Subspace identification for linear systems, Kluwer Academic, Boston.

Peeters, B., and De Roeck, G. (1999). "Reference-based stochastic subspace identification for output-only modal analysis." Mech. Syst. Sig. Process., $13(6), 855-878$.

Reynders, E. (2012). "System identification methods for (operational) modal analysis: Review and comparison." Arch. Comput. Methods Eng., 19(1), 51-124.

Reynders, E., Houbrechts, J., and De Roeck, G. (2012). "Fully automated (operational) modal analysis." Mech. Syst. Sig. Process., 29, 228-250.

Reynders, E., Schevenels, M., and Roeck, G. D. (2008). "MACEC: A $M A T L A B$ toolbox for experimental and operational modal analysis." Katholieke Univ. Leuven, Leuven, Belgium.

Stiros, S., and Moschas, F. (2014). "Rapid decay of a timber footbridge and changes in its modal frequencies derived from multiannual lateral deflection measurements." J. Bridge Eng., 10.1061/(ASCE)BE.1943 $-5592.0000629,05014005$.

Wenzel, H., and Pichler, D. (2005). Ambient vibration monitoring, John Wiley \& Sons, West Sussex, U.K.

Zhang, T., Wang, Y., and Tamura, A. (2010). "A frequency-spatial domain decomposition (FSDD) method for operational modal analysis." Mech Syst. Sig. Process., 24(5), 1227-1239.

Zhou, H. F., Ni, Y. Q., and Ko, J. M. (2011). "Eliminating temperature effect in vibration-based structural damage detection." J. Eng. Mech., 10 1061/(ASCE)EM.1943-7889.0000273,785-796 


\section{AD-HOC VIBRATION MONITORING SYSTEM FOR A STRESS-RIBBON FOOTBRIDGE: FROM DESIGN TO OPERATION}

Ibán, N., Soria, J.M., Magdaleno, A., Casado, C., Díaz, I.M., and Lorenzana, A.

SMART STRUCTURES AND SYSTEMS 22(1): 13-25. 2018/07

Engineering, Civil

\section{CR Impact Factor}

Factor de impacto 2.231. Rank Q1

DOI: $10.12989 /$ sss.2018.22.1.013

ISO: Smart. Struct. Syst.

JCR Abbrev: SMART STRUCT SYST

\begin{tabular}{l|l} 
JCR & ENGINEERING, CIVIL
\end{tabular}

\begin{tabular}{|c|c|c|c|}
\hline $\begin{array}{l}\text { Year } \\
\text { Yea }\end{array}$ & Rank & Quartile & JIF Percentile \\
\hline 2017 & $32 / 128$ & Q1 & 75.391 \\
\hline 2016 & $62 / 125$ & Q2 & 50.800 \\
\hline 2015 & $57 / 126$ & 02 & 55159 \\
\hline 2014 & $37 / 125$ & Q2 & 70.800 \\
\hline 2013 & $46 / 124$ & Q2 & 63.306 \\
\hline 2012 & $24 / 122$ & Q1 & 80.738 \\
\hline 2011 & $28 / 118$ & Q1 & 76.695 \\
\hline 2010 & $22 / 115$ & Q1 & 81.304 \\
\hline 2009 & $28 / 106$ & Q2 & 74.057 \\
\hline 2008 & 22/91 & Q1 & 76.374 \\
\hline 2007 & $49 / 89$ & Q3 & 45.506 \\
\hline 2006 & $27 / 83$ & Q2 & 68.072 \\
\hline 2005 & $80 / 80$ & Q4 & 0.625 \\
\hline
\end{tabular}

Smart Structures and Systems ISSN: 1738-1584

TECHNO-PRESS

PO BOX 33, YUSEONG,DAEJEON 305-600,SOUTH KOREA SOUTH KOREA

\section{Categories}

ENGINEERING, CIVIL - SCIE; ENGINEERING, MECHANICAL . $\mathrm{SCIE}$

\section{Key Indicators}

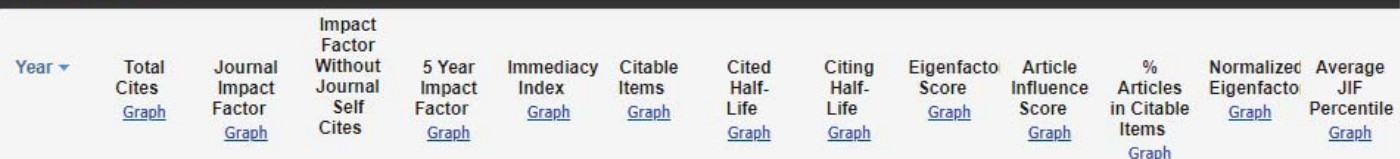

Graph

\begin{tabular}{|c|c|c|c|c|c|c|c|c|c|c|c|c|c|}
\hline 2017 & 1,597 & 2.231 & 1.682 & 2.083 & 1.057 & 123 & 3.3 & 7.0 & 0.00 & 0.415 & 100.00 & 0.34 & 70.829 \\
\hline 2016 & 989 & 1.382 & 1.072 & 1.436 & 0.293 & 123 & 3.9 & 7.4 & $0.00 \ldots$ & 0.288 & 100.00 & $0.21 \ldots$ & 47.296 \\
\hline 2015 & 761 & 1.138 & 0.792 & 1.528 & 0.159 & 145 & 4.1 & 8.3 & $0.00 \ldots$ & 0.341 & 100.00 & $0.21 \ldots$ & 48.229 \\
\hline 2014 & 568 & 1.368 & 1.060 & 1.352 & 0.265 & 117 & 3.9 & 8.1 & $0.00 \ldots$ & 0.298 & 100.00 & $0.15 \ldots$ & 63.000 \\
\hline 2013 & 497 & 1.160 & 0.915 & 1.428 & 0.380 & 71 & 3.5 & 8.3 & $0.00 \ldots$ & 0.359 & 100.00 & $0.18 \ldots$ & 57.695 \\
\hline 2012 & 352 & 1.430 & 1.140 & 1.276 & 0.177 & 62 & 2.9 & 7.8 & $0.00 \ldots$ & 0.314 & 100.00 & Not ... & 73.139 \\
\hline 2011 & 302 & 1.231 & 0.879 & 1.248 & 0.140 & 57 & 3.2 & 7.9 & $0.00 \ldots$ & 0.320 & 100.00 & Not ... & 71.542 \\
\hline 2010 & 235 & 1.316 & 0.778 & 1.292 & 0.281 & 64 & 2.7 & 6.3 & $0.001 \ldots$ & 0.339 & 98.44 & Not ... & 73.686 \\
\hline 2009 & 126 & 1.064 & 0.961 & 0.992 & 0.068 & 44 & 2.3 & 7.7 & $0.00 \ldots$ & 0.398 & 100.00 & Not ... & 67.645 \\
\hline 2008 & 101 & 1.137 & 0.666 & 1.205 & 0.235 & 51 & 2.1 & 7.5 & $0.00 \ldots$ & 0.370 & 98.04 & Not ... & 66.589 \\
\hline 2007 & 25 & 0.478 & 0.413 & 0.500 & 0.074 & 27 & Not ... & 6.7 & $0.00 \ldots$ & 0.192 & 96.30 & Not ... & 40.278 \\
\hline 2006 & 15 & 0.682 & 0.682 & Not ... & 0 & 24 & Not ... & 7.8 & Not ... & Not ... & 100.00 & Not ... & 57.754 \\
\hline 2005 & 1 & Not $\mathrm{A} \ldots$ & Not A... & Not ... & 0.045 & 22 & Not ... & 6.4 & Not ... & Not ... & 100.00 & Not ... & 1.330 \\
\hline
\end{tabular}

\begin{tabular}{c|c|c|c|} 
Aportaciones: & Experimentación & Procesado & Edición \\
\hline \multirow{2}{*}{} & Instrumentación & Matlab & Tablas \\
& Registros & Excel & Gráficas \\
& Tests & Sigview & Imágenes \\
\cline { 2 - 4 }
\end{tabular}




\title{
Ad-hoc vibration monitoring system for a stress-ribbon footbridge: from design to operation
}

\author{
Norberto Iban ${ }^{1 \mathrm{a}}$, Jose M. Soria ${ }^{2 \mathrm{~b}}$, Alvaro Magdaleno ${ }^{* 3}$, Carlos Casado ${ }^{1 \mathrm{c}}$, \\ Ivan M. Diaz ${ }^{2 \mathrm{~d}}$ and Antolin Lorenzana ${ }^{3 \mathrm{e}}$ \\ ${ }^{1}$ Centro Tecnológico CARTIF. Parque Tecnológico de Boecillo, 47151 Valladolid, Spain \\ ${ }^{2}$ E.T.S. de Ingenieros de Caminos, Canales y Puertos, Universidad Politécnica de Madrid, \\ Calle del Profesor Aranguren 3, 28040 Madrid, Spain \\ ${ }^{3}$ ITAP, Escuela de Ingenierias Industriales, Universidad de Valladolid, Paseo del Cauce 59, 47011 Valladolid, Spain
}

(Received January 31, 2017, Revised March 29, 2018, Accepted April 19, 2018)

\begin{abstract}
Pedro Gómez Bosque footbridge is a slender and lightweight structure that creates a pedestrian link over the Pisuerga River, Valladolid, Spain. This footbridge is a singular stress ribbon structure with one span of $85 \mathrm{~m}$ consisting on a steel plate and precast concrete slabs laying on it. Rubber pavement and a railing made of stainless steel and glass complete the footbridge. Because of its lively dynamics, prone to oscillate, a simple and affordable structural health monitoring system was installed in order to continuously evaluate its structural serviceability and to estimate its modal parameters. Once certain problems (conditioning and 3D orientation of the triaxial accelerometers) are overcome, the monitoring system is validated by comparison with a general purpose laboratory portable analyzer. Representative data is presented, including acceleration magnitudes and modal estimates. The evolution of these parameters has been analysed over one-year time.
\end{abstract}

Keywords: SHM; serviceability assessment; structural dynamics; modal parameters

\section{Introduction}

This work describes the design, installation and initial operation of a remotely controlled continuous vibration monitoring system on a footbridge. The singularity of the structure, its slenderness and the prescription of not affecting to its aesthetic in any way, together with cost restrictions, lead to the decision of designing low-cost MEMS-based triaxial accelerometers properly conditioned and embedded inside the handrail as structural vibration sensors. The monitoring system was validated by comparing the data measured by the MEMS accelerometers with conventional piezoelectric accelerometers. These tests demonstrated that these sensors are a competitive alternative to traditional ones and that the system is ready to be used for the dynamic characterization of the structure and to integrate a continuous structural health assessment

*Corresponding author, Ph.D. Student

E-mail: alvaro.magdaleno@uva.es

${ }^{\text {a }}$ Ph.D. Student

E-mail: noriba@catif.es

${ }^{\mathrm{b}} \mathrm{Ph}$.D. Student

E-mail: jm.soria@upm.es

${ }^{\mathrm{c}} \mathrm{Ph}$.D. Student

E-mail: carcas@cartif.es

${ }^{\mathrm{d}}$ Dr.

E-mail: ivan.munoz@upm.es

${ }^{\mathrm{e}} \mathrm{Dr}$.

E-mail: ali@eii.uva.es

Copyright () 2018 Techno-Press, Ltd.

http://www.techno-press.com/journals/sss\&subpage=7 and serviceability analysis.

The use of traditional techniques for life cycle management together with structural health monitoring new techniques enables more accurate identification for optimal maintenance strategies for a wide range of limit states (Orcesi et al. 2010). The long-term monitoring provides the best method to understand and quantify the real environmental loading and the corresponding structure response.

Multiple examples of structures equipped with monitoring systems can be found (Brownjohn et al. 2010, Swartz et al. 2010, Gomez et al. 2011, Moser and Moaveni 2013, Casciati et al. 2014): chimneys, wind turbines, masonry towers, bridges, footbridges, etc. The main problem for wide-spreading the implementation of these monitoring systems is the cost associated to purchasing, installation of the measuring system (sensors, acquisition equipment, wires, ...) and its operation maintenance. Many authors have conducted studies that involve the use of wireless technologies in order to reduce costs associated to wiring and installation (Shinozuka et al. 2004, Chen and Casciati 2014, Tokognon et al. 2017). However, these systems usually suffer communication problems in large structures and under environmental hazards. Additionally, it is not always possible to ensure wireless communication between sensors and problems with battery life arisen when long-term monitoring is required. These problems have been tackled by using energy harvesting systems (Guan and Liao 2006, Chen 2014), but they have not reached sufficient maturity yet. Another option to reduce the cost of monitoring systems is the one chosen in the structure under study: to use low-cost wired sensors and data loggers. Other 


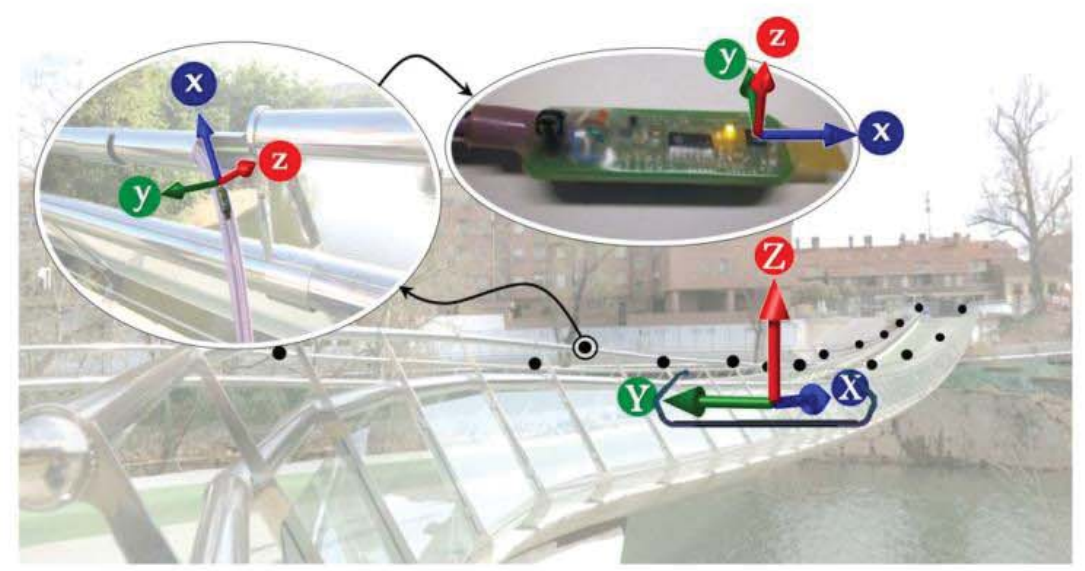

Fig. 1 Cross-section with the global axis, local axis for the MEMS accelerometers and their location (black points) in the footbridge

authors have also experienced with this kind of new promising technologies (Ceylan et al. 2013, Tan et al. 2011, Panigrahi et al. 2010, Caetano et al. 2011) in increasing development during the last decade.

\section{Structure description}

Pedro Gómez Bosque footbridge (see Fig. 1) mainly consists of a corten steel sheet of $94 \mathrm{~m}$ long, $3.6 \mathrm{~m}$ width and only $30 \mathrm{~mm}$ thick which is pre-tensioned and anchored to the two abutments, which are $85 \mathrm{~m}$ apart and $2 \mathrm{~m}$ not on a level. The complete steel sheet was on-site manufactured welding together 8-meter long plates. Precast concrete slabs of $5.2 \mathrm{~m}$ long, $0.75 \mathrm{~m}$ width and around $120 \mathrm{~mm}$ thick lay on the steel sheet. These slabs do not have bearing mission, that is, the only structural element between abutments is the steel sheet. The structure is completed by rubber pavement and a stainless steel and glass railing. More information about the structure can be seen in Narros (2011). All these structural and non-structural elements suppose, according to the project, a dead load around $\omega=23.6 \mathrm{kN} / \mathrm{m}$. Initial pretension on the steel sheet was adjusted so that, at the reference temperature $\left(20^{\circ} \mathrm{C}\right)$, displacement in the middle (sag) were limited to $\mathrm{L} / 50$ which means $1.7 \mathrm{~m}$. Using indirect computations, an axial tension of $H=12.54 \mathrm{MN}$ (in reference conditions) has been estimated so stresses in the steel are around $120 \mathrm{MPa}$. Considering a service overload of $\Delta \omega=15.7 \mathrm{KN} / \mathrm{m}$ and cold weather conditions, stresses could reach up to $192 \mathrm{MPa}$. Analytically estimated values for deflection $(\delta)$ and axial force $(H)$ are presented in Table 1 for the relevant design conditions. Note that a change in $15^{\circ} \mathrm{C}$ supposes a thermal elongation of $17 \mathrm{~mm}$ leading to a change around $1.25 \mathrm{MN}$ in the axial tension. Besides, as it is known (Strasky 2005, Lepidi and Gattulli 2012), the temperature not only affect to the static response but also to the frequency of the vibration modes, as Table 2 will show.
Table 1 Estimated static response for relevant project loading conditions

\begin{tabular}{cccc}
\hline \hline$\omega(\mathrm{kN} / \mathrm{m})$ & $\Delta t\left({ }^{\circ} \mathrm{C}\right)$ & $\delta(\mathrm{m})$ & $H(\mathrm{MN})$ \\
\hline 23.6 & 0.0 & 1.70 & 12.54 \\
23.6 & -15.0 & 1.55 & 13.79 \\
39.3 & 15.0 & 2.03 & 17.45 \\
39.3 & -15.0 & 1.77 & 20.03 \\
\hline
\end{tabular}

A previous operational modal analysis was carried out using a portable lab system (consisting on 8 piezoelectric accelerometers MMF-KS48C, with $1000 \mathrm{mV} / \mathrm{g}$ sensitivity and low frequency ranges connected to a MGCplus HBM data logger through IEPE modules). Natural frequencies and mode shapes were estimated using standard SSI methodology. About twenty vibration modes, including vertical, lateral, torsional and coupled modes, were well identified between 0.8 and $10 \mathrm{~Hz}$. This preliminary data is important to design the monitoring system and to choose the most appropriate technical specifications for the sensors and their number and location in the structure.

\section{Monitoring system}

From the functional and aesthetic point of view, the only possibility for installing the vibration sensors was to embed them into the $60 \mathrm{~mm}$ diameter CHS tube used as handrail. 18 triaxial accelerometers, 9 at each side of the deck, were positioned equidistant $10.625 \mathrm{~m}$ along the span (plotted with black points in Fig. 1). A temperature sensor, an anemometer and a vane installed in a nearby streetlight complete the system.

\subsection{Sensors description, conditioning and installation}

The vibration sensor chosen was the ADXL327 MEMS accelerometer developed by Analog Devices. The 
ADXL327 is a very small, low power, 3-axis accelerometer with signal conditioned voltage outputs. It can measure the static acceleration of gravity in tilt-sensing applications as well as dynamic acceleration at high sampling frequencies. The accelerometer properties are initially suitable (measurement range up to $\pm 2.5 \mathrm{~g}$, sensitivity up to $500 \mathrm{mV} / \mathrm{g}$, bandwidth up to $550 \mathrm{~Hz}$ ) to measure the expected dynamic response (in frequencies and in amplitudes) but it is not initially designed for long wire distances. To overcome this problem, MEMS device has been integrated in a circuit (Fig. 2) with other consumer electronic durables. First, a capacitor was placed in each axis in order to fix the measurement bandwidth to $100 \mathrm{~Hz}$. Then, as the accelerometer has to be supplied by $3.6 \mathrm{~V}$ to get its nominal sensitivity of $500 \mathrm{mV} / \mathrm{g}$. the power supply used is in $12 \mathrm{~V}$ and a voltage regulator to $3.6 \mathrm{~V}$ were integrated in the circuit board in order to avoid power losses by the long wires. As the impedance at each axis of the accelerometer output is high enough $(32 \mathrm{k} \Omega)$ to cause noise problems by the long wires, an operational amplifier was added to reduce the impedance to $10 \Omega$ and decrease the noise to $25 \mu \mathrm{g} / \sqrt{ } \mathrm{Hz}$. Also, a LED was included for power test. All the components, together with the end of its wire, are sealed using a thermo shrink-wrap plastic system (Fig. 1, right detail). The circuit resulting prototype is small enough $(50 \times 17 \times 8 \mathrm{~mm})$ for installing requirements.

Wires and sensors were immersed inside the handrail using a long wire guide. This fact introduced additional complications on the installation process as the orientation of the 3 axes of the sensor cannot be fixed beforehand. To overcome this problem, one of the axis of the triaxial accelerometer (x) was placed along the longitudinal direction of the board and its long side was aligned with the set of wires. In this way, after introducing the set of wires along the handrail (see left detail in Fig. 1), it can be assumed that the $\mathrm{x}$-axis for all the sensor remains in the vertical plane (XZ), although no initial guess can be made about the spatial orientation of the other two axes ( $y$ and $z$ ). With this installing procedure, yaw angle around local $\mathrm{z}$ axis is prevented but a certain pitch $(\alpha)$ and roll $(\beta)$ angles are still unknown (Fig. 3). A so called "static acceleration vector" $\left[\bar{a}_{x}, \bar{a}_{y}, \bar{a}_{z}\right]^{t}$ can be obtained averaging each axis register over enough time. Once transformed using the pitch and roll angles, this vector has to be the gravity vector $[0,0, g]^{t}$, as shown in Eq. (1).

$$
\begin{gathered}
{\left[\begin{array}{l}
0 \\
0 \\
g
\end{array}\right]=\left[\begin{array}{ccc}
\cos \alpha & 0 & \sin \alpha \\
0 & 1 & 0 \\
-\sin \alpha & 0 & \cos \alpha
\end{array}\right] \cdot\left[\begin{array}{ccc}
1 & 0 & 0 \\
0 & \cos \beta & \sin \beta \\
0 & -\sin \beta & \cos \beta
\end{array}\right]} \\
\cdot\left[\begin{array}{l}
\bar{a}_{x} \\
\bar{a}_{y} \\
\bar{a}_{z}
\end{array}\right]=[R] \cdot\left[\begin{array}{l}
\bar{a}_{x} \\
\bar{a}_{y} \\
\bar{a}_{z}
\end{array}\right]
\end{gathered}
$$

Solving the corresponding system of equations, it is possible to get $\alpha$ and $\beta$ so matrix $[R]$ is known and acceleration vector in the global coordinate system $\left[a_{X}, a_{Y}, a_{Z}\right]^{t}$ (see Fig. 1), once removed the static value, can be obtained for any record $\left[a_{x}, a_{y}, a_{z}\right]^{t}$ using Eq. (2).

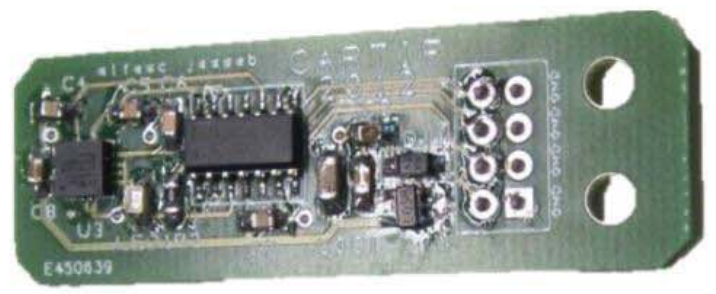

Fig. 2 Printed circuit board with all components

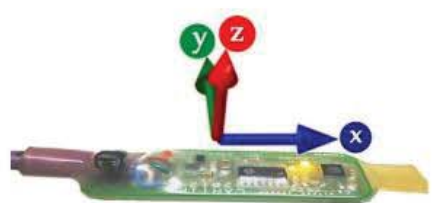

(a)

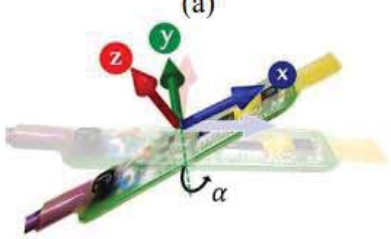

(b)

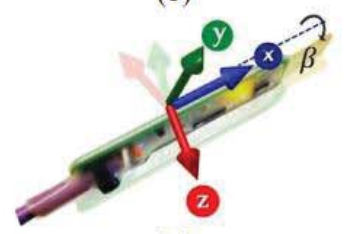

(c)

Fig. 3 Local $x, y, z$ axis (a) in each board after a pitch, (b) and a roll and (c) rotations

$$
\left[\begin{array}{l}
a_{X} \\
a_{Y} \\
a_{Z}
\end{array}\right]=[R] \cdot\left[\begin{array}{l}
a_{x} \\
a_{y} \\
a_{z}
\end{array}\right]-\left[\begin{array}{l}
0 \\
0 \\
g
\end{array}\right]
$$

As an example, applying this procedure to the data shown in Fig. 4(a), where $\left[\bar{a}_{x}, \bar{a}_{y}, \bar{a}_{z}\right]^{t}=[1.30,9.55,1.83]^{t}$, the resulting angles are $\alpha=7.61^{\circ}$ and $\beta=100.85^{\circ}$. The transformed acceleration vector $\left[a_{X}, a_{Y}, a_{Z}\right]^{t}$ is shown in Fig. 4(b). The angular values obtained might change slightly with the temperature (note that the set of wires is free to move inside the handrail) and because of that they are recalculated hourly.

The temperature sensors used for the monitoring system was model T0110 transmitter Comet with range -30 to $+80^{\circ} \mathrm{C}$ and accuracy $\pm 0.4^{\circ} \mathrm{C}$. The wind sentry used was model $03002 \mathrm{~L}$ from R. M. Young Company with range 0 to $50 \mathrm{~m} / \mathrm{s}$ and accuracy $\pm 0.5 \mathrm{~m} / \mathrm{s}$ for the speed and range $360^{\circ}$ and accuracy $\pm 5 \mathrm{~m} / \mathrm{s}$ for the direction. 


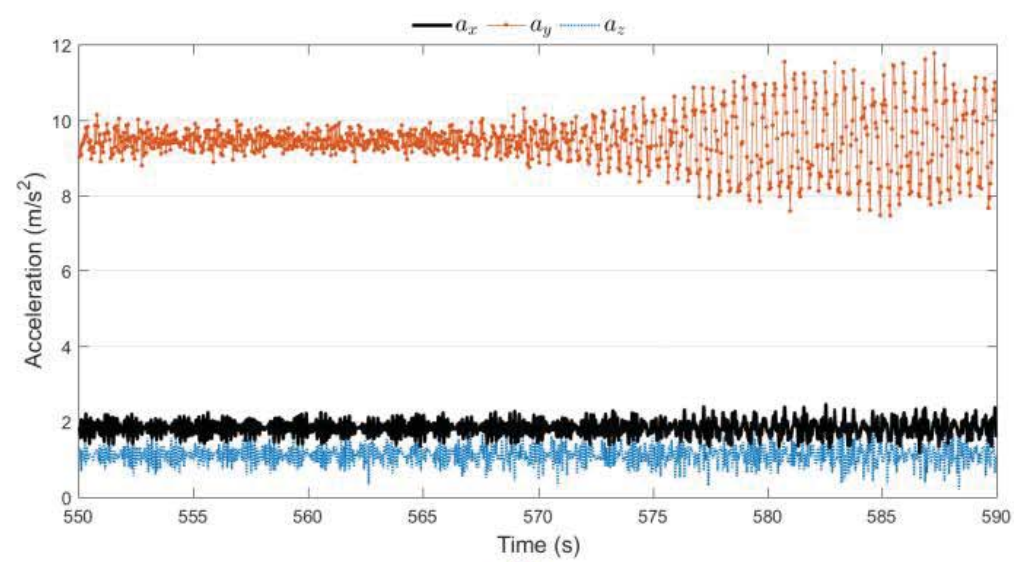

(a)

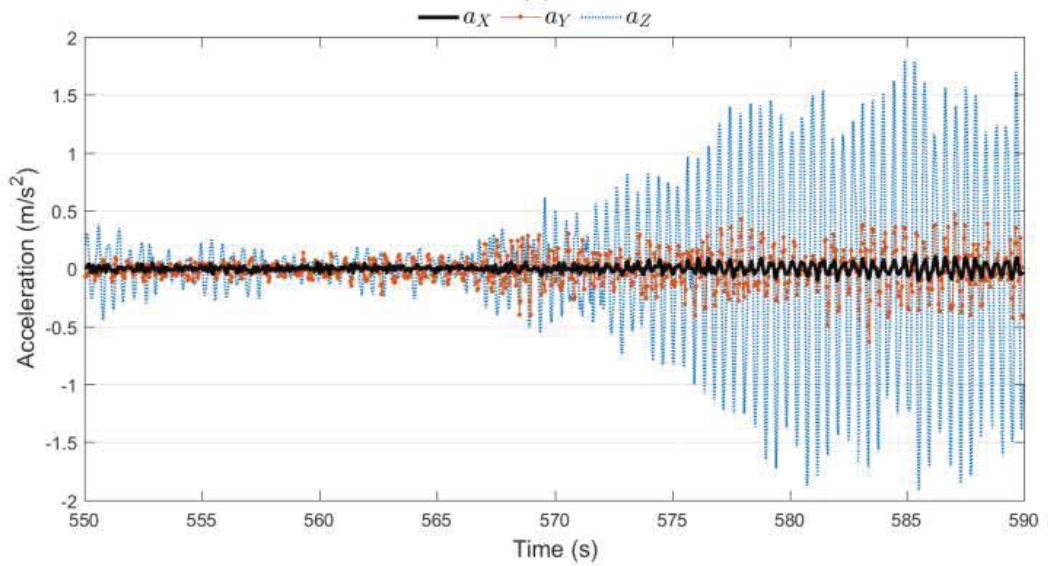

(b)

Fig. 4 Local x, y, z accelerations (a) and transformed ones (b) into the global axis (X, Y, Z)

\subsection{Lab calibration}

In order to calibrate the new devices and to evaluate their signal-to-noise ratio the following procedure was carried out. The portable lab system (equipped with the piezoelectric accelerometers) was placed together with the MEMS one connected to the longest wire (around 100 m). Both were located in a bending pinned beam (first mode at $2.27 \mathrm{~Hz}$, free damped response after an impulsive load, $0.18 \%$ damping). Results are shown in Fig. 5. Note that, regardless technical specifications and the electronic conditioning, for amplitudes below $0.02 \mathrm{~m} / \mathrm{s}^{2}$ the noise is very evident and induce increments in the RMS values in more than $10 \%$, so the use of the signal is limited. The three axis of each MEMS have the same amplitude calibration and signal-to-noise ratio. Same data-logger is used to record piezoelectric and MEMS signals. Even though, MEMS signal is $0.032 \mathrm{~s}$ delayed due to the MEMS electronic conditioning devices. This delay is the same for all the MEMS regardless the length of the wire, so this is not a problem for modal identification purposes if only MEMS accelerometers are used.

\subsection{Data logger}

As said before, the monitoring system comprises 18 triaxial accelerometers, a temperature sensor and an anemometer and vane in such a way that 57 voltage channels for the measurement system were needed. The data logger chosen was a CompactRIO 9076 from National Instruments with two 32 channels analogic input modules NI 9205. This data logger with a rugged hardware chassis has a stand-alone embedded control useful for real-time acquisition. The real-time processor is of $400 \mathrm{MHz}$ and Ethernet, USB and RS232 connections are available in this model. The modules have 32 single-ended analogic inputs with 16-bit resolution, $250 \mathrm{kS} / \mathrm{s}$ aggregate sampling rate and voltage range from $\pm 200 \mathrm{mV}$ to $\pm 10 \mathrm{~V}$.

The frequency sampling for each channel is set to $200 \mathrm{~Hz}$, enough to identify the modal parameters of the structure and to avoid aliasing problems (significant vibration modes have natural frequencies smaller than $10 \mathrm{~Hz}$ ). A file with the recorded data is saved each hour in order to post-process them and to prevent measurement failures. 

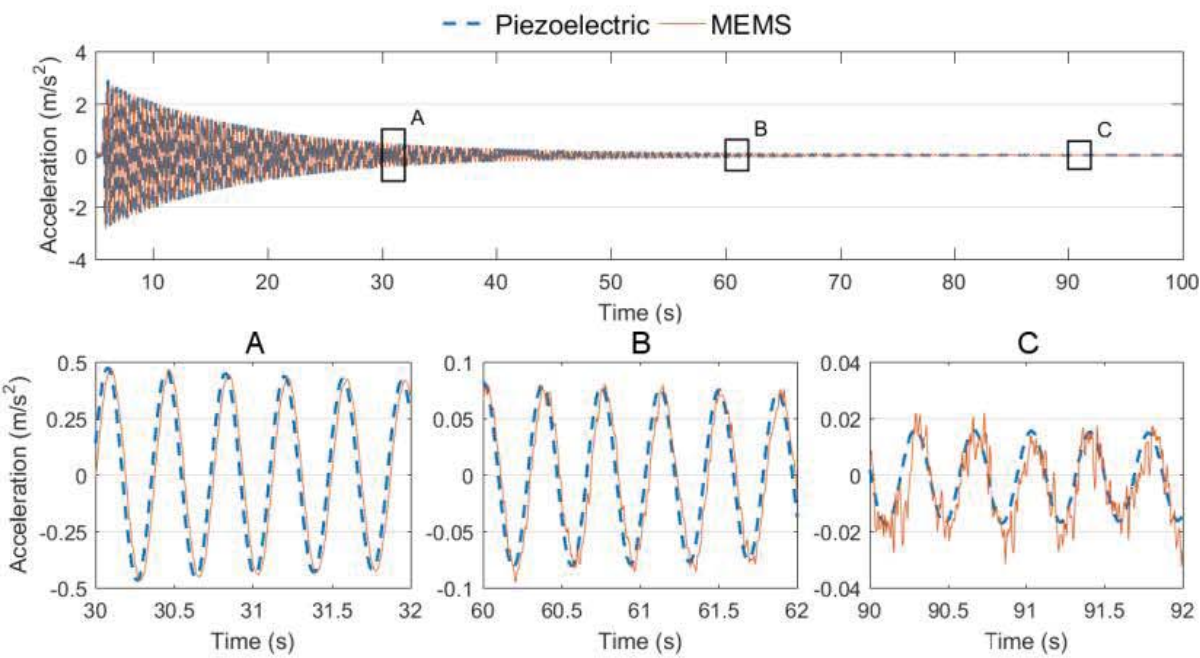

Fig. 5 Piezoelectric vs. MEMS devices

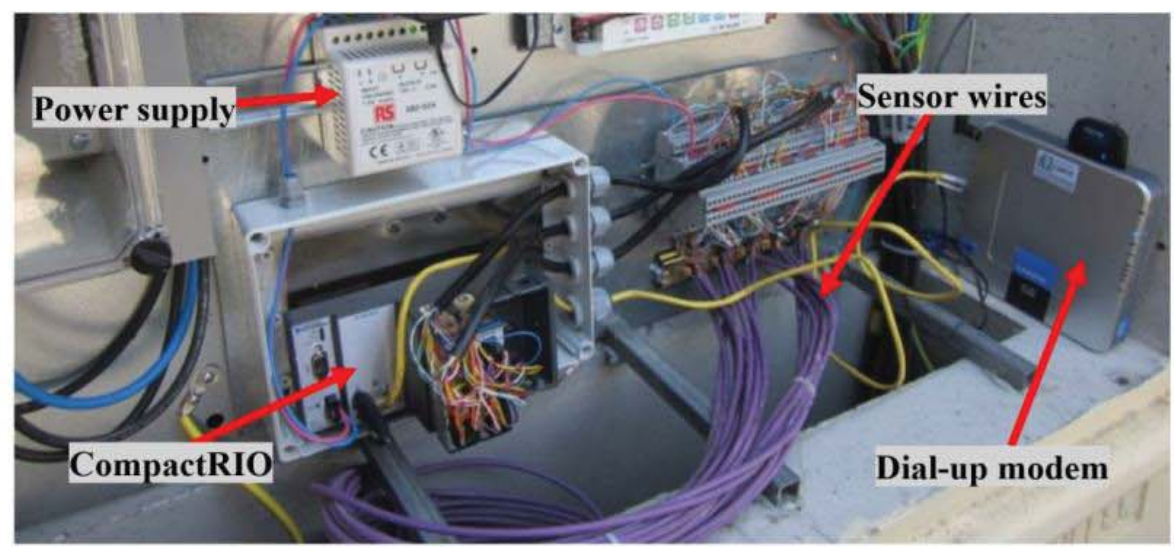

Fig. 6 Data logger, router and other devices

The two set of wires (one for each side of the railing) were long enough to reach the electrical cabinet sited near the footbridge where the data logger is installed. Fig. 6 shows the data logger and the two sets of wires, among other devices.

\subsection{In-situ validation}

Once the monitoring system was installed and ready to use, two additional checks were addressed. First, the location of each accelerometer was verified by lightly tapping on specific locations on the handrail, analyzing the response of the nearby accelerometers and identifying the one with more response, revealing its position accurately enough (around $120 \mathrm{~mm}$ ). With this procedure was also possible to find out some failures with 3 accelerometer units from the downstream side.
After that, experimental tests were carried out to check the performance of these new system. The structural response was registered when groups of pedestrians walking over the deck, both with the portable system and also with the newly MEMS-based monitoring system (Fig. 7). The piezoelectric accelerometers were levelled to measure the structural vertical accelerations. These values were compared (Fig. 8) with the acceleration in $\mathrm{Z}$ axis registered with the A4 MEMS accelerometers (the nearest one, located around one third of the bridge span). The two recorded data sets are very similar in time and frequency domains. The only difference is that one new frequency appears (around $4.8 \mathrm{~Hz}$ ) in the MEMS recordings. Those frequencies were identified as local natural frequencies for the handrail where MEMS are embedded. With the interest focused in modal identification and serviceability, the new frequencies are removed from the records after applying the corresponding band-stop filter. 


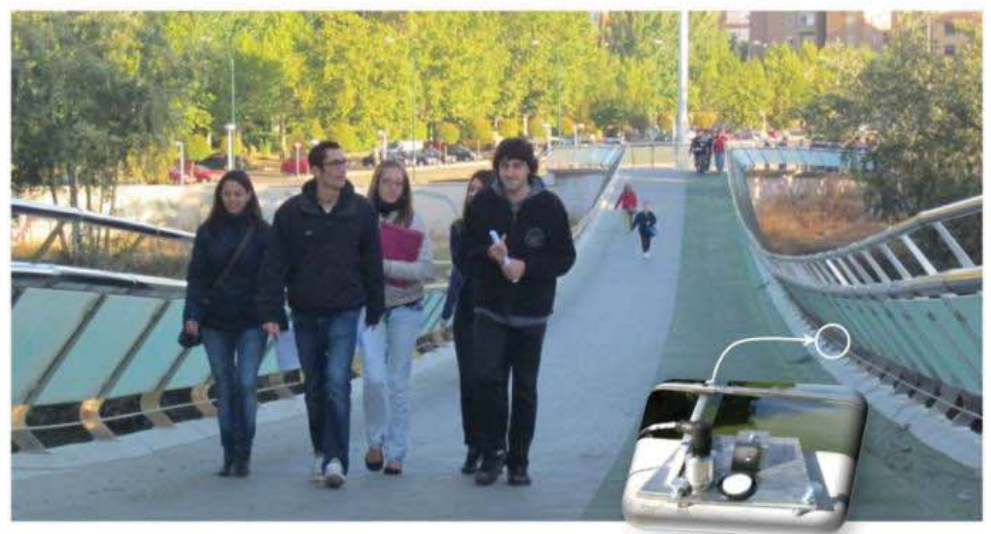

Fig. 7 Test for the in-situ validation comparing piezoelectric (detail view) versus A4 MEMS (embedded) records

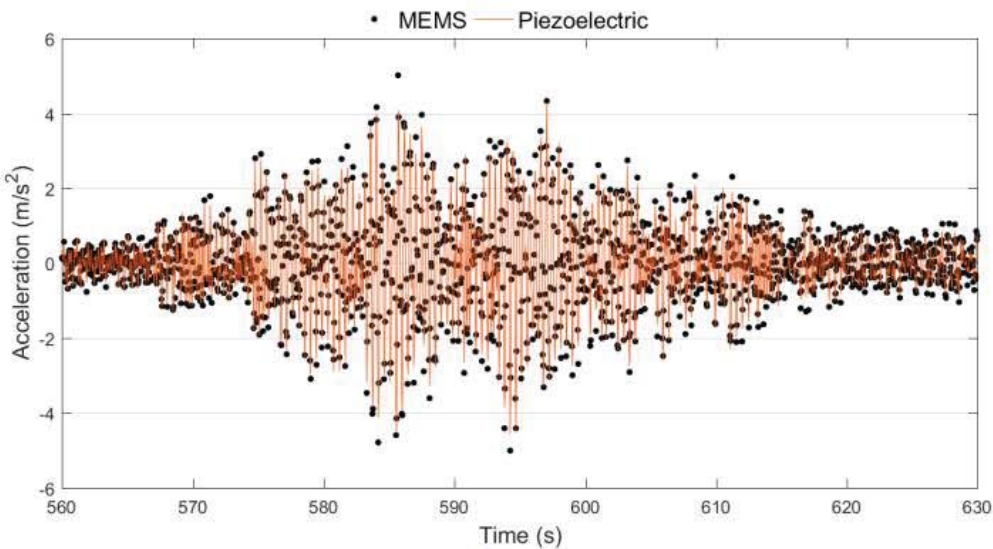

(a)

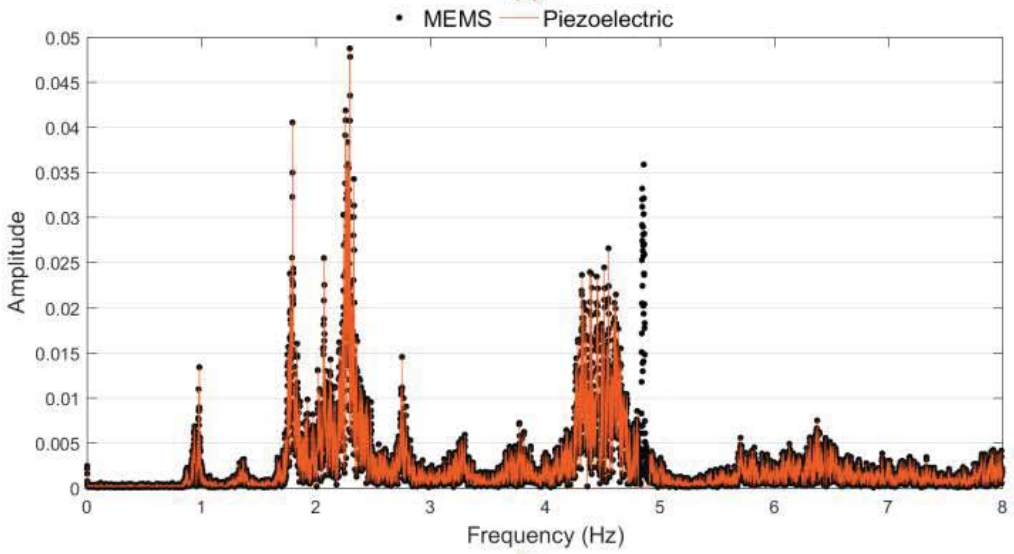

(b)

Fig. 8 Footbridge response registered with piezoelectric (blue) and A4 MEMS (red) accelerometers. (a) time domain and (b) frequency domain 


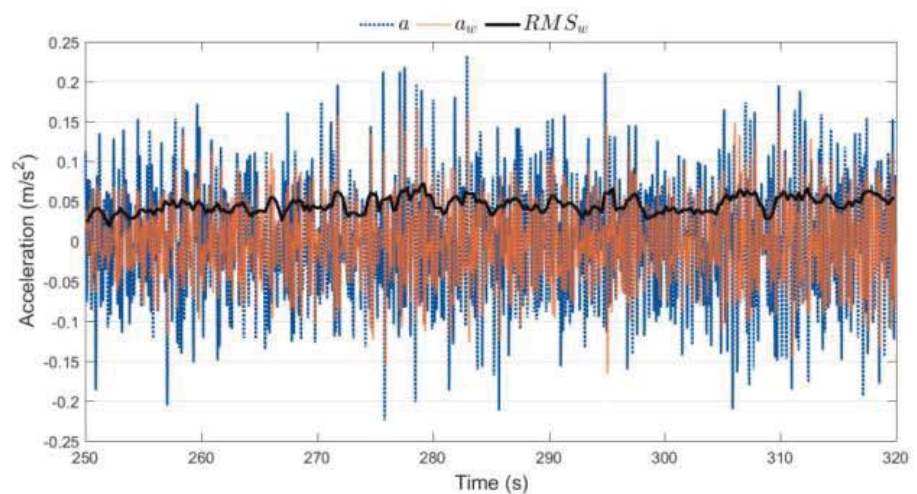

(a)

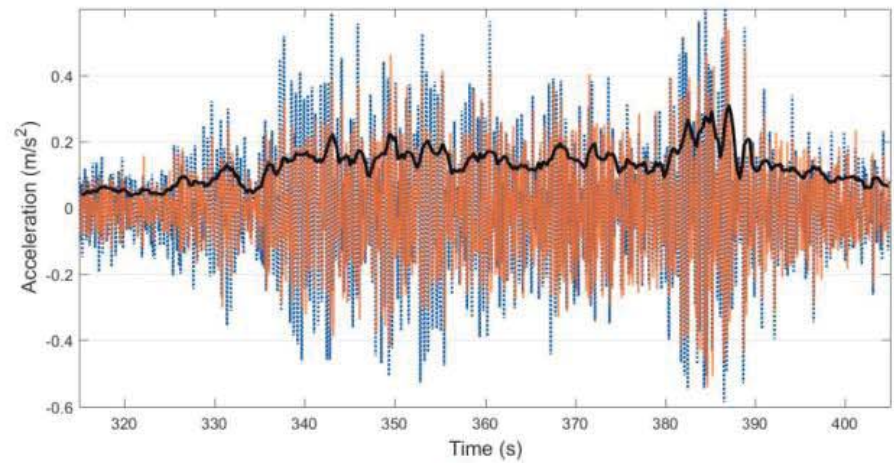

(b)

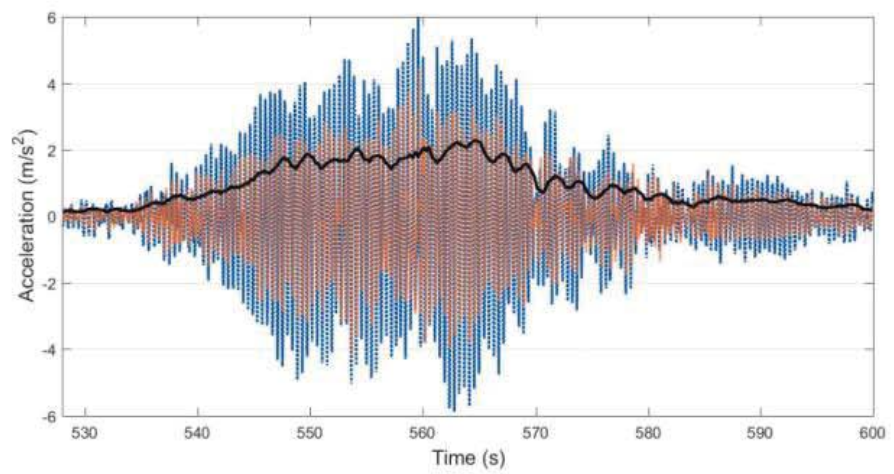

(c)

Fig. 9 A4 vertical accelerations and RMS trends when (a) no people crossing, (b) a group of 10 pedestrians crossing and (c) vandalism bouncing

\section{Monitoring results}

The operation of continuous monitoring systems leads to the accumulation of a huge amount of data that needs to be properly processed and analysed. For the accelerometer A4, vertical accelerations $a_{z}$, its weighted values $a_{Z w}$ (according to frequency weighting functions established in ISO 2631 for comfort criteria for standing pedestrian) and the weighted Root Mean Square (RMS) trend ( $1 \mathrm{~s}$ window) for three scenarios are presented in Fig. 9 during $75 \mathrm{~s}$ (averaged time that takes to cross the footbridge). Scenario (a) is for the structure under environmental conditions (no people crossing), (b) is for a group of 10 pedestrians and (c) is for vandalism bouncing. Mean weighted RMS values are $0.0265,0.145$ and $0.643 \mathrm{~m} / \mathrm{s}^{2}$ respectively.

Fig. 10 shows, for former scenario (b), the three components $\mathrm{X}, \mathrm{Y}$ and $\mathrm{Z}$ for the acceleration. Mean RMS values are $0.0191,0.0527$ and $0.173 \mathrm{~m} / \mathrm{s}^{2}$ respectively. 


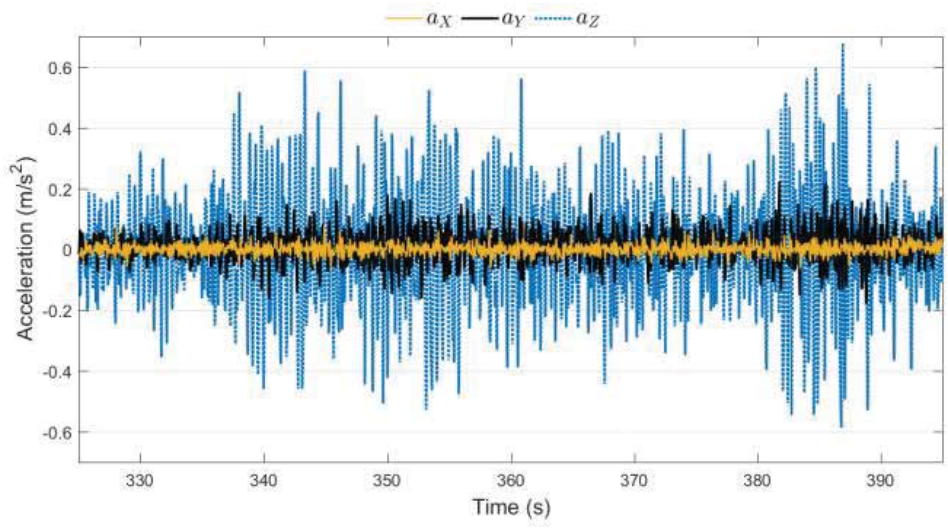

Fig. $10 \mathrm{~A} 4$ accelerations when a group of 10 pedestrians is crossing

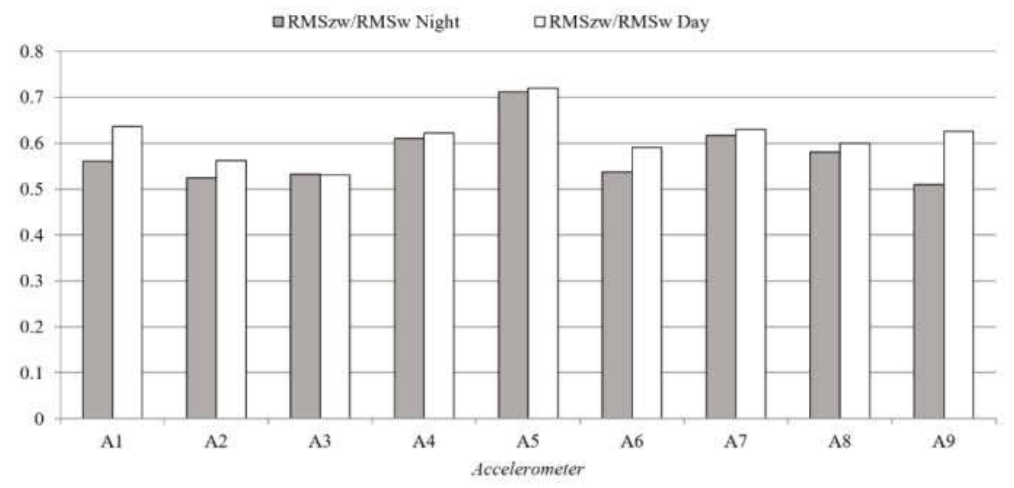

Fig. 11 Contribution of $a_{z}$ to the acceleration magnitude

\section{Post processed data}

In order to investigate the effect of pedestrians on the response of this lively stress-ribbon footbridge under normal operational conditions, hourly data is processed to get a representative parameter for the whole hour. Fig. 11 shows the contribution (in magnitude) of the vertical direction $(\mathrm{Z})$ to the whole acceleration vector $(\mathrm{X}, \mathrm{Y}$ and $\mathrm{Z})$. These values depend on the position of the accelerometers (from A1 to A9, in the upstream railing), but for all of them is around $60 \%$, both during daylight and at night hours. This means that the vertical vibrations are the prevailing ones but horizontal vibrations are not negligible. During daylight, considered from $8 \mathrm{am}$ to $5 \mathrm{pm}$, average use of the footbridge is more than one pedestrian at a time, being $\mathrm{RMS}_{\mathrm{Zw}}=0.125 \mathrm{~m} / \mathrm{s}^{2}$. During the night (from $11 \mathrm{pm}$ to $6 \mathrm{am}$ ) the $\mathrm{RMS}_{\mathrm{Zw}}$ is only $0.063 \mathrm{~m} / \mathrm{s}^{2}$.

Fig. 12 shows hourly parameters (peak, $\mathrm{RMS}_{\mathrm{w}}$ for the 3 axis and $\mathrm{RMS}_{\mathrm{Zw}}$ ) for one selected day. Some patterns can be observed (mainly day/night use, with maximum values around $9 \mathrm{am}$ and $6 \mathrm{pm}$ and minimum around $1 \mathrm{am}$ ). Presented values have been obtained averaging the parameters for the upstream accelerometers (from A1 to A9).
Mean values through the year are $0.418 \mathrm{~m} / \mathrm{s}^{2}$ for peak acceleration, $0.0934 \mathrm{~m} / \mathrm{s}^{2}$ for $\mathrm{RMS}_{\mathrm{w}}$ and $0.0532 \mathrm{~m} / \mathrm{s}^{2}$ for $\mathrm{RMS}_{\mathrm{Zw}}$.

Counting how many $\mathrm{RMS}_{\mathrm{w}}$ hourly data are inside certain ranges, is easy to determine the percentages shown in Fig. 13. ISO 2631, annex C.2.3 establishes comfort reactions to vibration environments for public transport according to the following ranges in terms of $\mathrm{RMS}_{\mathrm{w}}$ : Nonuncomfortable for less than $0.315 \mathrm{~m} / \mathrm{s}^{2}$, a little uncomfortable between 0.315 and $0.63 \mathrm{~m} / \mathrm{s}^{2}$, fairly uncomfortable between 0.5 and $1 \mathrm{~m} / \mathrm{s}^{2}$, uncomfortable between 0.8 and $1.6 \mathrm{~m} / \mathrm{s}^{2}$, very uncomfortable between 1.25 and $2.5 \mathrm{~m} / \mathrm{s}^{2}$ and extremely uncomfortable if greater than

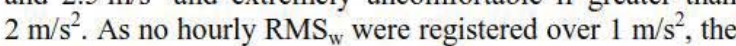
three last ranges do not appear in the case under study. Additionally, the first range was subdivided in two at $0.15 \mathrm{~m} / \mathrm{s}^{2}$, in order to get more detail information about comfortability. The resultant sub-ranges were classified as almost imperceptible up to $0.15 \mathrm{~m} / \mathrm{s}^{2}$ and noticeable between 0.15 and $0.315 \mathrm{~m} / \mathrm{s}^{2}$. Note that the footbridge over the months has good serviceability conditions, with most of the time in the non-uncomfortable range. Also Fig. 13 shows averaged values for the monthly temperatures. 


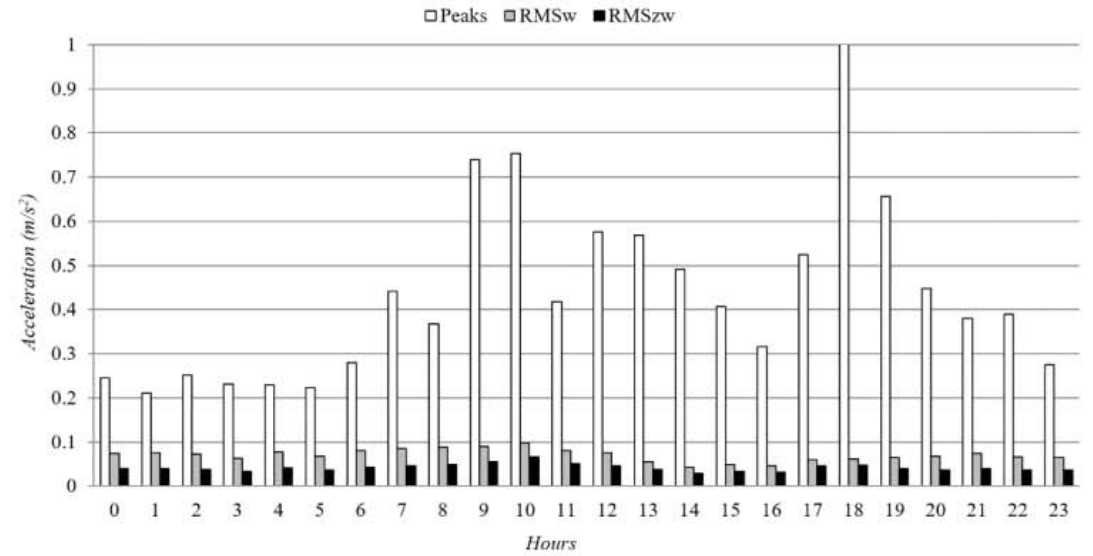

Fig. 12 Hourly parameters during a particular day

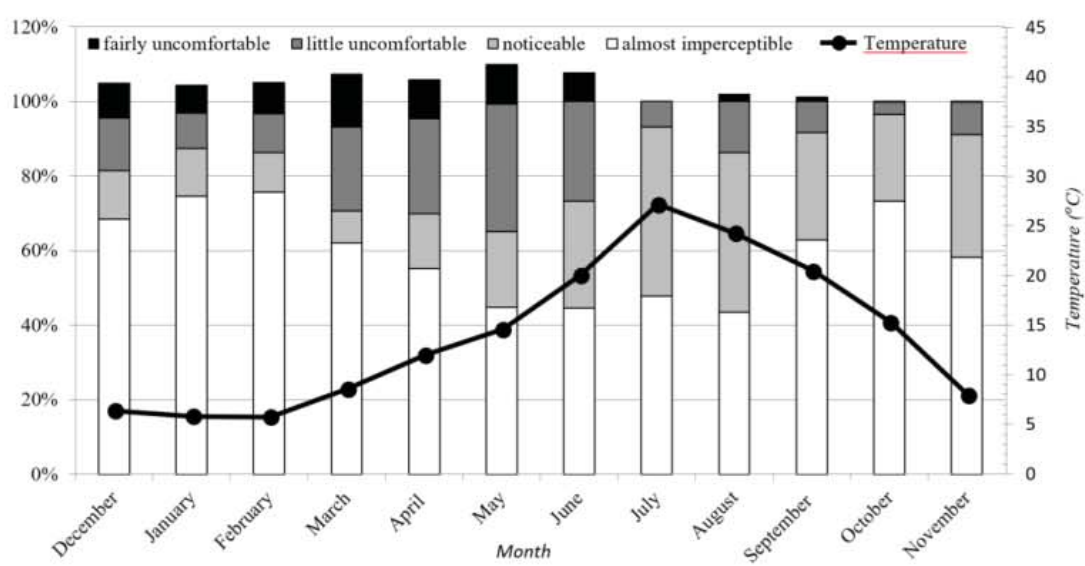

Fig. 13 Comfortability according ISO 2631

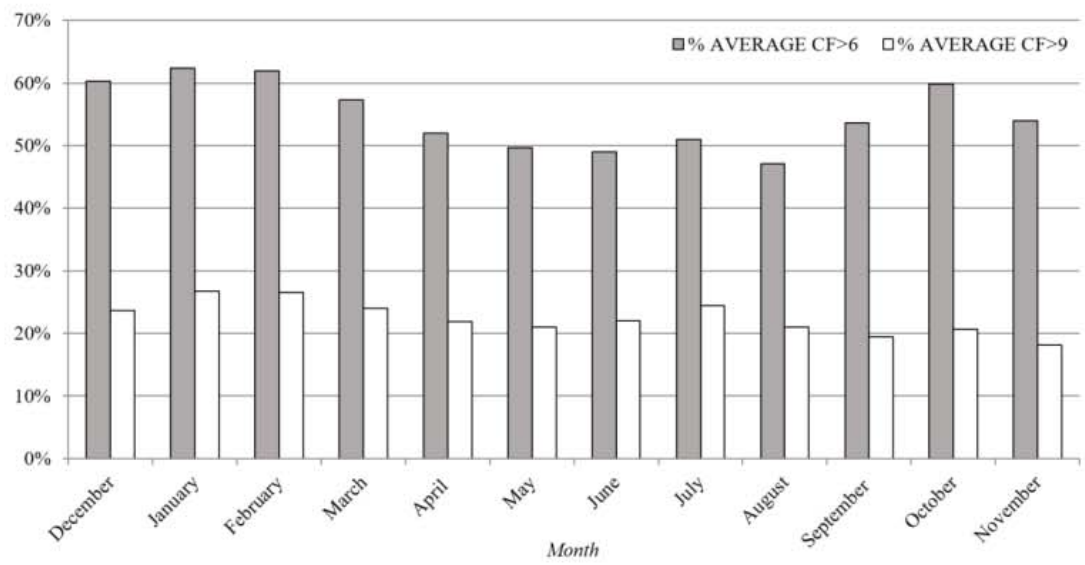

Fig. 14 Crest Factor exceeding 6 or 9 


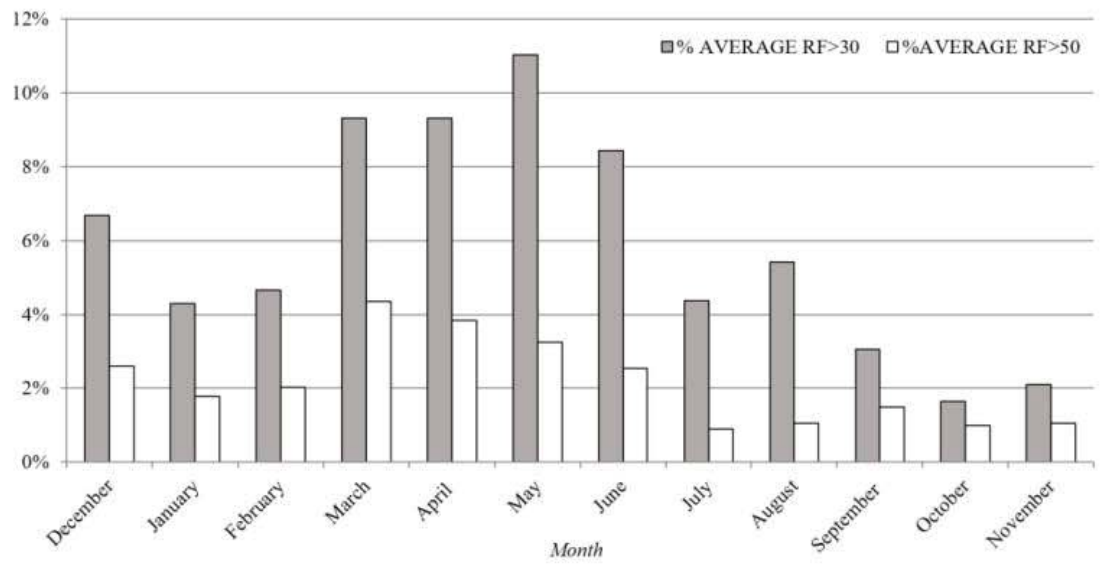

Fig. 15 Response Factor exceeding 30 or 50

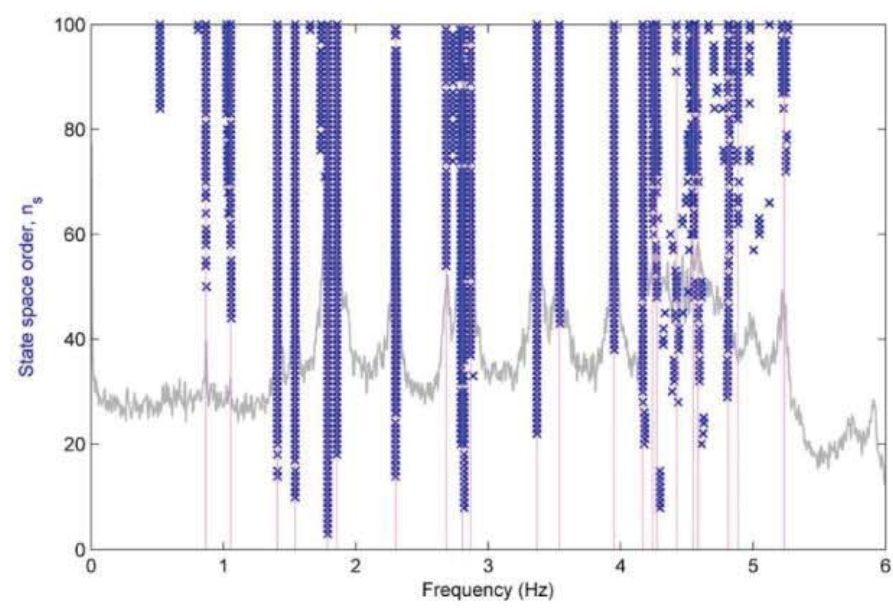

Fig. 16 Stabilization diagram using SSI algorithm up to order 100

ISO 2631 recommends the use of the $\mathrm{RMS}_{\mathrm{w}}$ as serviceability parameter only if crest factors are below 6 (annex C.1.1.3) or 9 (part 6.2.2). Crest factor is the ratio between peak value and corresponding $\mathrm{RMS}_{\mathrm{w}}$ during the same time of exposition (one hour has been taken). Fig. 14 shows than only around $20 \%$ of the time the crest factor exceeds the threshold of 9. For these cases, ISO 2631 recommends the use of additional parameters like the Maximum Transient Vibration Value (MTVV) or the Vibration Dose Value (VDV) to check serviceability criteria, although no ranges are depicted.

With the same objective of serviceability assessment, response factor is defined as the ratio between the RMS and the base curve defined in ISO 10137. The value of $0.005 \mathrm{~m} / \mathrm{s}^{2}$ is the reference (base curve) for vertical movements. Fig. 15 shows the percentages for $\mathrm{R}$ factor exceeding 30 and 50 , computed in hourly $\mathrm{RMS}_{\mathrm{w}}$ basis. The values of 30 and 50 are usually considered as reference limits for comfortability. Again, the low percentages obtained reveal the footbridge is adequate to the pedestrian use regardless its slenderness and its easily noticeable movements.

\section{Modal characterization}

Besides the evaluation of the response presented in the previous sections, one of the main interest of the monitoring system is the modal characterization under different external factors (temperature, pedestrian use, etc.). For that, several operational modal analyses (output-only) were performed. Although more recent and powerful methodologies already exist (like the one presented in Sadhu et al. (2014)), a more traditional identification technique based on Stochastic Subspace Identification (SSI) 


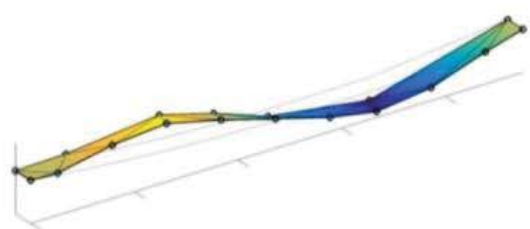

a) $\mathrm{BZ}_{2}$

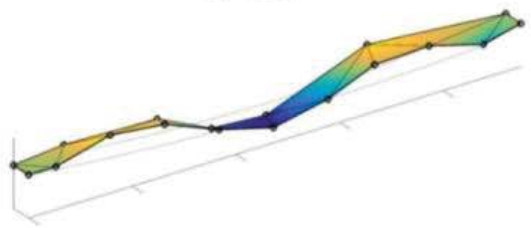

c) $\mathrm{BZ}_{3}$

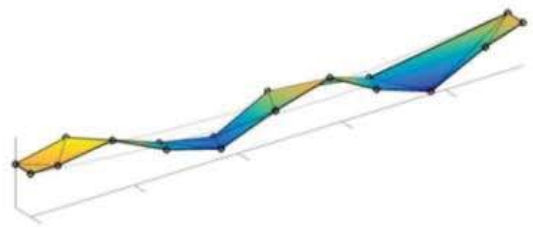

e) $\mathrm{BZ}_{4}$

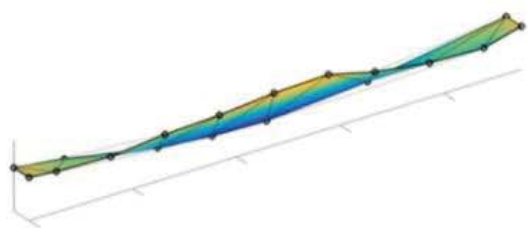

b) $\mathrm{BY}_{1}+\mathrm{TX}_{1}$

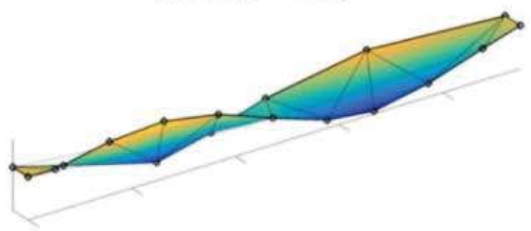

d) $\mathrm{BY}_{2}+\mathrm{TX}_{2}$

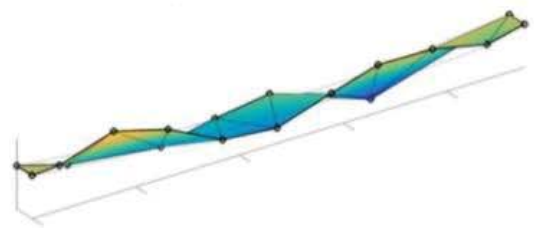

f) $\mathrm{BY}_{3}+\mathrm{TX}_{3}$

Fig. 17 First six mode shapes

Table 2 Experimental values of damping and frequency for the six first modes and their change with the temperature

\begin{tabular}{|c|c|c|c|c|c|c|c|}
\hline \multirow{2}{*}{ Mode } & \multirow{2}{*}{$\xi(\%)$} & \multicolumn{4}{|c|}{ Frequency $(\mathrm{Hz})$} & \multicolumn{2}{|c|}{ Frequency change $(\%)$} \\
\hline & & $5^{\circ} \mathrm{C}$ & $20^{\circ} \mathrm{C}$ & $35^{\circ} \mathrm{C}$ & Mean & $\%\left(5^{\circ} \mathrm{C}\right)$ & $\%\left(35^{\circ} \mathrm{C}\right)$ \\
\hline $\mathrm{BZ}_{2}$ & 0.18 & 0.895 & 0.868 & 0.840 & 0.868 & 3.1 & -3.2 \\
\hline $\mathrm{BY}_{1}+\mathrm{TX}_{1}$ & 0.20 & 1.005 & 1.050 & 1.096 & 1.050 & -4.3 & 4.4 \\
\hline $\mathrm{BZ}_{3}$ & 0.23 & 1.436 & 1.410 & 1.390 & 1.412 & 1.8 & -11.4 \\
\hline $\mathrm{BY}_{2}+\mathrm{TX}_{2}$ & 0.33 & 1.540 & 1.530 & 1.520 & 1.530 & 0.7 & -0.7 \\
\hline $\mathrm{BZ}_{4}$ & 0.14 & 1.840 & 1.780 & 1.730 & 1.783 & 3.4 & -2.8 \\
\hline $\mathrm{BY}_{3}+\mathrm{TX}_{3}$ & 0.13 & 2.310 & 2.230 & 2.150 & 2.230 & 3.6 & -3.6 \\
\hline
\end{tabular}

(Ubertini et al. 2013) is enough for the intended purposes of this work. Fig. 16 shows modal identification diagram and Fig. 17 presents the first 6 modes obtained for very low occupancy and negligible wind loading.

For the modal mode shapes, the notation used is $\mathrm{BZ}_{\mathrm{i}}$ for bending modes in the vertical $\mathrm{XZ}$ plane, $\mathrm{BY}_{\mathrm{i}}$ for bending modes in the horizontal $\mathrm{XY}$ plane and $\mathrm{TX}_{\mathrm{i}}$ for torsional modes around $\mathrm{X}$ axis. $\mathrm{i}$ is the number of antinodes of the corresponding mode. Generally, for these types of nonlinear structures, the frequency decreases when the temperature increases, but not a similar trend is evidenced for all the modes as seen in Table 2. Presented values were obtained from more than 1250 estimations based on hourly records.

\section{Conclusions}

The development and installation of a remotely control continuous vibration monitoring system on a stress-ribbon footbridge has been presented in this paper. This system is based on the use of low-cost triaxial MEMS acceleration sensors and was validated by comparing the response measured by the MEMS devices with conventional piezoelectric accelerometers mounted in a portable analyzer. As MEMS devices can measure gravity, spatial orientation is continuously adjusted by an automatic system based on Euler angles. These tests demonstrated that these low-cost sensors are a competitive alternative to traditional ones. Also, the system could be used to find correlations between the mechanical response and environmental data (Soria et al. 
2017) and, in the long term, evaluate changes in the modal properties due to fatigue or abutment resettlements.

For accelerations over $0.02 \mathrm{~m} / \mathrm{s}^{2}$ there are not significant differences between both piezoelectric and MEMS sensors. For serviceability purposes and taking into account the lively structure under study (acceleration values over $0.05 \mathrm{~m} / \mathrm{s}^{2}$ when it is crossed by a single pedestrian, as shown in Fig. 9(a)), the monitoring proposal is not only more affordable but also a practical alternative.

Interesting operation results have been presented, including serviceability analysis and modal identification for the first six modes. The next objective is to implement an automated operational modal analysis in order to analyze the changes on the modal properties along the time. The influence of environmental factors (including temperature and wind) and pedestrian traffic density will be analyzed in order to remove these effects from the modal properties, as other authors (Moser and Moaveni 2013) propose. Thus, such modal properties may be used for structural damage detection which is the final goal to be achieved.

\section{Acknowledgments}

The authors wish to acknowledge the collaboration of the Valladolid City Council and the partial support through the Research Projects BIA2011-28493, DPI2013-47441, BIA2014-59321 (Ministerio de Economía y Competitividad, Spanish Government) and FPU16/01339 grant (Ministerio de Educación, Cultura y Deporte, Spanish Government).

\section{References}

Brownjohn, J., Carden, E., Goddard, C. and Oudin, G. (2010), "Real-time performance monitoring of tuned mass damper system for a $183 \mathrm{~m}$ reinforced concrete chimney", J. Wind Eng. Ind. Aerod., 98(3), 169-179.

Caetano, E., Silva, S. and Bateira, J. (2011), "A vision system for vibration monitoring of civil engineering structures", Exp. Techniques, 35(4), 74-82.

Casciati, S., Tento, A., Marcellini, A. and Daminelli, R. (2014), "Long run ambient noise recording for a masonry medieval tower", Smart Struct. Syst., 14(3), 367-376.

Ceylan, H., Gopalakrishnan, K., Kim, S., Taylor, P.C., Prokudin, M. and Buss, A.F. (2013), "Highway infrastructure health monitoring using micro-electromechanical sensors and systems (MEMS)", J. Civil Eng. Management, 19(1), 188-201.

Chen, Z. (2014), "Energy efficiency strategy for a general realtime wireless sensor platform", Smart Struct. Syst., 14(4), 617641.

Chen, Z. and Casciati, F. (2014), "A low-noise, real-time, wireless data acquisition system for structural monitoring applications", Struct. Control Health Monit., 21(7), 1118-1136.

Gomez, H.C., Fanning, P.J., Feng, M.Q. and Lee, S. (2011), "Testing and long-term monitoring of a curved concrete box girder bridge", Eng. Struct., 33(10), 2861-2869.

Guan, M. and Liao, W.H. (2006), "On the energy storage devices in piezoelectric energy harvesting", Proceedings of the SPIE 6169, Smart Structures and Materials 2006: Damping and Isolation, San Diego, California, United States, March.

Lepidi, M. and Gattulli, V. (2012), "Static and dynamic response of elastic suspended cables with thermal effects", Int. J. Solids
Struct., 49(9), 1103-1116.

Moser, P. and Moaveni, B. (2013), "Design and development of a continuous monitoring system for the Dowling Hall Footbridge", Exp. Techniques, 37(1), 15-26.

Narros, A.J. (2011), "Pasarela peatonal Pedro Gómez Bosque sobre el río Pisuerga en la ciudad de Valladolid. Un nuevo récord de longitud en pasarelas colgadas de banda tesa", Revista Técnica Cemento Hormigón, 947, 80-86.

Orcesi, A.D., Frangopol, D.M. and Kim, S. (2010), "Optimization of bridge maintenance strategies based on multiple limit states and monitoring", Eng. Struct., 32(3), 627-640.

Panigrahi, R., Bhalla, S. and Grupta, A. (2010), "A low-cost variant of electro-mechanical impedance (EMI) technique for structural health monitoring", Exp. Techniques, 34(2), 25-29.

Sadhu, A., Hazraa, B. and Narasimhan, S. (2014), "Ambient modal identification of structures equipped with tuned mass dampers using parallel factor blind source separation", Smart Struct. Syst., 13(2), 257-280.

Shinozuka, M., Feng, M.Q., Chou, P., Chen, Y. and Park, C. (2004), "MEMS-based wireless real-time health monitoring of bridges", $3^{\text {rd }}$ International Conference on Earthquake Engineering, Nanjing, China, October.

Soria, J.M., Diaz, I.M. and Garcia-Palacios, J.H. (2017), "Vibration control of a time-varying model-parameter footbridge: study of semi-active implementable strategies", Smart Struct. Syst., 20(5), 525-537.

Strasky, J. (2005), Stress Ribbon and Cable-Supported Pedestrian Bridges, ( $1^{\text {st }}$ edition), Thomas Telford Publishing Ltd, London, United Kingdom.

Swartz, R.A., Lynch, J.P., Zerbst, S., Sweetman, B. and Rolfes, R. (2010), "Structural monitoring of wind turbines using wireless sensor networks", Smart Struct. Syst., 6(3), 183-196.

Tan, T.D., Anh, N.T. and Anh, G.Q. (2011), "Low-cost Structural Health Monitoring scheme using MEMS-based accelerometers", Proceedings of the 2nd International Conference on Intelligent Systems, Modelling and Simulation, Phnom Penh, Cambodia, January.

Tokognon, C.A., Gao, B., Tian, G.Y. and Yan, Y. (2001), "Structural Health Monitoring framework based on Internet of Things: A survey", IEEE Internet Things J., 4(3), 619-635.

Ubertini, F., Gentile, C. and Materazzi, A.L. (2013), "Automated modal identification in operational conditions and its application to bridges", Eng. Struct., 46, 264-278. 


\section{Notation}

The following symbols are used in this paper:

$$
\begin{array}{lll}
\bar{a}_{x}, \bar{a}_{y}, \bar{a}_{z}= & \begin{array}{l}
\text { average acceleration } \\
\text { in each local axis } \mathrm{x}, \mathrm{y}, \mathrm{z}\left(\mathrm{m} / \mathrm{s}^{2}\right) ;
\end{array} \\
a_{x}, a_{y}, a_{z}= & \text { acceleration in each local axis } \mathrm{x}, \mathrm{y}, \mathrm{z}\left(\mathrm{m} / \mathrm{s}^{2}\right) ; \\
a_{X}, a_{Y}, a_{Z}= & \text { acceleration in each global axis } \mathrm{x}, \mathrm{y}, \mathrm{z}\left(\mathrm{m} / \mathrm{s}^{2}\right) ; \\
\mathrm{g} & =\text { gravity acceleration }\left(\mathrm{m} / \mathrm{s}^{2}\right) ; \\
{[R]} & =\text { coordinate transform matrix; } \\
\mathrm{RMS}_{\mathrm{w}} & =\text { weighted Root Mean Squares; } \\
\mathrm{RMS}_{\mathrm{Zw}} & =\text { weighted Root Mean Squares } \\
& \text { in the global axis } \mathrm{Z} ; \\
\alpha & =\text { accelerometer local pitch angle }\left({ }^{\circ}\right) ; \text { and } \\
\beta & =\text { accelerometer local roll angle }\left({ }^{\circ}\right) .
\end{array}
$$




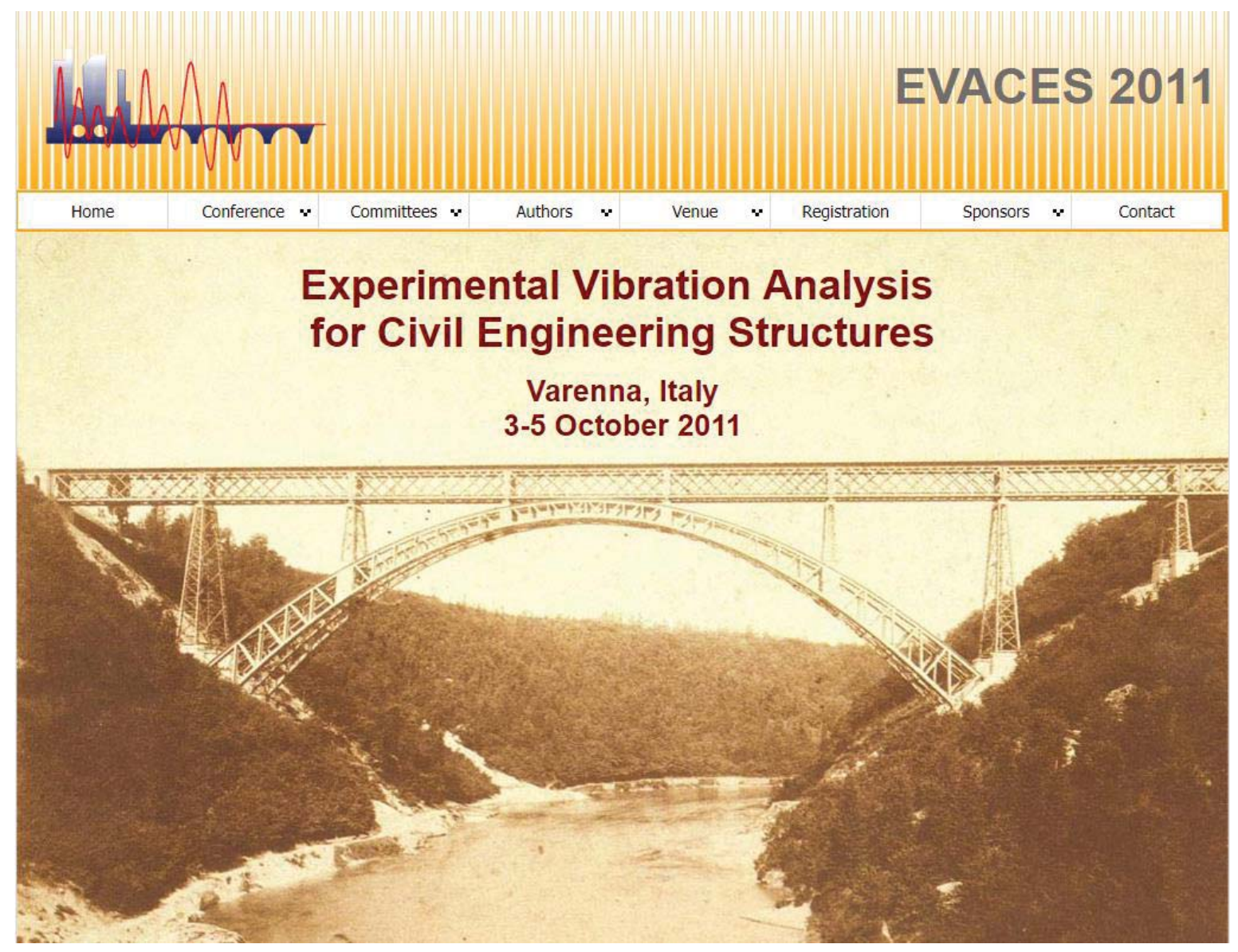

Melania Vasilica Istrate; Jesús de Sebastian Sanz; Ali Vasallo Belver; Carlos M. Casado Sanchéz; Norberto Ibán Lorenzana; Antolín Lorenzana Ibán; Alfonso V Poncela Mendez.

\begin{tabular}{c|c|c|c|} 
Aportaciones: & Experimentación & Procesado & Edición \\
\hline \multirow{2}{*}{} & Instrumentación & Matlab & Tablas \\
& Registros & Excel & Gráficas \\
& Tests & Sigview & Imágenes \\
\cline { 2 - 4 }
\end{tabular}




\title{
Improvement comfortability through adding soft rubber pavement on lively footbridges
}

\author{
Melania Istrate, Jesús de Sebastián, Ali Vasallo, Carlos Casado, Norberto Ibán \\ CARTIF Centro Tecnológico, Parque Tecnológico de Boecilllo, 47151 Valladolid, Spain \\ Antolín Lorenzana, Alfonso Poncela \\ ITAP, Escuela de Ingenierias Industriales. University of Valladolid, 47011, Valladolid, Spain.
}

\begin{abstract}
This work is a first attempt to quantify the effect of a soft pavement on the perceived sensations of the soil movement when walking. This type of pavements is usually made with agglomerates of chippings made from recycled tyres. When thicknesses of 3 or $4 \mathrm{~cm}$ are placed over the walkway of a lively footbridge, the movement of the structure (due to the users or to the wind) is partially masked by the softy soil. In this way, pedestrians usually do not complain about of movement of the structure as much as they could do in case of standard pavements. To quantify this effect, acceleration and jerk comparisons are made for three different scenarios: walking on rigid soil, walking on rubber soil and walking on a lively footbridge with rubber soil.
\end{abstract}

\section{INTRODUCTION}

Pedestrian loads are low intensity quasi-periodic loads. Applied to very stiff and massive structures this loads could hardly make them vibrate significantly. However, aesthetic, technical and technological developments lead to ever more slender and flexible footbridges and as a consequence they can vibrate significantly even under a single person and frequently require a thorough dynamic analysis.

In some footbridges, probably in project stages, using numerical techniques, or after a dynamic assessment, once built, through experimental techniques, different alternatives have to be proposed in order to avoid relevant vertical acceleration levels. Those alternatives tend to change the dynamic response by adding mass, or stiffness, or damping.

In this paper a novel alternative is analyzed: by adding a thick soft-rubber pavement, pour-inplace, softer than the one used in athletic training tracks, several effects are introduced. Although for standard footbridges, the additional mass (with no addition in stiffness) is irrelevant in changing natural frequencies or natural modes, for light footbridges, as steel or composite stress-ribbon ones, the effect could be appreciable. Also the rubber pavement improves the structural damping, being this effect very desirable for this kind of lively structures. But the main factor, analyzed in this paper, is its influence in two important aspects of the human-structure interaction process. The first one is that the flexibility of the pavement affects the way the load is exerted to the structure. The second one, and more important in the perception of the discomfort, is that the pavement also affects the way the pedestrian senses the acceleration of the structure. The following sections are devoted to quantify this second effect. 


\section{ACCELEROMETERS ON THE PEDESTRIAN BODY}

To record the accelerations during normal walking, 3 uniaxial accelerometers (PCB Piezotronics, model $352 \mathrm{C} 65$, high sensitivity, miniature ceramic shear ICP ${ }^{\circ}$ accel. $100 \mathrm{mV} / \mathrm{g}$, 0.5 to $10 \mathrm{k} \mathrm{Hz}$ ) have been installed on a standard pedestrian (75kg weight). As shown in Figure 1 , one is placed on his hip $(\mathrm{C})$, other on his heel $(\mathrm{T})$ and the third one on his toe $(\mathrm{P})$. All of them are in the vertical axis when the pedestrian is at rest. Accelerometer (C) almost remain in the vertical direction over the whole walking cycle but $(\mathrm{T})$ and $(\mathrm{P})$ can change in more than $80^{\circ}$. In figure 2, ten selected instants (Sánchez (1999)) of the walking cycle are shown in a schematic way, focusing in just one leg.

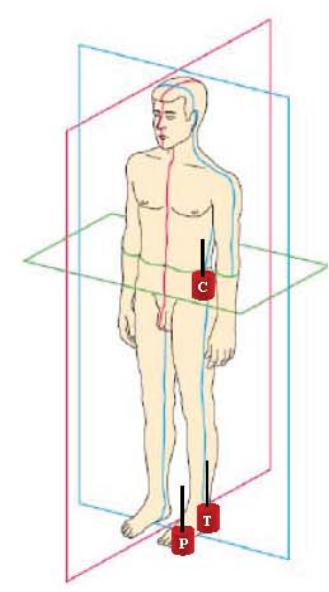

Figure 1. Accelerometers placed in the hip (C), heel $(\mathrm{T})$ and toe $(\mathrm{P})$

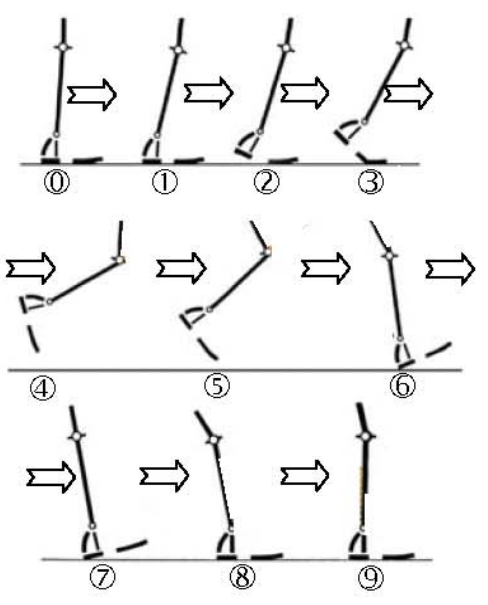

Figure 2. Schematic walking cycle in 10 frames

The three signals are recorded synchronously at a sample rate of $100 \mathrm{~Hz}$. The pedestrian was asked to walk normally at his normal pace (105bpm) (even though, the beep of a metronome was followed) on three different flat areas: (S) standard rigid pavement out of the footbridge, (R) rubber pavement before entering in the suspended footbridge and $(\mathrm{F})$ rubber pavement in the flat area of the middle of the footbridge (see figure 3 ).
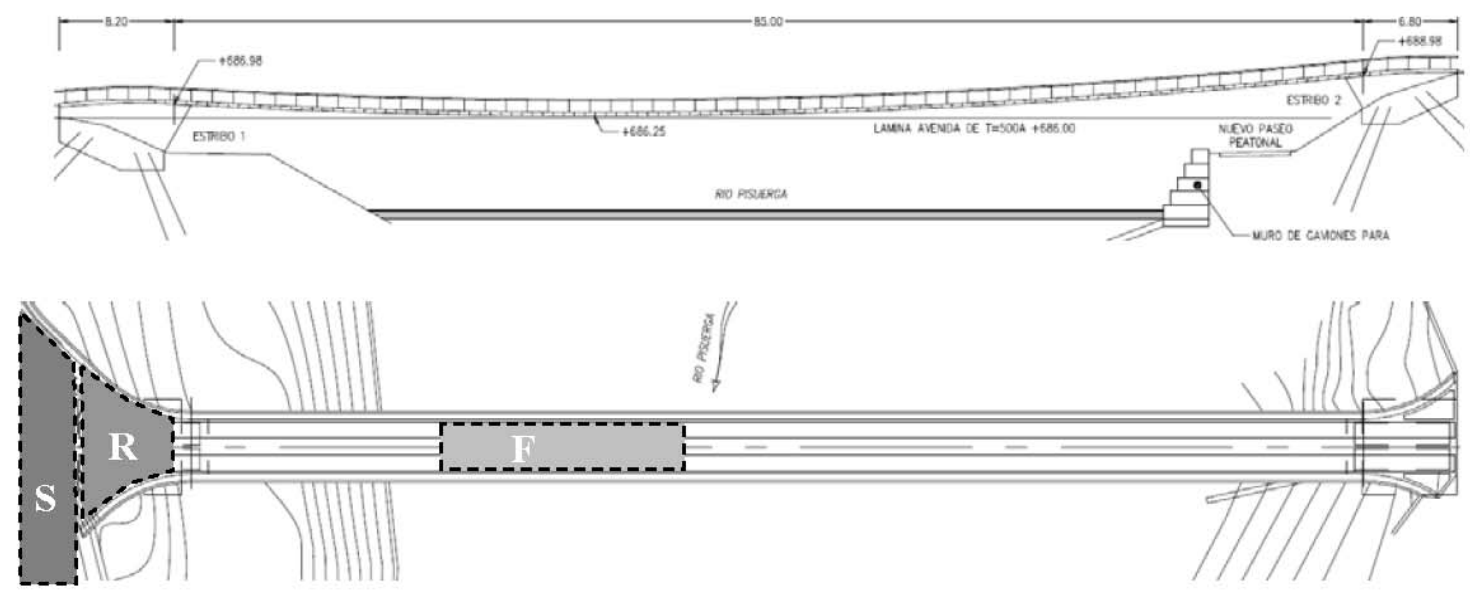

Figure 3. Footbridge drawings and walking areas 


\section{WALK CYCLES ON DIFFERENT SCENARIOS}

\subsection{Rigid pavement}

Recordings of the three accelerometers $(\mathrm{C}, \mathrm{T}$ and $\mathrm{P})$ for a representative cycle on rigid pavement are shown in figure 4 . For $105 \mathrm{bpm}$ the duration of the cycle is $1.14 \mathrm{~s}$. Accelerations in toe P and hell T are obviously greater than in the hip C and also more sharp and "noisy".

For each location ( $\mathrm{P}, \mathrm{T}$ or $\mathrm{C}$ ), ten standard cycles are shown in figure 5. All of then are matched in the instant when the toe lifts off the ground.

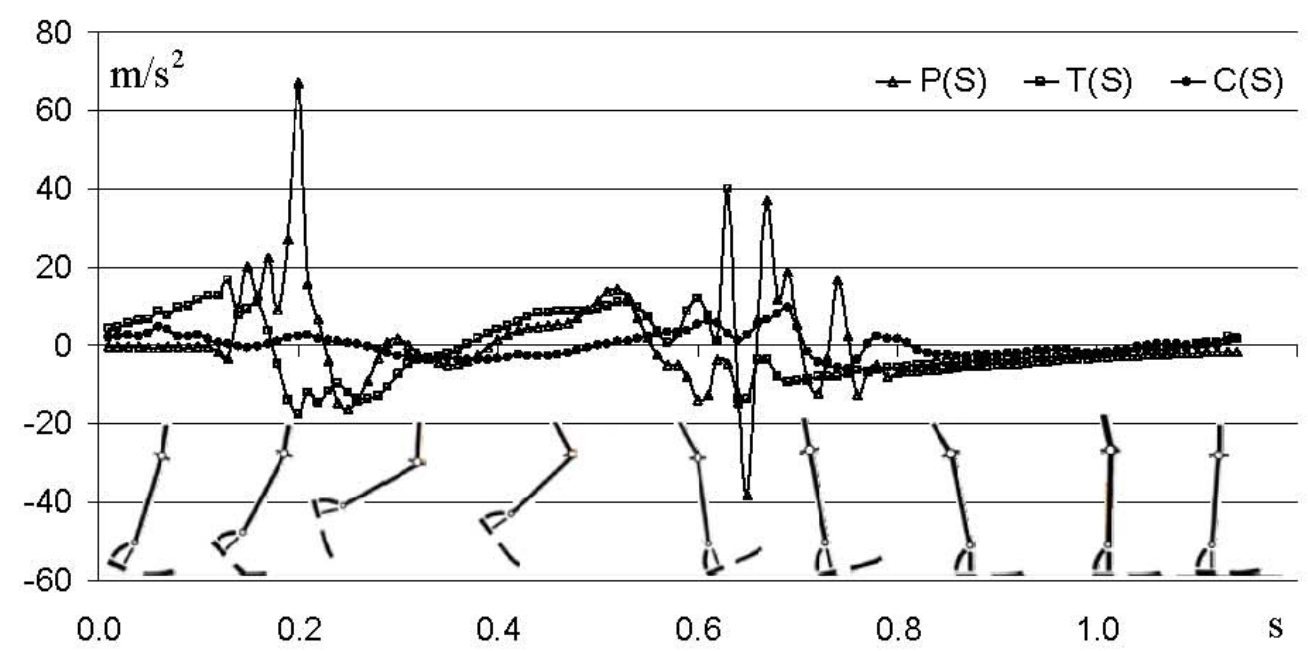

Figure 4. Accelerations on $\mathrm{C}, \mathrm{T}$ and $\mathrm{H}$ for a walking cycle when walking on rigid pavement
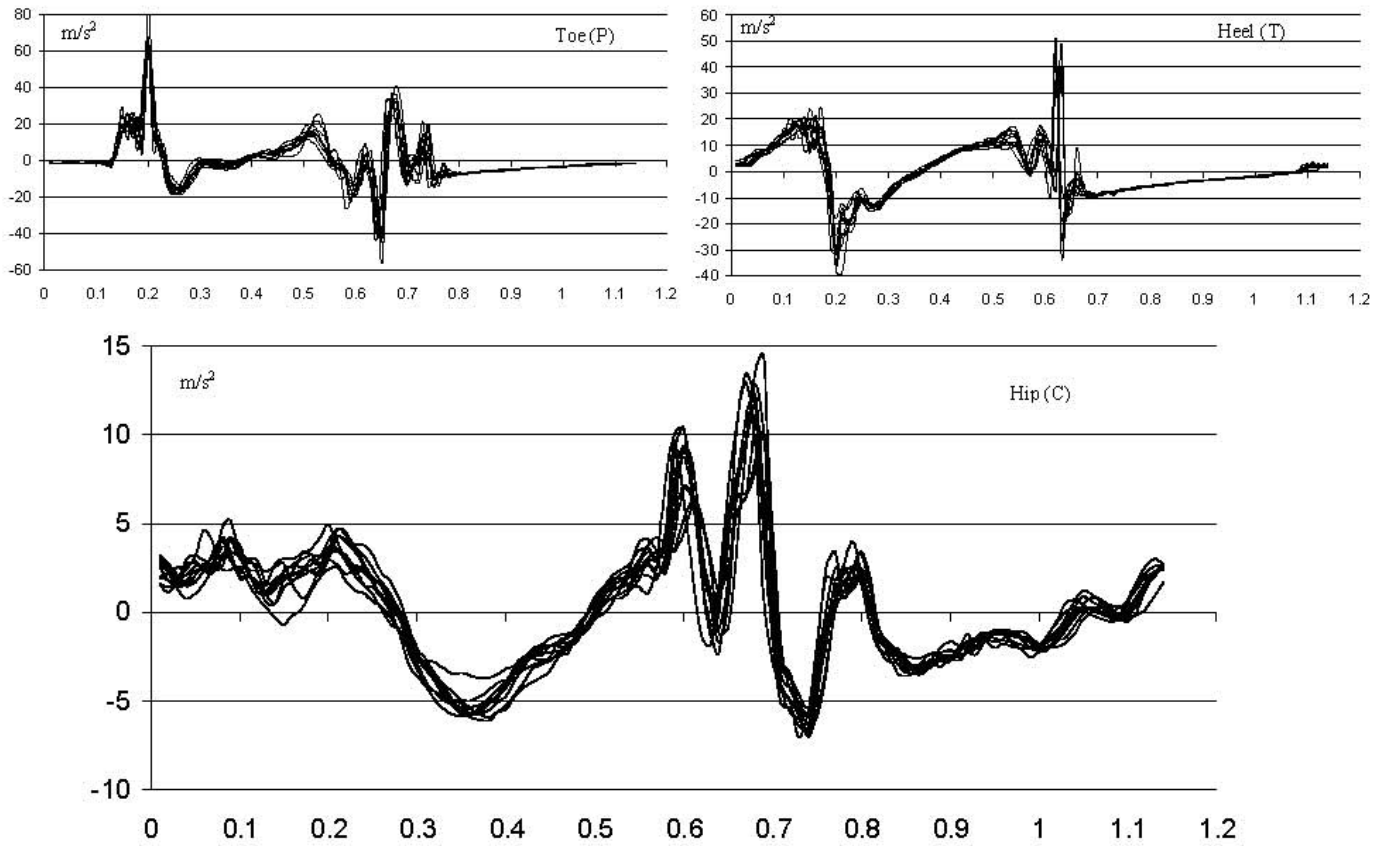

Figure 5. Ten walking cycles when walking on rigid pavement 
Figure 6 shows the rate of change of acceleration (that is, the derivative of acceleration with respect to time) or jerk for the cycle shown in figure 4 . Those jerks where obtained using standard $2\left(j_{2}\right) \circ 3\left(j_{3}\right)$ steps expressions for numerical first derivatives from the accelerations. Although some differences between $j_{2}$ and $j_{3}$ can be observed, only $j_{2}\left(\mathrm{~m} / \mathrm{s}^{3}\right)$ is going to be shown in figures 6,9 and 12 , together with respective accelerations $\left(\mathrm{m} / \mathrm{s}^{2}\right.$, scaled 100 times).
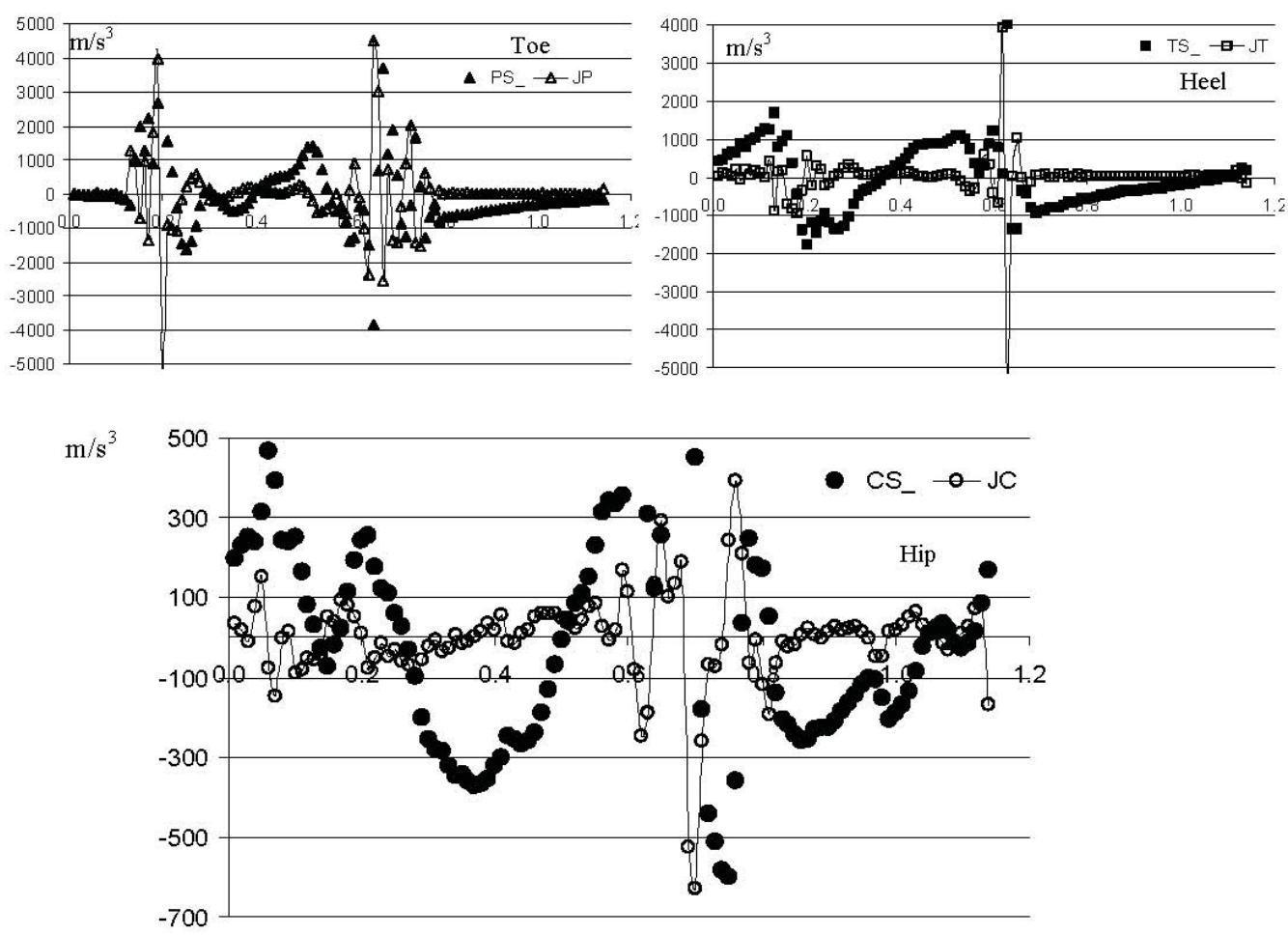

Figure 6. Accelerations on $\mathrm{C}, \mathrm{T}$ and $\mathrm{H}$ and corresponding jerks when walking on rigid pavement

\subsection{Rubber pavement before entering in the suspended footbridge}

In a similar way, the following figures show same data when walking on rubber pavement over solid soil.

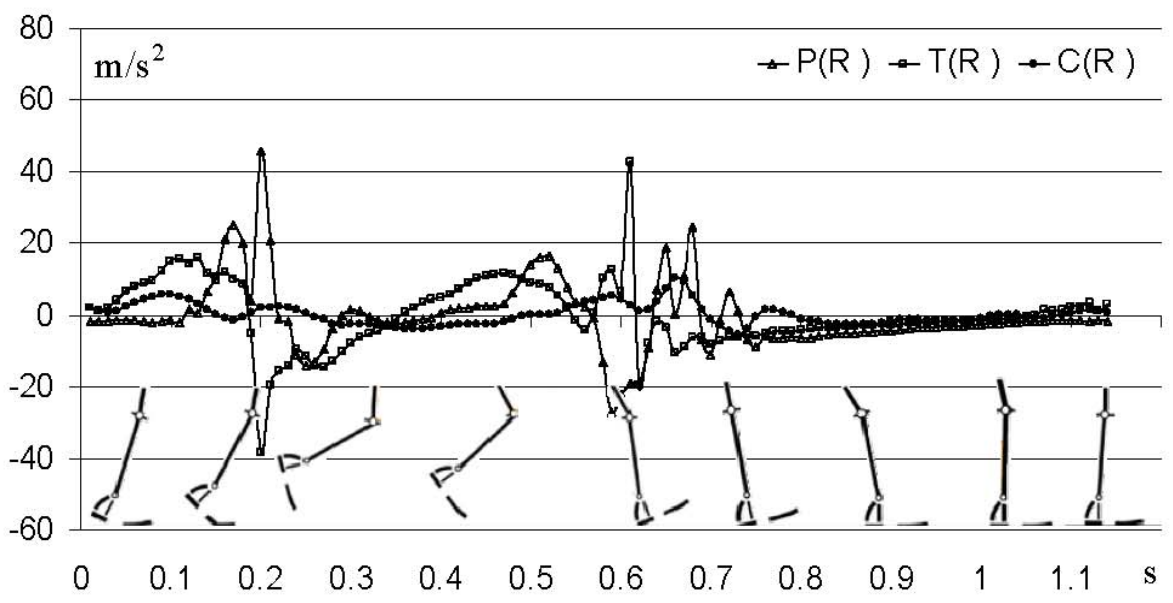

Figure 7. Accelerations on $\mathrm{C}, \mathrm{T}$ and $\mathrm{H}$ for a walking cycle when walking on rubber pavement 


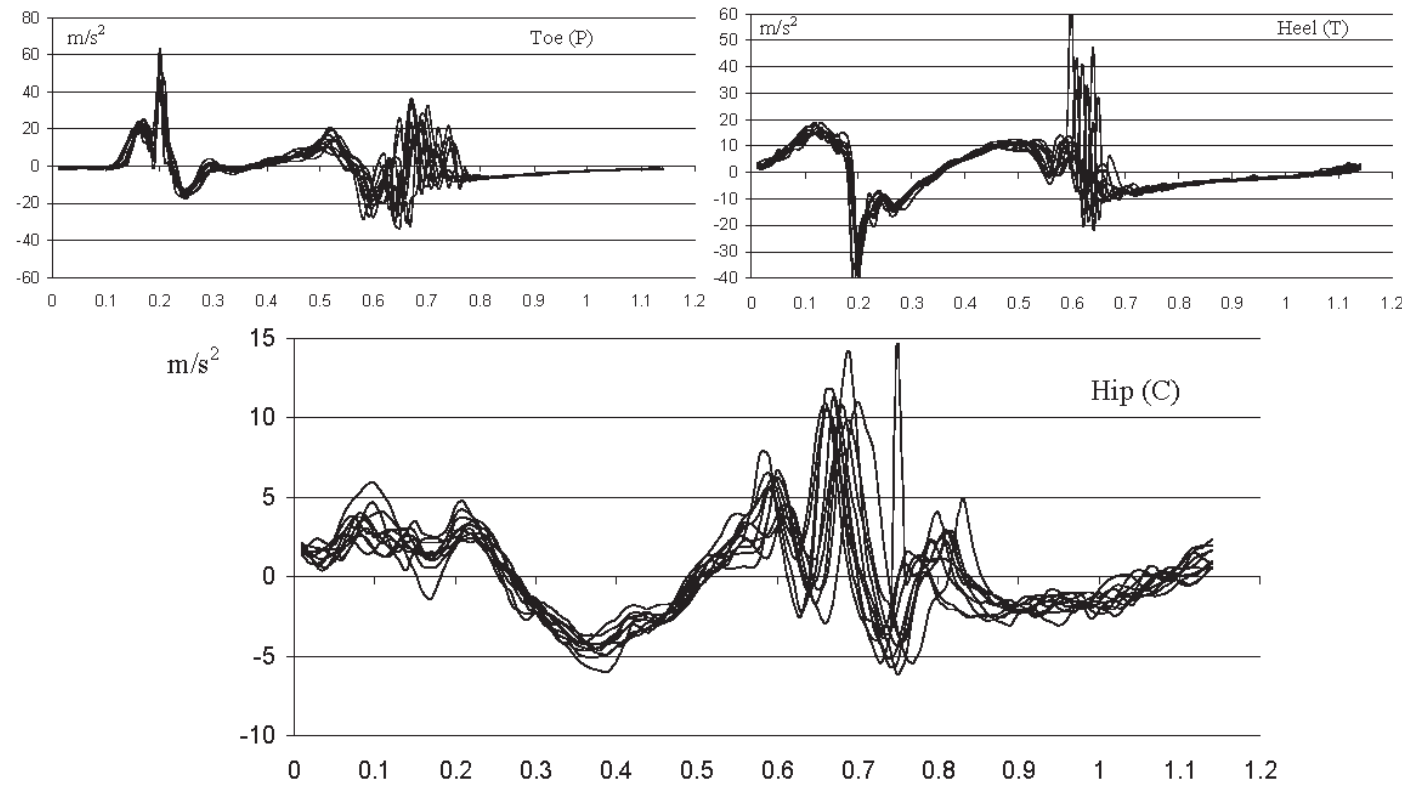

Figure 8 . Ten walking cycles when walking on rubber pavement
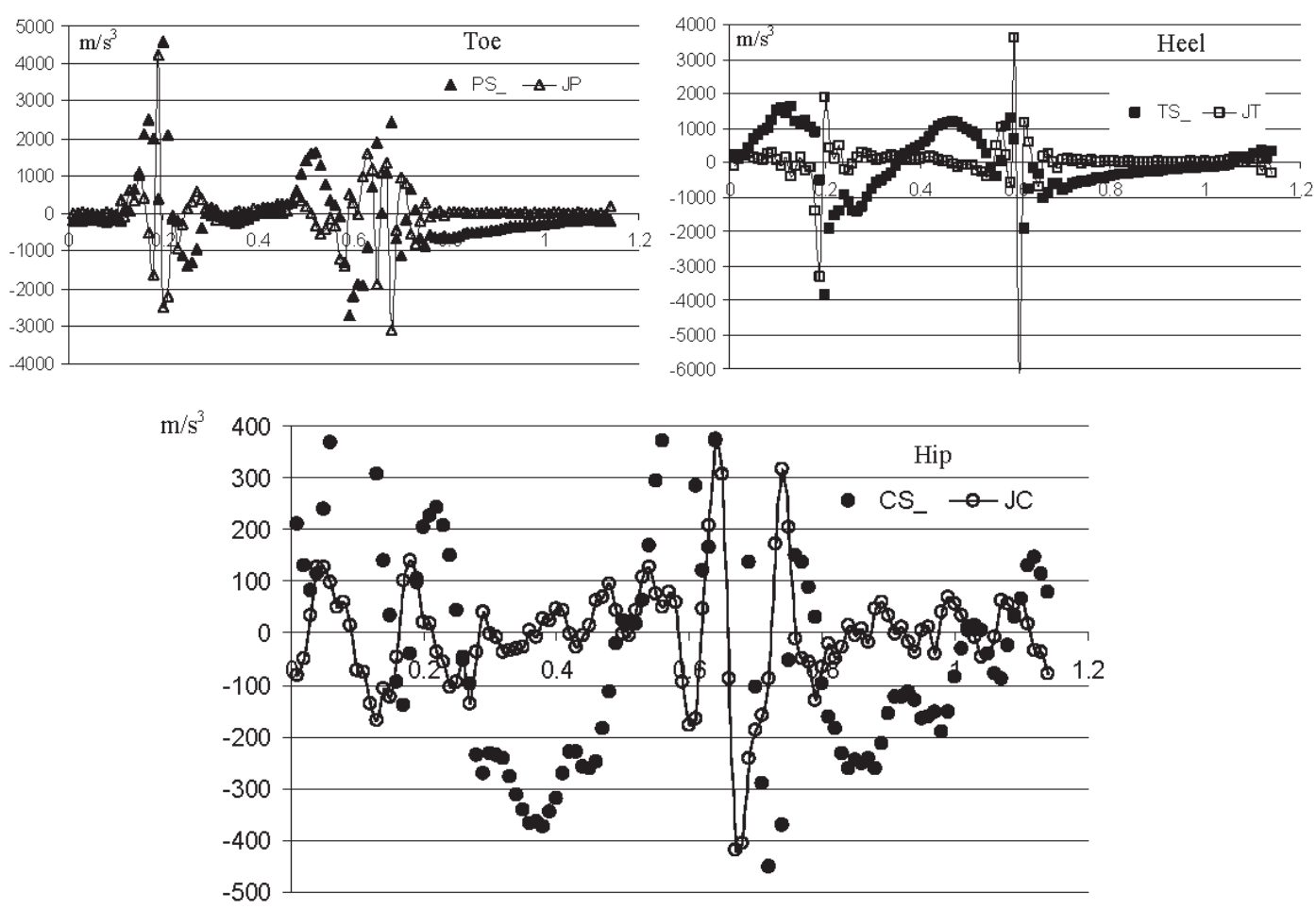

Figure 9. Accelerations on $\mathrm{C}, \mathrm{T}$ and $\mathrm{H}$ and corresponding jerks when walking on rubber pavement 


\subsection{Rubber pavement in the middle of the footbridge}

Also with the aim of comparison, similar data are shown in the following figures when walking on the rubber pavement over the footbridge, almost in the middle of the span. In this area, for the lively footbridge, some movements on its deck can be recorded. Figure 13 shows $11.4 \mathrm{~s}$ acceleration record during the time when the 10 walking cycles were recorded in this area. During this time, wind was calm and no other pedestrian were using the footbridge. In these circumstances, structural movement was so little and amplitudes were around 150 times less that the maximum amplitudes for the hip (C). Even though, some differences from scenario R can be noted.

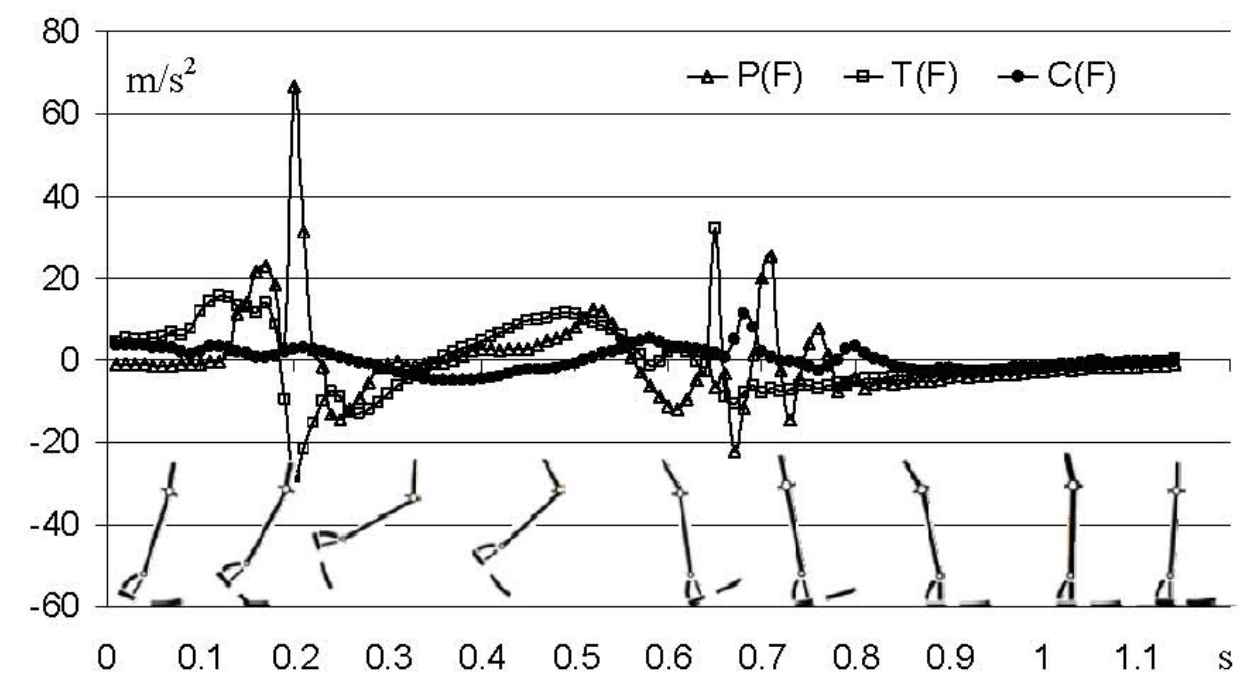

Figure 10. Accelerations on $\mathrm{C}, \mathrm{T}$ and $\mathrm{H}$ for a walking cycle when walking on the footbridge.
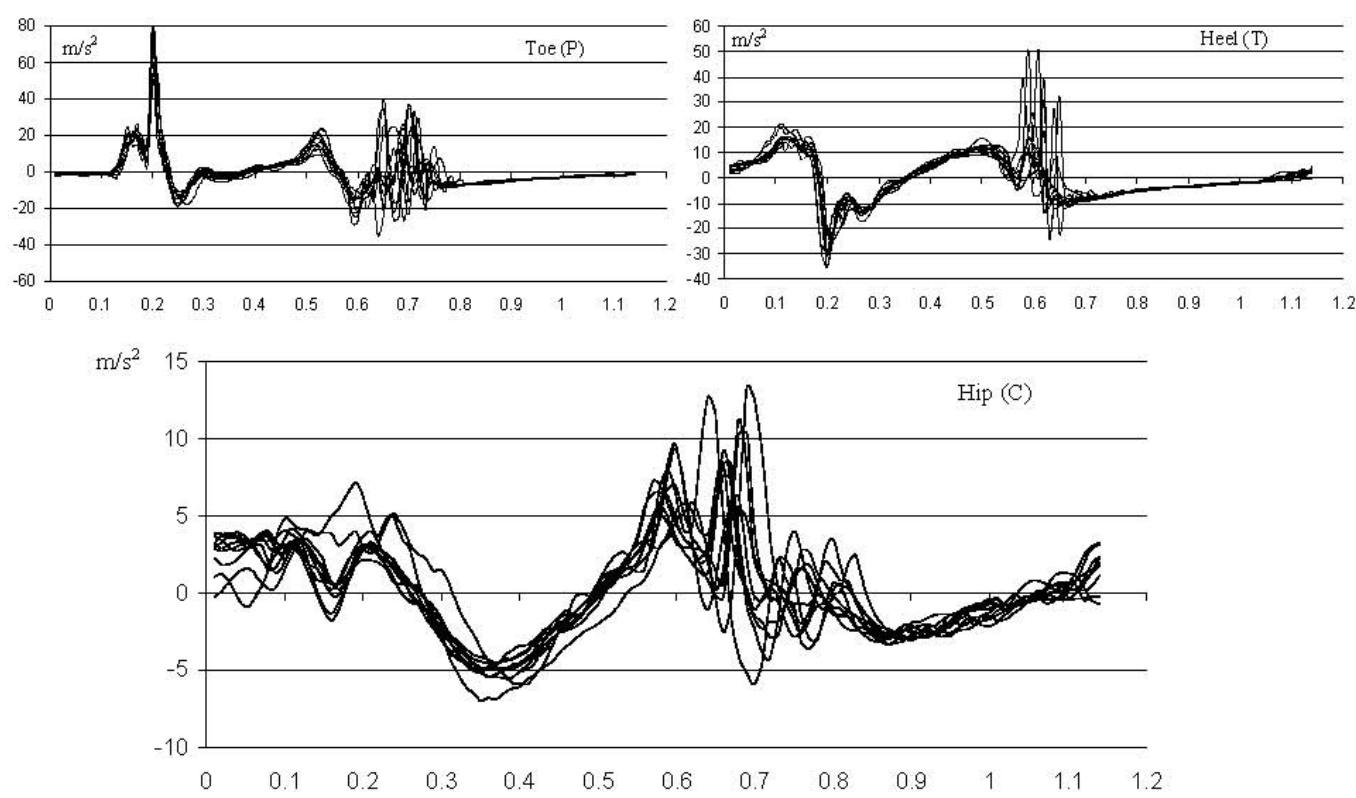

Figure 11. Ten walking cycles when walking on the footbridge. 

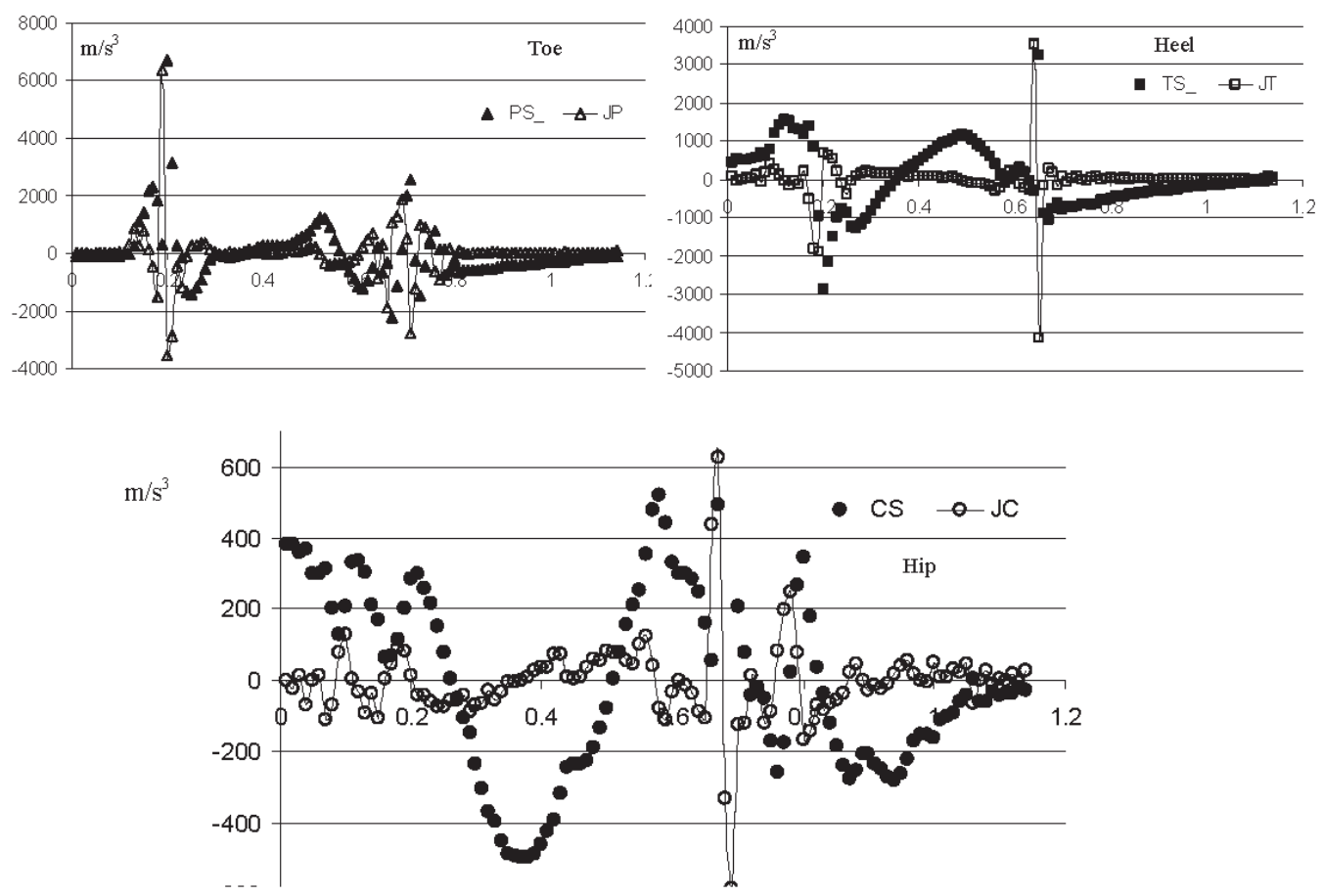

Figure 12. Accelerations on $\mathrm{C}, \mathrm{T}$ and $\mathrm{H}$ and corresponding jerks when walking on the footbridge.

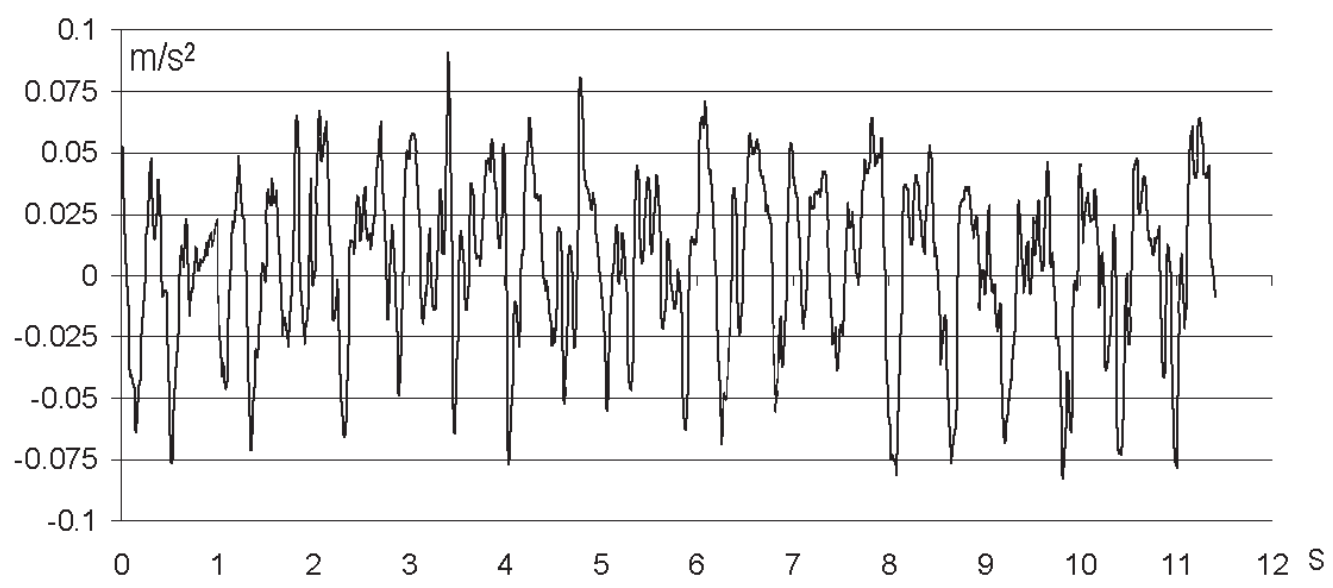

Figure 13. Accelerations on the walkway of the footbridge.

\section{CONCLUSIONS}

The shape of recordings in the representative walking cycles are similar. Some differences can be found in acceleration amplitudes, but more statistic analysis is required to get decisive conclusions. Despite of that, the decrease in amplitude (maximum minus minimum, once dropped the outlayers) between rigid ( $\mathrm{S}$ ) and rubber ( $\mathrm{R}$ and $\mathrm{F}$ ) pavement is about $20 \%$ for the toe, $15 \%$ for the heel and $23 \%$ for the hip. 
Although jerk is often used to measure the comfort of rides (elevators, trams, roller coasters, etc.), no relevant results can be obtained from the attempt done in this study of evaluate the jerk in toe, heel or hip. For that, probably more sample rate would be necessary together with statistical analysis.

Analyzing the timing and dispersion of walking cycles, a relevant conclusion can be found: when walking on soft pavement the cycles are not as similar, between themselves, as when walking on rigid pavement. In figures 8 and 11 is noticeable that the dispersion during the phase the heel contact the ground is much greater than in figure 5, not only for the heel, but also for the toe and the hip. Due to the sensation of softy pavement, it could be that the pedestrian mind was not as challenging to keep pace and therefore not as sensitive to ground motion perception.

\section{References}

Sánchez, J. 1999. Biomecánica de la marcha humana normal y patológica. Instituto de biomecánica de Valencia ISBN-13.9788495448125

Whittingtonm B.R. and Thelen, D.G. 2009. A simple mass-spring model with roller feet can induce the ground reactions observed in human walking. Journal of Biomechanical Engineering.Vol. 131

Hogan, N., 1990. Mechanical Impedance of Single- and Multi-Articular Systems. Multiple Muscle Systems: Biomechanics and Movement Organization. Springer-Verlag, New York.

Cheng, J.C. and Moura, J.M.F, 1997. Tracking human walking in dynamic scenes. Proc. of IEEE. Int. Conf. Image Processing, ICIP'97, Santa Barbara, CA, vol. 1, pp.137-140, 1997. 
R. Mayes · D. Rixen · D.T. Griffith · D. De Klerk · S. Chauhan S.N. Voormeeren $\cdot$ M.S. Allen Editors

\section{Topics in Experimental Dynamics Substructuring and Wind Turbine Dynamics,Volume 2}

Proceedings of the 30 th IMAC,

A Conference on Structural Dynamics, 2012

\section{SEM $\underline{\underline{\underline{T}} \text { Springer }}$}

Melania Vasilica Istrate; Norberto Ibán Lorenzana; Ali Vasallo Belver; Antolín Lorenzana Ibán; Iván Muñoz Díaz.

\begin{tabular}{c|c|c|c|} 
Aportaciones: & Experimentación & Procesado & Edición \\
\hline & Instrumentación & Matlab & Tablas \\
& Tests & Excel & Gráficas \\
& Sigview & Imágenes \\
\cline { 2 - 4 } & &
\end{tabular}




\title{
Discomfort evaluation on lively footbridges with soft-rubber pavement
}

\author{
M. Istrate ${ }^{1}$, N. Ibán ${ }^{1}, A$. Vasallo $^{1}$, A. Lorenzana ${ }^{2}$ and I.M. Diaz ${ }^{3}$ \\ ${ }^{I}$ CARTIF Centro Tecnológico, Parque Tecnológico de Boecilllo, 47151 Valladolid, Spain \\ ${ }^{2}$ ITAP, University of Valladolid, 47011, Valladolid, Spain. \\ ${ }^{3}$ E T S I Industriales, University of Castilla-La Mancha, Ciudad Real, Spain
}

\begin{abstract}
This paper deals with the measurement of the pedestrian perception of the movement of lively footbridges. Several tests on a $80 \mathrm{~m}$ single span stress-ribbon footbridge are presented. This footbridge is very slender and has a very low structural damping and several modes under $3 \mathrm{~Hz}$, resulting in sensible vertical movements. Despite of that, general users do not complain too much, probably because its pavement is made of a thick pour-in-place soft-rubber material.
\end{abstract}

When a pedestrian walks on a flexible pavement, in every step he notices how first the heel, then the toe, sinks and rises, and probably that feeling makes the pedestrian, unconsciously, no to be so demanding regarding the movement of the walkway. To verify this effect, we compare the recordings of 3 accelerometers installed on the pedestrian when he walks on four different scenarios. Two of the accelerometers are located on one of the pedestrian's shoes (one at the heel and the other one at the toe) and the third is placed on his hip (all of then in the right side of the body).

The walking scenarios are: rigid and thick soft pavement on solid soil and thin and thick soft pavenent on the footbridge walkway. Comparing the acceleration levels in these four scenarios some conclusions are reached.

\section{Introduction:}

Pedestrian loads are low intensity quasi-periodic loads. Applied to very stiff and massive structures this loads could hardly make them vibrate significantly. However, aesthetic, technical and technological developments lead to ever more slender and flexible footbridges and as a consequence they can vibrate significantly even under a single person and frequently require a thorough dynamic analysis.

In some footbridges, probably in project stages, using numerical techniques, or after a dynamic assessment, once built, through experimental techniques, different alternatives have to be proposed in order to avoid relevant vertical acceleration levels. Those alternatives tend to change the dynamic response by adding mass, or stiffness, or damping.

In this paper a novel alternative is analyzed: by adding a thick soft-rubber pavement, pour-in-place, softer than the one used in athletic training tracks, several effects are introduced. Although for standard footbridges, the additional mass (with no addition in stiffness) is irrelevant in changing natural frequencies or natural modes, for light footbridges, as steel or composite stress-ribbon ones, the effect could be appreciable. Also the rubber pavement improves the structural damping, being this effect very desirable for this kind of lively structures. But the main factor, analyzed in this paper, is its influence in two important aspects of the humanstructure interaction process. The first one is that the flexibility of the pavement affects the way the load is exerted to the structure. The second one, and more important in the perception of the discomfort, is that the pavement also affects the way the pedestrian senses the acceleration of the structure. The following sections are devoted to quantify this second effect.

\section{Evaluation of footbridge comfort according to standards and guidelines}

Modern pedestrian bridges are very often slender very flexible structures, where the first natural frequencies of vibration may fall close to dominant frequencies of the dynamic excitation due to walking or running. It is caused by technologically advanced materials used for their construction, with better strength parameters 
from those used before, together with the architectural trend for designing atypical and daring structures which quite often contradicts the classic principles of designing footbridges. The designer must take into account the phenomena of the man-bridge interaction and its vibration perception by human beings. Although such vibrations don't cause usually structural problems, they can induce some uncomfortable sensations. Vibrations of high amplitudes can cause a feeling of anxiety and fear, and even panic among pedestrians, affecting the functionality of the footbridge. Exceptionally, continuous vibration under standard service conditions, such as normal pedestrian use, may also cause fatigue that could damage the bearing structure and consequently affect structural safety. In addition, if the frequency of the actions is very close to the natural frequency of the structure itself and damping weak, resonance could occur if the actions are continuous, widening the vibration amplitude and raising the risk of structural collapse.

Some codes, standards or guidelines (ISO10137, EUROCODES 1 and 5, DIN4150, BS5400-6472, SBA1982, ENV1995, AISC1997, SETRA, HIVOSS, ...) establish maximum acceptable values of acceleration, normally expressed as function of the fundamental frequency of the footbridge. A detailed literature review on humaninduced dynamic loading of footbridges is given by Zivanovic et al [14]. In many of those codes, dynamic problems are addressed by defining limits for the natural frequencies of the structures or for the accelerations associated with pedestrian-induced vibrations. Such approaches are usually conservative and fail to deal with all the parameters relevant to human sensitivity to vibrations, which is highly subjective. This, together with the fact that the natural frequencies and accelerations calculated by analytical or numerical methods are subject to uncertainties, may hinder pedestrian bridge design.

The dynamic behaviour of footbridges depends on many parameters whose impact on vibrations is uncertain. These include material properties and mass, structural stiffness, including the boundary conditions, deck surfacing, guard rails, contribution of non-bearing elements, total damping, ....

Numerical simulation should be as realistic as possible with regard to all the parameters relevant to dynamic behaviour. Moreover, modelling the excitation (moving footfalls) is not easy and it is usually assumed to be a stationary harmonic force, i.e. the walking path is not taken into consideration. In general, the location of the stationary excitation and hence the location of the response are selected where the largest vibration amplitudes are expected (usually in the middle of the span). As a result, calculated responses can differ from one code to another in more than 4 times (has pointed out in [13]) and use to be considerable overestimated.

Once the response is obtained, the acceptance criteria is applied. Although some criteria are established not just in terms of RMS values of acceleration response at deck's midspan, usual recommended acceleration limits for footbridges are between 0.5 to $0.7 \mathrm{~m} / \mathrm{s}^{2}$ in the usual range of footbridges frequencies.

Note that for all those calculations, local properties can not be considered, so, i.e., in the same footbridge with two lanes (bicycle and pedestrian) with different pavements, computed RMS acceleration is unique, affecting to both lanes.

\section{Human perception}

In general, the perception and the individual judgement, whether vibrations are disturbing or not, are based on the psychological parameters and can lead to different limits, as certain persons can detect vibrations without being discomforted by them. Some of these parameters are difficult to quantify or are highly subjective. They include the number of simultaneous users; frequency of use; pedestrians' activity (walking, jogging, standing or sitting on the bridge); characteristics of the excitation forces (harmonic or transient); time of exposure; deck and guard rail transparency; height over ground level; footbridge appearance, if vibration is expected or not, etc.

It is considered that the vertical motion of the human body while walking is characterized by a relative motion between the center of gravity of the body $\left(\mathbf{u}_{\mathbf{b}}\right)$ and the deck $\left(\mathbf{u}_{\mathbf{g}}\right)$. This is the result of a cyclic sequence of vertical movements caused by the movement (flexing) of the lower limbs. In each cycle, the body moves down due to the bending of each leg and restores its position with the tightening of the respective leg. This vertical motion induces forces un the deck $(\mathbf{F}(\mathbf{t}))$ and is also influenced by the stiffness, damping, mass and other properties of the structure. Based on this, simple biodynamic models can be conceived, although its 
application to evaluation of the comfort of the pedestrian is still to come. Note that $\mathbf{F}(\mathbf{t})$ contains all the complexity of human being and the applied forces are governed by a very sophisticated control system: the human brain

Among other effects, in this paper we focus on walking on flexible pavement. When a pedestrian walks on a softy soil, in every step he notices how first the heel, then the toe, sinks and rises, and probably that feeling makes the pedestrian, unconsciously, no to be so demanding regarding the movement of the walkway. To verify this effect, we compare the recordings of 3 accelerometers installed on the pedestrian when he walks on four different scenarios. Two of the accelerometers are located on one of the pedestrian's shoes (one at the heel and the other one at the toe) and the third is placed on his hip (all of then in the right side of the body).

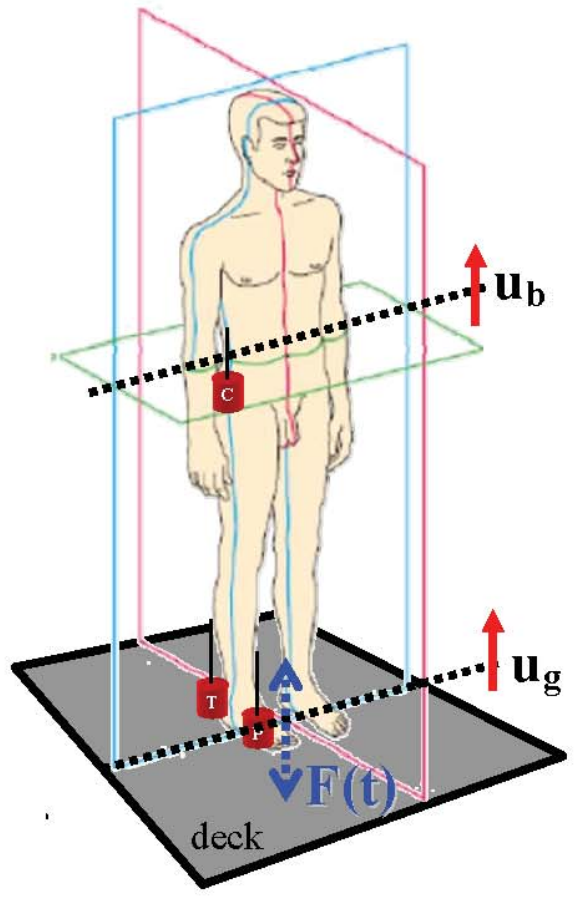

Figure 1. Accelerometers placed at pedestrian`s right hip, toe and heel.

\section{Methodology}

To record the accelerations during normal walking, 3 uniaxial accelerometers (PCB Piezotronics, model $352 \mathrm{C} 65$, high sensitivity, miniature ceramic shear ICP® accel. $100 \mathrm{mV} / \mathrm{g}, 0.5$ to $10 \mathrm{k} \mathrm{Hz}$ ) have been installed on the pedestrian (75kg weight). As shown in Figure 1, one is placed on his hip (C), other on his heel (T) and the third one on his toe $(\mathrm{P})$. All of them are in the vertical axis when the pedestrian is at rest. Accelerometer (C) almost remain in the vertical direction over the whole walking cycle but $(\mathrm{T})$ and $(\mathrm{P})$ can change in more than $80^{\circ}$. The three signals are recorded synchronously at a sample rate of $100 \mathrm{~Hz}$.

Several tests were conducted with same pedestrian (male, $1.80 \mathrm{~m}$ height, $80 \mathrm{~kg}$ weight) in similar conditions (clothes, rubber-soled shoes, ...) wearing the three accelerometers and walking with a standard pacing rate (105bpm) using a metronome. Typical pacing frequencies for a person walking generally lie between 1,6 and $2,4 \mathrm{~Hz}$. $50 \%$ of pedestrians walk at rates between 1,9 and $2,1 \mathrm{~Hz}$ and $95 \%$ of pedestrians walk at rates between 1,65 and 2,35 Hz. The scenarios to be compared are:

- (S) standard rigid pavement out of the footbridge,

- (R) rubber pavement before entering in the footbridge (thickness about $40 \mathrm{~mm}$ )

- (F1) rubber pavement on bicycle lane of the footbridge (thickness about $10 \mathrm{~mm}$ ).

- (F2) rubber pavement on pedestrian lane of the footbridge (thickness about $40 \mathrm{~mm}$ ). 
In figure 2, 18 selected instants of the walking cycle on (S) are shown in a schematic way (ground contact, stretching, rocking and swing) focusing in the right leg. Measured accelerations for the three accelerometers are plotted for a representative step, together with the estimated contact force when walking on rigid pavement. For $105 \mathrm{bpm}$ the duration of the cycle is $1.14 \mathrm{~s}$. Accelerations in toe $\mathrm{P}$ and heel $\mathrm{T}$ are obviously greater than in the hip C and also more sharpy and "noisy". The contact force (two legs) is estimated after Petersen (for a pacing frequency of $1.75 \mathrm{~Hz}$, for which the corresponding parameters for the $1^{\text {st }}, 2^{\text {nd }}$ and $3^{\text {rd }}$ harmonics are $0.240,0.108$ and 0.018 and phase lag are $\pi / 5$, amplitude normalized by relating them to the body weight of the pedestrian) and included in figure 2 for the sake of completeness.

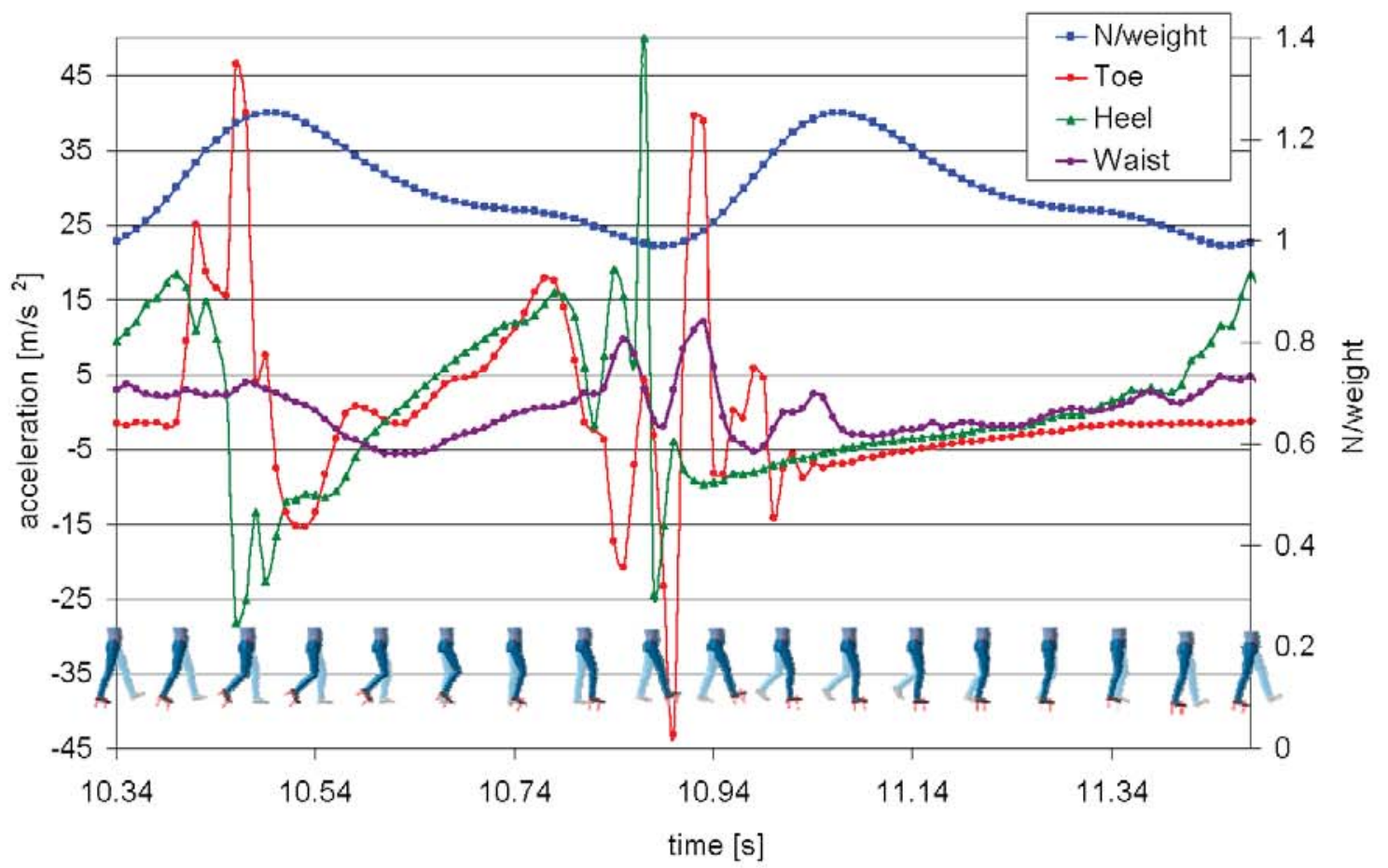

Figure 2. One cycle accelerometer recordings for hip, toe and heel.

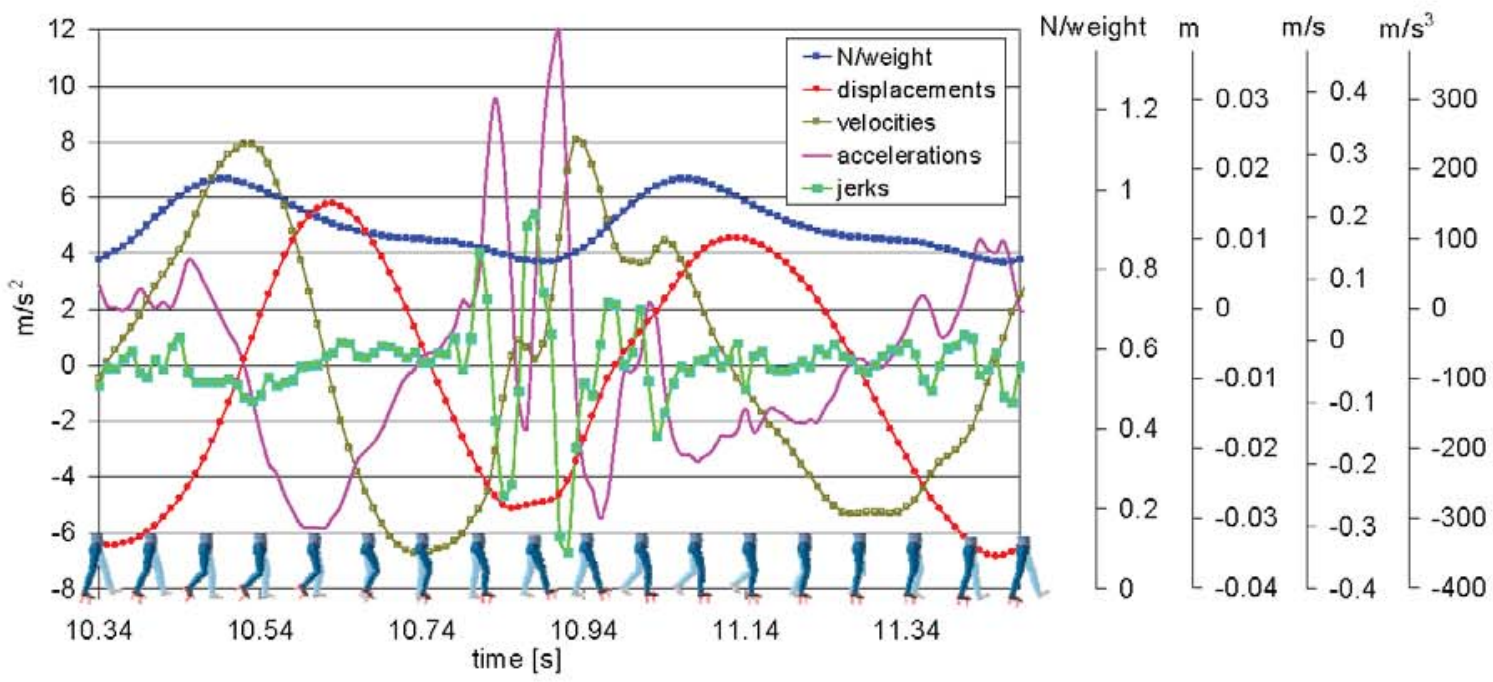

Figure 3. Hip acceleration and corresponding velocity, displacement and jerk. 
In figure 3, not only accelerations for the hip are presented, but also velocities and displacements (computed by numerical integration) and also jerks (numerical differentiation from the acceleration). All of these magnitudes (RMS and amplitudes during 100s recordings) are going to be compared for the four different scenarios.

For each location ( $\mathrm{P}, \mathrm{T}$ or $\mathrm{C}$ ), ten representative cycles (steps) are shown in figure 4 . All of then are matched in the instant when the toe lifts off the ground. For each step, also the following one is shown. Trying to get relevant information for understanding why walking on F2 is more comfortable than walking on F1, parameters $\Delta a_{0}, \Delta a_{1}, \bar{a}$ and $\Delta t$ are going to be evaluated for the four different scenarios. $\Delta a_{0}$ is the amplitude of the impact when the heel reach the ground (between mean values for the 10 selected cycles), $\Delta a_{1}$ is the acceleration interval in the next step, with mean value is $\bar{a}$, and $\Delta t$ is the corresponding time interval.

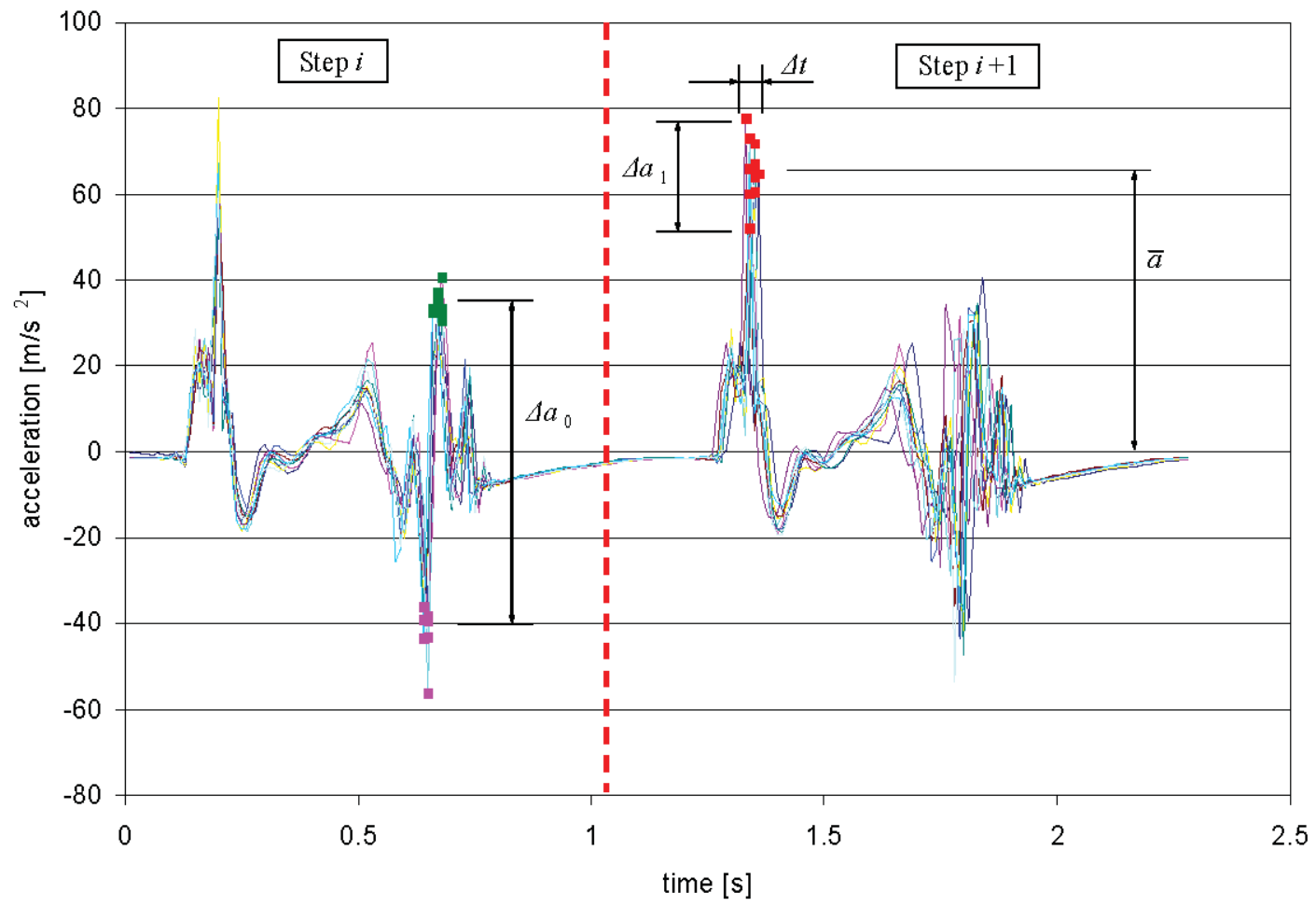

Figure 4. Toe accelerations during two cycles, 


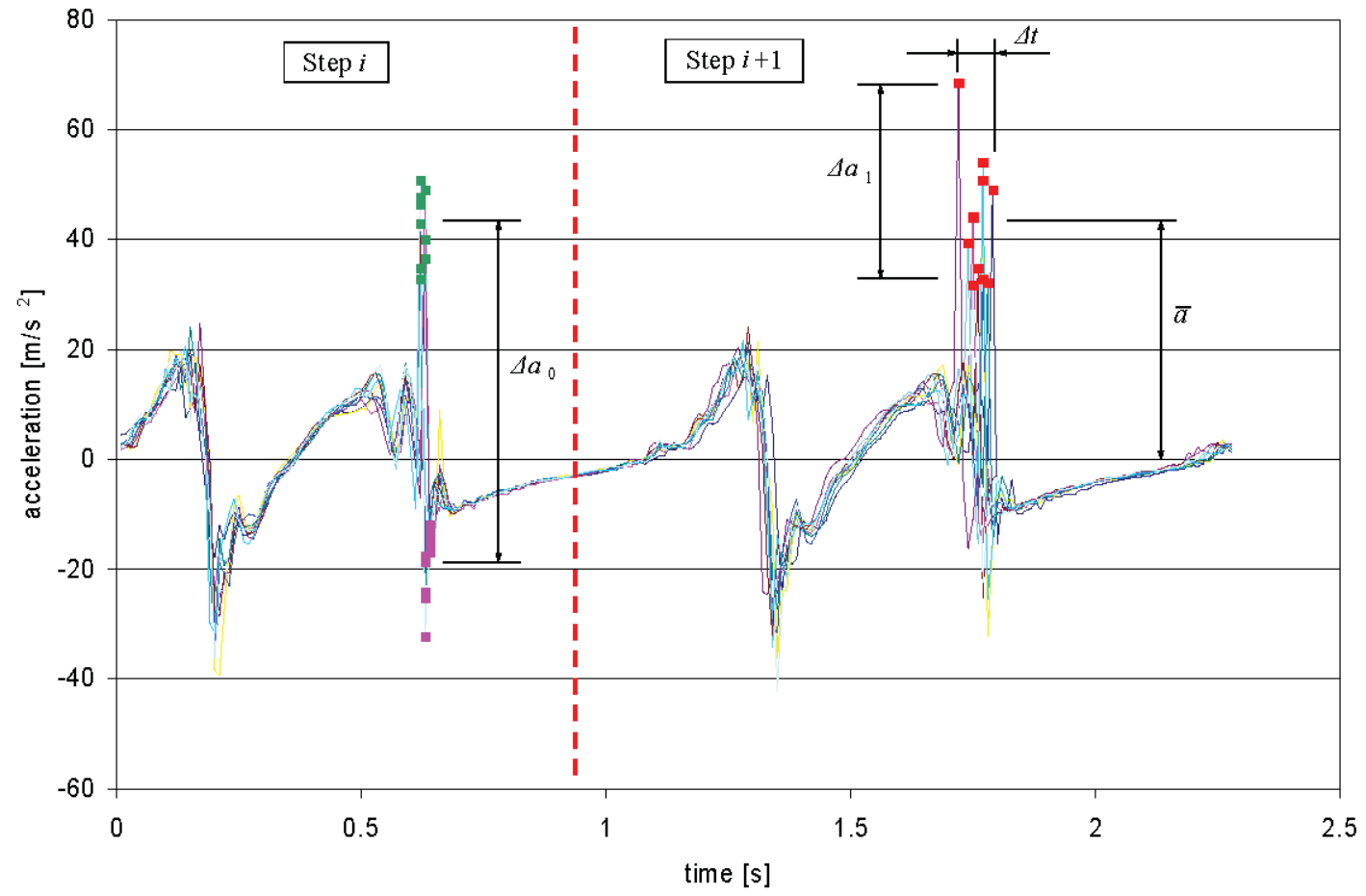

Figure 5. Heel accelerations during two cycles,

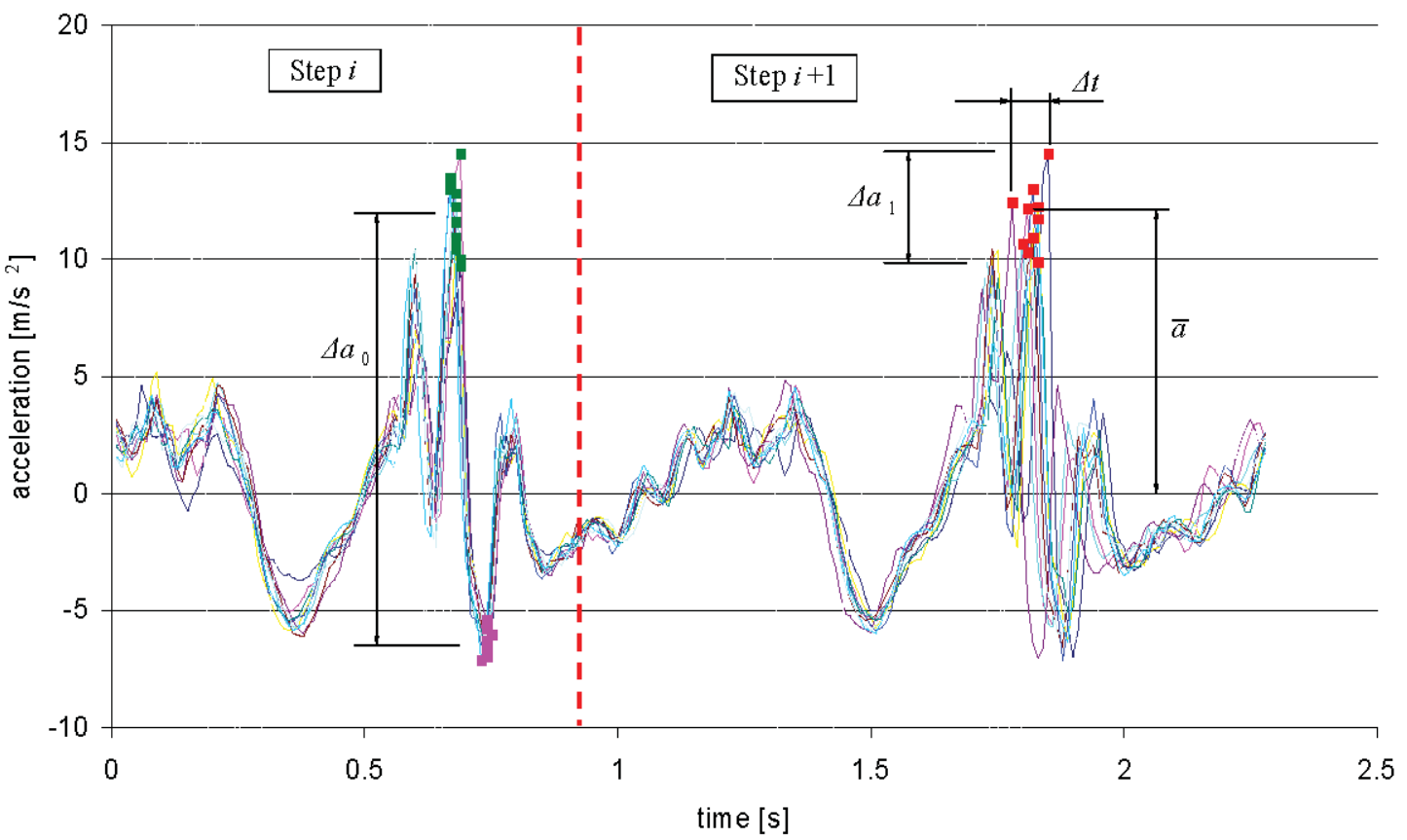

Figure 6. Hip accelerations during two cycles, 


\section{Results}

Numerical results are shown in the following tables. RMS values and maximum values of accelerations for 100 s recordings are presented for toe (table 1), heel (table 2) and hip (table 3a and b) for the four scenarios. Also corresponding jerks are computed and resented, and for the hip, also velocities and displacements.

\begin{tabular}{|c|c|c|c|c|}
\hline & $\mathrm{a}_{\mathrm{RMS}}$ & $\mathrm{a}_{\max }$ & $\mathrm{j}_{\text {RMS }}$ & $\mathrm{j}_{\max }$ \\
\hline$(\mathrm{S})$ & 11.31 & 82.14 & 1001.04 & 7133.6 \\
\hline$(\mathrm{F} 1)$ & 12.73 & 91.36 & 1148.04 & 8463.7 \\
\hline$(\mathrm{R})$ & 10.03 & 78.52 & 864.43 & 7136.3 \\
\hline$(\mathrm{F} 2)$ & 11.5 & 85.31 & 978.99 & 7840.6 \\
\hline
\end{tabular}

Table 1. Results for 100 s recording at Toe

\begin{tabular}{|c|c|c|c|c|}
\hline & $\mathrm{a}_{\mathrm{RMS}}$ & $\mathrm{a}_{\max }$ & $\mathrm{j}_{\text {RMS }}$ & $\mathrm{j}_{\max }$ \\
\hline$(\mathrm{S})$ & 9.56 & 68.36 & 775.45 & 6151.6 \\
\hline$(\mathrm{F} 1)$ & 10.07 & 64.57 & 827.45 & 8449.2 \\
\hline$(\mathrm{R})$ & 8.96 & 62.36 & 707.06 & 6776.2 \\
\hline$(\mathrm{F} 2)$ & 9.71 & 66.82 & 731.30 & 7697.8 \\
\hline
\end{tabular}

Table 2. Results for 100 s recording at Heel

\begin{tabular}{|c|c|c|c|c|}
\hline & $\mathrm{a}_{\mathrm{RMS}}$ & $\mathrm{a}_{\max }$ & $\mathrm{j}_{\text {RMS }}$ & $\mathrm{j}_{\max }$ \\
\hline$(\mathrm{S})$ & 3.23 & 14.33 & 141.08 & 736.5 \\
\hline$(\mathrm{F} 1)$ & 3.17 & 13.30 & 170.56 & 622.3 \\
\hline$(\mathrm{R})$ & 2.89 & 12.5 & 122.47 & 1851.6 \\
\hline$(\mathrm{F} 2)$ & 3.33 & 17.11 & 136.80 & 1159.0 \\
\hline
\end{tabular}

Table 3a. Results for 100 s recording at Hip

\begin{tabular}{|c|c|c|c|c|}
\hline & $\mathrm{v}_{\text {RMS }}$ & $\mathrm{d}_{\max }$ & $\mathrm{d}_{\text {RMS }}$ & $\mathrm{d}_{\max }$ \\
\hline$(\mathrm{S})$ & 0.219 & 0.469 & 0.0151 & 0.0387 \\
\hline$(\mathrm{F} 1)$ & 0.217 & 0.509 & 0.0199 & 0.0428 \\
\hline$(\mathrm{R})$ & 0.201 & 0.49 & 0.0183 & 0.0365 \\
\hline$(\mathrm{F} 2)$ & 0.233 & 0.546 & 0.0207 & 0.0398 \\
\hline
\end{tabular}

Table 3b. Results for 100 s recording at Hip

In a similar way, all the parameters defined in figures 4,5 and 6 are presented in tables 4,5 and 6 for 10 selected double cycles. Among all these data, the more relevant conclusion is that $\Delta t$ increase when pavement is more flexible.

\begin{tabular}{|c|c|c|c|c|}
\hline & $\Delta a_{0}$ & $\Delta t$ & $\Delta a_{1}$ & $\bar{a}$ \\
\hline$(\mathrm{S})$ & 76.39 & 0.03 & 25.53 & 65.76 \\
\hline$(\mathrm{F} 1)$ & 66.28 & 0.06 & 23.69 & 72.43 \\
\hline$(\mathrm{R})$ & 53.26 & 0.07 & 28.04 & 57.12 \\
\hline$(\mathrm{F} 2)$ & 51.47 & 0.07 & 36.48 & 65.95 \\
\hline
\end{tabular}

Table 4. Parameters for two cycle. Toe.

\begin{tabular}{|c|c|c|c|c|}
\hline & $\Delta a_{0}$ & $\Delta t$ & $\Delta a_{1}$ & $\bar{a}$ \\
\hline$(\mathrm{S})$ & 61.05 & 0.07 & 36.86 & 43.72 \\
\hline$(\mathrm{F} 1)$ & 45.21 & 0.15 & 38.28 & 35.65 \\
\hline$(\mathrm{R})$ & 52.03 & 0.19 & 23.78 & 34.66 \\
\hline$(\mathrm{F} 2)$ & 46.34 & 0.21 & 43.98 & 34.13 \\
\hline
\end{tabular}

Table 5. Parameters for two cycle. Heel. 


\begin{tabular}{|c|c|c|c|c|}
\hline & $\Delta a_{0}$ & $\Delta t$ & $\Delta a_{1}$ & $\bar{a}$ \\
\hline$(\mathrm{S})$ & 18.19 & $\mathbf{0 . 0 6}$ & 5.58 & 11.79 \\
\hline$(\mathrm{F} 1)$ & 14.87 & $\mathbf{0 . 1 5}$ & 7.27 & 11.50 \\
\hline$(\mathrm{R})$ & 15.59 & $\mathbf{0 . 1 7}$ & 5.55 & 11.41 \\
\hline$(\mathrm{F} 2)$ & 11.65 & $\mathbf{0 . 2 0}$ & 6.95 & 10.38 \\
\hline
\end{tabular}

Table 6. Parameters for two cycle. Hip.

\section{Conclusions}

The shape of recordings in the representative walking cycles are similar. Some differences can be found in acceleration amplitudes, but more statistic analysis is required to get decisive conclusions. Although jerk is often used to measure the comfort of rides (elevators, trams, roller coasters, etc.), no relevant results can be obtained from the attempt done in this study of evaluate the jerk in toe, heel or hip.

Analyzing the timing and dispersion of walking cycles, a relevant conclusion can be found: when walking on soft pavement the cycles are not as similar, between themselves, as when walking on rigid pavement. The dispersion $\Delta t$ is much greater for $(\mathrm{R})$ and $(\mathrm{F} 2)$, as expected.

Accelerations recorded in the deck during F1 and F2 events were very similar, with RMS values about $0.064 \mathrm{~m} / \mathrm{s}^{2}$ and maximum values about $0.52 \mathrm{~m} / \mathrm{s}^{2}$. The corresponding FFT reveals dominant contribution at the frequencies $1.07,1.73$ and $2.24 \mathrm{~Hz}$. Corresponding numerical computed displacements were about $2.78 \mathrm{~mm}$ maximum, with RMS about $1.17 \mathrm{~mm}$. Modal masses and modal dampings are yet to be determined. During those recordings, no more that 5 people (less than 0.02 person $/ \mathrm{m}^{2}$ ) were crossing the footbridge. In those conditions, according to usual acceptance criteria, the dynamical behaviour of the footbridge is adequate $\left(<0.7 \mathrm{~m} / \mathrm{s}^{2}\right)$. But another source of discomfort could be that the ground is or not in the expected position. Bearing in mind the values for $\Delta t$ given in table 6 , one step can be $\Delta t / 2$ faster or slower than the previous ones. In that time, according to figure 7 , expected vertical displacement in the hip can be around $1.8 \mathrm{~mm}$ for (S) and around $15 \mathrm{~mm}$ for F2, even though, it is not difficult neither uncomfortable to walk on the rubbered footbridge (F2). Movements of the deck are more strongly perceived in (F1), although $\Delta t$, and is less than for (F2). Due to the sensation of softy pavement, it could be that the pedestrian mind was not as challenging to keep pace and therefore not as sensitive to ground motion perception, as vibrations are expected after walking on (R)

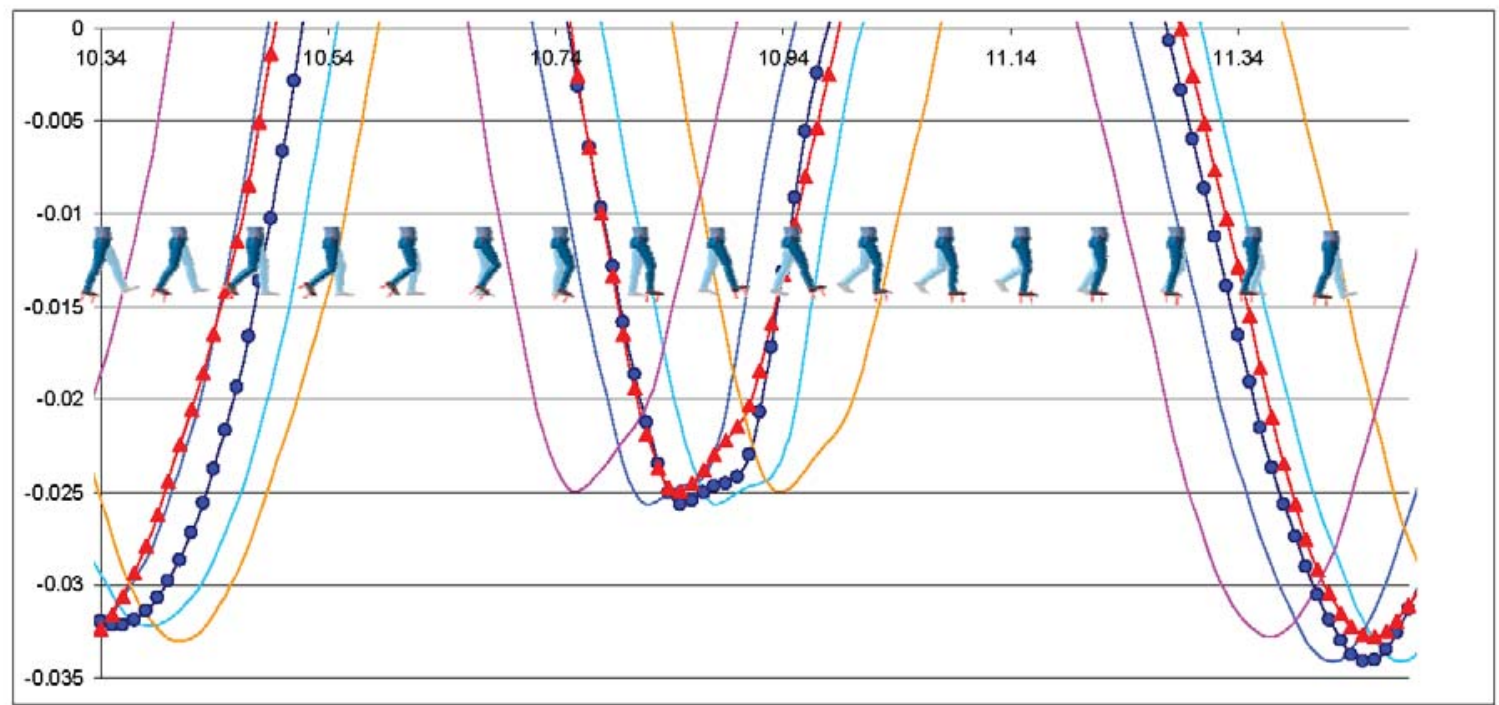

Figure 7. Expected hip displacements (circled line for (S) and triangled line for (F2)) and corresponding displacements for possible faster or slower steps. 


\section{Acknowledgment}

The results of this paper are partly obtained within the framework of a current research project, BIA201128493-C02-02, financed by the "Ministerio de Ciencia e Innovación", Spanish government.

\section{References}

1. Cheng, J.C. and Moura, J.M.F. Tracking human walking in dynamic scenes. Proc. of IEEE. Int. Conf. Image Processing, ICIP'97, Santa Barbara, CA, vol. 1, pp.137-140, 1997.

2. European Committee for Standardization CEN:EN1991-2, UK National Annex to Eurocode 1Actions on structures, Part 2: Traffic load on bridges, 2003

3. European Committee for Standardization CEN:EN1995-2, Eurocode 5- Design of timber structures, Part 2: Traffic load on bridges, 2003

4. Federation international du beton, Guidelines for the design of footbridges, FIB Bulletin No. 32 , Lausenne, 2006.

5. Figueiredo FP, Silva JGS, Lima LRO, Vellasco PCG, Andradec SAL, A parametric study of composite footbridges under pedestrian walking loads, 30(3), 605-615, 2008.

6. HIVOSS, Design of Footbridge guidelines, Human Induced Vibrations of Steel Structures, 2008

7. Hogan, N. Mechanical Impedance of Single-and Multi-Articular Systems. Multiple Muscle Systems: Biomechanics and Movement Organization. Springer-Verlag, New York. 1990

8. International Standards Organization, ISO 10137:2004, Bases for design of structure, serviceability of buildings and pedestrian walkways against vibration, Geneva, 2005.

9. Petersen, C., Dynamik der Baulonstruktionen, Vierweg Braunchweig/Wiesbaden, 1996.

10. Racic V, Pavic A, Brownjohn JMW, Experimental identification and analytical modelling of human walking forces: Literature review, JOURNAL OF SOUND AND VIBRATION, 326(12), 1-49, 2009

11. Sánchez, J. Biomecánica de la marcha humana normal y patológica. Instituto de biomecánica de Valencia (in Spanish) ISBN-13.9788495448125, 1999

12. Setra. Technical guide Footbridge: Assesment of vibration behavior of footbridges under pedestrian loading, Paris, 2006.

13. Zivanovic S, Pavic A, and Ingolfsson E.T., Modelling spatially unrestricted pedestrian traffic on footbridges, ASCE Journal of Structural Engineering, 136 (10), 1296-1308. 2010

14. Zivanovic S, Pavic A, Reynolds $P$, Vibration serviceability of footbridges under human-induced excitation: a literature review, Journal of sound and vibration, 279(1-2), 1-74, 2005

15. Whittingtonm B.R. and Thelen, D.G. A simple mass-spring model with roller feet can induce the ground reactions observed in human walking. Journal of Biomechanical Engineering.Vol. 131, 2009 


\section{IMAC-XXXI \\ Conference and Exposition on Structural Dynamics}

Engineering Nonlinearities in

Structural Dynamics

Hyatt Regency Orange County

Garden Grove, CA USA

February 11 - 14, 2013
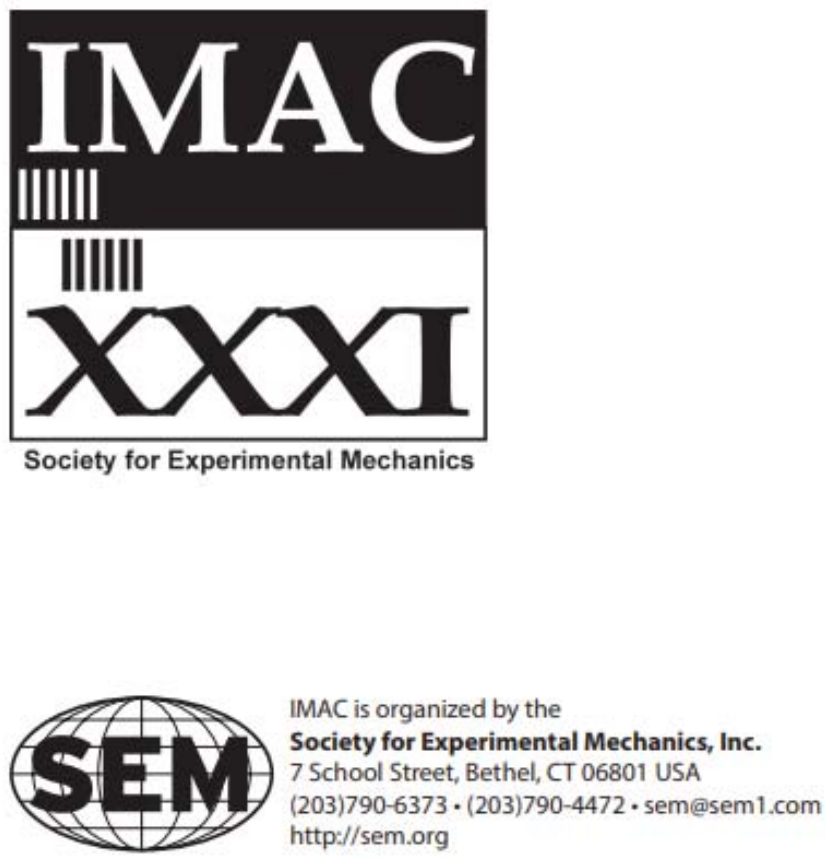

Melania

Vasilica Istrate; Stana Zivanovic; Antolín Lorenzana Ibán; Norberto Ibán Lorenzana; Hipe V. Dan.

\begin{tabular}{l|c|c|c|} 
Aportaciones: & Experimentación & Procesado & Edición \\
\hline \multirow{n}{*}{} & & Matlab & Tablas \\
& & Excel & Gráficas \\
& & Sigview & Imágenes \\
\cline { 2 - 4 }
\end{tabular}




\title{
Quantifying differences between walking locomotion on rigid and flexible pavements
}

\author{
M.V. Istrate ${ }^{1}$, S. Zivanovic ${ }^{2}$, A. Lorenzana ${ }^{3}$, N. Ibán ${ }^{1}$ and H.V. Dang ${ }^{2}$ \\ 1 CARTIF Centro Tecnológico, Parque Tecnológico de Boecilllo, 47151 Valladolid, Spain \\ 2 School of Engineering, University of Warwick, Coventry CV4 7AL, UK \\ ${ }^{3}$ ITAP, University of Valladolid, 47011, Valladolid, Spain
}

\begin{abstract}
In this work it is explored, with the quantification of vibration, the differences between locomotion on rigid and flexible pavements. It attempts, primarily, to explain human responses and the way in which the various influential factors combine

The influence of the type of supporting surface is quantified using several vibration measures defined in ISO-2631, such as weighted r.m.s acceleration, MTVV and VDV. Four scenarios are analysed. These are walking on: (1) a rigid pavement, (2) a flexible pavement, (3) a lively footbridge with rigid pavement, and (4) a lively footbridge, with a flexible pavement.
\end{abstract}

The differences between the investigated scenarios are analysed by comparing trajectories of different parts of the pedestrian's body recorded while walking on the four supporting surfaces.

The trajectories are traced using a motion capture system consisting of six infrared cameras and a number of reflective markers attached to the human anatomical landmarks.

It was found that the type of surface has an influence on RMS and MTVV values. Averaged values (for all the markers) in each scenario can be related to the pedestrian perception of the movement.

\section{Introduction:}

Human vibration is a multi-disciplinary subject involving knowledge from disciplines as diverse as engineering, ergonomics, mathematics, medicine, physics, physiology, psychology and statistics. Each one brings its own technical term which may not always be understood by those from another field.

The shaking of the human body - a complex, active, intelligent, dynamic, structure - should not be expected to have a single, simple, or easily predictable consequence. Vibration may be a source of pleasure or the cause of pain. Whether a motion causes annoyance, discomfort, interference with activities, impaired health or motion sickness depends on many factors - including the characteristics of the motion, the characteristics or the activities of the exposed person, and other aspects of the environment

This paper quantifies the perception of the vibration and the diverse effects of vibration on the body walking on rigid and flexible surface. It attempts, primarily, to explain human responses and the way in which the various influential factors combine.

The quantification of human response to vibration walking on rigid and flexible pavement is concerned with establishing relationships between various effects (e.g. impaired comfort, activities or health) and their causes (e.g. vibration conditions, other environmental conditions, or subject characteristics). So, the human walking locomotion is influenced by various factors such as type of shoes, type of supporting surface, whether or not the person is carrying loads, whether people are walking alone or in group, etc.

\section{Effects of body vibration}

Whole-body vibration is capable of producing a wide variety of different effects. It can generate a range of subjective sensation which can be quantified in many different ways. Both simple and complex activities can be disturbed by vibration affection the various components of a task, form the input of information to the body (e.g. vision) thought 
to the output of information from the body (e.g. hand control). Physiological parameters may be disturbed by vibration with wither transitory effects or permanent changes.

The principal approach to the determination of the growth in sensation with increasing vibration magnitude has been by means of Stevens' power law (Stevens, 1975). Miwa (1968a) reported a reduction in the exponent with an increase in vibration magnitude. Howarth and Griffin (1988a) found frequency dependence in the exponent for lateral vibration which might be explained by a higher exponent for stimuli which are less uncomfortable. Howarth (1987) found a value near unity for the exponent when studying subjective response to shocks with peak magnitudes up to about $1 \mathrm{~g}$.

It is well known that at low frequencies (below 1 or $2 \mathrm{~Hz}$ depending on the vibration direction and body orientation) the forces acting on the body are approximately proportional to the input acceleration and the same movement is transmitted throughout the entire body (Handbook of Human Vibration). At slightly higher frequencies various body resonances tend to amplify the motion and overall discomfort is influenced by sensation in different parts of the body (e.g. abdomen, thorax, shoulder, face) as the frequency is increased. If the frequency is increased further, the body provides increasing attenuation of vibration so as eventually to reduce the location of discomfort to that in close proximity to the vibration input (Whitham and Griffin, 1978b). Such general considerations imply that at low frequencies, where the body responds as a virtually rigid system, discomfort will tend to be proportional to acceleration. For vibration in the vertical direction there is increased sensitivity to seat acceleration in this region and, considering the amplification associated with biodynamic responses, sensitivity may be expected to be approximately double that at lower frequencies. Maximum discomfort occurs in the frequency range from $4 \mathrm{Ho} \mathrm{Hz}$ and those vibrations at frequencies above $10 \mathrm{~Hz}$ are of relatively minor importance.

Sensitivity to acceleration does not vary greatly with frequency in the range $0.5-2 \mathrm{~Hz}$ (Handbook of Human Vibration). It might now be concluded that sensitivity to vertical vibration is similar at all frequencies in the range 1$30 \mathrm{~Hz}$.

It has been shown elsewhere (e.g. Griffin, 1975a) that changes in posture can greatly alter the transmission of vibration to the body and it is clear that such changes can alter vibration discomfort. Vibration magnitudes in excess of about $3 \mathrm{~ms}-2$ r.m.s. can be exceedingly uncomfortable and subjects would be very likely to attempt to ameliorate the sensations they cause. At high frequencies, small postural changes can greatly reduce the transmission of vibration to the body, whereas at low frequencies posture has less effect.

Vibration discomfort also depends on frequency of use; pedestrians' activity (walking, jogging, standing or sitting on the bridge); characteristics of the excitation forces (harmonic or transient); time of exposure; deck and guard rail transparency; height over ground level; footbridge appearance, if vibration is expected or not, type of shoes, the type of supporting surface (rigid or flexible), etc.

It is considered that the vertical motion of the human body while walking is characterized by a relative motion between the centre of gravity of the body $\left(\mathbf{u}_{\mathbf{b}}\right)$ and the deck $\left(\mathbf{u}_{\mathbf{g}}\right)$. This is the result of a cyclic sequence of vertical movements caused by the movement (flexing) of the lower limbs. In each cycle, the body moves down due to the bending of each leg and restores its position with the tightening of the respective leg. This vertical motion induces forces on the deck $(\mathbf{F}(\mathbf{t}))$ and is also influenced by the stiffness, damping, mass, type of supporting surface and other properties of the structure. Based on this, simple biodynamic models can be conceived, although its application to quantify the comfort of the pedestrian is still to come. Note that $\mathbf{F}(\mathbf{t})$ contains all the complexity of human being and the applied forces are governed by a very sophisticated control system: the human brain.

Among other effects, in this paper we are focused on quantify comfort while walking on rigid and flexible pavement. When a pedestrian walks on a softy soil on a lovely structure, the vibration is transmitted to lower level to the bridge and consequently the comfort on the vibration from the pedestrian is improved.

To quantify the differences between walking locomotion on rigid and flexible pavement we carried out several experiments using a motion capture system with external human participant (woman, $1.60 \mathrm{~m}$ height, $46 \mathrm{~kg}$ weight, 6 US shoe size) in 20 meter footbridge in strong floor lab, at differences frequencies.

The experiment process involves human walking on the footbridge in Strong Floor Laboratory on those scenarios:

(1) rigid footbridge

(2) one foam on rigid footbridge

(3) double foam on rigid footbridge

(4) a lovely footbridge with a rigid pavement 
(5) a lovely footbridge with a flexible pavement with one foam

(6) a lovely footbridge with a flexible pavement with double foam

Test subject was asked to walk on all those scenarios at 5 different frequencies: $2.2 \mathrm{~Hz}, 2.4 \mathrm{~Hz}, 2.3 \mathrm{~Hz}, 1.6 \mathrm{~Hz}$ and $2.0 \mathrm{~Hz}$ (using the metronome). Each test session is ranging for 1 to 3 hours including time of calibrating system and the test subjects, and changing the pavement of the footbridge.

\section{Vibration magnitude}

There are many possible means by which the magnitude of an oscillatory motion (vibration) can be measured. With a large-amplitude low-frequency motion it is possible to see the displacement between the maximum movement in one direction and the peak movement in the opposite direction, using in our case the Vicon Series motion capture. The Vicon is a suite of networked MX T-Series motion capture cameras, hardware devices, and software applications that provide real-time and offline digital-optical motion capture data.

Even if in practice, the distance it used to be difficult to measure with VICON we manage to have the displacement even when it was too small to be detected by the view.

The magnitude of the oscillation may alternatively be defined by the velocity, which is more directly related to the energy involved in the movement. Although there are various good reasons for quantifying the vibration severity in terms of velocity, instrumentation for measuring the acceleration of the oscillation is, at present generally more convenient. Many standards therefore advocate that the severity of human vibration exposures should be expressed in terms of the vibration acceleration rather than velocity or the displacement.

Some codes, standards or guidelines (ISO10137, EUROCODES 1 and 5, DIN4150, BS5400-6472, SBA1982, ENV1995, AISC1997, SETRA, HIVOSS, ...) quantify the effects of vibration establish maximum acceptable values of acceleration, normally expressed as function of the fundamental frequency of the structures. A detailed literature review on human-induced dynamic loading of footbridges is given by Zivanovic [14]. In many of those codes, dynamic problems are addressed by defining limits for the natural frequencies of the structures or for the accelerations associated with pedestrian-induced vibrations. Such approaches are usually conservative and fail to deal with all the parameters relevant to human sensitivity to vibrations, which is highly subjective.

R.m.s. (root-mean-square value, the measure in greatest use in engineering), acceleration, MTVV and VDV are defined under ISO-2631 in order to quantify vibration magnitudes which can lead to different conclusions in a range of common conditions. This generally occurs if any of the measures gives a significantly different value when determined over only part of the vibration exposure. Motions containing occasional shocks, those consisting of intermittent periods of vibration and all other non-stationary vibration conditions fall into this category.

Neither peak nor average measures reflect the importance of the duration of the motion event: the peak value is determined by the magnitude at one instant while the r.m.s. magnitude can either increase or decrease with increasing duration. If all motions were "well-behaved" it might be possible to summarize human response to vibration by a simple curve in which the "acceptable" magnitude of r.m.s. acceleration depended on the period of exposure. However, for real-world exposures in which the vibration characteristics vary greatly from moment to moment, the period over which the r.m.s. magnitude or displacement given by the VICON SYSTEM, determined is not always apparent and the r.m.s. or displacement value can sometimes be shown to be an inappropriate measure. For such motions a cumulative measure (sometimes called a "dose") is more reliable. For whole-body vibration the vibration dose value provides a convenient measure of the total severity and this has been found to correlate well with some responses to vibration. The vibration dose value can be applied either to a single shock, a mixture of shocks and vibration, or a full day exposure to vibration of various types. A similar measure (using a different time dependency) is used to obtain energy-equivalent magnitudes of hand-transmitted vibration.

British Standard 6842 provides guidance on factors which influence the severity of hand transmitted vibration and describes how the severity of vibration exposure should be quantified. The assessment hand-transmitted vibration is based on daily exposures expressed as $8 \mathrm{~h}$ "energy-equivalent" frequency-weighted root-mean-square (r.m.s)

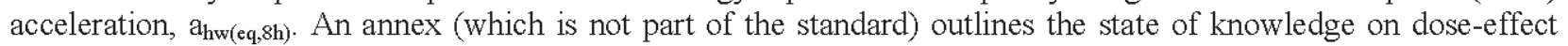
relationships for hand-transmitted vibration. The annex explains that the use of the energy - equivalent timedependency is convenient and appears reasonable, but may allow excessively high vibration magnitudes for short duration exposure. It is suggested that if a vibration magnitude is doubled, the exposure period (i.e. years of exposure) before the first onset of finger blanching will tend to be halved. 


\section{Methodology}

In order to analyse the influence of the type of supporting surface and quantifies using vibration measures defined in ISO - 2631, such as weighted r.m.s acceleration, MTVV and VDV, we carried out several experiments with external human participants (woman, $1.60 \mathrm{~m}$ height, $46 \mathrm{~kg}$ weight, 36 size of foot) in 20 meter footbridge in strong floor lab, at differences frequencies and using a motion capture system.

To record the displacement during normal walking in 6 different situations we needed the Vicon System. Six infrared cameras were mounted on two steel frames $(12.5 \mathrm{~m}$ from the beginning of the footbridge and at $16.5 \mathrm{~m}$ respectively); two video cameras are positioned at two ends of the footbridge, and one along the side of the footbridge.

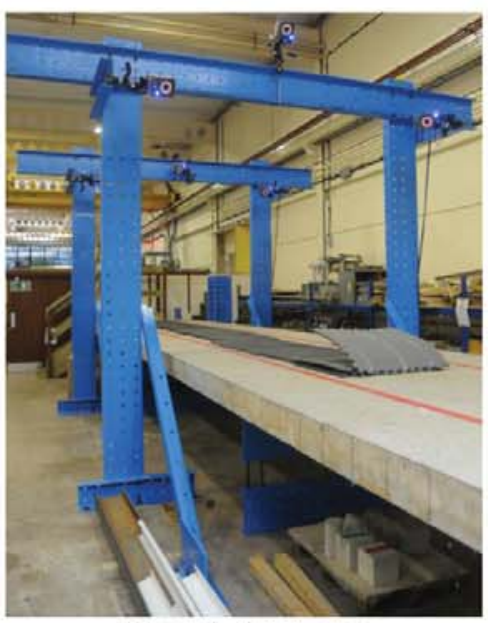

Figure 1. Test area

On the footbridge we located some markers in order to indicate the range of VICON cameras (current estimation is 6.5 meter, equivalent to $8-10$ walking steps) and to have the displacement of the footbridge in those points. One of the markers was located at the second accelerometers, at the middle of the footbridge.

Four accelerometers were involved on the tests. Three of them were on the footbridge surface: one at $14 \mathrm{~cm}$ (was used to determine the moment test subject entering the footbridge) from the beginning of the footbridge, in the start point of the tests, another one at $10 \mathrm{~m}$, and the last one at $12.5 \mathrm{~m}$. In order to know the moment when we leave the footbridge, one of the accelerometers was located at the platform to access to the stairs. The four signals are recorded synchronously at a sample rate.

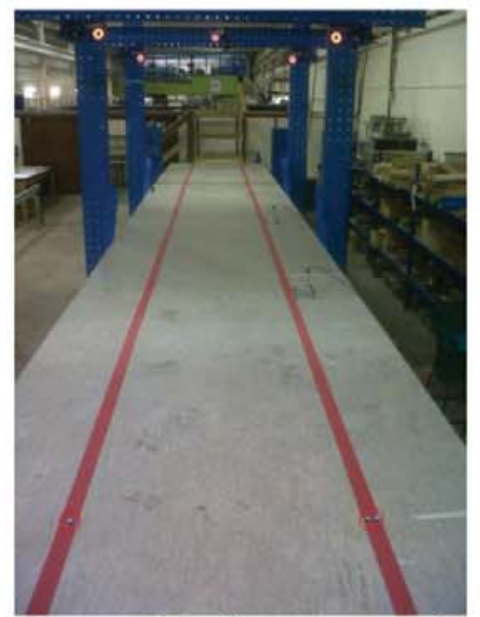

Figure2. Markers and accelerometers on the footbridge

For the tests which involved the flexible pavement we use approximately a total of $42 \mathrm{~m}$ of foam in order the cover all the footbridge and the platform of the steers, in one and double thicknesses. Ethylene Vinyl Acetate is the material that we use during the tests with flexible material. EVA is a space age material that can be produced in a range of 
different hardness's to suit most applications; it is completely impervious to liquids. Being a semi-rigid foam EVA wall matting will simply dent when kicked and then slowly recover, it is rapidly becoming more popular than traditional plastic Stockboard (re-cycled polyethylene sheet) which has a tendency to warp in hot conditions. 4 Interlocking pieces cover $1.48 \mathrm{sq}$ metres/16 square feet (multiple sets can be purchased and connected to cover big areas).

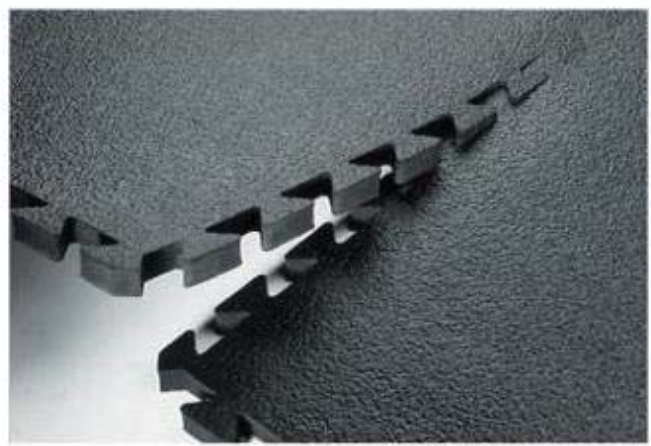

Figure3. Ethylene Vinyl Acetate

Laboratory experimentation requires vibrators to expose experimental subjects to motion. In our tests the motion of the footbridge was generated by the test subjects during the walk. The tests subject was instrumented with eighteen reflective markers on the body's bony landmarks and calibrated with the cameras. Each marker has a diameter of 14 $\mathrm{mm}$, and the markers were placed symmetrically on the right and on the left on the following body parts: head, shoulder, elbow, wrist, elbow, hip, knee, ankle, toe_i, toe_e.

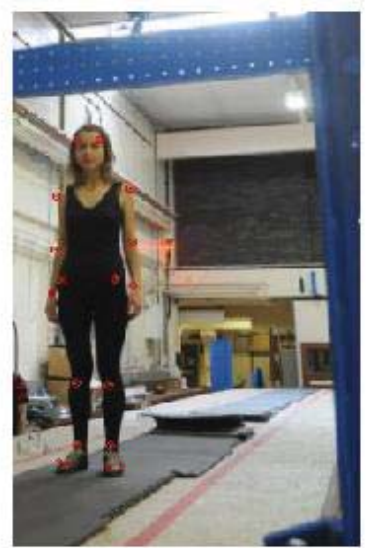

Figure4. Markers placed at test subject parts of body

Several tests were conducted with same pedestrian in the same conditions. Wearing a tight sport suits in order to have the markers in contact with the different parts of the body and to get their displacement during the walk on the footbridge and without changing during all the tests the same type of the shoes in order to have the same rubbersoled shoes.

Through the recording, displacement in $\mathrm{X}, \mathrm{Y}$ and $\mathrm{Z}$ were provided. 


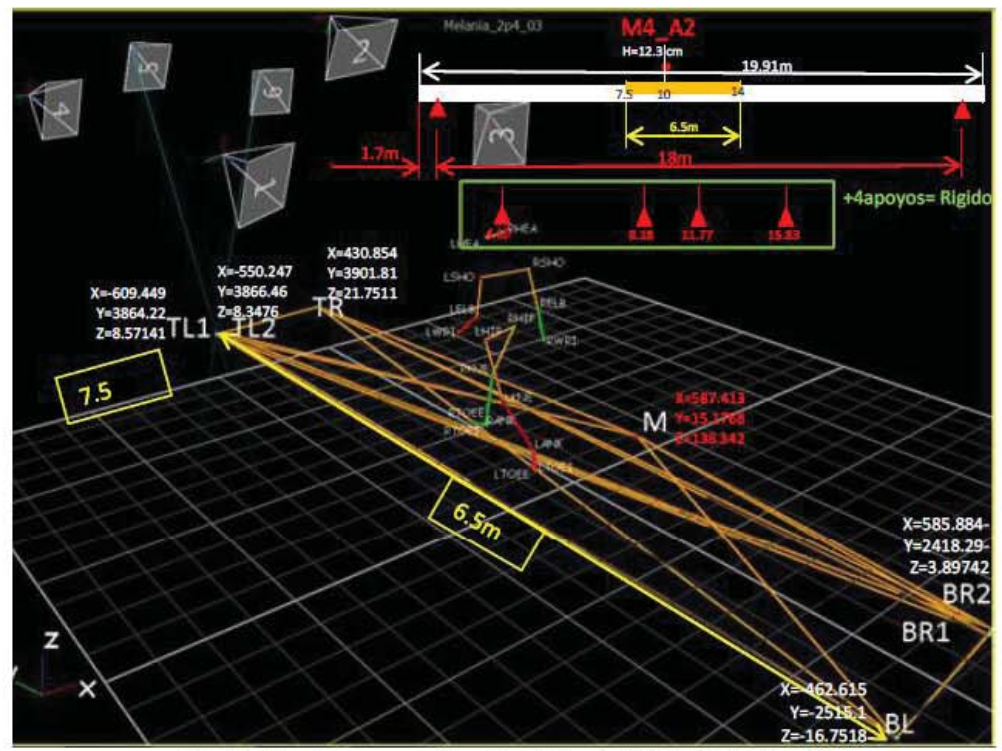

Fig5: Test area and test subject (VICON view)

Test subject was asked to walk on all those scenarios:
(1) rigid footbridge
(2) one foam on rigid footbridge (foam thickness about XXXmm-medir el FOAM)
(3) double foam on rigid footbridge (foam thickness about XXXmm)
(4) a lovely footbridge with a rigid pavement
(5) a lovely footbridge with a flexible pavement with one foam (foam thickness about XXXmm)
(6) a lovely footbridge with a flexible pavement with double foam (foam thickness about XXXmm)

The characteristics of the lovely footbridge are:

- $\quad$ First bending mode 2.38; Second one 9.09; Third one 18.83

- First torsional mode $16.67 \mathrm{~Hz}$; Second torsional mode $18.51 \mathrm{~Hz}$

- Damping ratio $0.3 \%$ at $0.2 \mathrm{~m} / \mathrm{s} 2 ; 0.6 \%$ at $1.2 \mathrm{~m} / \mathrm{s} 2$

After each test, the system was stopped and the researcher exported the test result and carried out some preliminary analysis to ensure the quality of captured data.

When all tests were finished all data were exported in order to get the displacement files for each frequency, test and instrumented body part in order to have the most realistic point of view of the response of the body when walking on different surfaces.

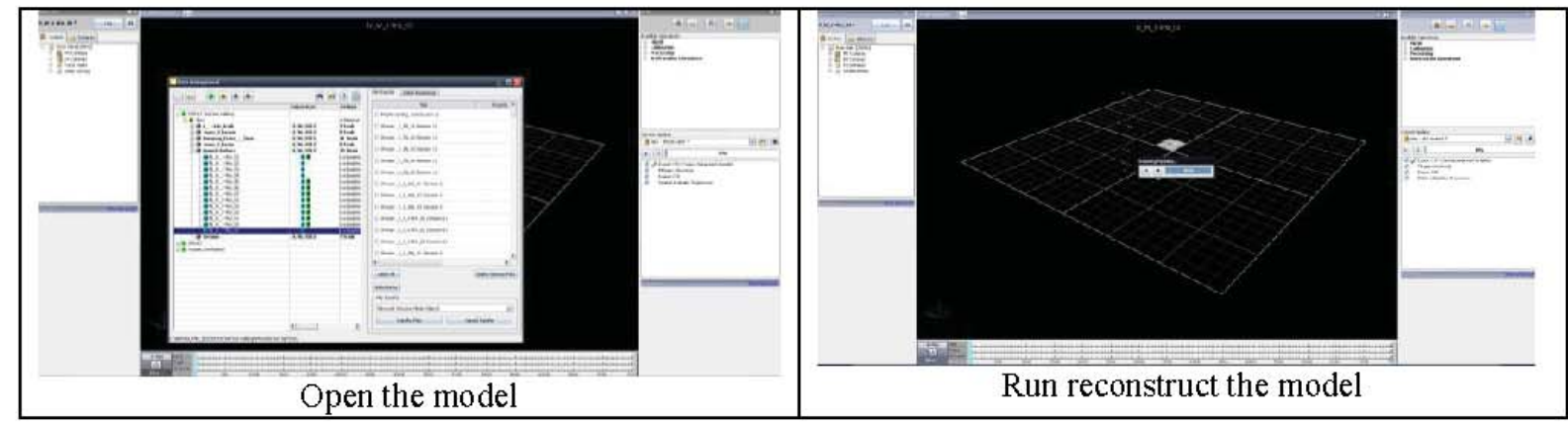




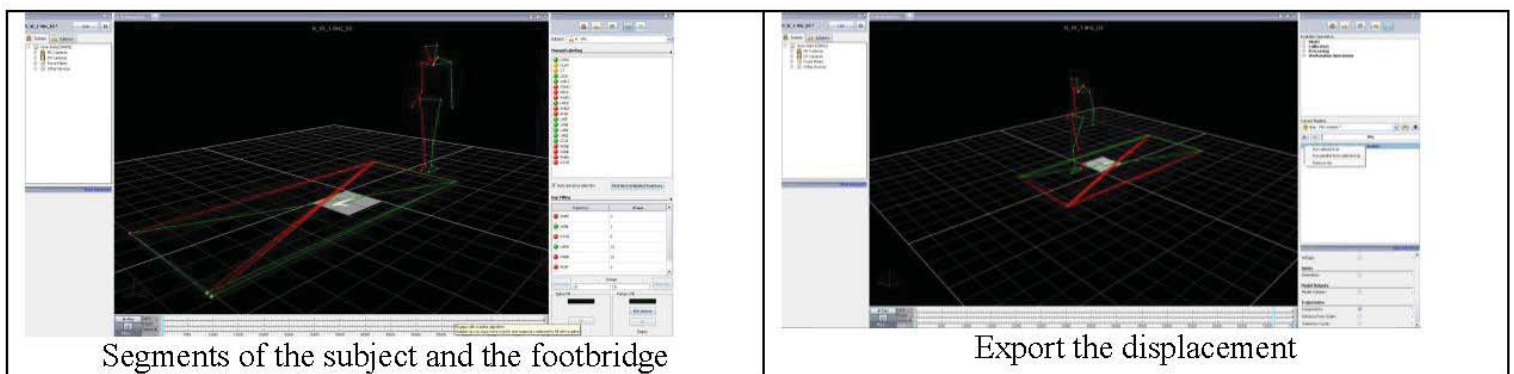

In Figure 6, we can see for both situations, rigid and lovely footbridge, without flexible surface at $2 \mathrm{~Hz}$ and $2.4 \mathrm{~Hz}$, that the time and the distance of the steps are different when the frequency is different. For $2 \mathrm{~Hz}$ the test subject walked 1.44 metres in one second.
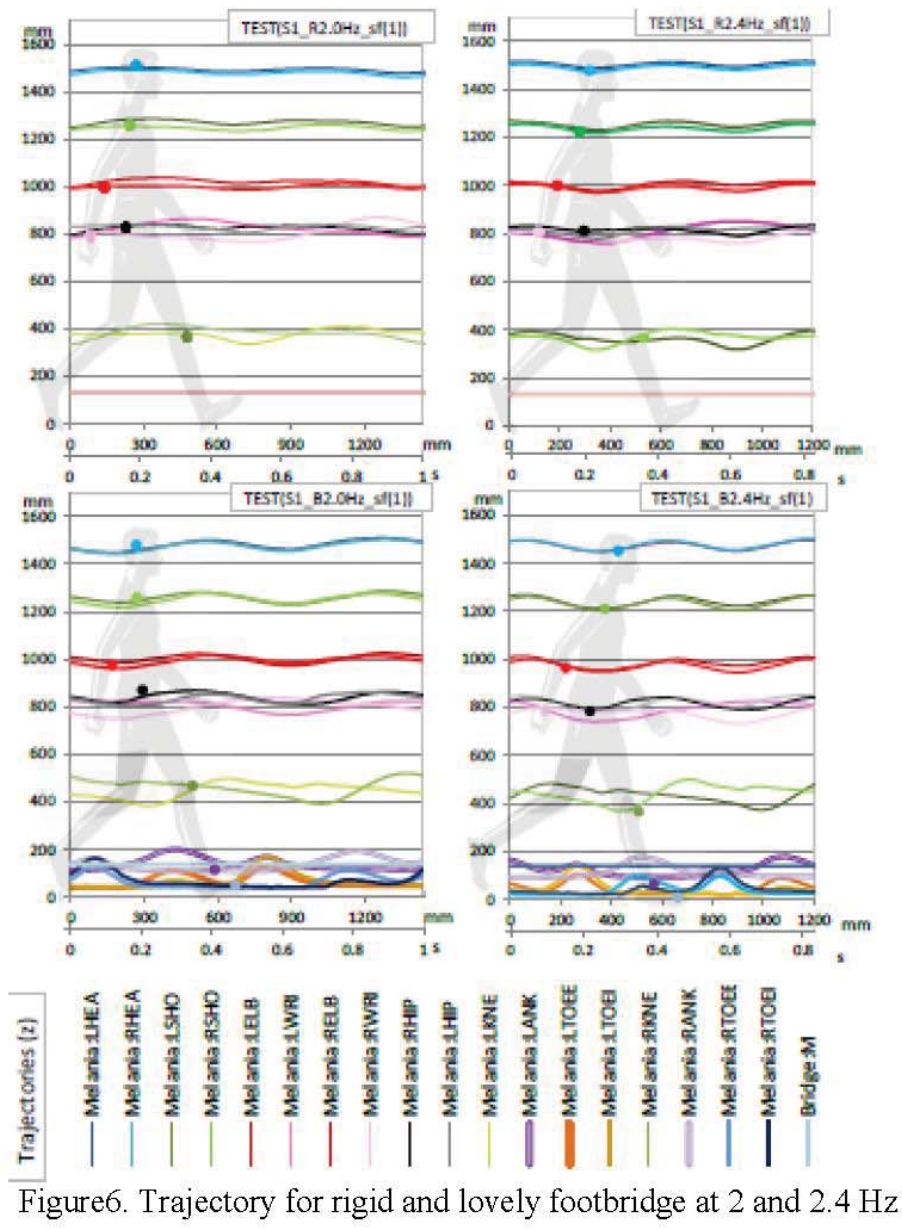

The acceleration of the lovely footbridge which was recorded by the accelerometer located in the middle of the footbridge as we can see in the Figure 7 decreased when the test subjects was walking on soft pavement with double foam at a frequency of $2.4 \mathrm{~Hz}$.

It is necessary to remark that the accelerometers are always located on the structure, in avoidance of the influence of the foam and its thickness in the registering of the data. 

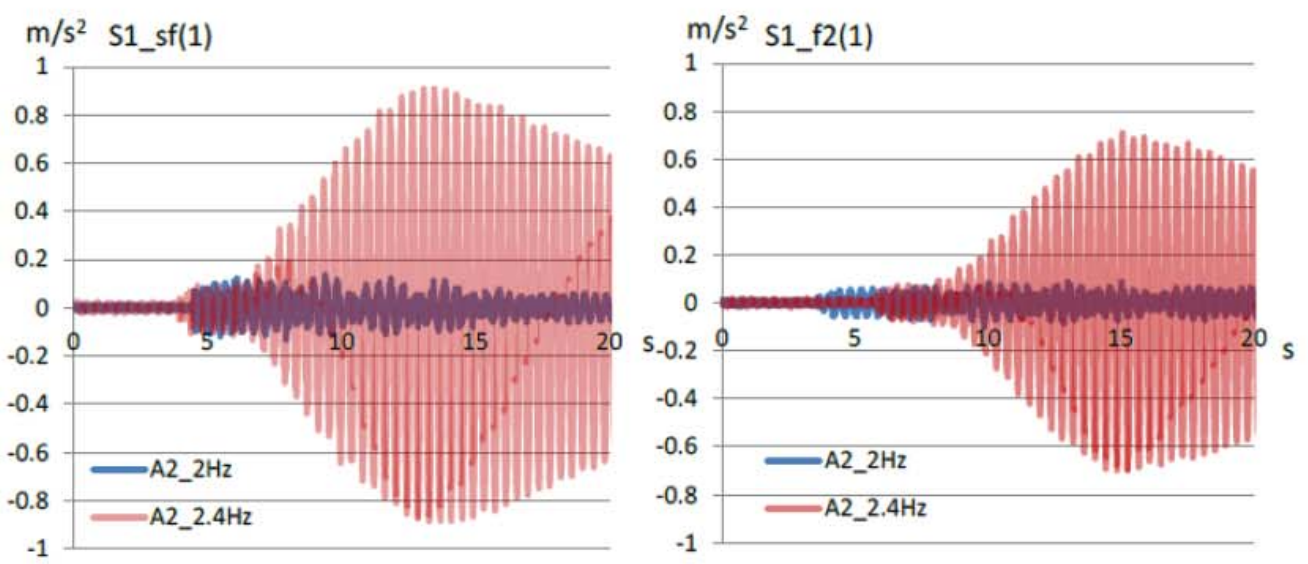

Figure 7: Acceleration of the footbridge walking at 2 and $2.4 \mathrm{~Hz}$

After post-processing the displacement recorded by Vicon System at the markers located on the head, we can see that the acceleration of the head decreases when we are walking on flexible surface. Figure8.

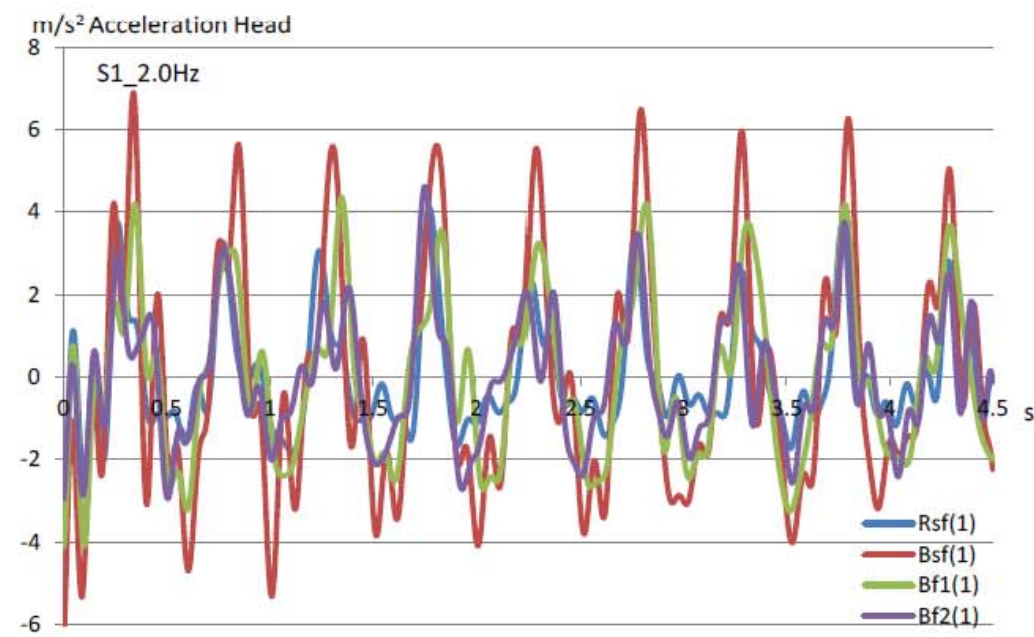

Figure8: Acceleration on the head walking on lovely footbridge on different surfaces

Walking at $2.4 \mathrm{~Hz}$ on rigid and lovely footbridge on different surfaces as we can see in the next figure the behaviour of the body walking in lovely footbridge on flexible surface (double foam) is almost similar to the behaviour of the body walking on rigid footbridge and on rigid surface.

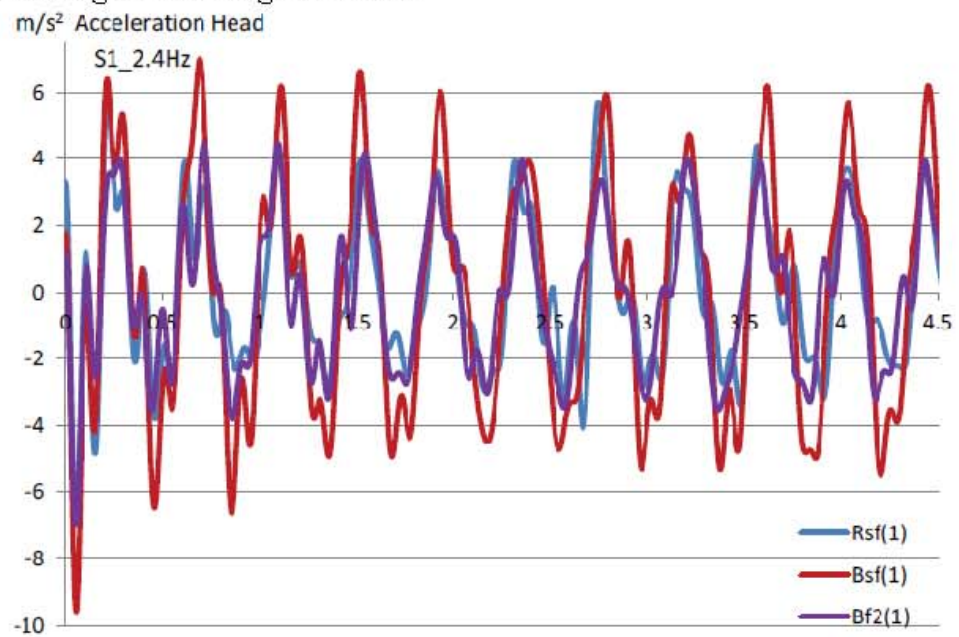

Figur9: Acceleration of the head on $2.4 \mathrm{~Hz}$ for rigid and lovely footbridge 


\section{Results}

Numerical results are shown in the following tables. RMS values and maximum values of accelerations for 200 s recordings are presented for all the scenarios at $2 \mathrm{~Hz}$ and $2.4 \mathrm{~Hz}$ for markers located on the head and footbridge. Therefore, corresponding bridge displacement, step time and distance are computed and presented.

(1) rigid footbridge

\begin{tabular}{|c|c|c|c|c|c|c|c|c|}
\hline $\begin{array}{c}\text { Frequency } \\
\text { (Hz) }\end{array}$ & \multicolumn{3}{|c|}{ Footbridge } & \multicolumn{5}{c|}{ Test Subject Head } \\
\hline \multirow{2}{*}{2} & $\mathrm{D}(\mathrm{mm})$ & $\mathrm{a}_{\mathrm{w}}^{\max }$ & $\mathrm{RMS}_{\mathrm{w}}$ & $\mathrm{D}(\mathrm{mm})$ & $\mathrm{a}_{\mathrm{w}} \max ^{\max }$ & $\mathrm{RMS}_{\mathrm{w}}$ & $\begin{array}{c}\text { Time } \\
\text { Step }(\mathrm{s})\end{array}$ & $\begin{array}{c}\text { Distance } \\
\text { Step }(\mathrm{m})\end{array}$ \\
\cline { 2 - 9 } & $\approx 0$ & $\approx 0$ & $\approx 0$ & 20.045 & 2.785 & 0.8341 & 1 & 1.44 \\
\hline
\end{tabular}

\begin{tabular}{|c|c|c|c|c|c|c|c|c|}
\hline $\begin{array}{c}\text { Frequency } \\
\text { (Hz) }\end{array}$ & \multicolumn{3}{|c|}{ Footbridge } & \multicolumn{5}{c|}{ Test Subject Head } \\
\hline \multirow{2}{*}{2.4} & $\mathrm{D}(\mathrm{mm})$ & $\mathrm{a}_{\mathrm{w}}^{\max }$ & $\mathrm{RMS}_{\mathrm{w}}$ & $\mathrm{D}(\mathrm{mm})$ & $\mathrm{a}_{\mathrm{w}}^{\max }$ & $\mathrm{RMS}_{\mathrm{w}}$ & $\begin{array}{c}\text { Time } \\
\text { Step(s) }\end{array}$ & $\begin{array}{c}\text { Distance } \\
\text { Step (m) }\end{array}$ \\
\cline { 2 - 9 } & $\approx 0$ & $\approx 0$ & $\approx 0$ & 24.442 & 3.1091 & 1.2369 & 1 & 1.2 \\
\hline
\end{tabular}

(2) one foam on rigid footbridge

\begin{tabular}{|c|c|c|c|c|c|c|c|c|}
\hline $\begin{array}{c}\text { Frequency } \\
\text { (Hz) }\end{array}$ & \multicolumn{3}{|c|}{ Footbridge } & \multicolumn{5}{c|}{ Test Subject } \\
\hline \multirow{2}{*}{2} & $\mathrm{D}(\mathrm{mm})$ & $\mathrm{a}_{\mathrm{w}}^{\max }$ & $\mathrm{RMS}_{\mathrm{w}}$ & $\mathrm{D}(\mathrm{mm})$ & $\mathrm{a}_{\mathrm{w}}^{\max }$ & $\mathrm{RMS}_{\mathrm{w}}$ & $\begin{array}{c}\text { Time } \\
\text { Step }(\mathrm{s})\end{array}$ & $\begin{array}{c}\text { Distance } \\
\text { Step }(\mathrm{m})\end{array}$ \\
\cline { 2 - 9 } & $\approx 0$ & $\approx 0$ & $\approx 0$ & 23.889 & 2.321 & 0.7916 & 1 & 1.44 \\
\hline
\end{tabular}

\begin{tabular}{|c|c|c|c|c|c|c|c|c|}
\hline $\begin{array}{c}\text { Frequency } \\
\text { (Hz) }\end{array}$ & \multicolumn{3}{|c|}{ Footbridge } & \multicolumn{5}{c|}{ Test Subject } \\
\hline \multirow{2}{*}{2.4} & $\mathrm{D}(\mathrm{mm})$ & $\mathrm{a}_{\mathrm{w}}{ }^{\max }$ & $\mathrm{RMS}_{\mathrm{w}}$ & $\mathrm{D}(\mathrm{mm})$ & $\mathrm{a}_{\mathrm{w}}{ }_{\max }$ & $\mathrm{RMS}_{\mathrm{w}}$ & $\begin{array}{c}\text { Time } \\
\text { Step }(\mathrm{s})\end{array}$ & $\begin{array}{c}\text { Distance } \\
\text { Step }(\mathrm{m})\end{array}$ \\
\cline { 2 - 9 } & $\approx 0$ & $\approx 0$ & $\approx 0$ & 22.833 & 2.7293 & 1.1372 & 1 & 1.2 \\
\hline
\end{tabular}

(3) double foam on rigid footbridge

\begin{tabular}{|c|c|c|c|c|c|c|c|c|}
\hline $\begin{array}{c}\text { Frequency } \\
\text { (Hz) }\end{array}$ & \multicolumn{3}{|c|}{ Footbridge } & \multicolumn{5}{c|}{ Test Subject } \\
\hline \multirow{2}{*}{2} & $\mathrm{D}(\mathrm{mm})$ & $\mathrm{a}_{\mathrm{w}}^{\max }$ & $\mathrm{RMS}_{\mathrm{w}}$ & $\mathrm{D}(\mathrm{mm})$ & $\mathrm{a}_{\mathrm{w}}^{\max }$ & $\mathrm{RMS}_{\mathrm{w}}$ & $\begin{array}{c}\text { Time } \\
\text { Step }(\mathrm{s})\end{array}$ & $\begin{array}{c}\text { Distance } \\
\text { Step }(\mathrm{m})\end{array}$ \\
\cline { 2 - 9 } & $\approx 0$ & $\approx 0$ & $\approx 0$ & 19.697 & 2.321 & 0.7916 & 1 & 1.44 \\
\hline
\end{tabular}

\begin{tabular}{|c|c|c|c|c|c|c|c|c|}
\hline $\begin{array}{c}\text { Frequency } \\
\text { (Hz) }\end{array}$ & \multicolumn{3}{|c|}{ Footbridge } & \multicolumn{5}{c|}{ Test Subject } \\
\hline \multirow{2}{*}{2.4} & $\mathrm{D}(\mathrm{mm})$ & $\mathrm{a}_{\mathrm{w}}^{\max }$ & $\mathrm{RMS}_{\mathrm{w}}$ & $\mathrm{D}(\mathrm{mm})$ & $\mathrm{a}_{\mathrm{w}}^{\max }$ & $\mathrm{RMS}_{\mathrm{w}}$ & $\begin{array}{c}\text { Time } \\
\text { Step }(\mathrm{s})\end{array}$ & $\begin{array}{c}\text { Distance } \\
\text { Step }(\mathrm{m})\end{array}$ \\
\cline { 2 - 9 } & $\approx 0$ & $\approx 0$ & $\approx 0$ & 23.679 & 3.7384 & 1.16565 & 1 & 1.2 \\
\hline
\end{tabular}

(4) a lovely footbridge with a rigid pavement

\begin{tabular}{|c|c|c|c|c|c|c|c|c|}
\hline $\begin{array}{c}\text { Frequency } \\
\text { (Hz) }\end{array}$ & \multicolumn{3}{|c|}{ Footbridge } & \multicolumn{5}{c|}{ Test Subject } \\
\hline \multirow{2}{*}{2} & $\mathrm{D}(\mathrm{mm})$ & $\mathrm{a}_{\mathrm{w}}{ }_{\max }$ & $\mathrm{RMS}_{\mathrm{w}}$ & $\mathrm{D}(\mathrm{mm})$ & $\mathrm{a}_{\mathrm{w}}{ }_{\mathrm{max}}$ & $\mathrm{RMS}_{\mathrm{w}}$ & $\begin{array}{c}\text { Time } \\
\text { Step }(\mathrm{s})\end{array}$ & $\begin{array}{c}\text { Distance } \\
\text { Step }(\mathrm{m})\end{array}$ \\
\cline { 2 - 9 } & $\approx 0.7$ & 0.064 & 0.018 & 43.119 & 2.862 & 1.2689 & 1 & 1.44 \\
\hline
\end{tabular}

\begin{tabular}{|c|c|c|c|c|c|c|c|c|}
\hline $\begin{array}{c}\text { Frequency } \\
\text { (Hz) }\end{array}$ & \multicolumn{3}{|c|}{ Footbridge } & \multicolumn{5}{c|}{ Test Subject } \\
\hline \multirow{2}{*}{2.4} & $\mathrm{D}(\mathrm{mm})$ & $\mathrm{a}_{\mathrm{w}}{ }_{\max }$ & $\mathrm{RMS}_{\mathrm{w}}$ & $\mathrm{D}(\mathrm{mm})$ & $\mathrm{a}_{\mathrm{w}}{ }_{\mathrm{max}}$ & $\mathrm{RMS}_{\mathrm{w}}$ & $\begin{array}{c}\text { Time } \\
\text { Step }(\mathrm{s})\end{array}$ & $\begin{array}{c}\text { Distance } \\
\text { Step }(\mathrm{m})\end{array}$ \\
\cline { 2 - 9 } & $\approx 7.8$ & 0.475 & 0.1483 & 44.302 & 3.9522 & 1.7079 & 1 & 1.2 \\
\hline
\end{tabular}


(5) a lovely footbridge with a flexible pavement with one foam

\begin{tabular}{|c|c|c|c|c|c|c|c|c|}
\hline $\begin{array}{c}\text { Frequency } \\
\text { (Hz) }\end{array}$ & \multicolumn{3}{|c|}{ Footbridge } & \multicolumn{4}{c|}{ Test Subject } \\
\hline \multirow{2}{*}{2} & $\mathrm{D}(\mathrm{mm})$ & $\mathrm{a}_{\mathrm{w}}^{\max }$ & $\mathrm{RMS}_{\mathrm{w}}$ & $\mathrm{D}(\mathrm{mm})$ & $\mathrm{a}_{\mathrm{w}}^{\max }$ & $\mathrm{RMS}_{\mathrm{w}}$ & $\begin{array}{c}\text { Time } \\
\text { Step(s) }\end{array}$ & $\begin{array}{c}\text { Distance } \\
\text { Step (m) }\end{array}$ \\
\cline { 2 - 10 } & $\approx 0.6$ & 0.057 & 0.0143 & 32.902 & 2.668 & 0.8752 & 1 & 1.44 \\
\hline
\end{tabular}

\begin{tabular}{|c|c|c|c|c|c|c|c|c|}
\hline $\begin{array}{c}\text { Frequency } \\
\text { (Hz) }\end{array}$ & \multicolumn{3}{|c|}{ Footbridge } & \multicolumn{4}{c|}{ Test Subject } \\
\hline \multirow{2}{*}{2.4} & $\mathrm{D}(\mathrm{mm})$ & $\mathrm{a}_{\mathrm{w}}^{\max }$ & $\mathrm{RMS}_{\mathrm{w}}$ & $\mathrm{D}(\mathrm{mm})$ & $\mathrm{a}_{\mathrm{w}}$ & $\mathrm{RMS}_{\mathrm{w}}$ & $\begin{array}{c}\text { Time } \\
\text { Step }(\mathrm{s})\end{array}$ & $\begin{array}{c}\text { Distance } \\
\text { Step }(\mathrm{m})\end{array}$ \\
\cline { 2 - 9 } & $\mathbf{x x x}$ & 0.414 & 0.1296 & 37.966 & 3.81825 & 1.4653 & 1 & 1.2 \\
\hline
\end{tabular}

(6) a lovely footbridge with a flexible pavement with double foam

\begin{tabular}{|c|c|c|c|c|c|c|c|c|}
\hline $\begin{array}{c}\text { Frequency } \\
\text { (Hz) }\end{array}$ & \multicolumn{3}{|c|}{ Footbridge } & \multicolumn{4}{c|}{ Test Subject } \\
\hline \multirow{2}{*}{2} & $\mathrm{D}(\mathrm{mm})$ & $\mathrm{a}_{\mathrm{w}}^{\max }$ & $\mathrm{RMS}_{\mathrm{w}}$ & $\mathrm{D}(\mathrm{mm})$ & $\mathrm{a}_{\mathrm{w}} \max$ & $\mathrm{RMS}_{\mathrm{w}}$ & $\begin{array}{c}\text { Time } \\
\text { Step }(\mathrm{s})\end{array}$ & $\begin{array}{c}\text { Distance } \\
\text { Step }(\mathrm{m})\end{array}$ \\
\cline { 2 - 9 } & $\approx 0.3$ & 0.063 & 0.0163 & 32.095 & 1.795 & 0.7191 & 1 & 1.44 \\
\hline
\end{tabular}

\begin{tabular}{|c|c|c|c|c|c|c|c|c|}
\hline $\begin{array}{c}\text { Frequency } \\
\text { (Hz) }\end{array}$ & \multicolumn{3}{|c|}{ Footbridge } & \multicolumn{4}{c|}{ Test Subject } \\
\hline \multirow{2}{*}{2.4} & $\mathrm{D}(\mathrm{mm})$ & $\mathrm{a}_{\mathrm{w}} \max$ & $\mathrm{RMS}_{\mathrm{w}}$ & $\mathrm{D}(\mathrm{mm})$ & $\mathrm{a}_{\mathrm{w}} \max$ & $\mathrm{RMS}_{\mathrm{w}}$ & $\begin{array}{c}\text { Time } \\
\text { Step (s) }\end{array}$ & $\begin{array}{c}\text { Distance } \\
\text { Step }(\mathrm{m})\end{array}$ \\
\cline { 2 - 10 } & $\approx 6$ & 0.348 & 0.11 & 25.194 & 2.9628 & 1.182 & 1 & 1.2 \\
\hline
\end{tabular}

\section{Conclusions}

As results show, in the first scenario the head acceleration increases with the frequency. When located the foam on the rigid footbridge (the second and third scenarios) the head acceleration decreases.

On the lovely footbridge, as the frequency increases, higher is the displacement measured on the head of the subject and also on the footbridge.

It is concluded that, while walking, foam helps to get an adequate vibration amplitude and acceleration. Thanks to the foam, such values, in terms of characteristic acceleration, are very close to the one with a rigid sole, as an attenuation in the head amplitude is observed.

\section{Acknowledgment}

The results of this paper are partly obtained within the framework of a current research project, BIA2011-28493C02-02, financed by the "Ministerio de Ciencia e Innovación", Spanish government and Santander-Warwick project "Pedestrian Locomotion and Perception of Vibration on Lively Surfaces of Different Hardness".

\section{References}

1. M.J. Griffin, Handbook of Human Vibration, Human Factors Research Unit, Institute of Sound and Vibration Research, The University Southampton 1996

2. Stevens, S.S. Psychophysics. New York: Wiley, 1975.

3. European Committee for Standardization CEN:EN1991-2, UK National Annex to Eurocode 1-Actions on structures, Part 2: Traffic load on bridges, 2003

4. European Committee for Standardization CEN:EN1995-2, Eurocode 5- Design of timber structures, Part 2: Traffic load on bridges, 2003

5. Federation international du beton, Guidelines for the design of footbridges, FIB Bulletin No. 32 , Lausenne, 2006.

6. HIVOSS, Design of Footbridge guidelines, Human Induced Vibrations of Steel Structures, 2008

7. International Standards Organization, ISO 10137:2004, Bases for design of structure, serviceability of buildings and pedestrian walkways against vibration, Geneva, 2005. 
8. Setra. Technical guide Footbridge: Assesment of vibration behavior of footbridges under pedestrian loading, Paris, 2006.

9. Zivanovic S, Pavic A, and Ingolfsson E.T., Modelling spatially unrestricted pedestrian traffic on footbridges, ASCE Journal of Structural Engineering, 136 (10), 1296-1308. 2010

10. Zivanovic S, Pavic A, Reynolds $\mathrm{P}$, Vibration serviceability of footbridges under human-induced excitation: a literature review, Journal of sound and vibration, 279(1-2), 1-74, 2005

11 . 
SIMPLIE MECHANICAL MODEL FOR HUMAN-STRUCTURE INTERACTION DURING WALKING ALONG A SLENDER STRUCTURE

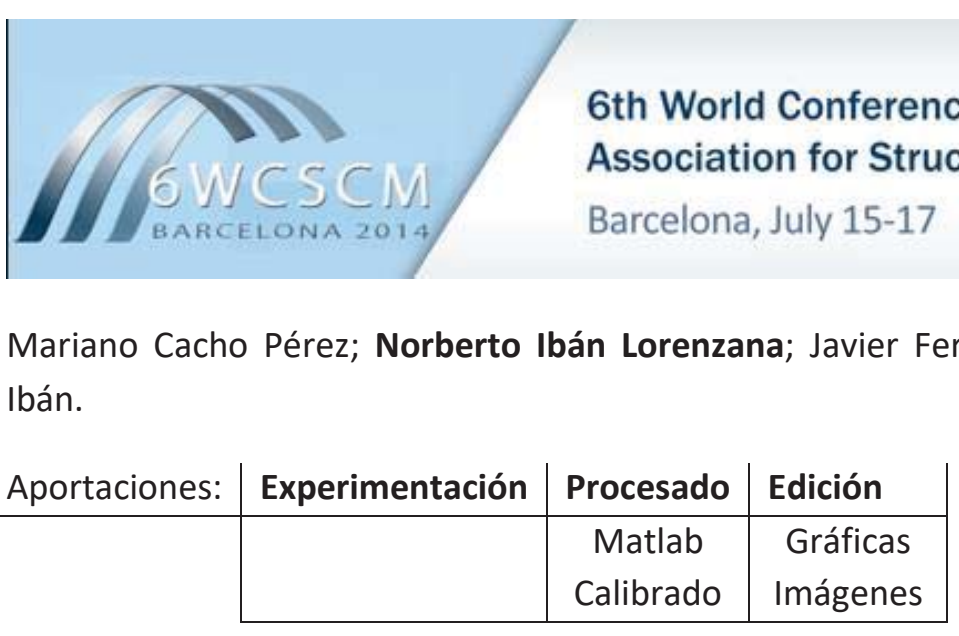




\title{
Simple mechanical model for human-structure interaction during walking along a slender structure
}

\author{
M. Cacho-Perez ${ }^{1}$, N. Iban ${ }^{2}$, J. Fernandez ${ }^{3}$ and A. Lorenzana ${ }^{4}$
}

\begin{abstract}
This work focuses on evaluating the vertical movements that appear when a pedestrian is walking on a slender beam-like structure. For that, the pedestrian is modelled by a dynamic system consisting on a concentrated mass, located in its center of masses, supported by two springs which simulate the stiffness of the legs. The success of this simple mechanical model is that the resulting contact forces are well adjusted to those observed experimentally for human gait. In this way, the structure is undergoing the moving mass and is loaded with realistic forces, resulting in a proper assembly to study interaction effects. The dynamic response of the beam is obtained at any coordinate by the modal superposition method, considering a finite number of modes. Differential equations of the resulting coupled problem are solved using proper numerical techniques (variable time-step Runge Kutta method). Solutions obtained for different scenarios (depending on the mass of the pedestrian with respect to the mass of the beam and on the pace) are presented and qualitative and quantitative results are presented.
\end{abstract}

\section{NOMENCLATURE}

$\Delta u(t)$ horizontal displacement increment of COM

$\dot{y}(x, t)$ velocity of the beam

$\phi_{i}(x)$ vibration modes

$\theta_{0} \quad$ angle of attack

$\theta_{l} \quad$ ángulo con la horizontal de la pierna motriz

$\theta_{t} \quad$ ángulo con la horizontal de la pierna posterior

$c_{s} \quad$ damping ratio of the beam

$c_{\text {leg }} \quad$ leg damping

$E(t)$ energy of human body at time "t"

$E_{0} \quad$ initial energy input of human body

EI flexion stiffness of the beam

$F \operatorname{ctrl}(t)$ horizontal control force

$g \quad$ gravity acceleration

$k_{\text {leg }} \quad$ leg stiffness

$L_{0} \quad$ rest length of leg
$L_{l} \quad$ length of the leading leg

$L_{t} \quad$ length of the trailing leg

$m_{h} \quad$ lumped mass

$T \quad$ kinetic energy

$u$ horizontal displacements of COM

$v_{l} \quad$ velocidad axial de la pierna motriz

$v_{t} \quad$ velocidad axial de la pierna posterior

$x_{l} \quad$ horizontal position of the leading leg

$x_{t} \quad$ horizontal position of the trailing leg

$y \quad$ displacement of the beam

$y^{\prime \prime} \quad$ curvature of the beam

$Y_{i}(t)$ modal coordinates of the bridge

$y_{l} \quad$ vertical displacement of beam at the points of contact of the leading leg

$y_{t} \quad$ vertical displacement of beam at the points of contact of the trailing leg

vertical displacements of COM

\section{INTRODUCTION}

The Human-Structure Interaction (HSI) is an important topic but relatively new in the design of slender structures occupied and dynamically excited by people.

The basic mechanics of human locomotion can be associated to a mass-spring biped model considering two flexible rods with dampers and assuming proper initial conditions. The basis mechanisms of human walking motion appear just when the two degree of freedom system is governed by the corresponding equations of motion.

This bipedal model improves the classical one consisting on the inverted pendulum. That simple model is useful to describe the exchange between potential and kinetic energy during the simple support phase (support on one foot) however not adequately predicts the ground reaction forces (GRFs) and movement of the center of mass throughout a normal gait cycle. Bipedal models consisting on two inverted pendulums coupled, allow for stable limit cycles showing that bipedal gait is a function of the dynamic properties of the leg. The model also account for the vertical and fore-aft. characteristics of the ground reaction forces observed during human walking[1], [2], [3], [4], [5].

More complex walking models use more detailed representations of the leg including springs and dampers, multi-segment or neuromuscular structures[6]. Although these models describe the dynamics of walking accurately and indicate that the flexible leg is considered relevant to reproduce human gait, they are too complex to serve as conceptual models.

The structure considered in this work consists of a simply supported beam. The beam is loaded in the vertical plane by the reaction forces generated in the contact points by the bipedal model when "walking" along the beam. From the point

*This work was supported University of Valladolid (Spain) and CARTIF

${ }^{1} \mathrm{M}$. Cacho-Perez Author is with Escuela de Ingenierias Industriales, University of Valladolid, Paseo del Cauce 59, Spain cacho@eii. uva . es

${ }^{2}$ N. Iban Researcher is with Centro Tecnologico CARTIF, Parque Tecnologico de Boecillo, 205, Boecillo Valladolid, Spain noribale cartif. es

${ }^{3}$ J. Fernandez Researcher is with Universidad Politecnica de Madrid, Madrid, Spain jfernandezmeetsii.upm. es

${ }^{4}$ A. Lorenzana Author is with Centro Tecnologico CARTIF, Parque Tecnologico de Boecillo, 205, Boecillo Valladolid, Spain ant lor e cartif . es 
of view of the mechanical assembly, the beam under such an excitation is a forced system whose space-time response must be obtained using explicit time integration schemes.

\section{HUMAN-STRUCTURE DYNAMIC INTERACTION SYSTEM}

A pedestrian is simulated as a bipedal model with two DOFs as shown in figure 1. The human body is modeled as a lumped mass $m_{h}$ at the center of mass (COM) and the two legs are described as two massless, linear springs of equal rest length $L_{0}$ with stiffness $k_{l e g}$ and a constant damper $c_{l e g}$ [2]. A passive spring provides a compliant mechanism to absorb collision impacts and to generate push-off impulses, whereas the damper restrains excessive motion of COM. Both the springs and dampers act independently and they influence the model dynamics only during standing when the spring and damper forces oppose the gravitational force of the human body.

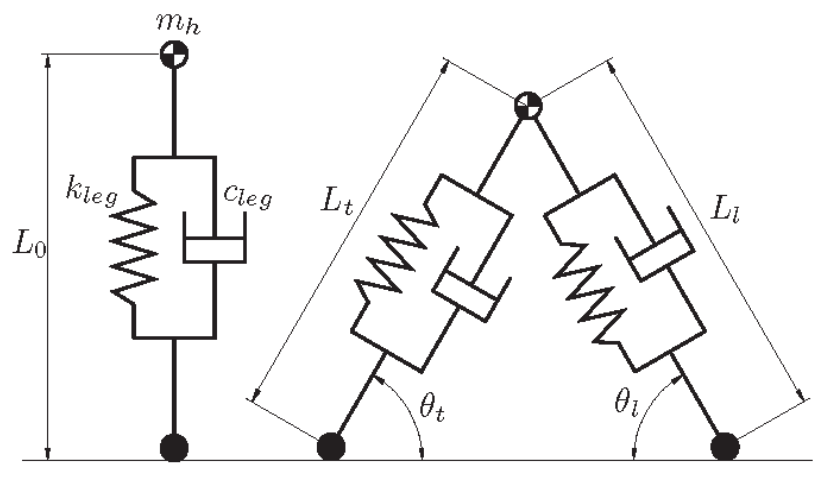

Fig. 1. Human model

A complete step, defined as the interval between "heel-strike" of progressive footfalls, is divided into two periods: single support phase and double support phase. The double support phase is considered to begins with "touch down" (TD) of leading leg and ends with "touch off" (TO) of trailing leg as shown in figure 2, where the single support phase begins. Then, the trailing leg is repositioned ahead of the body's COM at a given angle of attack $\theta_{0}$ and becomes the leading leg for the next step. When the trailing leg hits the ground, the single support phase is completed.

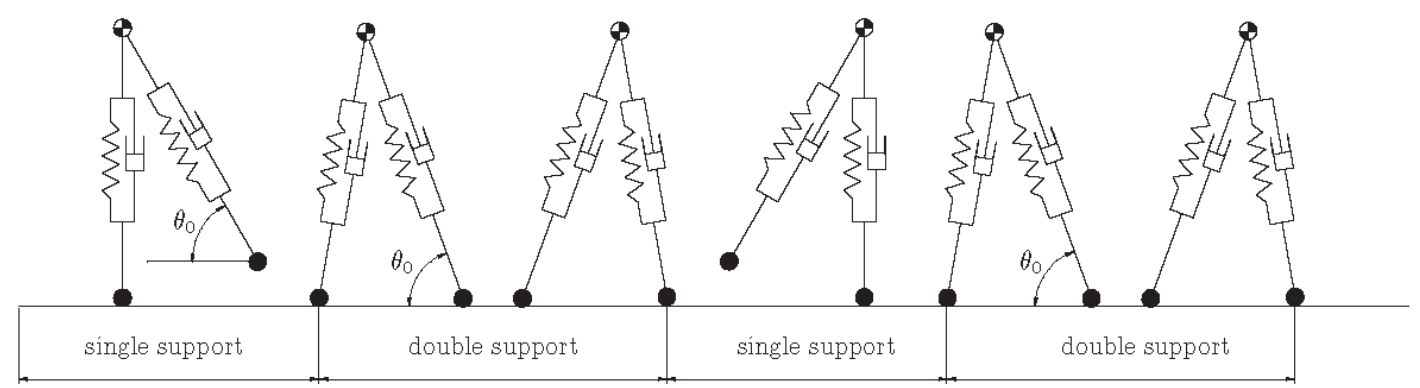

Fig. 2. Schematic of the biomechanical walking model

\section{II-A. Equations of motion}

Consider the simple supported beam with the bipedal model as shown in figure 3 which represent the pedestrian walking along the footbridge. The beam, with uniform cross-section of area $A$ and moment of inertia $I_{z}$, is free to bend, according to the Euler Bernoulli theory and the bipedal model.

The equations of motion governing the vibration of the bridge and pedestrian are derived from the Lagrangian equation. The kinetic energy $T$ and potential energy $V$ of human-structure interaction system in double support phase can be obtained as

$$
\begin{gathered}
T=\frac{1}{2} m_{h} \dot{z}^{2}+\frac{1}{2} m_{h} \dot{u}^{2}+\frac{1}{2} \int_{0}^{L} m \dot{y}(x, t)^{2} d x \\
V=\frac{1}{2} k_{l e g}\left(L_{l}-L_{0}\right)^{2}+\frac{1}{2} k_{l e g}\left(L_{t}-L_{0}\right)^{2}+m_{h} g z+\frac{1}{2} \int_{0}^{L} E I\left(y^{\prime \prime}(x, t)\right)^{2} d x
\end{gathered}
$$




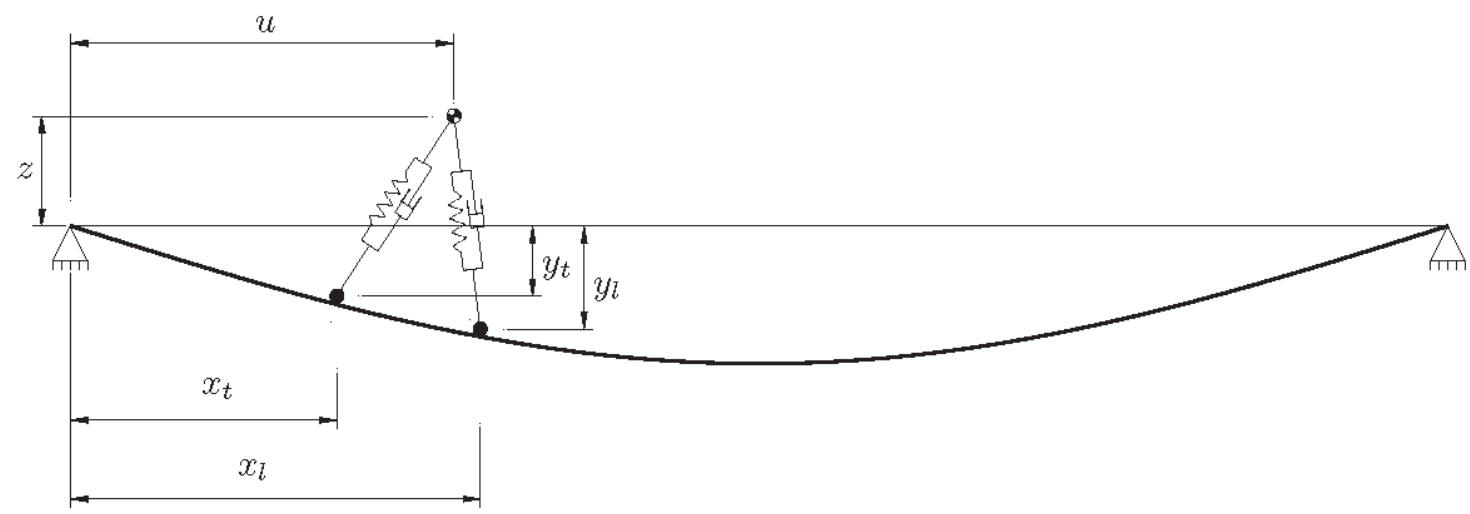

Fig. 3. Mathematical model for the dynamic analysis of the footbridge

The motion of the COM is described by the generalized coordinate $(z, u)$, where $z$ and $u$ denote the vertical and horizontal displacements of the COM respectively; $y(x, t)$ is the displacement of the beam; $E$ and $m$ are Young's modulus of material and the mass per unit length of the beam; $g$ is the acceleration due to gravity; $L_{l}$ and $L_{t}$ are the length of two legs, the subscripts " $\mathrm{l}$ " and " $\mathrm{t}$ " indicate the leading and trailing legs, respectively; $y$ " $(x, t)$ is the curvature of beam.

By modal superposition method, the vertical displacement of the beam can be expressed as

$$
y(x, t)=\sum_{i=1}^{n} \phi_{i}(x) Y_{i}(t)
$$

where $\phi_{i}(x)$ are the assumed vibration modes that satisfy the boundary conditions and $Y_{i}(t)$ are the modal coordinates of the beam. Taking $n=3$ or more leads to the same results from the numerical point of view.

The length of the leading and trailing leg are respectively

$$
\begin{aligned}
& L_{l}=\sqrt{\left(x_{l}-u\right)^{2}+\left(z-y_{l}\right)^{2}} \\
& L_{t}=\sqrt{\left(u-x_{t}\right)^{2}+\left(z-y_{t}\right)^{2}}
\end{aligned}
$$

where $y_{l}$ and $y_{t}$ are the vertical displacement of beam at the points of contact of the extreme of leading and the trailing legs; $x_{l}$ and $x_{t}$ are the horizontal position of the leading and the trailing leg, respectively.

To include the effect of damping in the equations of motion it is convenient to define the Rayleigh's energy dissipation function as:

$$
F=\frac{1}{2} c_{l e g} v_{l}^{2}+\frac{1}{2} c_{l e g} v_{l}^{2}+\frac{1}{2} \int_{0}^{L} c_{s} \dot{y}(x, t)^{2} d x
$$

where $c_{l e g}$ is the damping coefficient of each leg; $v_{l}$ and $v_{t}$ are the longitudinal speeds of each leg and $c_{s}$ is the damping ratio of the beam.

The axial spring speed may be obtained from the time derivative of the length of the legs in the equation (3):

$$
\begin{aligned}
& v_{l}=\left(\dot{z}-\dot{y}_{l}\right) \sin \theta_{l}-\dot{u} \cos \theta_{l} \\
& v_{t}=\left(\dot{z}-\dot{y}_{t}\right) \sin \theta_{t}+\dot{u} \cos \theta_{t}
\end{aligned}
$$

where $\theta_{l}$ and $\theta_{t}$ are the angle of the leading and the trailing leg, respectively.

Generalized forces corresponding to the coordinates $\left(Y_{1}, Y_{2}, \ldots, Y_{n}, z, u\right)$ are calculated as:

$$
\begin{gathered}
Q_{i}=-\frac{\partial F}{\partial \dot{Y}_{i}}(i=1,2, \ldots, n) \\
Q_{n+1}=-\frac{\partial F}{\partial \dot{z}} \\
Q_{n+2}=-\frac{\partial F}{\partial \dot{u}}
\end{gathered}
$$


Lagrange equations for the assembled system are then given by:

$$
\begin{gathered}
\frac{d}{d t}\left(\frac{\partial T}{\partial \dot{Y}_{i}}\right)+\frac{\partial V}{\partial Y_{i}}=Q_{i}(i=1,2, \ldots, n) \\
\frac{d}{d t}\left(\frac{\partial T}{\partial \dot{z}}\right)+\frac{\partial V}{\partial z}=Q_{n+1} \\
\frac{d}{d t}\left(\frac{\partial T}{\partial \dot{u}}\right)+\frac{\partial V}{\partial u}=Q_{n+2}
\end{gathered}
$$

Substituting (1) and (6) into (7) results in the dynamic equation of the human-structure interaction system in matrix form as $(8)$.

$$
\mathbf{M} \ddot{\mathbf{U}}+\mathbf{C} \dot{\mathbf{U}}+\mathbf{K} \mathbf{U}=\mathbf{F}(t)
$$

where $\mathbf{M}, \mathbf{C}, \mathbf{K}, \mathbf{U}, \dot{\mathbf{U}}, \ddot{\mathbf{U}}$ and $\mathbf{F}(t)$ are the mass, damping and stiffness matrices, the displacement, velocity, acceleration and force vectors, respectively. For the present case, the mass, damping, stiffness matrices, and the force vector can be expressed as

$$
\begin{aligned}
\mathbf{M} & =\left[\begin{array}{cccccc}
M_{1} & 0 & \cdots & 0 & 0 & 0 \\
0 & M_{2} & \cdots & 0 & 0 & 0 \\
\vdots & \vdots & \ddots & \vdots & \vdots & \vdots \\
0 & 0 & \cdots & M_{n} & 0 & 0 \\
0 & 0 & \cdots & 0 & m_{h} & 0 \\
0 & 0 & \cdots & 0 & 0 & m_{h}
\end{array}\right]_{(n+2) \times(n+2)} \\
\mathbf{C} & =\left[\begin{array}{cccccc}
c_{1,1} & c_{1,1} & \cdots & c_{1, n} & c_{1, n+1} & c_{1, n+2} \\
c_{2,1} & c_{2,2} & \cdots & c_{2, n} & c_{2, n+1} & c_{2, n+2} \\
\vdots & \vdots & \ddots & \vdots & \vdots & \vdots \\
c_{n, 1} & c_{n, 2} & \cdots & c_{n, n} & c_{n, n+1} & c_{n, n+2} \\
c_{n+1,1} & c_{n+1,2} & \cdots & c_{n+1, n} & c_{n+1, n+1} & c_{n+1, n+2} \\
c_{n+2,1} & c_{n+2,2} & \cdots & c_{n+2, n} & c_{n+2, n+1} & c_{n+2, n+2}
\end{array}\right]_{(n+2) \times(n+2)} \\
\mathbf{K} & =\left[\begin{array}{ccccccc}
\omega_{1}^{2} M_{1} & 0 & \cdots & 0 & -k_{t, v} \phi_{1}\left(x_{t}\right)-k_{l, v} \phi_{1}\left(x_{l}\right) & 0 \\
0 & \omega_{2}^{2} M_{2} & \cdots & 0 & -k_{t, v} \phi_{2}\left(x_{t}\right)-k_{l, v} \phi_{2}\left(x_{l}\right) & 0 \\
\vdots & \vdots & \ddots & \vdots & \vdots & \vdots \\
0 & 0 & \cdots & \omega_{n}^{2} M_{n} & -k_{t, v} \phi_{n}\left(x_{t}\right)-k_{l, v} \phi_{n}\left(x_{l}\right) & 0 \\
0 & 0 & \cdots & 0 & k_{t, v}+k_{l, v} & 0 \\
0 & 0 & \cdots & 0 & 0 & k_{t, h}-k_{l, n}
\end{array}\right]_{(n+2) \times(n+2)} \\
\mathbf{F}(t) & =\left[\begin{array}{lllllll}
0 & 0 & \cdots & 0 & -m_{h} g & 0
\end{array}\right]_{(n+2)}^{T} \\
\mathbf{U} & =\left[\begin{array}{lllllll}
Y_{1} & Y_{2} & \cdots & Y_{n} & z & u
\end{array}\right]_{(n+2)}^{T}
\end{aligned}
$$


in which

$$
\begin{aligned}
& c_{i, i}=2 \zeta_{i} \omega_{i} M_{i}+c_{l e g} \phi_{i}\left(x_{l}\right)^{2} \sin ^{2} \theta_{l}+c_{l e g} \phi_{i}\left(x_{t}\right)^{2} \sin ^{2} \theta_{t} \\
& c_{i, j}=c_{j, i}=c_{l e g} \phi_{i}\left(x_{l}\right) \phi_{j}\left(x_{l}\right) \sin ^{2} \theta_{l}+c_{l e g} \phi_{i}\left(x_{t}\right) \phi_{j}\left(x_{t}\right) \sin ^{2} \theta_{t} \\
& c_{i, n+1}=-c_{l e g} \phi_{i}\left(x_{l}\right) \sin ^{2} \theta_{l}-c_{l e g} \phi_{i}\left(x_{t}\right) \sin ^{2} \theta_{t} \\
& c_{i, n+2}=c_{l e g} \phi_{i}\left(x_{l}\right) \sin \theta_{l} \cos \theta_{l}-c_{l e g} \phi_{i}\left(x_{t}\right) \sin \theta_{t} \cos \theta_{t} \\
& c_{n+1, j}=-c_{l e g} \phi_{j}\left(x_{l}\right) \sin ^{2} \theta_{l}-c_{l e g} \phi_{j}\left(x_{t}\right) \sin ^{2} \theta_{t} \\
& c_{n+2, j}=c_{l e g} \phi_{j}\left(x_{l}\right) \sin \theta_{l} \cos \theta_{l}-c_{l e g} \phi_{j}\left(x_{t}\right) \sin \theta_{t} \cos \theta_{t} \\
& c_{n+1, n+1}=c_{l e g} \sin ^{2} \theta_{l}+c_{l e g} \sin ^{2} \theta_{t} \\
& c_{n+1, n+2}=c_{n+2, n+1}=-c_{\text {leg }} \sin \theta_{l} \cos \theta_{l}+c_{\text {leg }} \sin \theta_{t} \cos \theta_{t} \\
& c_{n+2, n+2}=c_{l e g} \cos ^{2} \theta_{l}+c_{l e g} \cos ^{2} \theta_{t} \\
& k l, v=k_{l e g}\left(1-\frac{L_{0}}{L_{l}}\right)\left(\frac{y_{l}}{z}-1\right) \\
& k t, v=k_{l e g}\left(1-\frac{L_{0}}{L_{t}}\right)\left(1-\frac{y_{t}}{z}\right) \\
& k l, h=k_{l e g}\left(1-\frac{L_{0}}{L_{l}}\right)\left(\frac{x_{l}}{u}-1\right) \\
& k t, h=k_{l e g}\left(1-\frac{L_{0}}{L_{t}}\right)\left(1-\frac{x_{t}}{u}\right) \\
& \phi_{i}(x)=\left\{\begin{array}{l}
0 \quad x<0 \\
\sin \left(\frac{i \pi x}{L}\right) \quad 0 \leq x \leq L \\
0 \quad x>L
\end{array}\right.
\end{aligned}
$$

It can be seen from $(10)$ that $\left(k_{l, v}, k_{t, v}\right)$ and $\left(k_{l, h}, k_{t, h}\right)$ are the effective vertical and horizontal stiffness, respectively. The effective vertical stiffness $\left(k_{l, v}, k_{t, v}\right)$ determined from a combination of the leg stiffness $\left(k_{l e g}\right)$, the displacement of the COM $(u, v)$ and the displacement of structure $(y)$, corresponds to the vertical motion of the COM rather than any physical spring associated with the leg stiffness in the model. Therefore, the equations of motion of the human-structure system are coupled in terms of the interacting force at the contact point. Note that damping and stiffness matrices are time varying and that although the leg stiffness $\left(k_{l e g}\right)$ is constant during walking, the effective leg stiffness is non linear as it will be discussed later.

All the above analysis is based on the double support phase. The analysis process for the single support phase is similar but with all the coefficients relating to the trailing leg set to zero.

\section{II-B. Feedback mechanism}

A damped compliant walking model is able to reproduce a one-step gait cycle that consists of the single and double support phases. This model requires an energy input mechanism to maintain the steady walking gait because energy has been dissipated within the system damping in the walking process. This energy consumption is distributed through out the gait cycle[3]. To provide the additional energy to the system, one possibility is to apply a control force to the COM in a feed-back or feed-forward manner[2]. In this way, the control force can be modeled as a varying distribution over one gait cycle supposed to be generated by human in walking.

Assuming the external work in horizontal direction equals to the energy loss in the process. The control force can be obtained from the following equation:

$$
F_{c t r l}(t)=\frac{E_{0}-E(t)}{\Delta u(t)}
$$

where $F_{c t r l}(t), E_{0}, E(t)$ and $\Delta u(t)$ are the horizontal control force, initial energy input, actual energy of the bipedal system and incremental horizontal displacement of COM at time "t", respectively.

The total energy of the human body $E(t)$ including the potential energy and the kinetic energy is given by

$$
E(t)=\frac{1}{2} m_{h} \dot{z}^{2}+\frac{1}{2} m_{h} \dot{u}^{2}+\frac{1}{2} k_{l e g}\left(L_{0}-L_{l}\right)^{2}+\frac{1}{2} k_{l e g}\left(L_{0}-L_{t}\right)^{2}+m_{h} g z
$$

This time-varying control force must be included in $(9)$ as

$$
\mathbf{F}(t)=\left[\begin{array}{llllll}
0 & 0 & \cdots & 0 & -m_{h} g & F_{c t r l}(t)
\end{array}\right]_{(n+2)}^{T}
$$




\section{DYNAMIC ANALYSIS OF STRUCTURE}

If the pedestrian moves on a footbridge, the instantaneous mass and stiffness matrices of the HSI system should be used for the solution of the instantaneous natural frequencies of the entire system. The challenging aspects of the study lie in the fact that a slightly damped structure system and a highly damped human body system are combined to form a new system. In this study, the instantaneous modal properties of the entire system will be obtained by making the Laplace transform to the equation (8)

$$
\left|\mathbf{M} s^{2}+\mathbf{C s}+\mathbf{K}\right|=0
$$

For a damped MDOF system, the $i$ th natural frequencies $f_{i}$ and damping ratios $\zeta_{i}$ are respectively given as

$$
f_{i}=\frac{1}{2 \pi} \operatorname{Im}\left(s_{i}\right), \quad \zeta_{i}=\frac{\operatorname{Re}\left(s_{i}\right)}{\operatorname{Im}\left(s_{i}\right)}
$$

In this paper, the dynamic response of a footbridge subjected to pedestrian motion at every time step " $\mathrm{t}$ " may be obtained in the following steps:

1. Input the geometric and physical parameters for the models of the footbridge and the pedestrian.

2. Perform a modal analysis to obtain the frequencies and the corresponding damping ratios of the footbridge alone.

3. The initial conditions of the footbridge and the pedestrian are specified, such as: the initial displacement and velocity of the COM at time $t_{0}$, the position for the first leg to touch down and time increment $\Delta t$.

4. Construct the overall mass, stiffness and damping matrices of the HSI system at initial time.

5. Compute the initial acceleration of the HSI system from the initial stiffness, damping matrices and force vector of system based on the equilibrium of force.

6. For each time step:

a) Determine the time dependent position of the two feet.

b) Compute the compressions of two legs.

c) Compute the effective vertical stiffness, effective horizontal stiffness, effective horizontal damping and effective vertical damping of two legs.

d) Assemble the overall mass, damping, stiffness matrices and force vector of the HSI system.

e) Compute the length of the trailing leg and determine the step cycle if it is in the double support phase or in the single support phase. If the length of trailing leg is larger than the rest length of leg, compute the distance between the COM and the assumed contact point with the structure for the next step cycle. If the distance between the COM and the assumed contact point equal to the rest length of leg, a new step cycle starts.

f) Compute the control force.

g) Update the overall force vector.

h) Determine the acceleration of HSI system at the end of time increment using a Runge-Kutta method of fourth order.

i) Repeat to obtain the dynamic response of the HSI system for next time step until the end of time history is reached.

The initial conditions must be determined in such a way that gives rise to a stable human walk cycle as set out in reference[3].

\section{NUMERICAL STUDY}

Two examples consisting on a pedestrian walking along a rigid and a flexible beam are presented. In both cases, the pedestrian is modeled with a mass of $m_{h}=80 \mathrm{~kg}$, legs $L_{0}=1 \mathrm{~m}$ long, stiffness $k_{\text {leg }}=20 \mathrm{kN} / \mathrm{m}$, damping $\zeta_{h}=8 \%$ and walking pace $f_{p}=2,0 \mathrm{~Hz}$. With these data, speed is $1,2 \mathrm{~m} / \mathrm{s}$ and the angle of attack is just $\theta_{0}=69^{\circ}$.

\section{IV-A. Pedestrian on a rigid beam}

The beam considered in this first scenario is $L=11,0 \mathrm{~m}$ long, with bending rigidity of $E I=1,64 \cdot 10^{8} \mathrm{Nm} \mathrm{m}^{2}$, mass per unit length of $m=1,364 \cdot 10^{3} \mathrm{kgm}^{-1}, \zeta_{i}=0,3 \%$ damping ratio and first bending mode at $4,5 \mathrm{~Hz}$. The static deflection under its own weight is $15,6 \mathrm{~mm}$ and pedestrian in the middle only adds $0,13 \mathrm{~mm}$ more. Figures 5 and 6 shows cinematics of the middle cross-section of the beam. Static response of 15,73 is increased up to $24,1 \mathrm{~mm}(52 \%)$ due to dynamic effects. Note that the ratio of the masses (footbridge/pedestrian) is 187,5. Figure 7 shows the interaction forces between bipedal model and the beam at any instant. It is curious to note that even with the simple bipedal model used the shape of these forces is one that can be experimental determined using a force-plate. Vertical displacement and acceleration of the COM are presented in figures 8 and 9. Maximum displacement is around $50 \mathrm{~mm}$ and maximum acceleration is around $6 \mathrm{~m} / \mathrm{s}^{2}$, being these values the standard ones when walking along a rigid pavement. Note that in both responses the cinematics of the COM nearly is the expected when no interaction is taken into account, so the COM is not affected by the movement of the beam. 


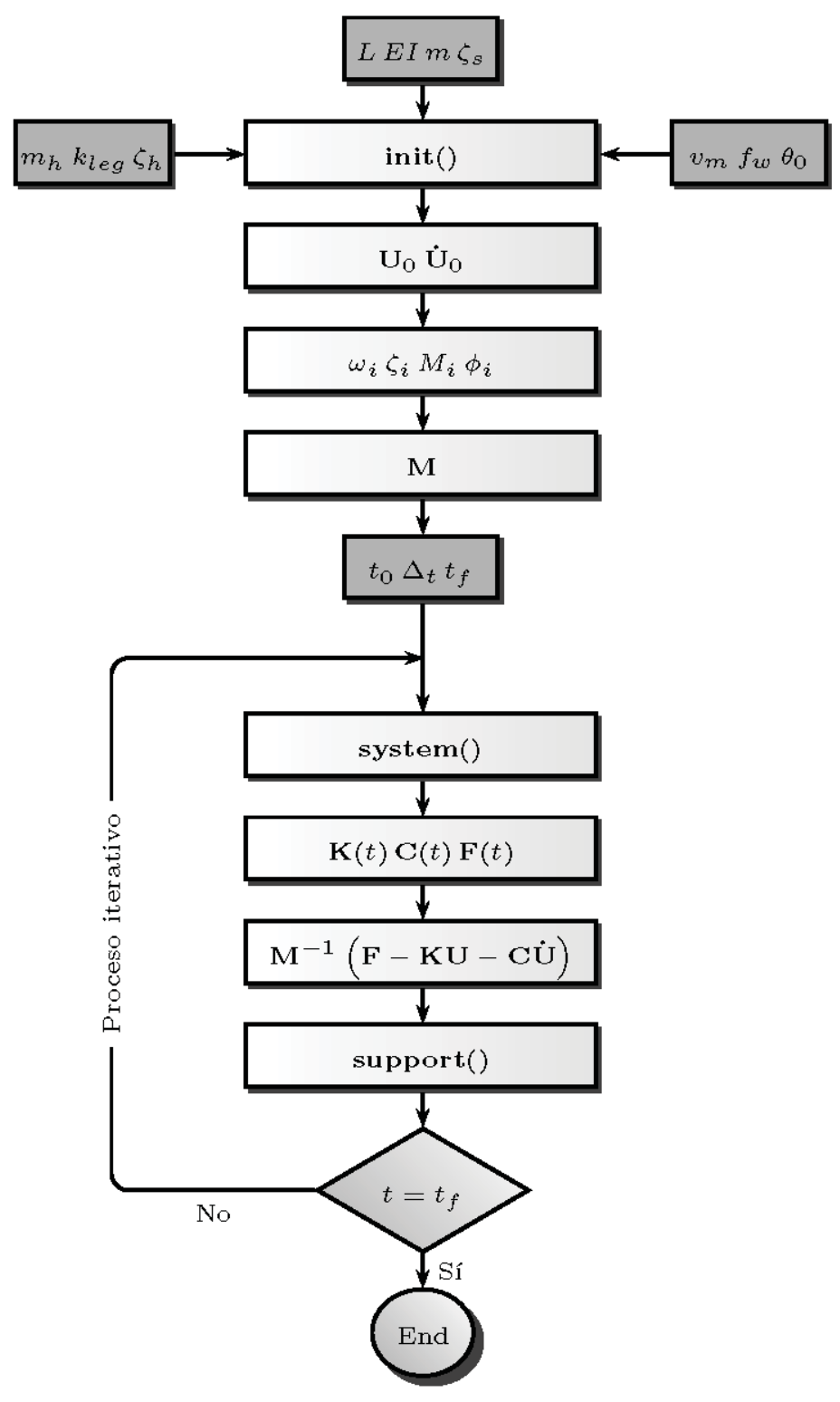

Fig. 4. Procedure of time response analysis

Figure 10 shows the reduced values of the control force necessary to maintain the gait. Figures 11 and 12 are similar to figures 5 and 6 but for a case in which the pace is just $2,25 \mathrm{~Hz}$, half the natural frequency of the beam. Because of the resonant phenomenon, displacements are almost 10 times greater and accelerations more than 14 times.

\section{IV-B. Pedestrian on a flexible beam}

In this case the beam is $L=9,0 \mathrm{~m}$ long, with bending rigidity of $E I=0,034 \cdot 10^{8} \mathrm{Nm}^{2}$ (48 times lower), mass per unit length of $m=230 \mathrm{Kg} / \mathrm{m}$ (almost 6 times lighter), $\zeta_{i}=0,3 \%$ damping ratio and first bending mode at $2,375 \mathrm{~Hz}$. In this case, the static deflection under its own weigth is $55,9 \mathrm{~mm}$ increased in $3,45 \mathrm{~mm}$ when the pedestrian rest in the middle. Figures 13 and 14 shows cinematics of the middle cross-section of the beam. Static deflection is increased upto $94 \mathrm{~mm}$ and in its dynamic movement the beam goes upwards upto $29 \mathrm{~mm}$. Accelerations increase 25 times with respect to the first example and also the control forces increase in a significant way (around 40 times).

\section{CONCLUSIONS}

A simple assembled system can be used to analytically describe the interaction effects that appear in a lightweight footbridge when crossed by a pedestrian. The model predict not only the expected behaviour on the footbridge but also the cinematic response in the pedestrian center of mass, that can be related to comfort and serviceability. 


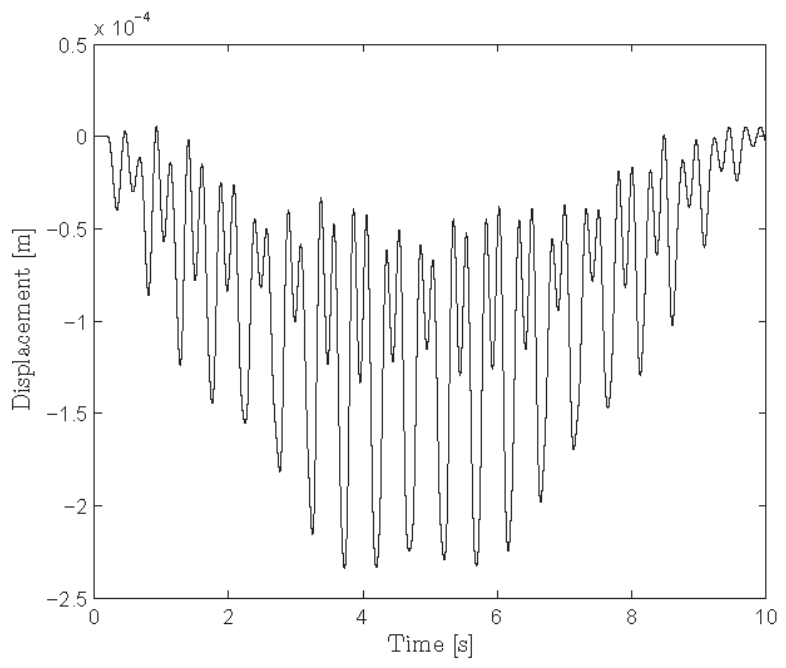

Fig. 5. Deflections in the middle cross-section of the beam crossed by the bipedal model

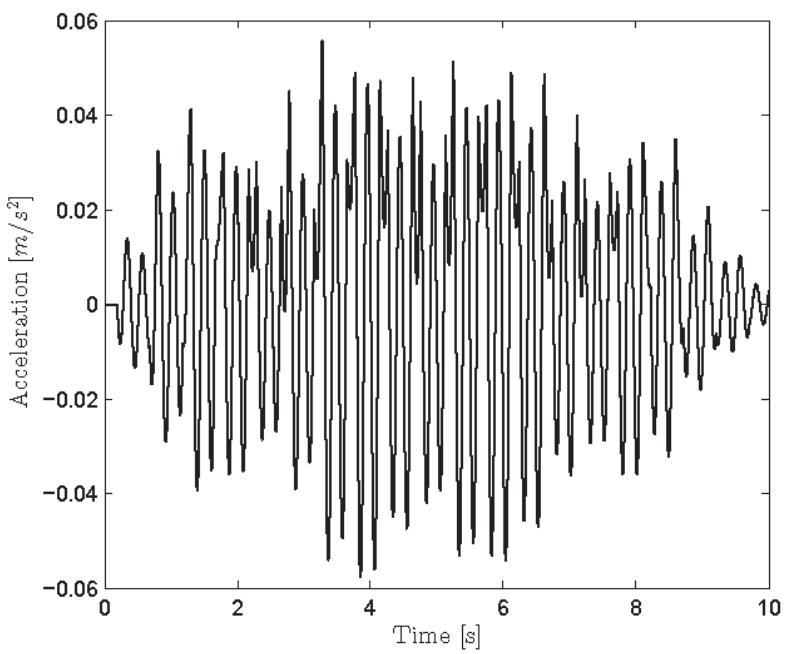

Fig. 6. Accelerations in the middle cross-section of the beam crossed by the bipedal model.

\section{ACKNOWLEDGMENT}

Authors wish to acknowledge to the partial support throught Research Project BIA2011-28493-C02-02 ("Ministerio de Economía y Competitividad", Spanish Government).

\section{REFERENCES}

[1] H. Geyer, A. Seyfarth, and R. Blickhan, "Compliant leg behaviour explains basic dynamics of walking and running," Proceedings of the Royal Society B: Biological Sciences, vol. 273(1603), pp. 2861-2867, 2006.

[2] S. Kim and S. Park, "Leg stiffness increases with speed to modulate gait frequency and propulsion energy," Journal of Biomechanics, vol. 44, pp. 1253-1258, 2011.

[3] B. Whittington and D. Thelen, "A simple mass-spring model with roller feet can induce the ground reactions observed in human walking," Journal of Biomechanical Engineering, vol. 131(011013), pp. 1-8, 2009.

[4] J. Qin, S. Law, Q. Yang, and N. Yang, "Pedestrian-bridgedynamicinteraction,including human participation," Journal of Sound and Vibration, vol. 332, pp. 1107-1124, 2013.

[5] _ "Finite element analysis of pedestrian-bridge dynamic interaction," Journal of Applied Mechanics, vol. 81 (4), pp. 041 001-1, 2014.

[6] M. Pandy, "Simple and complex models for studying muscle function in walking," Phil. Trans. R. Soc. B, vol. 358, pp. 1501-1509, 2003. 


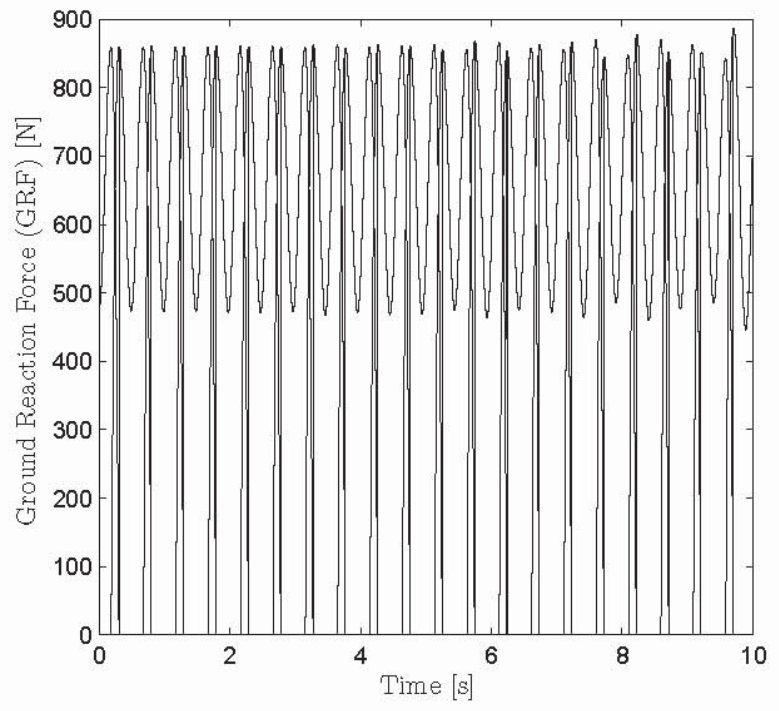

Fig. 7. Vertical ground reaction force

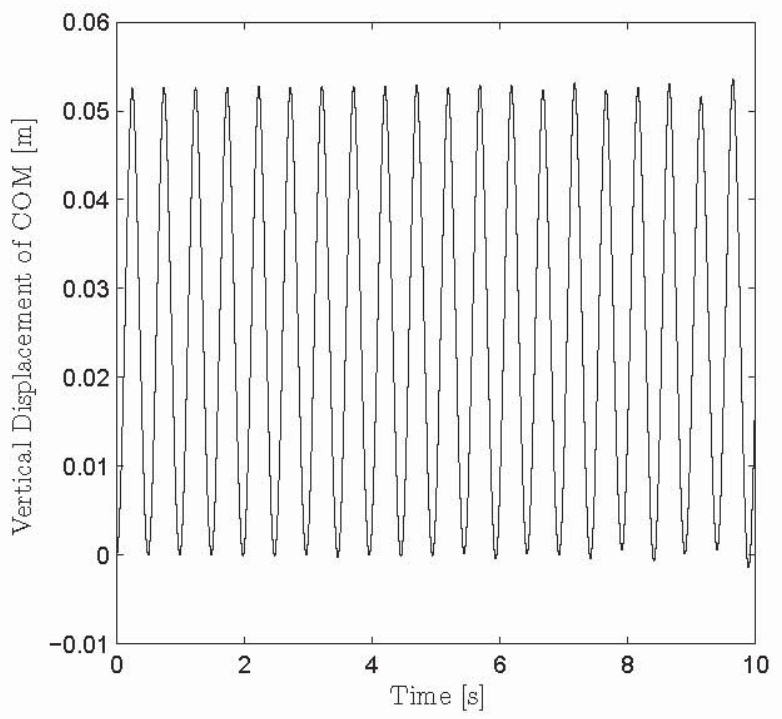

Fig. 8. Vertical displacement of center of mass (COM) 


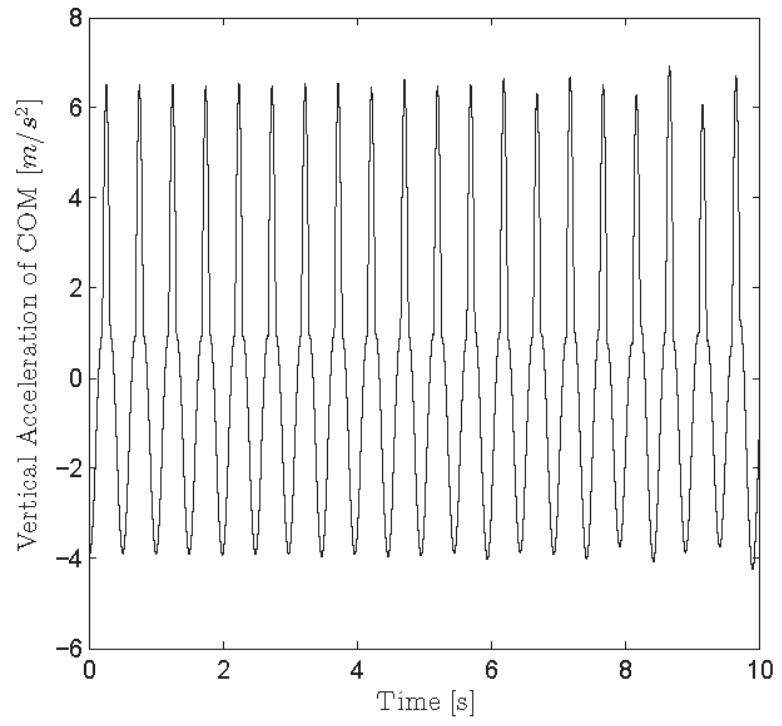

Fig. 9. Vertical acceleration of center of mass (COM)

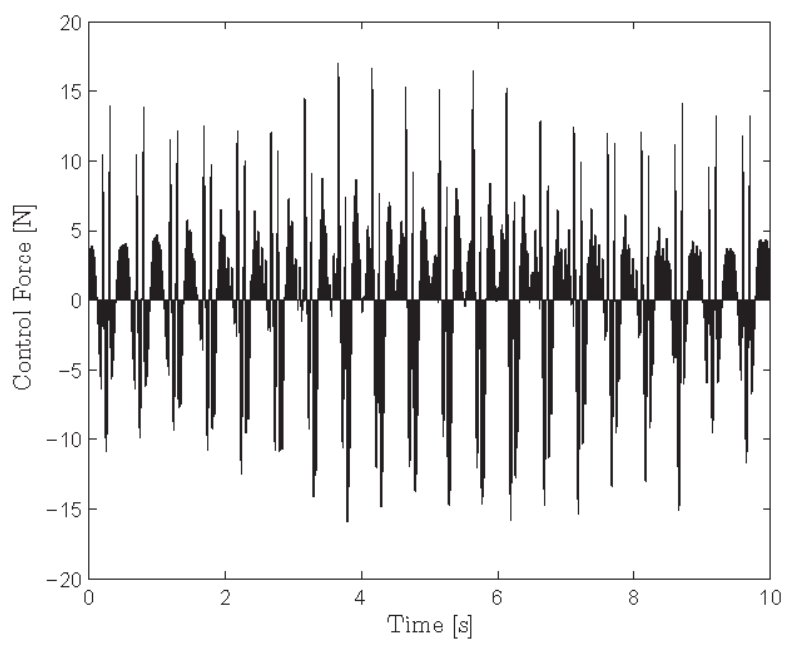

Fig. 10. Control force

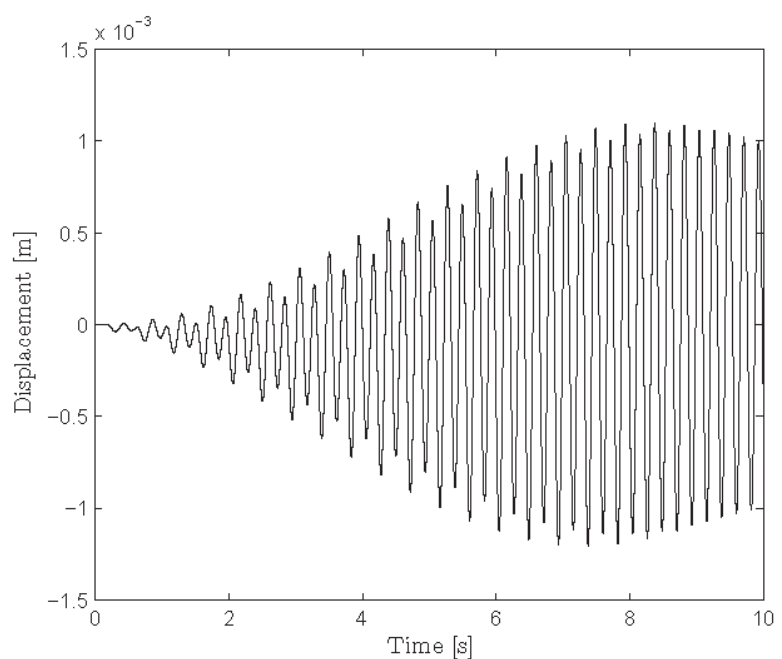

Fig. 11. Deflections in the middle cross-section of the beam $\left(f_{p}=2,25 \mathrm{~Hz}\right)$ 


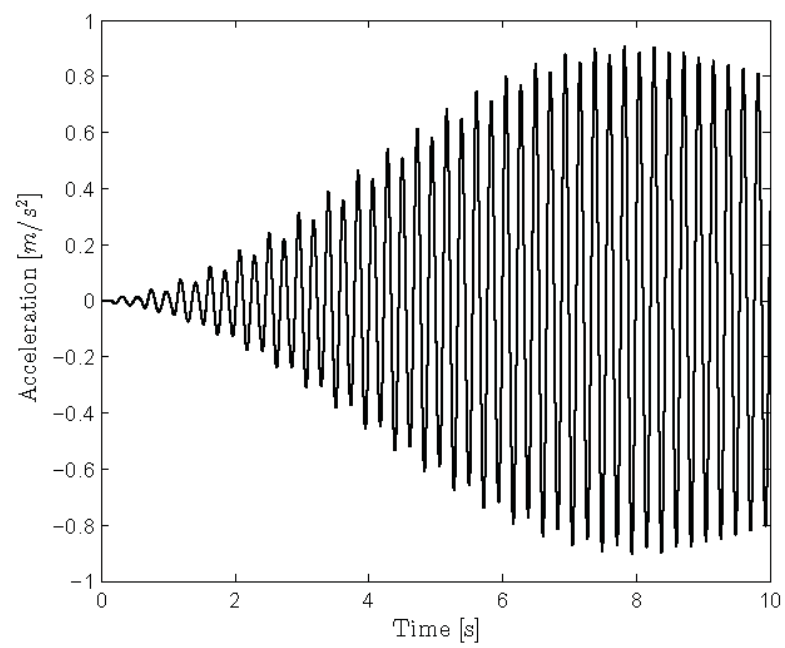

Fig. 12. Accelerations in the middle cross-section of the beam $\left(f_{p}=2,25 \mathrm{~Hz}\right)$

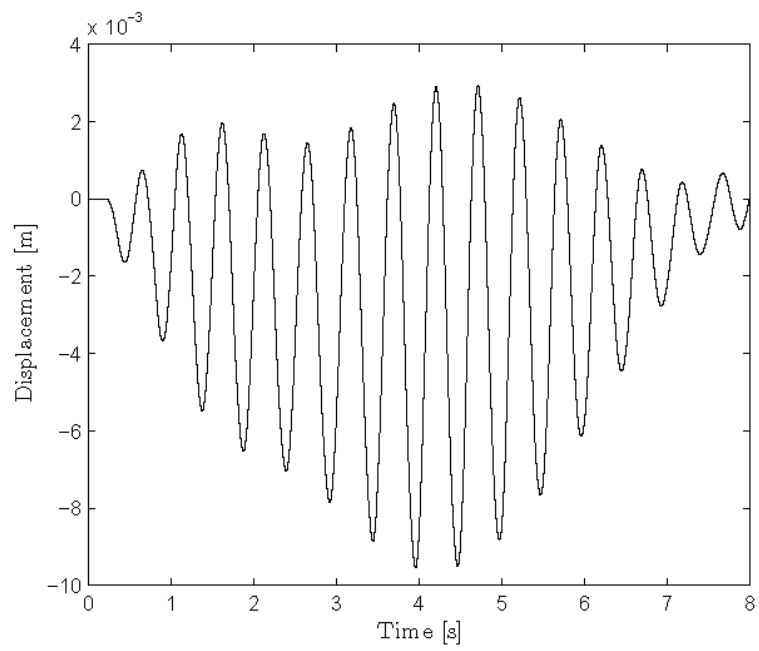

Fig. 13. Deflections in the middle cross-section of the beam

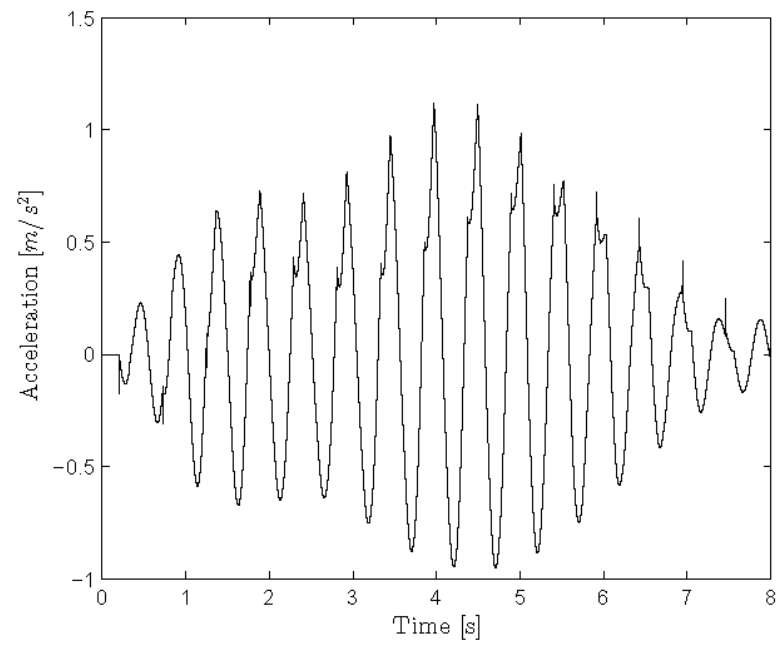

Fig. 14. Accelerations in the middle cross-section of the beam 
ONE YEAR OF THE STRUCTURAL HEALTH MONITORING OF PEDRO GÓMEZ BOSQUE FOOTBRIDGE

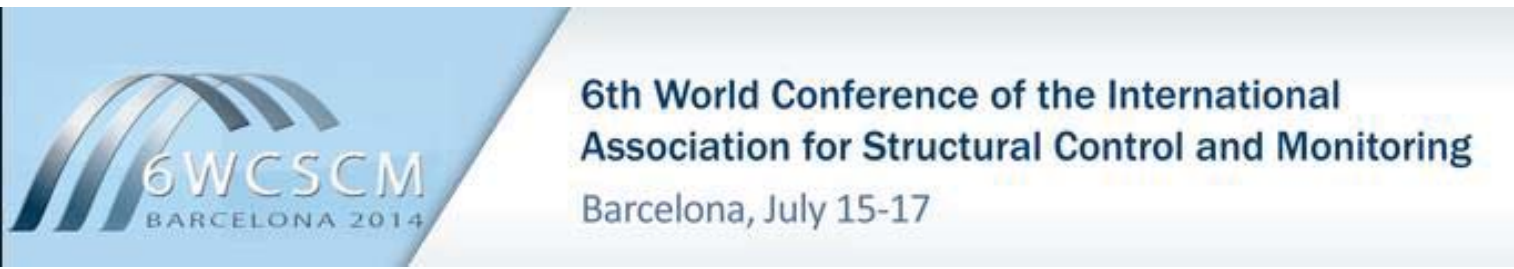

Antolín Lorenzana Ibán; Alfonso V. Poncela Méndez; Jesús de Sebastián Sanz; Norberto Ibán Lorenzana; Melania Vasilica Istrate; Ali Vasallo Belver; José Pereda Llamas; Iván Muñoz Díaz; Carlos M. Casado Sanchéz; Javier Castaño Lerma

\begin{tabular}{c|c|c|c|} 
Aportaciones: & Experimentación & Procesado & Edición \\
\hline \multirow{2}{*}{ Instalación } & Matlab & Tablas \\
& Instrumentación & Excel & Gráficas \\
& Registros & Sigview & Imágenes \\
& & Defensa \\
\cline { 2 - 4 }
\end{tabular}




\title{
One year of the structural health monitoring of Pedro Gómez. Bosque footbridge
}

\author{
Antolín Lorenzana, Alfonso V. Poncela, Jesús Sebastián, Norberto Ibán, Melania V. Istrate, Ali \\ Vasallo, José Pereda, Iván M. Díaz, Carlos M. Casado, Javier Castaño.
}

\begin{abstract}
Pedro Gómez Bosque footbridge is a slender and lightweight structure that creates a pedestrian link over the Pisuerga River, Valladolid city, Spain. This footbridge, built in 2011, is a singular stress ribbon structure with only one span of $85 \mathrm{~m}$ consisting on a steel plate ( $3.6 \mathrm{~m}$ width and $0.03 \mathrm{~m}$ thick) and precast concrete slabs laying on it. Rubber pavement and a railing made of stainless steel and glass complete the footbridge. Because of the singularity of this footbridge, prone to oscillate, and the increasing interest in structural integrity and user's comfort and safety, a simple and affordable structural health monitoring system (18 triaxial accelerometers embedded in the handrail, and also wind and temperature sensor in a nearby tower) was installed in 2012 in order to continuously evaluate some serviceability parameters and to estimate the modal values of the structure. Also the system allows, using postprocessing techniques, find correlations between the mechanical response and environmental data and, in the long term, evaluate changes in the modal properties due to fatigue or abutment resettlements. After some verifications, the monitoring system is operative since December'12 and representative data is presented in the paper. The data includes some acceleration magnitudes (peak and weighted RMS and MTVV values, among other parameters established in ISO 2631) and also modal parameters (natural frequencies, modes and modal damping) and some dependencies with temperature and estimated pedestrian use. The variation of these parameters can be analysed over one year time.
\end{abstract}

\section{INTRODUCTION}

This work describes the development and installation of a remotely controlled continuous vibration monitoring system on a footbridge. Also some results after the first year of operation are presented. The singularity of the structure, its slenderness and the prescription of not affecting to its aesthetic in any way, together with economic restriction, leads to the decision of designing low-cost MEMS-based accelerometers embedded inside the handrail. The monitoring system was validated by comparing the data measured by the MEMS accelerometers with conventional piezoelectric accelerometers. These tests demonstrated that these sensors are a competitive alternative to traditional ones and that the system is ready to be used for the dynamic characterization of the structure and to integrate a continuous structural health assessment.

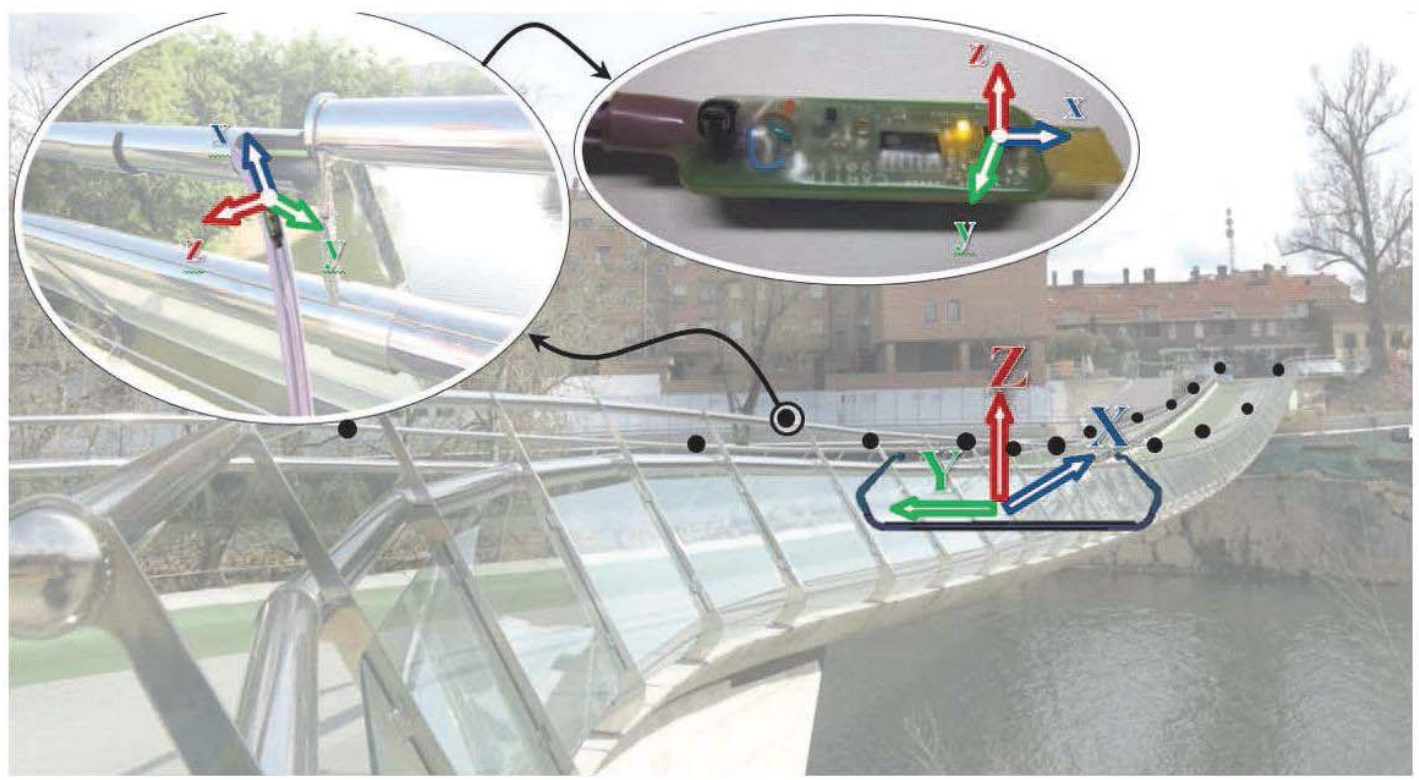

Figure 1: Cross-section with the global axis, local axis for the MEMS accelerometers and their location in the footbridge.

Antolín Lorenzana is with the ITAP, Universidad de Valladolid, Spain (corresponding author to provide phone: +34 983423529; e-mail: ali@eii.uva.es). Alfonso V. Poncela is with teh IT AP, Universidad de Valladolid, Spain (e-mails: poncela@eii.uva.es). Jesús Sebastián is with Cartif Research Centre, Boecillo (Valladolid), Spain (e-mail: jesseb@cartif.es). Norberto Ibán is with Cartif Research Centre, Boecillo (Valladolid), Spain (e-mail: noriba@cartif.es). Ali Vasallo is with Cartif Research Centre, Boecillo (Valladolid), Spain (e-mail: alivas@cartif.es). Melania V. Istrate is with Cartif Research Centre, Boecillo (Valladolid), Spain (e-mail: melist@cartif.es)

José Pereda is with Escuela de Ingenierías Industriales, Universidad de Valladolid, Spain (e-mail: pereda@eii.uva.es).

Iván M. Díaz is with the Department of Continuum Mechanics and Structures, ETSCCP, UPM, (Madrid) Spain (ivan.munoz@upm.es)

Carlos M. Casado is with Cartif Research Centre, Boecillo (Valladolid), Spain (e-mail: carcas@cartif.es).

Javier Castaño is with Cartif Research Centre, Boecillo (Valladolid), Spain (e-mail: javcas@cartif.es). 


\section{STRUCTURE DESCRIPTION}

Pedro Gómez Bosque footbridge (see figure 1) mainly consists of a Corten steel sheet of $94 \mathrm{~m}$ long, $3.6 \mathrm{~m}$ width and only 30 $\mathrm{mm}$ thickness which is pre-tensioned and anchored to the two abutments, which are 85 apart and 2 meters not on a level. The complete steel sheet is manufactured welding together 8-meter long sheets. Precast concrete slabs of $5.2 \mathrm{~m} \mathrm{long,} 0.75 \mathrm{~m}$ width and around $120 \mathrm{~mm}$ thickness lay on the steel sheet. These slabs do not have bearing mission, that is, the only structural element is the steel sheet. The structure is completed by rubber pavement and a stainless steel and glass railing. All these structural and functional parts suppose $23.6 \mathrm{KN} / \mathrm{m}$. Initial pre-tension on the steel sheet was adjusted so that, at reference temperature $20^{\circ} \mathrm{C}$, displacem ent in the middle (sag) were limited to $\mathrm{L} / 50$ with means $1.7 \mathrm{~m}$. Using indirect computations, an axial tension of 12.5 $\mathrm{MN}$ has been estimated so in normal conditions stresses in the steel are around $120 \mathrm{MPa}$. Considering a service overload of $15.7 \mathrm{KN} / \mathrm{m}$ and cold whether conditions, stresses could reach up to $192 \mathrm{MPa}$.

A previous operational modal analysis was carried out using a portable system (consisting on piezoelectric accelerometers MMF-KS48C, with $1000 \mathrm{~m} \mathrm{~V} / \mathrm{g}$ sensitivity and low frequency ranges connected to a MGCplus HBM data logger through ICP modules). Natural frequencies and mode shapes were estimated using the FDD and SSI methods. Twenty vibration modes, including vertical, lateral, torsional and coupled modes, between 0.8 and $10 \mathrm{~Hz}$ were estimated. These parameters were important to design the system monitoring and to choose the most appropriate sensor technical specifications and their location in the structure.

\section{MONTORING SYSTEM}

The monitoring system comprises 18 triaxial accelerometers, 9 at each side of the deck, a temperature sensor and an anemometer and vane. The accelerometers, embedded in the $60 \mathrm{~mm}$ diameter CHS tube used as handrail, were positioned equidistant $10.625 \mathrm{~m}$ along the span (plotted with black points in figure 1).

\section{A. Sensors}

The vibration sensor chosen was the ADXL327 MEMS accelerometer developed by ANALOG DEVICES [13]. The ADXL 327 is a very small, low power, 3-axis accelerom eter with signal conditioned voltage outputs. It can measure the static acceleration of gravity in tilt-sensing applications as well as dynamic acceleration at high sampling speeds. This accelerometer has good characteristics (measurement range up to $\pm 2.5 \mathrm{~g}$, sensitivity up to $500 \mathrm{~m} \mathrm{~V} / \mathrm{g}$, bandwidth up to $550 \mathrm{~Hz}$ ) but it not initially designed for long wire distances. To overcome this problem, MENS device has been integrated in a circuit with other consumer electronic durables. First, a capacitor was placed in each axis in order to fix the measurem ent bandwidth to $100 \mathrm{~Hz}$. Then, as the accelerometer has to be supplied by $3.6 \mathrm{~V}$ to get its nominal sensitivity of $500 \mathrm{~m} \mathrm{~V} / \mathrm{g}$. the power supply used is in $12 \mathrm{~V}$ and a voltage regulator to $3.6 \mathrm{~V}$ were integrated in each board in order to avoid power losses by the long wires. As the impedance at each axis of the accelerometer output is high enough $(32 \mathrm{k} \Omega)$ to cause noise problems by the long wires, an operational amplifier was added to reduce the impedance to $10 \mathrm{~m} \Omega$ and reduce the noise to $25 \mu \mathrm{g} / \mathrm{V} \mathrm{Hz}$.

The circuit board (see central detail in figure 1) with all the components is small enough (17 x $50 \mathrm{~mm})$ for installing requirements. One of the axis of the triaxial accelerometer (X) was placed along the longitudinal direction of the board and its long side was aligned with the set of wires. In this way, after introducing the set of wires along the handrail (see left detail in figure 1), it can be assumed that the $\mathrm{x}$-axis for all the sensor remains in the vertical plane, although no guess can be made about the other two axis (y and $\mathrm{z}$ )

The temperature sensors used for the monitoring system was model T0110 transmitter (Comet) with range -30 to $+80^{\circ} \mathrm{C}$ and accuracy $\pm 0.4^{\circ} \mathrm{C}$. The wind sentry used was model 03002L (R. M. Young Company) with range 0 to $50 \mathrm{~m} / \mathrm{s}$ and accuracy $\pm 0.5 \mathrm{~m} / \mathrm{s}$ for the speed and range $360^{\circ}$ and accuracy $\pm 5^{\circ}$ for the direction.

\section{B. Lab validation}

Two types of test were performed to validate the MENS device. The first one consisted in amplitude calibration and in signalto-noise ratio evaluation. For that, the portable system (piezoelectric accelerometer used as a blank, under ideal conditions) was place together with the MEMS one connected to the longest wire (around $100 \mathrm{~m}$ ). Both of them were located in a vibrating beam (first mode at $2.27 \mathrm{~Hz}$, free damped response after an impulsive load, $0.18 \%$ damping). Results are show in figure 2 . Note that, regardless technical specifications and the electronic conditioning, for amplitudes below $0.02 \mathrm{~m} / \mathrm{s}^{2}$ the noise is very evident and induce increments in the RMS values in more than $10 \%$, so the use of the signal is limited. 

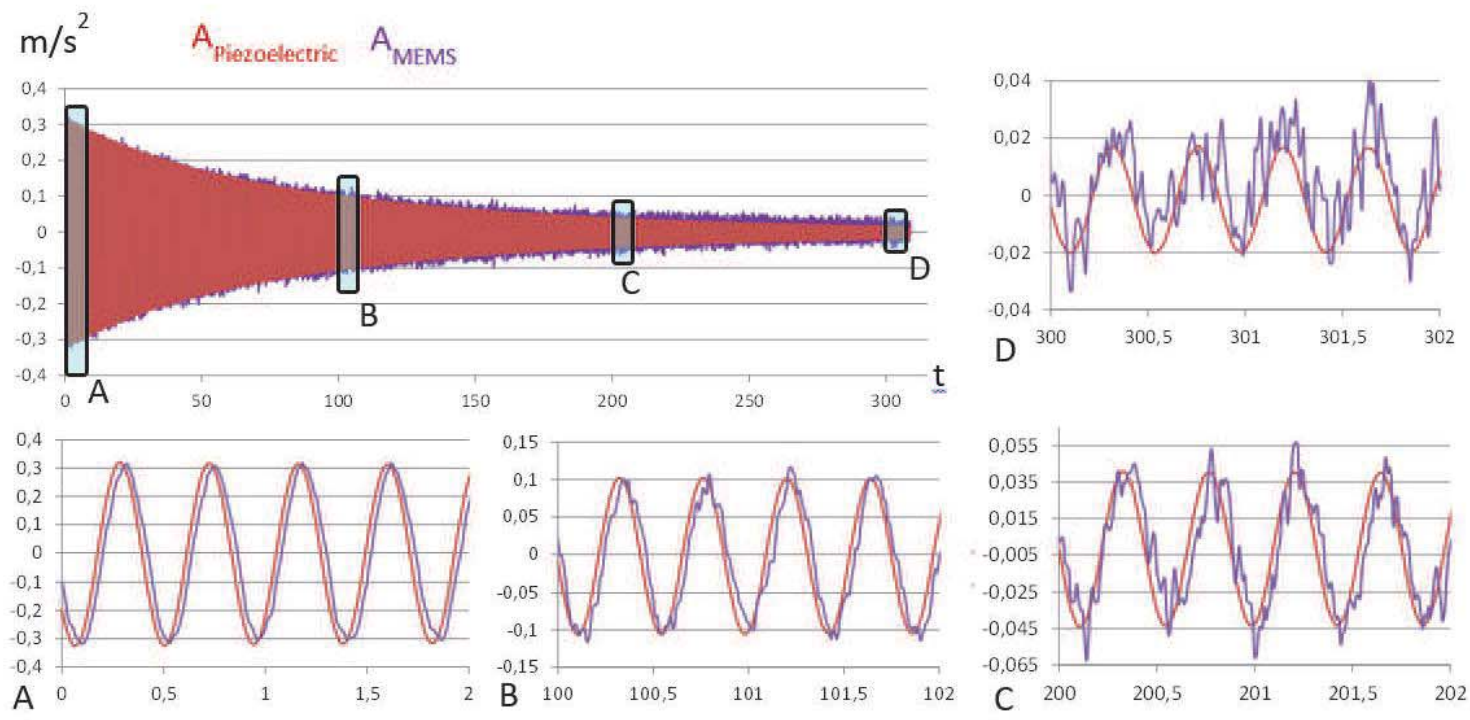

Figure 2. Piezoelectric.vs.MEMS devices

The other validation consisted on check the angular matrix algorithm needed to change local $\mathrm{x}, \mathrm{y}$ and $\mathrm{z}$ axis to the global reference $\mathrm{X}, \mathrm{Y}, \mathrm{Z}$. For that, using the ability of MEMS accelerometers to measure from $0 \mathrm{~Hz}$ (static acceleration) and providing $\mathrm{x}$ _local axis was in the XZ global plane, the recorded acceleration vector (once averaged during $60 \mathrm{~s}$, as footbridge is always in motion) and the gravity acceleration vector $(0,0,-9.81) \mathrm{m} / \mathrm{s} 2$ was used to find the Euler angles. As, for the installation procedure, no rotation is permitted in $\mathrm{Z}$ axis $(\gamma=0)$, there is enough data to find the other two angles $(\alpha$ and $\beta)$. Once all the angles are known, every recorded data is change from the local coordinates to the global ones and the gravity constant $\mathrm{g}$ is removed from the transformed $\mathrm{Z}$ records, so all the acceleration data moves around zero as usual. In this way, the transformed signal matches, in the 3 axis, with the one registered by 3 piezoelectric accelerometers mounted in trihedron disposition using the portable system. Figure 3 shows one example in which $\alpha=258.3^{\circ}$ and $\beta=10.7^{\circ}$. These angular values can change slightly with the temperature (note that the set of wires is free to move inside the handrail) and because of that it is recalculated from time to time.

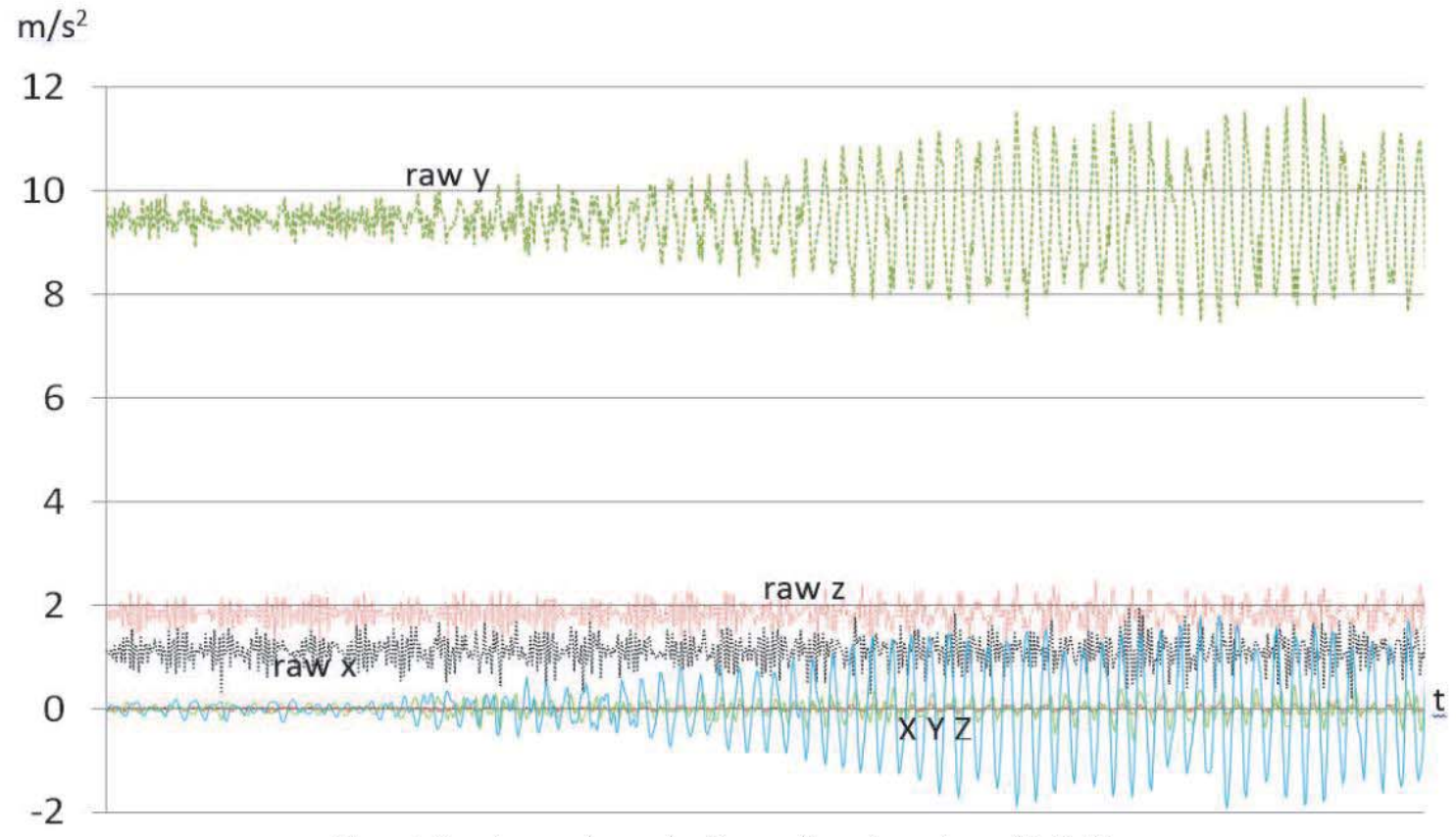

Figure 3. Local $\mathrm{x}, \mathrm{y}$ and $\mathrm{z}$ accelerations and transformed ones $(\mathrm{X}, \mathrm{Y}, \mathrm{Z})$.

\section{Data logger}

As said before, the monitoring system comprises 18 triaxial accelerometers, a temperature sensor and an anemometer and vane in such a way that 57 voltage channels for the measurement system were needed. The data logger chosen was a state-ofthe-art CompactRIO 9076 (National Instruments) with two 32 channels analogic input modules NI 9205. This data logger with a rugged hardware chassis has a stand-alone embedded control useful for real-time acquisition. The real-time processor is of 
$400 \mathrm{MHz}$ and Ethernet, USB and RS232 connections are available in this model. The modules have 32 single-ended analogic inputs with 16-bit resolution, $250 \mathrm{kS} / \mathrm{s}$ aggregate sampling rate and voltage range from $\pm 200 \mathrm{mV}$ to $\pm 10 \mathrm{~V}$.

The frequency sampling for each channel is set to $200 \mathrm{~Hz}$, enough to identify the modal parameters of the structure and to avoid aliasing problems (significant vibration modes have natural frequencies smaller than $10 \mathrm{~Hz}$ ). A file with the recorded data is created each hour in order to prevent measurement failures.

The two set of wires (one for each side) were long enough to reach the electrical cabinet sited near the footbridge where the data logger is installed. Figure 4 shows the data logger and the two set of wires, among other devices.

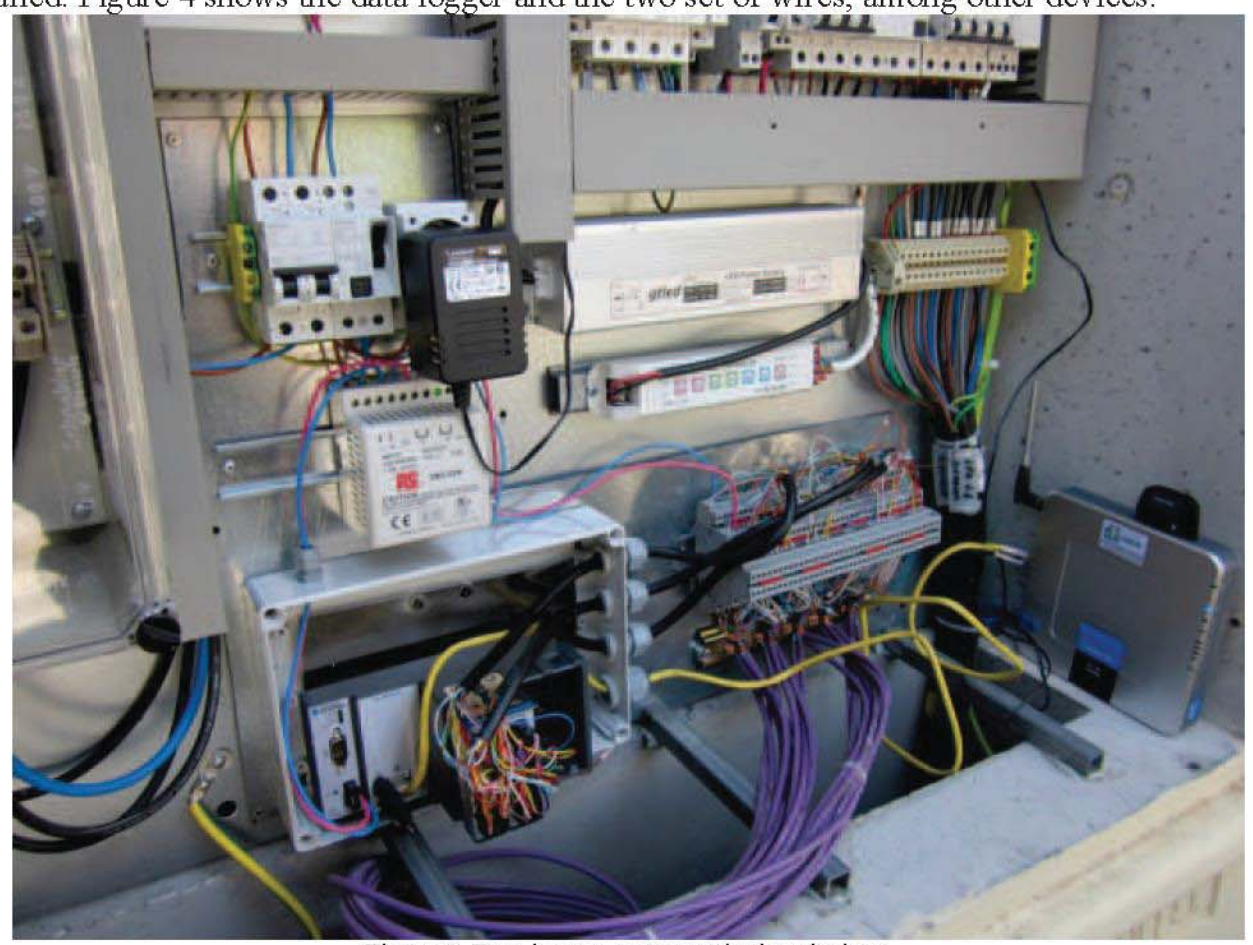

Figure 4. Data logger, router and other devices.

\section{In situ validation}

Once the monitoring system was installed and ready to record data, two additional checkings were addressed. First, it was checked that the accelerometers were positioned in the right place by lightly tapping on specific locations on the handrail, analysing the response of the nearby accelerometers and identifying the ones with more response, revealing their position. Then, experimental tests were carried out to check the performance of these new sensors. With groups of pedestrians walking over the deck, the structural response was registered with the portable system and also with the designed MEMS devices (Figure 5).

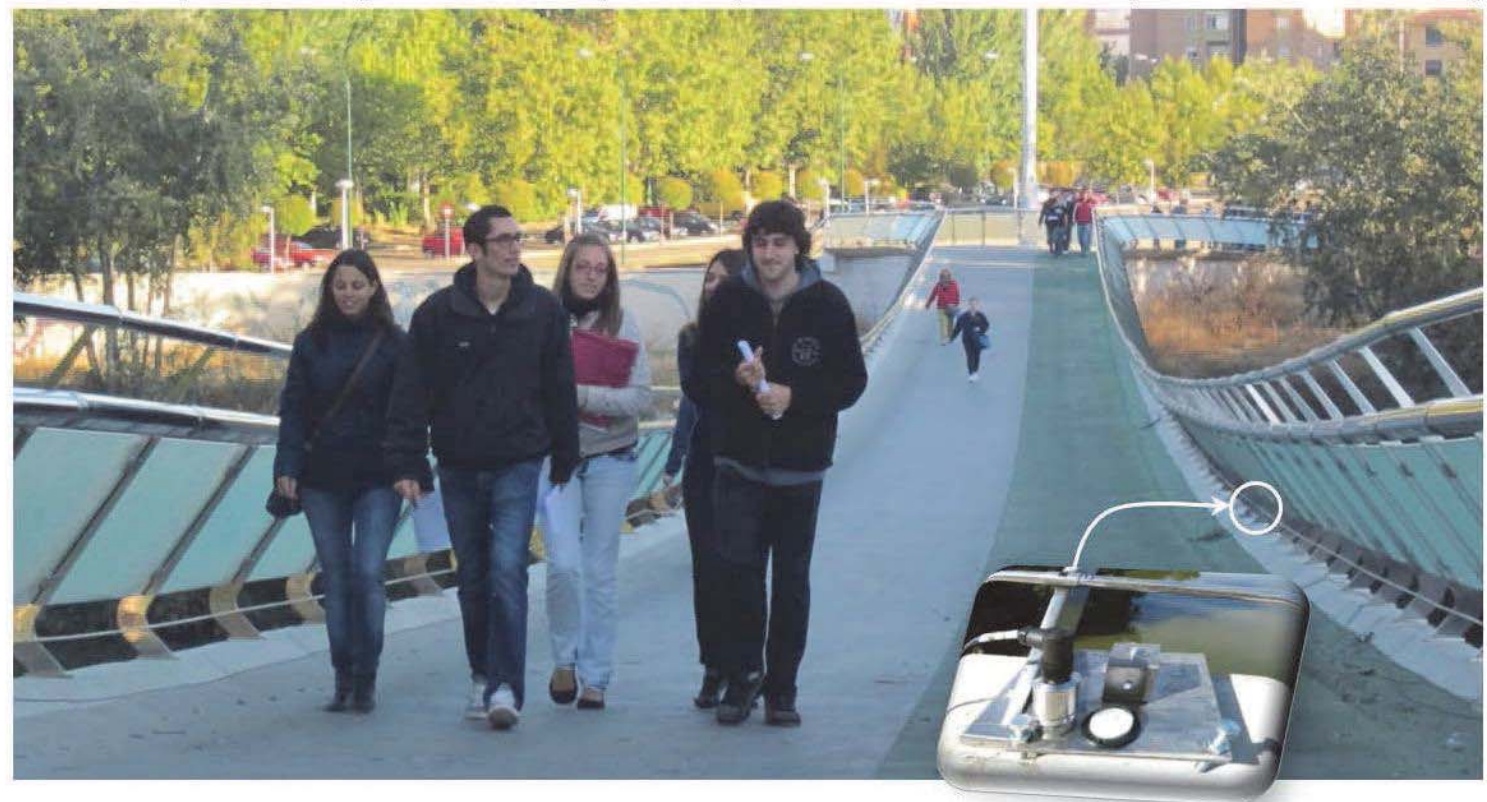

Figure 5. In situ validation comparing piezoelectric versus MEMS records. 
The piezoelectric accelerometers were levelled to measure the structural acceleration in absolute axes. These values were compared with the acceleration in absolute axes registered with the MEMS accelerometers (once transformed to the global reference). Figure 6 shows the acceleration measured with both of them in the $Z$ axis. The two recorded data are very similar in time and frequency domains. The only difference is that new frequencies appear (around 4.8, 9.5 Hz) in the MEMS recordings. Those frequencies were identified as local natural frequencies for the handrail where MEMS are embedded.
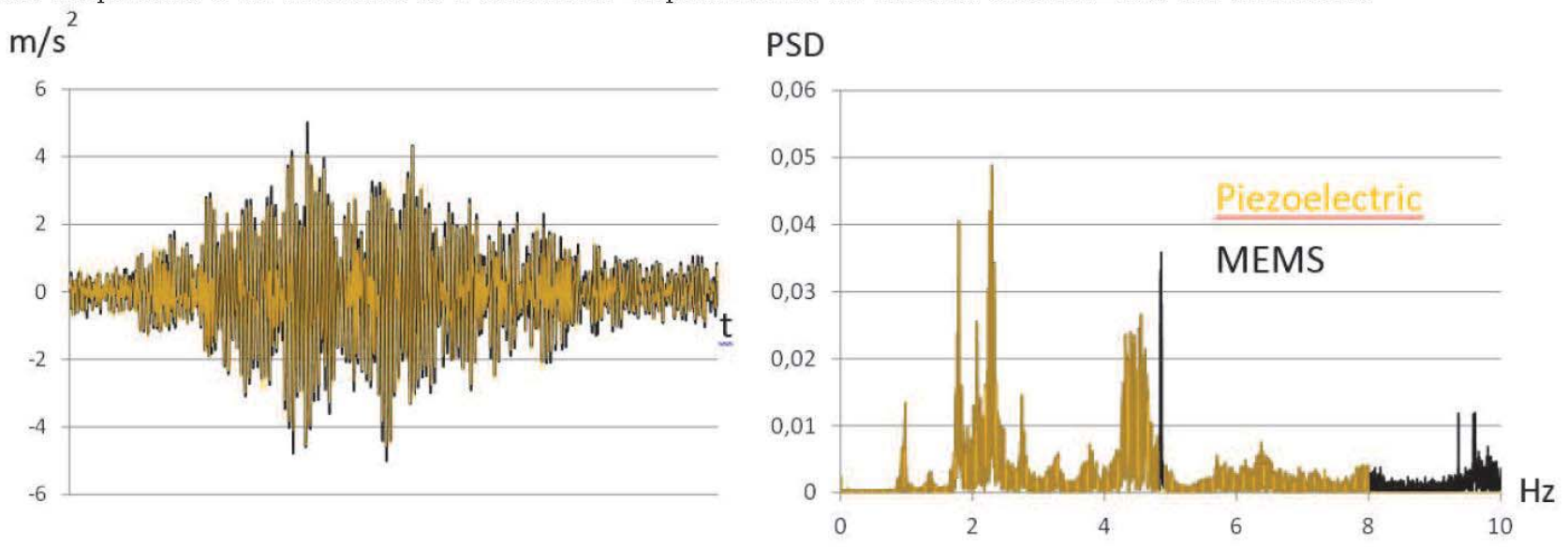

Figure 6. Footbridge response in real loading conditions (according to figure 5) registered with piezoelectric (yellow) and MEMS (black) accelerometers. Left: time domain. Right: frequency domain.

\section{MONitoring RESUlts}

The operation of continuous dynamic monitoring systems leads to the accumulation of a huge amount of data that needs to be processed, analysed and interpreted precisely. Time vertical accelerations $\mathrm{a}_{\mathrm{z}}$, its weighted values $\mathrm{a}_{\mathrm{zw}}$ (according to frequency weighting functions established in ISO 2631 for comfort criteria for standing pedestrian) and the weighted RMS trend (1 s) for three scenarios are presented in figure 7 during $75 \mathrm{~s}$ (averaged time that takes to cross the footbridge). Scenario a) is for no people crossing, b) is for a group of 10 pedestrians and c) is for vandalism bouncing. Mean weighted RMS values are $0.0265,0.145$ and 0.643 respectively.

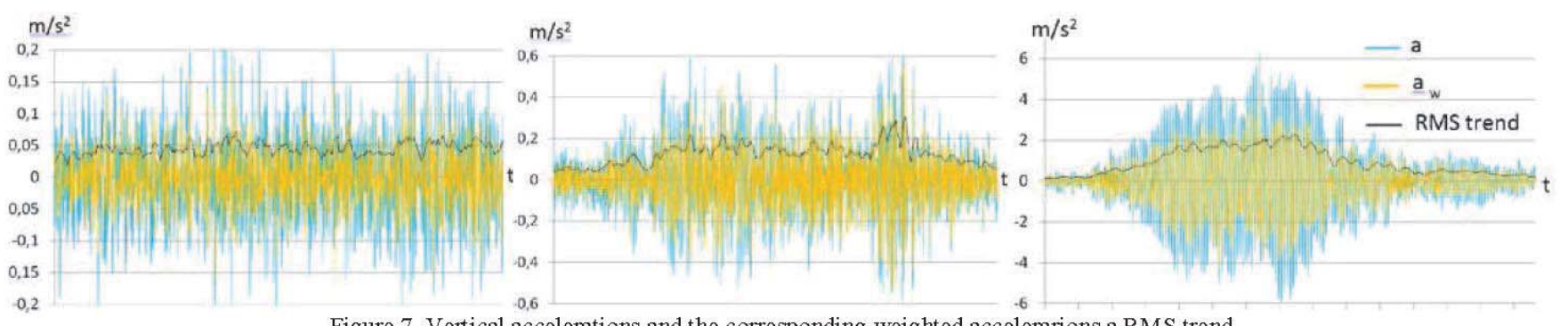

Figure 7. Vertical accelerations and the corresponding weighted accelerarions a RMS trend.

Figure 8 shows, for former scenario $\mathrm{b}$ ), the three components $\mathrm{X}, \mathrm{Y}$ and $\mathrm{Z}$ for the acceleration. Mean RMS values are $0.0191,0.0527$ and $0.173 \mathrm{~m} / \mathrm{s}^{2}$ respectively.

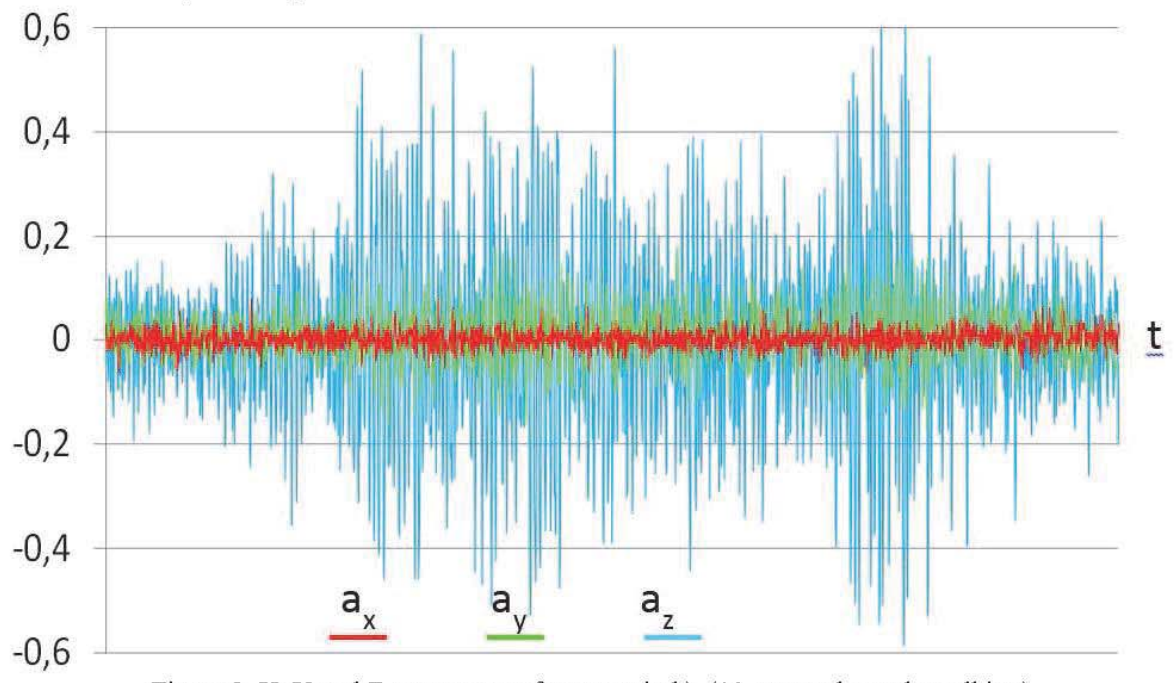

Figure 8. X, Y and Z components for scenario b) (10 grouped people walking) 


\section{POSTPROCESED DATA}

In order to investigate the effect of pedestrians on the response of the lively stress-ribbon footbridge under normal operational conditions, hourly data is processed to get a representative parameter (peak, mean weighted RMS, MTVV, ..) for the whole hour. Figure 9 shows the contribution (in magnitude) of the vertical direction (Z) to the whole acceleration vector (X, Y and Z). These values depend on the position of the accelerometers (from A1 to A9, in the upstream railing), but for all of them is around $60 \%$, both during daylight) and at night hours. During daylight, considered from 8am to $5 \mathrm{pm}$, average use of the footbridge is more than one pedestrian at a time, being $\mathrm{RMS}_{z w}=0.125$. During the night (from $11 \mathrm{pm}$ to $6 \mathrm{am}$ ) the $\mathrm{RMS}_{\mathrm{zw}}$ is only $0.063 \mathrm{~m} / \mathrm{s}^{2}$.

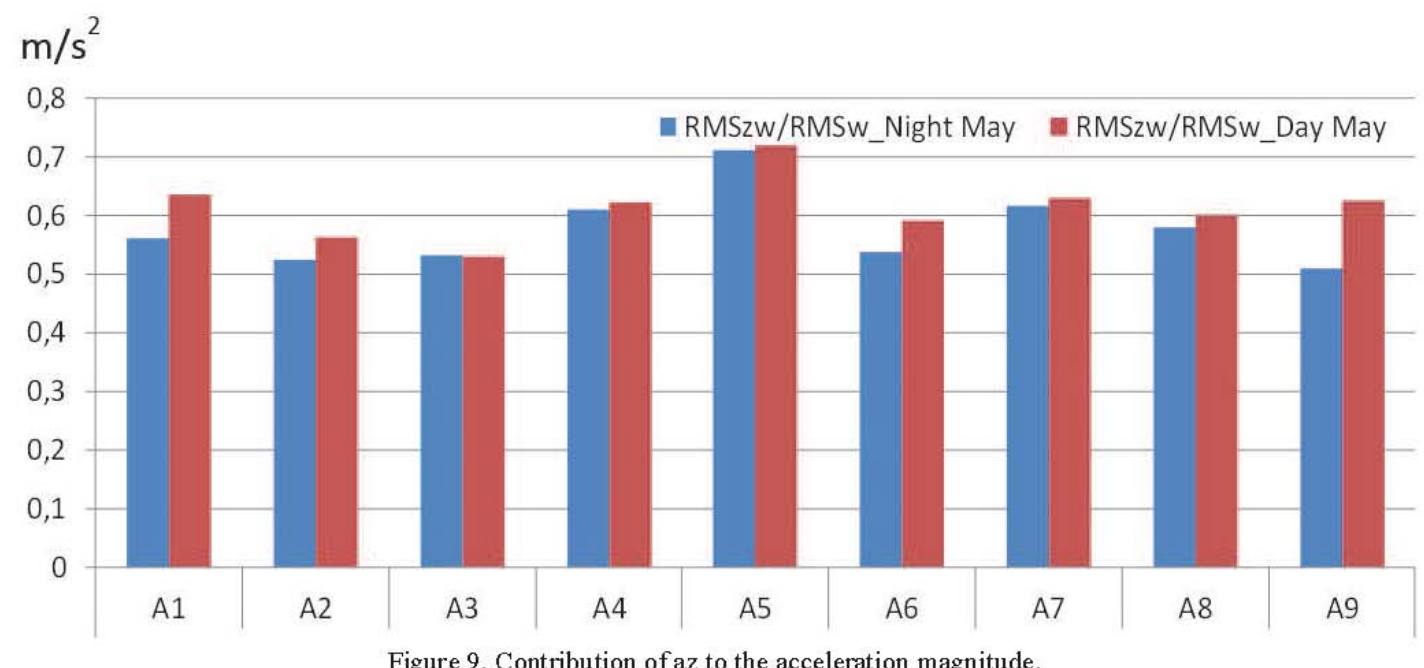

Figure 10 shows hourly parameters (peak, $\mathrm{RMS}_{\mathrm{w}}$ for the 3 axis, $\mathrm{RMS}_{\mathrm{zw}}$ and MTVV) for one selected day (6th May, fig.10a), month (May, fig. 10b) and for the whole year (fig.10c). Some patterns can be observed (mainly day/night use, with maximum values around $9 \mathrm{am}$ and $6 \mathrm{pm}$ and minimum around $3 \mathrm{am}$ ). Presented values are obtained averaging the parameters for the upstream accelerometers (from A1 to A9). Mean values through the year are $0.418 \mathrm{~m} / \mathrm{s}^{2}$ for peak acceleration, $0.0934 \mathrm{~m} / \mathrm{s}^{2}$ for RMS , $0.0532 \mathrm{~m} / \mathrm{s}^{2}$ for $\mathrm{RMS}_{z \mathrm{w}}$ and $0.122 \mathrm{~m} / \mathrm{s}^{2}$ for MTVV.

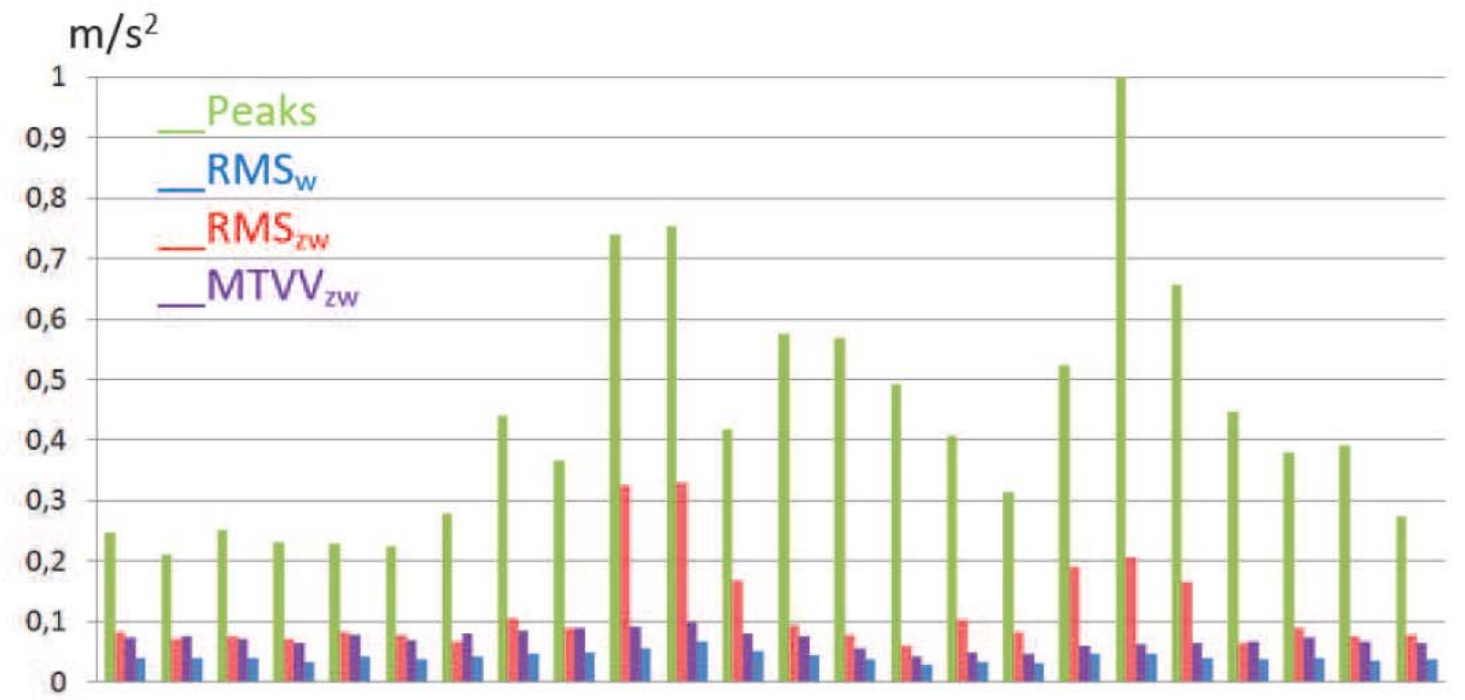

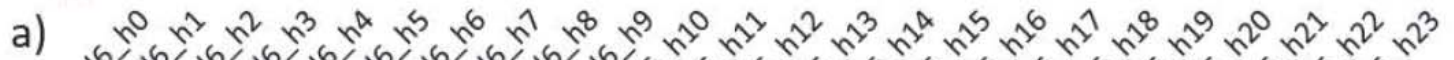

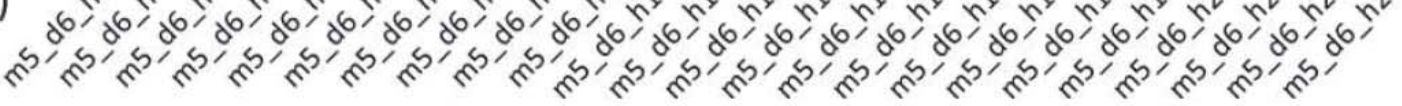




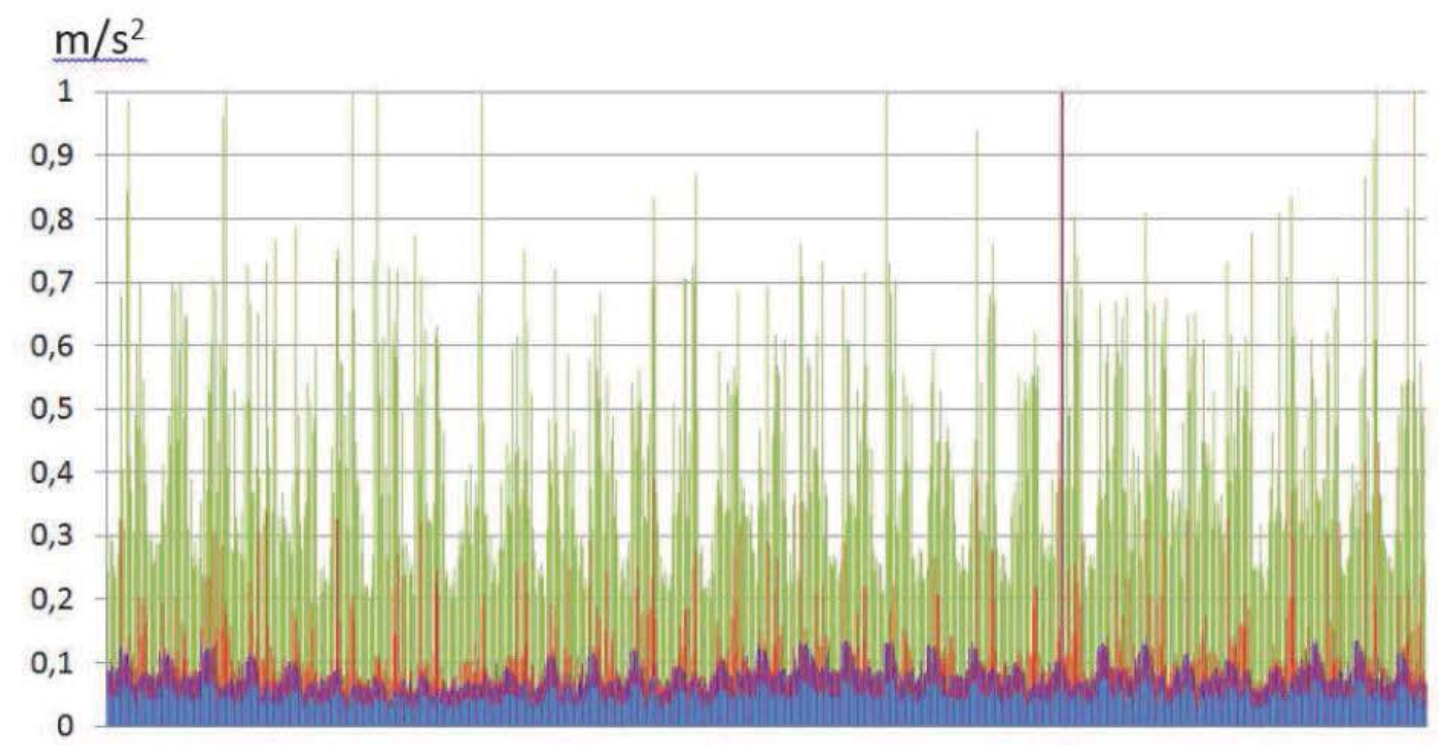

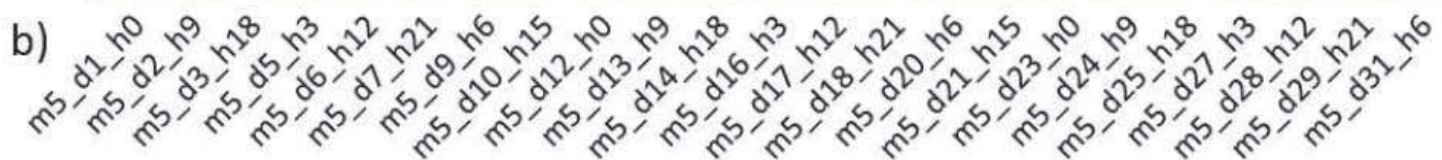

$$
\mathrm{m} / \mathrm{s}^{2}
$$

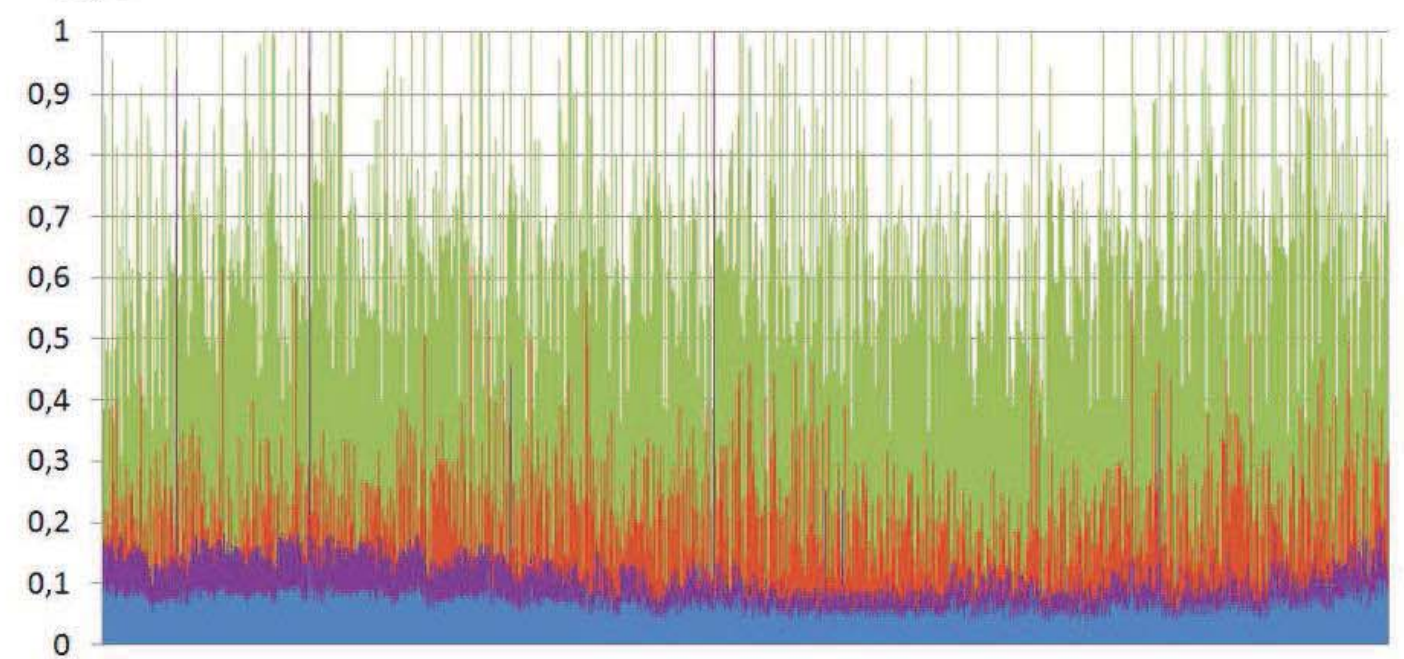

c)

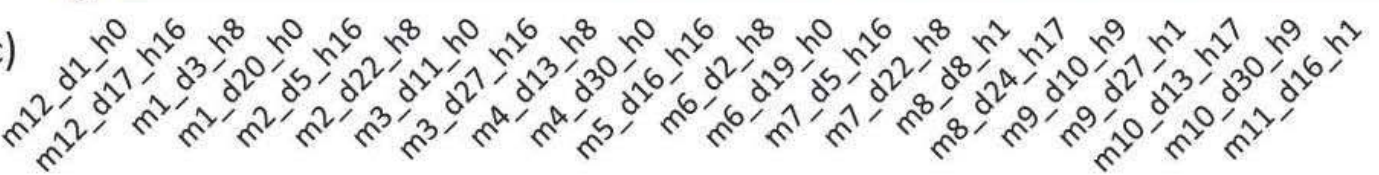

Figure 10-Hourly parameters for a day (a), a month (b) and for the whole year (c)

Counting how many $\mathrm{RMS}_{\mathrm{w}}$ hourly data are inside certain ranges, is easy to determine the percentages shown in figure 11 . ISO 31 , annex C.2.3 establishes comfort reactions to vibration environments for public transport according to the following ranges terms of $\mathrm{RMS}_{\mathrm{w}}$ : Non uncomfortable for less than $0.315 \mathrm{~m} / \mathrm{s}^{2}$, a little uncomfortable between 0.315 and $0.63 \mathrm{~m} / \mathrm{s}^{2}$, fairly comfortable between 0.5 and $1 \mathrm{~m} / \mathrm{s}^{2}$, uncomfortable between 0.8 and $1.6 \mathrm{~m} / \mathrm{s}^{2}$, very uncomfortable between 1.25 and $2.5 \mathrm{~m} / \mathrm{s}^{2}$ d extremely unc omfortable if greater than $2 \mathrm{~m} / \mathrm{s}^{2}$. As no hourly $\mathrm{RMS}_{\mathrm{w}}$ were registered over $1 \mathrm{~m} / \mathrm{s}^{2}$, the three last ranges do not pear in case under study. Additionally, the first range was subdivided in two at $0.15 \mathrm{~m} / \mathrm{s}^{2}$, in order to get more detail information out comfortability. The resultant sub-ranges were classified as almost imperceptible up to $0.15 \mathrm{~m} / \mathrm{s}^{2}$ and noticeable between 15 and $0.315 \mathrm{~m} / \mathrm{s}^{2}$. Note that the footbridge over the months has good serviceability conditions, with most of the time in the non comfortable range. 


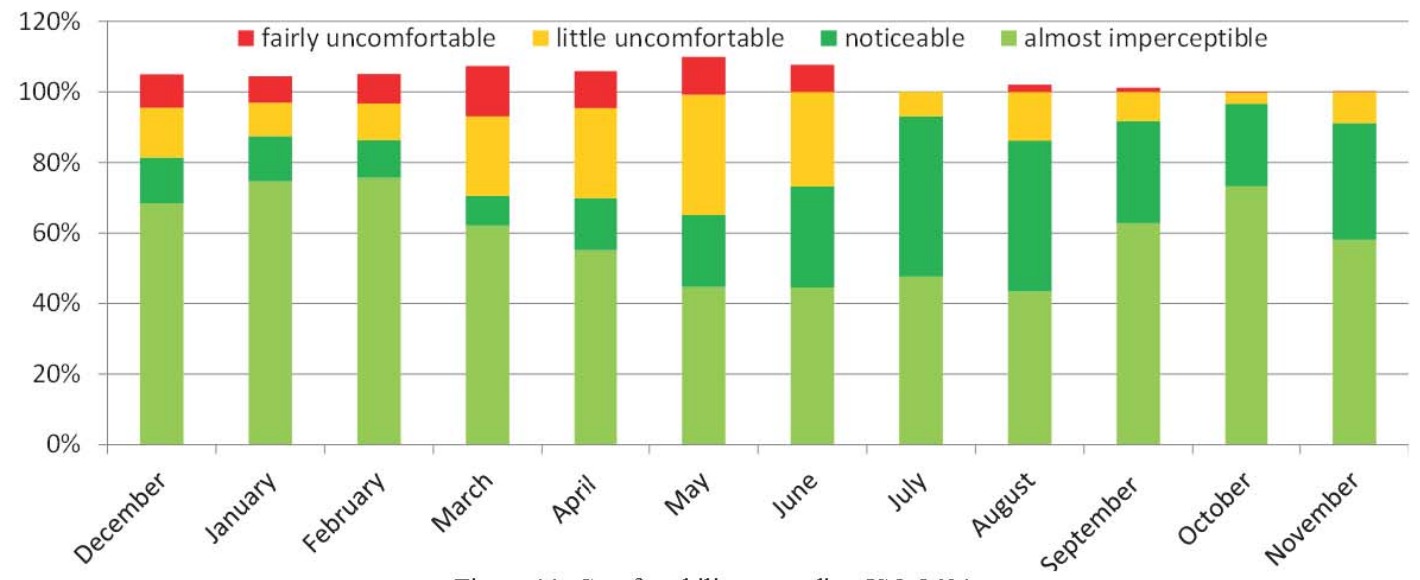

Figure 11. Comfortability according ISO 2631

ISO 2631 recommends the use of the $\mathrm{RMS}_{\mathrm{w}}$ as serviceability parameter only if crest factors are below 6 (annex C.1.1.3) or 9 (part 6.2.2). Crest factor is the ratio between peak value and corresponding $\mathrm{RMS}_{\mathrm{w}}$ during the same time of exposition (one hour has been taken). Figure 12 shows than only around $20 \%$ of the time the crest factor exceeds the threshold of 9 . For this cases, ISO 2631 recommends the use of additional parameters like MTVV or VDV to check serviceability criteria, although no ranges are depicted. Note that hourly MTVV have been already presented in figure 10.

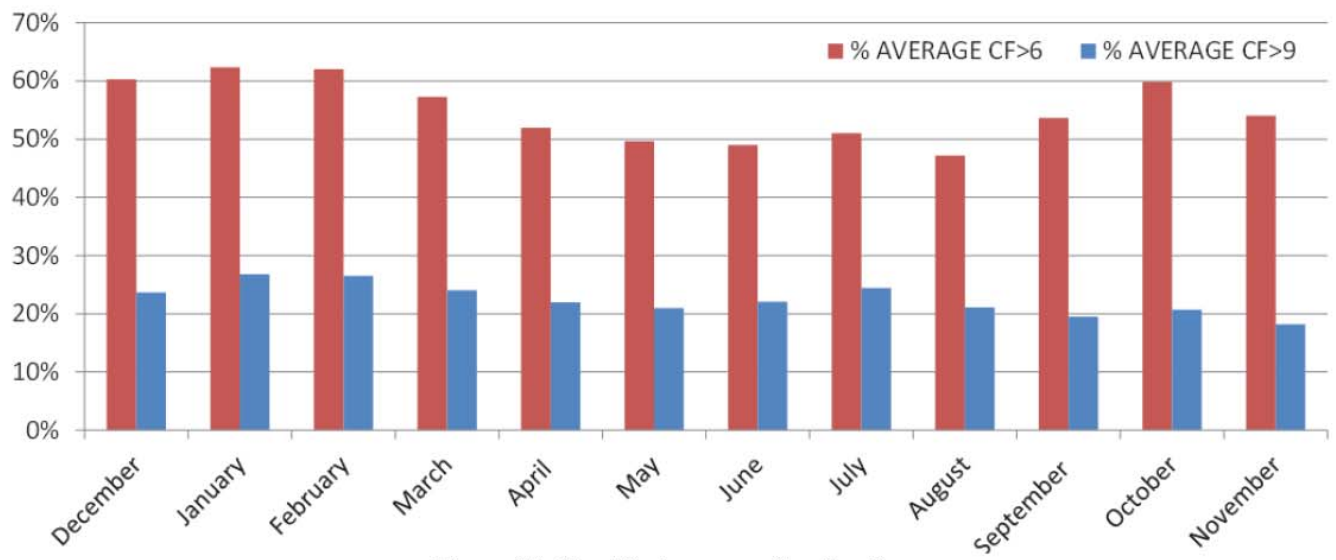

Figure 12. Crest Factor exceeding 6 or 9.

With the same objective of serviceability assessment, response factor is defined as $\mathrm{RMS}_{\mathrm{w}}$ to base curve ratio defined in ISO 10137. The value of $0.005 \mathrm{~m} / \mathrm{s}^{2}$ is the reference (base curve) for vertical movements. Figure 13 shows the percentages for $\mathrm{R}$ factor exceeding 30 and 50 , computed in hourly $\mathrm{RMS}_{\mathrm{w}}$ basis. The values of 30 and 50 are usually considered as reference limits for comfortability. Again the low percentages obtained reveal the footbridge is adequate to the pedestrian use regardless its slenderness.

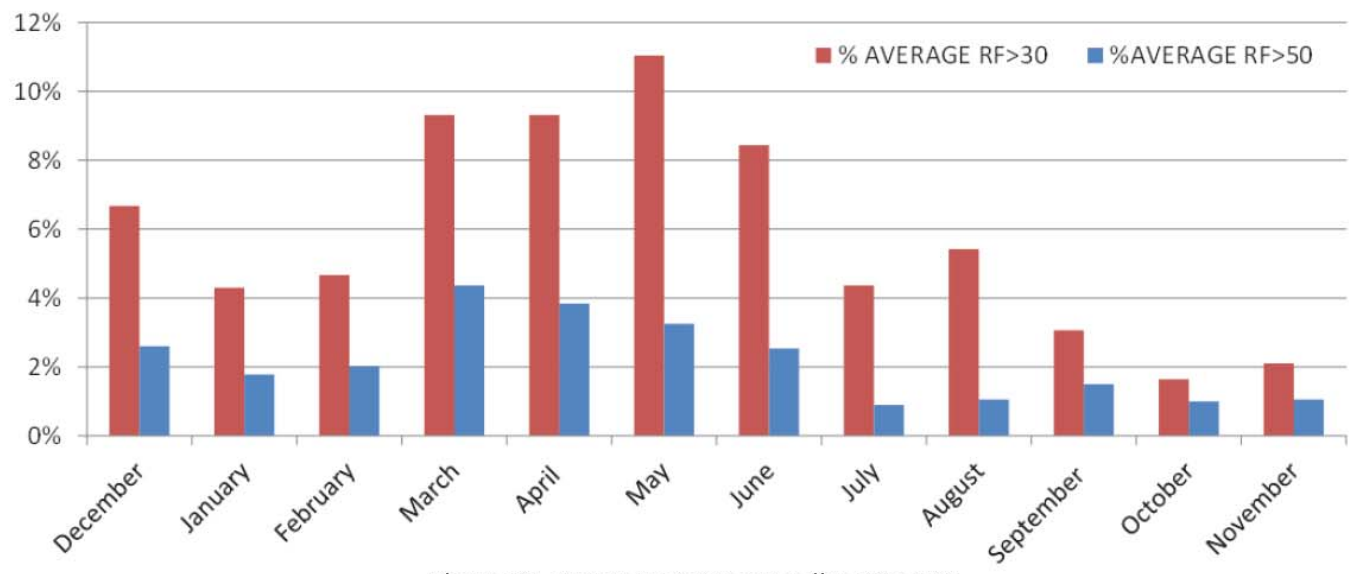

Figure 13. Response Factor exceeding 30 or 50 


\section{MODAL CHARACTERIZATION}

Besides the evaluation of the response as presented in the previous sections, one of the main interest in the monitoring system is the modal characterization at different conditions (temperature, pedestrian use, etc.). For that, several operational modal analysis were performed using different identification techniques. Figure 14 shows modal identification diagram for order 50 and figure 15 presents the first 7 modes obtained for very low occupancy and no wind loading but for different temperatures. Presented values were obtained from more than 50 estimations based on hourly records. Linear regression for all cases was used, with $\mathrm{R}^{2}>0.96$. Handrails are around $4 \mathrm{~m}$ apart, although for graphic reasons in figure 15 the distance taken has been $10 \mathrm{~m}$.

For the modes, the notation used is BZ_i for bending modes in the vertical XZ plane, BY_ i for bending modes in the horizontal $\mathrm{XY}$ plane and TX_i for torsional modes around $\mathrm{X}$ axis. $\mathrm{i}$ the number of antinodes of the corresponding mode. It is interesting to note that the frequency for the BZ 1 mode is higher than the one for BZ 2 .

Generally, for these types of non linear structures, the frequency decreases when the temperature increases, but not a similar trend is evidenced for all the modes as seen in table 1. Surprisingly, frequency for BZ_1 mode increases with the temperature.

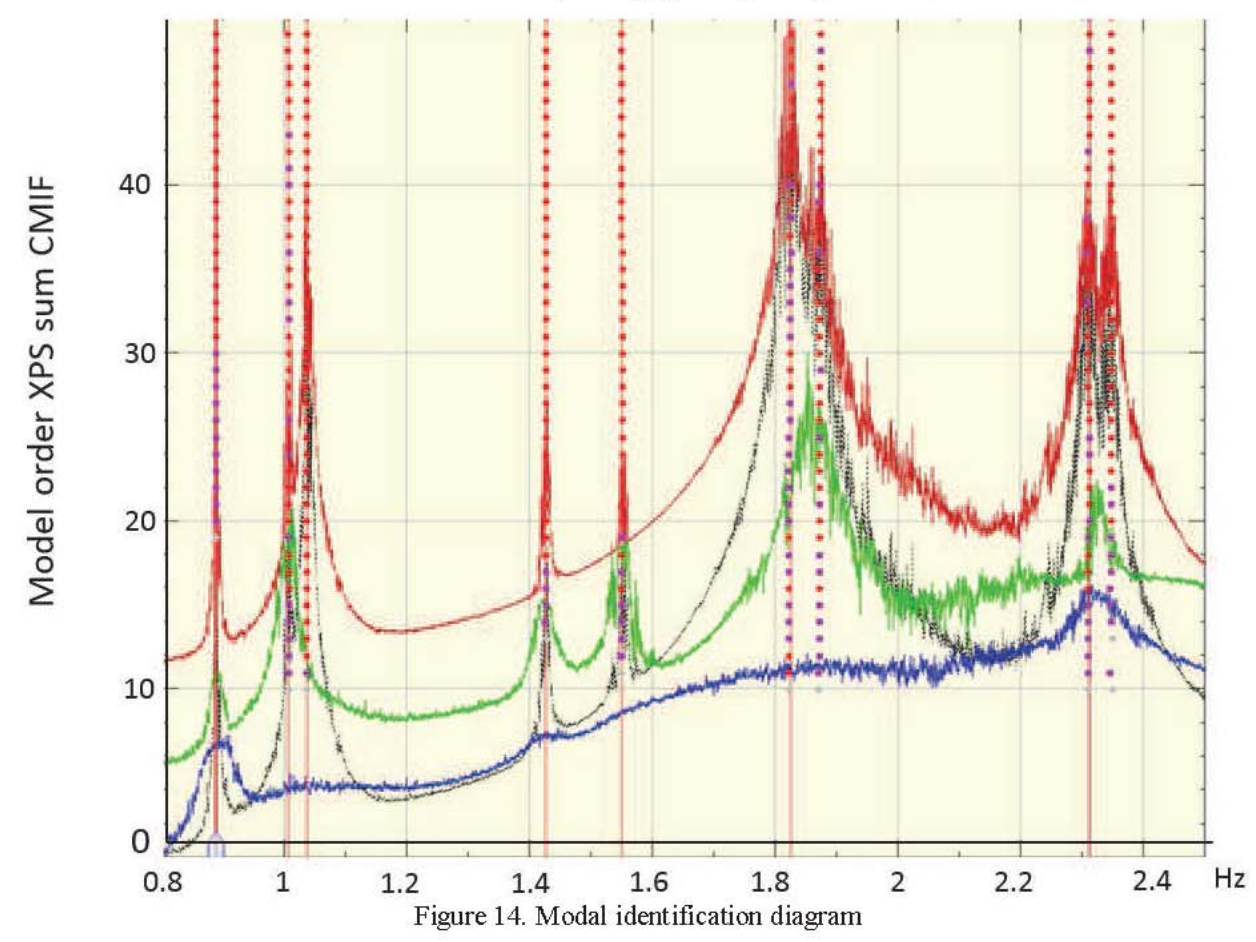

TABLE 1. EXPERIMENTAL VALUES OF DAMPING AND FREQUENCY FOR THE SEVEN FIRST MODES AND THEIR CHANGE WITH THE TEMPERATURE

\begin{tabular}{|c|c|c|c|c|c|c|c|}
\hline & \multirow[b]{2}{*}{ Damping\% } & \multicolumn{4}{|c|}{ Frequency (Hz) } & \multicolumn{2}{|c|}{ Frequency change (\%) } \\
\hline & & $59 \mathrm{C}$ & $209 \mathrm{C}$ & $35 \circ \mathrm{C}$ & average & $\%(5 \circ \mathrm{C})$ & $\%(35 \div \mathrm{C})$ \\
\hline BZ_2 & 0,18 & 0,895 & 0,868 & 0,840 & 0,868 & $3,1 \%$ & $-3,2 \%$ \\
\hline BZ_1 & 0,18 & 0,980 & 1,020 & 1,050 & 1,017 & $-3,9 \%$ & $2,9 \%$ \\
\hline$\overline{B Z} \_3$ & 0,23 & 1,436 & 1,410 & 1,390 & 1,412 & $1,8 \%$ & $-1,4 \%$ \\
\hline BY_2+TX_2 & 0,33 & 1,540 & 1,530 & 1,520 & 1,530 & $0,7 \%$ & $-0,7 \%$ \\
\hline BZ_ 4 & 0,14 & 1,840 & 1,780 & 1,730 & 1,783 & $3,4 \%$ & $-2,8 \%$ \\
\hline BY $3+T_{1} 3$ & 0,13 & 2,310 & 2,230 & 2,150 & 2,230 & $3,6 \%$ & $-3,6 \%$ \\
\hline
\end{tabular}

\section{CONCLUSIONS}

This paper has presented the development and installation of a remotely control continuous vibration monitoring system on a stress-ribbon footbridge. The monitoring system is based on the use of new low-cost MEMS acceleration sensors. The monitoring system was validated by comparing the response measured by the MEMS devices with conventional piezoelectric accelerometers mounted in a portable system. These tests demonstrated that these sensors are a competitive alternative to traditional ones (and much cheaper).

Preliminary postprocesing and serviceability analysis has been presented together with modal identification for the first seven modes and their dependence on the temperature. The next objective is to implement an automated operational modal analysis in order to analyse the changes on the modal properties along the time. The influence of environmental factors (including wind) and pedestrian traffic density will be analysed in order to remove these effects from the modal properties. Thus, such modal properties may be used for structural damage detection. 


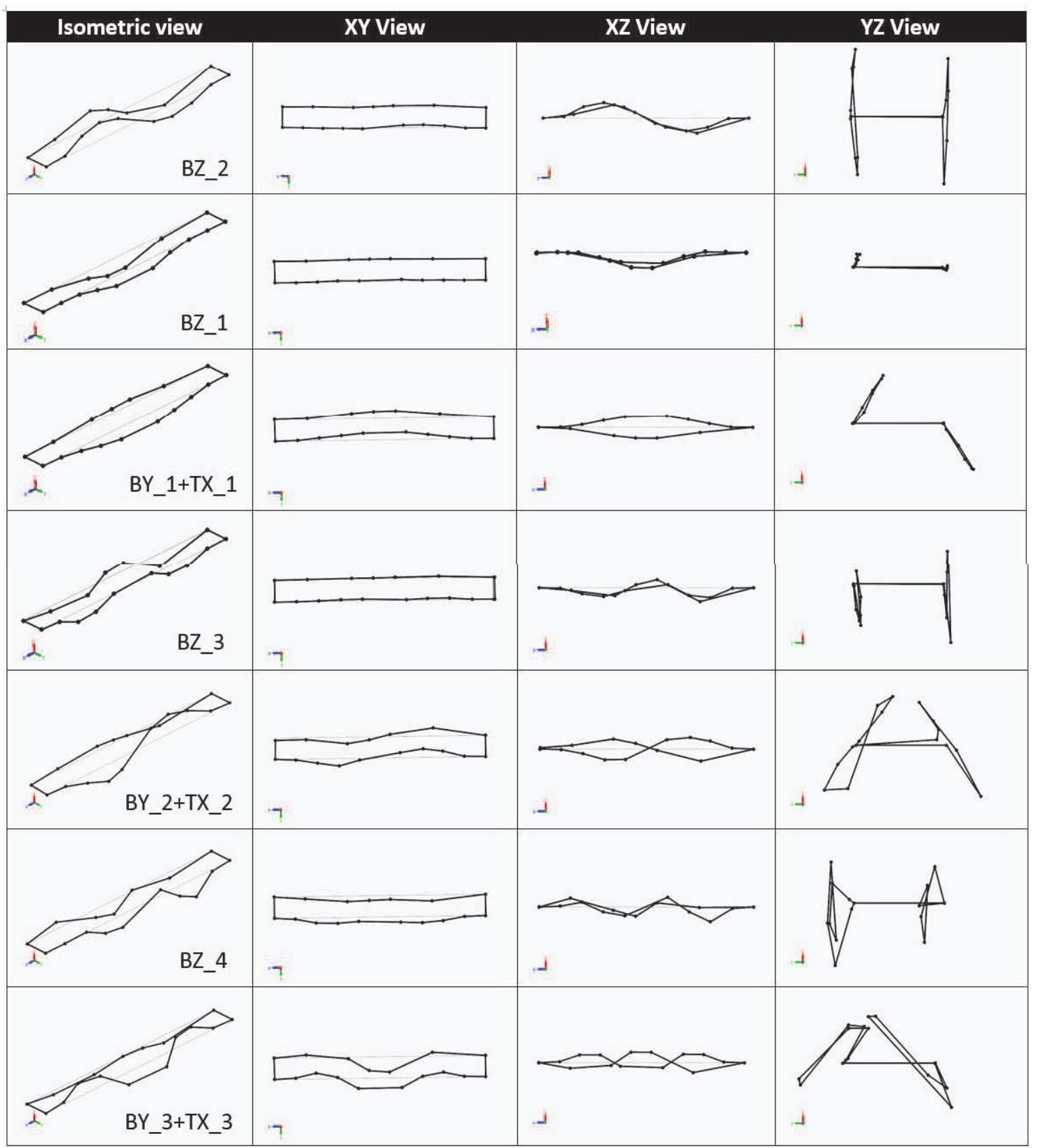

Figure 15. First seven vertical, transversal and torsional mode shapes

\section{ACKNOWLEDGMENT}

This work has been partially funded by the Spanish Government Research Program with the Grant BIA2011-28493.

\section{REFERENCES}

[1] H. C. Gomez, P. J. Fanning, M. Q. Feng, S. Lee. Testing and long-term monitoring of a curved concrete box girder bridge. Engineering Structures, $33,2861-2869,2011$

[2] W.H. Hu, E. Caetano, and A. Cuhna, "Structural health monitoring of a stress-ribbon footbridge," Eng. Struct., vol. 47, pp. 578-593, 2012.

[3] P. Moser, B. Moaveni. Design and Deployment of a Continuous Monitoring System for the Dowling Hall Footbridge. Experimental Techniques, 37 , $15-26,2013$.

[4] J.P. Ou, H. Li, Y. Yu. Development and performance of wireless sensor network for structural health monitoring. Proceedings of SPIE 11th Annual International Symposium on Smart Structures and Materials, 5391, 765-773, 2004.

[5] J. de Sebastián, A. Escudero, R. Arnaz, I.M. Díaz, A. Poncela, and A. Lorenzana, "A low-cost vibration monitoring system for a stress-ribbon footbridge," in 6th ECCOMAS Conference on Smart Structures and Materials, 2013.

[6] M. Shinozuka, M. Q. Feng, P. Chou, Y. Chen, C. Park. MEMS-based wireless real-time health monitoring of bridges. 3rd International Conference on Earthquake Engineering, 2004.

[7] B. F. Jr. Spencer, M. E. Ruiz-Sandoval, N. Kurata, Smart sensing technology: opportunities and challenges, Structural Control and Health Monitoring. $11,349-368,2004$. 
VIBRATION MONITORING OF A STEEL-PLATED STRESS-RIBBON FOOTBRIDGE: EFFECTS OF ENVIRONMENTAL AND OPERATIONAL FACTORS ON MODAL PROPERTIES

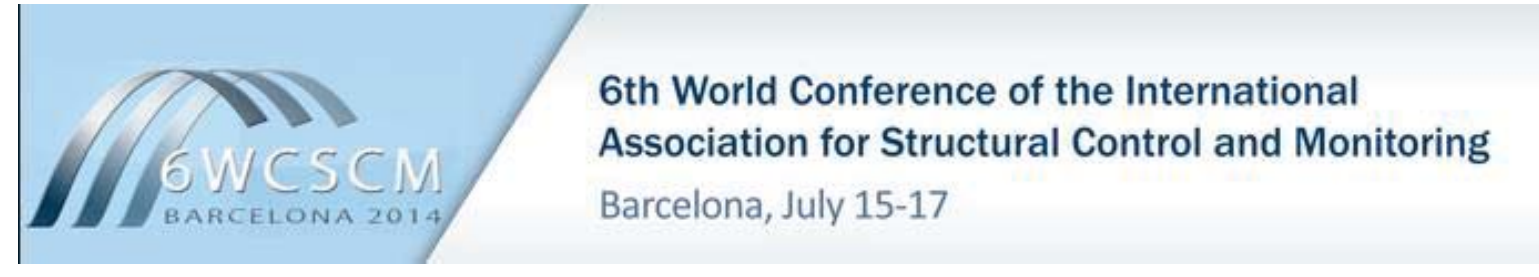

Iván Muñoz Díaz; José Manuel Soria Herrera; Norberto Ibán Lorenzana; Mariano Cacho Pérez; Jaime García Palacios.

\begin{tabular}{l|c|c|c|} 
Aportaciones: & Experimentación & Procesado & Edición \\
\hline \multirow{2}{*}{ Instalación } & Matlab & Tablas \\
& Instrumentación & Excel & Gráficas \\
\cline { 2 - 4 }
\end{tabular}




\title{
Vibration Monitoring of a Steel-plated Stress-ribbon Footbridge: Effects of Environmental and Operational Factors on Modal Properties
}

\author{
Iván M. Díaz, José M. Soria, Norberto Ibán, Mariano Cacho Pérez, Jaime García-Palacios
}

\begin{abstract}
A low-cost vibration monitoring system has been installed on an as-built steel-plated stress-ribbon footbridge sited in Valladolid (Spain). This system measures continuously: the acceleration (using 18 triaxial MEMS accelerometers distributed along the structure), the ambient temperature and the wind velocity and direction. Automated output-only modal parameter estimation is carried out in order to extract the modal parameters, i.e., the natural frequencies, damping ratios and modal shapes. Thus, the modal parameters are statistically correlated with the environmental (temperature and wind) and operational (vibration level) factors. The correlates obtained enables to remove the influence of these spurious factors on modal estimates. This point is of vital importance in the implementation of a structural health monitoring system which uses the modal parameters as damage-sensitive features since these spurious factors may mask subtle damages.
\end{abstract}

\section{INTRODUCTION}

The long-term vibration monitoring of civil engineering structures is increasingly used to monitor both the structure integrity and the vibration serviceability. A number of examples of bridges and footbridges equipped with a monitoring system can be found [1], [2]. In order to assess the structural integrity, vibration-based structural health monitoring systems using output-only modal estimation techniques are usually proposed [3], [4]. These systems have to cope with changing environmental conditions that might mask important changes of meaningful features for damage detection. Thus, the removal of spurious factors on meaningful features is of vital importance in the implementation of a structural health monitoring system which uses modal parameters as damage-sensitive features since these factors may mask subtle damage.

The main problem for wide spreading the use of monitoring systems is the cost associated to the installation of the measuring system. Recently, a successful attempt of reducing cost of monitoring systems has been carried out by the authors through the use of low-cost MEMS accelerometers to measure structural vibrations. Thus, a new low-cost continuous vibration monitoring system using MEMS-based accelerometers has been developed and installed on Pedro Gómez Bosque footbridge (PGB) (Valladolid, Spain). Thus, this system measures continuously: the acceleration (using 18 triaxial MEMS accelerometers distributed along the structure), the ambient temperature and the wind velocity and direction [5]. PGB footbridge is a singular steel-plated stress-ribbon footbridge with one span of $85 \mathrm{~m}$ that provides minimal visual impact on the surroundings [6]. This is a slender and lightweight structure born by a pre-tensioned catenary-shape steel band. Its dynamic behaviour is quite complicated showing lateral, torsional and vertical modes, low natural frequencies and low damping ratios, which might lead to excessive human and wind-induced vibrations (and might compromise the vibration serviceability limit state).

Automated output-only modal parameter estimation has been carried out using the Stochastic Subspace Identification (SSI) based on the covariance-driven method in order to extract the modal parameters, i.e., the natural frequencies, damping ratios and modal shapes [7]. Thus, the objective of this work is to analyse the influence of the environmental (temperature and wind velocity) and operation (vibration level) factors on the modal parameter estimates. A raw data coming from the developed monitoring system has been processed and preliminary analyses have been carried out. More concretely, the multiple linear regression (MLR) method has been used to correlate natural frequency estimates and the ambient temperature, as well as averaged vibration levels. The obtained results reveal that temperature has a significant effect on the variation of frequencies for this particular structure. However, the influence of vibration level is not as clear as the temperature but its influence is also significant. Moreover, it has been shown that wind velocity does not influence significantly any of the modal parameters. The correlates obtained have enabled to mitigate their influences on modal estimates. Thus, it has been shown that modal estimates after the removal of environmental/operational effects do not shown any clear dependency.

The paper continues with the description of the structure and its monitoring system. The influence of environmental/operational factors on the modal estimates for a set of tests and the proposed procedure to remove their

Iván M. Díaz is with the Department of Continuum Mechanics and Theory of Structures, E.T.S de Ingenieros de Caminos, Universidad Politécnica de Madrid, ES 28040, Madrid, Spain (corresponding au thor to provide phone: +34 9133667 00, ext. 14; e-mail: ivan.munoz@upm.es).

José Manuel Soria is a master's student of Structural Engineering at E.T.S de Ingenieros de Caminos, Universidad Politécnica de Madrid, ES 28040, Madrid, Spain (e-mail: jm.soria@alumnos.upm.es)

Norberto Ibán is with Cartif Research Centre, Boecillo (Valladolid), Spain (e-mail: noriba@cartif.es).

Mariano Cacho Perez is with the Escuela de Ingenierías Industriales, Universidad de Valladolid, Spain (e-mails: cacho@eii.uva.es).

Jaime García Palacios is with the Department of Hydraulic and Energy Engineering, E.T.S de Ingenieros de Caminos, Universidad Politécnica de Madrid, ES 28040, Madrid, Spain (e-mail: jaime.garcia.palacios@upm.es). 
influences are described in Section III. In Section IV, the correlation analysis for the same set of tests and the removal of environmental/operational effects are carried out. Finally, some conclusions are drawn and suggestion for future work are given.

\section{VIBRATION MONITORING OF PEDRo GÓMEZ BOSQUE FOOTBRIDGE}

\section{A. Structure description}

PGB footbridge, sited in Valladolid (Spain), is a slender and lightweight structure that creates a pedestrian link over the Pisuerga River between a sport complex and the city centre (Fig. 1). This bridge, built in 2011, is a singular stress-ribbon footbridge with only one span of $85 \mathrm{~m}$ that provides minimal impact on the surroundings. The structure mainly consists of a Corten steel sheet of $94 \mathrm{~m}$ long, $3.6 \mathrm{~m}$ width and only $30 \mathrm{~mm}$ thick which is pre-tensioned and anchored to the two abutments. The complete steel sheet is fabricated by welding 8-meter long sheets. A number of 110 precast concrete slabs of $5.2 \mathrm{~m}$ long, $0.75 \mathrm{~m}$ width and around $120 \mathrm{~mm}$ thick lay on the steel sheet [6]. These slabs do not have bearing mission in such a way that the only structural element is the steel sheet. The structure is completed by rubber flooring and a stainless steel glass handrail.

\section{B. Monitoring system}

A structural vibration monitoring system was devised in order to continuously estimate the modal parameters of the structure and be able to assess their changes under varying environmental conditions [5]. Therefore, apart from the accelerometers needed to perform a modal analysis, sensors for the wind and environmental temperature conditions were installed. The monitoring system comprises 18 triaxial accelerometers, 9 at each side of the deck, a temperature sensor and an anemometer and vane, summing thus 57 continuous measuring channels (see Fig. 2). The accelerometers were positioned equidistant along the span. Wires and acceleration sensors were installed inside the handrail so the structure aesthetic was not modified in any way. This fact introduced additional complications: i) the installation process was a laborious task, and ii) additional angular transformations are required to obtain the acceleration vector in the structure axes for each accelerometer.

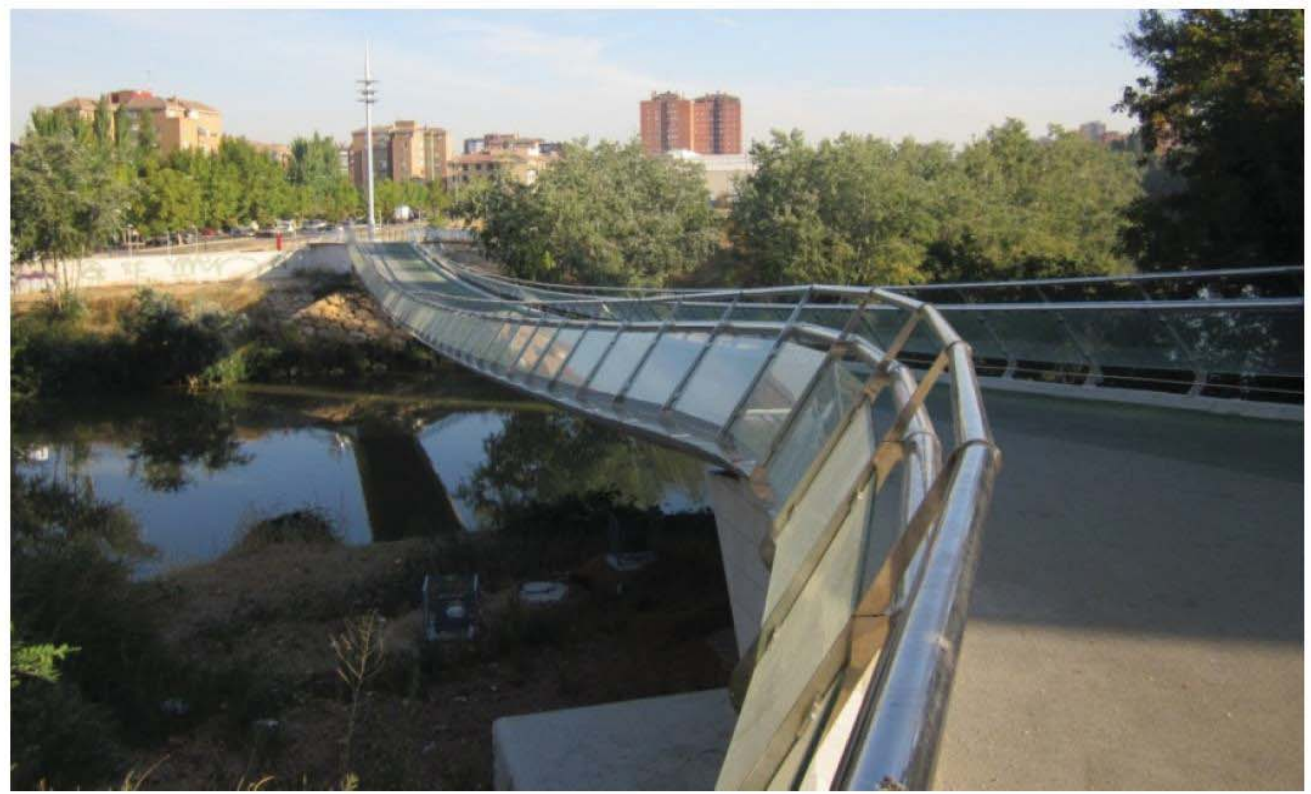

(a) Pedestrian view at the footbridge entry

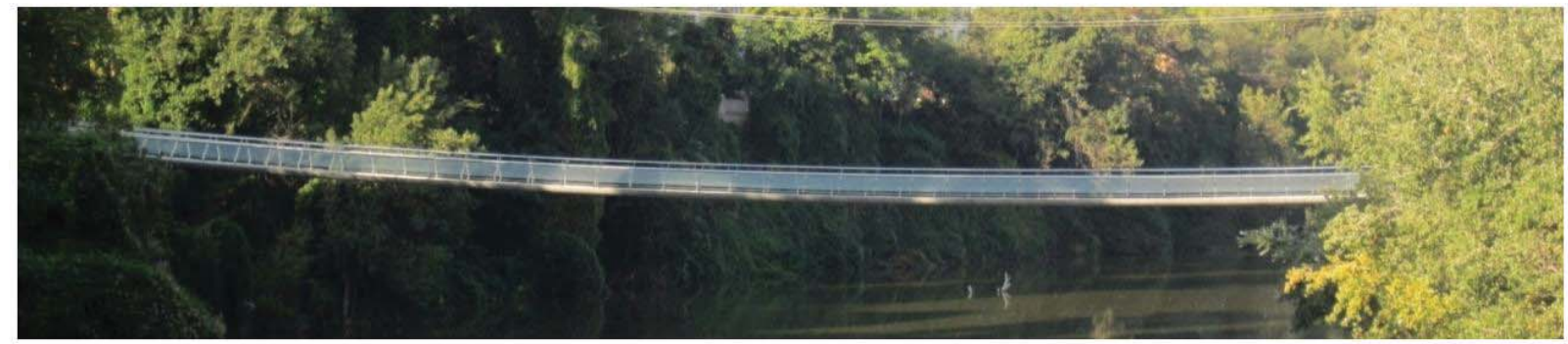

(b) Landscape view

Figure 1. Pedro Gómez Bosque Footbridge. 
The vibration sensor used for the monitoring system was the low-cost MEMS accelerometer ADXL327 (ANALOG DEVICES) able to measure the static acceleration of gravity. The key properties of this sensor are: measurement range up to \pm $2.5 \mathrm{~g}$, sensitivity up to $500 \mathrm{mV} / \mathrm{g}$ and bandwidth up to $550 \mathrm{~Hz}$. However, this sensor is not designed to transmit the signal over long distances. An ad hoc conditioning circuit was design to enhance its long-distance performance. The achieved signal-tonoise ratio was $25 \mu \mathrm{g} / \mathrm{VHz}$, which was considered to be enough for monitoring the structural vibrations. Finally, the sensing system was completed by a temperature sensor (model T0110 transmitter of Comet) and a wind sentry (model 03002L of R.M. Young Company) to measure the speed and direction of the wind.

The monitoring system then comprises 57 voltage channels that are processed continuously. The data logger CompactRIO 9076 (National Instruments) with two NI 9205 with 32 analog input channels are used for real-time data acquisition. The frequency sampling for each channel was chosen to be $200 \mathrm{~Hz}$, enough to identify the modal parameters of the structure and to avoid aliasing problems during the post-processing. A file with the recorded data is created each hour.

The actual orientation of the accelerometer installed inside the handrail is unknown. However, taking into account the following (see Fig. 3): (i) the longitudinal axis of each accelerometer (x) matches with the longitudinal axis of the footbridge, and (ii) the accelerometers are able to measure from $0 \mathrm{~Hz}$ (gravity acceleration), the Euler angles between the accelerometer coordinate system and the structure coordinate system can be calculated. Then, the transformation matrix between both coordinate systems is obtained, and then, the acceleration in the absolute axes can be finally calculated.

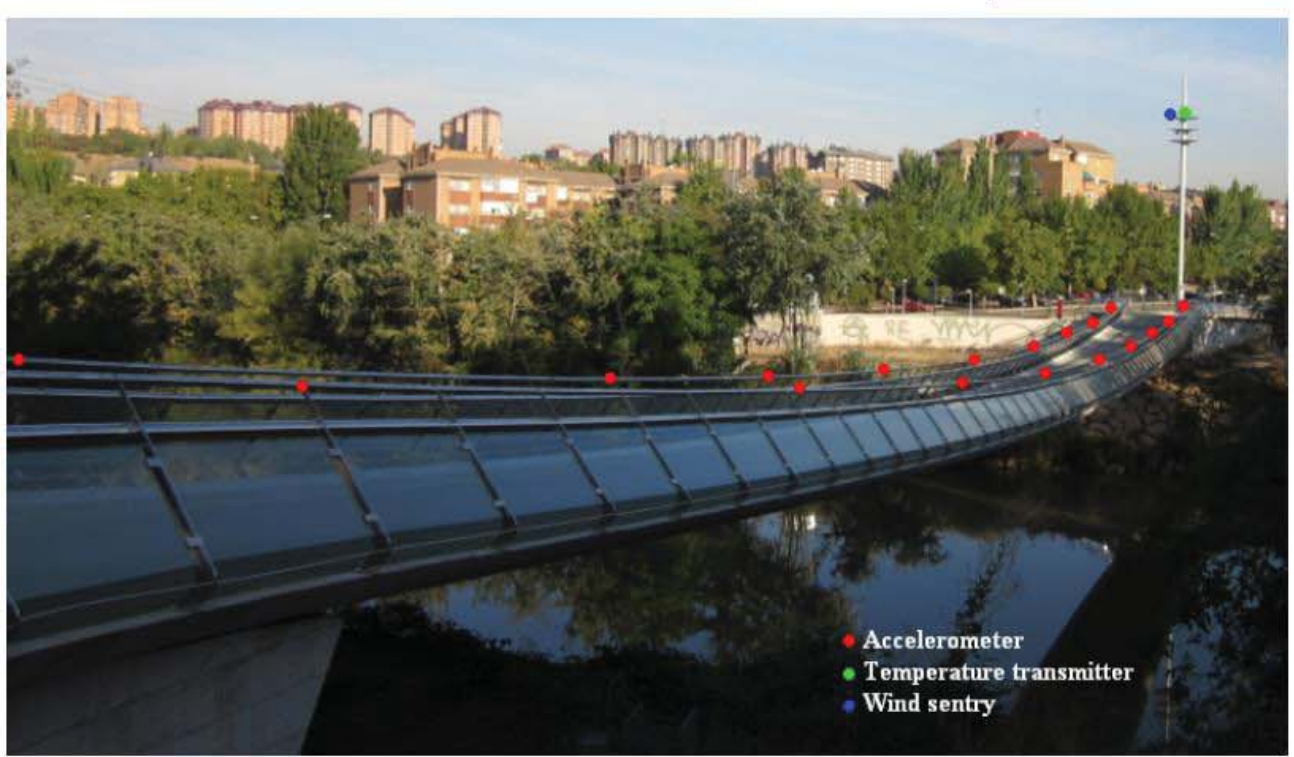

Figure 2. Sensors distribution on the structure.

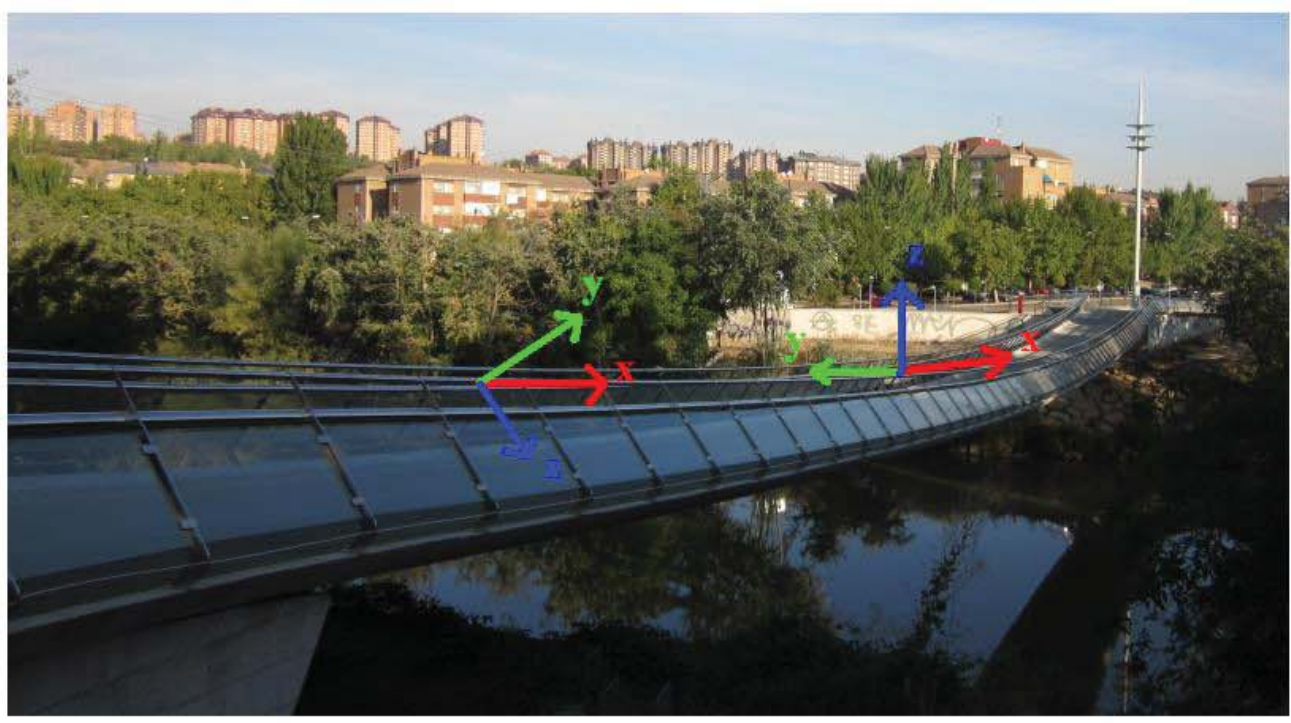

Figure 3. Accelerometer axes and structure axes. 


\section{ENVIRONMENTAL AND OPERATIONAL EFFECTS ONMODAL PROPERTIES}

The procedure to analyse data and remove spurious effects is described in this Section and some plots are shown to illustrate these effects.

\section{A. Continuous modal identification}

From the acquired data, an automated output-only modal analysis, usually known as operational modal analysis (OMA), has been implemented in order to estimate the natural frequencies, damping ratios and modal shapes. The OMA is carried out using the covariance-driven SSI [7] that has been implemented in MATLAB. SSI is generally considered to be most powerful class of the known identification techniques for natural input modal analysis in the time domain.

The method carried out to remove the environmental/operational effects is depicted in Fig. 4 . The procedure can be divided into the following steps:

- $\quad$ Take the last $N$ tests, $N$ being the number of tests. $N$ should be representative of the variability of the modal estimates.

- For each $i$ test, the OMA is carried out. Thus, a number of modes for each $i$ test are identified, denoted as $r_{i}$. Preprocessing parameters and OMA parameters have to be adequately taken to obtain the $r_{i}$ estimates.

- Determine the vibration modes that are identified for a maximum number of tests, i.e., the vibration modes that become apparent from more tests are detected. To carry out this step, the modal assurance criterion (MAC) is used. A matrix of MAC for all of $r_{i}$ estimates for each test of the total $N$ tests. That is, a number of $\left[\sum_{i=1}^{N} r_{i}\right]$ estimates are compared using MAC. Thus, through the matrix of MAC is possible to identify those modes that are more repeated along the $N$ tests. Three tolerances have been defined for this purpose:

- The first one is the MAC value that allows to group estimates corresponding to the same vibration mode. The number of coincidences is the number of estimates of each group.

- The second one is included in order to reject modes are not repeated sufficiently to be considered as significant modes. The, groups with low number of coincidences are automatically rejected.

- The third one is finally included to detect groups of estimates that are actually estimation of the same mode. Then, if more than one group correspond to the estimation of the same mode of vibration, the one with a maximum number of coincidences is taken.

- From above procedure, the most significant modes of the dynamic response of the structure are detected for the $N$ tests.

- Variations of these selected modes are studied using a statistical model in order to make modal parameters independent of environmental/operational factors. Thus, corrected modal parameters are derived.

- The statistical model used, obtained through a MLR, consists of fitting linearly independent nonlinear variables (that are function of environmental/operational measurements). The independent variables have been selected according to its statistical relevance. The independent variables are generally considered as function of the ambient temperature, structure acceleration and wind speed.

In the case of PGB footbridge monitoring system, the acquisition time taken for the OMA is 1 hour (with an initial sampling frequency of $200 \mathrm{~Hz}$ ). Before the identification, a digital low-pass filter at $5.6 \mathrm{~Hz}$ and a decimation with a factor of 16 are applied to the raw data in order to make the modal identification more accurate in the frequency range of $0-5 \mathrm{~Hz}$. Several vibration modes with natural frequencies below $5 \mathrm{~Hz}$ are successfully identified.

$N=744$ is the number of tests taken for the month of May 2013. Note that the repeatability of modes with more coincidences is lower than this value. This is due to the fact that a number of tests are performed under very low vibration amplitude conditions (mainly at night) leading to un-sense estimates that, obviously, cannot be considered within the analysis.

Table I shows the results obtained from running the procedure of Fig. 4 for $N$ test. The mode with a natural frequency of $1.758 \mathrm{~Hz}$ will be identified as Mode 1 and the one at $3.971 \mathrm{~Hz}$ as Mode 2 from now on. The influence of environmental/operational factors on these modes is analysed here. 


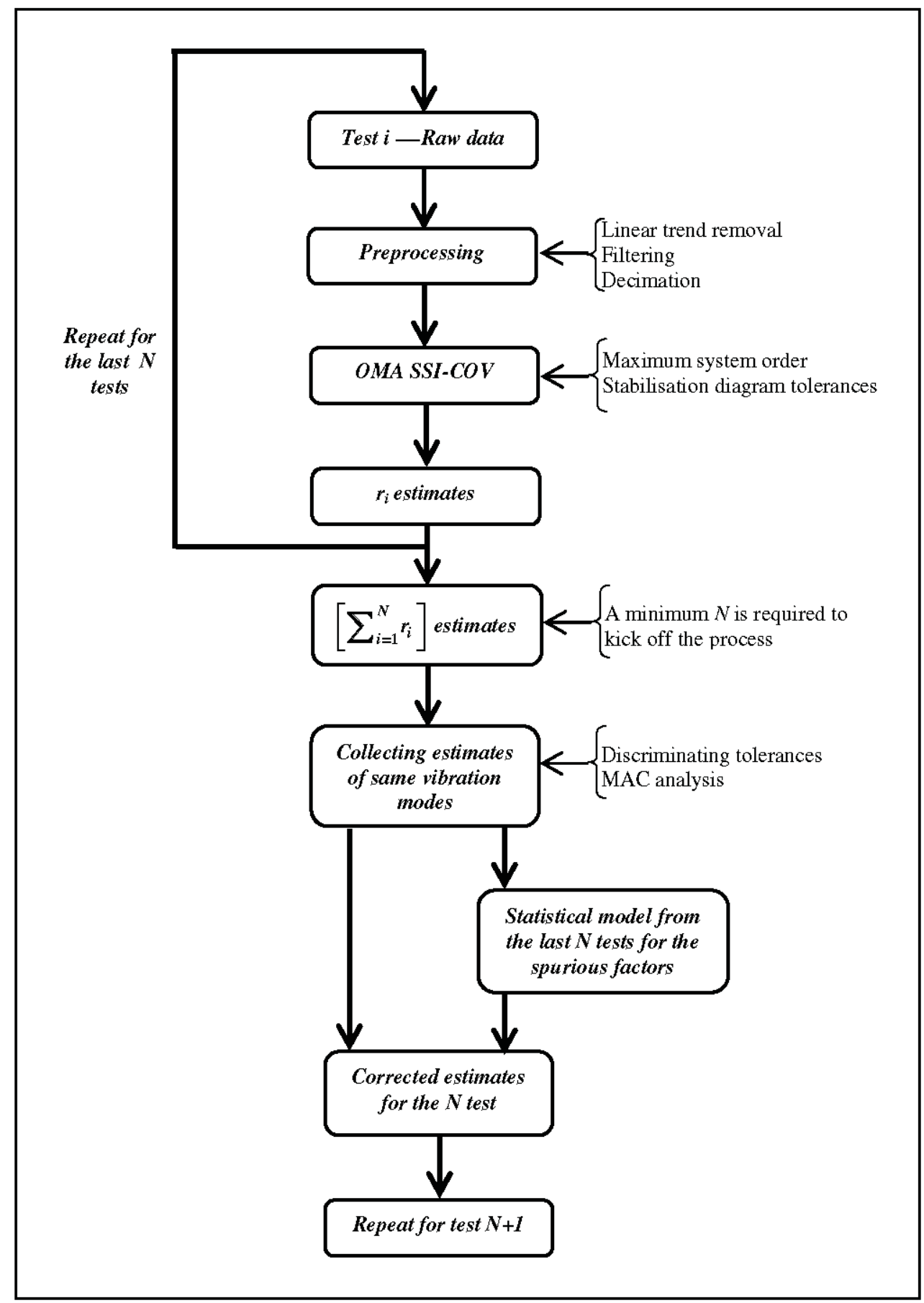

Figure 4. Modal estimation correction based on a moving statistical model.

\section{B. Effects of temperature}

For this structure type, the temperature is usually the main spurious factor. Fig. 5 shows the frequency estimates for Mode 1 and 2 and the temperature measurements for the period considered. It is clear that both natural frequencies oscillate mainly due to the variation of temperature. It is also observed that as temperature decreases, the identified frequency decreases. Note that this is the expected trend for vertical modes of a catenary-shape structure [9]. Fig. 6 shows the frequency estimates versus the temperature of the tests. A mainly linear trend is observed for both modes. 
TABLE I. MODAL PARAMETER ESTIMATION REPEATABILITY FOR $N=744$ TESTS

\begin{tabular}{|c|c|c|}
\hline $\begin{array}{c}\text { Repeatability (number } \\
\text { of coincidences) }\end{array}$ & Frequency $(\mathrm{Hz})$ & Damping ratio $(\%)$ \\
\hline 237 & 1.064 & 0.301 \\
\hline 307 & 1.407 & 0.292 \\
\hline 301 & 1.545 & 0.725 \\
\hline 389 & 1.785 & 0.350 \\
\hline 164 & 1.857 & 0.598 \\
\hline 153 & 2.282 & 0.398 \\
\hline 340 & 3.365 & 0.352 \\
\hline 330 & 3.573 & 0.749 \\
\hline 367 & 3.971 & 0.355 \\
\hline 267 & 4.268 & 0.731 \\
\hline 298 & 4.609 & 0.500 \\
\hline 252 & 5.274 & 0.548 \\
\hline
\end{tabular}

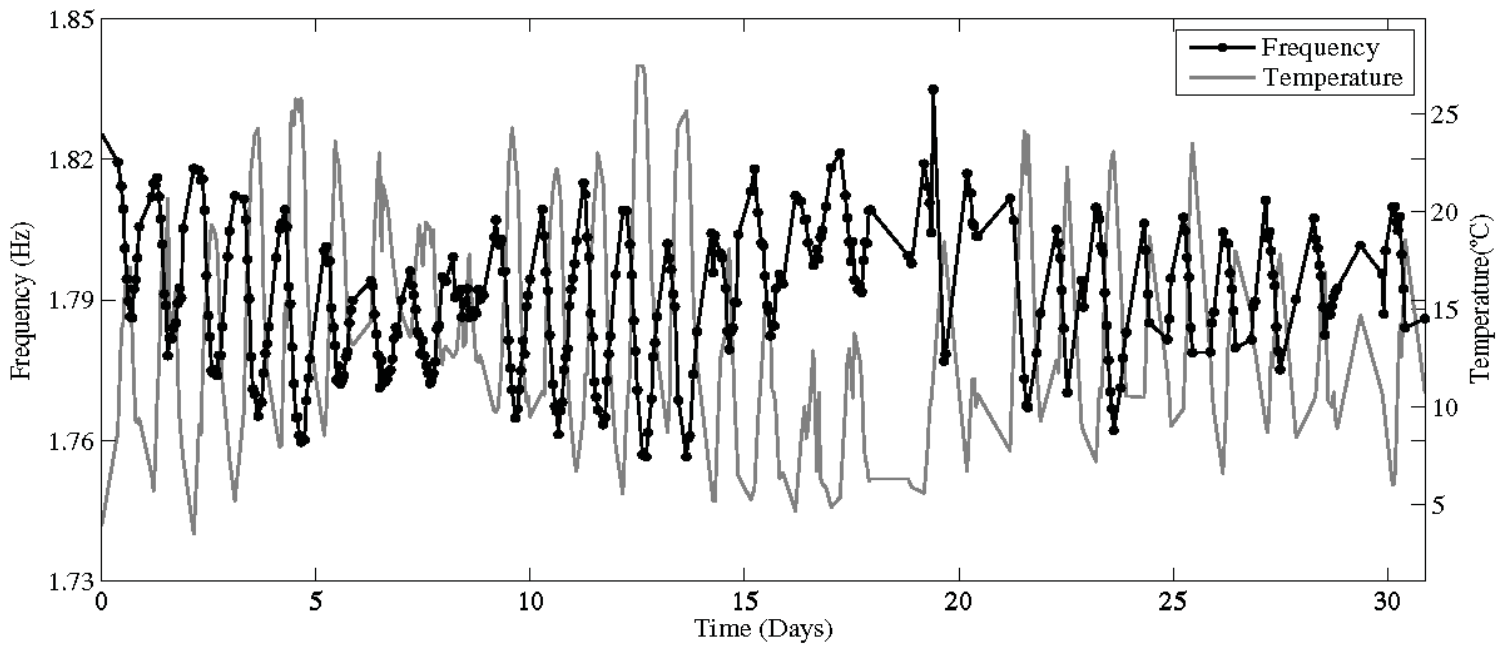

(a) Mode 1 (Number of coincidences: 389 )

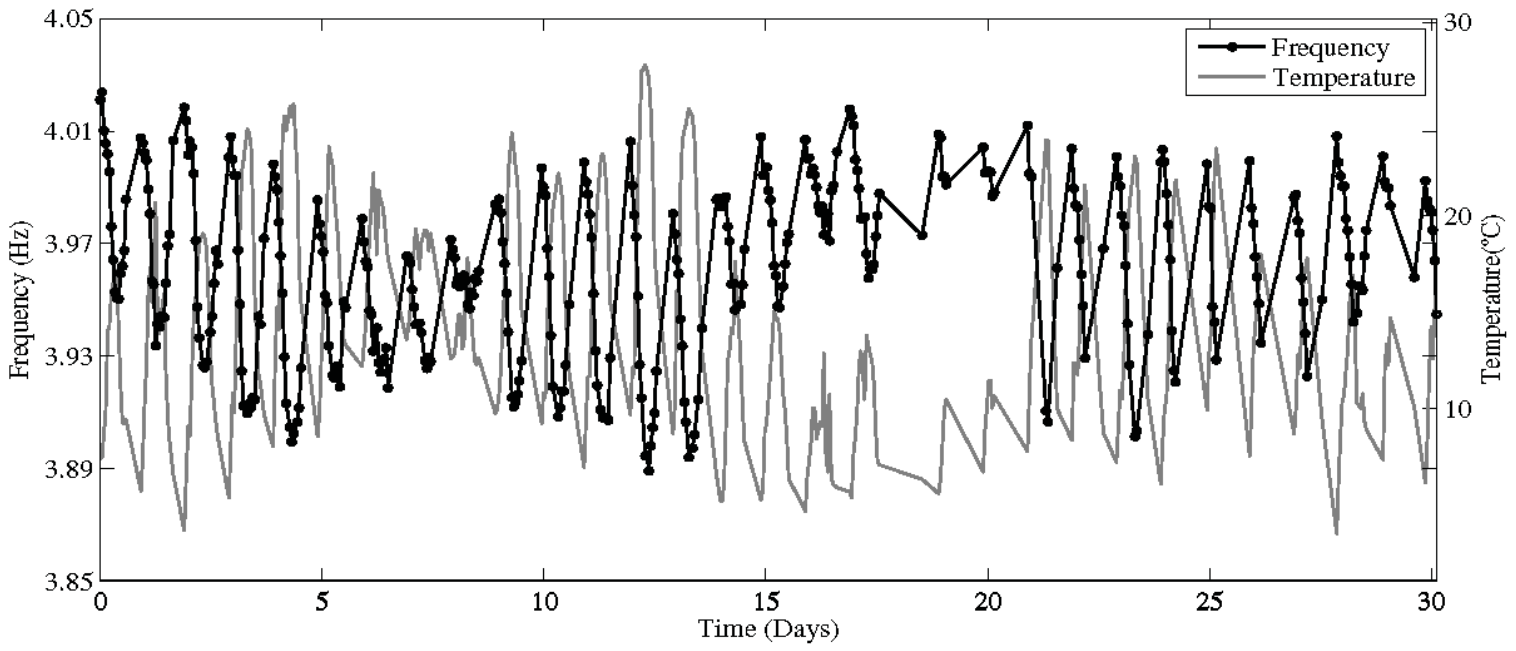

(b) Mode 2 (Number of coincidences: 367 )

Figure 5. Frequency estimates and averaged temperature recorded over time. 


\section{Effects of vibration level}

To take into account the operational factor, the root-mean-square (RMS) acceleration is used as a global indicator of the vibration level of a whole test. Fig. 7 shows the frequency estimates versus RMS acceleration. For both modes, the frequency decreases as the acceleration level increases. This is the trend usually found [3]. Surprisingly, the damping ratios do not show clear dependencies with the level of vibration or with environmental factors. Usually, damping ratios increase as acceleration level increase.

\section{Effects of wind level}

No clear dependency of any of the modal parameters has been observed with RMS wind velocity. As an example, Fig. 8 shows the natural frequency estimates versus RMS wind velocity for Modes 1 and 2.

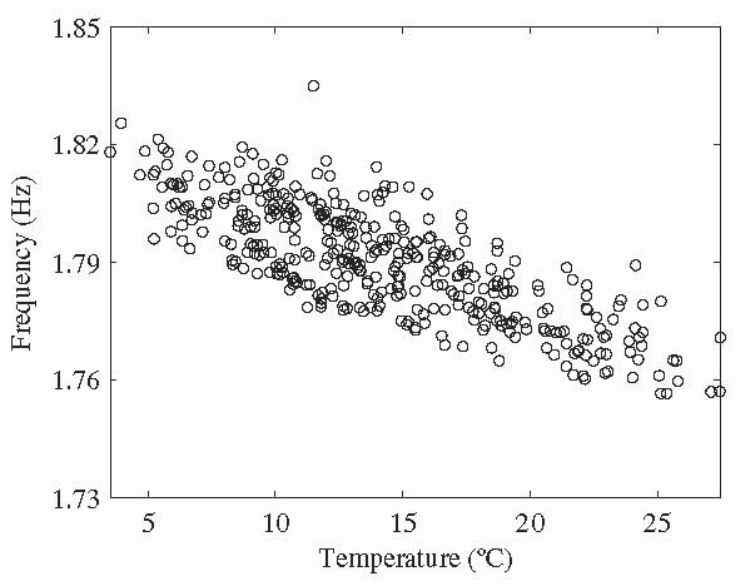

(a) Mode 1

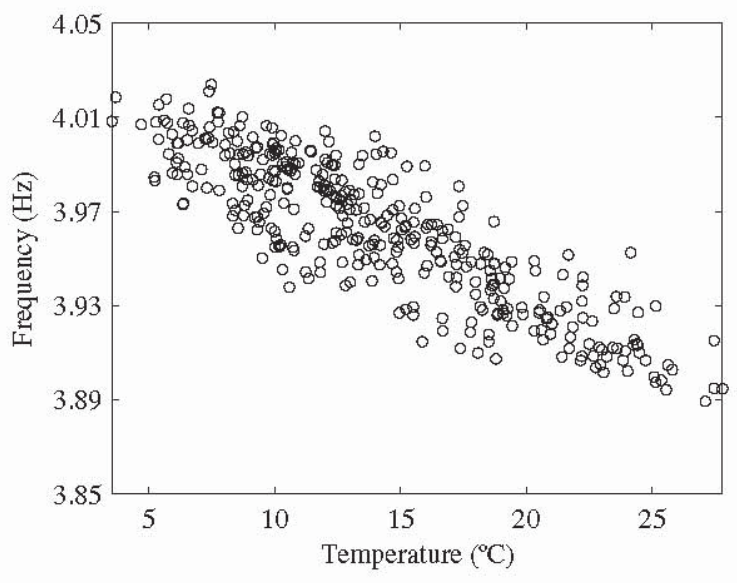

(b) Mode 2

Figure 6. Frequency estimates versus temperature.

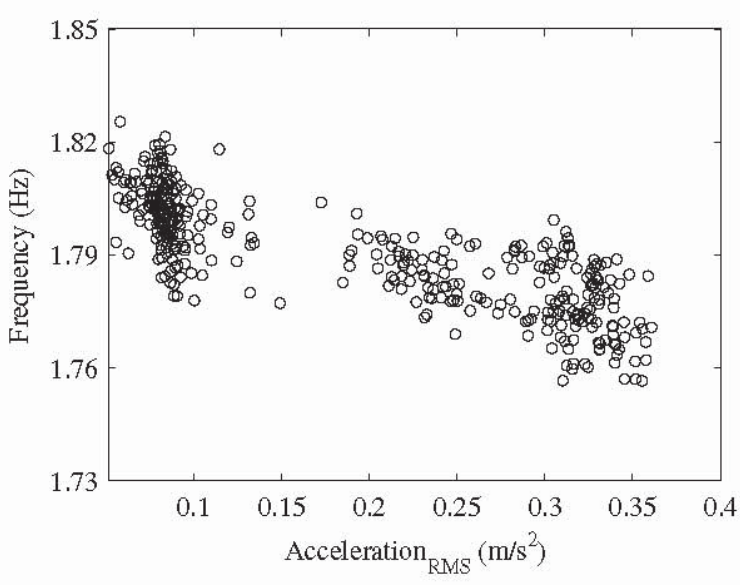

(a) Mode 1

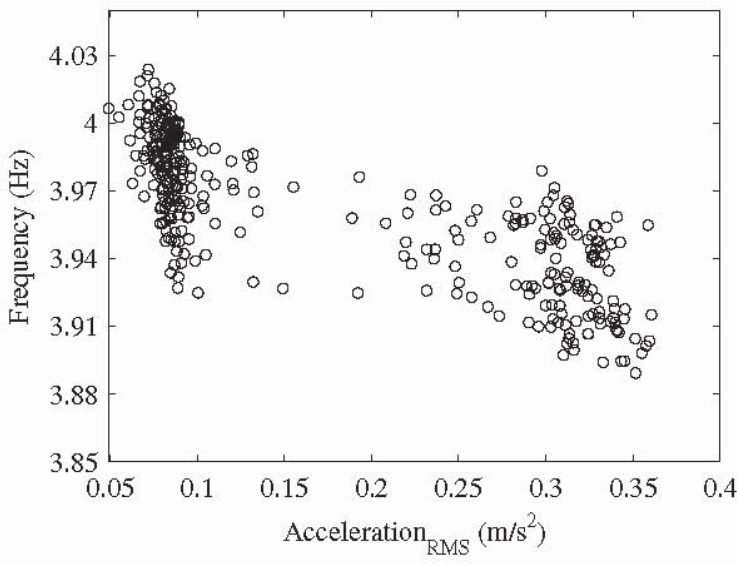

(b) Mode 2

Figure 7. Frequency and damping estimates versus RMS acceleration of the test.

\section{STATISTICAL ANALYSIS}

A correlation analysis has been carried out in order to study the influence of the aforementioned factors on the natural frequencies. The SPSS suite of software has been used for this purpose.

The most appropriate technique to study the dependence of a dependent variable, as is the natural frequency estimation, with other independent variables is the multiple regression. In this work, a MLR has been employed considering as independent variables, variables that may be nonlinear function of the ambient temperature, RMS acceleration and RMS wind velocity. Hence, possible nonlinear dependencies of environmental/operational measures are explored. Then, the frequency is generally considered as function of these measures, 


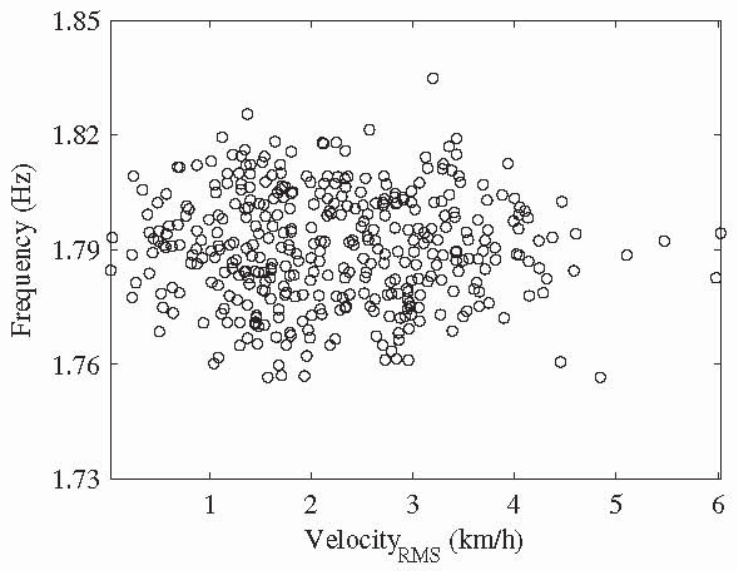

(a) Mode 1

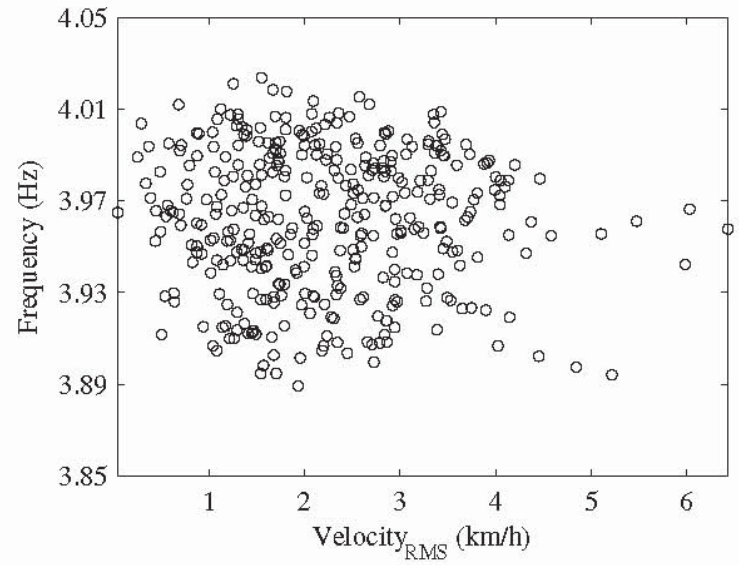

(b) Mode 2

Figure 8. Frequency estimates versus RMS wind velocity

$$
f=g\left(T, a_{R M S}, \mathrm{v}_{R M S}\right),
$$

where $f$ is the frequency estimate, $T$ is the temperature, $a_{R M S}$ is the total RMS acceleration, $v_{R M S}$ is the total RMS velocity wind. Then, (1) is taken as

$$
f=\beta_{0}+\sum_{i=1}^{m} \beta_{i} \cdot Z_{i}
$$

where $Z_{i} \in\left[z_{i}, z_{i}^{2}, \ldots, z_{i}^{n}, 1 / z_{i}, 1 / z_{i}^{2}, \ldots, 1 / z_{i}^{n}\right]$ are de independent variables, $z_{i}$ can be $T, a_{R M S}$ and $v_{R M S}$, and $\beta_{i}$ are the coefficient of the linear-least square solutions. Once the method is applied, the determination factor $R^{2}$ is used to assess the model.

The MLR method presented above has been applied to frequency and damping ratio estimates of both modes. For the frequencies estimates, high $R^{2}$ factors have been achieved; however, for damping ratios the $R^{2}$ factors achieved have been very low. Then, no dependence on the considered variables has been obtained for damping ratios.

For both frequencies a quite good approximation has been achieved, using the following model

$$
f=\beta_{o}+\beta_{1} \cdot T+\frac{\beta_{2}}{a_{R M S}},
$$

which shows proportional dependency 0 on the temperature and inversely proportional to the acceleration. Higher order dependencies do not increase substantially $R^{2}$. In order to extract the corrected frequencies (i.e. the spurious effects are removed), model (3) is rewritten as

$$
f=\left(\beta_{0}+\beta_{1} \cdot \bar{T}_{N}+\frac{\beta_{2}}{\bar{a}_{R M S_{N}}}\right)+\beta_{1} \cdot\left(T-\bar{T}_{N}\right)+\beta_{2} \cdot\left(\frac{1}{a_{R M S}}-\frac{1}{\bar{a}_{R M S_{N}}}\right),
$$

where $\bar{T}_{N}$ and $\bar{a}_{R M S_{N}}$ are the mean values of temperature and RMS acceleration for the $N$ tests, respectively. The corrected frequency (considering the last $N$ tests to obtain the model) is

$$
f^{*}=\beta_{0}+\beta_{1} \cdot \bar{T}_{N}+\frac{\beta_{2}}{\bar{a}_{R M S_{N}}},
$$

Table II shows the values of model statistical coefficients for Mode 1 and Mode 2 . Note that $\beta_{1}$ is negative, as expected. Note also that the obtained values of $R^{2}$ indicate that the model represent quite well natural frequency estimates variability. For the group of test corresponding to Mode $1, \bar{T}_{N}$ and $\bar{a}_{R M S}$ are $12.15^{\circ} \mathrm{C}$ and $0.134 \mathrm{~m} / \mathrm{s}^{2}$, respectively, and for Mode 2 these values are $11.98^{\circ} \mathrm{C}$ and $0.122 \mathrm{~m} / \mathrm{s}^{2}$. Fig. 9 shows the frequency estimates and the statistical model. It can be appreciated that, 
$R^{2}$ and frequency estimates shown of Fig. 9, the statistical model of Mode 2 has a better fit than Mode 1. Finally, Table ws the corrected frequency estimates and the frequency estimate for last coincidence.

TABLE II. MODELS STATISTICAL PARAMETERS

\begin{tabular}{|l|l|l|l|}
\hline \multicolumn{1}{|c|}{$\beta_{0}$} & \multicolumn{1}{|c|}{$\beta_{1}$} & \multicolumn{1}{|c|}{$\beta_{2}$} & \multicolumn{1}{c|}{$R^{2}$} \\
\hline 1.802 & -0.002 & 0.001 & 0.77 \\
\hline 3.998 & -0.004 & 0.003 & 0.86 \\
\hline
\end{tabular}

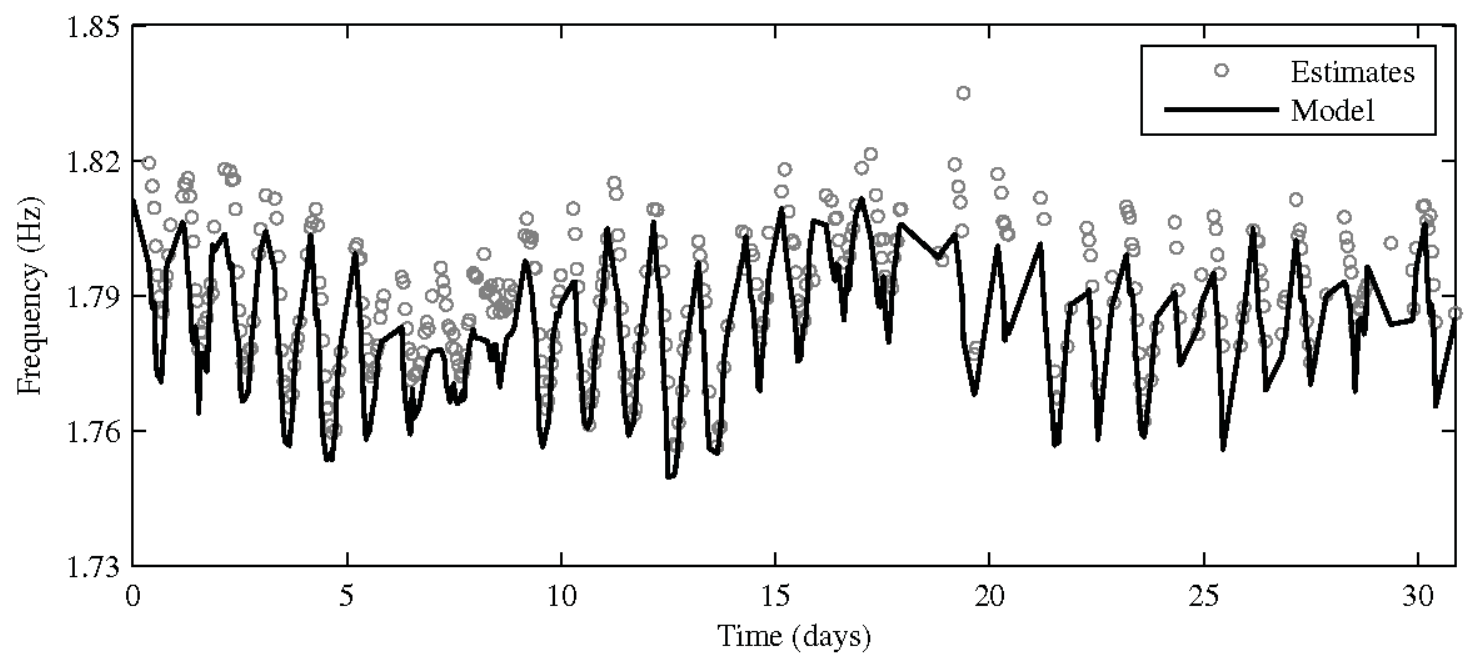

(a) Mode 1

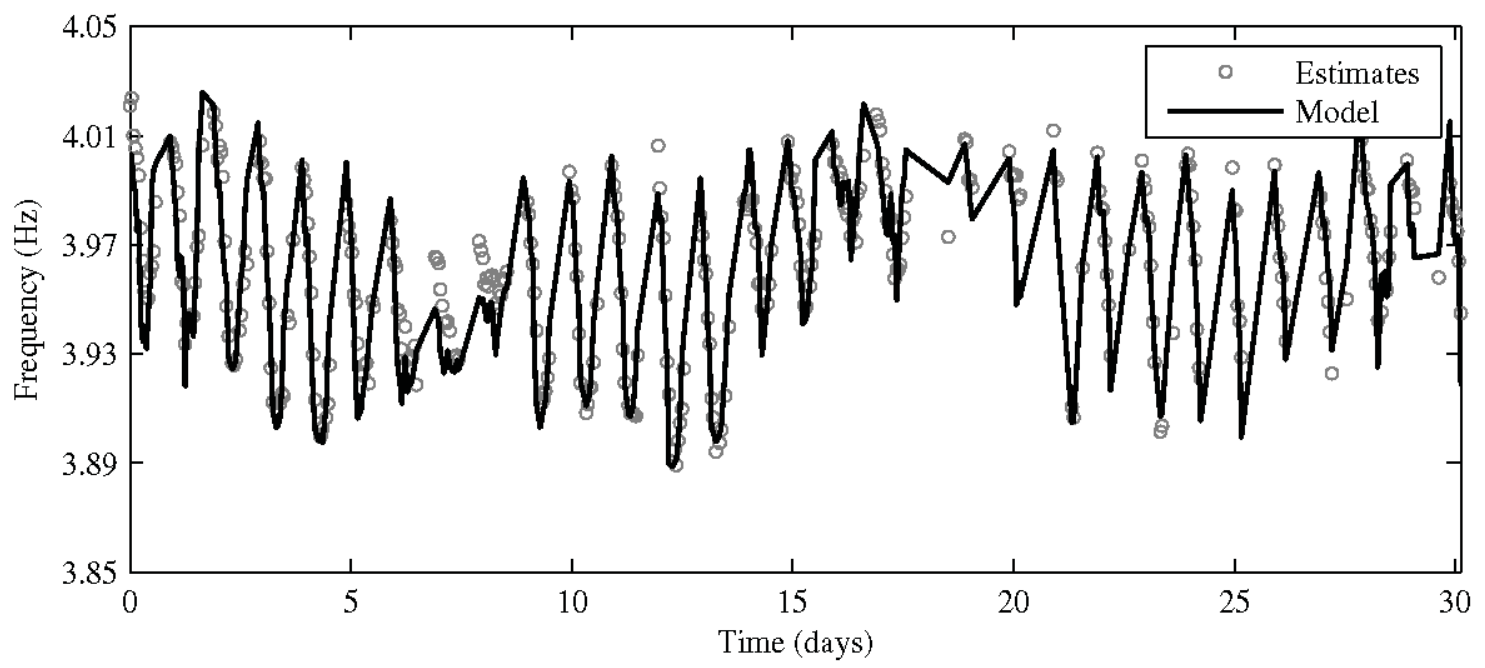

(b) Mode 2

Figure 9. Frequency estimates and the statistical model.

TABLE III. CORRECTED FREQUENCY ESTIMATES

\begin{tabular}{|l|l|l|}
\hline \multicolumn{1}{|c|}{ Mode } & \multicolumn{1}{c|}{$f^{*}$} & \multicolumn{1}{c|}{$f$} \\
\hline 1 & 1.778 & 1.786 \\
\hline 2 & 3.949 & 3.945 \\
\hline
\end{tabular}




\section{CONCLUSION}

A preliminary analysis of the influence of environmental/operational factors on modal properties for an in-service footbridge has been carried out throughout this paper. The structure is a stress-ribbon footbridge which modal properties are very sensitive to temperature changes. The natural frequencies estimates have been correlated with the temperature and acceleration level. A correction of these estimates has been proposed in such a way that the corrected frequencies might be used as damage-sensitive features in a Structural Health Monitoring System.

The next step is to analyse a whole-year monitoring including more quantities (such as maximum acceleration value, vibration dose value, temperature change during a test, etc.) representative of the environmental and operational factors. Then, a more precise model might be obtained and different modal parameter correction might be proposed.

\section{ACKNOWLEDGMENT}

This work has been partially funded by the Spanish Government Research Program with the Grant BIA2011-28493 and also funded in part by the research project SETH, with reference IPT-2012-0703-380000, of INNPACTO Program from Ministry of Economy and Competitiveness of Spain.

\section{REFERENCES}

[1] H. C. Gomez, P. J. Fanning, M. Q. Feng, and S. Lee, "Testing and Long-term Monitoring of a Curved Concrete Box Girder Bridge," Engineering Structures, vol. 33, pp. 2861-2869, 2011.

[2] P. Moser, and B. Moaveni, "Design and Deployment of a Continuous Monitoring System for the Dowling Hall Footbridge," Experimental Techniques, vol. 37, pp. 15-26, 2013.

[3] A. Deraemaeker, E. Reynders, G. De Roeck, and J. Kullaa, "Vibration-based structural health monitoring using output-only measurements under changing environment," Mechanical System and Signal Processing, vol. 22, no. 1, pp. 34-56, 2008.

[4] W.H. Hu, E. Caetano, and A. Cuhna, "Structural health monitoring of a stress-ribbon footbridge," Engineering Structures, vol. 47, pp. 578-593, 2012.

[5] J. de Sebastián, A. Escudero, R. Arnaz, I.M. Díaz, A. Poncela, and A. Lorenzana, "A low-cost vibration monitoring system for a stress-ribbon footbridge," in 6th ECCOMAS Conference on Smart Structures and Materials, 2013.

[6] A. J. Narros, "Pasarela Peatonal 'Pedro Gómez Bosque' sobre el Río Pisuerga en la Ciudad de Valladolid. Un Nuevo Récord de Longitud en Pasarelas Colgadas de Banda Tesa," (in Spanish), Revista Técnica Cemento-Hormigón, vol. 947, pp. 80-86, 2011.

[7] B. Peeters, and G. De Roeck, "Reference-based Stochastic Subspace Identification for Output-only Modal Analysis", Mechanical System and Signal Processing, vol. 13, no. 6, pp. 855-878, 1999.

[8] FIB. Bulletin 32. Guidelines for the Design of Footbridges, Fédération Internationale du Béton, 2005.

[9] D. Cobo del Arco, A.C. Aparicio and A.R. Mari, "Preliminary design of prestressed concrete stress ribbon bridge," Journal of Bridge Engineering, vol. 6, no. 4, pp. 234-242, 2001. 
FINITE ELEMENT MODEL UPDATING OF A LIVELY FOOTBRIDGE

6th IOMAC

INTERNATIONAL

OPERATIONAL

MODAL

ANALYSIS

CONFERENCE

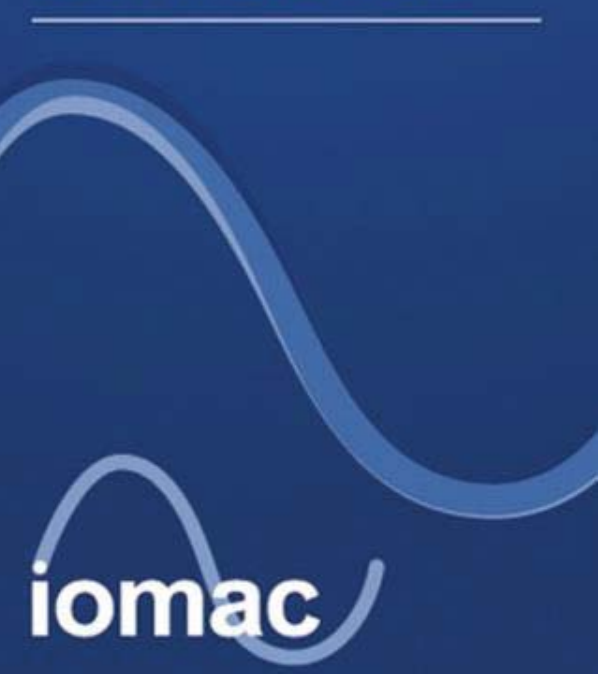

12th - 14th May 2015

Gijón/Spain

Norberto Ibán Lorenzana; Javier Castaño Lerma; F. Javier Cara Cañas; Javier Fernández Martínez; AntolínLorenzana Ibán.

\begin{tabular}{c|c|c|c|} 
Aportaciones: & Experimentación & Procesado & Edición \\
\hline & Instrumentación & Artemis & Tablas \\
Registros & FEMTools & Gráficas \\
Tests & Matlab & Imágenes \\
& & Defensa \\
\hline
\end{tabular}




\title{
FINITE ELEMENT MODEL UPDATING OF A LIVELY FOOTBRIDGE
}

\author{
Ibán $N .{ }^{1}$, Castaño $J^{2}$, Cara $J .{ }^{3}$, Fernández $J .^{4}$, Cacho-Pérez $M{ }^{5}$, Muñoz $I^{6}$, Lorenzana $A{ }^{7}$ \\ ${ }^{2}$ Junior Researcher, Centro Tecnológico Cartif, Valladolid, Spain, noriba@cartif.es \\ 2 Junior Researcher, Centro Tecnológi co Cartif, Valladolid, Spain, javcas@ cartif.es \\ ${ }^{3}$ Junior Lecturer, Dr, Universidad Politécnica de Madrid, Spain, fjcara@etsii.upm.es \\ ${ }^{4}$ Senior Researcher, Universidad Politécnica de Madrid, Spain, jfernandezm@etsii.upm.es \\ ${ }^{5}$ Lecturer, Dr, EII, Universidad de Valladolid, Spain, cacho@eii.uva.es \\ ${ }^{6}$ Senior Lecturer, Dr, Universidad Politécnica de Madrid, Spain, ivan.munoz@upm.es \\ ${ }^{7}$ Senior Lecturer, Dr, ITAP, Universidad de Valladolid, Spain, ali@eii.uva.es
}

\begin{abstract}
This paper presents finite element analyses, experimental measurements and finite element model updating of a lively footbridge consisting on an arched main span $40 \mathrm{~m}$ long and several access minor spans. Firstly, a finite element model of the bridge is created in a commercial CAE software and static and modal response were numerically estimated. Then, experimental measurements using static loading test and ambient vibration tests are performed. Initial finite element model is adjusted to match with the static response by fitting some selected parameters. Modal parameters (natural frequencies, mode shapes and modal damping) are extracted and after that the current finite element model is updated. Among the selected parameters, semi-rigid connections in some joints, concrete Young's modulus and mass density of the concrete deck (to account on pavement mass) were selected to minimize the differences between numerical and experimental structural response. Sensitivity of the modal response to these parameters is also shown. At the end of the study, good agreement between analytical and experimental results is achieved, revealing the suitability of the entire process.
\end{abstract}

Keywords: Conference, Operational, Modal, Analysis

\section{INTRODUCTION}

Although in the past, civil engineering sector made extensive use of simple models (usually SDOF) to estimate the dynamic response of bridge type structures, nowadays is usual to model the structure using modern CAE abilities. SDOF models have proved insufficient for the accurate modelling of slender footbridge structures as they cannot represent some effects as the closely spaced modes of vibration which frequently occur in practice. Additionally, modern footbridges become increasingly slender and prone to oscillate under pedestrian loading, so there is a much greater need for vibrations to be considered at the design stage. Having the FE methods the capability for the accurate modelling 
of the dynamic behaviour, and becoming CAE software more affordable, civil engineering practitioners do not hesitate in their use. However, with regard to lively structural design, there is a general lack of expertise in FE modelling, particularly with regard to their vibration serviceability performance, being not rare that the model does not match with the real structure.

The way forward for developing such expertise is by linking modal testing and FE analysis by the updating of the models of representative structures and extract design guidelines.

This type of approach is the standard in the mechanical and aerospace engineering sectors, but it is only recently that the civil engineering community has begun to adopt this advanced technology.

The aim of the paper is to describe a procedure for the use of test data in the manual and automatic updating of FE models. The exercise is done using the ANSYS FE code [1] in conjunction with FEMtools [2], a state-of-the-art updating software.

\section{STRUCTURE DESCRIPTION}

The footbridge is an urban link with several minor access spans and one main $40 \mathrm{~m}$ long arched central lively span. Most of the structural members are constructed using tubular steel profiles. An aerial photograph of the footbridge and 3D isometric view of its FE model is depicted in Figure 1. More information about the structure can be found in [23].

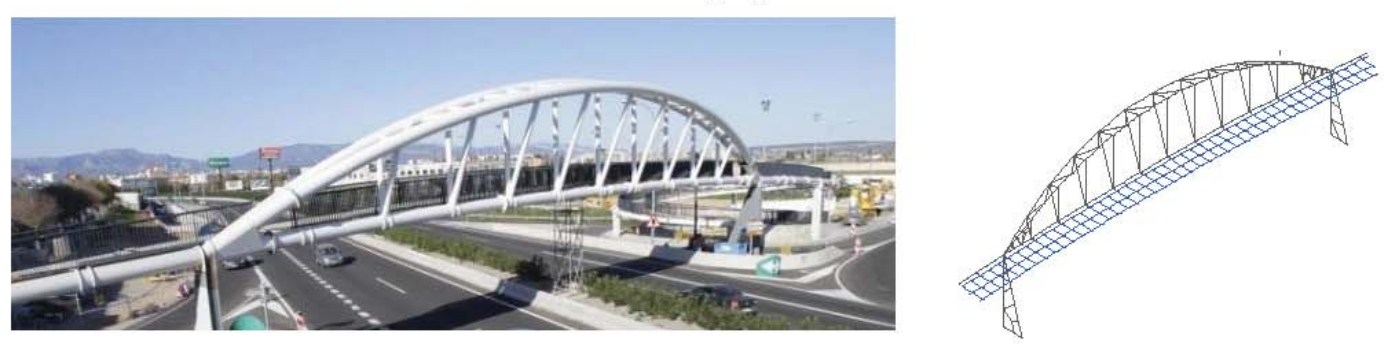

Figure 1. Footbridge under study.

\section{FE MODELLING}

The initial FE model, with over 600 Beam3D elements for the steel members and 120 Shell4 elements for the deck, modelled in ANSYS [1] is suitable, after minor changes, for importation to the FEMtools [2] software. Several cross section types are considered for the steel skeleton but for the deck just one constant thickness element $(200 \mathrm{~mm})$ is used. The handrails on the bridge, although are rigidly attached to the deck, are considered non-structural and then not modelled. However, additional mass for their consideration can be taken into account and distributed over the deck. The FE mesh is given in Figure 2 together with the experimental test grid (green points). Note that, when the model is going to be correlated with the results from test data, it is important to ensure that the nodes of the FE mesh are coincident with the locations of the test points [4].

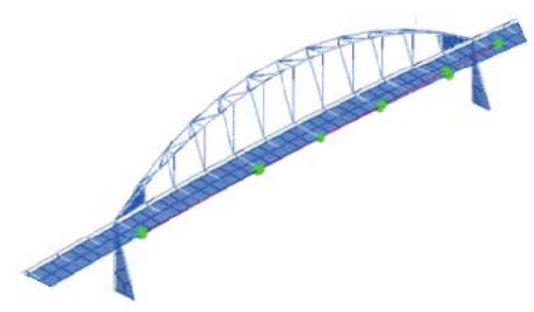

Figure 2. FEM mesh and signal acquisition points. 
Using this initial model, deflection for the nominal static loading case was $24.17 \mathrm{~mm}$ and the first three vibration modes are shown in Figure 3 . Note than in the first mode, torsional effects are predominant, in the second the main effect is vertical bending while in the third one is transversal bending. Table 1 shows the corresponding natural frequencies.

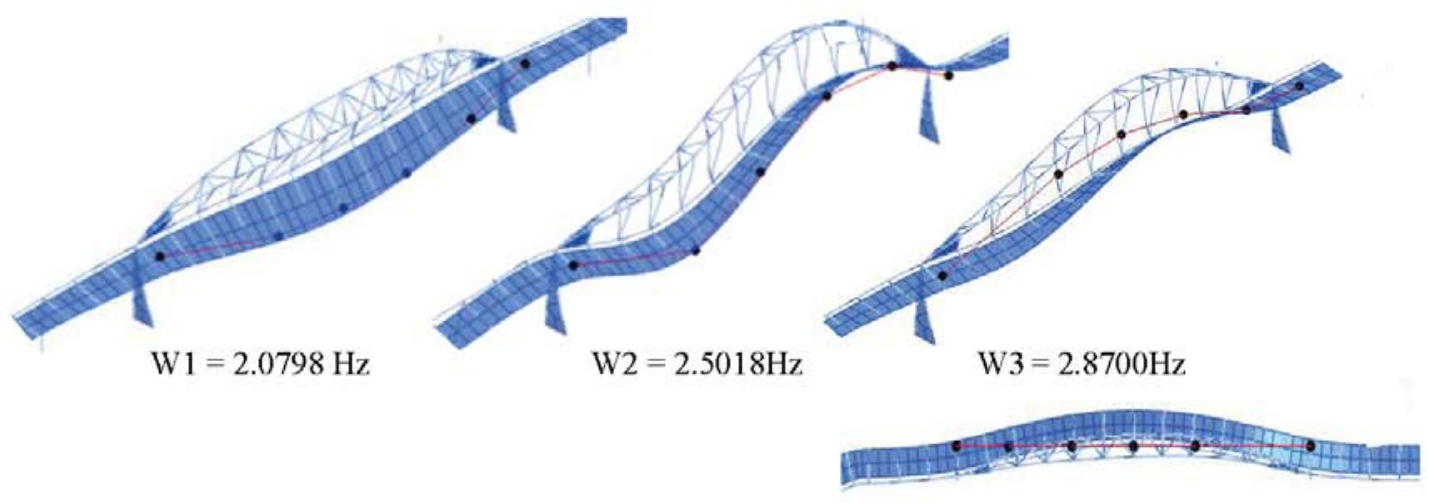

Figure 3. First three natural mode shapes.

\section{TESTING}

A simple static loading test was carried out to determine the central deflection when a load of 20 tonnes is placed on the central span deck, resulting in $32 \mathrm{~mm}$. Also a simple modal ambient testing programme is conducted. Ten minutes recordings for vertical acceleration in the 4 selected central points (Figure 1) are registered at $200 \mathrm{~Hz}$. Figure 4 shows the data and, after postprocesing using SSI method (using MATHLAB), estimated frequencies and dampings are shown in Table 1. Similar results can be obtained using FEMTools routines, based on a global poly-reference Least Squares Complex Frequency (pLSCF) method. The damping values reported are not used in the following updating exercise. Corresponding mode shapes are presented in Figure 3 (black polygonal line).

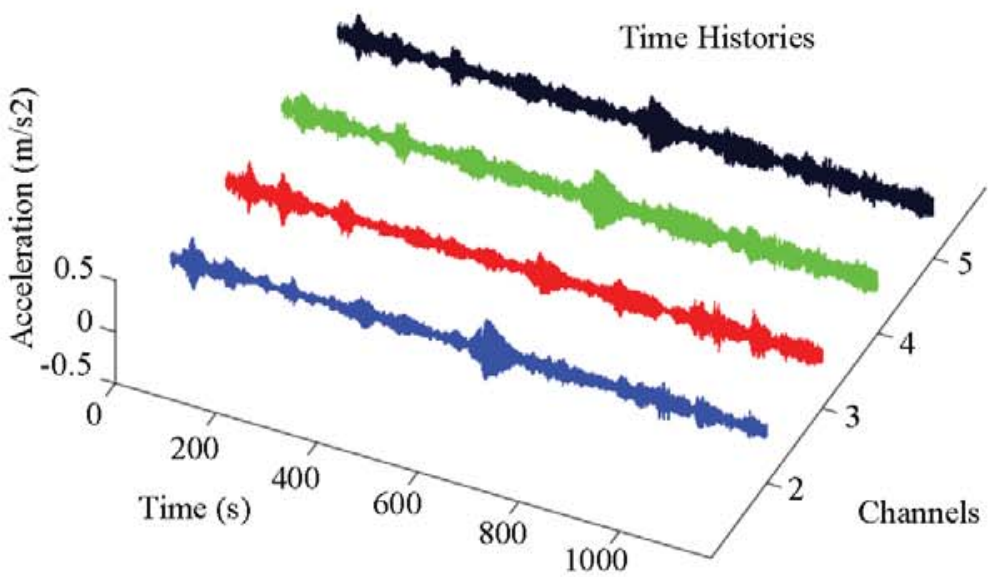

Figure 4. 10 minutes ambient vibration records corresponding to the testing points shown Figure 2

Table 1. Modal frequencies and dampings estimated using operational modal analysis.

\begin{tabular}{ccc} 
Mode & Frecuency & Damping \\
\hline w1 & 2.081 & 0.19 \\
w2 & 2.502 & 0.24 \\
w3 & 2.877 & 0.37 \\
\hline
\end{tabular}




\section{CORRELATION BETWEEN MODELS AND MANUAL UPDATING}

Table 2 shows the comparison of natural frequencies of experimental and FE vertical modes. Obviously, although MAC values are high, updating is needed for the frequency values, but before proceed with the selection of the parameters to be changed, static considerations are taken into account.

Table 2.Experimental and initial numerical (FE model \#0) frequencies.

\begin{tabular}{cccc} 
Mode & OMA & FEM\#0 & MAC \\
\hline w1 & 2.081 & 2.105 & 99.1 \\
w2 & 2.502 & 2.889 & 98.7 \\
w3 & 2.877 & 3.153 & \\
\hline
\end{tabular}

Prior to attempting to update the FE model in FEMtools in an automatic way, it is recommended to experiment with selected input parameters by hand. The initial FEM is not accounting for the inherent flexibility of the steel joints. It is because of that the experimental static deflection was $33 \%$ larger than the numerical one. Once identified that most of the flexibility were concentrated in the connections between the lower cord of the arch and the transverse beams that support the deck, a semi-rigid joint was defined and their value manually adjusted to match with the measured deflection, resulting in a bending lost of about $\mathrm{F}=83 \%$ (considering that a perfect rigid joint has a value of $100 \%$ ) After introducing this effect, the static deflection is the expected one $(32 \mathrm{~mm})$ and the numerical modal response turned, has shown in Table 3.

Table 3.Experimental and numerical (FE model \#1) frequencies. Semi-rigid joints.

\begin{tabular}{cccc} 
Mode & OMA & FEM\#1 & MAC \\
\hline w1 & 2.081 & 1.988 & 99.4 \\
w2 & 2.502 & 2.689 & 99.1 \\
w3 & 2.877 & 2.939 & \\
\hline
\end{tabular}

This reduction in the bending capacity of the connections is considered too large to be consistent, so other sources of discrepancies should be searched. In this case, after having a look to the deformed configuration and realizing about the large rigidity of the deck (that was acting like an arch itself), it is decided to decrease the Young's modulus of elasticity used to simulate the concrete of the deck (Eh). In doing so, several pairs of values for $\mathrm{F}$ and $\mathrm{Eh}$ can be found. After a detail modelling of the referred tubular connection, value for $\mathrm{F}$ was adjusted to $21 \%$. With this value for $\mathrm{F}$, the corresponding value for $\mathrm{Eh}$ is $0.9 \mathrm{e} 10 \mathrm{~N} / \mathrm{m}^{2}$. Note that this finding suppose a $70 \%$ decrement (initial value vas $\mathrm{Eh}=3 \mathrm{e} 10 \mathrm{~N} / \mathrm{m}^{2}$ ). In nominal conditions it is not consistent such a big reduction but after knowing the on-site construction procedure carried through in pouring the concrete, in more than one layer, and the self-supporting formwork used (generating about $50 \%$ reduction in the concrete thickness in about $50 \%$ of the plant surface), the results obtained was assumed to make sense. Note that the structural effect is similar to reduce the thickness of the Shell4 element used for modelling the concrete. In this new assumption, modal results is shown in Table 4.

Table 4.Experimental and numerical (FE model \#2) frequencies. Semi-rigid joints and reduced concrete modulus.

\begin{tabular}{cccc} 
Mode & OMA & FEM\#2 & MAC \\
\hline w1 & 2.081 & 1.939 & 99.3 \\
w2 & 2.502 & 2.583 & 99.3 \\
w3 & 2.877 & 2.680 & \\
\hline
\end{tabular}

Although the adjusted FE model is closed enough to the real structure, additional improvement is possible, as presented in the next section. 


\section{AUTOMATIC UPDATING}

At this point, for conducting the automatic updating exercise it is necessary to choose additional parameters to change. It is recommended to act over the parameters with more indeterminacy. At this stage, the mass distribution along the deck (including steel formwork, reinforcement bars, concrete, pavement and hand railing) is chosen as a local parameter for each of the 120 shell elements considered in the central span.

Initial density for the shell elements was $2300 \mathrm{~kg} / \mathrm{m}^{3}$ and final values after the automatic modal updating are shown in Figure 5. Changes in the range of $+50 \%$ and $-75 \%$ is accepted. Final values for the density of the 120 shell elements cover all the range. The resulting mean value for the 70 elements in the central span is $2168 \mathrm{~kg} / \mathrm{m}^{3}$. Note that this value is a bit low for any reinforced concrete slab. This result, together with the low Eh found in the previous section (70\% reduction), suggests that if the deck thickness had been reduced, both parameters (Eh and mean density) had been not change that much.

For the referred values, modal response is presented in Table 5. The tendency is to remove mass from the middle and to add it near the supports in the central span. This tendency match with the existence of a big manhole cover in the central part of the deck.

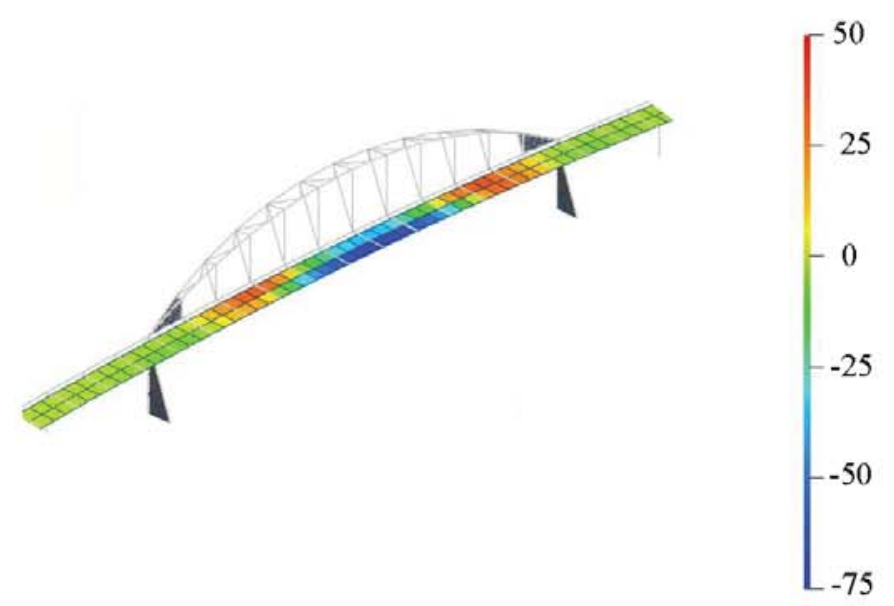

Figure 5. Percentage changes for the mass distribution on the deck elements.

Table 5.Experimental and numerical ( $\mathrm{FE}$ model \#2u) frequencies. Semi-rigid joints, reduced concrete modulus and unequal mass distribution.

\begin{tabular}{cccc} 
Mode & OMA & FEM\#2u & MAC \\
\hline w1 & 2.081 & 2.0809 & 99.4 \\
w2 & 2.502 & 2.5022 & 99.6 \\
w3 & 2.877 & 2.680 & \\
\hline
\end{tabular}

Table 5 show the best agreement after the manual and automated updating. For the automatic procedure, MAC values of the analytical and measured mode shape pairs together with natural frequencies values were used as an updating criterion. FEMtools updating software uses well-proven iterative, parametric, modal and FRF-based updating algorithms using sensitivity coefficients and weighting values (Bayesian estimation). The procedure can be configurated with different confidence level for the different targets (natural frequencies, mode shapes, etc). It is also recommended to physically examine the mode shapes and assign lower confidence factors if the shapes appear to be erratic. In the case under study, as mode 3 is mainly in horizontal direction and experimental tests only account for vertical accelerations, trying to match this mode does not make sense. The following Table 6 shows the best-fitted values that the automatic updating procedure can achieve for the models 
$\# 0$, \#1 and \#2 when unequal mass distribution is allowed and confidence level for mode 1 is set to $99 \%$ and for mode 2 to $95 \%$.

Table 6.Experimental and best numerical frequencies for models $\# 0$ and $\# 1$ with unequal mass distribution.

\begin{tabular}{cccc} 
Mode & OMA & FEM\#0u & FEM\#1u \\
\hline w1 & 2.081 & 2.0789 & 2.0798 \\
w2 & 2.502 & 2.5858 & 2.5761 \\
\hline
\end{tabular}

\section{SENSITIVITY ANALYSIS}

As former described, manual updating is important, as it enables the analyst to appreciate the possible effect that each selected parameter may have on the static and modal response of the structure. This is extremely important as it provides a basis for judging whether the results obtained from the automatic procedure are sensible. Besides, unless reasonable starting values of the updating parameters are given, the FEMtools software may have difficulty in improving the correlation between the experiments and the analysis. The software has the possibility to know, through a sensitivity analysis, if the selected parameters are worthy to change or not. Besides, note that without additional information (static deflection, connection flexibility, ...), automatic updating would not have been able to adjust the model in the way done manually. In this work, automatic updating is reserved for final adjustment to match with the modal response without affect to the static deflection. This highlights one of the potential problems of the blind application of automatic updating procedures.

Figure 6 shows the sensitivity of the selected parameters to the first, second and third modes. Note that when concrete density is considered global, it affect in the same direction to all the considered modes, so, to move up the first frequency and down the second one (as required in model $\# 0$, \#1 and \#2) is not possible simultaneously.

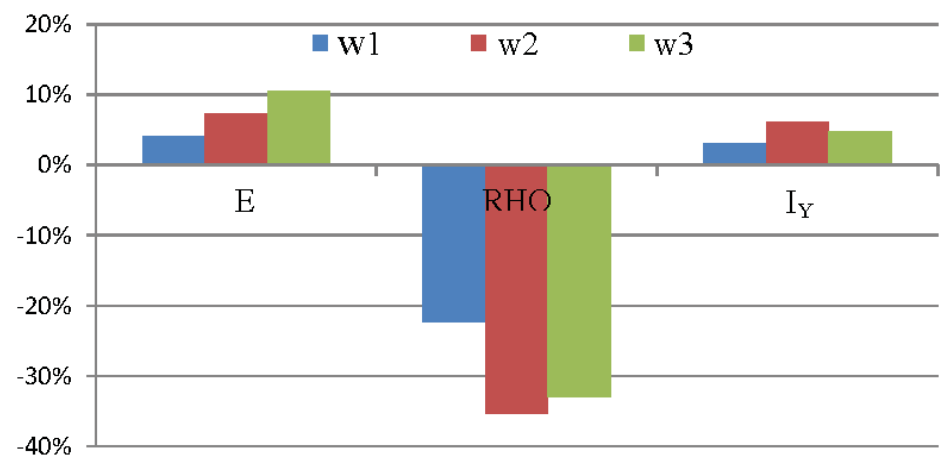

Figure 6.Concrete flexibility (Eh), concrete density (rho) and semi-rigid joints (F) sensitibity.

When concrete density is considered local, the corresponding sensitivity chart is the one presented in Figure 7a (for mode 1) and Figure $7 \mathrm{~b}$ (for mode 2) 


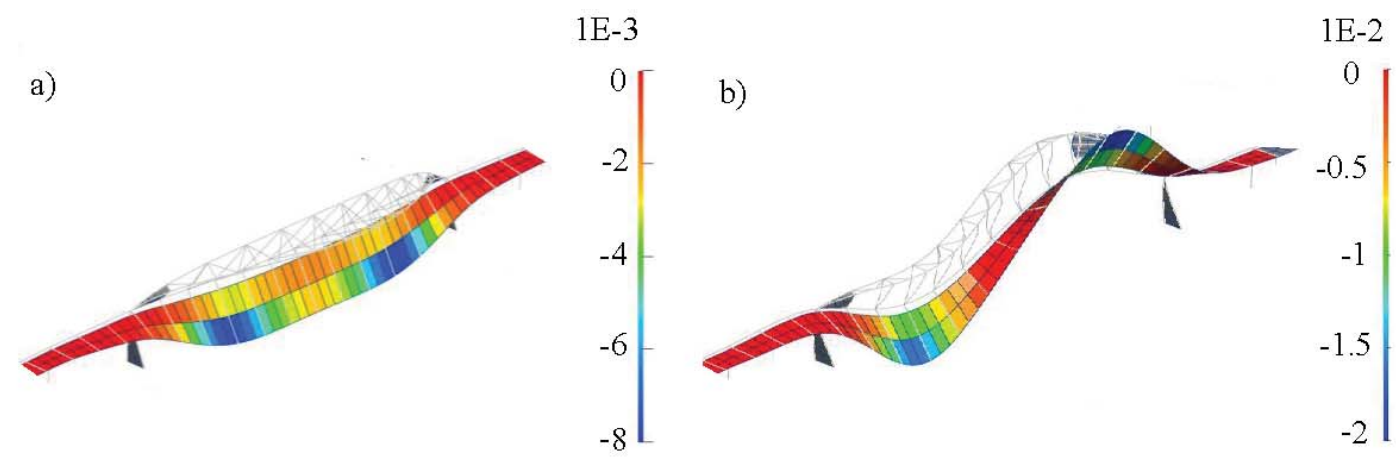

Figure 7.Local concrete density sensitivity for mode 1 a) and mode 2 (b).

\section{CONCLUSIONS}

Unlike aerospace or automotive engineering, the designs for most civil engineering structures are oneoff. This requires designers to ensure that the structure performs satisfactorily, first time. Hence, the immediate benefit of updating models of existing civil structures, which are already designed and built, is not as obvious as, for example, in automobile design. It is important to stress here that the main advantage of this exercise to civil engineering is not in the improvements of existing prototypes and their numerical models. The principal benefit is more reliable modelling to assist in future designs of similar structures. Consequently, increased knowledge, from the updating of FE models, based upon prototype testing could be extremely valuable to designers in the future.

The procedure of FE model updating using modal test data of full-scale structures has be applied successfully to a particular lively footbridge.

The blind application of the automatic updating procedures built in purposely developed software can easily produce meaningless results in the case of civil engineering applications.

Unless the initial input parameters are sufficiently close to the final values, the highly sensitive updating software may not find a good solution. In addition, if only natural frequencies are used for updating, then unrealistic values for theselected parameters may be predicted.

Difference between the analytical natural frequencies and the experimental results was reduced through the progresive adjusted models ( $\# 0, \# 1, \# 2$ and $\# 2 \mathrm{u}$, Table 2, Table 3, Table 4 and Table 5). However, the MAC values were not significantly improved (they were already good enough).

\section{ACKNOWLEDGEMENTS}

The authors would like to thank D. Javier Henche (Grahen Ingenieros S.L.) and D. Victor Darder (Melchor Mascaró) for giving us the opportunity to work with them. Also authors wish to acknowledge to the partial support through Research Project BIA2011-28493-C02-02 (MINECO, Spanish Government).

\section{REFERENCES}

[1] ANSYS v5.2 Users Manual, ANSYS, 1995

[2] FEMtools Model Updating Theoretical Manual, Dynamic Design Solution, Leuven, 2008.

[3] Pavic, A., Hartely, M. J. \& Waldron, P. (1998) Updating of the Analytical Models of Two Footbridges Based on Modal Testing of Full-Scale Structures. ISMA23.

[4] Turek, M., Ventura, C. \& Dasconte, E. (2010) Model updating of the Ironworkers Memorial Second Narrows Bridge, Vancouver, Canada. IMAC. Jacksonville, Florida. 
[5] Ribeiro, D., Calçada, R., Delgado, R., Brehm, M., Zabel, V., Finite element model updating of a bowstring-arch railway bridge based on

[6] experimental modal parameters, Engineering Structures, 40 (2012) 413-435.

[7] Friswell M., Mottershead J.E., Finite Element Model Updating in Structural Dynamics, Kluwer, Dordrecht, 1995.

[8] Brownjohn J.M.W., Xia P.Q., Hao H., Xia Y., Civil structure condition assessment by FE model updating: Methodology and case studies, Finite Elements in Analysis and Design, 37 (2001) 761775 .

[9] Teughels A, Maeck J, De Roeck G. Damage assessment by FE modal updating using damage functions. Computers and Structures 2002; 80(25):1869-1879.

[10] Bayraktar, A., Altunisik, A.C., Sevim, B. and Turker, T. (2007), "Modal testing and finite element model calibration of an arch type steel footbridge", Steel. Compos. Struct., 7(6), 487502.

[11] Modak, S.V., Kundra, T.K. and Nakra, B.C. (2002), "Comparative study of model updating methods using experimental data", Compos. Struct., 80, 437-447

[12] Zapico, J.L., Gonzalez, M.P., Friswell, M.I., Taylor, A.J. and Crewe, A.J. (2003), "Finite element model updating of a small scale bridge", J. Sound. Vib., 268, 993-1012

[13] Zivanovic, S., Pavic, A. and Reynolds, P. (2007), "Finite element modelling and updating of a lively footbridge: the complete process", J. Sound. Vib., 301, 126-145

[14] Kim G.H., Park Y.S., An improved updating parameter selection method and finite element model update using multiobjective optimisation technique, Mechanical Systems and Signal Processing 18 (1) (2004) 59-78.

[15] Wu J.R., Li Q.S., Finite element model updating for a high-rise structure based on ambient vibration measurements, Engineering Structures 26 (7) (2004) 979-990.

[16] Modak S.V., Kundra T.K., Nakra B.C., Studies in dynamic design using updated models, Journal of Sound and Vibration 281 (3-5) (2005) 943-964.

[17] Zivanovic' S., Pavic A., Reynolds P., Modal testing and finite element model tuning of a lively footbridge structure, Engineering Structures 28 (6) (2006) 857-868.

[18] Mottershead J. E., Friswell M. I., "Model updating in structural dynamics: a survey," Journal of Sound and Vibration, vol. 167, no. 2, pp. 347-375, 1993.

[19] Zarate B. A., Caicedo J. M., "Finite element model updating: multiple alternatives," Engineering Structures, vol. 30, no. 12, pp. 3724-3730, 2008.

[20] Kim G.H., Park Y.S., "An improved updating parameter selection method and finite element model update using multiobjective optimisation technique," Mechanical Systems and Signal Processing, vol. 18, no. 1, pp. 59-78, 2004.

[21] Li W.M., Hong J.Z., "New iterative method for model updating based on model reduction," Mechanical Systems and Signal Processing, vol. 25, no. 1, pp. 180-192, 2011.

[22] Imergun, M., and Visser, W.J., A Review of Model Updating techniques, Journal of Sound and vibration, ASME, 9-20, January 1991.

[23] Chulvi M., Henche J., PASARELA SOBRE LA VÍA DE CINTURA MA-20 EN PALMA DE MALLORCA, V Congreso nacional de ACHE, Asociación científico-técnica del hormigón estructural, Barcelona 2011 
DYNAMIC CHARACTERIZATION, MODELLING AND MODEL UPDATING OF A LIVELY FOOTBRIDGE

International Conference on

Mechanical Models in

Structural Engineering

Norberto Ibán Lorenzana; Javier Castaño Lerma; José Manuel Soria Herrera; Iván Muñoz Díaz; Antolín Lorenzana Ibán.

\begin{tabular}{c|c|c|c|} 
Aportaciones: & Experimentación & Procesado & Edición \\
\hline & Instrumentación & Artemis & Tablas \\
& Registros & FEMTools & Gráficas \\
& Tests & Matlab & $\begin{array}{c}\text { Imágenes } \\
\text { Defensa }\end{array}$ \\
\cline { 2 - 4 } & & &
\end{tabular}




\title{
Dynamic characterization, modelling and model updating of a lively footbridge
}

\author{
Ibán, Norberto ${ }^{1}$; Castaño, Javier ${ }^{1}$; Soria, José $M^{2}$.; Díaz, Iván $M^{2}{ }^{2}$; Lorenzana, Antolín ${ }^{3}$
}

\begin{abstract}
This paper presents finite element analyses, experimental measurements and finite element model updating of a lively footbridge consisting on an arched main span $40 \mathrm{~m}$ long and several shorter access spans. Firstly, a finite element model of the bridge is created in a commercial CAE software and static and modal response are numerically estimated. Then, experimental measurements using static loading test and ambient vibration tests are performed. Initial finite element model is adjusted to match with the static response by fitting some selected parameters. Modal parameters (natural frequencies, mode shapes and modal damping) are extracted and after that the current finite element model is updated. Among the selected parameters, semi-rigid connections in some joints, concrete Young's modulus and mass density of the concrete deck (to account on pavement mass) are selected to minimize the differences between numerical and experimental structural response. Sensitivity of the modal response to these parameters is also shown. At the end of the study, good agreement between analytical and experimental results is achieved, revealing the suitability of the entire process.
\end{abstract}

Keywords: Operational Modal Analysis, Static Loading Test, Vibration, Civil Structures.

\section{INTRODUCTION}

Although in the past, civil engineering sector made extensive use of approximate models to estimate the dynamic response of bridge type structures, nowadays is usual to model the structure using current CAE abilities. Simple discrete models have proved insufficient for the accurate modelling of slender footbridge structures as they cannot represent some effects as the closely spaced modes of vibration which frequently occur in practice. Additionally, modern footbridges become increasingly slender and prone to oscillate under pedestrian loading, so there is a much greater need for vibrations to be considered at the design stage. Having the FE methods the capability for the accurate modelling of the dynamic behaviour, and becoming CAE software more affordable, civil engineering practitioners do not hesitate in their use. However, with regard to lively structural design, there is a lack of expertise in FE modelling, particularly with regard to their vibration serviceability performance, being not rare that the model does not match with the real structure.

The way forward for developing such expertise is by linking modal testing and FE analysis by the updating of the models of representative structures and extract general design guidelines. This type

\footnotetext{
${ }_{1}^{1}$ Mechanical Engineering Division. CartifResearch Center(Spain).noriba@cartif.es, javcas@cartif.es

${ }^{2}$ Dpto. CMM and Theory of Structures. ETSICCP, UPM (Spain). im.soria@upm.es; ivan.munoz@upm.es

${ }^{3}$ EII/ITAP, University of Valladolid (Spain). ali@eii.uva.es (Corresponding author)
} 


\section{Dynamic characterization, modelling and model updating of a lively footbridge Third International Conference on Mechanical Models in Structural Engineering University of Seville. 24-26 june 2015.}

of approach is the usual in, for example, the aerospace engineering sectors [1-6], but it is only recently that the civil engineering community has begun to adopt this advanced technology [7-11].

The aim of the paper is to describe a procedure for the use of test data in the manual and automatic updating of FE models. The exercise is done using the ANSYS FE code [12] in conjunction with FEMTools [13], a state-of-the-art updating software.

\section{STRUCTURE DESCRIPTION}

The footbridge is an urban link with several minor access spans and one main 40m long arched central lively span. Most of the structural members are constructed using tubular steel profiles. An aerial photograph of the footbridge and 3D isometric view of its FE model is depicted in Figure 1. More information about the structure can be found in [14].
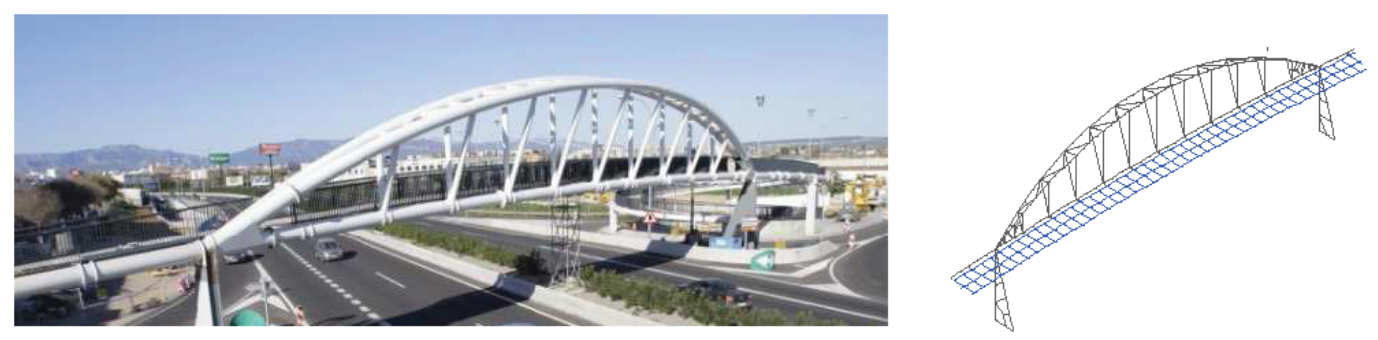

Figure 1. Footbridge under study: photograph and numerical FE model.

\section{FE MODELLING}

The initial FE model, comprising over 600 beam 3D elements for the steel members and 120 shell elements for the deck, modelled in ANSYS [12] is suitable, after minor changes, for importation to the FEMtools [13] software. Several cross section types are considered for the steel skeleton but for the deck just one constant thickness element $(200 \mathrm{~mm})$ is used. The handrails on the bridge, although are rigidly attached to the deck, are considered non-structural and then not modelled. However, additional mass for their consideration can be taken into account and distributed over the deck.

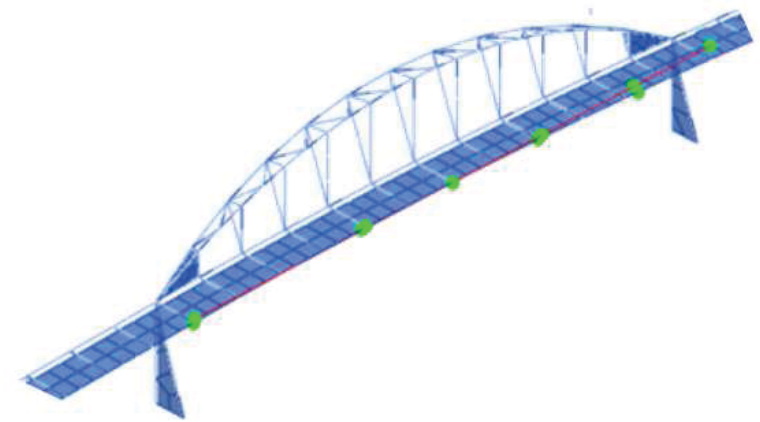

Figure 2. FEM mesh and signal acquisition points.

The FE mesh is given in Figure 2 together with the experimental test grid (green points). Note that, when the model is going to be correlated with the results from test data, it is important to ensure that the nodes of the FE mesh are coincident with the locations of the test points $[15,16]$. 
Norberto Ibán, Javier Castaño; José M Soria; Iván M. Díaz, Antolín Lorenzana

Using this initial model, maximum deflection for the nominal static loading case was $24.17 \mathrm{~mm}$ and the first three vibration modes and natural frequencies are shown in Figure 3 . Note than in the first mode, torsional effects are predominant, in the second one the main effect is vertical bending while the third one is mainly transversal bending (as shown in the additional Figure $3 \mathrm{c}$ ).

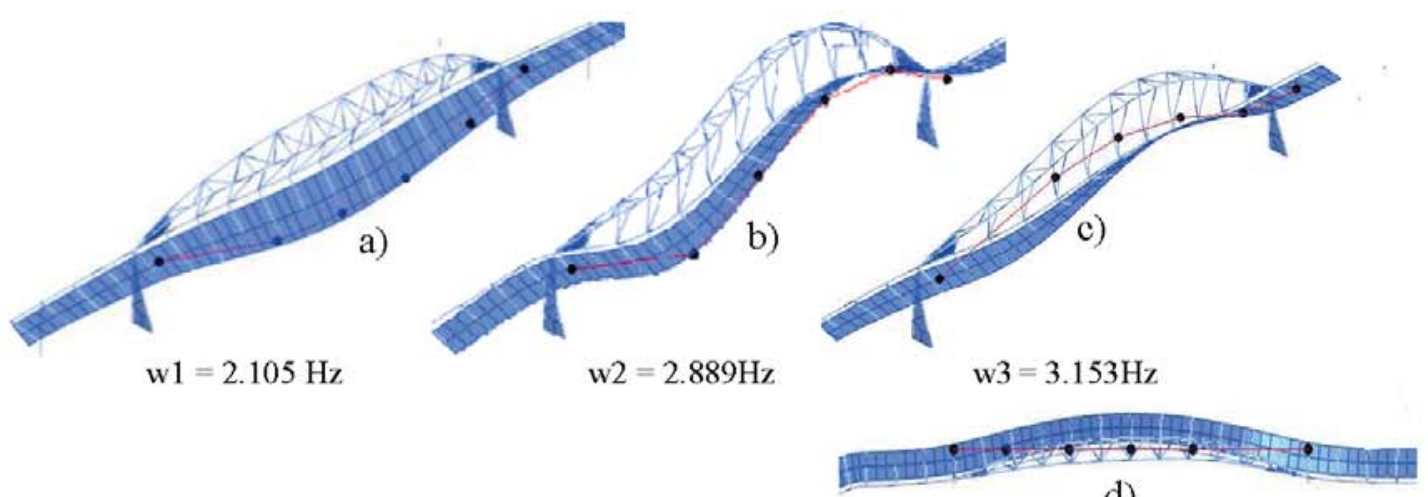

d)

Figure 3. First three natural mode shapes.

\section{TESTING}

A simple static loading test is carried out to determine the central deflection when a load of 20 tonnes is placed on the central span deck, resulting in $32 \mathrm{~mm}$. Also a simple modal ambient testing programme is conducted. Ten minutes recordings for vertical acceleration in the 4 selected central points (Figure 12) are registered at $200 \mathrm{~Hz}$. Figure 4 shows the data and, after postprocesing using SSI method (using MATHLAB), estimated frequencies and dampings are shown in Table 1. Similar results can be obtained using FEMTools routines, based on a global poly-reference Least Squares Complex Frequency (pLSCF) method. The damping values reported in Table 1 are not used in the following updating exercise, they are included to realise how low they are. Corresponding mode shapes are over-displayed in Figure 3 (black polygonal line).

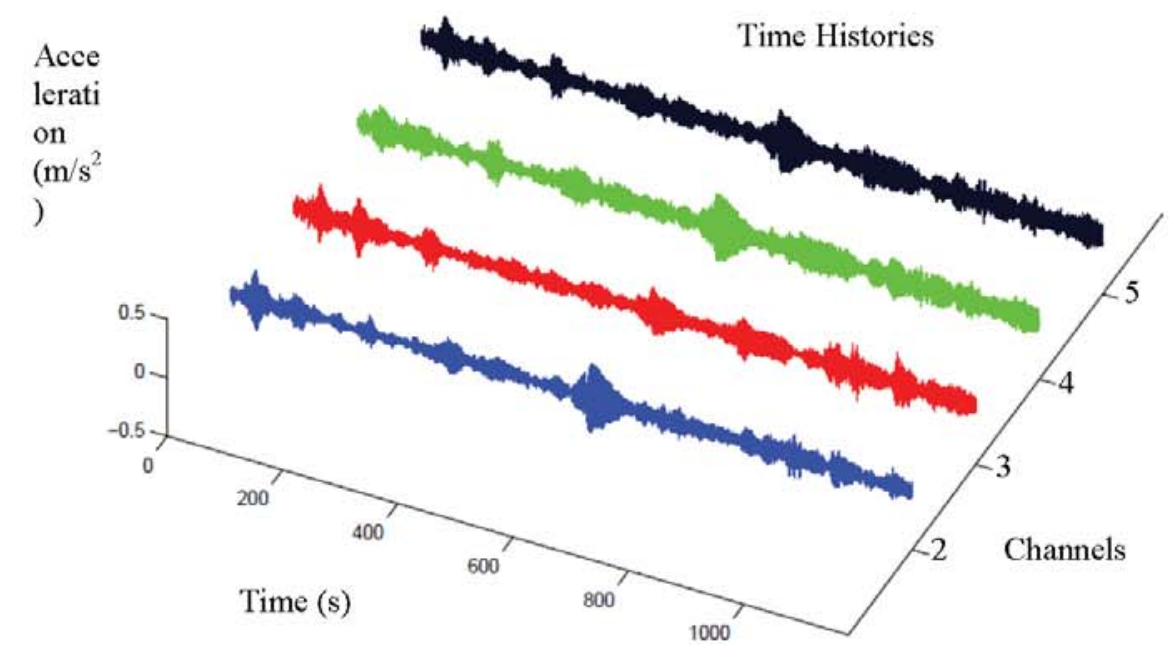

Figure 4. 10 minutes ambient vibration records corresponding to the testing points shown Figure 2. 
Dynamic characterization, modelling and model updating of a lively footbridge

Third International Conference on Mechanical Models in Structural Engineering

University of Seville. 24-26 june 2015.

Table 1. Modal frequencies and dampings estimated using operational modal analysis.

\begin{tabular}{ccc}
\hline Mode & Frecuency $(\mathrm{Hz})$ & Damping (\%) \\
\hline w1 & 2.081 & 0.31 \\
w2 & 2.502 & 0.75 \\
w3 & 2.877 & 0.60 \\
\hline
\end{tabular}

\section{CORRELATION BETWEEN MODELS AND MANUAL UPDATING}

Table 2 shows the comparison of natural frequencies of experimental (OMA) and FE vertical modes. Obviously, although MAC values are high, updating is needed for the frequency values, but before proceed with the selection of the parameters to be changed, static considerations are going to be taken into account. Note that the third mode is include just for checking purposes (it is maily a horizontal mode and only vertical accelerations are recorded)

Table 2. Experimental and initial numerical (FE model \#0) frequencies.

\begin{tabular}{cccc}
\hline Mode & OMA & FEM\#0 & MAC \\
\hline w1 & 2.081 & 2.105 & 99.1 \\
w2 & 2.502 & 2.889 & 98.7 \\
w3 & 2.877 & 3.153 & \\
\hline
\end{tabular}

Prior to attempting to update the FE model in FEMtools in an automatic way, it is recommended to experiment with selected input parameters by hand. The initial FEM is not accounting for the inherent flexibility of the steel joints and other effects. It is because of that the experimental static deflection was $33 \%$ larger than the numerical one. Once identified that most of the flexibility were concentrated in the connections between the lower chord of the arch and the transverse beams that support the deck, a semi-rigid joint was defined and their value manually adjusted to match with the measured deflection, resulting in a bending lost of about $\mathrm{F}=83 \%$ (considering that a perfect rigid joint has a value of $0 \%$ and an hinge one is $100 \%$ ). After introducing this effect, the static deflection is the expected one $(32 \mathrm{~mm})$ and the numerical modal response turned, has shown in Table 3.

Table 3. Experimental and numerical (FE model \#1) frequencies. Semi-rigid joints.

\begin{tabular}{cccc}
\hline Mode & OMA & FEM\#1 & MAC \\
\hline w1 & 2.081 & 1.988 & 99.4 \\
w2 & 2.502 & 2.689 & 99.1 \\
w3 & 2.877 & 2.939 & \\
\hline
\end{tabular}

This reduction in the bending capacity of the connections is considered too large to be consistent with the joint design and welding procedure, so other sources of discrepancies should be searched. In this case, after having a look to the deformed configuration under the static loading and realizing about the significant rigidity of the deck (that was acting like an arch itself), it is decided to decrease the Young's modulus of elasticity used to simulate the concrete of the deck (Ec). In doing so, several pairs of values for $\mathrm{F}$ and $\mathrm{EC}$ can be found. After a detail modelling of the referred steel connection, value for $\mathrm{F}$ was adjusted to $21 \%$. With this value for $\mathrm{F}$, the corresponding value for $\mathrm{Ec}$ is 0.9 $1010 \mathrm{~N} / \mathrm{m}^{2}$. Note that this finding suppose a $70 \%$ decrement (initial value vas $\mathrm{Ec}=31010 \mathrm{~N} / \mathrm{m}^{2}$ ). In 
Norberto Ibán, Javier Castaño; José M Soria; Iván M. Diaz, Antolín Lorenzana

nominal conditions it is not consistent such a big reduction but after knowing the on-site construction procedure carried through in pouring the concrete, in more than one layer, and the selfsupporting formwork used (generating about 50\% reduction in the concrete thickness in about 50\% of the plant surface), the results obtained was assumed to make sense. Note that the structural effect is similar to reduce the thickness of the shell elements used for modelling the concrete. In this new assumption, modal estimations are shown in Table 4. Although the adjusted $\mathrm{FE}$ model is closed enough to the real structure, additional improvement are possible, as presented in the next section.

Table 4. Experimental and numerical (FE model \#2) frequencies.

Semi-rigid joints and reduced concrete modulus.

\begin{tabular}{cccc}
\hline Mode & OMA & FEM\#2 & MAC \\
\hline w1 & 2.081 & 1.939 & 99.3 \\
w2 & 2.502 & 2.583 & 99.3 \\
w3 & 2.877 & 2.680 & \\
\hline
\end{tabular}

\section{AUTOMATIC UPDATING}

At this point, for conducting the automatic updating exercise it is necessary to choose additional parameters to change. It is recommended to act over the parameters with more indeterminacy. At this stage, the mass distribution along the deck (including steel formwork, reinforcement bars, concrete, pavement and hand railing) is chosen as a local parameter for each of the 120 shell elements considered in the central span.

Initial density for the shell elements was $\rho c=2300 \mathrm{~kg} / \mathrm{m}^{3}$ and final values after the automatic modal updating are shown (in a chart way showing percentage of change) in Figure 5 . Changes in the range of $+50 \%$ and $-75 \%$ are accepted. Final values for the density of the 120 shell elements cover all the range. The resulting mean value for the 70 elements in the central span is $2168 \mathrm{~kg} / \mathrm{m}^{3}$. Note that this value is a bit low for any reinforced concrete slab. This result, together with the low Ec found in the previous section (70\% reduction), suggests that if the deck thickness had been reduced (from $200 \mathrm{~mm}$ to, for example, $150 \mathrm{~mm}$ ), both parameters ( $\mathrm{Ec}$ and mean density) had been not change that much (but that exercise is out of the scope of this paper). Besides, the tendency is to remove mass from the middle and to add it near the supports in the central span. This tendency is consistent with the existence of a big manhole cover in the central part of the deck.

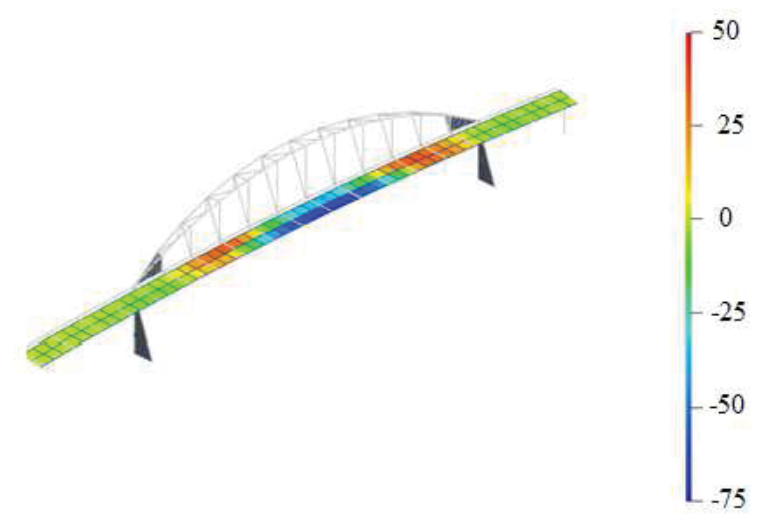

Figure 5. Percentage changes for the mass distribution on the deck elements. 
Dynamic characterization, modelling and model updating of a lively footbridge

Third International Conference on Mechanical Models in Structural Engineering University of Seville. 24-26 june 2015.

Table 5. Experimental and numerical (FE model \#2u) frequencies.

Semi-rigid joints, reduced concrete modulus and unequal mass distribution.

\begin{tabular}{cccc}
\hline Mode & OMA & FEM\#2u & MAC \\
\hline w1 & 2.081 & 2.0809 & 99.4 \\
w2 & 2.502 & 2.5022 & 99.6 \\
w3 & 2.877 & 2.680 & \\
\hline
\end{tabular}

For the referred values, modal response is presented in

Table 5, that shows the best agreement after the manual and automated updating. For the automatic procedure, MAC values of the analytical and measured mode shape pairs together with natural frequencies values were used as an updating criterion. FEMtools updating software uses wellproven iterative, parametric, modal and FRF-based updating algorithms using sensitivity coefficients and weighting values (Bayesian estimation). The procedure can be configurated with different confidence level for the different targets (natural frequencies, mode shapes, etc). It is also recommended to physically examine the mode shapes and assign lower confidence factors if the shapes appear to be erratic or even not pairing them (as has been done for mode 3 ) if they are weakly correlated The following Table 6 shows the best-fitted values that the automatic updating procedure can achieve for the models \#0 and \#1 when unequal mass distribution is allowed and confidence level for mode 1 is set to $99 \%$ and for mode 2 to $95 \%$.

Table 6. Experimental and best numerical frequencies for models $\# 0$ and $\# 1$ with unequal mass distribution.

\begin{tabular}{cccc}
\hline Mode & OMA & FEM\#0u & FEM\#1u \\
\hline w1 & 2.081 & 2.0789 & 2.0798 \\
w2 & 2.502 & 2.5858 & 2.5761 \\
\hline
\end{tabular}

\section{SENSITIVITY ANALYSIS}

As former described, manual updating is important, as it enables the analyst to quantify the possible effect that each selected parameter may have on the static and modal response of the structure. This is extremely important as it provides a basis for judging whether the results obtained from the automatic procedure are suitable. Besides, unless reasonable starting values of the updating parameters are given, the FEMtools software may have difficulty in improving the correlation between the experiments and the analysis. The software has the possibility to know, through a sensitivity analysis, if the selected parameters are worthy to change or not. Besides, note that without additional information (static deflection, connection flexibility, ...), automatic updating would not have been able to adjust the model in the way done manually. In this work, automatic updating is reserved for final adjustment to match with the modal response without affect to the static deflection. This highlights one of the potential problems of the blind application of automatic updating procedures. 
Norberto Ibán, Javier Castaño; José M Soria; Iván M. Díaz, Antolín Lorenzana

Figure 6 shows the sensitivity of the selected parameters to the first, second and third modes. Note that when concrete density $\rho c$ is considered global, it affect in the same direction to all the considered modes, so, to move up the first frequency and down the second one (as required in model \#0, \#1 and \#2) is not possible simultaneously.

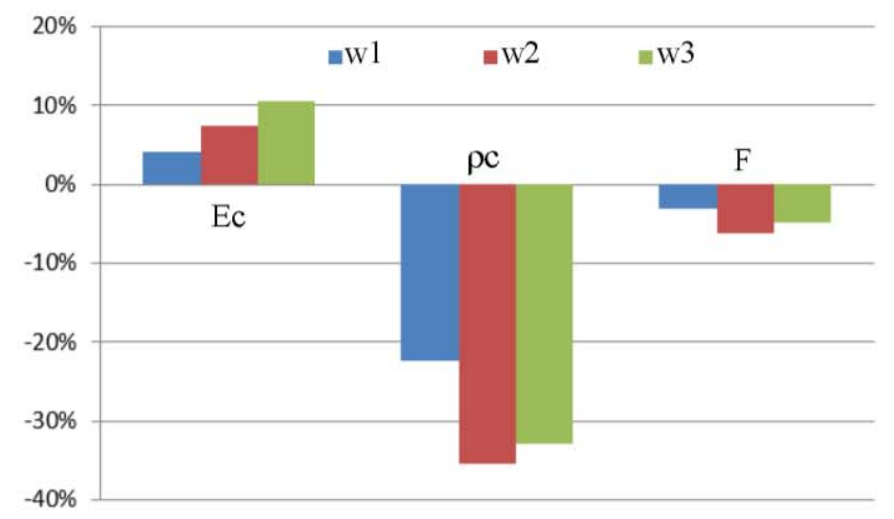

Figure 6. Concrete flexibility (Ec), concrete density $(\rho c)$ and semi-rigid joints (F) sensitibity.

When concrete density is considered local, the corresponding sensitivity chart is the one presented in Figure $7 \mathrm{a}$ (for mode 1 ) and Figure $7 \mathrm{~b}$ (for mode 2)

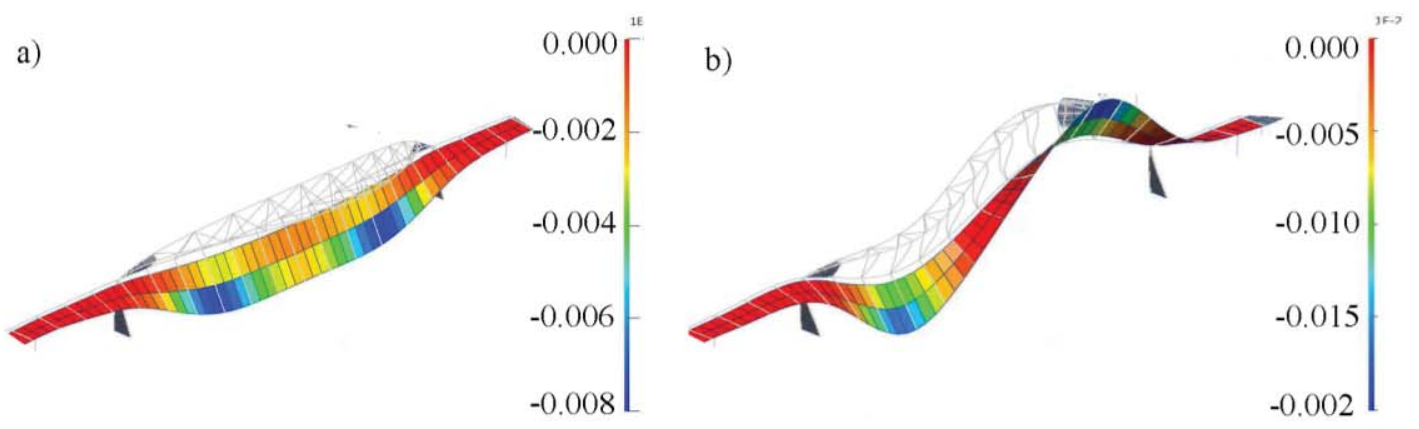

Figure 7. Local concrete density sensitivity for mode 1 (a) and mode 2 (b).

\section{DYNAMIC RESPONSE}

The structural damping has been introduced using the Rayleigh damping procedure. The damping coefficients alpha and beta have been set to achieve an approximate damping of $0.35 \%$ for all the considered modes. This damping ratio has been obtained adjusting the exponential free-decay curve in the structural response shown in Figure 8 in the range 32 to 60 seconds. Figure 8 shows the dynamic test consisting in a controlled input force (via electrodynamic shaker) in the middle of the footbridge from second 4 to second 32 just at the first frequency of the structure. After that, the shaker is turned off (although some force is recorded, as the moving mass of the shaker is moving together with the structure). 
Dynamic characterization, modelling and model updating of a lively footbridge Third International Conference on Mechanical Models in Structural Engineering University of Seville. 24-26 june 2015

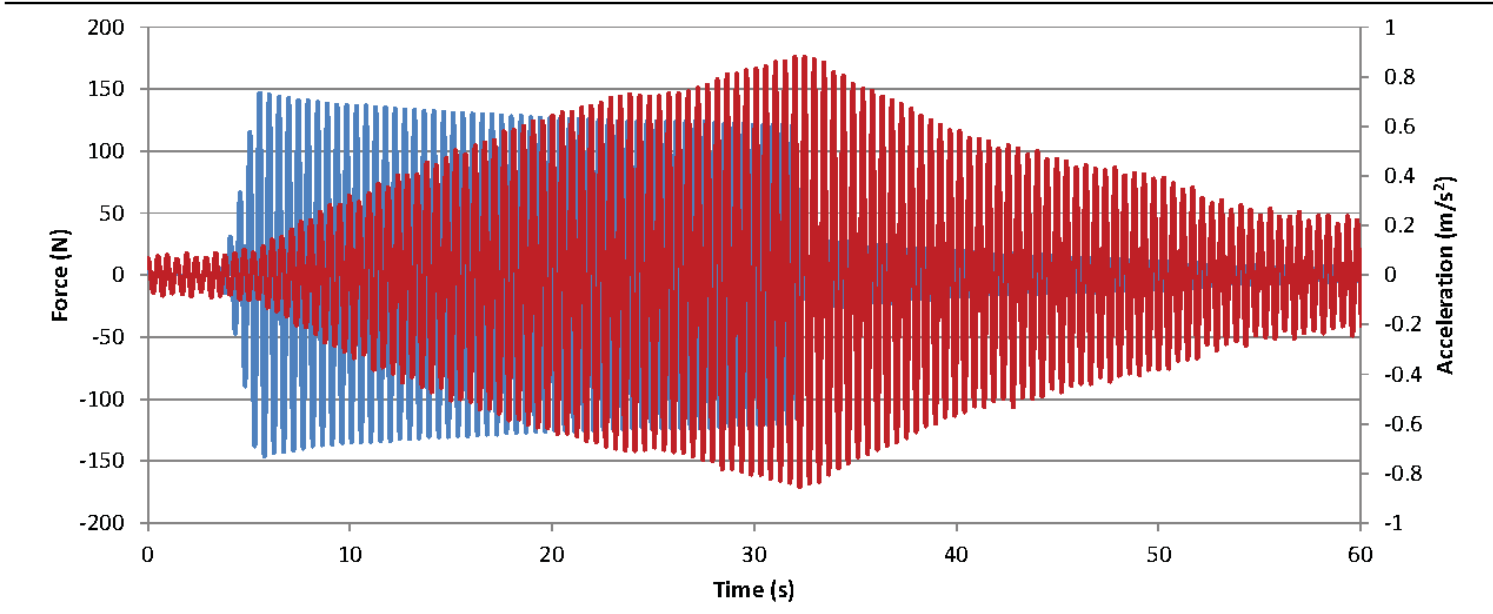

Figure 8. Experimental input force and corresponding response.

In order to check that the updated model is able to estimate the measured forced response, to simulations are performed. For that, a theoretical sinusoidal input force (from $4 \mathrm{~s}$ to $32 \mathrm{~s}$, amplitude $130 \mathrm{~N}$, at resonance) is applied, equivalent to the experimental one, as shown in Figure 9.

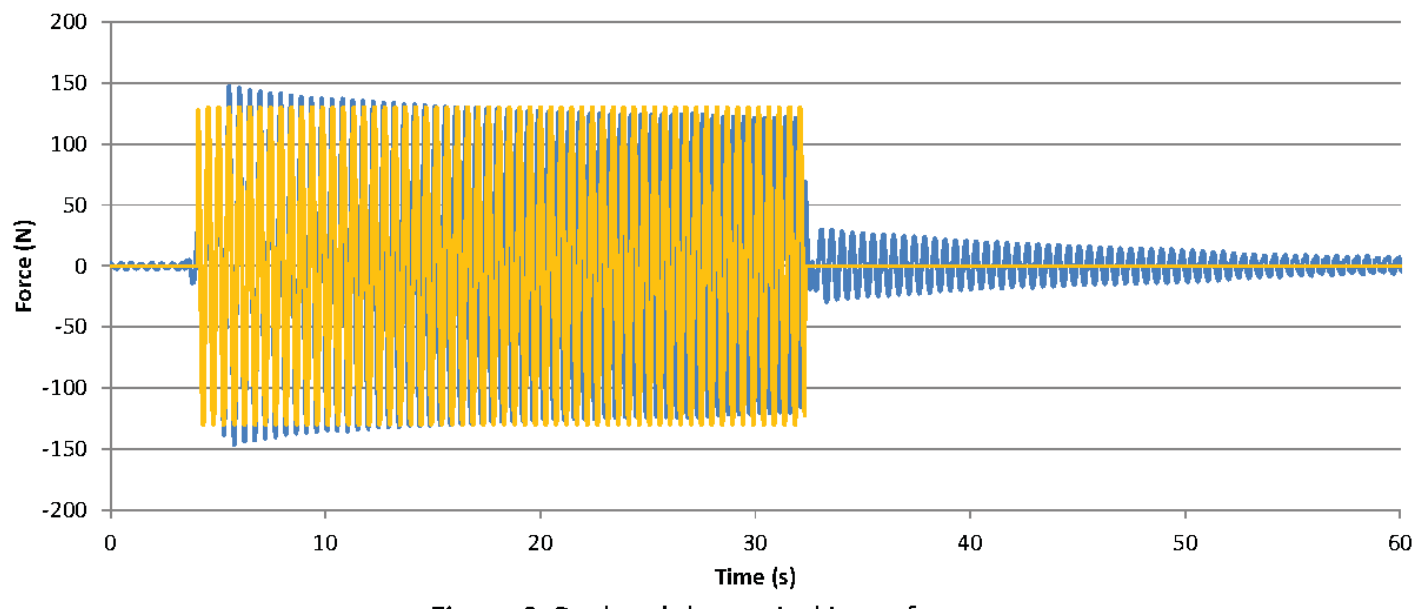

Figure 9. Real and theoretical input forces

The simulated responses are shown in Figure 10. Note the good agreement to the real one.

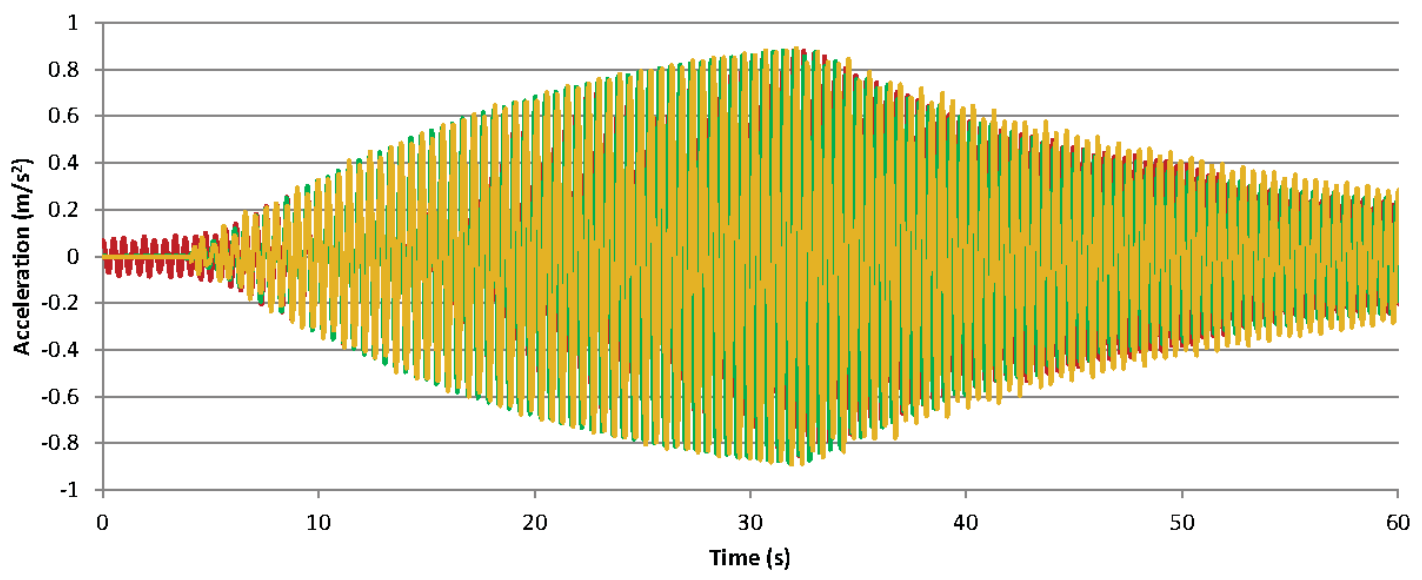


Nonberto Ibán, Javier Castaño; José M Soria; Iván M. Díaz, Antolín Lorenzana

Figure 10. Simulated responses compared with the real one

\section{CONCLUSIONS}

The procedure of FE model updating using static test data and modal test data of full-scale structures has be applied successfully to a particular lively footbridge. Progressive updating steps are shown in Figure 11. Three based steps (FEM\#1, FEM\#2 and FEM\#2u) are enough to get a FE model matching with the static and modal test data.

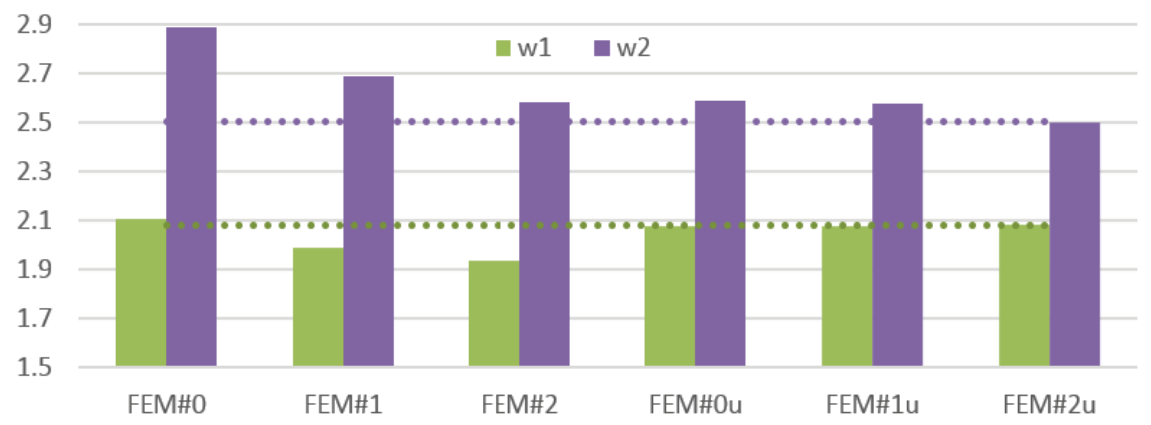

Figure 11. Successive adjustments.

Unlike aerospace or automotive engineering, the designs for most civil engineering structures are one-off. This requires designers to ensure, first time, that the structure performs satisfactorily. Hence, the immediate benefit of updating models of existing civil structures, which are already designed and built, is not as obvious as, for example, in other engineering design industrial sectors. It is important to stress here that the main advantage of this exercise for students and civil engineers is not in the improvements of existing prototypes and their numerical models. The principal benefit is a more reliable modelling to assist in future designs of similar structures. Consequently, increased knowledge, from the updating of FE models, based upon prototype [17] or full scaling testing could be extremely valuable to designers in the future.

The blind application of the automatic updating procedures built in purposely developed software can easily produce meaningless results. It is critical the practitioner assistance over the complete process.

Unless the initial input parameters are sufficiently close to the final values, any highly sensitive updating software may not find a good solution. In addition, if only natural frequencies are used for updating, then unrealistic values for the selected parameters may be predicted.

Once the model is properly updated, it can be used to estimate the dynamic response of the structure.

\section{ACKNOWLEDGMENTS}

The authors would like to thank D. Javier Henche (Grahen Ingenieros S.L.) and D. Victor Darder (Melchor Mascaró) for giving us the opportunity to work with them. Also authors wish to 


\section{Dynamic characterization, modelling and model updating of a lively footbridge Third International Conference on Mechanical Models in Structural Engineering University of Seville. 24-26 june 2015 .}

acknowledge to the partial support through Research Project BIA2011-28493-C02-02 (MINECO, Spanish Government).

\section{REFERENCES}

[1] Modak S.V., Kundra T.K., Nakra B.C., (2005). Studies in dynamic design using updated models, Journal of Sound and Vibration 281 (3-5) 943-964.

[2] Zarate B. A., Caicedo J. M., (2008). Finite element model updating: multiple alternatives, Engineering Structures, vol. 30, no. 12, pp. 3724-3730.

[3] Bayraktar, A., Altunisik, A.C., Sevim, B. and Turker, T. (2007). Modal testing and finite element model calibration of an arch type steel footbridge, Steel. Compos. Struct., 7(6), 487-502.

[4] Li W.M., Hong J.Z., (2011) New iterative method for model updating based on model reduction, Mechanical Systems and Signal Processing, vol. 25, no. 1, pp. 180-192.

[5] Imergun, M.,and Visser, W.J., (1991). A Review of Model Updating techniques, Journal of Sound and vibration, ASME, 9-20.

[6] Kim G.H., Park Y.S., (2004). An improved updating parameter selection method and finite element model update using multiobjective optimisation technique, Mechanical Systems and Signal Processing 18 (1) 59-78.

[7] Mottershead J. E., Friswell M. I., (1993) Model updating in structural dynamics: a survey, Journal of Sound and Vibration, vol. 167, no. 2, pp. 347-375.

[8] Friswell M., Mottershead J.E., (1995). Finite Element Model Updating in Structural Dynamics, Kluwer, Dordrecht.

[9] Wu J.R., Li Q.S., (2004). Finite element model updating for a high-rise structure based on ambient vibration measurements, Engineering Structures 26 (7) 979-990.

[10] Ribeiro, D., Calçada, R., Delgado, R., Brehm, M., Zabel, V., (2012). Finite element model updating of a bowstring-arch railway bridge based on experimental modal parameters, Engineering Structures, 40 413-435.

[11] Zivanovic, S., Pavic, A. and Reynolds, P. (2007), Finite element modelling and updating of a lively footbridge: the complete process, J. Sound. Vib., 301, 126-145

[12] ANSYS v15. (2014). User's Manual, ANSYS.

[13] FEMtools Model Updating Theoretical Manual, (2008) Dynamic Design Solution, Leuven.

[14] Chulvi M., Henche J., (2011). Pasarela sobre la vía de cintura MA-20 en Palma de Mallorca, V Congreso nacional de ACHE, Asociación científico-técnica del hormigón estructural, Barcelona.

[15] Zivanovic' S., Pavic A., Reynolds P., (2006). Modal testing and finite element model tuning of a lively footbridge structure, Engineering Structures 28 (6) 857-868.

[16] Pavic, A., Hartely, M. J. \& Waldron, P. (1998) Updating of the Analytical Models of Two Footbridges Based on Modal Testing of Full-Scale Structures. ISMA23.

[17] Zapico, J.L., Gonzalez, M.P., Friswell, M.I., Taylor, A.J. and Crewe, A.J. (2003). Finite element model updating of a small scale bridge, J. Sound. Vib., 268, 993-1012 
A PROCEDURE TO TRACK VIBRATION MODES UNDER CHANGING EXTERNAL FACTORS: APPLICATION TO A PEDESTRIAN BRIDGE

International Conference on

Mechanical Models in

Structural Engineering

Iván Muñoz Díaz; José Manuel Soria Herrera; Jaime García Palacios; Norberto Ibán Lorenzana; Antolín Lorenzana Ibán.

\begin{tabular}{c|c|l|l|} 
Aportaciones: & Experimentación & Procesado & Edición \\
\hline & $\begin{array}{c}\text { Instrumentación } \\
\text { Registros }\end{array}$ & & Imágenes \\
\cline { 2 - 4 } & & & \\
\hline
\end{tabular}




\title{
A procedure to track vibration modes under changing external factors: application to a pedestrian bridge
}

Soria, José M. ${ }^{1}$; Díaz, Iván M. ${ }^{2}$; García-Palacios, Jaime H. ${ }^{3}$; Ibán, Norberto"; Lorenzana, Antolín ${ }^{5}$

\begin{abstract}
A low-cost vibration monitoring system has been developed and installed on an urban steel- plated stress-ribbon footbridge. The system continuously measures: the acceleration (using 18 triaxial MEMS accelerometers distributed along the structure), the ambient temperature and the wind velocity and direction. Automated output-only modal parameter estimation based on the Stochastic Subspace Identification (SSI) is carried out in order to extract the modal parameters, i.e., the natural frequencies, damping ratios and modal shapes.
\end{abstract}

Thus, this paper analyzes the time evolution of the modal parameters over a whole-year data monitoring. Firstly, for similar environmental/operational factors, the uncertainties associated to the time window size used are studied and quantified. Secondly, a methodology to track the vibration modes has been established since several of them with closely-spaced natural frequencies are identified. Thirdly, the modal parameters have been correlated against external factors. It has been shown that this stress-ribbon structure is highly sensitive to temperature variation (frequency changes of more than $20 \%$ ) with strongly seasonal and daily trends.

Keywords: Modal analysis; Footbridge; Continuous dynamic monitoring; Environmental effects.

\section{INTRODUCTION}

The long-term vibration monitoring of civil engineering structures is increasingly used to monitor both, the structure integrity and the vibration serviceability. A number of examples of bridges and footbridges equipped with a monitoring system can be found $[7,9,10,16]$. In these monitoring systems, the vibrations due to traffic or wind are measured and recorded. These data can be used to continuously extract the modal parameters (natural frequencies, damping ratios and modal shapes) which may be employed to assess the structural integrity since structural damages lead to changes in the modal parameters. Thus, vibration-based Structural Health Monitoring (SHM) systems using automated output-only modal identification (also known as Operational Modal Analysis, OMA) have been extensively proposed, for instance $[8,13]$. One of the main problems of these systems is that they have

\footnotetext{
${ }^{1}$ Dpto. CMM and Theory of Structures. ETSICCP, UPM (Spain).im.soria@upm.es (Corresponding author)

2 Dpto. CMM and Theory of Structures.ETSICCP, UPM (Spain).ivan.munoz@upm.es

${ }^{3}$ Dpto. Civil Engineering: Hidraulic and Energy. ETSICCP, UPM (Spain). jaime.garcia.palacios@upm.es

${ }^{4}$ Mechanical Engineering Division. Cartif Research Center (Spain). noriba@cartif.es

${ }^{5}$ Ell/ITAP, Universidad de Valladolid (Spain). ali@eli.uva.es
} 
to cope with changing environmental/operational conditions that often significantly affect the modal estimation.

The main obstacle for a more widespread adoption of these monitoring systems is the cost associated to their installation. Recently, a successful attempt to reduce the cost of a monitoring system has been carried out through the use of low-cost sensors to measure structural vibrations on a footbridge. Thus, a low-cost continuous vibration monitoring system using small MEMS (Micro Electro-mechanical Systems) accelerometers has been developed and installed on Pedro Gómez Bosque (PGB) footbridge (Valladolid, Spain) in order to track its long-term dynamic performance. The system continuously measures: the acceleration (using 18 triaxial MEMS accelerometers distributed along the structure), the ambient temperature and the wind velocity and direction [18]. PGB footbridge is a singular steel-plated stress-ribbon footbridge with a single span of $85 \mathrm{~m}$. The dynamic behavior shows several low-frequency vibration modes with closely-spaced natural frequencies and low damping ratios.

A procedure to track vibration modes has been programmed to carry out an automatic modal parameter estimation. This procedure has to cope with vibration modes with closely-spaced natural frequencies. In this case, sorting vibration modes using frequency criteria and removing outliers that lay out of intervals of frequency variation might not be adequate $[14,16]$. This paper describes the detailed procedure carried out to track vibration modes of PGB footbridge over time. The procedure uses three tolerances based on the Modal Assurance Criterion (MAC). This approach allows reliable monitoring of vibration modes that are maintained over time.

Regarding the use of modal parameter variations as possible damage detector in structures, it is necessary to observe the modal variations over time due to the influence of some external agents acting on the undamaged structure $[12,14]$. It is important to evaluate the magnitude of this modal variation, as well as the main factors that influence the relationship between them. The temperature is usually the most significant environmental factor [20]. However, other factors, such as operational or boundary conditions, may significantly affect the modal estimates [1, 12]. Finite Element (FE) models are usually updated using the modal parameters $[4,15]$. However, when the modal parameters show significant variability with changing environmental factors, the updated model might not be as accurate as required [2]. Hence, it is important to estimate uncertainties in the modal parameter identification in order to establish the degree of confidence of the updated model. This updated model can be useful to guarantee a successful structural intervention during structural rehabilitation $[6,11]$. That is, nondestructive tests, such as an OMA, together with calibrated models greatly benefit reliable structural evaluations.

The paper continues with the description of the structure and its monitoring system. Section 3 analyzes the uncertainties associated to a single time history record. The output-only modal parameter estimation using different data blocks is carried out. Thus, uncertainties due to the selection of the data block are quantified. The results of continuous dynamic analysis are described in Section 4. A tracking method to follow the evolution of the persistent vibration modes over time is proposed. The influence of the environmental/operational factors on the modal estimates is studied. Finally, some conclusions are drawn and suggestions for future work are given. 


\section{THE FOOTBRIDGE AND ITS VIBRATION MONITORING}

\subsection{Structure description}

PGB footbridge, sited in Valladolid (Spain), is a slender and lightweight structure that creates a pedestrian link over the Pisuerga River between a sport complex and the city centre (see Figure 1). This bridge, built in 2011, is a singular stress-ribbon footbridge born by a pretensioned catenary-shape steel band with a single span of $85 \mathrm{~m}$ that provides minimal impact on the surroundings. The structure mainly consists of a Corten steel band of $94 \mathrm{~m}$ long, $3.6 \mathrm{~m}$ wide and only $30 \mathrm{~mm}$ thick which is pre-tensioned and anchored to the two abutments. The complete steel band is fabricated by welding 8-meter long sheets and a number of 110 precast concrete slabs lay on the steel band [17]. These slabs do not have bearing capacity in such a way that the only structural element is the band. The structure is completed by rubber flooring and a stainless steel glass handrail.

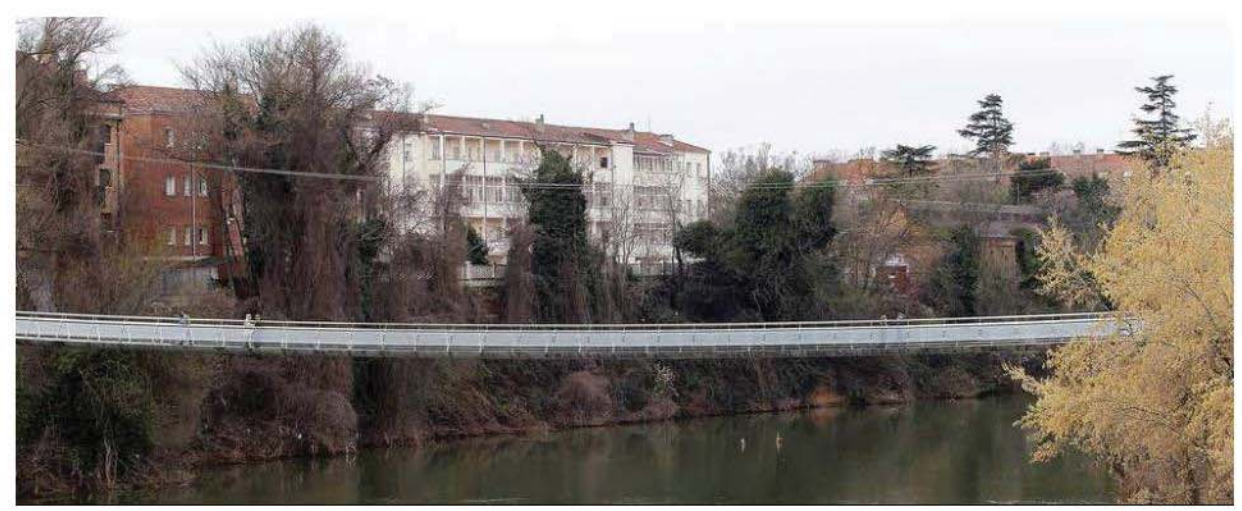

Figure 1. Pedro Gómez Bosque footbridge. Landscape view.

\subsection{Monitoring system}

A structural vibration monitoring system was devised in order to continuously estimate the modal parameters of the structure and to assess their changes under varying environmental conditions. Therefore, apart from the accelerometers needed to perform a modal analysis, sensors for the wind and environmental temperature conditions were installed. The monitoring system comprises 18 triaxial accelerometers, 9 at each side of the deck, a temperature sensor and an anemometer with a vane. Wires and acceleration sensors were installed inside the handrail so the structure aesthetic was not modified in any way. This fact introduced additional complications: (i) the installation process was a laborious task, and (ii) additional angular transformations are required to obtain the acceleration vector in the structure axes for each accelerometer.

The vibration sensor used for the monitoring system was the low-cost MEMS accelerometer ADXL327 (ANALOG DEVICES) able to measure the static acceleration of gravity. The ADXL327 is a very small, low power, 3-axis accelerometer with signal condition voltage output. The key properties of this sensor are: measurement range up to $\pm 2.5 \mathrm{~g}$, sensitivity up to $500 \mathrm{mV} / \mathrm{g}$ and bandwidth up to $550 \mathrm{~Hz}$. However, this sensor is not designed to transmit the signal over long distances. To overcome this problem, an ad-hoc conditioning circuit was designed to enhance its long-distance performance. First, three 
capacitors, one to each channel, were placed to fix the frequency bandwidth to $100 \mathrm{~Hz}$. Second, since the accelerometer has to be supplied by $3.6 \mathrm{~V}$ to get its maximum nominal sensitivity of $500 \mathrm{mV} / \mathrm{g}$, the power supply unit of $12 \mathrm{~V}$ and a voltage regulator to $3.6 \mathrm{~V}$ were integrated into each circuit board in order to avoid power losses by the long distance wires. Thirdly, an operational amplifier was used to reduce significantly the output impedance, achieving thus a good signal-to-noise ratio for acceleration parameter (constant sensitivity and low noise). The achieved signal-to-noise ratio was $25 \mu \mathrm{g} / \sqrt{\mathrm{Hz}}$, which was considered to be enough for monitoring the structural vibrations. Finally, each circuit board with all its components was covered with a plastic coating to protect it from environmental conditions. Then, the accelerometers were ready to be installed inside the tube of the handrail. The sensing system was completed by a temperature sensor (model T0110 transmitter of Comet) and a wind sentry (model $03002 \mathrm{~L}$ of R.M. Young Company) to measure the speed and direction of the wind. The temperature sensor and wind sentry were installed on the public light tower sited closed to the structure (see Figure 2).

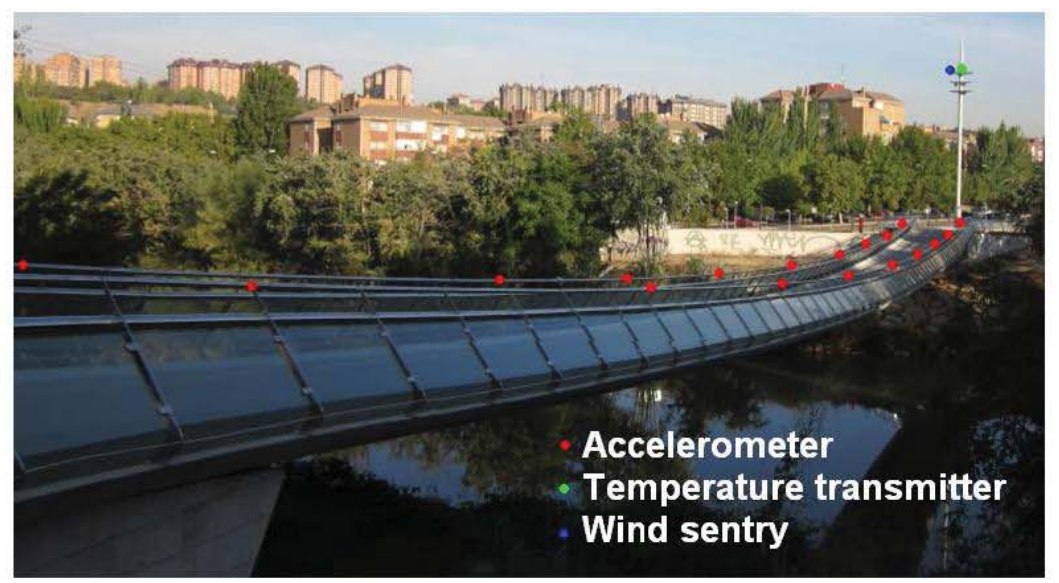

Figure 2. Monitoring system. Distribution of sensors.

The monitoring system then comprises 57 voltage channels that are processed continuously. The data logger CompactRIO 9076 (National Instruments) with two NI 9205 with 32 analog input channels is used for real-time data acquisition. The frequency sampling for each channel was chosen to be $200 \mathrm{~Hz}$, enough to identify the modal parameters of the structure and to avoid aliasing problems during the post-processing. The actual orientation of the accelerometers installed inside the handrail is unknown. However, the Euler angles between the accelerometer coordinate system and the structure coordinate system can be derived taking into account the following: (i) the longitudinal axis of each accelerometer matches with the longitudinal axis of the footbridge, and (ii) the accelerometers are able to measure acceleration due to gravity. Therefore, the transformation matrix between both coordinate systems is obtained, and then, the acceleration in the global axes can be finally calculated [18]. Before its final installation, a laboratory validation was carried out and after the installation, an in-situ validation was performed by comparing against conventional piezoelectric accelerometers.

\section{PEERED ANALYSIS OF ONE TEST}

The uncertainties associated to the modal identification of one test, corresponding to the record measured on 01/05/2013 at 19:16 (60-minute test), are analyzed herein. The dynamic behavior of the structure is mainly governed by the vertical response (previous time-history analyses have shown that 
lateral and longitudinal accelerations are small and negligible, respectively, as compared to vertical ones). That is the reason why this analysis concentrates on the vertical vibration. The process followed is, firstly, the signal processing undertaken before the modal identification is presented. Afterwards, using SSI-cov technique is applied to different 20 -minute time windows of the 60 -minute test.

\subsection{Data processing}

The vertical response of the structure for 1-hour test is analyzed (with an initial sampling frequency of $200 \mathrm{~Hz}$ ). The signal is filtered by a low-pass Butterworth filter of order 4 with a cutoff frequency of $5 \mathrm{~Hz}$. A decimation factor of 16 is applied obtaining a Nyquist frequency of $6.25 \mathrm{~Hz}$. As an example, Figure 3a and $b$ show the filtered and decimated response in time and frequency domain, respectively, corresponding to the four central channels for upstream side. Up to ten peaks below $4 \mathrm{~Hz}$ can be observed in Figure $3 \mathrm{~b}$.

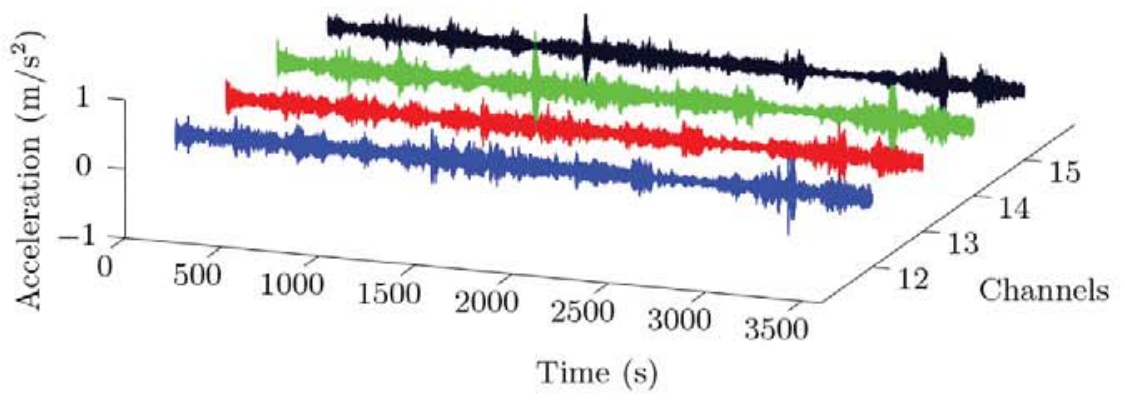

(a) Time domain.

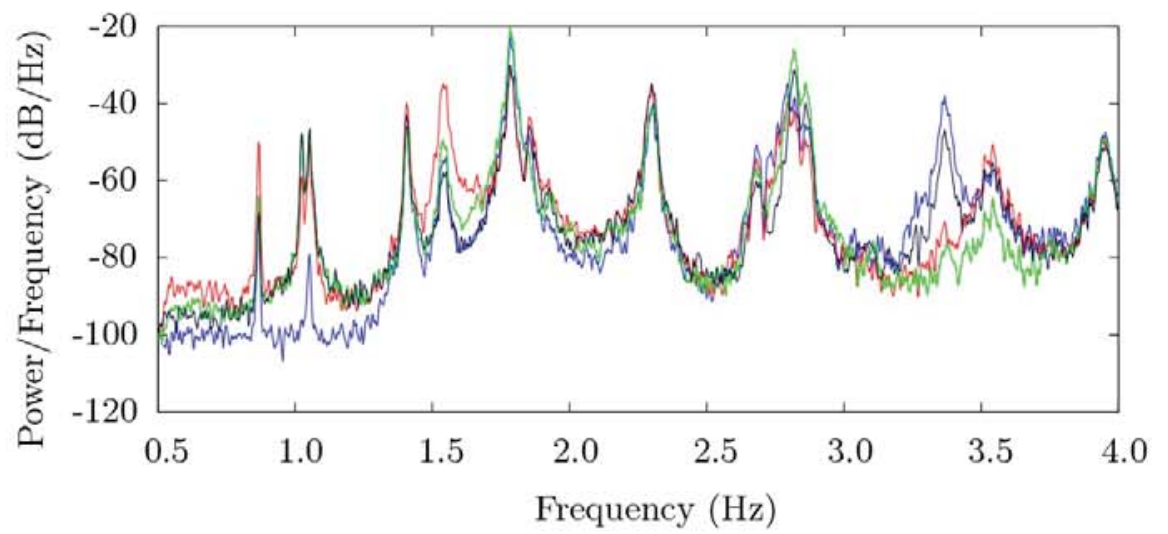

(b) Frequency domain.

Figure 3. Processed raw data of 4 central channels for upstream side.

\subsection{Operational Modal Analysis using the same SSI technique}

The modal parameters have been tracked over time to capture the dynamic behavior of the structure as best as possible. As a rule of thumb, the minimum duration of the measurement should be at least 
1000 cycles of the lowest natural frequency is expected to be identified [19]. This duration is usually recommended as the minimum one for noise-contaminated signals and close vibration modes. Therefore, this duration, which corresponds approximately to 20 minutes, has been adopted here to carry out the modal tracking.

Three consecutive windows of 20-minute data are considered to identify the modal parameters using only SSI-cov. These results are compared with those obtained using the 60 -minute record. Table 1 shows the estimates obtained from the four data blocks. A MAC correlation between the modal shapes estimated by three techniques has been carried out. Modes that exhibit a MAC value greater than 0.95 for all of the cross values are highlighted in bold. Modes with natural frequencies over $4 \mathrm{~Hz}(0.8$ times the cutoff frequency of the filter) are not included. Modes that exhibit a MAC value greater than 0.95 for all of the cross values are highlighted in bold. The average temperature for each time window was $16.42,13.84$ and $11.56{ }^{\circ} \mathrm{C}$, respectively, and $13.94{ }^{\circ} \mathrm{C}$ for the 60 -minute record.

Table 1. Natural frequencies and damping ratios identified by SSI-cov and different time blocks.

\begin{tabular}{|c|c|c|c|c|c|c|c|c|}
\hline \multirow{2}{*}{ Mode } & \multicolumn{2}{|c|}{$60 \mathrm{~min}}$. & \multicolumn{2}{|c|}{$1^{\text {st }} 20 \mathrm{~min}}$. & \multicolumn{2}{|c|}{$2^{\text {nd }} 20 \mathrm{~min}}$. & \multicolumn{2}{|c|}{$3^{\text {rd }} 20 \mathrm{~min}}$. \\
\hline & $f(\mathrm{~Hz})$ & $\zeta(\%)$ & $f(\mathrm{~Hz})$ & $\zeta(\%)$ & $f(\mathrm{~Hz})$ & $\zeta(\%)$ & $f(\mathrm{~Hz})$ & $\zeta(\%)$ \\
\hline- & 0.8671 & 0.3352 & 0.8663 & 0.2526 & - & - & 0.8660 & 1.0824 \\
\hline- & - & - & 1.0251 & 0.3793 & 1.0243 & 0.1433 & 1.0281 & 1.8147 \\
\hline 1 & 1.0548 & 0.9622 & 1.0536 & 0.3755 & 1.0518 & 0.3513 & 1.0535 & 0.4883 \\
\hline 2 & 1.4077 & 0.3792 & 1.4073 & 0.3523 & 1.4059 & 0.5874 & 1.4093 & 0.2594 \\
\hline 3 & 1.5408 & 0.6762 & 1.5408 & 0.5343 & 1.5395 & 0.7945 & 1.5431 & 0.7658 \\
\hline 4 & 1.7869 & 0.4483 & 1.7884 & 0.5036 & 1.7882 & 0.6227 & 1.7833 & 0.4014 \\
\hline 5 & 1.8571 & 0.6381 & 1.8567 & 0.6340 & 1.8574 & 0.6775 & 1.8569 & 0.4995 \\
\hline- & - & - & 1.9260 & 0.3870 & - & - & - & - \\
\hline 6 & 2.3020 & 0.4799 & 2.3022 & 0.4444 & 2.3020 & 0.5353 & 2.3014 & 0.4788 \\
\hline- & 2.6819 & 0.3206 & - & - & 2.6802 & 0.2709 & 2.6836 & 0.2546 \\
\hline- & - & - & - & - & - & - & 2.7306 & 0.4594 \\
\hline- & - & - & - & - & 2.7848 & 0.3825 & - & - \\
\hline- & 2.8051 & 0.5159 & 2.8097 & 0.7520 & - & - & 2.8041 & 0.4918 \\
\hline- & - & - & - & - & 2.8147 & 0.1976 & - & - \\
\hline- & 2.8682 & 0.3238 & - & - & - & - & 2.8631 & 0.3248 \\
\hline- & - & - & 2.9171 & 0.2887 & - & - & - & - \\
\hline 7 & 3.3674 & 0.4485 & 3.3680 & 0.4194 & 3.3659 & 0.4449 & 3.3709 & 0.4587 \\
\hline 8 & 3.5375 & 0.8723 & 3.5356 & 0.6417 & 3.5361 & 0.9920 & 3.5343 & 0.8376 \\
\hline 9 & 3.9487 & 0.5106 & 3.9443 & 0.4427 & 3.9458 & 0.5759 & 3.9552 & 0.3504 \\
\hline
\end{tabular}

Table 2 presents a summary of the selected modes. The table shows the mean values for the 20 -minute tests and the maximum errors compared with the results obtained with the 60 -minute test. In this case, the maximum errors obtained are $0.2855 \%$ and $61.09 \%$ for frequencies and damping ratios respectively. The errors in natural frequency estimates using 20 minutes as compared with 60 are negligible. 
Table 2. Summary of identified mode frequencies and statistical comparison for the 20-minute against 1-hour time blocks: mean frequency, mean damping and corresponding errors.

\begin{tabular}{ccccc}
\hline \multirow{2}{*}{ Mode } & \multicolumn{2}{c}{ Frequency } & \multicolumn{2}{c}{ Damping } \\
\cline { 2 - 5 } & $\bar{f}(\mathbf{H z})$ & Error $(\%)$ & $\bar{\zeta}(\%)$ & Error $(\%)$ \\
\hline 1 & 1.0530 & 0.2849 & 0.4050 & 61.09 \\
2 & 1.4075 & 0.2416 & 0.3997 & 32.80 \\
3 & 1.5411 & 0.2336 & 0.6982 & 26.02 \\
4 & 1.7866 & 0.2855 & 0.5092 & 22.13 \\
5 & 1.8570 & 0.0377 & 0.6037 & 17.80 \\
6 & 2.3019 & 0.0348 & 0.4862 & 9.090 \\
7 & 3.3683 & 0.1484 & 0.4410 & 3.930 \\
8 & 3.5353 & 0.0905 & 0.8238 & 35.05 \\
9 & 3.9484 & 0.2761 & 0.4563 & 22.55 \\
\hline
\end{tabular}

Figure 4 shows an example of identified modal shapes corresponding to the lowest six modes obtained with SSI-cov for the 60-minute test.

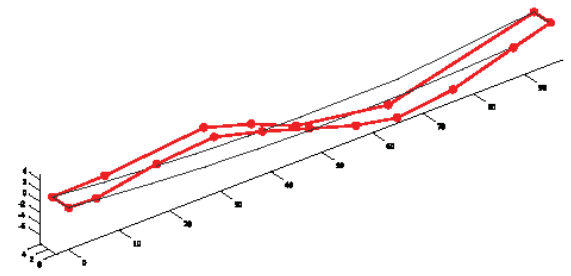

(a) $f=0.87 \mathrm{~Hz}$

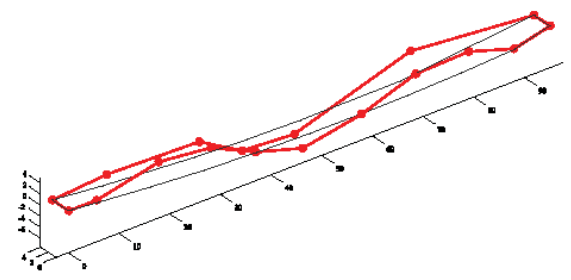

(c) $f=1.41 \mathrm{~Hz}$

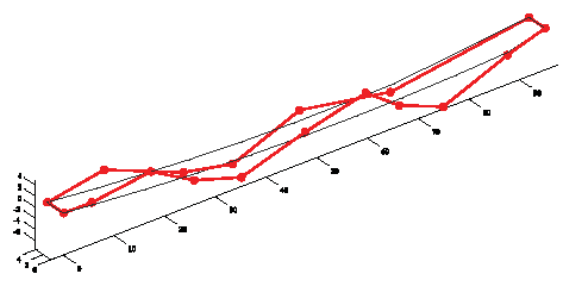

(e) $f=1.79 \mathrm{~Hz}$

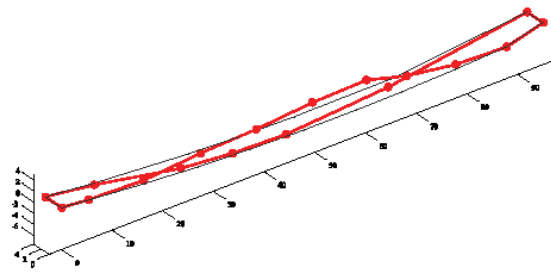

(b) $f=1.05 \mathrm{~Hz}$

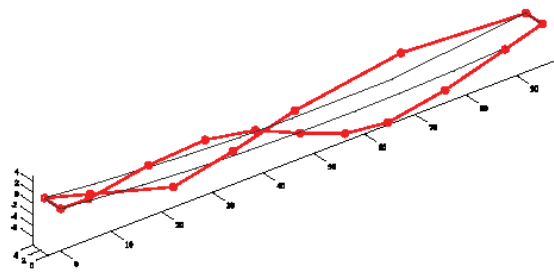

(d) $f=1.55 \mathrm{~Hz}$

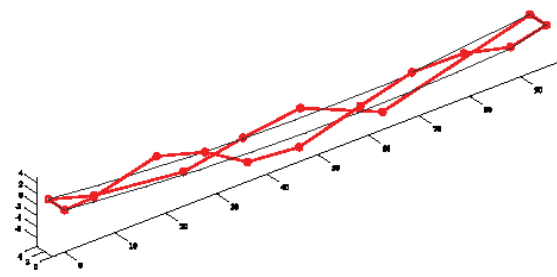

(f) $f=1.86 \mathrm{~Hz}$

Figure 4. First six modes shapes obtained with SSI-cov. 


\section{CONTINUOUS DYNAMIC ANALYSIS}

The procedure carried out to track the vibration modes is depicted in Figure 5. The results obtained from 1-year of continuous dynamic monitoring are described from now on. A method to track the evolution of the main vibration modes over time is described. Then, the influence of the environmental/operational factors on the modal estimates is studied.

\subsection{Tracking of modal properties}

For a single test, no special treatment on SSI itself to separate closely-spaced frequencies is considered. However, in a dynamic continuous monitoring framework, the vibrations modes must be carefully tracked since their natural frequencies can be similar and even can change their order. Therefore, a procedure to link modal parameters identified from each data set that are associated with the same vibration mode is needed. A criterion based on selecting a mode within a fixed frequency range could lead to wrong results due to the variation of frequency ranges between different tests. As a consequence, it proposes a tracking method in order to follow the evolution of the main vibration modes over time. From the acquired data, an automated OMA has been implemented using SSI-cov. The procedure carried out is depicted in Figure 5 . The process can be divided into the following steps:

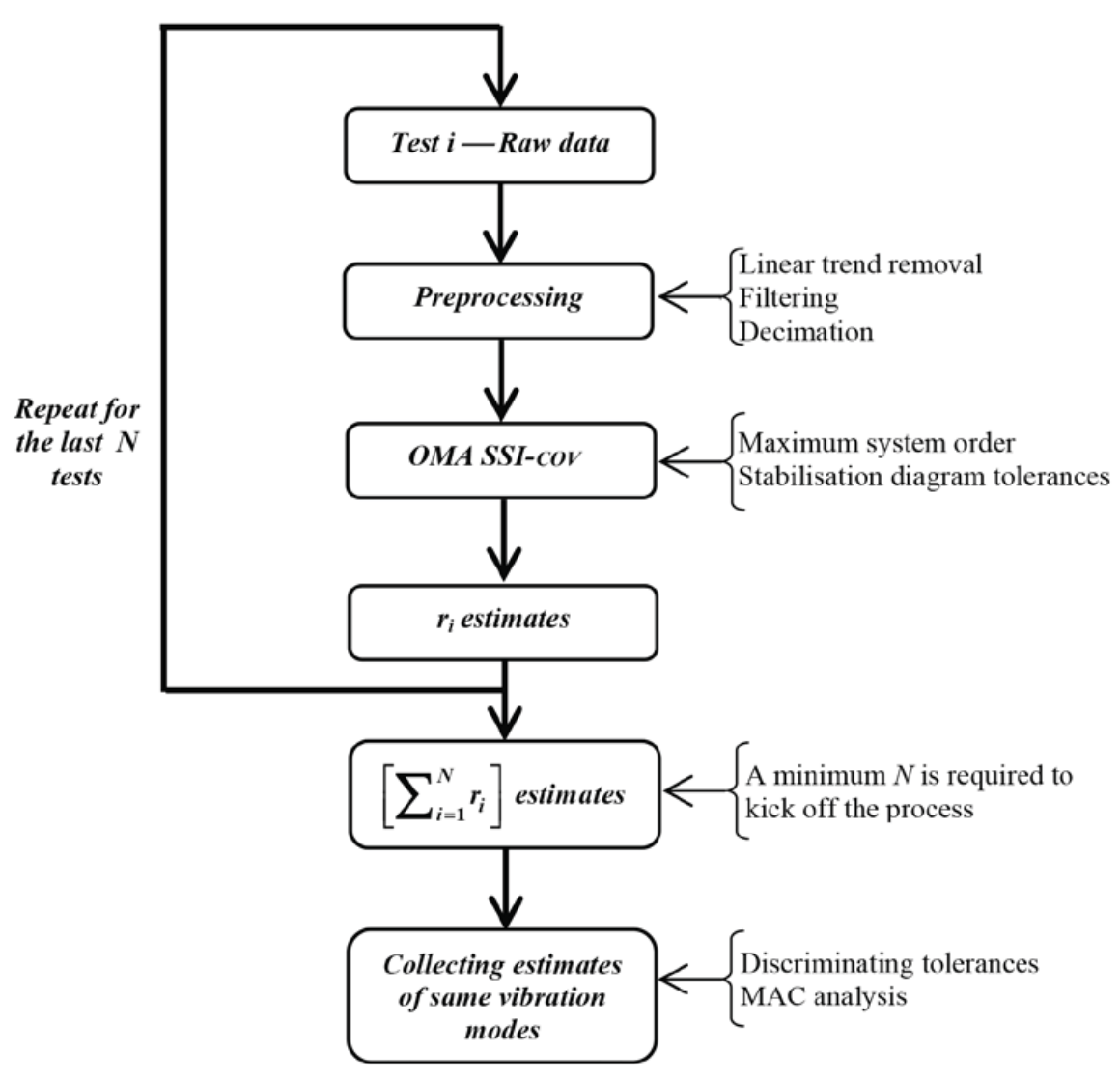

Figure 5. Tracking procedure for modal parameters. 
- Take the last $N$ tests, $N$ being the number of tests. $N$ should be representative of the variability of the modal estimates.

- For each test, the OMA is carried out. Thus, a number of modes for each test is identified and denoted as $r_{i}$ (with $i=1 \ldots N$ ).

- The objective is to find modal estimates that correspond to the same persistent mode over time. Each modal shape estimate is compared with all the remainder estimates within the $N$ tests and a counter increases each time that two mode shapes match. The counter indicates the repeatability of a vibration mode. This is done for all the modal shape estimates. To carry out this step, the MAC value is used. That is, a number of $\left[\sum_{i=1}^{N} r_{i}\right]$ estimates are compared using the MAC value. Three tolerances have been defined for this purpose:

- tol $_{1}$ : the first one is a MAC value that allows to group estimates corresponding to the same vibration mode. The repeatability is the number of estimates of a group.

- $\mathrm{tol}_{2}$ : the second one is included in order to reject groups that are not repeated sufficiently to be considered as significant modes. This tolerance is the lower limit of success ratio, that is, groups with low repeatibility are automatically rejected.

- tol 3 : the third one is a MAC value finally included to detect groups of estimates that are actually estimations of the same mode. Then, if more than one group correspond to the estimation of the same mode, the one with higher repeatability is selected.

- From above procedure, the most significant modes of the dynamic response of the structure are detected for the $\mathrm{N}$ tests.

- Variations of these selected modes are statistically studied and corrected modal parameters are derived.

The above tracking method is applied to consecutive time-history records every 20 minutes using SSIcov. A number of $N=21643$ tests have been taken for the whole year 2013. If computational burdens appear, the procedure explained above must be modified slightly. In that case, the tests should be divided into sub-blocks $(N=500)$ to solve the problem. That done, you just have to join each sub-block with the next sub-block using the $t o l_{1}$.

The tolerances chosen to carry out the tracking were: $t o l_{1} \geq 0.95, \operatorname{tol}_{2} \geq 40 \%$ and $t o l_{3} \leq 0.80$. Up to nine vibration modes below $4 \mathrm{~Hz}$ have been tracked. Table 3 shows the following statistics of the estimation: mean, standard deviation, absolute percentage variation and their repeatability (the success ratio is included between brackets). Note that the fourth mode, with a frequency around $1.79 \mathrm{~Hz}$ (and with a damping ratio of only $0.42 \%$ ) is prone to be excited by pedestrian walking.

Table 3. Summary of identified natural frequencies and damping ratios for one year monitoring and their statistics: mean frequency, mean damping, standard deviation and corresponding variation.

\begin{tabular}{cccccccc}
\hline & \multicolumn{3}{c}{ Frequency } & \multicolumn{3}{c}{ Damping } & \multirow{2}{*}{ Mode } \\
\cline { 2 - 6 } & $\bar{f}(\mathbf{H z})$ & Std & $\boldsymbol{v}(\%)$ & $\bar{\zeta}(\%)$ & Std & $\boldsymbol{v}(\%)$ & Reatability \\
\hline 1 & 1.0482 & 0.0152 & 14.23 & 0.3665 & 0.1710 & 147.89 & $9667(44.7 \%)$ \\
2 & 1.4145 & 0.0107 & 35.26 & 0.3381 & 0.1513 & 110.74 & $10619(49.1 \%)$ \\
3 & 1.5440 & 0.0181 & 27.63 & 0.6498 & 0.2357 & 133.62 & $9886(45.7 \%)$ \\
4 & 1.7937 & 0.0291 & 20.27 & 0.4192 & 0.1502 & 221.88 & $13817(63.8 \%)$ \\
5 & 1.8594 & 0.0168 & 6.87 & 0.5718 & 0.1605 & 234.74 & $9936(45.9 \%)$ \\
6 & 2.3117 & 0.0425 & 15.01 & 0.3753 & 0.1474 & 128.54 & $8746(40.4 \%)$ \\
7 & 3.3821 & 0.0549 & 42.95 & 0.3868 & 0.1191 & 103.96 & $12210(56.4 \%)$ \\
8 & 3.5512 & 0.0524 & 51.87 & 0.7226 & 0.1884 & 157.48 & $9237(42.7 \%)$ \\
9 & 3.9619 & 0.0624 & 8.95 & 0.3853 & 0.1185 & 230.82 & $10183(57.8 \%)$ \\
\hline
\end{tabular}


The frequency distribution for each mode is shown in Figure 6 . There are some modes $(3,5$ and 8$)$ whose frequencies have a very narrow distribution, indicating that: (i) they do not change significantly and (iii) they might be already used for SHM. Figure 7 shows the damping ratio distribution for each mode. It can be observed that the damping of these modes of the structure are very low, except for modes 3,5 and 8 . These modes are the same which also have a very narrow distribution frequency.

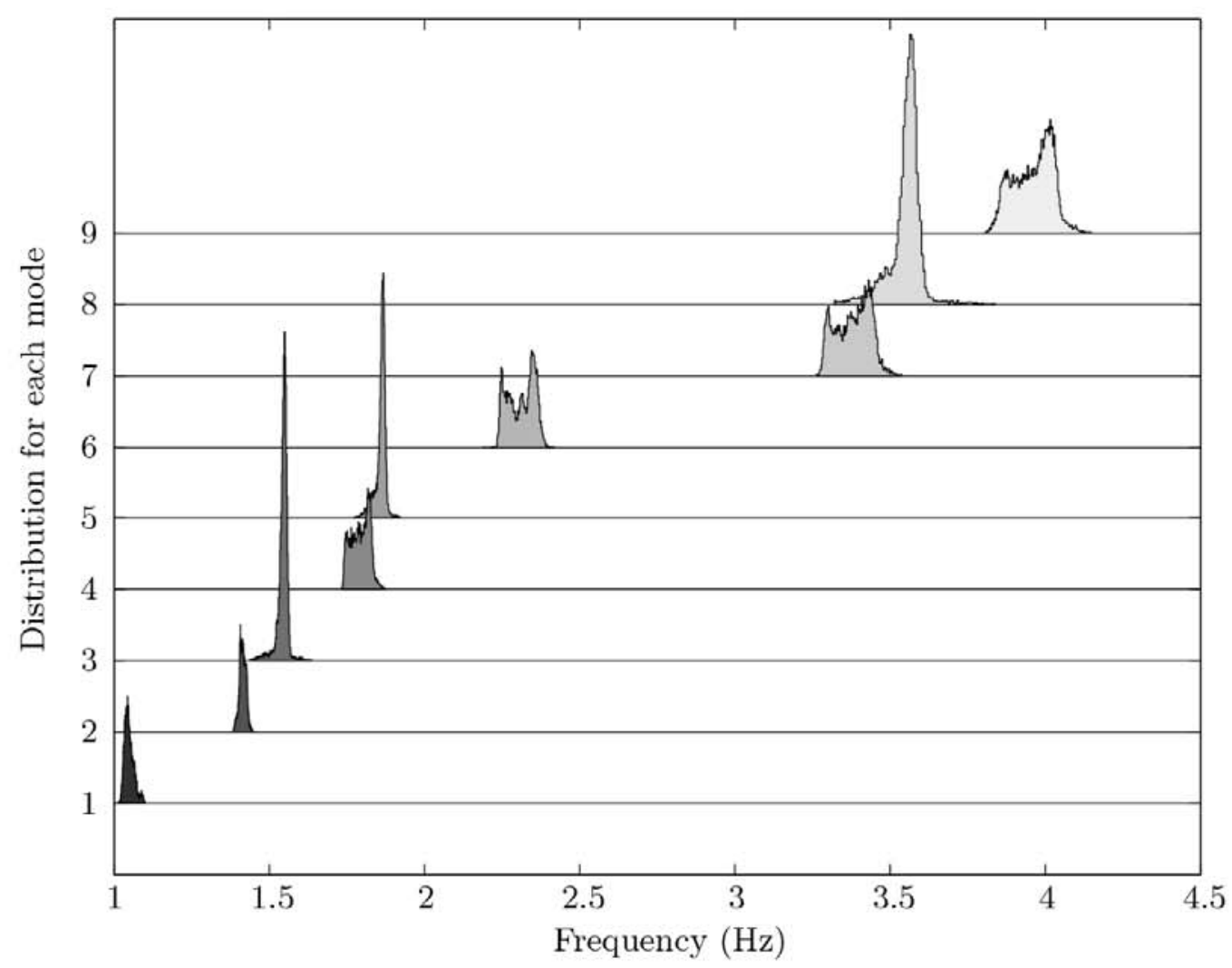

Figure 6. Overlaid distributions of the identified natural frequencies.

It can be seen that the repeatability of modes is quite lower than total number of tests. Figure 8 shows the time history and PSD results of two tests at day and night time corresponding with 15:00 and 3:00 hours respectively. Although, vibration levels are similar, the frequency contents show significant differences between both tests. We should comment that the signal to noise ratio and the sensitivity of the conditioned sensors is not high, anyway, when the structure is in use, structural vibrations arise and the monitoring system has success in the estimation. Remind that the monitoring system is much cheaper than a conventional one. 


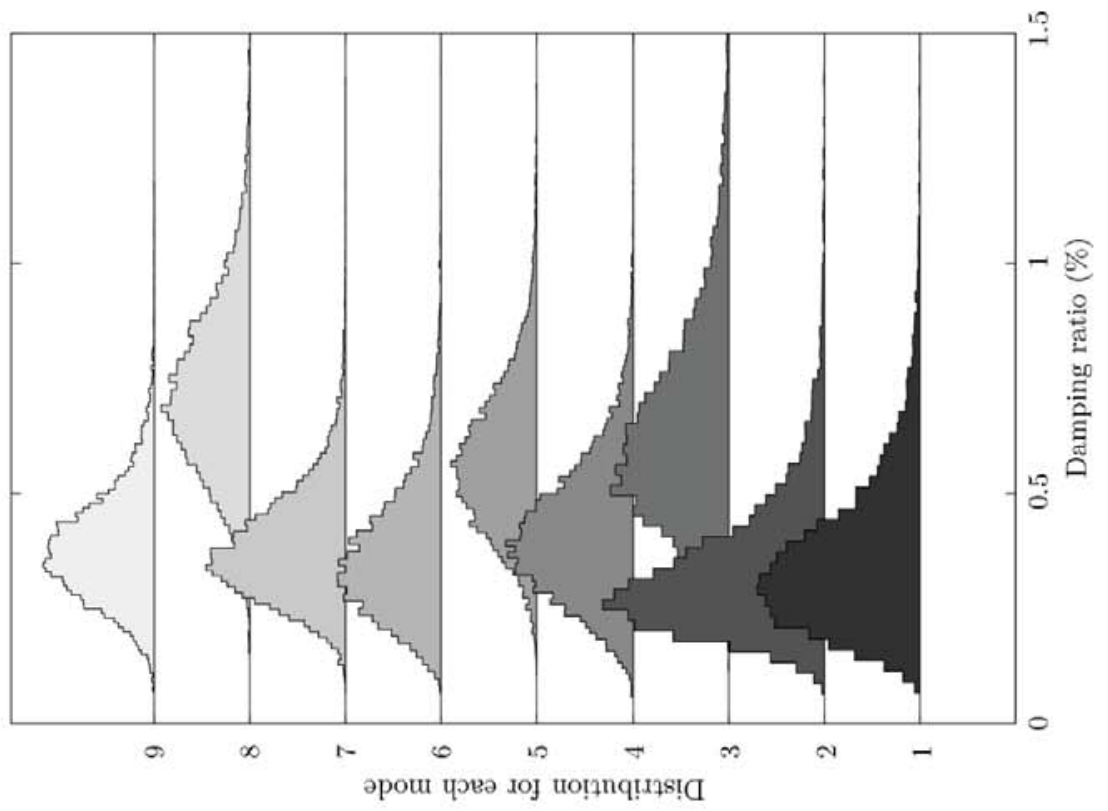

Figure 7. Overlaid distributions of the identified natural damping ratios.

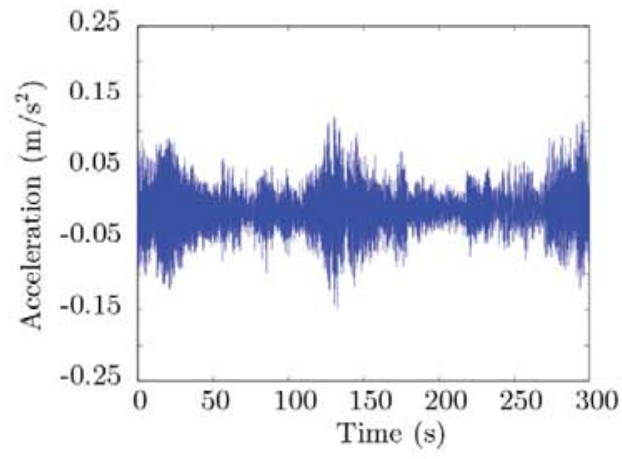

(a) Time history day test.

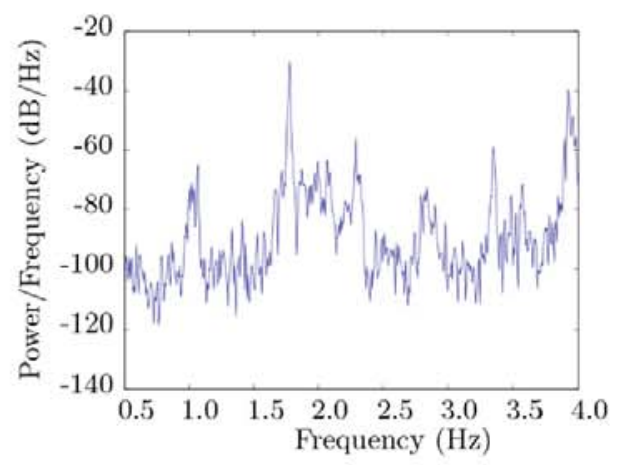

(c) PSD day test.

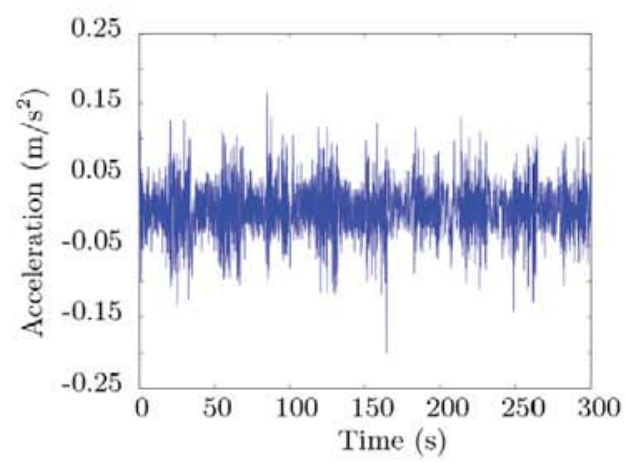

(b) Time history night test.

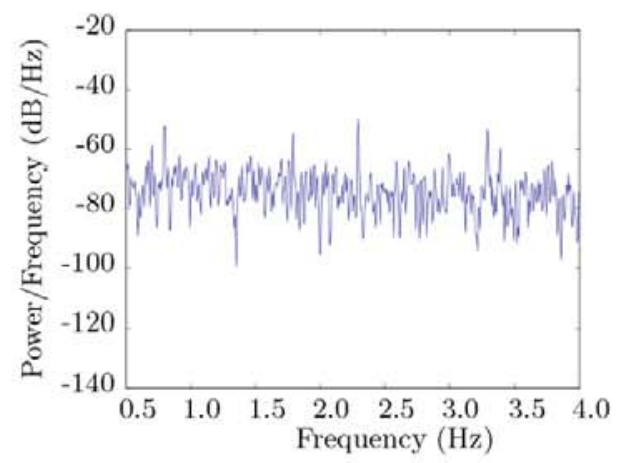

(d) PSD night test.

Figure 8. Results at day and night test. 
This is due to the fact that some of them are performed under very low vibration conditions leading to wrong estimates that, obviously, are not tracked by the method. The pedestrian traffic over the structure during the day hours induces on the structure the necessary environmental energy that allows successful identification. However, the lack of this excitation during the night hides the real structural response inside the signal noise. Figure 9 shows hourly distribution of successful identifications obtained for the fourth mode selected (see Table 3).

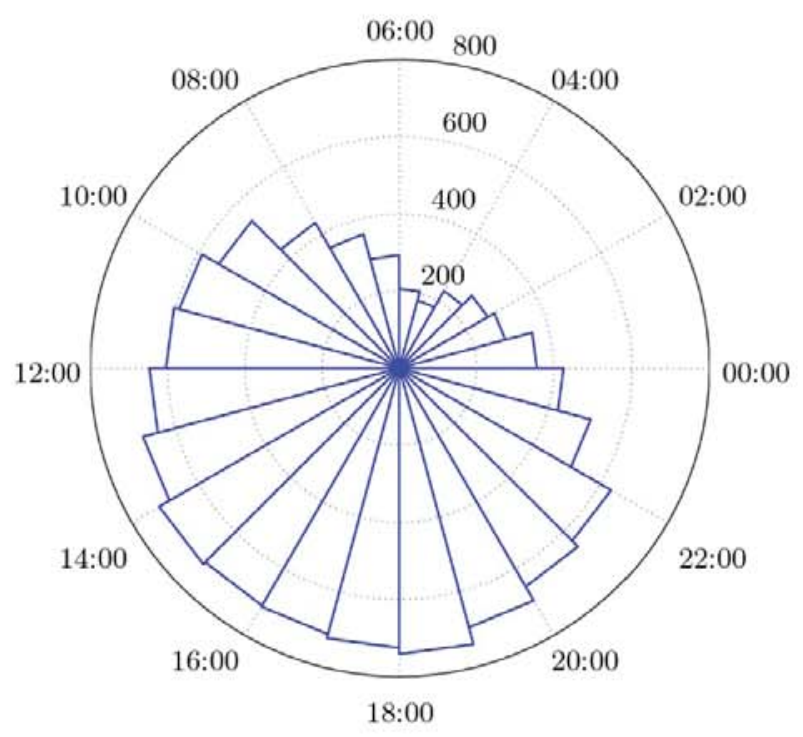

Figure 9. Distribution per hour of the repeatability for mode 4.

The time variation of the natural frequency estimates over a year for the lowest ninth modes is shown in Figure 10a. Figure 10b presents a zoom showing that the tracking method is able to identify two closely-spaced natural frequencies. Although the monitoring has been operating since January $1^{\text {st }} 2013$ up to now, some occasional stops due to minor technical problems and maintenance tasks are observed in the figure. 


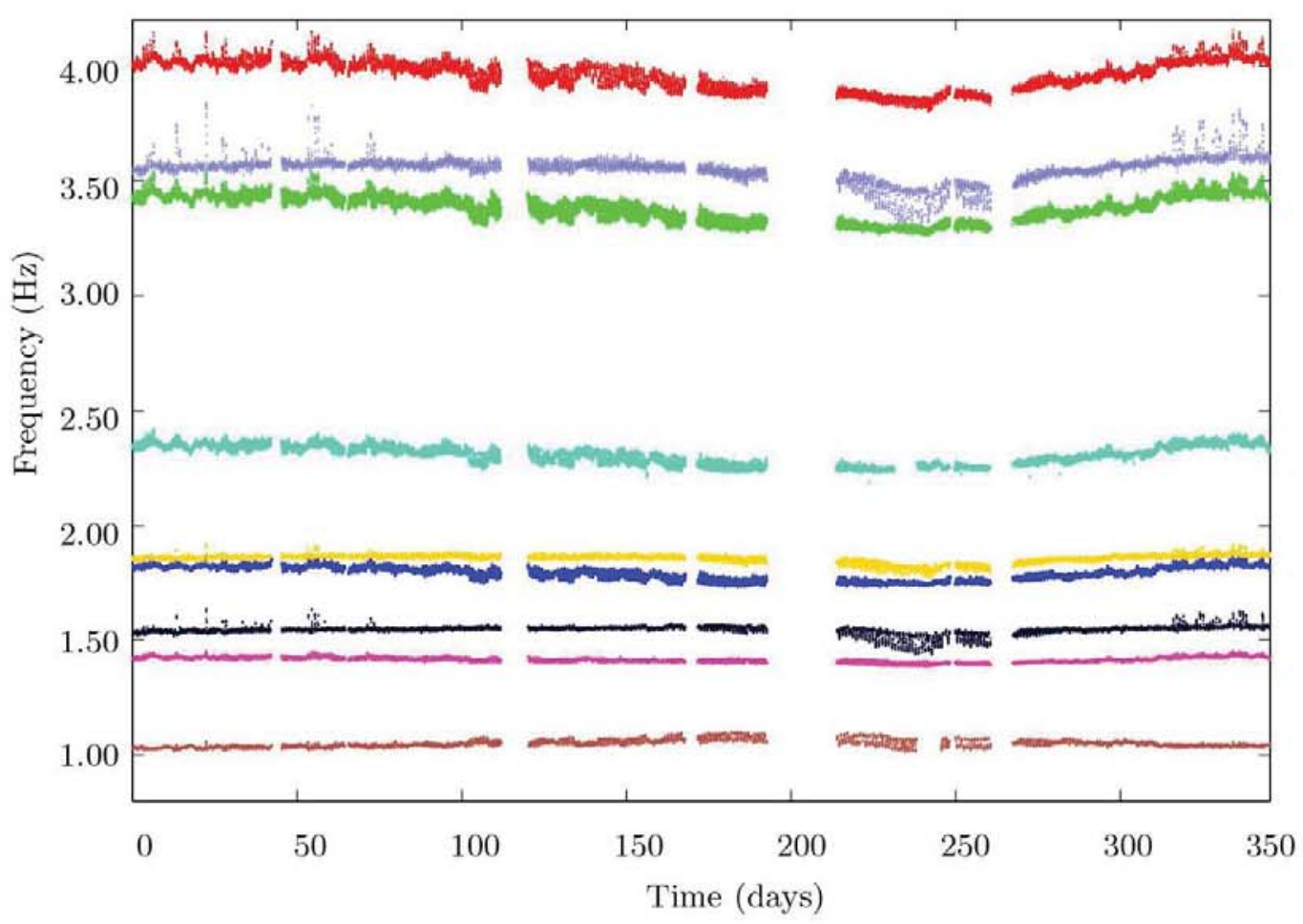

(a) Complete view.

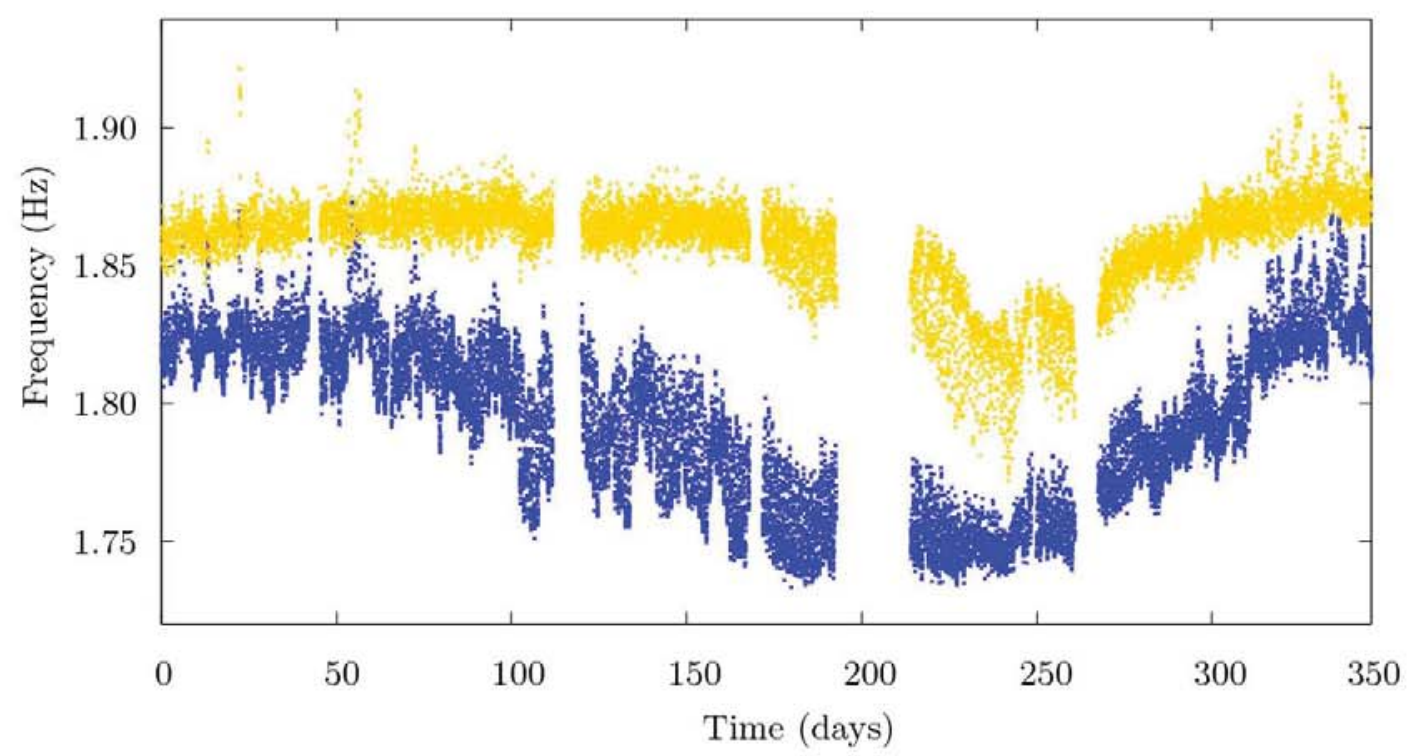

(b) Zoom view of the fourth and fifth vibration modes.

Figure 10. Tracked frequency estimates for the whole year. 


\subsection{Effects of external factors}

A strong seasonal and daily trends with temperature have been identified. Figure 11 shows the time evolution of the frequency estimates of the fourth mode, in the left axis, and temperature, in the right axis. It is clearly observed the seasonal (Figure 11a) and daily trend (Figure 11b).

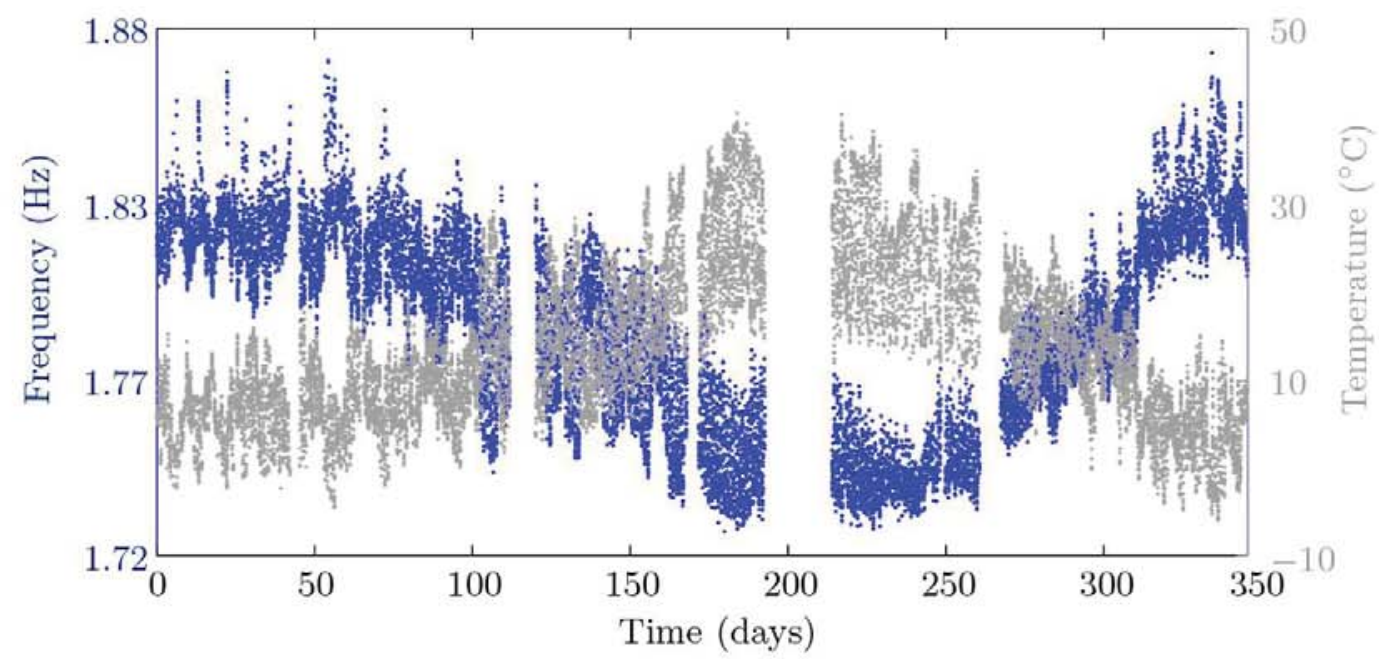

(a) Complete view.

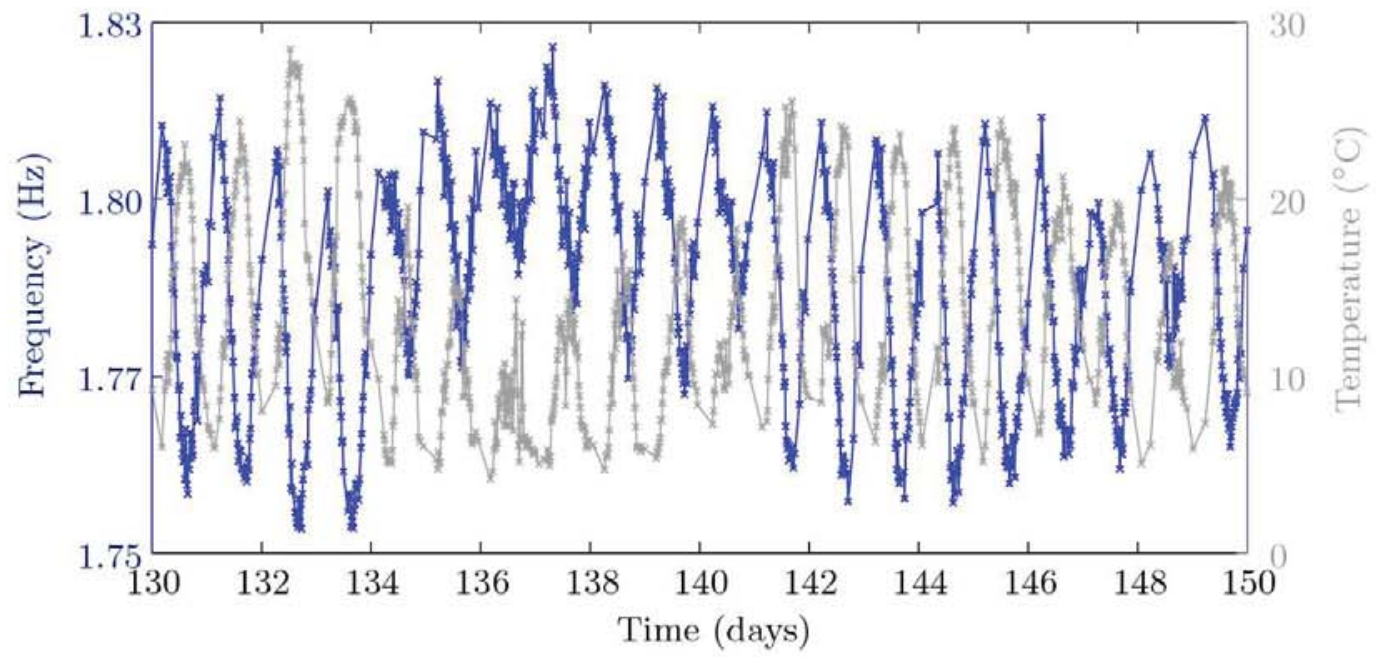

(b) Zoom view of 20 days.

Figure 11. Frequency estimates and temperature recorded for mode 4.

Figure 12 shows the frequency estimates versus temperature for mode 1 (Figure 12a) and mode 4 (Figure 12b) of Table 3. It is noted that pure vertical response behaves similarity to the equivalent 
the project are: ISOLUX CORSÁN, FCC CO, GEOCISA, CSIC and UPM. The authors also acknowledge the

financial support provided by Research Project DPI2013-47441-P.

\section{REFERENCES}

[1] Avci, O. (2014). Modal Parameter Variations due to Joist Bottom Chord Extension Installations on Laboratory Footbridges. Journal of Performance of Constructed Facilities 04014140. DOI: 10.1061/(ASCE)CF.1943-5509.0000635.

[2] Bayraktar, A., Altunişik, A.C., Sevim, B. \& Türker, T. (2009). Modal Testing, Finite-Element Model Updating, and Dynamic Analysis of an Arch Type Steel Footbridge. Journal of Performance of Constructed Facilities, 23(2), pp. 81-89. DOI: 10.1061/(ASCE)0887-3828(2009)23:2(81).

[3] Cacho-Perez, M., Frechilla, N., Diaz, I.M. \& Lorenzana, A. (2014). Simplified mechanical model for a stress-ribbon monitorized footbridge. Analylitical and experimental results. In: $6^{\text {th }}$ World Conference on Structural Control and Monitoring. Barcelona (Spain): Proceedings of the WCSCM, pp. 358-368.

[4] Cismaşiu, C., Narciso, A.C. \& Amarante dos Santos, F.P.P. (2014). Experimental Dynamic Characterization and Finite-Element Updating of a Footbridge Structure. Journal of Performance of Constructed Facilities 64014116. DOI: 10.1061/(ASCE)CF.1943-5509.0000615.

[5] Cobo del Arco, D., Aparicio, A.C. \& Marí, A.R. (2001). Preliminary design of prestressed concrete stress ribbon bridge. Journal of Bridge Engineering 6, pp. 234-242.

[6] Costa, B.J.A., Magalhães, F., Cunha, A. \& Figueiras, J. (2014). Modal Analysis for the Rehabilitation Assessment of the Luiz I Bridge. Journal of Bridge Engineering 19(12), 05014006. DOI: 10.1061/(ASCE)BE.1943-5592.0000632.

[7] Cross, E.J., Koo, K.Y., Brownjohn, J.M.W. \& Worden, K. (2013). Long-term monitoring and data analysis of the Tamar Bridge. Mechanical Systems and Signal Processing, 35, pp. 16-34. DOI: 10.1016/j.ymssp.2012.08.026.

[8] Deraemaeker, A., Reynders, E., Roeck, G. De \& Kullaa, J. (2008). Vibration-based structural health monitoring using output-only measurements under changing environment. Mechanical Systems and Signal Processing, 22(1), pp. 34-56. DOI: 10.1016/j.ymssp.2007.07.004.

[9] Gomez, H.C., Fanning, P.J., Feng, M.Q. \& Lee, S. (2011). Testing and long-term monitoring of a curved concrete box girder bridge. Engineering Structures, 33(10), pp. 2861-2869. DOI: 10.1016/j.engstruct.2011.05.026.

[10] Hu, W.H., Caetano, E. \& Cuhna, A. (2012). Structural health monitoring of a stress-ribbon footbridge. Engineering Structures, 47, pp. 578-593. 
suspended cable as well as its thermal behavior [3]. Therefore, for these modes (such as mode 4), increasing temperature leads to an increase into the ribbon sag producing a reduction of band tension and leading to a decrease of their natural frequencies [5]. However, mode 1 (of Table 3 and Figure 4b) does not follow this pattern since this is a torsional mode.

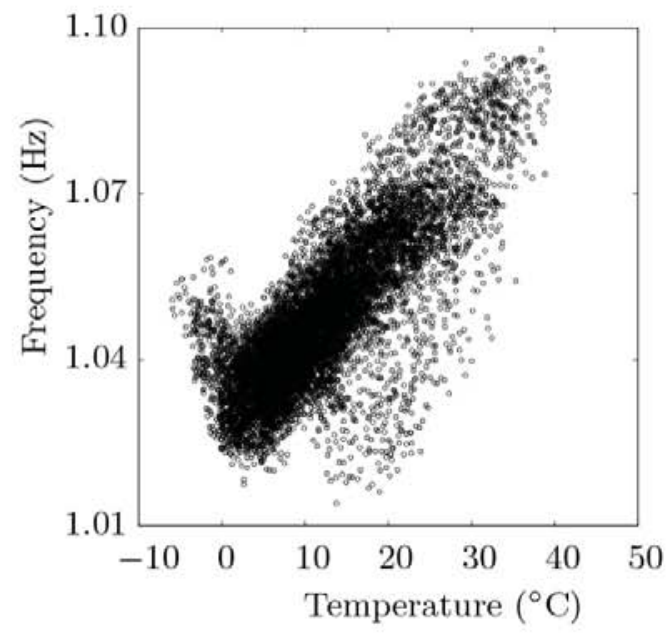

(a) Mode 1.

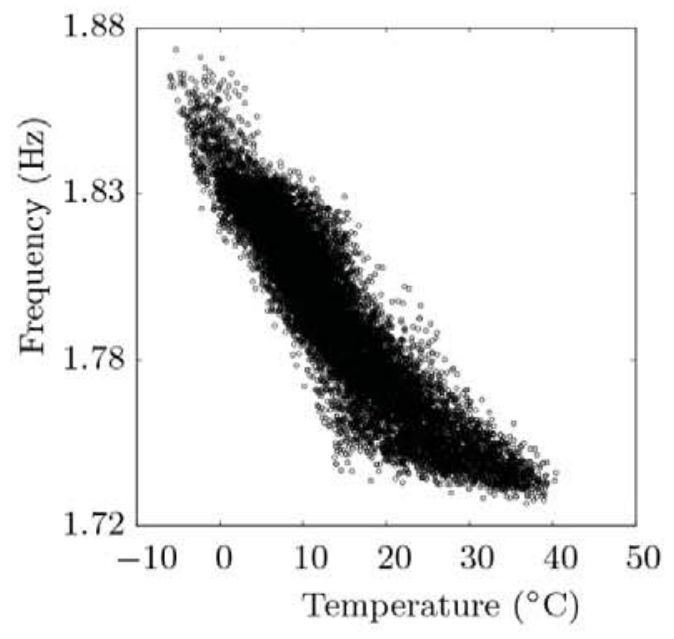

(b) Mode 4.

Figure 12. Frequency estimates versus temperature for modes 1 and 4 .

No other visual evidence of the correlation between the frequency estimates and other factors, different from the temperature, have been found (neither with the wind velocity nor the operational values). Regarding damping ratios, no clear visual dependencies with any external factor have been found.

\section{CONCLUSIONS}

A low-cost vibration monitoring system based on MEMS accelerometers has been successfully installed on a singular stress-ribbon footbridge and it is currently providing live data to be analyzed. It has been demonstrated that these low-cost sensors, carefully conditioned, can be a competitive alternative to traditional ones. Thus, using this innovate system, this paper has focused mainly on a procedure to track the modal parameters of structure and their time evolution over whole-year. For this particular stress-ribbon structure, it has been demonstrated that is highly-sensitive to temperature variation (frequency changes of more than 20\%). Natural frequencies are quite close and time-varying (mainly due to temperature for the test structure). Thus, a tracking method based on three different tolerances and that makes use of the MAC value has been proposed.

Future work will consider the development of a FE model for this strongly non-linear structure and its model updating. Results obtained in this paper are essential for the development of a reliable model that might be used with a SHM system.

\section{ACKNOWLEDGMENTS}

This work is supported by project SETH of INNPACTO Program, with reference IPT-2012-0703-380000 from Ministry of Economy and Competitiveness of Spain, and the institutions/companies working in 
[11] Ivorra, S., Foti, D., Bru, D., \& Baeza, F.J. (2013). Dynamic Behavior of a Pedestrian Bridge in Alicante, Spain. Journal of Performance of Constructed Facilities. DOI: 10.1061/(ASCE)CF.19435509.0000556 .

[12] Koo, K.Y., Brownjohn, J.M. W., List, D. I. \& Cole, R. (2013). Structural health monitoring of the Tamar suspension bridge. Structural Control and Health Monitoring, 20(4), pp. 609-625. DOI: $10.1002 /$ stc. 1481 .

[13] Magalhães, F., Cunha, A. \& Caetano, E. (2012). Vibration based structural health monitoring of an arch bridge: From automated OMA to damage detection. Mechanical Systems and Signal Processing, 28, pp. 212-228. DOI: 10.1016/j.ymssp.2011.06.011.

[14] Magalhães, F., Cunha, A: \& Caetano, E. (2008). Dynamic monitoring of a long span arch bridge. Engineering Structures, 30(11), pp. 3034-3044. DOI: 10.1016/j.engstruct.2008.04.020.

[15] Moaveni, B. \& Behmanesh, I. (2012). Effects of changing ambient temperature on finite element model updating of the Dowling Hall Footbridge. Engineering Structures, 43, pp. 58-68. DOI: 10.1016/j.engstruct.2012.05.009.

[16] Moser, P. \& Moaveni, B. (2013). Design and deployment of a continuous monitoring system for the dowling hall footbridge. Experimental Techniques, 37(1), pp. 15-26. DOI: 10.1111/j.17471567.2011.00751.x.

[17] Narros, A.J. (2011). Pasarela Peatonal "Pedro Gómez Bosque" sobre el Río Pisuerga en la Ciudad de Valladolid. Un Nuevo Récord de Longitud en Pasarelas Colgadas de Banda Tesa. Revista Técnica Cemento-Hormigón, 947, pp. 80-86 (in spanish).

[18] de Sebastián, J., Escudero, A., Arnaz, R., Díaz, I.M., Poncela, A. \& Lorenzana, A. (2013). A low-cost vibration monitoring system for a stress-ribbon footbridge. In: 6th ECCOMAS Conference on Smart Structures and Materials.

[19] Wenzel, H. \& Pichler, D. (2005). Ambient vibration monitoring. John Wiley \& Sons.

[20] Zhou, H. F., Ni, Y. Q. \& Ko, J. M. (2011). Eliminating Temperature Effect in Vibration-Based Structural Damage Detection. Journal of Engineering Mechanics, 137(12), pp. 785-796. DOI: 10.1061/(ASCE)EM.1943-7889.0000273. 
SERVICEABILITY CONDITIONS OF PEDESTRIAN STRUCTURES USING A SIMPLIFIED MOVING MASS MODEL

(2) International Conference on
Mechanical Models in
Structural Engineering

Álvaro Magdaleno González; Mariano Cacho Pérez; Javier Castaño Lerma; Norberto Ibán Lorenzana; Iván Muñoz Díaz; Antolín Lorenzana Ibán.

\begin{tabular}{c|c|c|l|} 
Aportaciones: & Experimentación & Procesado & Edición \\
\cline { 2 - 4 } & Registros & Matlab & Imágenes \\
\cline { 2 - 4 }
\end{tabular}




\title{
Serviceability conditions of pedestrian structures using a simplified moving mass model
}

\author{
Magdaleno, Álvaro ${ }^{1}$; Cacho-Pérez, Mariano ${ }^{1}$; Castaño, Javier ${ }^{2}$; Ibán, Norberto ${ }^{2}$; Díaz, Iván $M^{3}$; Lorenzana, \\ Antolín ${ }^{1}$
}

\begin{abstract}
Se presenta un modelo discreto de un peatón, consistente en una masa con un único grado de libertad que se desplaza a velocidad constante, interactuando dinámicamente con el sistema estructural consistente en una viga biapoyada mallada con elementos barra $2 \mathrm{D}$ tipo pórtico plano. Cuando la viga es suficientemente rígida y pesada, los resultados son similares a los obtenidos con modelos de fuerzas móviles. Sin embargo, si la viga es ligera, el efecto de la masa del peatón puede ser apreciable, obteniéndose una respuesta más realista. El modelo acoplado permite estudiar la interacción entre el peatón y la estructura y tras los resultados obtenidos se concluye la validez de la formulación para estimar por simulación el comportamiento en servicio de este tipo de estructuras peatonales esbeltas.
\end{abstract}

Keywords: lively footbridges, pedestrian structure interaction.

\section{INTRODUCTION}

Estructuras tales como forjados de grandes luces, pasarelas peatonales o escaleras esbeltas pueden ser excitadas por los usuarios al realizar actividades como andar, correr o saltar. La excitación producida podría alcanzar niveles de vibración excesivos, sobrepasando los valores de confort recomendados en las normativas. El factor decisivo en el dimensionamiento de este tipo de estructuras suele ser el estado límite de servicio de vibraciones (ELSV).

En las distintas recomendaciones de las normativas o guías de diseño se incluyen modelos muy simplificados de cargas producidas por humanos. En general se reducen a modelos discretos y a cargas armónicas fijas de utilidad limitada en el dimensionamiento de la estructura en lo referido a ELSV. Además suele ser crítico el comportamiento dinámico en condiciones de excitación a frecuencias cercanas a las naturales de la estructura (resonancia) y en estos casos la respuesta está muy influenciada por el amortiguamiento estructural, el cual es difícil de determinar con precisión en la etapa de diseño. Esto deriva en que, en general, los diseñadores no confíen demasiado en dichos modelos de carga y usualmente se prescriban ensayos experimentales una vez la estructura ha sido construida. En caso de no cumplir con las limitaciones en aceleraciones, se abre una problemática

\footnotetext{
${ }^{1}$ EII/ITAP, University of Valladolid (Spain). alvaro.magdaleno@alumnos.uva.es, cacho@eil.uva.es, ali@eil.uva.es (Corresponding author)

${ }^{2}$ Mechanical Engineering Division, CARTIF Research Center(Spain).javcas@cartif.es, noriba@cartif.es

${ }^{3}$ Dpto. CMM and Theory of Structures. ETSICCP, UPM (Spain).ivan.munoz@upm.es
} 


\section{Serviceability conditions of pedestrian structures using a simplified moving mass model Third International Conference on Mechanical Models in Structural Engineering University of Seville. 24-26 June 2015.}

con varias posibles soluciones (aumentar la rigidez, incorporar sistemas de amortiguamiento, etc.) con repercusiones estructurales, estéticas y económicas.

La creciente capacidad computacional hace pensar en la posibilidad de simular de una forma realista la acción peatonal sobre las estructuras. Para ello es necesario no solo la posibilidad de incluir cargas móviles (como ya se hace en la guía francesa SETRA) sino también la correspondiente masa del peatón, junto con una estimación del amortiguamiento estructural y del que los peatones (activos o pasivos) aportan a la estructura. Tras ello se espera poder asegurar por simulación la adecuación de la estructura al tránsito peatonal y minimizar el impacto de intervenciones estructurales al poderse rediseñar convenientemente en etapas previas a la construcción.

La influencia de los peatones parados o sentados (pasivos) en el comportamiento dinámico de las estructuras se ha estudiado en numerosos trabajos de investigación [1-7]. Sin embargo no está tan clara la influencia que tienen los peatones activos (andando, corriendo o saltando) en el comportamiento dinámico del conjunto. En este trabajo se formula un modelo simple (consistente en una masa, un muelle y un amortiguador) el cual se acopla a la estructura, resolviéndose el conjunto mediante técnicas numéricas de integración directa.

Se presentan dos ejemplos correspondientes al tránsito de un peatón por dos pasarelas sencillas (tipo viga biapoyada), una de ellas ligera y otra más pesada. Para similar comportamiento modal (relación entre rigidez y masa de la viga) se comprueba que los resultados obtenidos para el caso en el que la viga es mucho más pesada que el peatón coinciden con modelos donde solo se considera la acción de la carga móvil (SETRA). Cuando la viga es más ligera, el hecho de no ser despreciable la masa del peatón hace que el ensamblaje varíe sus frecuencias en función de la posición de la masa. Este acoplamiento hace que el problema sea no lineal, apareciendo fenómenos de interacción que lleva a resultados distintos que los obtenibles sin incorporar la masa.

\section{THE MODEL AND ITS EQUATIONS}

La estructura será tratada mediante un modelo de elementos finitos, cuyas ecuaciones pueden expresarse de forma compacta como se ilustra en la ecuación (1), empleando para ello las matrices masa $(\mathbb{M})$, amortiguamiento $(\mathbb{C})$ y rigidez $(\mathbb{K})$. El vector $\boldsymbol{q}$ contiene los grados de libertad asociados a los nodos resultantes de discretizar la estructura en elementos finitos tipo pórtico plano y a cada nodo se le asocian 3 grados de libertad: desplazamiento horizontal $\left(u_{i}\right)$, desplazamiento vertical $\left(v_{i}\right)$ y giro de la sección $\left(\theta_{i}\right)$

$$
\mathbb{M} \ddot{\boldsymbol{q}}+\mathbb{C} \dot{\boldsymbol{q}}+\mathbb{K} \boldsymbol{q}=F \quad \text { con } \boldsymbol{q}=\left\{\begin{array}{l}
u_{i} \\
v_{i} \\
\theta_{i}
\end{array}\right\}
$$

Por su parte, el vector $F$ contiene las fuerzas equivalentes que se aplican sobre cada uno de los grados de libertad, resultado de transformar las cargas aplicadas sobre la estructura. En el modelo aquí tratado la única excitación sobre la estructura es la fuerza de contacto entre el peatón y la viga por la que circula. 
La formulación de las ecuaciones (1), así como el cálculo de sus matrices asociadas, se realiza mediante la aplicación del formalismo de Lagrange, calculando para su aplicación las energías cinética y potencial del elemento. Dicho cálculo implica el conocimiento del campo continuo de desplazamientos en el interior del elemento $(u(x)$ y $v(x))$, campo que se obtiene mediante la interpolación de los valores de los grados de libertad de los nodos extremos del elemento empleando para tal fin unas funciones de forma polinómicas: de grado 1 para interpolar el campo de desplazamiento horizontal y de grado 3 para el campo de desplazamiento vertical, como se muestra en las ecuaciones (2) donde se llama $i=1$ al nodo izquierdo del elemento e $i=2$ al nodo derecho.

$$
\begin{aligned}
& u(x)=\left(1-\frac{x}{L}\right) u_{1}+\left(\frac{x}{L}\right) u_{2} \\
& v(x)=\left(1-3 \frac{x^{2}}{L^{2}}+2 \frac{x^{3}}{L^{3}}\right) v_{1}+x\left(1-\frac{x}{L}\right)^{2} \theta_{1}+\left(3 \frac{x^{2}}{L^{2}}-2 \frac{x^{3}}{L^{3}}\right) v_{2}+\frac{x^{2}}{L}\left(\frac{x}{L}-1\right) \theta_{2}
\end{aligned}
$$

El poder emplear funciones de forma polinómicas de grado 3 responde al hecho de que giros y flecha están íntimamente relacionados gracias a la hipótesis de Euler-Bernoulli bajo la cual se ha modelizado el elemento viga, el cual establece que una sección inicialmente plana y perpendicular a la línea media de una viga permanece plana y perpendicular a la misma línea tras deformación.

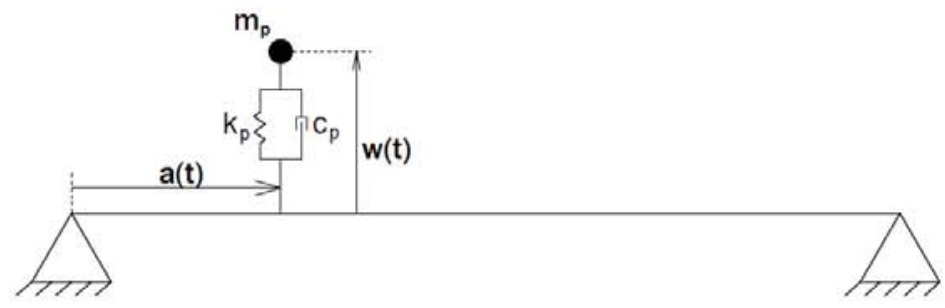

Figura 1. Modelo MCK

El modelo de peatón empleado consiste en una masa puntual $\left(m_{p}\right)$ ligada elásticamente a la estructura mediante un resorte $\left(k_{p}\right)$ y un amortiguador $\left(c_{p}\right)$ desplazándose el conjunto a velocidad constante por la viga tal y como se aprecia en la figura (1). Requiere, pues, de un grado de libertad adicional $w$ a los considerados para la estructura para poder definir su desplazamiento vertical. Este grado de libertad adicional se incluirá al final del vector $\boldsymbol{q}$. La ubicación dentro de la viga no requiere de grado de libertad adicional pues su posición es conocida en todo instante de tiempo, ecuación (3) donde $x_{0}$ es la posición de partida del peatón y $c$ su velocidad.

$$
a(t)=x_{0}+c t
$$

La obtención de las ecuaciones que lo rigen es muy sencilla aplicando la segunda ley de Newton, o de equilibrio dinámico, en la dirección vertical. Se obtienen dos expresiones, ecuaciones (4) y (5): una ecuación de movimiento y una ecuación de acoplamiento dinámico, expresión que determina en función de los grados de libertad del problema el valor de la fuerza de contacto peatón / estructura a lo largo del tiempo. 


$$
\begin{aligned}
& m_{p} \ddot{w}+c_{p}(\dot{w}-\dot{v})+k_{p}(w-v)=-m_{p} g \\
& F(t)=-m_{p} g-m_{p} \ddot{w}=c_{p}(\dot{w}-\dot{v})+k_{p}(w-v)
\end{aligned}
$$

La ecuación de movimiento está obtenida suponiendo para el resorte una longitud natural del resorte nula, al estar las coordenadas $w$ y $v$ expresadas ambas respecto del mismo origen. Ésta última, $v$, la deflexión del punto de contacto entre peatón y viga, se puede además expresar en términos de los grados de libertad del problema $\left(v_{i}, \theta_{i}\right)$ mediante las funciones de forma empleadas para la formulación de los elementos finitos, ecuación (2). Puesto que las ecuaciones se integrarán con la ayuda de Matlab, el cual permite actualizar el problema en cada instante de tiempo mediante una función programada por el usuario, se podrá ubicar al peatón y calcular el valor de las funciones de forma con el fin de incluirlo en las posiciones correspondientes dentro de las matrices del problema. Se muestra en la figura (2) un diagrama de flujo resumiendo las operaciones que se realizan durante el cálculo, siendo el solver el responsable de invocar a la función programada por el usuario. Esta figura hace asimismo referencia al espacio de estados al que se transforman las ecuaciones para su mejor empleo, transformación que se expresa en la ecuación (6).

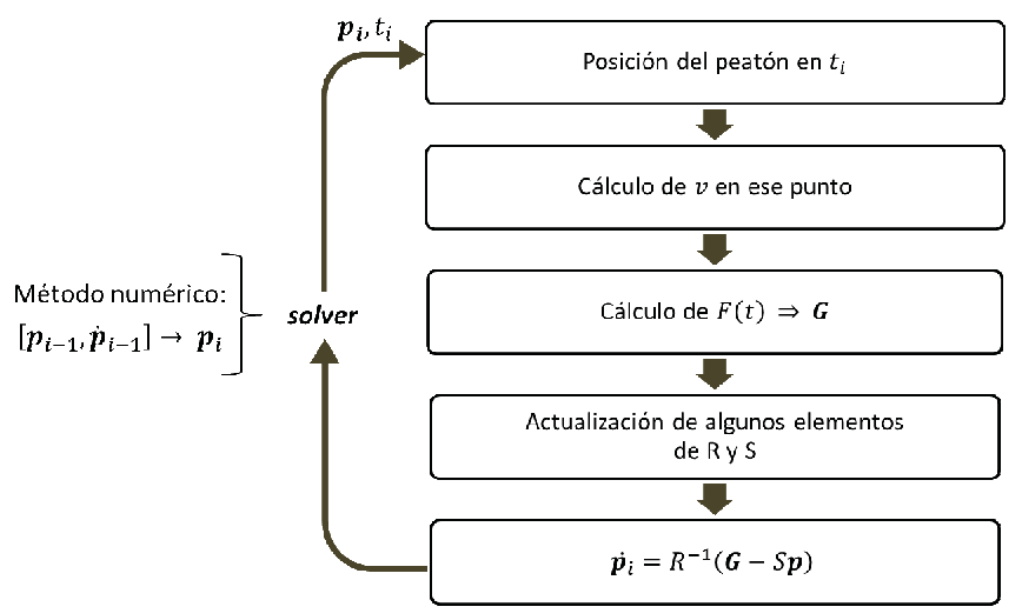

Figura 2. Diagrama de flujo de operaciones para la resolución numérica de las ecuaciones.

$$
R \dot{\boldsymbol{p}}+S \boldsymbol{p}=\boldsymbol{G} \quad \text { con } \boldsymbol{p}=\left\{\begin{array}{l}
\boldsymbol{q} \\
\dot{\boldsymbol{q}}
\end{array}\right\}, \quad R=\left[\begin{array}{cc}
-\mathbb{K} & \emptyset \\
\varnothing & \mathbb{M}
\end{array}\right], \quad S=\left[\begin{array}{ll}
\emptyset & \mathbb{K} \\
\mathbb{K} & \mathbb{C}
\end{array}\right], \quad \boldsymbol{G}=\left\{\begin{array}{l}
\emptyset \\
\boldsymbol{F}
\end{array}\right\}
$$

Gracias a este enfoque, es posible además calcular la fuerza de contacto en cada instante de tiempo en función del valor de los grados de libertad en cada momento e introducir su valor en el vector de fuerzas equivalentes $F$, aplicando la transformación necesaria en función de su posición relativa dentro del elemento afectado. Dicha posición será asimismo calculada en cada paso de integración de forma sencilla gracias a la hipótesis de velocidad de tránsito $c$ constante.

Con el problema así planteado, y los cálculos debidamente programados en Matlab, se pueden realizar las simulaciones oportunas para la evaluación del efecto de la inclusión de una masa en un modelo de peatón. La primera de las simulaciones a realizar es de verificación, comparando la 
respuesta que se obtiene para un problema determinado con la proporcionada por una fuente externa. En este caso se empleará la solución a un problema planteado y resuelto por Neves et al. [8], que trata el mismo modelo MCK que el aquí mostrado. Se muestra en la figura 3a la solución obtenida para su mismo problema por aplicación del software programado, en la figura $3 b$ la obtenida en [8] y en la figura $3 c$ la comprobación de que ambas son efectivamente iguales, superponiendo adecuadamente de las dos anteriores.

(a)

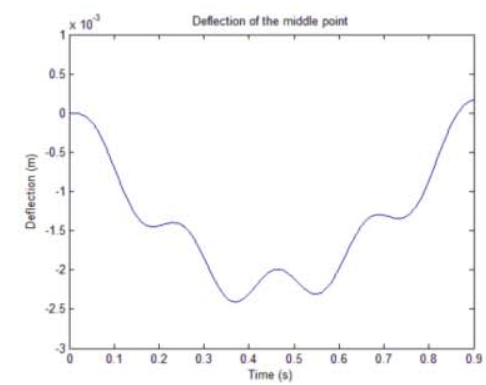

(b)

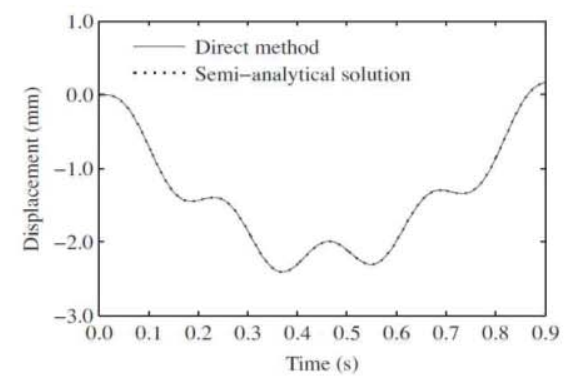

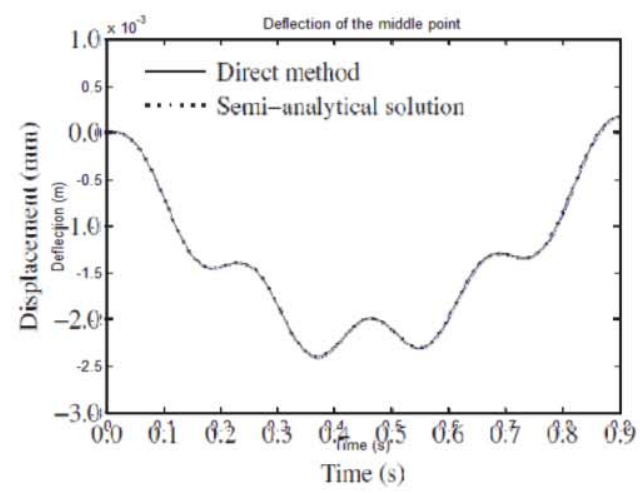

(c)

Figura 3. Verificación de la programación del modelo. (a) Simulación propia; (b) obtenida de [8]; (c) superposición de ambas.

\section{FIRST EXAMPLE: MASSIVE FOOTBRIDGE}

Se trata en primer lugar un problema de la figura (4), con los parámetros que se muestran en la misma. En este caso el peatón tiene una masa insignificante $(0.0425 \%)$ con relación a la masa de la viga. Al abordar el problema mediante el modelo MCK como el expuesto anteriormente se plantea una cuestión que concierne al escaso número de parámetros del modelo, los cuales no permiten establecer simultáneamente valores "realistas" de masa, rigidez y frecuencia de paso del peatón (entendida ésta como frecuencia de oscilación del modelo MCK). Se priorizará la frecuencia de paso del peatón, pues la respuesta que se obtenga será comparada con la proporcionada por la aplicación de la guía de diseño propuesta por el Sétra, donde ese parámetro es un valor decisivo. Así, se ajustará el valor de la rigidez del resorte convenientemente para que la frecuencia del sistema añadido coincida con el paso de la marcha.

Se contempla además un último parámetro de la simulación: la condición inicial correspondiente a la posición de la masa, $w_{0}$ (el resto de condiciones iniciales son nulas). Este parámetro se puede establecer de forma que se controle la amplitud de oscilación de la masa, y con ella, la fuerza transmitida a la viga. Se escogerá este valor tal que el valor mínimo del valor absoluto de la fuerza 
Serviceability conditions of pedestrian structures using a simplified moving mass model Third International Conference on Mechanical Models in Structural Engineering University of Seville. 24-26 June 2015.

aplicada sobre la viga coincida con el valor mínimo de la fuerza aplicada por el modelo del Sétra. Siendo este valor de $F_{\min }=473.4 \mathrm{~N}$, la condición inicial del peatón se calcula como en la ecuación (7). Es preciso notar que $w$ está referido respecto de la indeformada de la viga, que el resorte posee longitud natural nula y que la masa está sometida a la acción de la gravedad. Es por este motivo que la condición inicial es negativa.

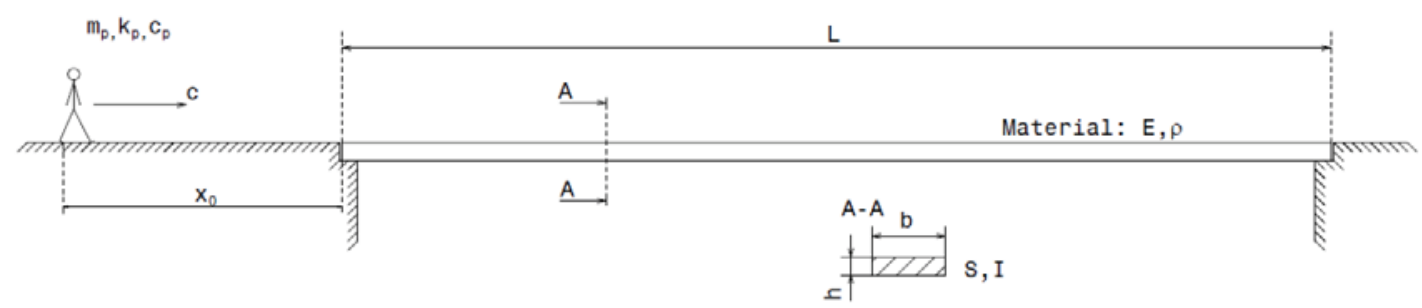

Parámetros de simulación

$$
\begin{array}{lll}
L=50 \mathrm{~m} & m_{p}=80 \mathrm{Kg} & f_{p}=2 \mathrm{~Hz} \\
h x b=0.4 \times 1.2 \mathrm{~m}^{2} & k_{p}=12633.1 \mathrm{~N} / \mathrm{m} & x_{0}=5 \mathrm{~m} \\
E=2.1 \cdot 10^{11} \mathrm{~Pa} & c_{p}=0 \mathrm{Ns} / \mathrm{m} & c=0.8 \mathrm{~m} / \mathrm{s} \\
\rho=7850 \mathrm{Kg} / \mathrm{m}^{3} & & w_{0}=-0.037473 \mathrm{~m}
\end{array}
$$

Figura 4. Esquema y datos de la simulación. Viga pesada

$$
w_{0}=-\frac{F_{\min }}{k_{p}}=-0.0375 \mathrm{~m}
$$

La simulación de este problema proporciona los resultados de la figura (5a), donde se aprecia la deflexión del punto medio de la viga a lo largo del tiempo y la fuerza de reacción de la viga sobre el peatón. En cuanto a la deflexión del punto medio, como se puede apreciar está compuesta por un total de tres oscilaciones superpuestas: en primer lugar, la curva propia de la deflexión debida al peso del peatón; en segundo lugar, la oscilación propia asociada a la primera frecuencia de la viga (en torno a $0.37 \mathrm{~Hz}$ ); por último, la oscilación impuesta por la oscilación del modelo MCK sobre la viga, que sucede a unos $2 \mathrm{~Hz}$.

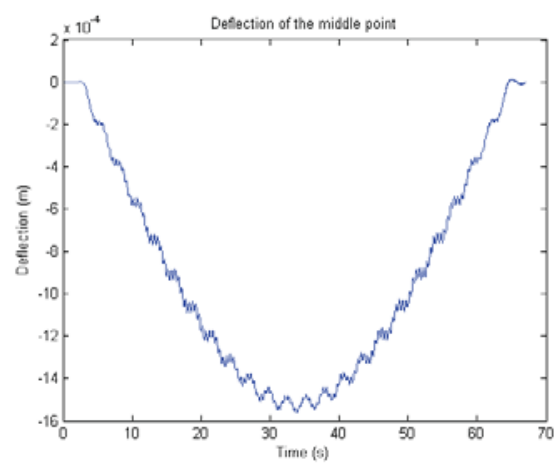

(a)

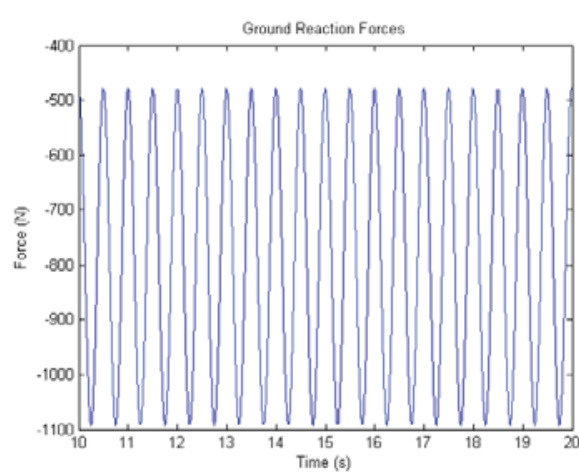

(b)

Figura 5. Resultados de la simulación aplicando el modelo MCK. a) Deflexión del punto medio de la viga a lo largo del tiempo. b) Extracto de la fuerza de contacto entre modelo y estructura. 
En la figura (5b) se muestra un extracto de las fuerzas de contacto que oscilan de forma uniforme entre los $500 \mathrm{~N}$ y los $1100 \mathrm{~N}$ aproximadamente.

Se resuelve ahora el problema empleando el modelo de fuerza puntual propuesto por la guía de diseño estructural Sétra de la ecuación (8) (con $g$ la aceleración de la gravedad y $m_{p}$ y $f_{p}$ los parámetros de masa y frecuencia de paso del peatón), cuya gráfica se muestra en la figura (6a) junto al desplazamiento vertical del punto medio de una viga transitada por ella.

$$
F(t)=m_{p} g\left(1+0.4 \sin \left(2 \pi f_{p} t\right)+\sum_{j=2}^{3} 0.1 \sin \left(2 \pi j f_{p} t-\frac{\pi}{2}\right)\right)
$$

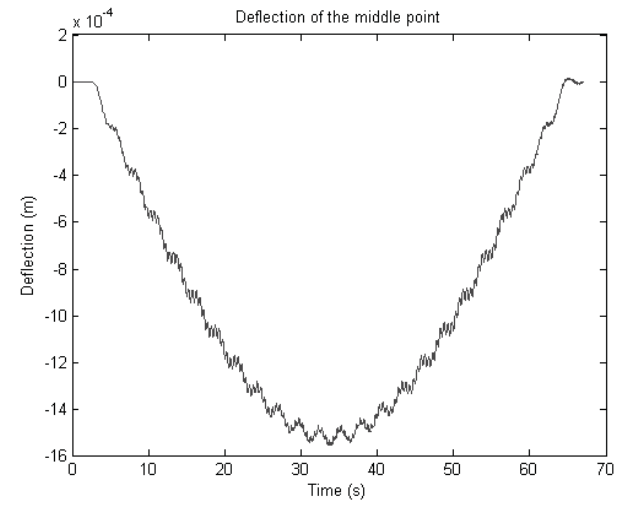

(a)

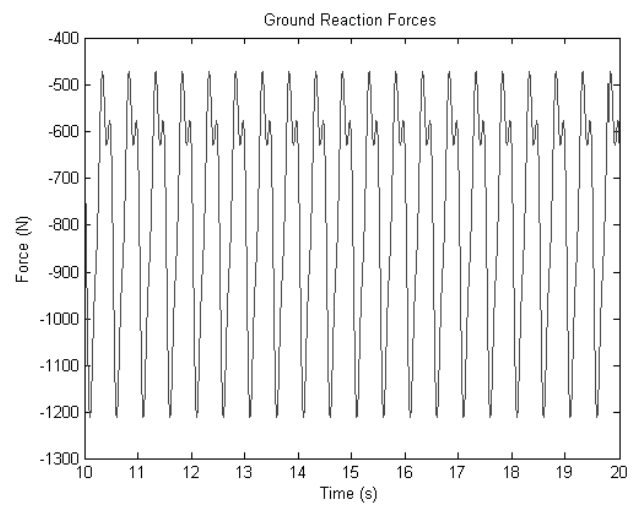

(b)

Figura 6. Resultados de la simulación aplicando el modelo Sétra. A la izquierda, deflexión del punto medio de la viga a lo largo del tiempo. A la derecha, extracto de la fuerza de contacto entre modelo y estructura.

Como se aprecia, ambas respuestas, así como las excitaciones, son muy similares en ambos casos. Se muestran, a modo de comparación, ambas curvas superpuestas en la figura (7), donde queda patente que las diferencias entre la respuesta proporcionada por la aplicación de cada modelo es realmente pequeña. Se puede calcular un valor cuadrático medio de la diferencia entre ambas respuestas, que en este caso es de $R M S_{\Delta}=6.84 \cdot 10^{-6} \mathrm{~m}$ (calculado mediante la ecuación (9) donde $N$ es el número de pasos temporales) varios órdenes de magnitud inferior al valor máximo de la respuesta.

$$
R M S_{\Delta}=\sqrt{\frac{1}{N} \sum_{i=1}^{N}\left(v_{i, M C K}-v_{i, S E T R A}\right)^{2}}
$$


Serviceability conditions of pedestrian structures using a simplified moving mass model Third International Conference on Mechanical Models in Structural Engineering University of Seville. 24-26 June 2015.

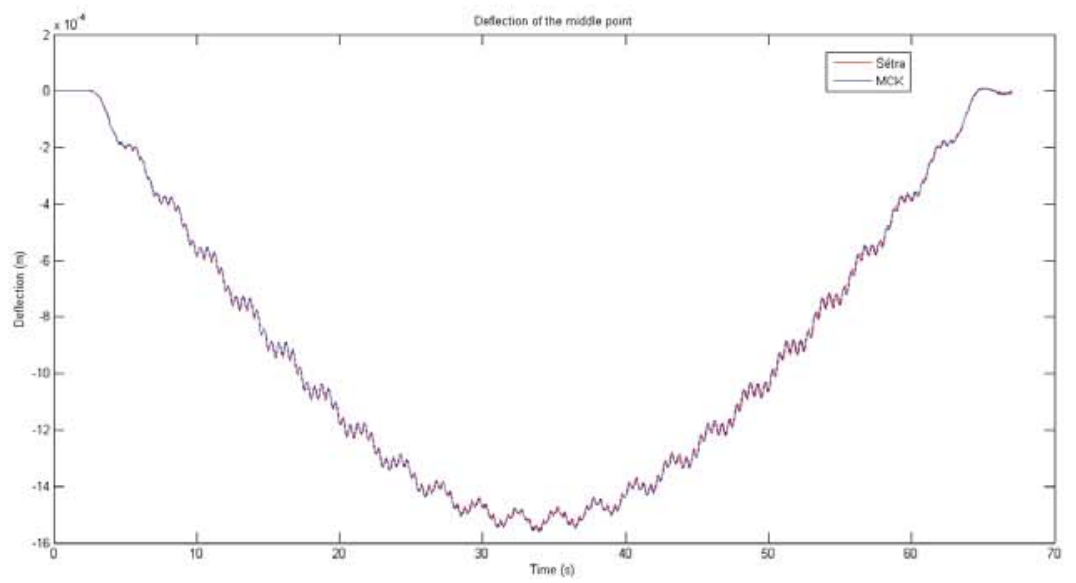

Figura 7. Comparación de la respuesta del punto medio de la viga proporcionada por la aplicación de los modelos MCK y Sétra.

Como en general las condiciones de confortabilidad (o estado límite de servicio respecto a vibraciones) se establecen en términos de aceleraciones, se presenta en la figura (8) las aceleraciones del punto medio correspondientes a ambos casos (MCK y SETRA). El RMS de cada una es, respectivamente, $0.0354 \mathrm{~m} / \mathrm{s}^{2}$ y $0.0549 \mathrm{~m} / \mathrm{s}^{2}$.

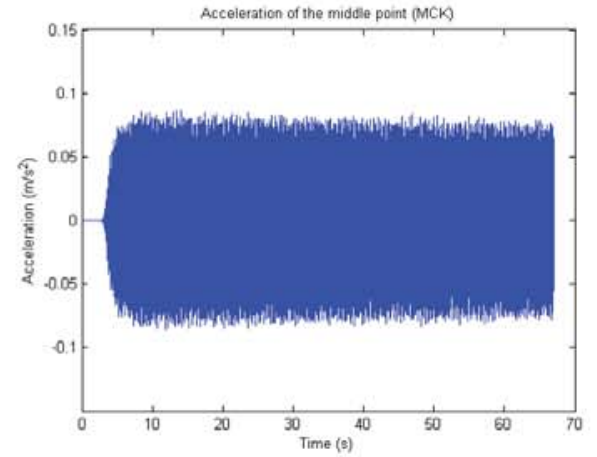

(a)

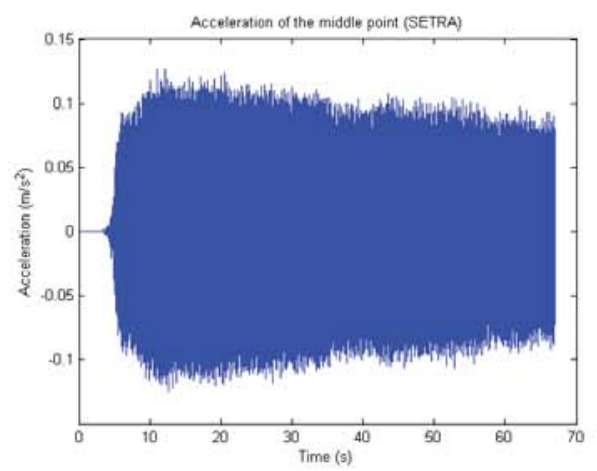

(c)

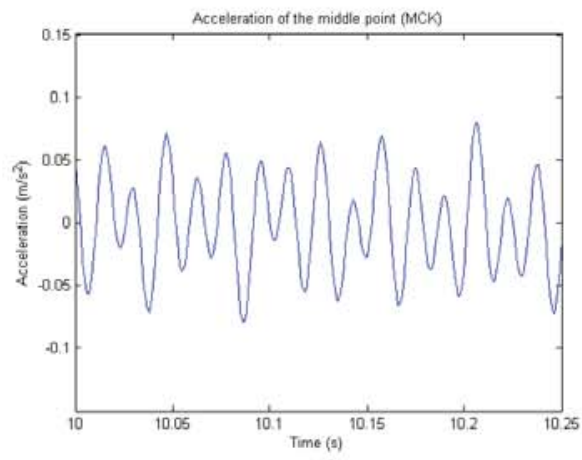

(b)

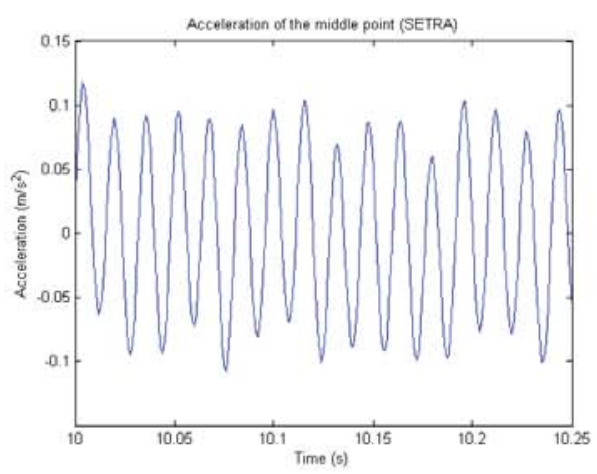

(d)

Figura 8. Aceleración del punto medio de la viga pesada: (a) y (b), modelo MCK; (c) y (d), modelo Sétra. 
Nótese adicionalmente que con el modelo MCK es posible conocer la evolución temporal de las variables cinemáticas de la masa, las cuales se presentan en la figura (9). En este caso, el RMS de la aceleración es $2.71 \mathrm{~m} / \mathrm{s}^{2}$, mucho mayor que $0.0354 \mathrm{~m} / \mathrm{s}^{2}$. Este valor, correspondiente a la masa que modela el peatón, grado de libertad inexistente en el modelo SETRA, podría ser más significativo para evaluar el confort de la estructura que el correspondiente al punto medio de la misma. Comentar adicionalmente que en este ejemplo, al ser la estructura muy rígida y pesada, los valores indicados corresponderían a un caminar normal.

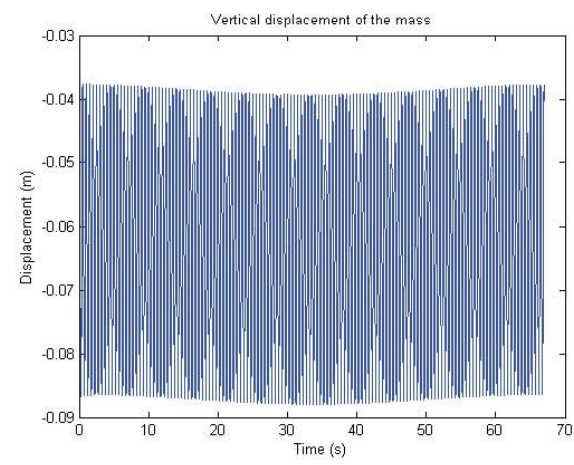

(a)

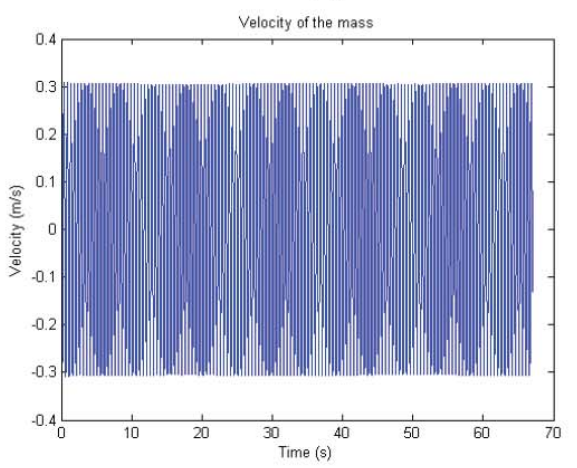

(c)

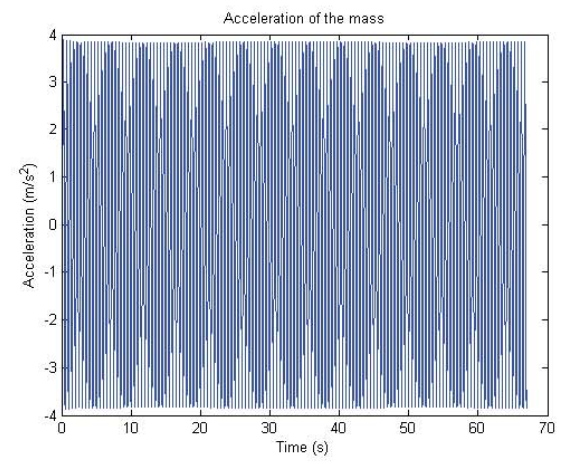

(e)

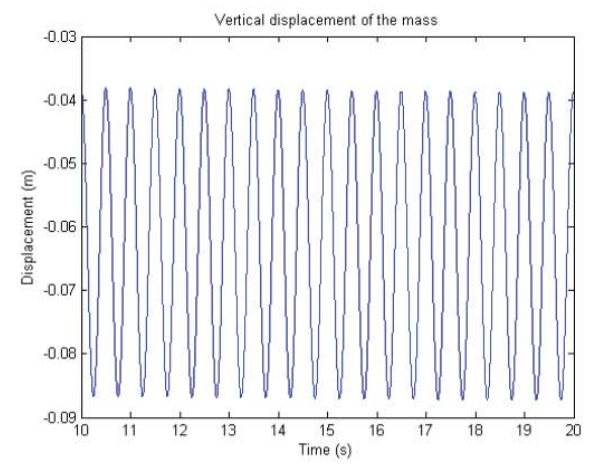

(b)

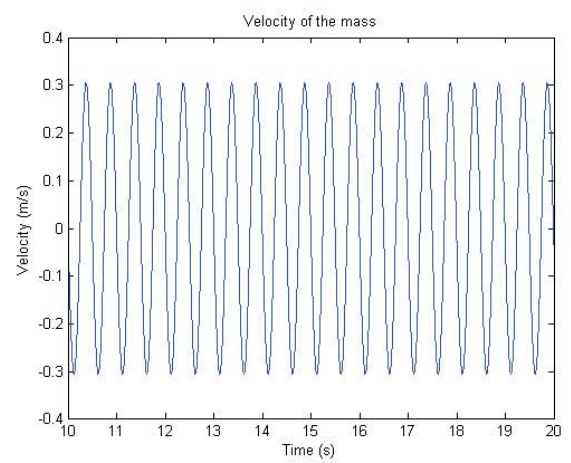

(d)

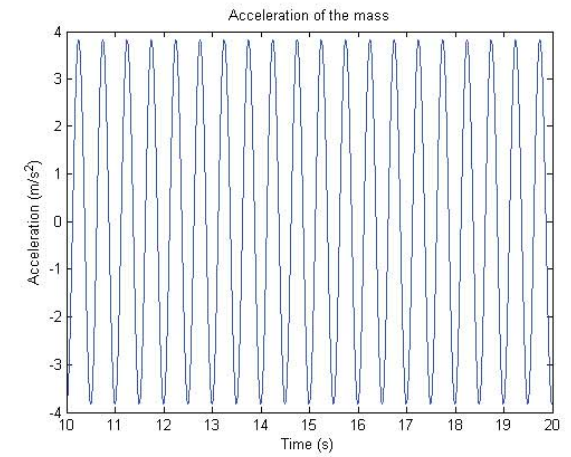

(f)

Figura 9. Respuesta de la masa: Desplazamiento vertical (a),(b); velocidad (c), (d); y aceleración $(\mathrm{e}),(\mathrm{f})$. 


\section{SECOND EXAMPLE: LIGHTWEIGHT FOOTBRIDGE}

Se simulará en este ejemplo un problema similar al precedente, solo que reduciendo notablemente la masa de la viga sin modificar su longitud ni su comportamiento modal. Para ello, es necesario y suficiente cumplir con la expresión (10), siendo $C$ un valor constante. Para observar claramente el efecto de este cambio, se opta por reducir la masa de la viga en un factor 1000, con lo que la masa del peatón pasa a ser un $42.45 \%$ de la masa de la viga y por tanto nada despreciable frente a ésta.

$$
\frac{E I}{\rho S}=C
$$

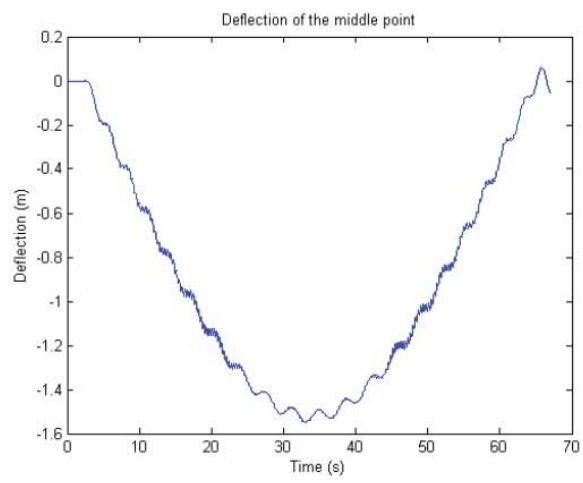

(a)

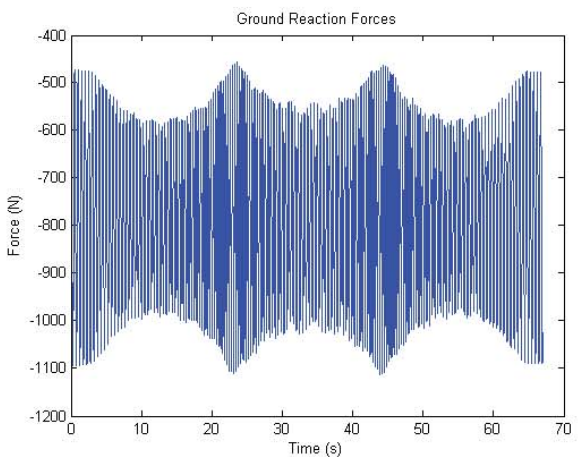

(b)

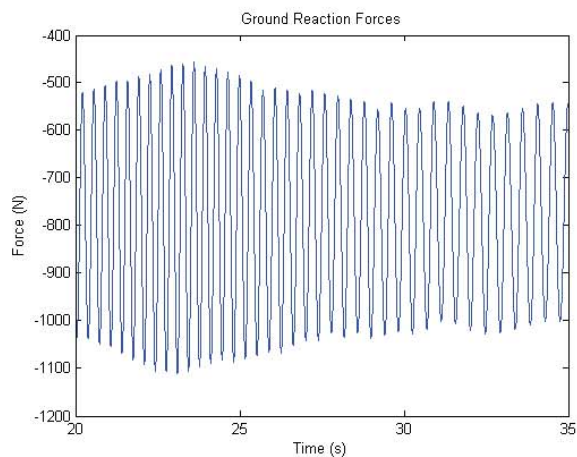

(c)

Figura 10. Resultados de la simulación aplicando el modelo MCK a la viga ligera. Arriba, deflexión del punto medio de la viga a lo largo del tiempo. Abajo, fuerza de contacto entre modelo y estructura.

Es preciso notar que el modelo del peatón no ha sido modificado. En esta situación, las respuestas que se obtienen se muestran en la figura (10). En referencia a estas curvas se pueden realizar varias apreciaciones. En primer lugar, y como cabría esperar, se aprecia cómo la respuesta del punto medio de la viga, figura (10a), se ha multiplicado de forma global por 1000 en relación a la respuesta de la viga más pesada. En segundo lugar, debido a la gran deflexión que sufre la viga en esta situación, la interacción entre viga y modelo se manifiesta de forma más acusada afectando a la oscilación de la masa y con ella a la fuerza de contacto entre ambos, figura (10b), la cual adquiere una forma global bastante característica. Los valores extremos de esta fuerza, sin embargo, no se han visto modificados: ésta oscila entre los 500 y los $1100 \mathrm{~N}$ aproximadamente. 

Antolín Lorenzana

La respuesta asociada a la aplicación del modelo del Sétra, figura (11), como cabría esperar, es muy similar a la obtenida para la viga más pesada (multiplicada por un factor 1000) pues la expresión de la fuerza aplicada es la misma al no verse modificados los parámetros del peatón, el cual conserva una masa de $80 \mathrm{Kg}$ y una frecuencia de paso de $2 \mathrm{~Hz}$.

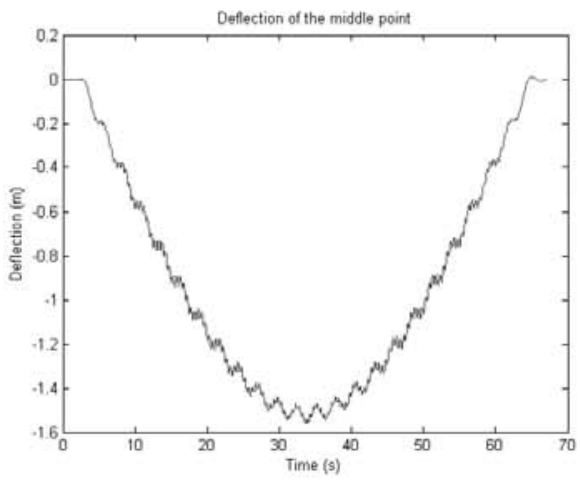

(a)

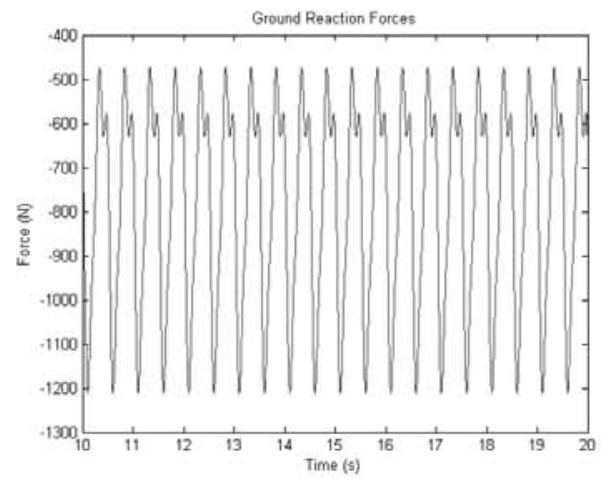

(b)

Figura 11. Resultados de la simulación aplicando el modelo Sétra a la viga ligera. A la izquierda, deflexión del punto medio de la viga a lo largo del tiempo. A la derecha, fuerza de contacto entre modelo y estructura.

Comparativamente ambas respuestas son similares, si bien se observan mayores diferencias que en el ejemplo anterior, como se muestra en la figura (12).

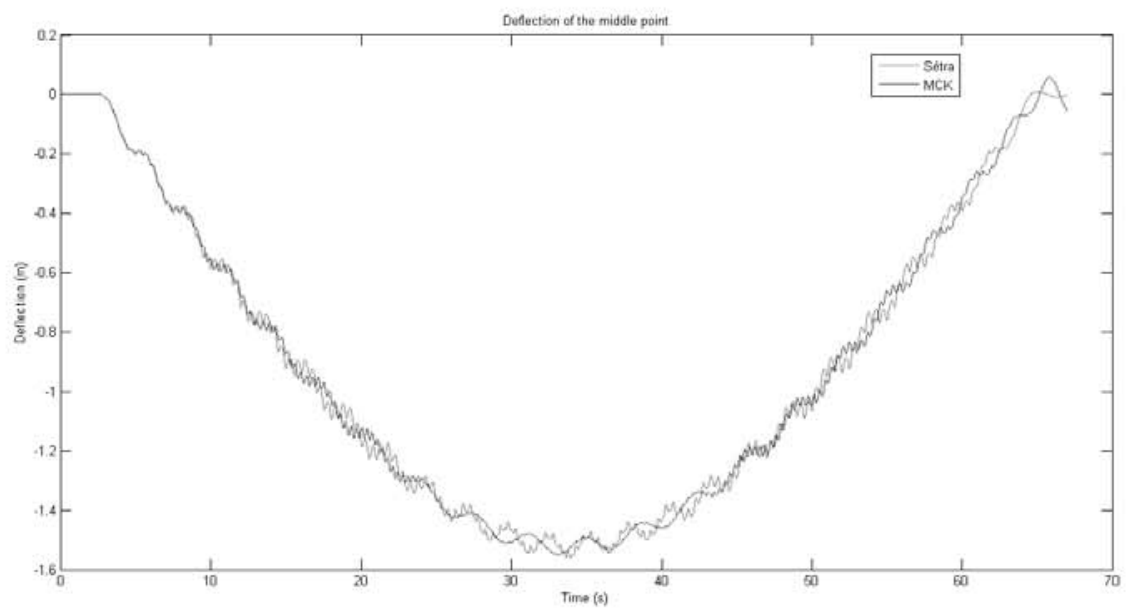

Figura 12. Comparación de la respuesta del punto medio de la viga proporcionada por la aplicación de los modelos MCK y Sétra.

Además de la apreciable diferencia entre la amplitud de las oscilaciones de ambas respuestas, inferior para la respuesta asociada al modelo másico, se puede observar una notable diferencia en cuanto a la frecuencia de oscilación propia de la viga, la cual se ha visto reducida por la presencia de la masa del peatón. Es más, se observa claramente cómo las primeras oscilaciones ocurren a una frecuencia muy parecida (próxima a la primera frecuencia propia de la viga) y cómo progresivamente 
se van distanciando las crestas, reduciéndose la frecuencia a medida que la masa se encuentra en torno al punto medio de la viga.

Este hecho queda patente en la figura (13), evolución temporal de la primera frecuencia propia de oscilación de la viga con el modelo, la cual ha sido obtenida resolviendo el problema de valores propios conducente a obtener las frecuencias y modos propios del ensamblaje en cada paso de tiempo de integración de las ecuaciones. Aunque hay tres curvas superpuestas, las dos correspondientes a la viga más pesada y a la simulación del modelo Sétra (sin masa) se superponen, pues la variación es prácticamente nula para el primer caso y exactamente nula para el segundo.

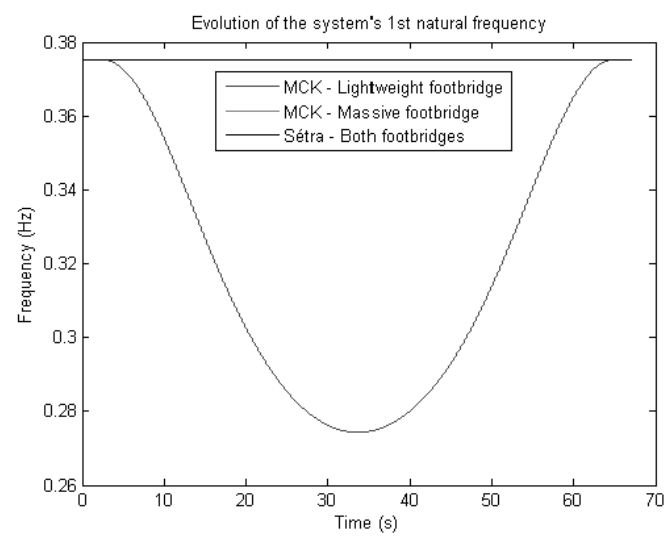

Figura 13. Evolución temporal de la primera frecuencia propia del sistema viga + masa.

En cambio, cuando la masa del peatón no es despreciable frente a la masa de la viga, la primera frecuencia propia de oscilación del problema evoluciona notablemente en el tiempo, alcanzando su valor mínimo hacia la mitad de la simulación (cuando el modelo alcanza las inmediaciones del punto medio de la viga). Este fenómeno, de gran relevancia para las simulaciones en las que intervienen estructuras muy ligeras o una multitud de peatones (suma total de las masas del mismo orden de magnitud que la masa de la viga), no se puede reproducir por la aplicación de un modelo de fuerza puntual como es el propuesto por la gran mayoría de guías de diseño estructural, como es la del Sétra.

Análogamente al ejemplo anterior, se presentan en la figura (14) las aceleraciones del punto medio correspondientes a ambos casos (MCK y SETRA). EI RMS de cada una es, respectivamente, $2.00 \mathrm{~m} / \mathrm{s}^{2}$ y $2.68 \mathrm{~m} / \mathrm{s}^{2}$. 


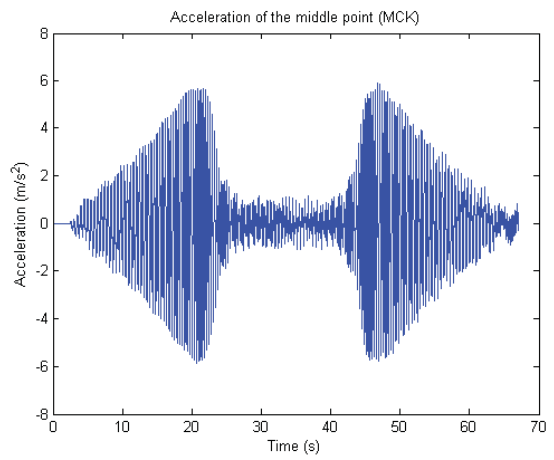

(a)

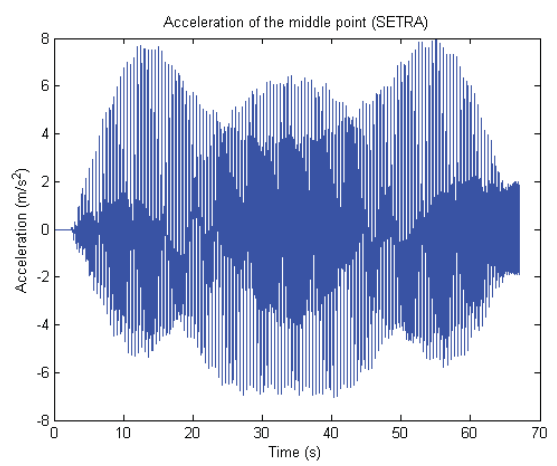

(b)

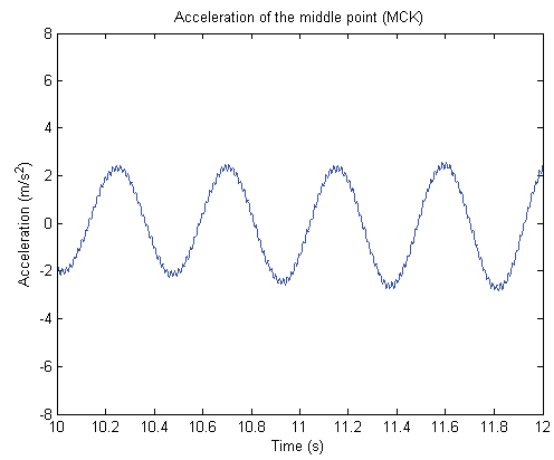

(b)

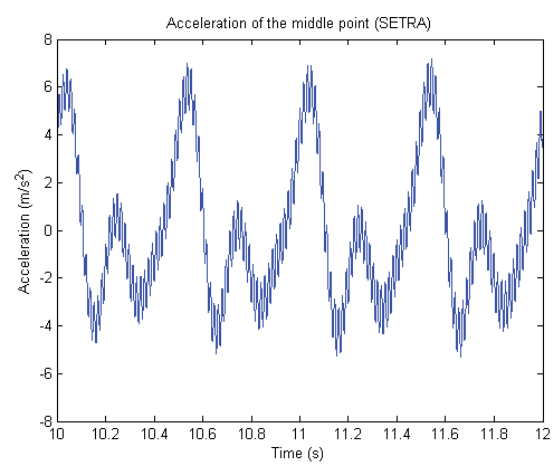

(c)

Figura 14. Aceleración del punto medio de la viga ligera: (a) y (b), modelo $M C K$; (c) y (d), modelo Sétra.

La figura (15) presenta el desplazamiento, velocidad y aceleración a lo largo del tiempo del grado de libertad correspondiente a la masa móvil. En este caso, el RMS de la aceleración es $2.23 \mathrm{~m} / \mathrm{s}^{2}$. Este valor es ligeramente inferior que en el ejemplo 1 (caminar normal) lo cual no es lo esperado, ya que en principio, al ser la viga más flexible, la cinemática de la masa puntual debería ser más acusada. Este comportamiento podría responder al hecho de que las amplitudes de aceleración y desplazamiento en movimientos armónicos están relacionadas por medio de un factor $\omega^{2}$. Aunque este sistema no responde exactamente como tal debido al acoplamiento entre modelo y estructura, sí que posee de alguna forma el carácter de aquél. Por ello, al haberse comprobado el descenso de la frecuencia de oscilación fundamental en figura (13), es razonable que las amplitudes de velocidad y aceleración sean proporcionalmente inferiores. También podría deberse a I sencillez del modelo, incapaz de tener en cuenta la compleja interacción peatón/estructura. 
Serviceability conditions of pedestrian structures using a simplified moving mass model Third International Conference on Mechanical Models in Structural Engineering University of Seville. 24-26 June 2015.

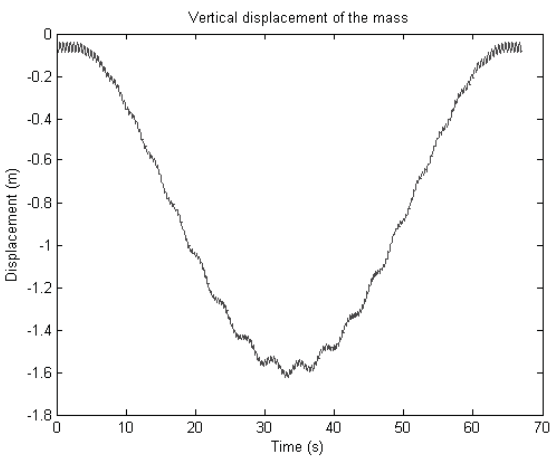

(a)

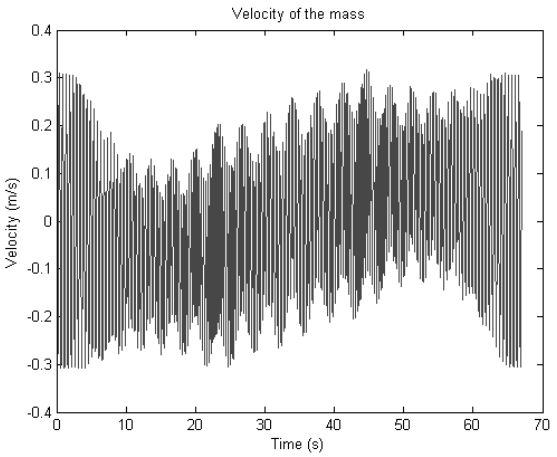

(c)

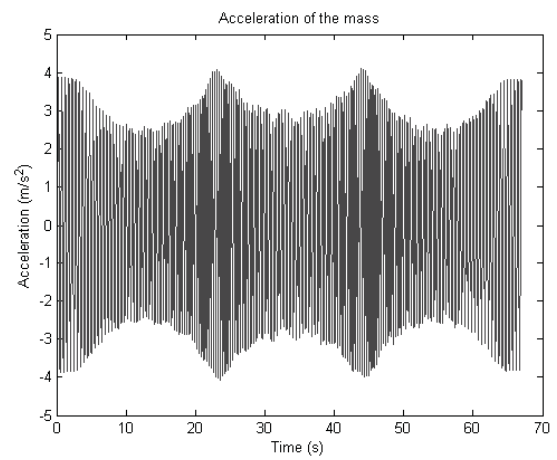

(e)

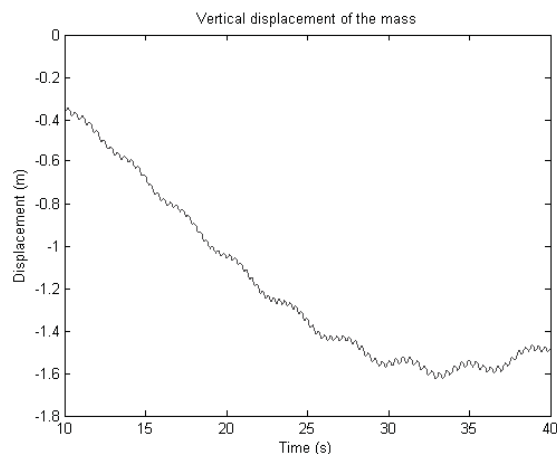

(b)

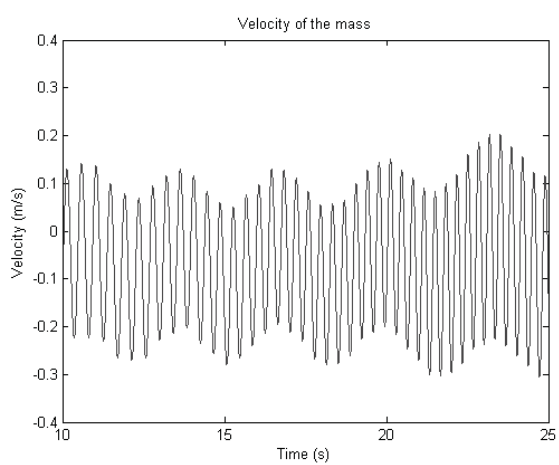

(d)

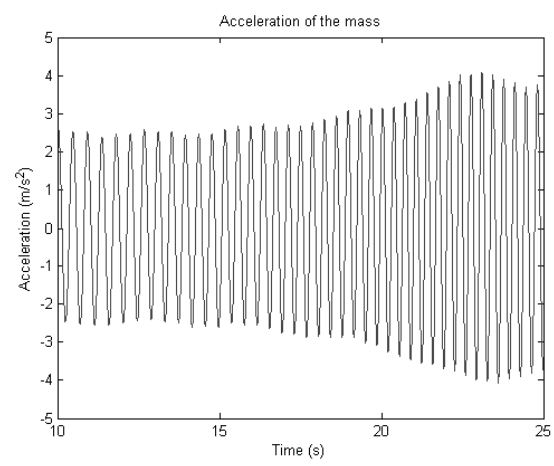

(f)

Figura 15. Respuesta de la masa: Desplazamiento vertical (a),(b); velocidad (c), (d); y aceleración (e), (f).

\section{CONCLUSIONS}

El modelo formulado permite considerar el efecto de la masa que los peatones aportan a la estructura sobre la que transitan, influyendo en el comportamiento dinámico del conjunto.

Cuando la masa del peatón es despreciable frente a la de la estructura, el resultado es similar al obtenido mediante formulaciones más simples basadas en fuerzas móviles, cuya resolución puede abordarse mediante métodos lineales de superposición modal. Sin embargo, cuando se considera la masa móvil, el sistema ensamblado es no lineal y debe ser resuelto mediante técnicas de integración directa. 
Álvaro Magdaleno, Mariano Cacho-Pérez, Javier Castaño, Norberto Ibán; Iván M. Díaz, Antolín Lorenzana

La presencia de la masa puntal móvil no solo permite cuantificar su influencia en la respuesta de la estructura (aspecto que un modelo de fuerza móvil no puede predecir) sino que permite conocer el comportamiento cinemático de dicha masa y con él las aceleraciones a las que el peatón está sometido, relacionables con la confortabilidad de la marcha.

Con el modelo simple formulado se obtienen resultados que deben ser validados frente a modelos más sofisticados o frente a resultados experimentales.

\section{ACKNOWLEDGMENTS}

This work has been partially funded by the Spanish Government Research Program with the Grant BIA2011-28493.

\section{REFERENCES}

[1] Sebastián, J., Muñoz-Díaz, I., Casado, C. M., Poncela, A., Lorenzana, A. (2013). Evaluation of acceleration estimates due to pedestrian loading on an in-service footbridge. Informes de la Construcción, 65, 335-348.

[2] Aktan, A. E., Farhey, D. N., Helmicki, A. J., Brown, D. L., Hunt, V. J., Lee, K. L., Levi, A. (1997). Structural identification for condition assessment: experimental arts. Journal of Structural Engineering, 123(12),1674-1684.

[3] Geyer, H., Seyfarth, A., Blickhan, R. (2006). Compliant leg behaviour explains basic dynamics of walking and running, Proceedings of the Royal Society B: Biological Sciences, vol. 273(1603), pp. 2861-2867.

[4] Kim, S., Park, S. (2011). Leg stiffness increases with speed to modulate gait frequency and propulsion energy, Journal of Biomechanics, vol. 44, pp. 1253-1258.

[5] Qin, J., Law, S., Yang, Q., Yang, N. (2003). Pedestrian-bridge dynamic interaction, including human participation," Journal of Sound and Vibration, vol. 332, pp. 1107-1124.

[6] Pandy, M. (2003). Simple and complex models for studying muscle function in walking, Phil. Trans. R. Soc. B, vol. 358, pp. 1501-1509.

[7] Whittington, B., Thelen, D. (2009). A simple mass-spring model with roller feet can induce the ground reactions observed in human walking," Journal of Biomechanical Engineering, vol. 131(011013), pp. 1-8.

[8] Neves, S.G.M. (2012).A direct method for analyzing the vertical vehicle-structure interaction". Engineering Structure, vol. 34, pp. 414-420. 
SIMULATION OF THE RESPONSE OF A LIVELY FOOTBRIDGE UNDER PEDESTRIAN LOADING WITH TWO TUNED MASS DAMPERS FOR ITS TWO FIRST MODES (2.1HZ AND 2.5HZ)

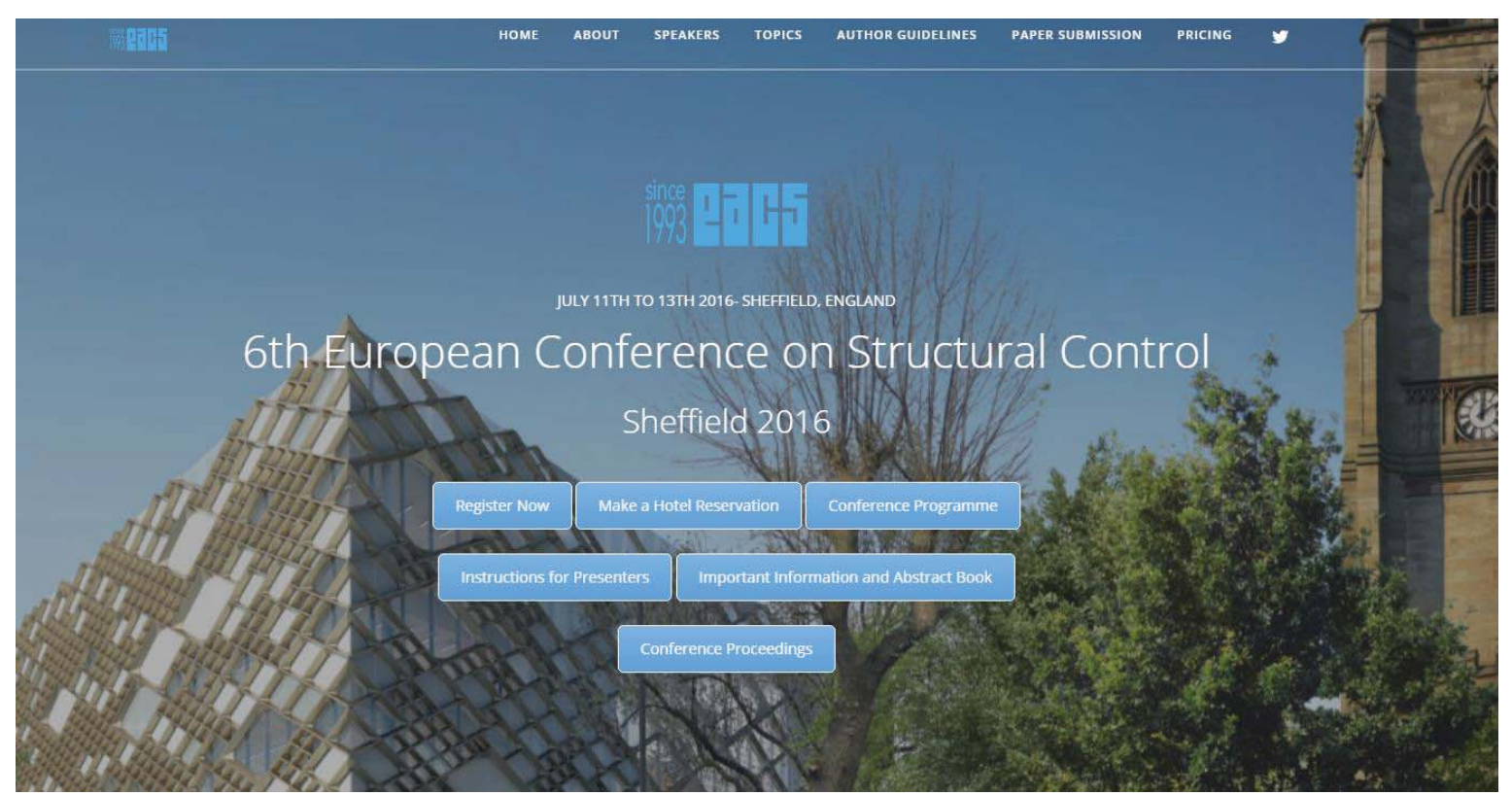

Norberto Ibán Lorenzana; Javier Castaño Lerma; Álvaro Magdaleno González; Mariano Cacho Pérez; Alberto Fraile de Lerma; Antolín Lorenzana Ibán.

\begin{tabular}{c|c|c|c|} 
Aportaciones: & Experimentación & Procesado & Edición \\
\hline & $\begin{array}{c}\text { Instrumentación } \\
\text { Registros } \\
\text { Tests }\end{array}$ & Matlab & Tablas \\
& FEMTools & $\begin{array}{c}\text { Gráficas } \\
\text { Imágenes }\end{array}$ \\
\cline { 2 - 4 }
\end{tabular}




\title{
Simulation of the response of a lively footbridge under pedestrian loading with two tuned mass dampers for its two first modes $(2.1 \mathrm{~Hz}$ and $2.5 \mathrm{~Hz})$
}

\author{
Norberto Ibán ${ }^{1}$, Javier Castaño ${ }^{1}$, Álvaro Magdaleno ${ }^{2}$, Mariano Cacho ${ }^{2}$, Alberto Fraile ${ }^{3}$, \\ Antolín Lorenzana*2 \\ ${ }^{1}$ Fundación CARTIF, Parque Tecnológico de Boecillo, Boecillo (Valladolid), Spain \\ ${ }^{2}$ ITAP. EII. Universidad de Valladolid, Valladolid, Spain \\ ${ }^{3} U P M$, Escuela Técnica Superior de Ingenieros Industriales, Madrid, Spain
}

\begin{abstract}
Structures subjected to excitations like human induced vibrations may produce large accelerations and serviceability limit state problems. Passive, semi-active and active vibration controls have been proposed as possible solutions to reduce the vibration level at civil structures such as bridges, multistorey buildings or slender floor structures, among others [1]. It is known that Tuned Mass Dampers (TMD) mitigates the vibration response of a structure by increasing its damping through the application of inertial forces generated in response to the movement of the structure [2]. Recently, different TMD implementations have been proposed in order to improve the tuning of mechanical parameters. In the case of structures with spatially distributed and closely spaced natural frequencies, the TMD design may not be obvious because Den Hartog's theory [3] may not be applied due to the existence of a coupling between the motions of the vibration modes of the structures and the used TMD's [4]. Alternative design techniques are applied for the case under study consisting on an arched bridge with a main span $40 \mathrm{~m}$ long and several shorter access spans. The first two first modes are at $2.1 \mathrm{~Hz}$ and $2.5 \mathrm{~Hz}$, both in the range prone to be excited by walking. Also the third one (at $3.18 \mathrm{~Hz}$ ) could be excited by runners.

For the simulation, firstly, a finite element model of the bridge is created in a commercial CAE software and static and modal response is numerically estimated. Then, experimental measurements using static loading test and ambient vibration tests are performed. Initial finite element model is adjusted to match with the static response by fitting some selected parameters. Modal parameters (natural frequencies, mode shapes and modal damping) are extracted and after that the current finite element model is updated. Once the numerical model is calibrated, TMDs are attached. The problem of finding the optimal location and tuning is not a simple one. For understanding the coupled response, several simulations are carried out, from the logical one (TMD located just in the middle of the main span and tuned at $2.1 \mathrm{~Hz}$ ) to others. The responses of the footbridge for different scenarios (depending on the number of TMDs installed and their position) are compared in order to extract some interesting conclusions.
\end{abstract}

Keywords: Structural control, Passive vibration control, tuned mass damper, optimal control.

\section{INTRODUCTION}

Although in the past, civil engineering sector made extensive use of approximate models to estimate the dynamic response of bridge type structures, nowadays is usual to model the structure using current $\mathrm{CAE}$ abilities. Simple discrete models have proved insufficient for the accurate modelling of slender footbridge structures as they cannot represent some effects as the closely spaced modes of vibration which frequently occur in practice. Additionally, modern footbridges become increasingly slender and prone to oscillate under pedestrian loading, so there is a much 
greater need for vibrations to be considered at the design stage. Having the FE methods the capability for the accurate modelling of the dynamic behavior, and becoming CAE software more affordable, civil engineering practitioners do not hesitate in their use. However, with regard to lively structural design, there is a lack of expertise in FE modelling, particularly with regard to their vibration serviceability performance, being not rare that the model does not match with the real structure. The way forward for developing such expertise is by linking modal testing and FE analysis by the updating of the models of representative structures and extract general design guidelines. This type of approach is the usual in, for example, the aero space engineering sectors [5, 6], but it is only recently that the civil engineering community has begun to adopt this advanced technology $[7,9]$.

The aim of the paper is to describe a procedure for the use of updated FE models with TMDs attached to estimate the response in terms of accelerations and evaluate the serviceability of the assembly.

\section{STRUCTURE DESCRIPTION AND F.E. MODELING}

The footbridge under study is an urban link with several minor access spans and one main $40 \mathrm{~m}$ long arched central lively span. Most of the structural members are constructed using tubular steel profiles. An aerial photograph of the footbridge and 3D isometric view of its FE model is depicted in figure 1. More information about the structure can be found in [10]. Updated modeshapes 1 and 2 are shown in figure 2.a The structural damping (Rayleigh type) was set to $0.32 \%$.
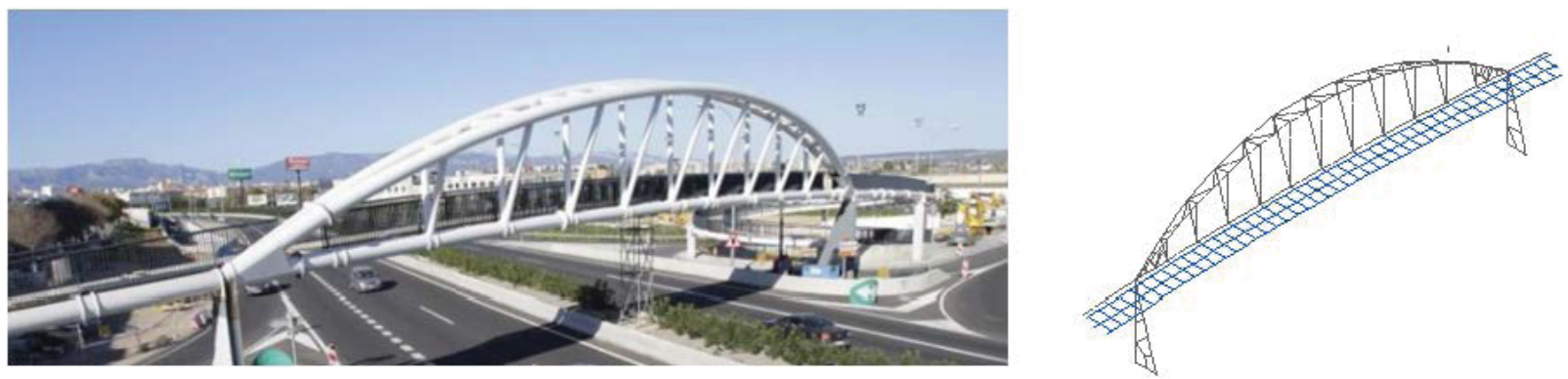

Figure 1. Footbridge under study: photograph and numerical FE model.

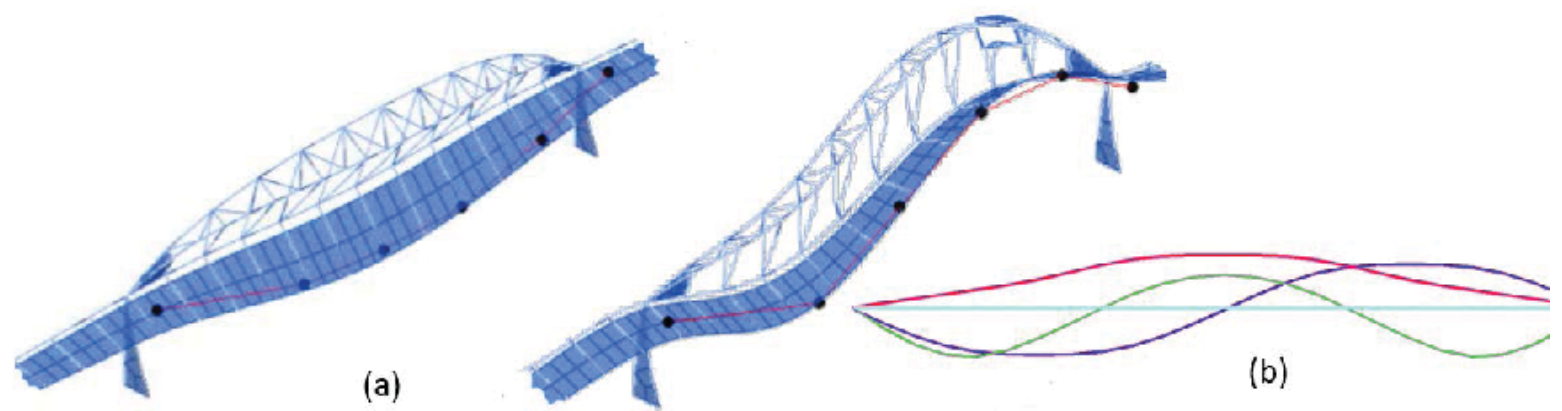

Figure 2. 3D F.E. model mode-shapes

Although it would be possible to applied the methodology using the 3D F.E. model, in order to make more efficient simulations, a less time consuming F.E. model has been created. In this case, just a 2D equivalent structure meshed in 12 elements and modeled using Euler beam elements has been used. Both models exhibit similar vertical modes (see figure 2.b), which are the interesting ones for the problem under study (pedestrian loading vertical response). Being $L$ the length of the fo otbridge, note that the second mode-shape has a node at $6 \mathrm{~L} / 12$ and the nodes of the third modeshapes are located at $4 \mathrm{~L} / 12$ and $8 \mathrm{~L} / 12$. In the next section, the dynamic problem is establish using the state space approach. 


\section{SPACE STATE MODELING}

The dynamic equation to be solved is:

$\mathbb{M} \ddot{q}+\mathbb{C} \dot{q}+\mathbb{K} q=F$

Where $\mathbb{M}$ is the mass matrix and $\mathbb{K}$ is the stiffness matrix. $\mathbb{C}$ is the damping matrix, evaluated through modal damping values $\xi_{i}$ according to the following equations

$$
\begin{aligned}
& V=\left[\phi_{1}\left|\phi_{2}\right| \ldots \mid \phi_{n}\right] \\
& \widetilde{\mathbb{C}}=V^{T} \mathbb{C} V \rightarrow \mathbb{C}=\left(V^{T}\right)^{-1} \widetilde{\mathbb{C}} V^{-1}=\left(V \widetilde{\mathbb{C}}^{-1} V^{T}\right)^{-1} \\
& \widetilde{\mathbb{C}}=\operatorname{diag}\left(2 \xi_{i} \omega_{i}\right)
\end{aligned}
$$

Only bending dof are considered (vertical deflection and angle, named generalized displacements):

$$
q=\left[\begin{array}{lllllllll}
v_{1} & \theta_{1} & v_{2} & \theta_{2} & v_{3} & \theta_{3} & \ldots & v_{n} & \theta_{n}
\end{array}\right]^{T}
$$

and standard procedures for meshing and assembling must be applied to all the matrices. Also boundary conditions (simple supported beam) must be included in the former formulation.

$\mathrm{F}$ is the input force, affecting to the dof considered. $\mathrm{u}(\mathrm{t})$ is the harmonic function and $\mathcal{F}$ is the vector containing the amplitudes of that force in the corresponding dof.

$$
F=\mathcal{F} u(t)
$$

Any TMD means an additional dof to be added in the matrix formulation. For that, when $m$ TMDs are considered the displacement vector q changes into q':

$$
q^{\prime}=\left[q^{T}\left|w_{1}\right| w_{2}|\ldots| w_{m}\right]^{T}
$$

And for any TMD the corresponding matrices to be assembled are:

$$
M_{t}=\left[\begin{array}{cc}
0 & 0 \\
0 & m_{t}
\end{array}\right] \quad C_{t}=\left[\begin{array}{cc}
c_{t} & -c_{t} \\
-c_{t} & c_{t}
\end{array}\right] \quad K_{t}=\left[\begin{array}{cc}
k_{t} & -k_{t} \\
-k_{t} & k_{t}
\end{array}\right]
$$

Where $m_{t}, c_{t}$ and $k_{t}$ are the moving mass of the TMD, its stiffness and its damping.

Considering as input the harmonic function $(u(t))$ and as output just the acceleration (y) in one selected dof, the dynamic equation of motion can be rewritten as:

$$
\begin{aligned}
& \dot{x}=A x+B u \\
& y=C x+D u
\end{aligned}
$$

Where $\mathrm{x}$ is the state vector defined as

$$
x=\left[\begin{array}{c}
q \\
\dot{q}
\end{array}\right]
$$

$\mathrm{y}$ is the output vector $y=\ddot{q}_{i}, \mathrm{u}$ is the input $u=u(t)$ and the new space state matrices are:

$$
A=\left[\begin{array}{cc}
\emptyset_{n x n} & I_{n x n} \\
-\mathbb{M}^{-1} \mathbb{K} & -M^{-1} \mathbb{C}
\end{array}\right] \quad B=\left[\begin{array}{c}
\emptyset_{n x 1} \\
\mathbb{M}^{-1} \mathcal{F}
\end{array}\right] \quad C=A(n+i, \text { all }) \quad D=B(n+i)
$$

Where $\emptyset_{n x n}$ is the square zero matrix $I_{n x n}$ is the identity matrix, $\mathrm{C}=A(n+i, a l l)$ is the row of the A matrix with the acceleration of the $\mathrm{i}$-th dof, and $D=B(n+i)$ is the $\mathrm{i}$-th element of the vector $\mathrm{B}$. Once all the system is established, the transfer function is defined as

$$
G_{i}(s)=\frac{\ddot{Q}_{i}(s)}{U(s)} \quad \ddot{Q}_{i}(s)=\mathcal{L}\left\{\ddot{q}_{i}(t)\right\} \quad U(s)=\mathcal{L}\{u(t)\}
$$

where $\mathcal{L}\{\}$ is the Laplace operator. After some manipulations the former equations become

$$
G_{i}(s)=\frac{\ddot{Q}_{i}(s)}{U(s)}=\frac{Y(s)}{U(s)}=C\left(s I_{2 n \times 2 n}-A\right)^{-1} B+D
$$

where $I_{2 n \times 2 n}$ is the identity matrix. The frequency response function (FRF) to be used in the following parts is just the magnitude of the Bode diagram of this transfer function, with is evaluated in Matlab using the following standard commands:

$$
S Y S=s s(A, B, C, D) ; \quad G=t f(S Y S) ; \quad M A G=\operatorname{bode}(G, W) ; \quad \text { semilogy }(W, \text { squeeze }(M A G))
$$

\section{FREQUENCY RESPONSE WITH TMDS AND SERVICEABILITY ESTIMATION}

For all the studied cases, a tonne inertial moving mass is added (being the $2 \%$ of the total mass of the simplified model of the footbridge) in one or two TMDs (500kg each). The TMD may be tuned to mode 1 (w1) or mode 2 (w2) and located in some point (q) along the beam. To 
simplified the continuous problem, only 11 discrete locations are considered (as the structure is discretized in 12 beam elements) so point $\mathrm{q}$ is at $\mathrm{jL} / 12$ from the left end of the structure. The notation will be TMDwi_jL/12 which means that the TMD is tuned for the mode $i(i=1,2)$ and located in $\mathrm{jL} / 12(\mathrm{j}=1 . .11)$.

All numerical values for the estimation of the response are obtained from the FRFs. In all the cases, the excitation point (force) and the response (acceleration) will be the same (p) and the notation will be $\mathbf{F R F}(\mathbf{p}, \mathbf{T M D w i} \mathbf{j} \mathbf{L} / \mathbf{1 2})$. Also note that only the selected 11 discretized points $p$ are going to be considered. In this way, the notation FRF(3L/12, TMDw1 5L/12) stands for the amplification factors in the point $3 \mathrm{~L} / 12$ when the force is acting in $3 \mathrm{~L} / 12$ and the TMD is located at $\underline{5 \mathrm{~L} / 12 \text { and tuned for mode } 1 .}$

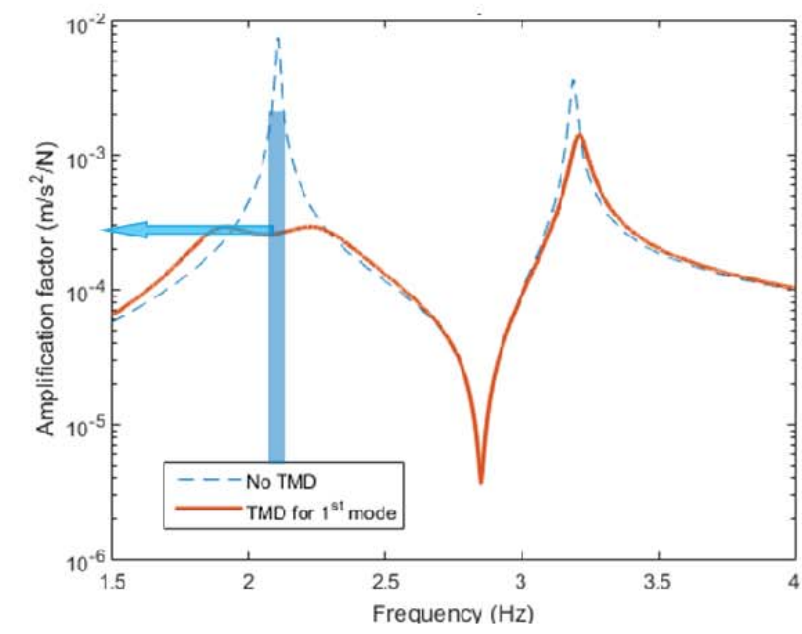

Figure 3. FRF(6L/12, TMDw1_6L/12)

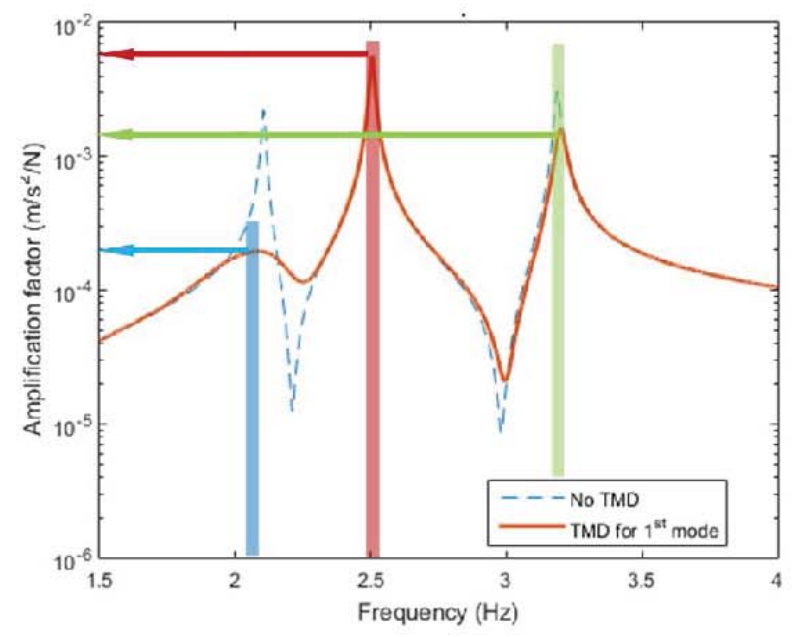

Figure 4. $F R F\left(3 L / 12, T M D w 1 \_6 L / 12\right)$

\subsection{TMD tuned at mode 1}

To start with, a logical scenario consisting on one TMD tuned in the center of the structure and tuned to its first mode $(2.044 \mathrm{~Hz}, \xi=0.134)$ is considered (TMDw1_6L/12). The figure 3 shows the FRF(6L/12, TMDw1_6L/12). It is noteworthy that the first peak has been flattened and the peak at $\mathrm{w} 3$ is almost not affected. In order to see the response for mode 2, a FRF out of $6 \mathrm{~L} / 12$ must be evaluated as that position is a node of mode 2. Figure 4 shows $\operatorname{FRF}(3 \mathrm{~L} / 12$, TMDw1_6L/12), revealing, as expected, that the TMDw1_6L/12 does not affect the response in mode 2 .

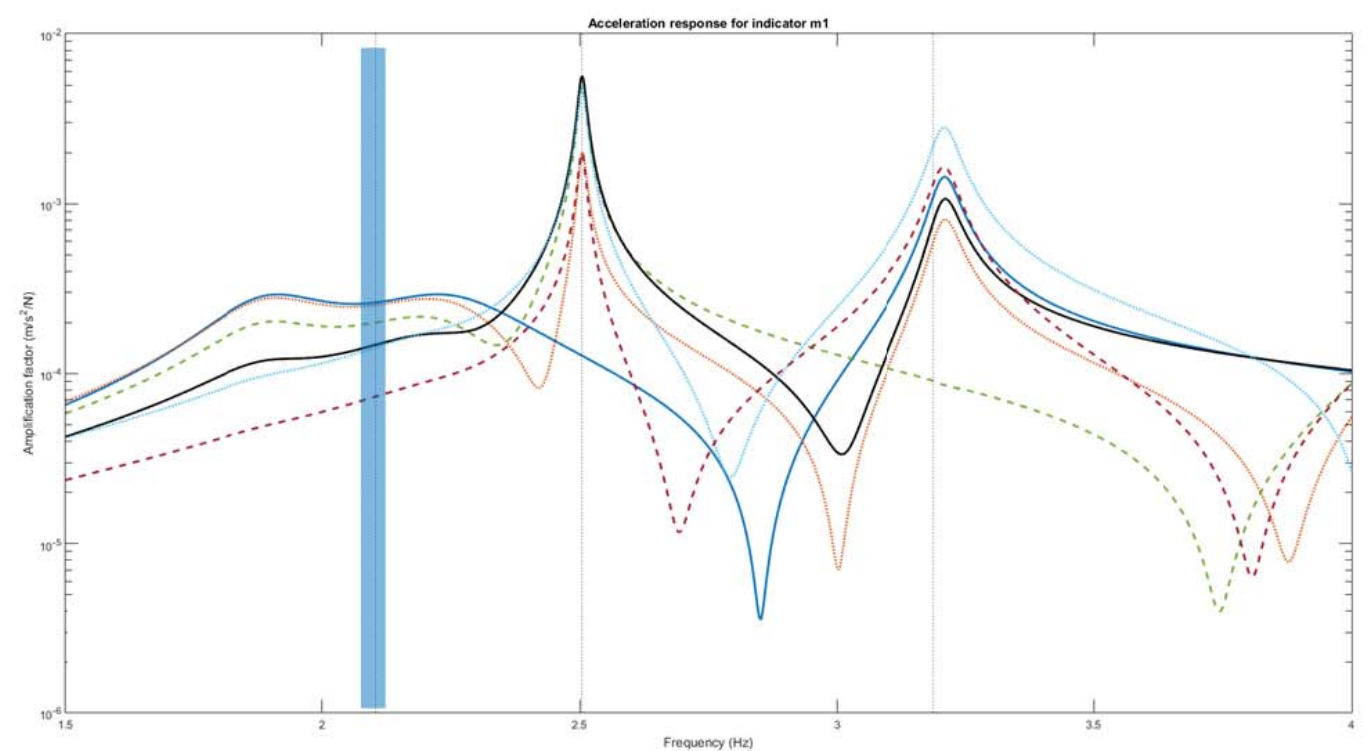

Figure 5. FRF(iL/12, TMDw1_6L/12), $i=1,2,3,4,5$ and 6 
If installing a TMDw1 is under consideration is due to the possibility of large vibrations when a pedestrian is crossing at a pace coincident with w1. Although the pedestrian crossing is a transient problem, in order to estimate the vibration dose the auto FRFs at $i \mathrm{~L} / 12(\mathrm{i}=1 . .11)$ are going to be used. Note that during the crossing, the pedestrian is the one that excites the structure and perceives its vibration. Thus, at the middles $(6 \mathrm{~L} / 12)$ the amplification factor is 0.00029 (figure 3 ) and at $3 \mathrm{~L}$ $/ 12$ it decreased to 0.00015 (blue arrow in figure 4). Following this logic, figure 5 shows how the amplification factor is increasing as the pedestrian approaches the center. Figure 6 shows a detail for frequencies around $\mathrm{w} 1$ and in Table 1 are the corresponding values. Table 1 also shows the values for the cases in which pedestrian pace is w2 and w3 (red and green arrows in figure 4). Note that these first 3 modes are prone to be excited by walking or running.

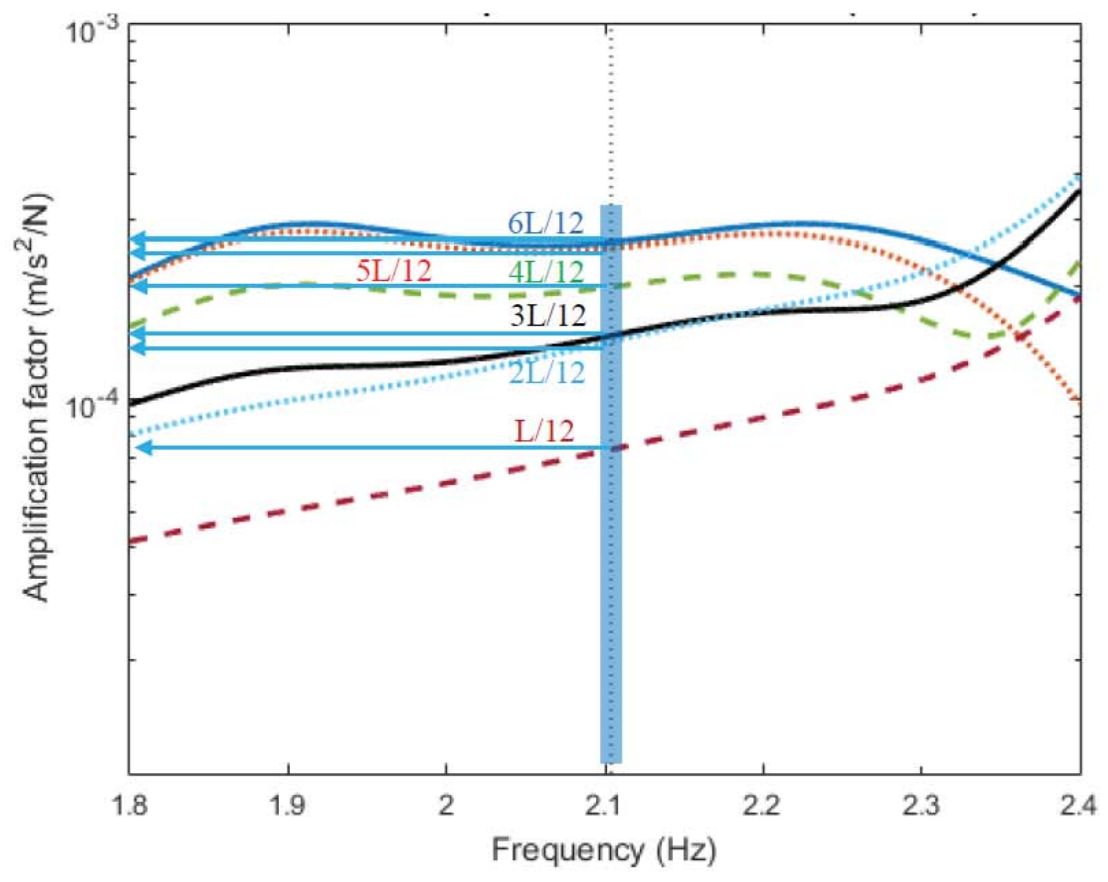

Figure 6. Detail for the FRF(iL/12, TMDw1_6L/12), $i=1,2,3,4,5$ and 6

In addition Table 1 shows the cumulatively amplification factors for the crossing at w1, w2 and $\mathrm{w} 3$ pace. For a clearer display, information in Table 1 is shown graphically in figure 7 . It can be seen how, in comparison with figure 8 (response without TMD), the installed TMDw1_6L/12 is very effective for crossing at $\mathrm{w} 1$ and also affects significantly the response for crossing at $\mathrm{w} 3$ pace.

Table 1, Amplification factors for TMDw1 $j L / 12$

\begin{tabular}{c|c|c|c}
\hline TMDw1_ & $w 1$ & $w 2$ & $w 3$ \\
\hline $\mathrm{L} / 12$ & 0.00007 & 0.00198 & 0.00165 \\
\hline $2 \mathrm{~L} / 12$ & 0.00014 & 0.00493 & 0.00281 \\
\hline $3 \mathrm{~L} / 12$ & 0.00015 & 0.00563 & 0.00107 \\
\hline $4 \mathrm{~L} / 12$ & 0.00022 & 0.00495 & 0.00000 \\
\hline $5 \mathrm{~L} / 12$ & 0.00028 & 0.00201 & 0.00081 \\
\hline $6 \mathrm{~L} / 12$ & 0.00029 & 0.00000 & 0.00143 \\
\hline $7 \mathrm{~L} / 12$ & 0.00028 & 0.00201 & 0.00081 \\
\hline $8 \mathrm{~L} / 12$ & 0.00022 & 0.00495 & 0.00000 \\
\hline $9 \mathrm{~L} / 12$ & 0.00015 & 0.00563 & 0.00107 \\
\hline $10 \mathrm{~L} / 12$ & 0.00014 & 0.00493 & 0.00281 \\
\hline $11 \mathrm{~L} / 12$ & 0.00007 & 0.00198 & 0.00165 \\
\hline$\Sigma$ & 0.00199 & 0.03900 & 0.01411 \\
\hline & & &
\end{tabular}




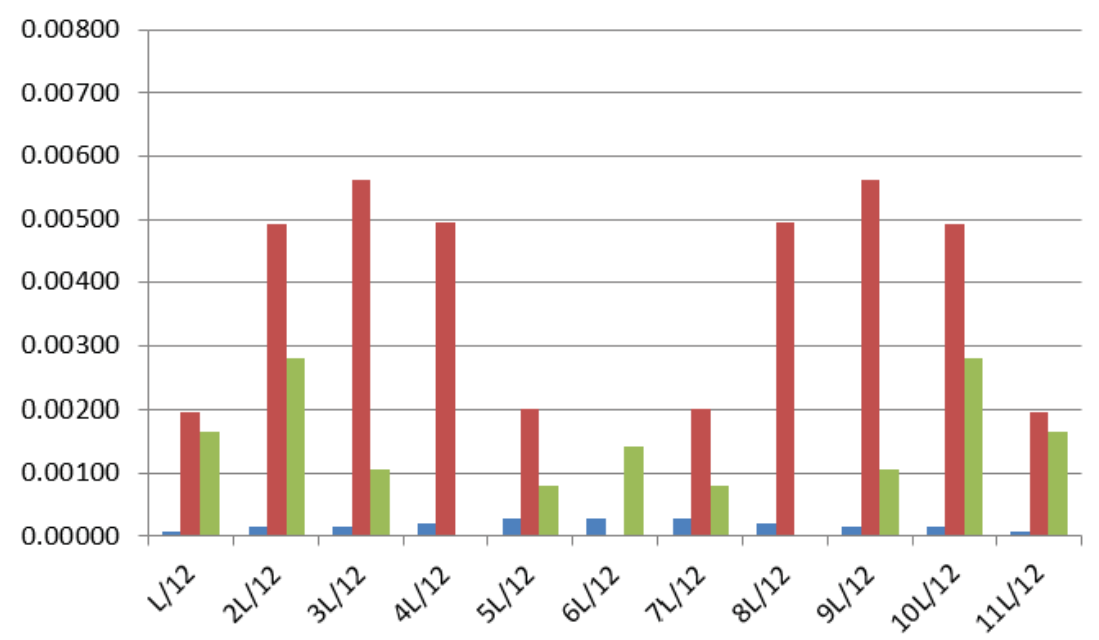

Figure 7. Amplification factors for TMDw1 $j L / 12$

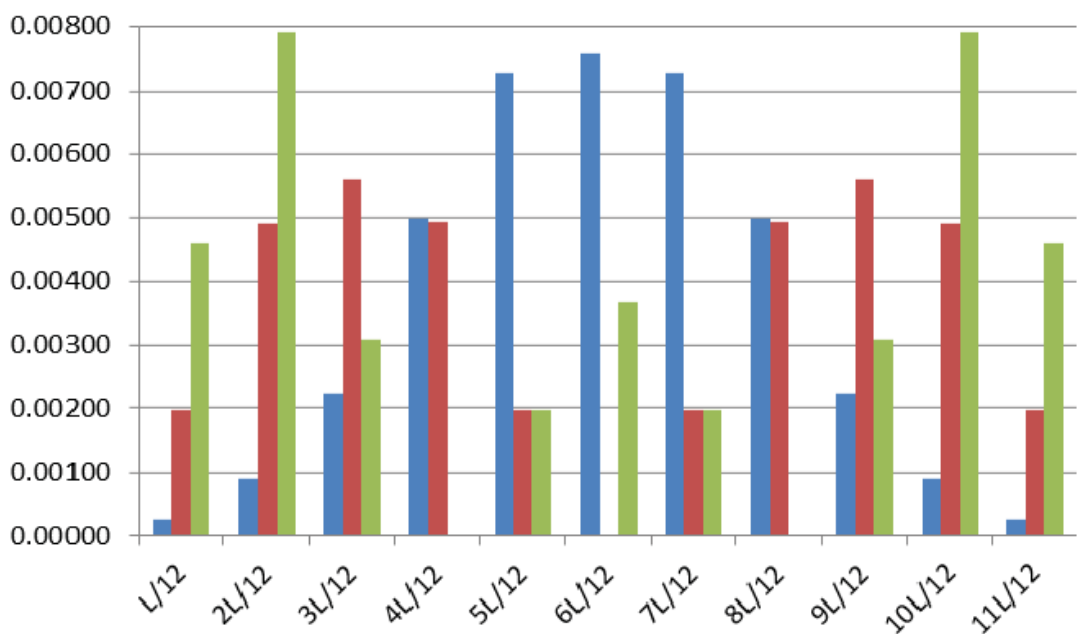

Figure 8. Amplification factors without TMD

It would be worthy to wonder about the response when TMDw1 were located at $\mathrm{j} / 12$ for $\mathrm{j} \neq$ 6 (and tuned properly). Figure 9 shows the response for the case of $j=3$, resulting to be the optimum location for crossings at $\mathrm{w} 1, \mathrm{~m} 2$ and $\mathrm{m} 3$ (averaged values assuming same number of crossings at each pace) as shown in figure 10 .

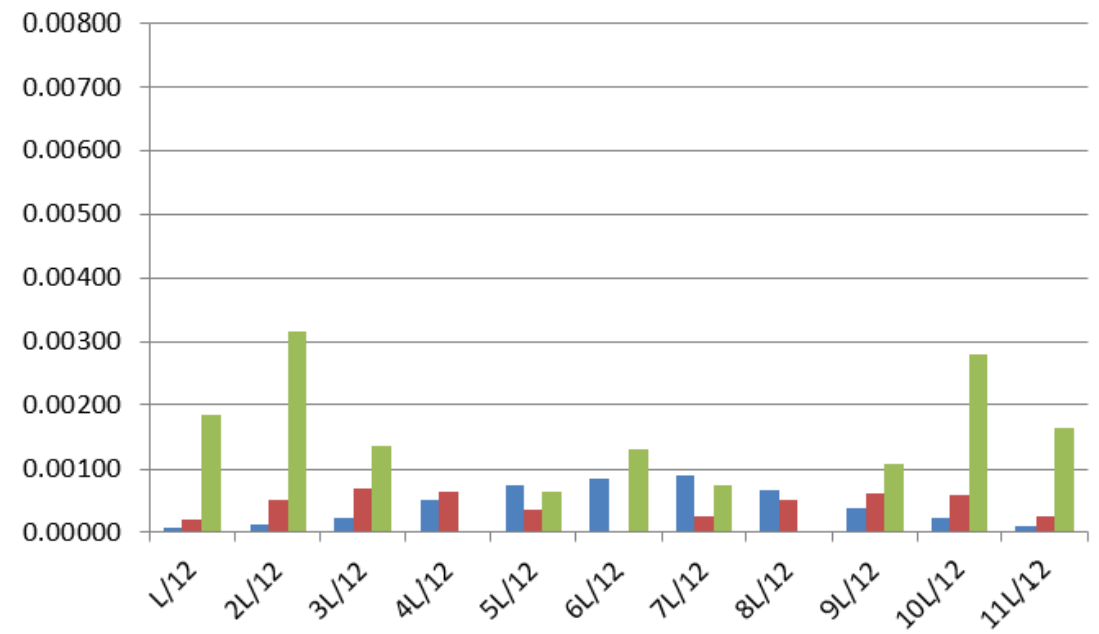

Figure 9. Amplification factors for TMDw1_3L/12 


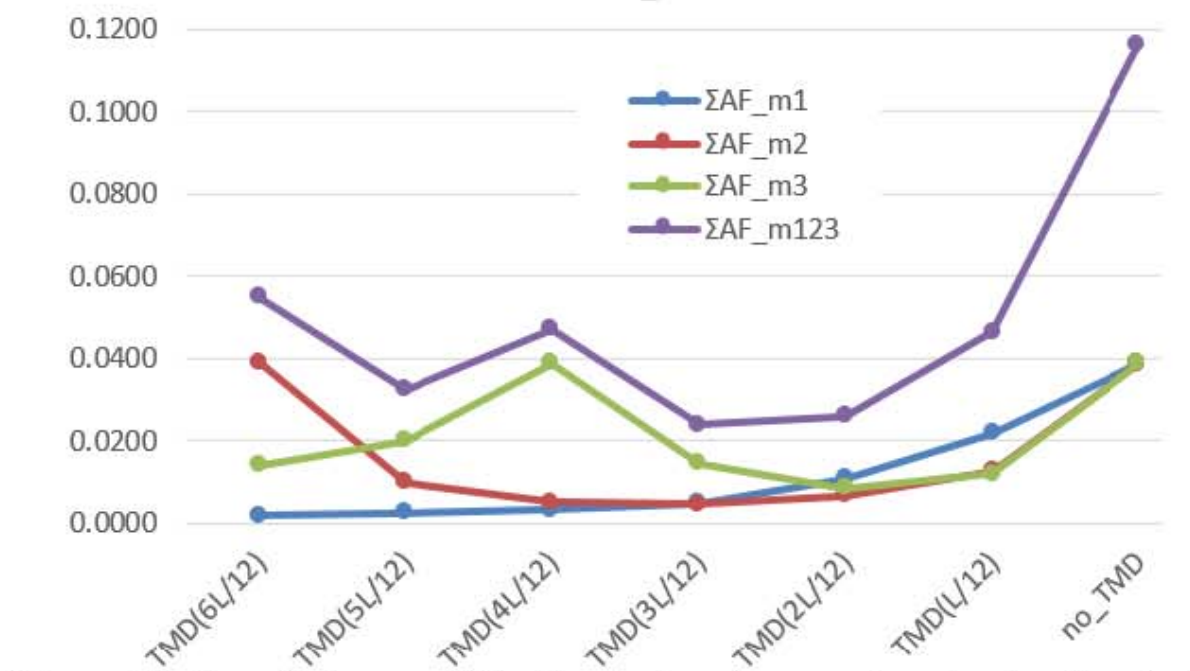

Figura 10. Cumulative amplification factors for crossing at $w 1, w 2$ and $w 3$

\subsection{TMD tuned at mode 2}

Now the problem is where to install a TMD tuned to mode 2 (TMDw2). When it is located at $3 \mathrm{~L} / 12$ (TMDw2_3L/12) and optimally tuned $(2.4818 \mathrm{~Hz}, \xi=0.10)$ the response in $3 \mathrm{~L} / 12$ is shown in figure 11

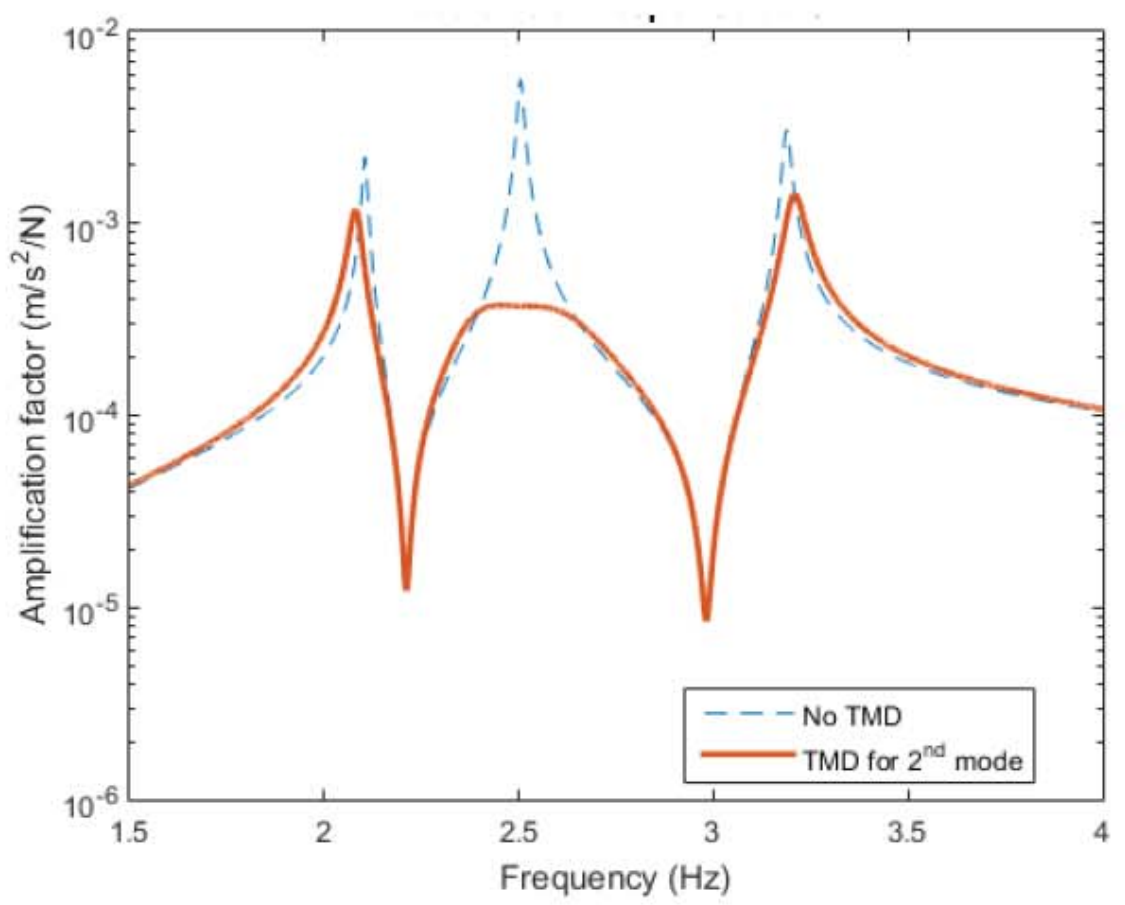

Figure 11. FRF(3L/12,TMDw2_3L/12)

For comparison reasons, figure 12 shows FRF(TMDw1_6L/12) and FRF(TMDw2_6L/12) (figure 12.a) and also FRF(TMDw1_3L/12) and FRF(TMDw2_3L/12) (figure 12.b)

Similar to the previous case, the amplification factors in point $3 \mathrm{~L} / 12$ are shown in figure 13. In this case, when the location of the TMDw2 is changed the results are shown in figure 14 revealing that if only crossings at w2 pace are considered, the best position is the logical one $(3 \mathrm{~L} / 12)$ but for a cumulative response it is better to locate the TMDw2 at $2 \mathrm{~L} / 12$ 


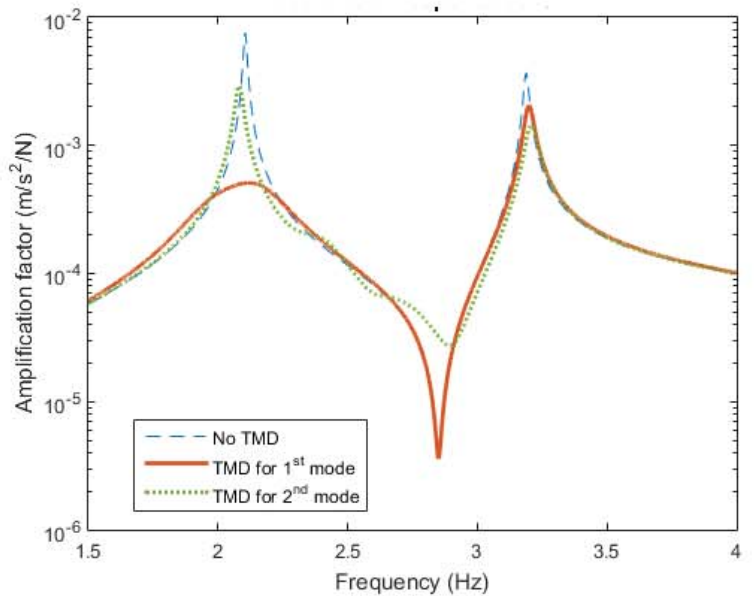

Figure 12.a. FRF(TMDw1_6L/12) and FRF(TMDw2_GL/12)

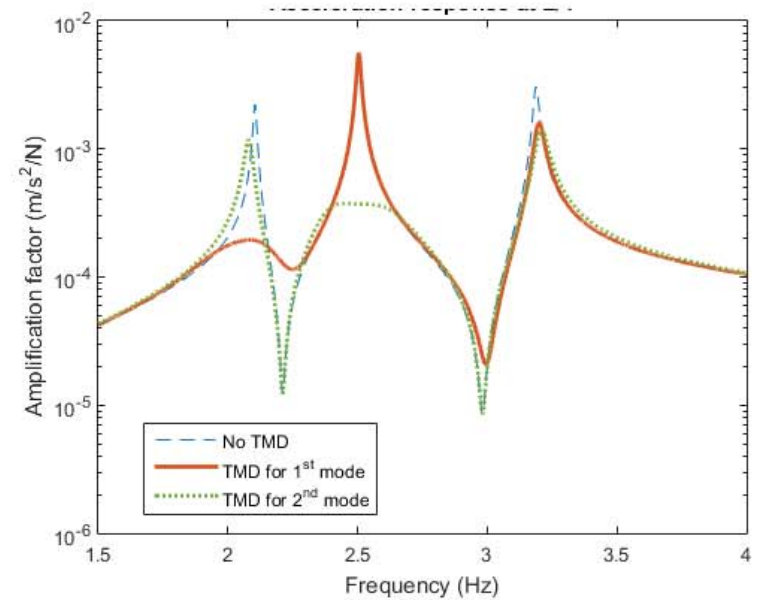

Figure 12.b. FRF(TMDw1 3L/12) and FRF (TMDw2 $3 L / 12)$

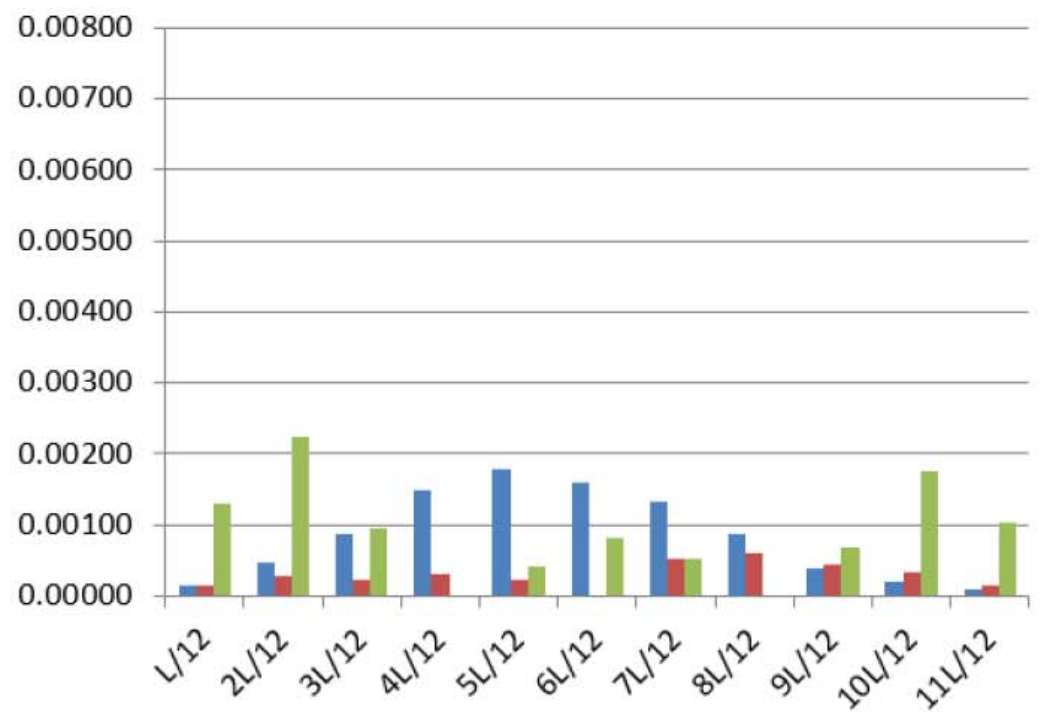

Figure 13. Amplification factors for TMDw2_ $3 L / 12$

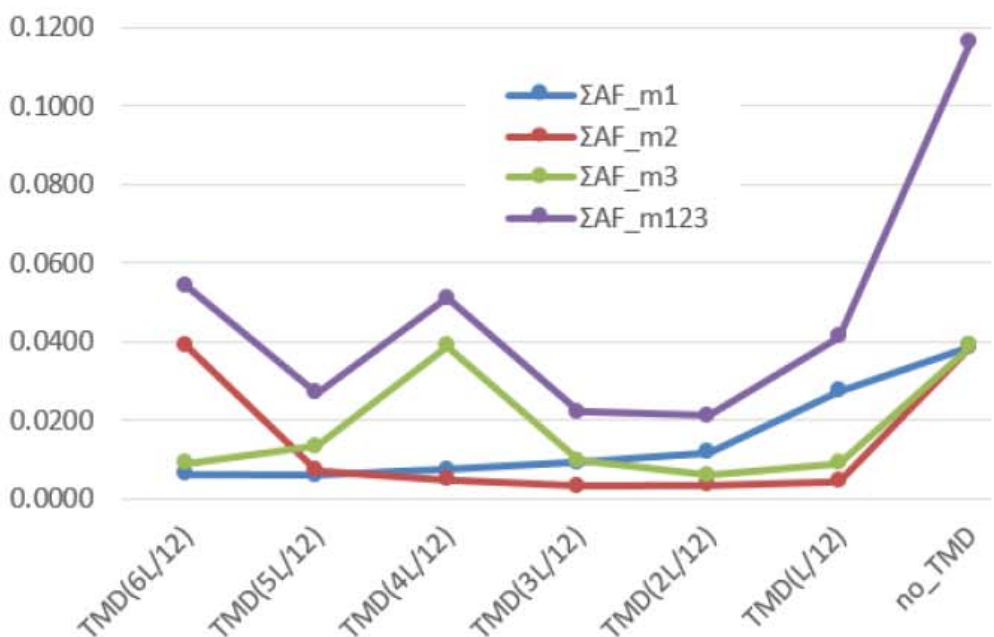

Figure 14 Cumulative amplification factors for crossing at $w 1, w 2$ and $w 3$ 


\subsection{Two TMDs, tuned at mode 1 and mode 2}

Another scenario, now with 2 TMDs, is considered. In this case, one TMDw1 with a moving mass of $500 \mathrm{~kg}$ is located at $6 \mathrm{~L} / 12$ and another one (TMDw2), same mass, located at $3 \mathrm{~L} / 12$. Both are optimally tuned $(2.073 \mathrm{~Hz}, \xi=0.10$ for TMDw1 and $2.496 \mathrm{~Hz}, \xi=0.08$ for TMDw2). Corresponding $\mathrm{FRF}(3 \mathrm{~L} / 12, \mathrm{TMDw} 1 / \mathrm{TMDW} 2)$ is shown in figure 15 and the corresponding amplification factors in figure 16. Cumulative amplification factors for crossings at $w 1, w 2$ and w3 are $0.00267,0.00382$ y 0.0140 , respectivelly, with an average value of 0.00682 .

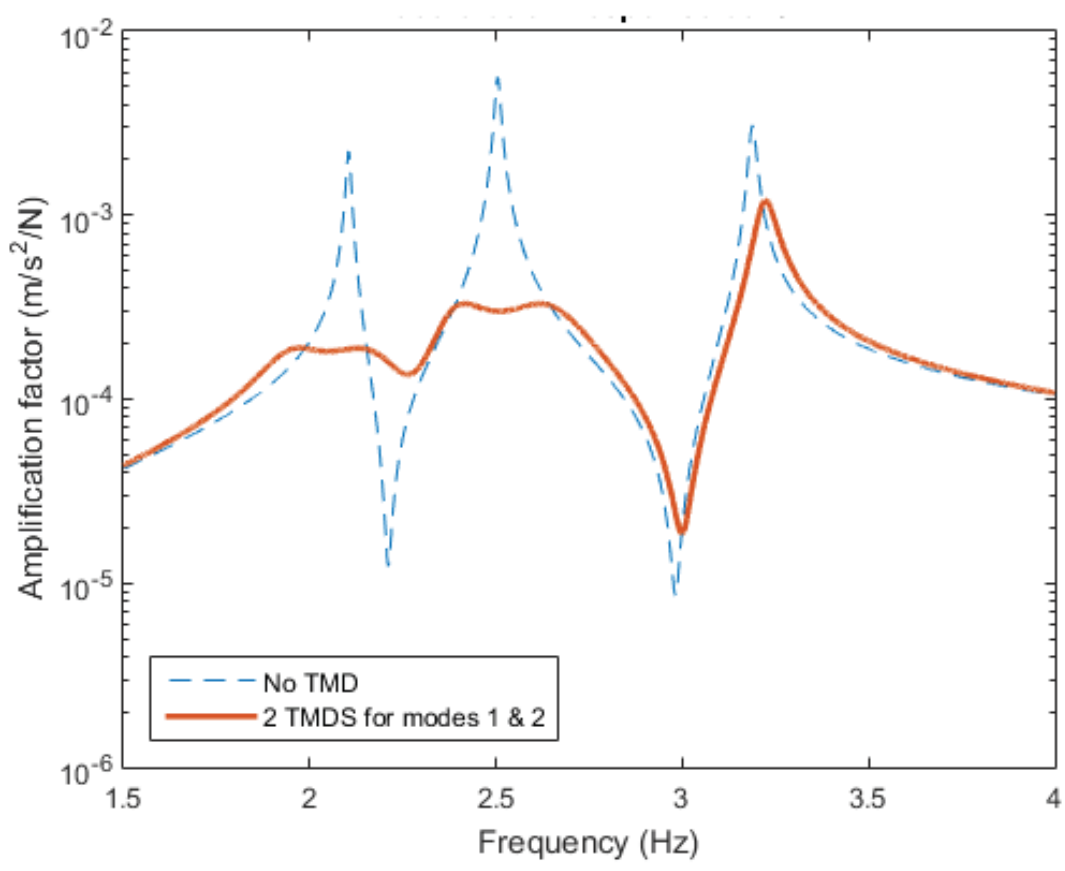

Figure 15. FRF (3L/12, TMDW1_6L/12/TMDW2_3L/12)

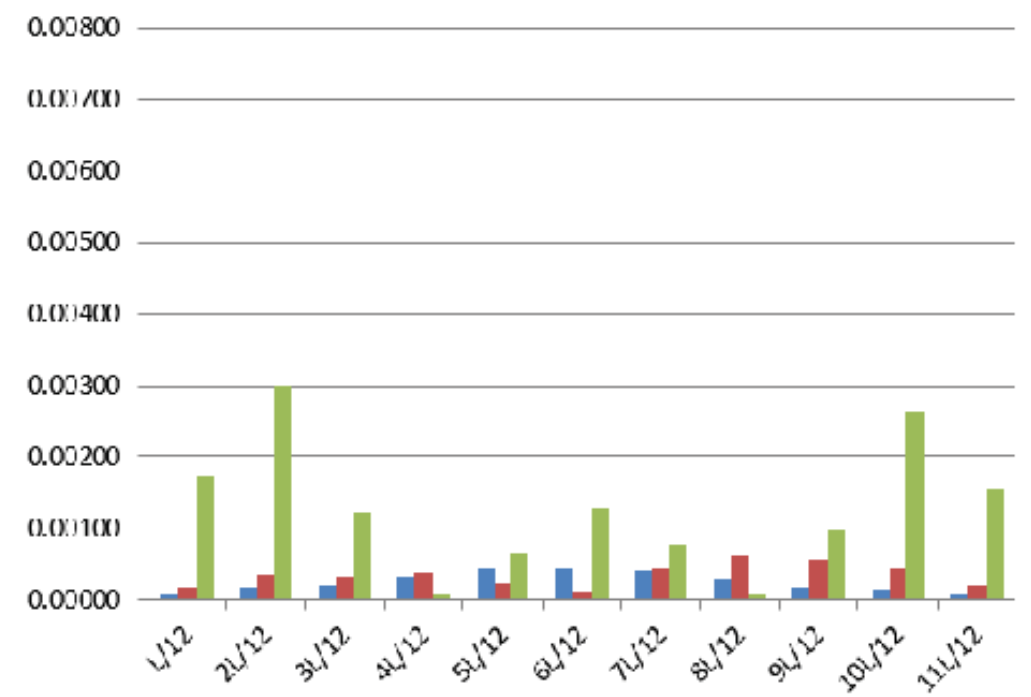

Figure 16. Amplification factors for TMDw1_6L/12/TMDw2_3L/12

Change the locations of these TMDs will be and interesting problem, as some reduction is expected. Nevertheless, for the discrete problem (only 11 possible locations) there are 55 events and a great computational effort should be paid in order to find the optimal location for TMDw1 and TMDw2 together. 


\section{CONCLUSIONS}

According to former sections, some conclusions can be drawn:

- If only crosssings at w1 pace are expected, the best TMD is TMDw1_6L/12 (lower point of the red line in figure 17. When it is located at $\mathrm{jL} / 12(\mathrm{j} \neq 6)$, the cummulative amplification factor is bigger although the TMD is optimally re-tuned. Good reductions are also expected when installing the TMD tuned to mode 2 (TMDw2, green line). Blue line is the cummulative amplification factor for the case TMDw1_6L/12 and TMDw2_3L/12, which is also a very good solution.

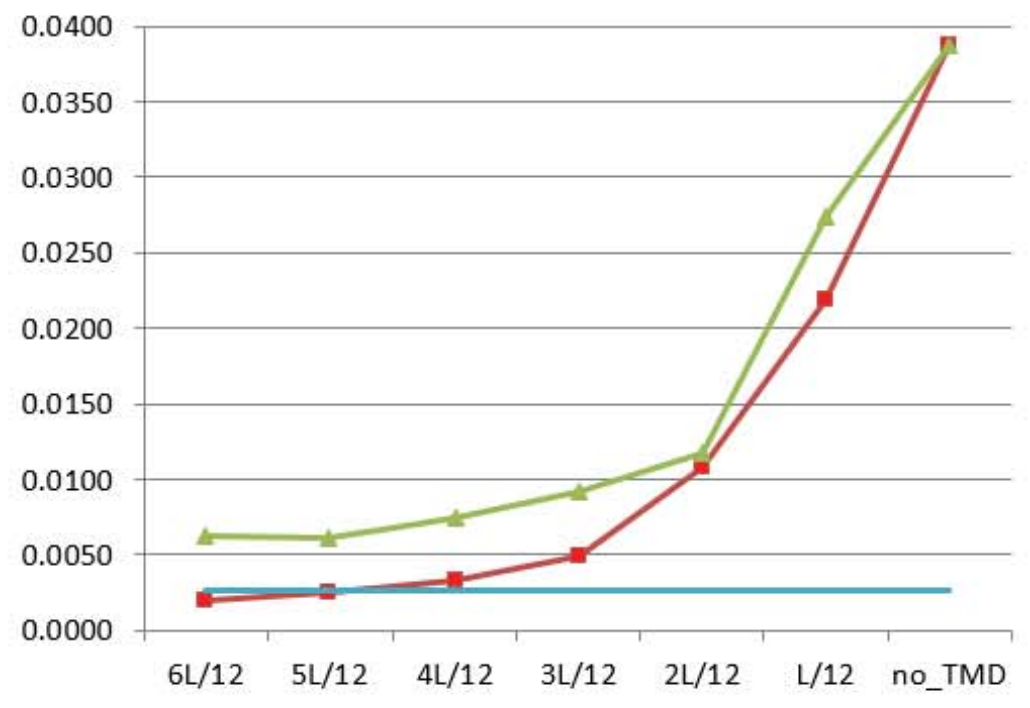

Figure 17. Walking at wl pace.

- When crossing at $\mathrm{w} 2$ pace the best response is obtained for TMDw2_3L/12 (green line in figure 18). It is also effective to instal TMDw1_3L/12 (red line). The solution with 2 TMDs is also a good one.

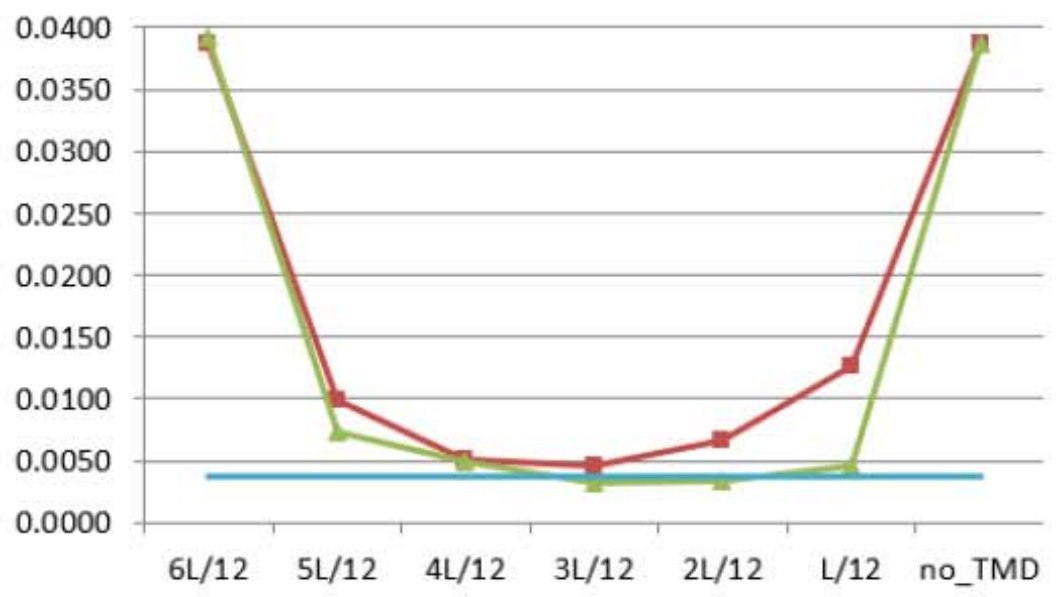

Figure 18. Walking at w2 pace.

- When crossing at w3 pace (figura 19), it is better to use TMDw2_2L/12 (green line) although it is also effective TMDw1_2L/12. The proposed solution with 2 TMDs is worst. 


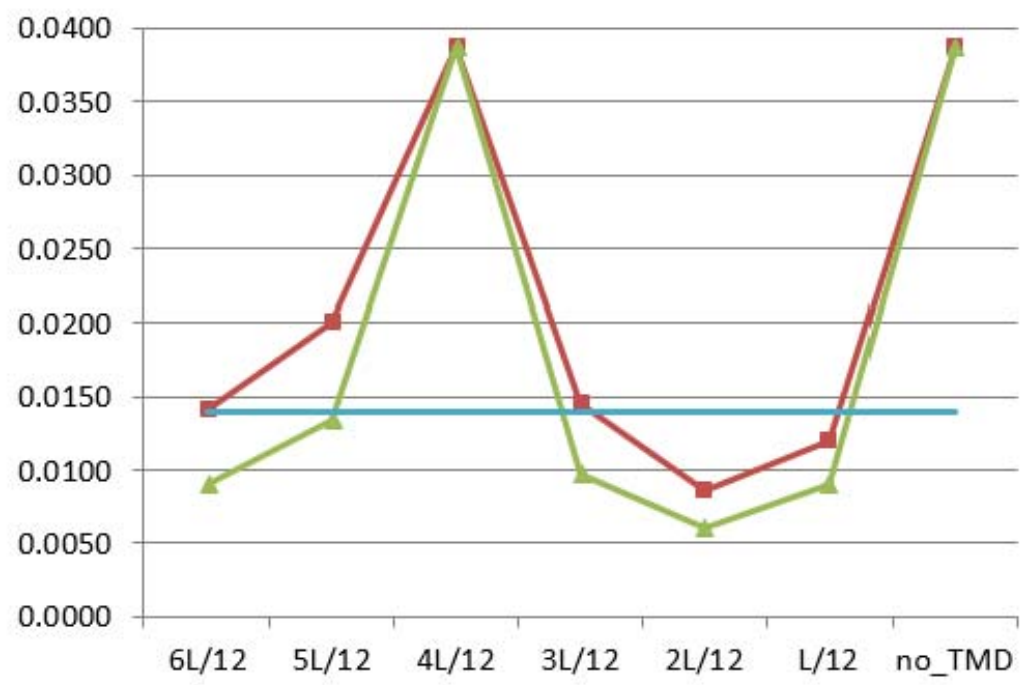

Figure 19. Walking at w3 pace.

- For evenly number of crossings at $\mathrm{w} 1, \mathrm{w} 2$ and $\mathrm{w} 3$ pace the best solution is to install TMDw2_2L/12 (figure 20, green line), with is equivalen to the solution with 2 TMDs (blue line)

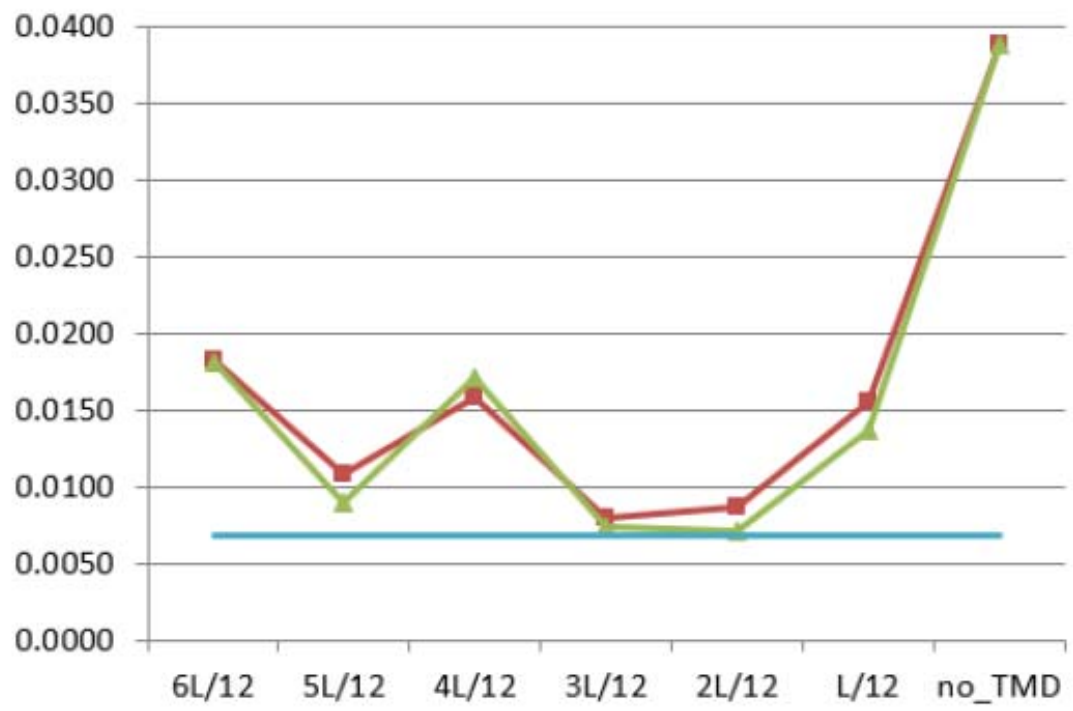

Figure 20. Average values (walking at $w 1, w 2$ and $w 3$ pace).

There are a lot of possibilities for a single TMD (other locations or TMDw3) and for two TMDs (TMDw1_TMDw2 for other locations than $6 \mathrm{~L} / 12$ and $3 \mathrm{~L} / 12$, or TMDw1_TMDw3, or TMDw2_TMDw3) or even for three TMDs (figure 21). The large number of alternatives leads to a optimization problem [11] to be studied in future coming studies. 


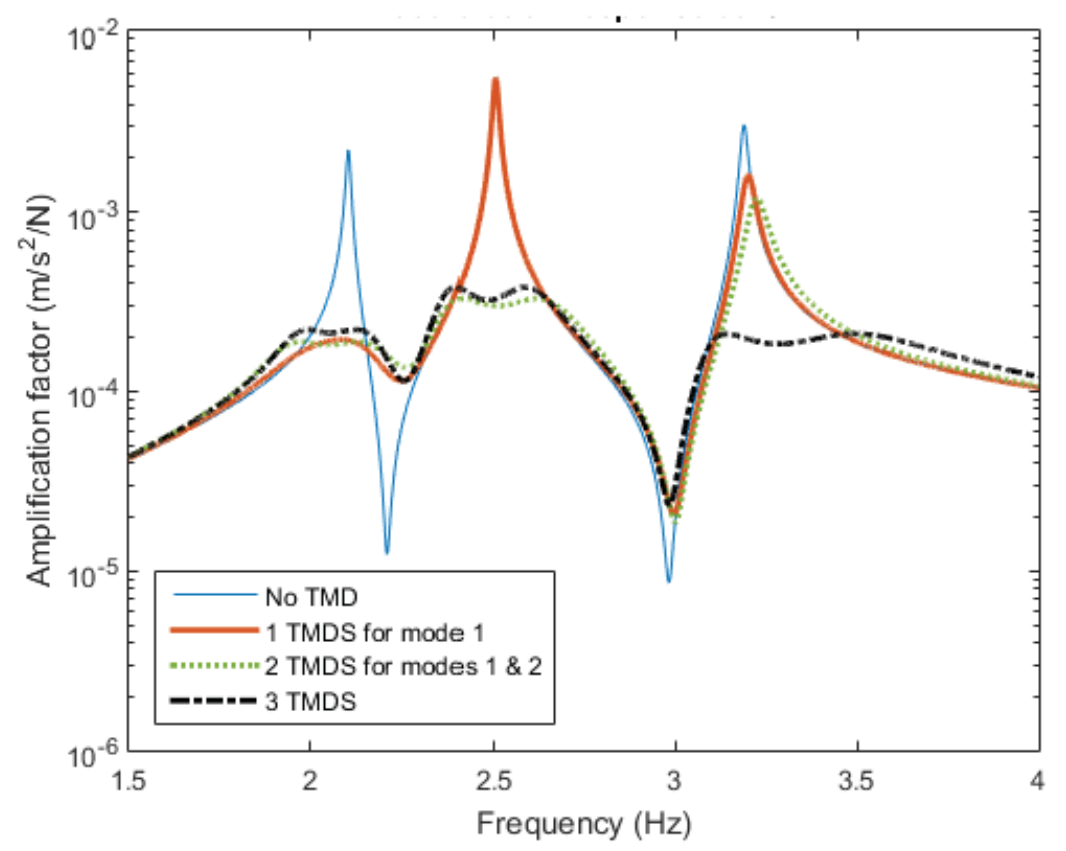

Figure 21: FRF(3L/12, TMDw1_6L/12\&TMDw2_3L/12\&TMDw4_2L/12)

\section{REFERENCES}

[1] Housner GW, Bergman, LA,Caughey TK, Chassiakos AG, Claus RO,Masri SF, Skelton RE, SoongTT, SpencerBF, Yao JTP. Structural control: Past, present, and future. Journal of Engineering Mechanics-ASCE $1997 ; 127: 887-971$

[2] Symans MD, Constantinou MC. Semi-active control systems for seismic protection of structures: a state-of-theart review. Engineering Structures 1999;21:469-487.

[3] Den Hartog J P. Mechanical Vibrations, 4th edition, McGraw-Hill, New York, 1956.

[4] Abé M, Igusa T. Tuned Mass Dampers for structures with closely spaced natural frequencies. Earthquake Enginnering and Structural Dynamics 1995; 24: 247-261.

[5] Zarate B. A., Caicedo J. M. "Finite element model updating: multiple alternatives," Engineering Structures, vol. 30 , no. 12 , pp. 3724-3730, 2008.

[6] Li W.M., Hong J.Z., "New iter ative method for model updating based on model reduction," Mechanical Systems and Signal Processing, vol. 25, no. 1, pp. 180-192, 2011.

[7] Mottershead J. E., Friswell M. I., "Model updating in structural dynamics: a survey," Journal of Sound and Vibration, vol. 167, no. 2, pp. 347-375, 1993.

[8] Ribeiro, D., Cal çada, R., Delgado, R., Brehm, M., Zabel, V., Finite el ement model updating of a bowstring-arch railway bridge based on experimental modal parameters, Engineering Structures, 40 (2012) 413-435.

[9] Zivanovic, S., Pavic, A. and Reynol ds, P. (2007), "Finite element modelling and updating of a lively footbridge: the complete process", J. Sound Vib., 301, 126-145

[10] Chulvi M., Henche J., Pasarela sobre la vía de cintura MA-20 en Palma de Mallorca, V Congreso nacional de ACHE, Asociación científico-técrica del hormigón estructural, Barcelona 2011

[11] Kim G.H., Park Y.S., An improved updating parameter selection method and finite element model update using multiobjective optimisation technique, Mechanical Systems and Signal Processing 18 (1) (2004) 59-78

\section{ACKNOWLEDGEMENT}

The authors wish to acknowledge to the partial support through Research Projects BLA201128493 and BLA2014-59321 ("Ministerio de Economía y Competitividad", Spanish Government). 
OPTIMAL DESIGN AND PRACTICAL IMPLEMENTATION OF EDDY-CURRENT TUNED MASS DAMPERS WITH PERMANENT MAGNETS FOR MULTI-STOREY BUILDINGS

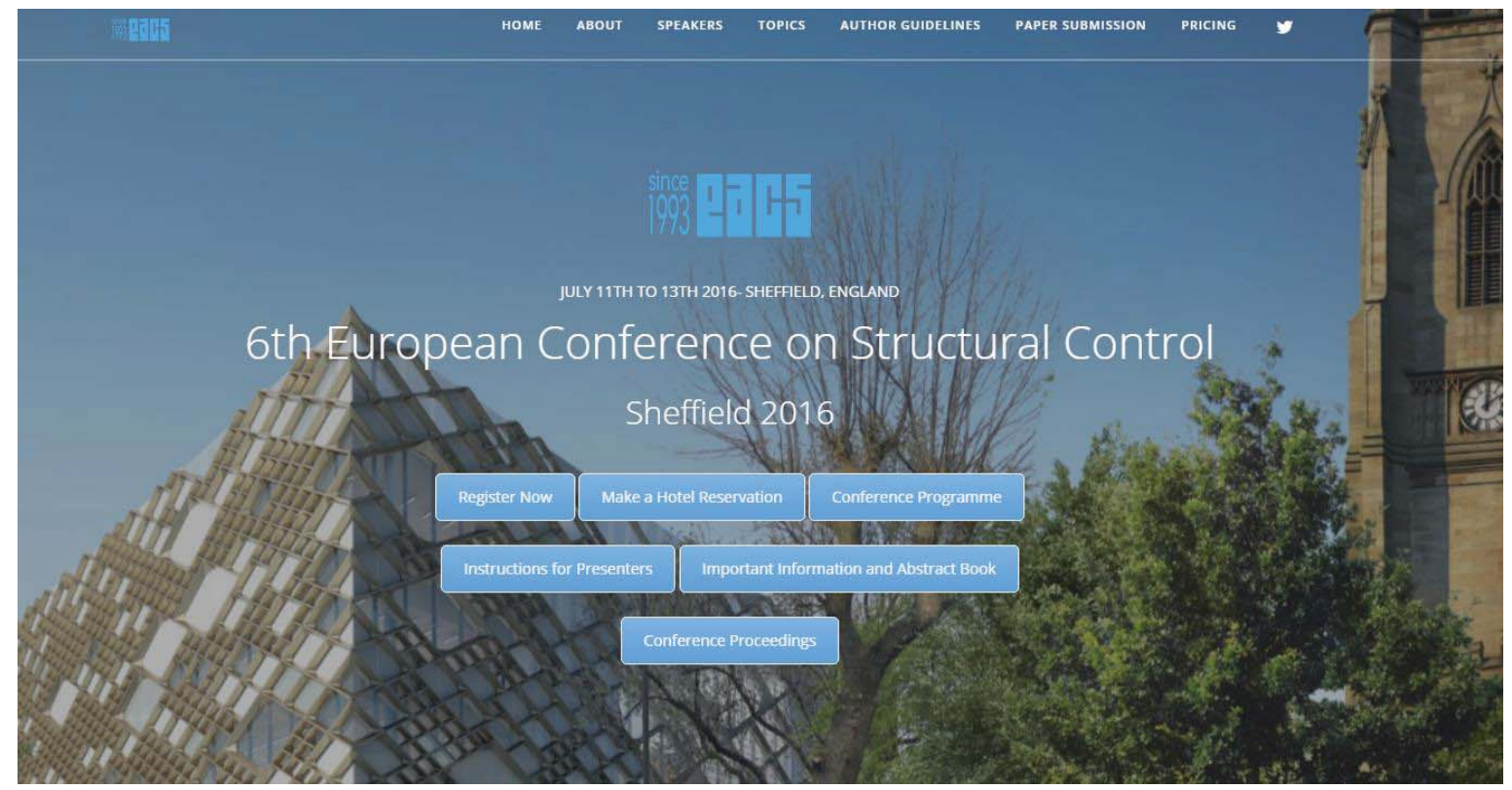

Álvaro Magdaleno Gonález; Emiliano Pereira González; Javier Castaño Lerma; Norberto Ibán Lorenzana;Iván Muñoz Díaz; Antolín Lorenzana Ibán.

\begin{tabular}{c|c|c|c|} 
Aportaciones: & Experimentación & Procesado & Edición \\
\hline & Prototipado & Matlab & Tablas \\
Instrumentación & & Gráficas \\
Registros & & \\
\cline { 2 - 4 }
\end{tabular}




\title{
OPTIMAL DESIGN AND PRACTICAL IMPLEMENTATION OF EDDY-CURRENT TUNED MASS DAMPERS WITH PERMANENT MAGNETS FOR MULTI-STOREY BUILDINGS
}

\author{
Álvaro Magdaleno ${ }^{1}$, Emiliano Pereira ${ }^{2}$, Javier Castaño ${ }^{3}$, Norberto Ibán ${ }^{3}$, Iván M. Díaz ${ }^{4}$ \& Antolín \\ Lorenzana, ${ }^{1}$ \\ ${ }^{1}$ ITAP, EII, Universidad de Valladolid, 47011, Valladolid, Spain \\ ${ }^{2}$ EPS, Universidad de Alcalá, 28805, Alcalá de Henares (Madrid), Spain \\ ${ }^{3}$ Centro Tecnológico CARTIF, 47151, Boecillo (Valladolid), Spain \\ ${ }^{4}$ ETSICCP, Universidad Politécnica de Madrid, 28040, Madrid, Spain \\ Corresponding author: Emiliano.Pereira@uah.es
}

\begin{abstract}
This work proposes an implementation example of two tuned mass dampers (TDM) on a reduced scale two storey building. The TMD, in which the damping is magnetically adjusted without contact, is a laboratory prototype built in CARTIF (Spain). This TMD consists on a one degree of freedom system formed by a permanent magnet (mass) fixed to a flexible link (elasticity) and an aluminium plate at an adjustable distance to the magnet (damping). The tuning of the TMDs is carried out by considering the passive system as a feedback controller. The system identification and the experimental results show the validity of theoretical approximations and the design criterions.
\end{abstract}

KEYWORDS: Structural control, Passive vibration control, Tuned mass damper, Optimization.

\section{INTRODUCTION}

Structures subjected to excitations like earthquake ground motions, human induced vibrations or machinery may produce structural damages (or even collapse) and serviceability limit state problems. Passive, semi-active and active vibration controls have been proposed as possible solutions to reduce the vibration level at civil structures such as bridges, multi-storey buildings or slender floor structures, among others [1].

Tuned Mass Dampers (TMD), which can be used for passive and semi-active control strategies, improves the vibration response of a structure by increasing its damping (i.e. energy dissipation) and/or stiffness (i.e. energy storage) through the application of forces generated in response to the movement of the structure [2]. Recently, different TMD implementations have been proposed in order to improve the tuning of mechanical parameters. For example, magnetic TMDs have been used due to its linear behaviour and since its damping coefficient can be easily and finely calibrated [3,4]. A pendulum with an adjustable length is used to tune the resonance of a Smart TMD in [5], which is used for a semiactive control strategy. Other example is found at [6], where a TMD based on shape memory alloys and eddy currents is utilized for implementing two adaptive control strategies. In the case of structures with spatially distributed and closely spaced natural frequencies, the TMD design may not be obvious because Den Hartog's theory [7] may not be applied due to the existence of a coupling between the motions of the 
vibration modes of the structures and the used TMD's [8]. Multi storey buildings are good examples of structures with spatially distributed and closely spaced natural frequencies. For example, Greco et al. [9] propose a robust optimum design of tuned mass dampers installed on multi-degree-of-freedom systems subjected to stochastic seismic actions. The robust design is formulated as a multi-objective optimization problem, in which both the mean and the standard deviation of the performance index are simultaneously minimized. Other similar examples can be found at [10] and [11]; however, simulation results are only presented in aforementioned references.

In this work, a system composed of two magnetic TDM devices based on a cantilever beam are implemented in a reduced scale two floor building [12]. The tuning of the TMD parameters is carried out by considering this passive vibration control (PVC) from the active vibration (AVC) control point of view (see reference [13]). This simplifies the design of this PVC because the coupling between the two main vibration modes is not a problem (as in Den Hartog's theory). In addition, this work designs and implements a magnetic TDM tuning based on minimizing the $H_{\infty}$ norm of the frequency response function (FRF) between the acceleration of the second floor and the acceleration of the ground. Simulation and experimental results are obtained to show: i) the advantages of a magnetic TMD which can be easy tuned after an experimental identification, ii) the validation of the model approximations for magnetic TMDs and iii) the design of TMDs can be carried out from and AVC point of view, which is an advantage compared with Den Hartog's theory for structures with natural frequencies spatially distributed and closely spaced.

\section{MODELING AND EXPERIMENTAL IDENTIFICATION}

The generalized framework to design robust TMD proposed in [13] is considered in this work. This framework is simplified and particularized to a two storey building, which makes the explanation easier to follow than [13] for this particular application.

The model of the magnetic TMD's is considered as [3], i.e. drag forces provided by magnetic dampers are assumed to be proportional to velocity. This assumption is demonstrated with experimental identification of the linear and time invariant model.

Fig. 1 right shows the magnetic TMD prototypes used in this work. Note that these TMD's can be fixed to the two storey building with the structure (4). The magnetic TMD is tuned as follows: i) the rigidity is changed by the link (1), ii) the mass is varied by adding standard hex nuts to the magnet (2) and iii) damping is configured by moving the plate (3) with respect to the magnet (2).

\subsection{Two storey building}

The two storey building can be modelled as a two degree of freedom system (see Fig. (2) 1eft), where the mass is concentrated at each floor $\left(m_{1}\right.$ and $\left.m_{2}\right), k_{1}$ and $c_{1}$ are, respectively, the first floor stiffness and damping coefficient (relative to the ground) and $k_{2}$ and $c_{2}$ are, respectively, the second floor linear stiffness and damping coefficient (relative to the first floor). 

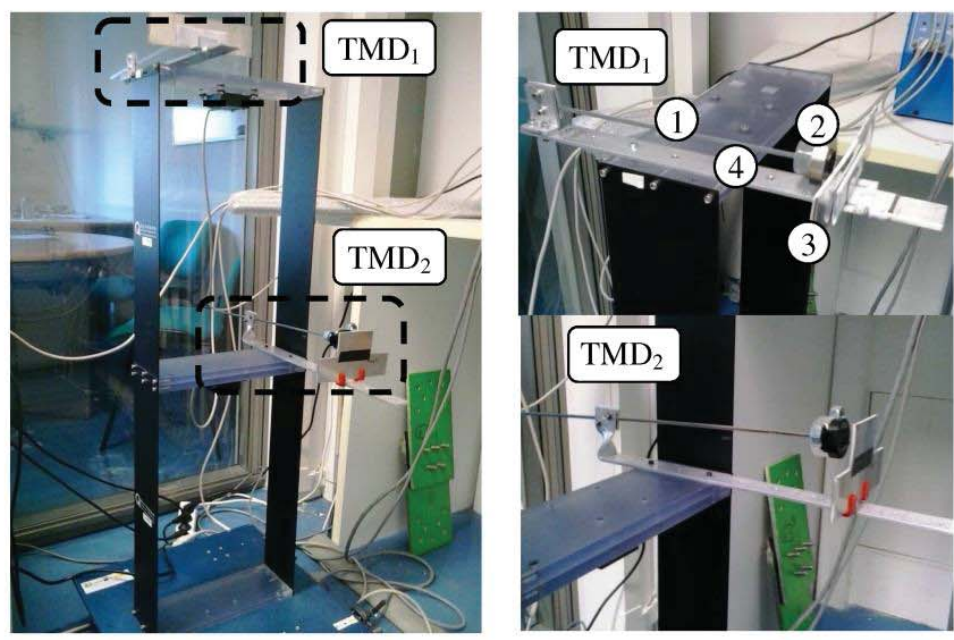

Figure 1: Two storey building (left) and details for the magnetic TMDs (right).
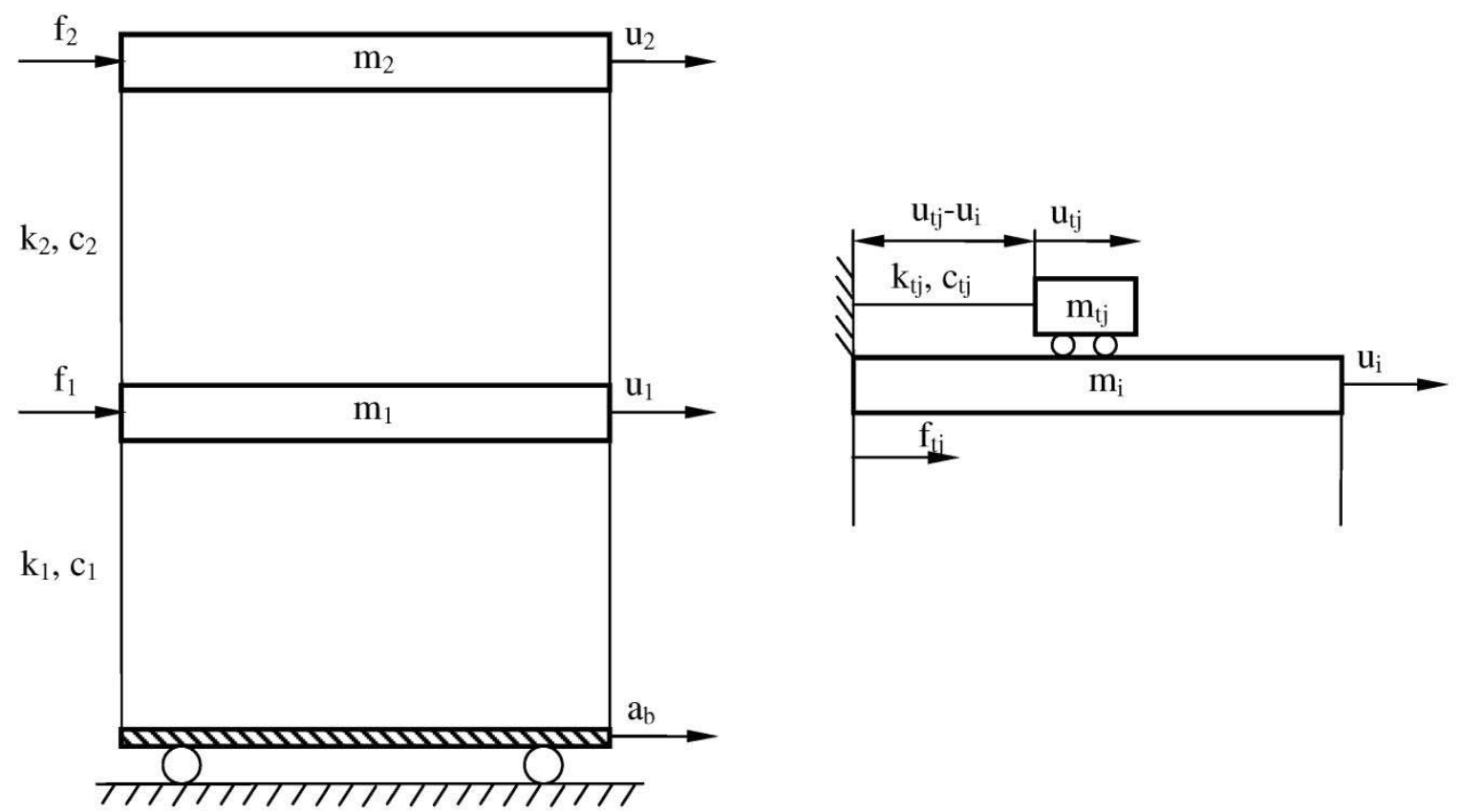

Figure 2: Two storey building (left) and TMD (right) models. 
If the applied forces in each floor $\left(f_{1}\right.$ and $\left.f_{2}\right)$ and the acceleration of the base $\left(a_{b}\right)$ are considered as inputs, the differential equation of the building can be represented as follows:

$$
\mathbf{M u ̈}+\mathbf{C u}+\mathbf{K u}=-\mathbf{M}\left[\begin{array}{c}
a_{b} \\
a_{b}
\end{array}\right]+\mathbf{f},
$$

where

$$
\mathbf{M}=\left[\begin{array}{cc}
m_{1} & 0 \\
0 & m_{2}
\end{array}\right], \mathbf{C}=\left[\begin{array}{cc}
c_{1}+c_{2} & -c_{2} \\
-c_{2} & c_{2}
\end{array}\right], \mathbf{K}=\left[\begin{array}{cc}
k_{1}+k_{2} & -k_{2} \\
-k_{2} & k_{2}
\end{array}\right], \mathbf{u}=\left[\begin{array}{l}
u_{1} \\
u_{2}
\end{array}\right], \mathbf{f}=\left[\begin{array}{l}
f_{1} \\
f_{2}
\end{array}\right],
$$

This model considers nodal coordinates or real displacements. This system can be represented in modal coordinates by obtaining the eigenvectors (mode shapes) and eigenvalues (natural frequencies):

$$
\left(-\omega_{i}^{2} \mathbf{M}+\mathbf{K}\right) \phi_{i}=0
$$

where the eigenvectors can be grouped in the following matrix:

$$
\Phi=\left[\begin{array}{ll}
\phi_{1} & \phi_{2}
\end{array}\right]=\left[\begin{array}{ll}
\phi_{11} & \phi_{21} \\
\phi_{12} & \phi_{22}
\end{array}\right],
$$

where $\phi_{i} j$ is the $j^{\text {th }}$ component of the $t^{\text {th }}$ mode shape. The relationship between nodal and modal coordinates is $\boldsymbol{u}=\boldsymbol{\Phi} \eta$. Then, after having pre-multiplied by $\Phi^{T}$ in order to uncouple the equation system, Eq. (1) in modal coordinates is

$$
\boldsymbol{\Phi}^{T} \mathbf{M} \boldsymbol{\Phi} \ddot{\eta}+\boldsymbol{\Phi}^{T} \mathbf{C} \boldsymbol{\Phi} \dot{\eta}+\boldsymbol{\Phi}^{T} \mathbf{K} \boldsymbol{\Phi} \eta=-\boldsymbol{\Phi}^{T} \mathbf{M}\left[\begin{array}{l}
a_{b} \\
a_{b}
\end{array}\right]+\boldsymbol{\Phi}^{T} \mathbf{f},
$$

The state space state model can be deduced from Eq. (5) by taking, as the state-space variables, the modal coordinates $(\eta)$ and their first derivatives $(\dot{\eta})$. Thus, if $\Phi^{T} \mathbf{M} \Phi=\tilde{\mathbf{M}}, \Phi^{T} \mathbf{C} \Phi=\tilde{\mathbf{C}}$ and $\Phi^{T} \mathbf{K} \Phi=\tilde{\mathbf{K}}$, the linear differential equation of the state space vector is

$$
\left[\begin{array}{l}
\dot{\boldsymbol{\eta}} \\
\ddot{\boldsymbol{\eta}}
\end{array}\right]=\left[\begin{array}{cc}
\mathbf{0}_{2,2} & \boldsymbol{I}_{2} \\
-\tilde{\mathbf{M}}^{-1} \tilde{\mathbf{K}} & -\tilde{\mathbf{M}}^{-1} \tilde{\mathbf{C}}
\end{array}\right]\left[\begin{array}{l}
\boldsymbol{\eta} \\
\dot{\eta}
\end{array}\right]-\left[\begin{array}{c}
\mathbf{0}_{2,2} \\
\tilde{\mathbf{M}}^{-1} \boldsymbol{\Phi}^{T} \mathbf{M}
\end{array}\right]\left[\begin{array}{l}
a_{b} \\
a_{b}
\end{array}\right]+\left[\begin{array}{c}
\mathbf{0}_{2,2} \\
\tilde{\mathbf{M}}^{-1} \boldsymbol{\Phi}^{T}
\end{array}\right] \mathbf{f},
$$

and the output equation is

$$
\left[\begin{array}{l}
\mathbf{y}_{1} \\
\mathbf{y}_{2}
\end{array}\right]=\left[\begin{array}{l}
\ddot{\mathbf{u}}_{1} \\
\ddot{\mathbf{u}}_{2}
\end{array}\right]+\left[\begin{array}{l}
a_{b} \\
a_{b}
\end{array}\right]=\left[\begin{array}{ll}
-\boldsymbol{\Phi} \tilde{\mathbf{M}}^{-1} \tilde{\mathbf{K}} & -\boldsymbol{\Phi} \tilde{\mathbf{M}}^{-1} \tilde{\mathbf{C}}
\end{array}\right]\left[\begin{array}{l}
\dot{\eta} \\
\ddot{\eta}
\end{array}\right]+\boldsymbol{\Phi} \tilde{\mathbf{M}}^{-1} \boldsymbol{\Phi}^{T} \mathbf{f}
$$

where $\boldsymbol{\Phi} \tilde{\mathbf{M}}^{-1} \Phi^{T} \mathbf{M}=\mathbf{I}_{2}$ and

$$
\tilde{\mathbf{M}}^{-1}=\mathbf{I}_{2}, \tilde{\mathbf{K}}=\left[\begin{array}{cc}
\omega_{1}^{2} & 0 \\
0 & \omega_{2}^{2}
\end{array}\right], \tilde{\mathbf{C}}=\left[\begin{array}{cc}
2 \xi_{1} \omega_{1} & 0 \\
0 & 2 \xi_{2} \omega_{2}
\end{array}\right] \text {. }
$$

Note that $y_{1}$ and $y_{2}$ are accelerations that can be measured with accelerometers mounted at first and second floor, respectively.

Once the system model is established, the following step is the experimental identification. A chirp signal between $0.5 \mathrm{~Hz}$ and $15 \mathrm{~Hz}$ with a duration of 300 seconds was applied to the base of the structure $\left(a_{b}\right)$. The FRF of the system, where $H_{2}$ mode is considered, and the FRF of the model adjusted by minimizing the means square error is shown at Figs. (3) and (4). 


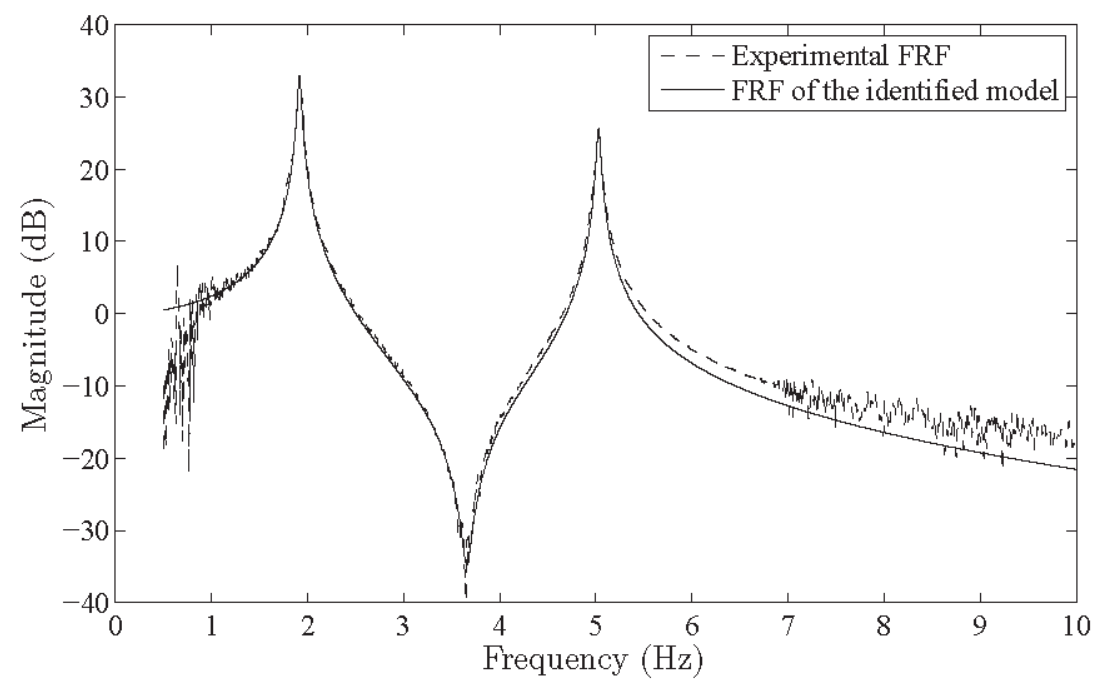

Figure 3: Structure identification example (first floor).

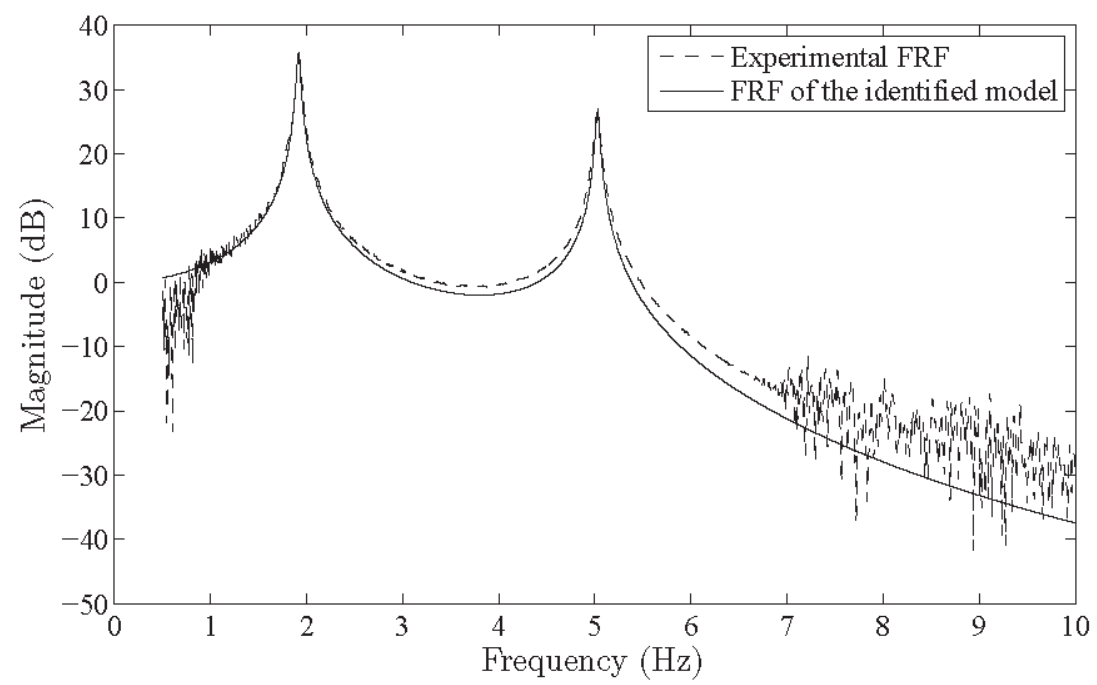

Figure 4: Structure identification example (second floor). 


\subsection{Magnetically damped TMD}

The TMD can be modelled as a one degree of freedom system (see Fig. (2) right), where $m_{t j}$ is the mass, $k_{t j}$ and $c_{t j}$ are the TMD linear stiffness and damping coefficient of the $j^{t h}$ TMD relative to the $i^{t h}$ floor.

If the accelerations of the base $\left(a_{b}\right)$ and $i^{\text {th }}$ floor are considered as inputs, the differential equation of the TMD can be represented as follows:

$$
m_{t, j} \ddot{u}_{t j}+c_{t, j} \dot{u}_{t, j}+k_{t, j} u_{t, j}-c_{t, j} u_{i}-k_{t, j} u_{i}=-m_{t, j} a_{b} .
$$

The force applied by the TMD to the $i^{\text {th }}$ floor is:

$$
f_{t, j}=k_{t, j}\left(u_{t, j}-u_{i}\right)+c_{t, j}\left(i_{t, j}-u_{i}\right)=k_{t, j} u_{r, i j}+c_{t, j} \dot{u}_{r, i j}
$$

If the relative displacement between $f^{\text {th }} \mathrm{TMD}$ and $i^{\text {th }}$ floor is defined as $u_{r, i j}=u_{t, j}-u_{i}$, the transfer function between the acceleration measured by an accelerometer placed at $i^{\text {th }}$ floor (denoted above as $y_{i}$ ) and $u_{r, i j}$ from Eq. (9) is as follows:

$$
U_{r, i j}(s)=-\frac{m_{t, j}}{m_{t, j} s^{2}+c_{t, j} s+k_{t, j}} Y_{i}(s) .
$$

Therefore, from Eqs. (10) and (11) can be deduced the following transfer function of the TMD

$$
F_{t, j}(s)=-\frac{m_{t, j}\left(c_{t, j} s+k_{t, j}\right)}{m_{t, j} s^{2}+c_{t, j} s+k_{t, j}} Y_{i}(s)=m_{t, j} \frac{2 \xi_{t, j} \omega_{t, j} s+\omega_{t, j}^{2}}{s^{2}+2 \xi_{t, j} \omega_{t, j} s+\omega_{t, j}^{2}} Y_{i}(s),
$$

where $\omega_{t, j}$ and $\xi_{t, j}$ are, respectively, the natural frequency and damping ratio of the $f^{t h}$ TMD as an isolated system.

The linear time invariant (LTI) model defined in Eq. (12) is identified by obtaining the initial conditions and the values of $\omega_{t, j}$ and $\xi_{t, j}$ that minimizing the least square error of an impact response. An example of the input signal considered in the system identification is shown at Fig. 5. Note that only the interval from 0.5 to 1.2 seconds is used for the system identification. It can be also observed from Fig. 5 that the model identification is pretty good and the hypothesis of LTI model for the magnetic TMD can be considered.

A set of system identifications was carried out to know the relationship between the damping ratio and distance between the magnet and the moving plate. Table 1 shows the identification of the magnetic TMD shown at Fig. 1, denoted as $1^{\text {st }}$ TMD.

\section{GENERAL CONTROL STRATEGY}

The state space model of the two storey building defined at Eqs. (6) and (7) and the transfer function of the magnetically damped TMD defined at Eq. (12) can be joint in a closed control loop (see Fig. 6). Note that the output force of each TMD is one of the inputs of the building. In addition, the input of each TMD is the output measured with one accelerometer placed at each floor. 


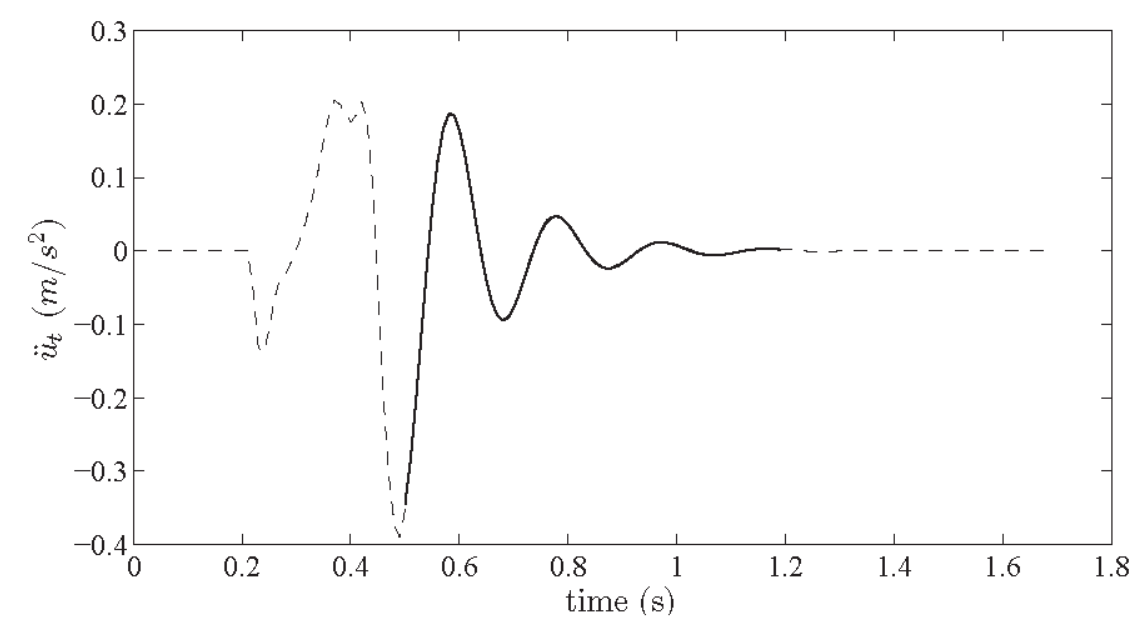

Figure 5: TMD identification example. (--) time response of the TMD when an impact is applied to the tip mass. (-) Output of the system model when the identified initial conditions are considered.

The general control scheme of Fig. (6) also includes the acceleration of the base ( $\left.a_{b}\right)$ and the parameters $\alpha_{11}, \alpha_{12}, \alpha_{21}$ and $\alpha_{22}$. This parameters allow us to place the $f^{\text {th }}$ TMD on $i^{\text {th }}$ floor $\left(\alpha_{i j}=1\right)$. That is, if the configuration is $\mathrm{TMD}_{1}$ at second floor and $\mathrm{TMD}_{2}$ at first floor, the values are $\alpha_{11}=0, \alpha_{12}=1$, $\alpha_{21}=1$ and $\alpha_{22}=0$. Note that any TMD cannot be placed in both floors at the same time. Therefore, the variables $\alpha_{i j}$ are treated as boolean variables satisfying the constraints $\alpha_{11}+\alpha_{21}=1$ and $\alpha_{12}+\alpha_{22}=1$, which are defined in the optimal control designs.

\section{OPTIMAL CONTROL DESIGN METHODOLOGY}

The optimal control design methodology consists on considering the TMDs as a closed loop control problem (like in [13]). In this work, two design criteria are considered. The first one finds the value of the vector $\mathbf{V}=\left[\alpha_{11}, \alpha_{12}, \alpha_{21}, \alpha_{22}, \omega_{t, 1}, \omega_{t, 2}, \xi_{t, 1}, \xi_{t, 2}\right]$ that minimizes the acceleration of one floor (i.e., minimize the value of $H_{\infty}$ norm of the FRF between $y_{i}$ and $a_{b}$ ). The second one finds the optimal value of $\mathrm{V}$ that minimizes the maximum of the mode shapes of one vibration mode (i.e., the maximum value of $\phi_{i}$ ).

The minimization is carried out by using the built-in function fminsearch of MATLAB. The file containing the objective function considers the four possible combinations of $\alpha_{i j}$ to find the optimal values of $\left[\omega_{t, 1}, \omega_{t, 2}, \xi_{t, 1}, \xi_{t, 2}\right]$ which minimize, as mentioned, the $H_{\infty}$ norm or the maximum value of $\phi_{i}$. In addition, the values of $m_{t, 1}$ and $m_{t, 2}$ are defined because the part (2) of each TMD (see Fig. 1 right) is fixed. In addition, the value of the objective variable is penalized when $\left[\omega_{t, 1}, \omega_{t, 2}, \xi_{t, 1}, \xi_{t, 2}\right]$ cannot be implemented in practice (i.e., maximum values for $\xi_{t, 1}, \xi_{t, 2}$ and non negative values for $\omega_{t, 1}, \omega_{t, 2}, \xi_{t, 1}$ and $\left.\xi_{t, 2}\right)$. 


\begin{tabular}{|l|l|l|l|}
\hline$\omega_{t}(\mathrm{rad} / \mathrm{s})$ & $\xi_{t}$ & $i_{t}(0)(\mathrm{m} / \mathrm{s})$ & $u_{t}(0)(\mathrm{m})$ \\
\hline 11.2586 & 0.0406 & 0.0005 & -0.0041 \\
\hline 11.2548 & 0.0457 & 0.0042 & -0.0045 \\
\hline 11.2793 & 0.0566 & 0.0040 & 0.0330 \\
\hline 11.2670 & 0.0672 & -0.0374 & 0.0031 \\
\hline 11.2727 & 0.0811 & -0.0400 & 0.0340 \\
\hline 11.2697 & 0.0981 & -0.0312 & 0.0035 \\
\hline 11.2937 & 0.1221 & -0.0423 & 0.0035 \\
\hline 11.2953 & 0.1538 & -0.0348 & 0.0031 \\
\hline 11.4047 & 0.2320 & -0.0278 & 0.0046 \\
\hline 11.5069 & 0.3143 & -0.0273 & 0.0043 \\
\hline 11.3660 & 0.5147 & -0.0304 & 0.0047 \\
\hline
\end{tabular}

Table 1: System identification of the device $\mathrm{TMD}_{1}$ shown at Fig. 1.

\section{SIMULATION AND EXPERIMENTAL RESULTS}

This section show an example of the design explained in Section 4 . The values of $m_{t, 1}$ and $m_{t, 2}$ are fixed in $0.107 \mathrm{~kg}$ and $0.072 \mathrm{~kg}$ respectively. In addition, the model defined in Eqs. (6) and (7) is updated for the four possible configurations of $\alpha_{11}, \alpha_{12}, \alpha_{21}$ and $\alpha_{22}$ to include the weight of the frame (part (4)) of each TMD. The algorithm can offer several "good configurations" depending on the success of the fminsearch function.

When minimizing the $H_{\infty}$ norm of the FRF between the acceleration of the second floor $\left(y_{2}\right)$ and the acceleration of the ground $\left(a_{b}\right)$, two (local) solutions are $\alpha_{11}=0, \alpha_{12}=1, \alpha_{21}=1$ and $\alpha_{22}=0$ (i.e., $\mathrm{TMD}_{1}$ placed at second floor and $\mathrm{TMD}_{2}$ placed at first floor) and $\alpha_{11}=0, \alpha_{12}=1, \alpha_{21}=0$ and $\alpha_{22}=1$ (i.e., both TMDS placed at the second floor). The simulation results for both designs are shown in Figs. 7 and 8. The values of TMDs parameters are: i) $\omega_{t, 1}=11.38 \mathrm{rad} / \mathrm{s}, \omega_{t, 1}=32.32 \mathrm{rad} / \mathrm{s}, \xi_{t, 1}=0.0595$ and $\xi_{t, 2}=0.0503$ for Design 1 and ii) $\omega_{t, 1}=10.71 \mathrm{rad} / \mathrm{s}, \omega_{t, 1}=23.29 \mathrm{rad} / \mathrm{s}, \xi_{t, 1}=0.0598$ and $\xi_{t, 2}=0.0525$ for Design 2, which can be implemented in practice. Note that the maximum value of the FRF between $y_{2}$ and $a_{b}$ (i.e., $H_{\infty}$ ) is approximately the same for both designs (about 19.4 dB in Fig. 8). Note that the reduction achieved with TMDs is approximately $16 \mathrm{~dB}$ in simulation (i.e., the acceleration of the second floor with TMDs is 6.3 time less than without them). However, Fig. 7 shows that Design 2 is worse than Design 1 for the first floor. Since the maximum acceleration measured at first floor of Design 2 is approximately $20 \mathrm{~dB}$, which is bigger than the second floor at both designs, Design 1 is implemented in practice to compared simulation and experimental results.

Figs. (9) and (10) show the FRF between $y_{1}$ and $a_{b}$ and between $y_{2}$ and $a_{b}$, respectively for Design 1. Note that simulation and experimental results are practically the same, which validate the models and the experimental identifications of the building and TMDs. 


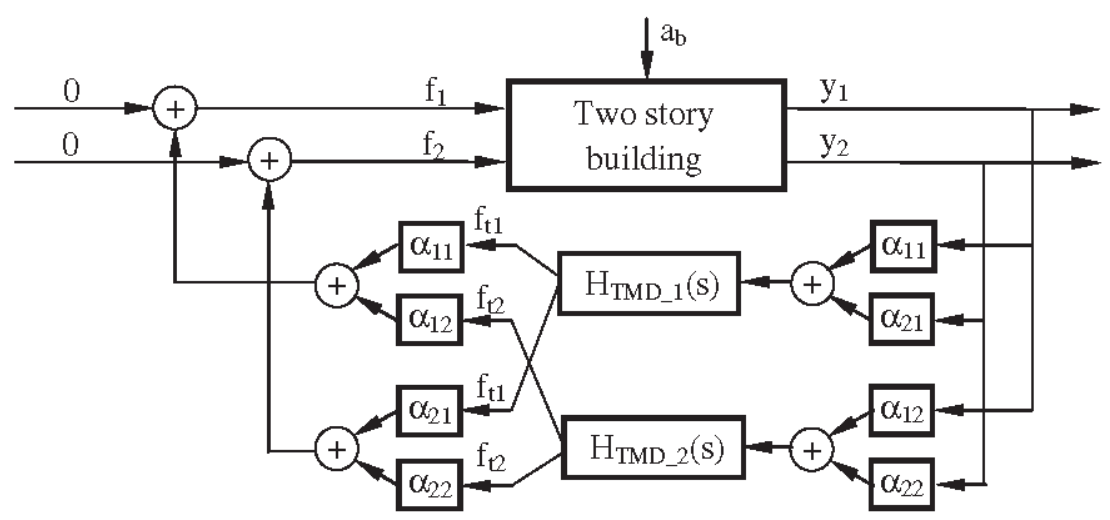

Figure 6: General control scheme.

\section{CONCLUSIONS}

Using simple TMD prototypes, in which the moving mass is guided by a flexible supporting plate (contact-free) and the damping is trusted to friction-free magnetic effect, enables the possibility to make accurate testing with TMDs and to validate theoretical models.

The results shown in this work validate the laboratory prototype of magnetically damped TMD built in CARTIF (Spain) as a PVC system. In addition, the design methodology simplifies the tuning of the parameters and allows to use it for more complex designs as the AVC implemented at [14].

Future works will be the application of these magnetically damped TMDs to more complex structures, where the control theory can be used to improve the performance of a set of TMDs applied to structures with natural frequencies spatially distributed and closely spaced. In addition, the definition of the functional (i.e., variables to be minimized) must be deeply studied in order to consider the maximum vibration level on the overall structure.

\section{ACKNOWLEDGMENT}

The authors wish to acknowledge to the partial support throught Research Projects BIA2011-28493, DPI2013-47441 and BIA2014-59321 ("Ministerio de Economía y Competitividad", Spanish Government).

\section{REFERENCES}

[1] G. Housner, L. Caughey, T. Chassiakos, R. Claus, S. Masri, R. Skelton, T. Soong, B. Spencer, J. Yao, Structural control: Past, present, and future, Engineering Mechanics-ASCE 123 (9) (1997) $887-971$.

[2] M. Symans, M. Constantinou, Semi-active control systems for seismic protection of structures: a state-of-the-art review, Engineering Structures 21 (6) (1999) 469-487. 


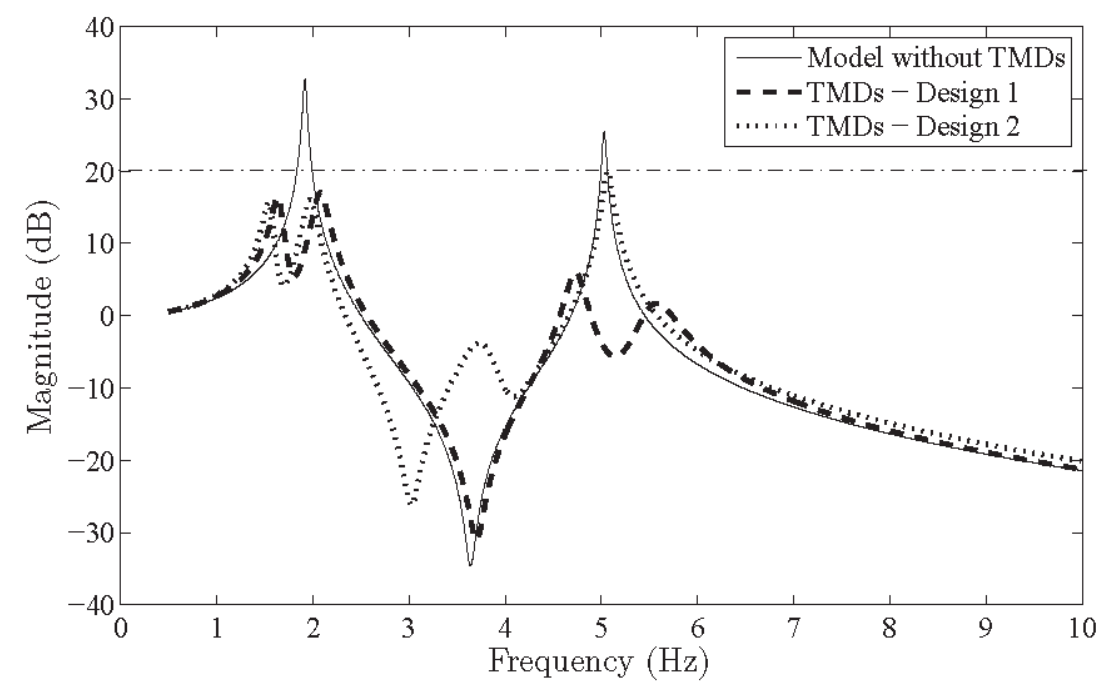

Figure 7: TMDs design. Simulation results for first floor.

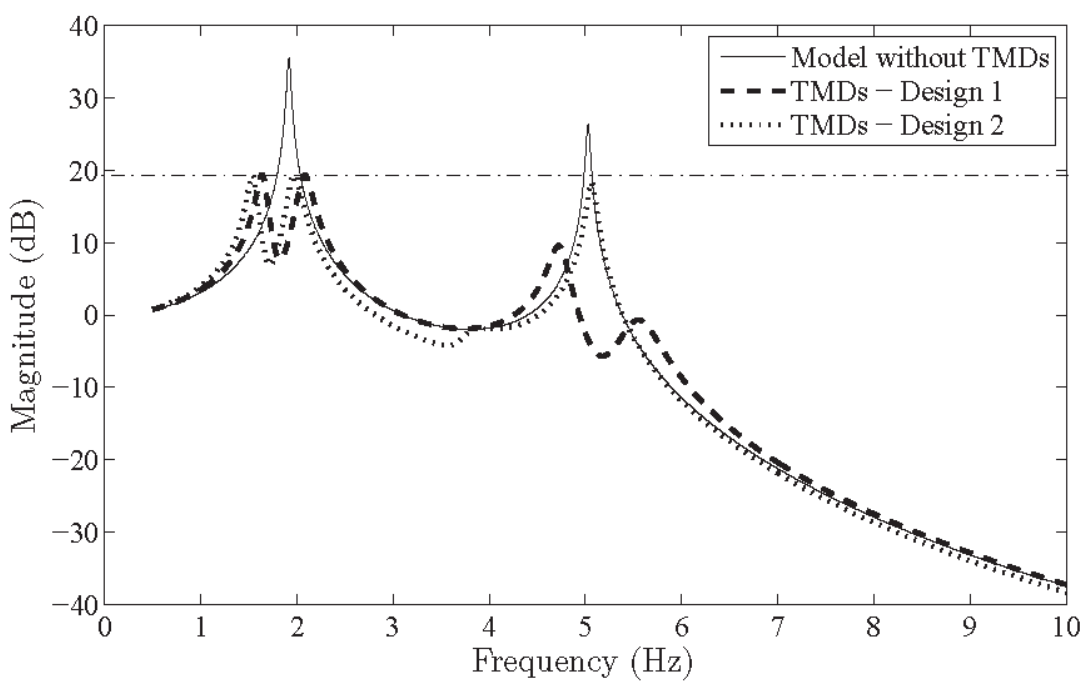

Figure 8: TMDs design. Simulation results for second floor. 


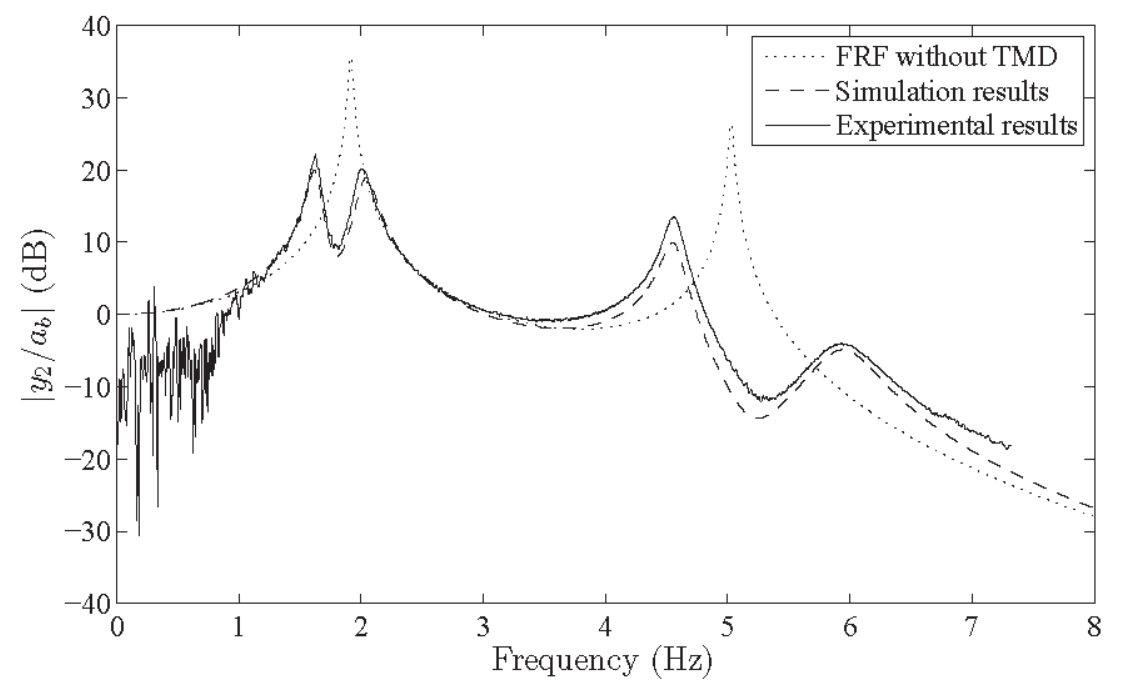

Figure 9: Simulation and experimental results for the first floor (Design 1).

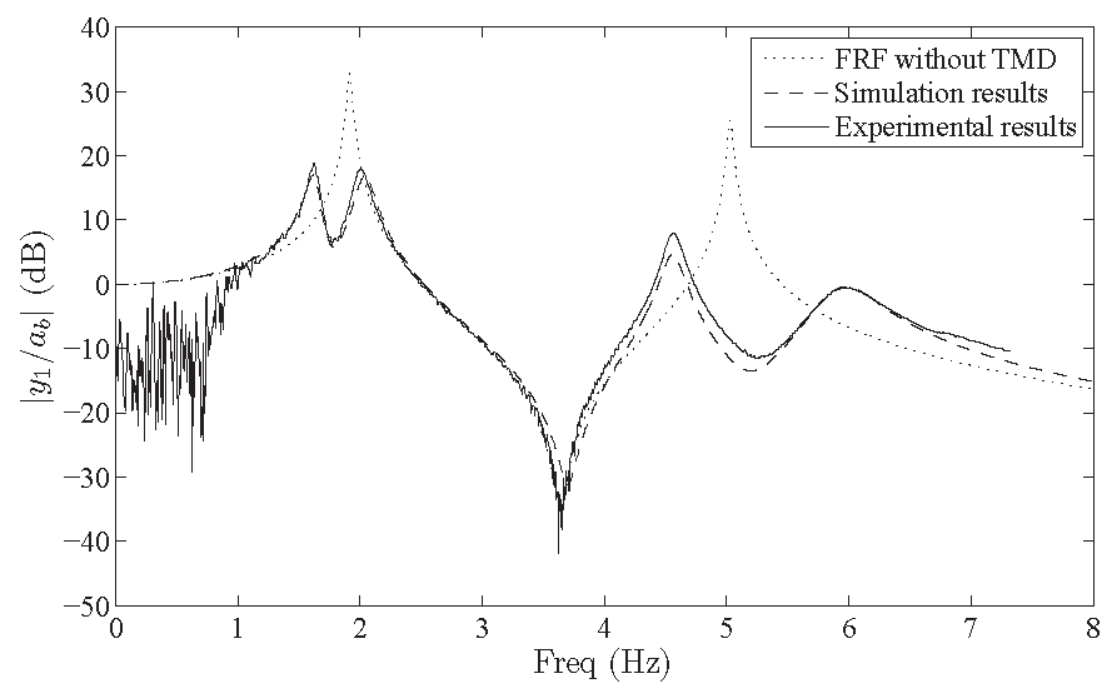

Figure 10: Simulation and experimental results for the second floor (Design 2). 
[3] F. Bourquin, G. Caruso, M. Peigney, D. Siegert, Magnetically tuned mass dampers for optimal vibration damping of large structures, Smart Materials and Structures 23 (8) (2014) 085009.

[4] Z. Wang, Z. Chen, Development and performance tests of an eddy-current tuned mass damper with permanent magnets, Journal of Vibration Engineering 26 (3) (2013) 374-379.

[5] C. Sun, S. Nagarajaiah, A. Dick, Family of smart tuned mass dampers with variable frequency under harmonic excitations and ground motions: closed-form evaluation, Smart Structures and Systems 13 (2) (2014) 319-341.

[6] M. Berardengo, A. Cigada, F. Guanziroli, S. Manzoni, Modelling and control of an adaptive tuned mass damper based on shape memory alloys and eddy currents, Journal of Sound and Vibration 349 (2015) 13-38.

[7] J. P. Den-Hartog, Mechanical Vibrations, New York: McGraw-Hill, 1956.

[8] M. Abe, T. Igusa, Tuned mass dampers for structures with closely spaced natural frequencies, Earthquake Engineering and Structural Dynamics 24 (1995) 247-261.

[9] R. Greco, A. Lucchini, G. Marano, Robust design of tuned mass dampers installed on multi-degreeof-freedom structures subjected to seismic action, Engineering Optimization 47 (8) (2015) 10091030.

[10] L. Fleck-Fade-Miguel, L. Fleck-Fadel-Miguel, R. Holdorf-Lopez, Robust design optimization of friction dampers for structural response control, Structural Control and Health Monitoring 332 (9) (2014) 6044-6062.

[11] A. D. N. Debnath, S. K. Deb, Frequency band-wise passive control of linear time invariant structural systems with h-infinity optimization.

[12] http://www.quanser.com, consulted at January 2016.

[13] A. Mohtat, E. Dehghan-Niri, Generalized framework for robust design of tuned mass damper systems, Journal of Sound and Vibration 330 (5) (2011) 902-922.

[14] E. Pereira, I. M. Díaz, E. J. Hudson, P. Reynolds, Optimal control-based methodology for active vibration control of pedestrian structures, Engineering Structures 80 (1) (2014) 153-162. 
A NEW PROCEDURE BASED ON TIME DOMAIN INDICATORS FOR OPTIMAL TMD TUNING ON FOOTBRIDGES

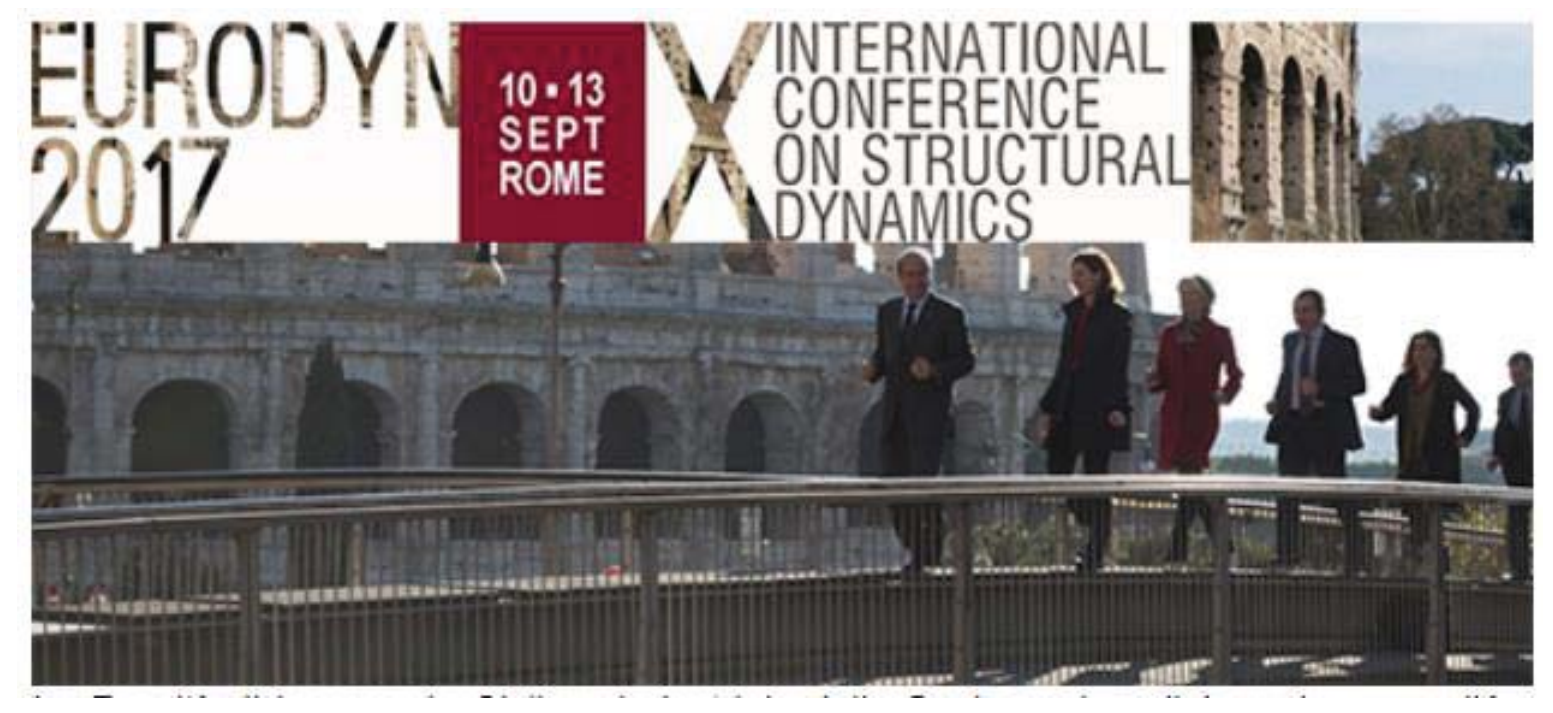

Álvaro Magdaleno Gonález; Norberto Ibán Lorenzana; Mariano Cacho Pérez; F.Javier Cara Cañas; Iván Muñoz Díaz; Antolín Lorenzana Ibán.

\begin{tabular}{c|c|c|c|} 
Aportaciones: & Experimentación & Procesado & Edición \\
\hline & $\begin{array}{c}\text { Instrumentación } \\
\text { Registros }\end{array}$ & Matlab & $\begin{array}{c}\text { Tablas } \\
\text { Gráficas }\end{array}$ \\
\cline { 2 - 4 }
\end{tabular}




\title{
A new procedure based on time domain indicators for optimal TMD tuning on footbridges
}

\author{
Magdaleno, A..$^{\text {a,* }}$ Ibán, N. ${ }^{\text {, }}$ Cacho-Pérez, M. ${ }^{\mathrm{a}}$, Cara, F.J. ${ }^{\mathrm{c}}$, Díaz, I.M. ${ }^{\mathrm{c}}$, Lorenzana, A. ${ }^{\mathrm{a}}$, \\ Pereira, E. ${ }^{\mathrm{d}}$ \\ "ITAP, EII, Universidad de Valladolid, Valladolid, Spain \\ ${ }^{b}$ CARTIF, Parque Tecnológico de Boecillo (Valladolid), Boecillo, Spain \\ "UPM, Escuela Superior de Ingenieros Industriales, Madrid, Spain \\ "Escuela Politécnica Superior, Universidad de Alcalá, ES 28805, Alcala de Henares (Madrid), Spain
}

\begin{abstract}
Structures subjected to excitations like human induced vibrations may produce large accelerations and serviceability limil state problems. Passive, semi-active and active vibration controls have been proposed as possible solutions to reduce the vibration level at civil structures such as bridges, multi-storey buildings or slender floor structures, among others. It is known that Tuned Mass Dampers (TMD) mitigates the vibration response of a structure by increasing its damping through the application of inertial forees generated in response to the movement of the structure. Recently, different TMD implementations have been proposed in order to improve their tuning. In the case of structures with spatially distributed and closely spaced natural frequencies the TMD design may not be obvious because Den Hartog's theory may not be applied due coupling effects between the modes of the structures and the used TMD's.

In this work, alternative design techniques are applied for the case under study consisting on a simplified model of a footbridge with a main span $40 \mathrm{~m}$ long. The first two modes are at $2.104 \mathrm{~Hz}$ and $2.505 \mathrm{~Hz}$, both in the range prone to be excited by walking or jogging ( 90 to $180 \mathrm{bpm}$ ). Also the third one (at $3.18 \mathrm{~Hz}$ ) could be excited by runners. Once the finite element model is calibrated, mitigation devices (one or two TMDs) are proposed. The problem of finding their optimal location and tuning is not a simple one. Note that any strategy based on FRFs (frequency response functions) is not only tedious (several FRFs should be considered along the footbridge) but also limited, as the pedestrian crossing is a transient effect and FRFs are for steady states. Some standard analysis are carried out for a range of crossings at different paces and several simulations are carried out considering multiple scenarios in which the TMDs are attached to different locations. After studying several proposals, the best solutions are compared also in the frequency domain in order to extract some interesting and nor obvious conclusions.

(c) 2017 The Authors. Published by Elsevier Ltd.
\end{abstract}

Peer-review under responsibility of the organizing committee of EURODYN 2017.

Keywords: Human induced vibrations; Tuned Mass Damper; Optimal design; Footbridges; Time response

\footnotetext{
* Corresponding author. Tel.: +34983423391

E-mail address: alvaro.magdaleno@uva.es
} 


\section{Introduction}

Although in the past, civil engineering sector made extensive use of approximate models to estimate the dynamic response of bridge type structures, nowadays is usual to model the structure using current CAE abilities. Simple discrete models have proved insufficient for the accurate modelling of slender footbridge structures as they cannot represent some effects as the closely spaced modes of vibration which frequently occur in practice. Additionally, modern footbridges become increasingly slender and prone to oscillate under pedestrian loading, so there is a much greater need for vibrations to be considered at the design stage. Having the FE methods the capability for the accurate modelling of the dynamic behaviour, and becoming CAE software more affordable, civil engineering practitioners do not hesitate in their use. However, with regard to lively structural design, there is a lack of expertise in FE modelling, particularly with regard to their vibration serviceability performance, being not rare that the model does not match with the real structure. The way forward for developing such expertise is by linking modal testing and FE analysis by the updating of the models of representative structures and extract general design guidelines. This type of approach is the usual in, for example, the aerospace engineering sectors $[5,6]$, but it is only recently that the civil engineering community has begun to adopt this advanced technology $[7,9]$.

The aim of the paper is to describe a procedure for the use of updated FE models with TMDs attached to estimate the response in terms of accelerations and evaluate the serviceability of the assembly.

\subsection{Structure description}

The footbridge under study is an urban link with several minor access spans and one main 40m long arched central lively span. Most of the structural members are constructed using tubular steel profiles. An aerial photograph of the footbridge and 3D isometric view of its FE model is depicted in Figure 1. More information about the structure can be found in [11]. Updated mode-shapes 1 and 2 are shown in Figure 2.a. The structural damping (Rayleigh type) was set to $0.32 \%$.
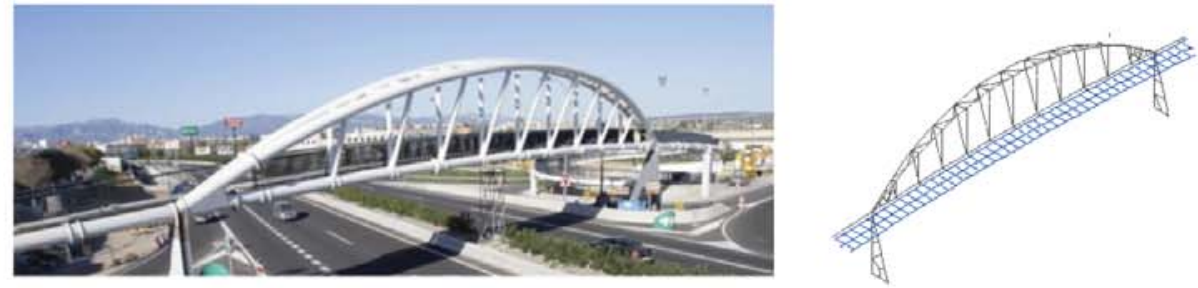

Fig. 1: Footbridge under study: photograph and numerical FE model

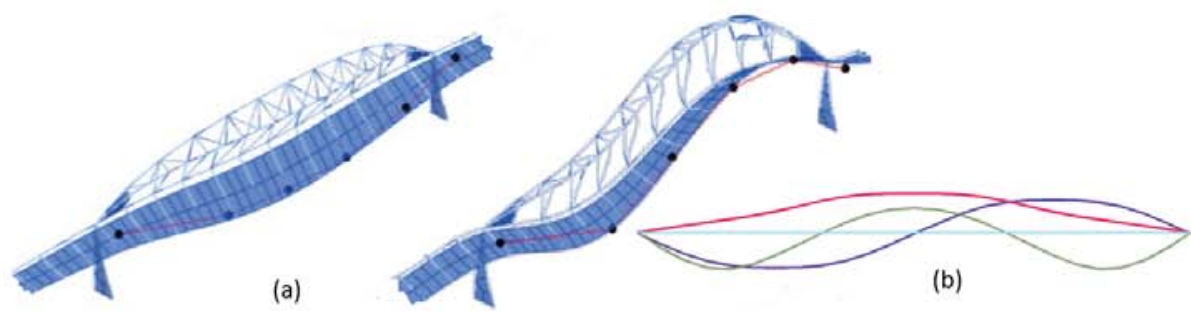

Fig. 2: Footbridge under study: photograph and numerical FE model

Although it would be possible to apply the methodology using the 3D F.E. model, in order to make more efficient simulations, a less time consuming F.E. model has been created. In this case, just a 2D equivalent structure meshed in 12 elements and modeled with Euler straight beam elements has been used. Both models exhibit similar vertical modes (see Figure 2.b), which are the interesting ones for the problem under study (pedestrian loading vertical response). Being $L$ the length of the footbridge, note that the second mode-shape has a node at $6 L / 12$ and the nodes of the third 
mode-shapes are located at $4 L / 12$ and $8 L / 12$. In the next section, the dynamic problem is established using the state space approach.

\section{Space state modeling}

The set of dynamic equations to be solved is $\mathbb{M} \ddot{q}+\mathbb{C} \dot{q}+\mathbb{K} q=F$, where $\mathbb{M}$ is the mass matrix and $\mathbb{K}$ is the stiffness matrix of the structure. $\mathbb{C}=\left(V \tilde{\mathbb{C}} V^{T}\right)^{-1}$ is the damping matrix, evaluated through modal damping values $\xi_{i}$, where $V$ is the modes matrix $V=\left(\phi_{1}, \phi_{2}, \ldots\right)$ and $\tilde{\mathbb{C}}$ is the modal damping matrix, a diagonal matrix defined as $\tilde{\mathbb{C}}=\operatorname{diag}\left(2 \xi_{i} \omega_{i}\right)$.

Only bending degrees of freedom are considered (vertical deflection and planar rotation). The vector of degrees of freedom is shown in Equation 1.

$$
q=\left[\begin{array}{lllllll}
v_{1} & \theta_{1} & v_{2} & \theta_{2} & \cdots & v_{n} & \theta_{n}
\end{array}\right]^{T}
$$

Standard procedures for meshing and assembling must be applied to all the matrices. Also boundary conditions of simple supported beam must be included in the former formulation. $F$ in Equation ?? is the input forces vector, affecting to the whole model. It can be expressed in terms of an harmonic function $u(t)$ and a vector of amplitudes $F_{0}$, as $F=F_{0} u(t)$.

Any TMD means an additional degree of freedom to be added in the matrix formulation. For that, when $m$ TMDs are considered to be included in the model the vector of degrees of freedom $q$ changes as shown in Equation 2 to take into account the displacements of those TMDs $\left(w_{i}\right)$.

$$
q^{\prime}=\left[\begin{array}{lllll}
q^{T} & w_{1} & w_{2} & \cdots & w_{n}
\end{array}\right]^{T}
$$

And for any TMD the corresponding matrices to be assembled are shown in Equation 3, where $m_{t}, c_{t}, k_{t}$ are the physical properties of a single TMD.

$$
M_{t}=\left[\begin{array}{cc}
0 & 0 \\
0 & m_{t}
\end{array}\right] \quad C_{t}=\left[\begin{array}{cc}
c_{t} & -c_{t} \\
-c_{t} & c_{t}
\end{array}\right] \quad K_{t}=\left[\begin{array}{cc}
k_{t} & -k_{t} \\
-k_{t} & k_{t}
\end{array}\right]
$$

Considering as input the former hamonic function $u(t)$ and as output just the acceleration in a set of selected degrees of freedom, the dynamic equations of motion can be rewritten in terms of a state vector $x$ (Equation 4) and the typical state-space matrices $A, B, C$ and $D$. A definition of matrices $A$ and $B$ is also provided in Equation 4, where $\varnothing_{n \times n}$ is an square zero matrix and $I_{x \times n}$ is the identity one. Matrices $C$ and $D$ are a set of rows of $A$ and $B$ corresponding to those degrees of freedom whose acceleration is wanted to be the output of the model.

$$
\begin{aligned}
& \dot{x}=A x+B u \\
& y=C x+D u
\end{aligned} \quad A=\left[\begin{array}{cc}
\varnothing_{n \times n} & I_{x \times n} \\
-\mathbb{M}^{-1} \mathbb{K} & -\mathbb{M}^{-1} \mathbb{C}
\end{array}\right] \quad B=\left[\begin{array}{c}
\varnothing_{n \times n} \\
\mathbb{M}^{-1} F_{0}
\end{array}\right]
$$

Once the system is established, the transfer function $G(s)$ between the input $u(t)$ and an output acceleration can be obtained after some manipulations and it is shown in Equation 5, where $\mathscr{L}$ is the Laplace operator.

$$
G(s)=\frac{\ddot{Q}(s)}{U(s)}=\frac{\mathscr{L}\{\ddot{q}(t)\}}{\mathscr{L}\{u(t)\}}=C\left(s I_{2 n \times 2 n}-A\right)^{-1} B+D
$$

The frequency response function (FRF) to be used in the following sections is just the magnitude of the Bode diagram of the former transfer function. The whole calculation is carried out in the Matlab environment using the standard functions: ss() for creating the state-space model, $t f()$ for obtaining the transfer function of the model and bode() for calculating its Bode diagram. Also the function lsim() would be used to obtain the time response of the model.

\section{Tuning for minimizing FRFs values}

For all the studied cases, a tonne inertial moving mass is added (being the $2 \%$ of the total mass of the simplified model of the footbridge) in one or two TMDs (500kg each). The TMD may be tuned to mode $1\left(w_{1}\right)$ or mode $2\left(w_{2}\right)$ 
and located in some point $(p)$ along the beam. To simplified the continuous problem, only 11 discrete locations are considered (as the structure is discretized in 12 beam elements) so point $p$ is at $j L / 12$ from the left end of the structure. The notation will be TMDi( $m ; \omega ; \xi ; j L / 12)$ which means that a TMD number $i$ with a moving mass of $m \mathrm{~kg}$ is tuned at $\omega \mathrm{Hz}$ with a damping of $\xi$ and located in $j L / 12$.

In this section, the numerical values for the estimation of the response are obtained from the FRFs. In all the cases, the excitation point (force) and the response (acceleration) will be the same. The standard approach to mitigate the response around mode 1 is to install a TMD in the middle of the span. The properties of this optimum TMD have been calculated in order to minimise the peak response of the FRF in the band of the $1^{\text {st }}$ mode, resulting in TMD1 $(1000 ; 2.0446 ; 0.131 ; 6 \mathrm{~L} / 12)$. Figure 3 a shows the FRF at point $6 \mathrm{~L} / 12$ for the original footbridge (in blue) and for the bridge with that TMD attached (in red).

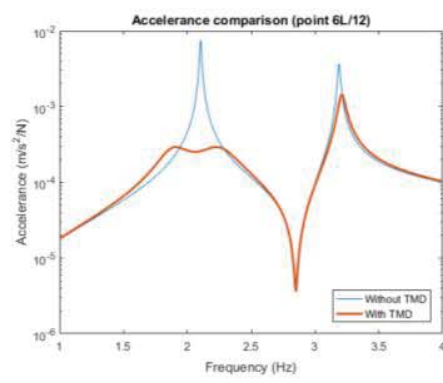

(a) Solution TMD1

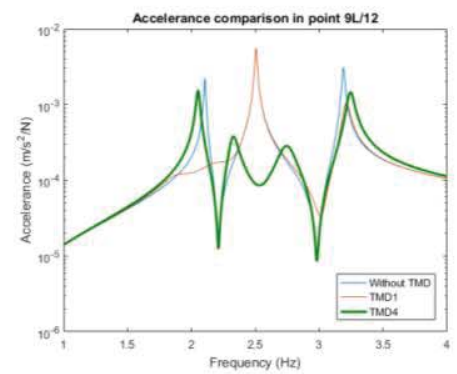

(b) Solution TMD4 vs. TMD1

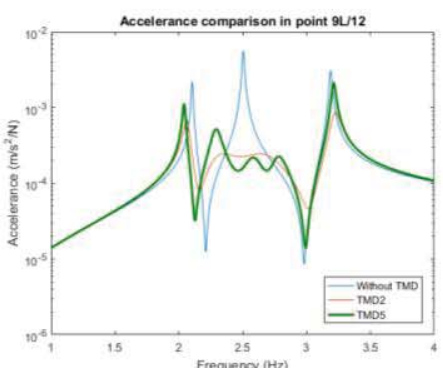

(c) Solution TMD5 vs. TMD2

Fig. 3: FRF for different TMDs

Even if this is the most common approach, the solution is only optimum when the excitation of the structure is harmonic at frequencies around $\omega_{1}$ and lasts enough time for the struture to reach the stationary response. Otherwise, the solution presented is only a good enough approximation and further analysis (see Section 4) would be necessary to be carried out.

\section{Performance indicators based on the time response under a moving force}

Assuming the usual force to be as Equation 6 for a pedestrian of $70 \mathrm{~kg}$ walking at $1.2 \mathrm{~m} / \mathrm{s}$ and a $\omega_{p}$ pace, the acceleration time response can be computed with the Matlab function $l \operatorname{sim}()$ in any node jL/12. For any of those responses, the Root Mean Square Trend (RMS trend) from ISO 2631 can be computed with Equation 7.

$$
\begin{aligned}
& F_{p}(t)=G+\sum_{i=1}^{n} G \alpha_{i} \sin \left(i \omega_{p} t-\phi_{i}\right) \\
& R M S_{j L / 12}\left(t_{0}\right)=\sqrt{\frac{1}{\tau} \int_{t_{0}-\tau}^{t_{0}} a(t)^{2} d t}
\end{aligned}
$$

The maximum value of the RMS trend can be also evaluated, obtaining the Maximum Transient Vibration Value $\left(M T V V_{j L / 12}=\max \left(R M S_{j L / 12}\left(t_{0}\right)\right)\right)$. Figure 4a shows the acceleration of node $7 \mathrm{~L} / 12$ during the crossing at pace of $\omega_{p}=\omega_{1}$ (resonant at mode 1), that turns out to be the node with the highest MTVV value at that pace. Also Figure 4a shows the same values for the case TMD1 is installed.

Figure $4 \mathrm{~b}$ shows all the RMS trend curves for the 11 selected nodes. The average of the 11 MTVV values $(0.04448)$ might look a good serviceability indicator, as according to ISO 10137, MTVV values are supposed to be correlated with the human motion perception. We denote this new time indicator by $\overline{m t v v}\left(\omega_{p}\right)$, defined in Equation 8 , where $\omega_{p}$ is the pace of the pedestrian. 


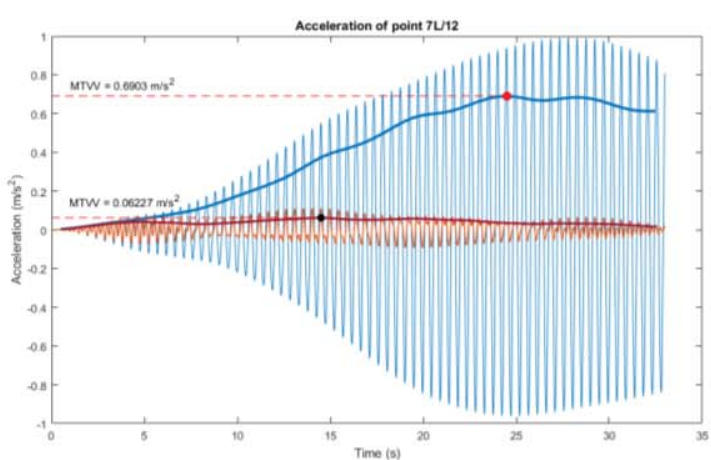

(a) Acceleration response of the node $7 \mathrm{~L} / 12$ for $w_{p}=w_{1}$

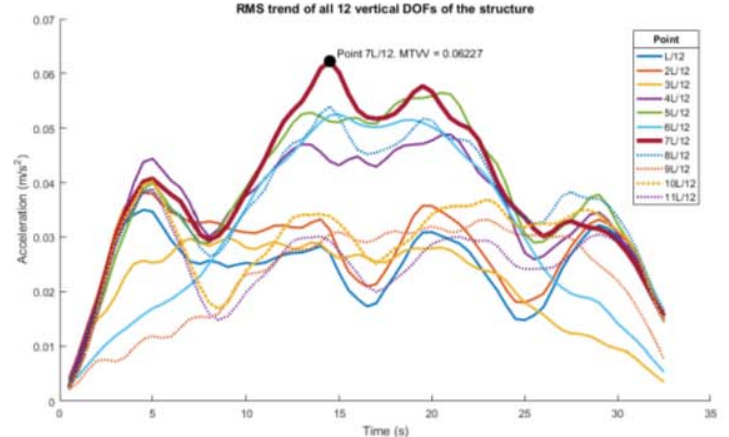

(b) RMS trend for he 11 internal nodes

Fig. 4: Time responses

$$
\overline{m t v v}\left(\omega_{p}\right)=\frac{1}{11} \sum_{j=1}^{11} M T V V_{j L / 12}
$$

Table 1 shows the $\overline{m t v v}$ values for crossing at $\omega_{1}$ pace and $\omega_{2}$ pace along the original footbridge $(0.43073$ and $0.33018)$ and also when the TMD1 $(1000 ; 2.0446 ; 0.131 ; 6 \mathrm{~L} / 12)$ is installed $(0.04448$ and 0.3305$)$. Note that in this last case $\overline{m t v v}$ value is almost the same, as the TMD is tuned to mode $1 . \omega_{1}$ and $\omega_{2}$ paces seem to be the more risky ones as resonance can appear but with the TMD1 installed other paces around $\omega_{1}$ (lets say, according to Figure $3 a$, from 1.9 to $2.3 \mathrm{~Hz}$ ) are equally risky.

For crossings at any other pace, the values of $\overline{m t v v}$ are different. In order to propose a time indicator valid for a significant pace range (from $\omega_{a}$ to $\omega_{b}$ ), the following one can be defined.

$$
\overline{\overline{m t v v}}=\frac{1}{n} \sum_{j=0}^{n} \overline{m t v v}\left(\omega_{a}+\frac{\omega_{b}-\omega_{a}}{n} j\right)
$$

In the range of walking, jogging or running paces, $\omega_{a}$ and $\omega_{b}$ are the range where the accelerances (FRF) are high. The definition of $n$ is an attempt to discretise the continuous problem. In the case under study, 9 crossing paces between 1.9 and $2.7 \mathrm{~Hz}$ (separated $0.1 \mathrm{~Hz}$ ) are selected. $\overline{\overline{m t v v}}$ values are also shown in Table 1. together with the relative changs regarding values for the footbridge without TMD.

Table 1: $\overline{\overline{m t v v}}$ values for each node

\begin{tabular}{lllllll}
\hline & $\omega_{1}$ & Performance & $\omega_{2}$ & Performance & $(1.9,2.7)$ & Performance \\
\hline (no TMD) & 0.43073 & - & 0.33018 & - & 0.07506 & - \\
TMD1 & 0.04448 & $89.67 \%$ & 0.33055 & $-0.11 \%$ & 0.05064 & $32.54 \%$ \\
TMD2 & 0.14174 & $67.09 \%$ & 0.04501 & $86.37 \%$ & 0.04059 & $45.93 \%$ \\
TMD3 & 0.05542 & $87.13 \%$ & 0.06528 & $80.23 \%$ & 0.04315 & $42.52 \%$ \\
\hline
\end{tabular}

Table 1 also shows two new scenarios. The former scenario (row TMD1) attended for installing a $1000 \mathrm{~kg}$ TMD to mitigate the first mode. Now, in the scenario TMD2 two $500 \mathrm{~kg}$ TMDs are going to be installed at locations 3L/12 and 9L/12 to mitigate the second mode. The optimum solution, attending FRF response (Figure 5a) is TMD2([500, 500]; [2.4618, 2.4618]; [0.116,0.116]; [3L/12,9L/12]). In the scenario TMD3 a TMD of $500 \mathrm{~kg}$ is installed at $6 \mathrm{~L} / 12$ to mitigate the first mode and another one at 3L/12 to mitigate the second one, resulting (see Figure 5b) in TMD3([500, 500]; $[2.073,2.496] ;[0.1,0.08] ;[6 \mathrm{~L} / 12,3 \mathrm{~L} / 12])$. Note in Table 1 the performance in all cases. 


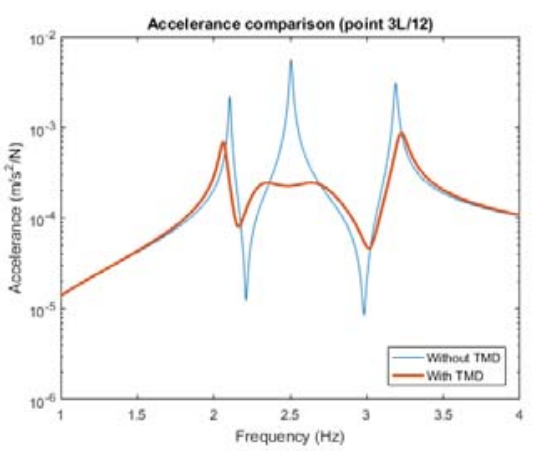

(a) TMD2 for second mode

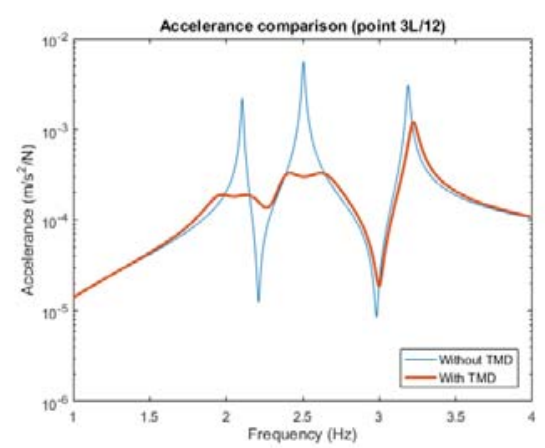

(b) TMD3 for first and second modes

Fig. 5: Accelerances of cases TMD2 and TMD3 at 3L/12

Once the $\overline{\overline{m t v v}}$ indicator is defined, it would be an engineering target to choose the location and tuning of the TMDs that minimise it, meaning that the response of the footbridge under a range of transient excitations is optimum. If only one TMD is going to be installed and the several crossing from 1.9 to $2.7 \mathrm{~Hz}$ (separated $0.1 \mathrm{~Hz}$ ) are to be considered, the solution that minimise the indicator is TMD4(1000; $2.537 ; 0.044 ; 9 \mathrm{~L} / 12)$. Figure $3 \mathrm{~b}$ shows the corresponding FRF function at point 9L/12 (compared with the original case and with TMD1). In the case with to $500 \mathrm{~kg}$ TMDs, the optimum solution (see Figure 3c) is TMD5([500, 500]; [2.4684, 2.621]; [0.0414,0.0314]; [9L/12,4L/12]). Table 2 summarises the response not only for the optimised range (1.9 to $2.7 \mathrm{~Hz}$ ) but also for crossings at $\omega_{1}$ and $\omega_{2}$.

Table 2: $\overline{\overline{m t v v}}$ values for each node

\begin{tabular}{llllll}
\hline & $\omega_{1}$ & Performance & $\omega_{2}$ & Performance & $(1.9,2.7)$ \\
\hline (no TMD) & 0.43073 & - & 0.33018 & - & 0.07506 \\
TMD4 & 0.11772 & $72.67 \%$ & 04263 & $87.09 \%$ & 0.04096 \\
TMD5 & 0.10286 & $76.12 \%$ & 0.03889 & $88.22 \%$ & $45.43 \%$ \\
\hline
\end{tabular}

Optimum design parameters in the cases TMD4 and TMD5 were found using the genetic algorithm of Matlab (function $g a()$ ). Any other solution obtained trying to minimise accelerances results in TMD designs not as good as TMD4 (only one TMD) or TMD5 (two TMDs). Table 3 shows $\overline{m t v v}$ and $\overline{\overline{m t v v}}$ values for the optimum designs TMD6, TMD7 and TMD8 where the optimization criterium is not to lower the accelerance peaks around $\omega_{1}$ and/or $\omega_{2}$ but the area under the accelerance curve in the $\pm 20 \%$ range around them. When just one TMD tuned at first mode is sought, the best solution is TMD6 $(1000 ; 2.0997 ; 0.0971 ; 4 \mathrm{~L} / 12)$. When second mode is reduced with two TMDs, TMD7([500,500]; [2.5514, 2.584]; [0.1012,0.1057]; [4L/12,8L/12]) is the best alternative. And if both modes are taken into consideration, TMD8([500,500]; [2.5331, 2.0913]; [0.0794, 0.0976]; [3L/12,7L/12]) is the best solution. Note that both indicators values for all the three best solutions are worse than those for TMD4 and TMD5.

Table 3: $\overline{\overline{m t v v}}$ values for each node

\begin{tabular}{llllll}
\hline & $\omega_{1}$ & Performance & $\omega_{2}$ & Performance & $(1.9,2.7)$ \\
\hline (no TMD) & 0.43073 & - & 0.33018 & - & 0.07506 \\
TMD6 & 0.06387 & $85.17 \%$ & 0.08540 & $74.14 \%$ & - \\
TMD7 & 0.08029 & $81.36 \%$ & 0.04664 & $85.88 \%$ & 0.04539 \\
TMD8 & 0.05851 & $86.42 \%$ & 0.06507 & $80.29 \%$ & 0.03885 \\
\hline
\end{tabular}




\section{Conclussions}

The engineering problem to mitigate the vibrations of slender structures under transient loadings is not a simple one. The problem of finding the best number of TMDs, their location and tuning can be addressed via frequency domain or via time domain. Traditional tuning strategies are based on minimising accelerance peaks around problematic vibration modes. With this strategy, proposal TMD1 only gets an overall $32.54 \%$ of performance versus $45.43 \%$ of TMD4 (tuned using the new proposed time strategy), both solutions using only one TMD. When two TMDs can be installed, performance improves from $44.93 \%$ (TMD2, based on frequency domain) to 55.23\% (TMD5, designed under the new approach).

\section{Acknowledgements}

The authors wish to acknowledge to the partial support through Research Projects BIA2011-28493, BIA201459321 and BIA2015-71942-REDT (Ministerio de Economía y Competitividad, Spanish Government).

\section{References}

[1] G.W. Housner, L.A. Bergman, T.K. Caughey, A.G. Chassiakos, R.O. Claus, S.F. Masri, R.E. Skelton, T.T. Soong, B.E. Spencer, J.T.P Yao. Structural control: Past, present and future. Journal of Engineering Mechanics-ASCE (1997); 127:887-971.

[2] M.D. Simans, M.C. Constantinou. Semi-active control systems for seismic protection of strctures: a state-of-the-art review. Engineering Structures $(1999) ; 21: 469-487$.

[3] J.P. Den Hartog. Mechanical Vibrations, 4th edition, McGraw-Hill, New York, 1956.

[4] M. Abe, T. Igusa. Tuned Mass Dampers for structures with closely spaced natural frequencies. Earthquake Enginnering and Structural Dynamics (1995); 24: 247-261.

[5] B.A. Zarate, J.M. Caicedo. Finite element model updating: multiple alternatives. Engineering Structures, vol. 30, no. 12, pp. 3724-3730, 2008.

[6] W.M. Li, J.Z. Hong. New iterative method for model updating based on model reduction. Mechanical Systems and Signal Processing, vol. 25, no. 1, pp. 180-192, 2011.

[7] J.E. Mottershead, M.I. Friswell. Model updating in structural dynamics: a survey. Journal of Sound and Vibration, vol. 167, no. 2, pp. 347-375, 1993.

[8] D. Ribeiro, R. Calada, R. Delgado, M. Brehm, V. Zabel. Finite element model updating of a bowstring-arch railway bridge based on experimental modal parameters. Engineering Structures, no. 40, pp. 413-435, 2012.

[9] S. Zivanovic, A. Pavic, P. Reynolds. Finite element modelling and updating of a lively footbridge: the complete process. Journal of Sound and Vibration, no. 301, pp. 126-145, 2007.

[10] M. Chulvi, J. Henche. Pasarela sobre la va de cintura MA-20 en Palma de Mallorca. V Congreso nacional de ACHE, Asociacin cientfico-tcnica del hormign estructural, Barcelona 2011.

[11] G.H. Kim, Y.S. Park. An improved updating parameter selection method and finite element model update using multiobjective optimisation technique. Mechanical Systems and Signal Processing 18 (1) pp. 59-78, 2004. 


\section{CMMOST 2017} 4th INTERNATIONAL CONFERENCE ON MECHANICAL MODELS IN

\section{STRUCTURAL ENGINEERING}

Madrid, SPAIN 29 Nov - 1 Dec

Technical University of Madrid ETSI de Caminos, Canales y Puertos

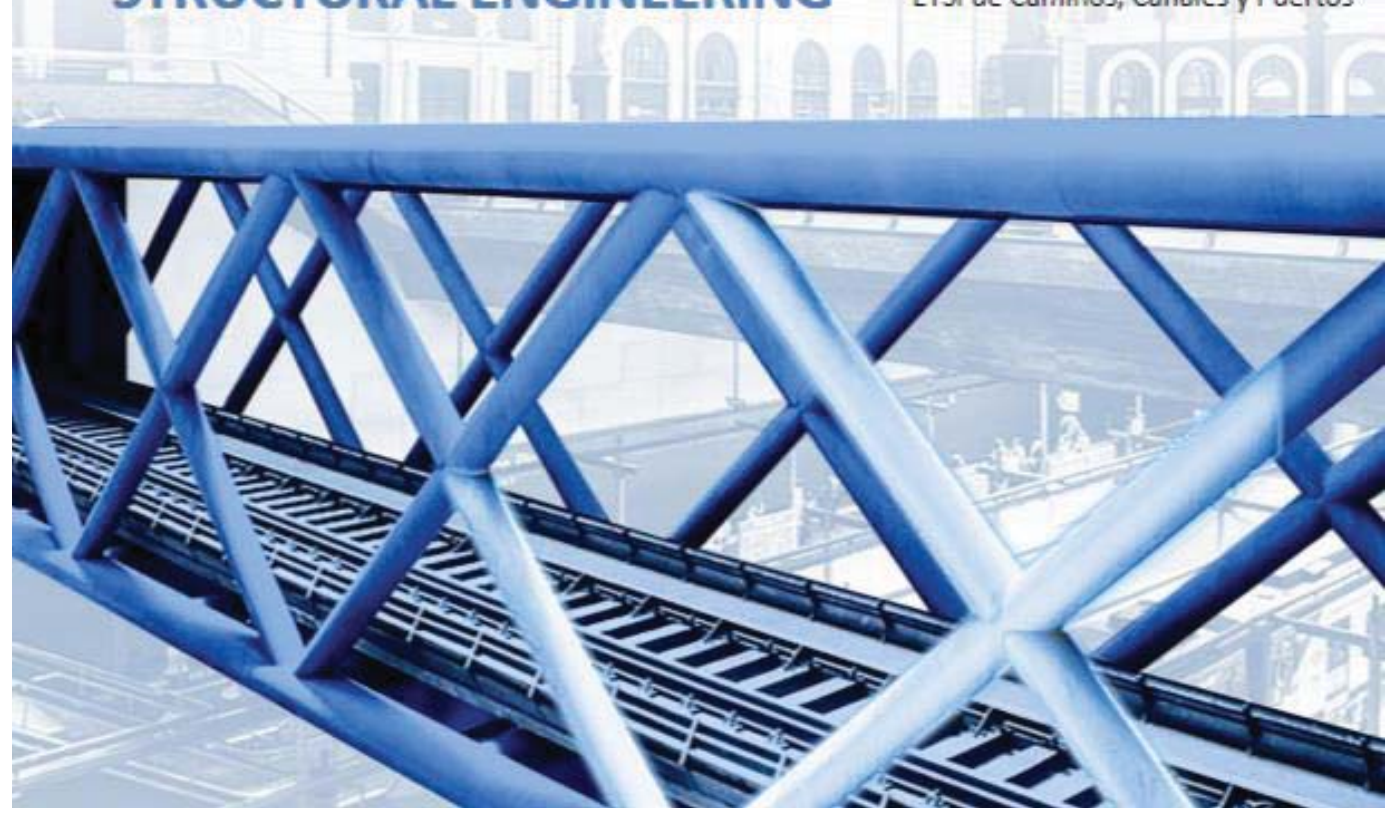

Ovidio Hérnandez; Alfonso V. Poncela Méndez; López, P; Norberto Ibán Lorenzana.

\begin{tabular}{c|c|c|c|} 
Aportaciones: & Experimentación & Procesado & Edición \\
\hline \multirow{2}{*}{$\begin{array}{c}\text { Prototipado } \\
\text { Instrumentación } \\
\text { Registros }\end{array}$} & Matlab & Tablas \\
\cline { 2 - 4 } & & Gráficas \\
\hline
\end{tabular}




\title{
Adjustable TMD (in stiffness and damping) using magnets and coils
}

\author{
Hernández Ovidio ${ }^{1}$, Poncela Alfonso ${ }^{2}$, López, Pablo ${ }^{2}$ and , Ibán Norberto ${ }^{2}$
}

\begin{abstract}
The work focuses on an adjustable tuned mass damper TMD, consisting of a moving mass, a spring and a damper with different pairs of magnets and coils attached. Where initial natural frequencies vary significantly in structural systems, it would be desirable to retune the inertial vibration mitigation devices. If the frequency of the system where the TMD is installed varies significantly, up or down, it will be possible to adapt the stiffness and damping by acting on the electromagnetic fields. Two magnets in opposition to two coils, placed symmetrically, whose field can be controlled by the variation of voltage, can change the stiffness of the spring. Depending on the polarity of the coils, a homogeneous response in repulsion or attraction can be stablished. When the magnets with the coils are in attraction the frequency decreases and when they are in repulsion the frequency increases, being the variation of the module of the frequency dependent on the intensity of the magnetic field. Likewise, the damping will be also adjusted to the new conditions of the structure, by the Eddy currents principle. For that, the interaction between an aluminium plate moving inside a magnetic field is modified by the voltage of another coil, allowing control of the damping.

These phenomena are applied in the lab case shown in Fig. 14, in order to provide a feasible benchmark to test.
\end{abstract}

Keywords: Tuned mass damper, passive and semiactive vibration control, repulsion or attraction, coils, electromagnetic fields.

\section{INTRODUCCIÓN}

Hoy en día algunas estructuras civiles tienen diseños estéticamente muy llamativos y en ocasiones son sensibles a cargas de uso habitual como caminar, correr, etc. A resultas de todo esto los usuarios pueden llegar a experimentar incomodidad durante el tránsito e incluso sensación de inseguridad que es necesario corregir.

El origen del problema radica en que estas estructuras poseen frecuencias naturales bajas (entre $1 \mathrm{y}$ $10 \mathrm{~Hz}$ ), que son coincidentes con las frecuencias que puedan generar los peatones, de ahí el problema suscitado. Cuando esto ocurre, se perciben oscilaciones y vibraciones que pueden resultar molestas. La solución más común para mitigar tales vibraciones es el ya conocido TMD (amortiguador de masas sintonizado, Tuned Mass Damper), que básicamente es un conjunto formado por una masa principal, resorte y amortiguador.

\footnotetext{
${ }^{1}$ ITAP, EII,Universidad de Valladolid,(SPAIN). ovidio.hernandez@alumnos.uva.es, Poncela@eii.uva.es.

${ }^{2}$ Centro Tecnológico CARTIF, Boecillo, Boecillo Valladoli(SPAIN).pablop@cartif.es,noriba@catif.es NOTA: hdez_96@hotmail.com
} 
Cuando este mecanismo (una vez adaptado a la estructura afectada) funciona correctamente, el sistema principal (estructura) se mueve en una dirección tal que excita al TMD (cuya masa móvil sigue con retraso el movimiento), logrando mitigar la vibración hasta niveles significativamente inferiores y posiblemente aceptables por los usuarios.

Este dispositivo lo que hace es desdoblar el pico de la función de respuesta en frecuencia FRF del sistema principal, disminuyendo por tanto el factor de amplificación de la respuesta en amplitudes y aceleraciones. Si el sistema principal no evoluciona a lo largo de su vida útil y mantiene sus características (masas, rigidez, amortiguamiento), el funcionamiento del TMD resulta efectivo. En caso contrario, las prestaciones decaen a medida que se desintoniza. Por esta razón, en este trabajo se plantea como solución la posibilidad de ajustarlo en todo momento a la situación particular de la estructura donde se halle instalado.

EI TMD adaptable (de aquí en adelante lo llama AEM-TMD) va a permitir que, aunque a lo largo de la vida útil de la estructura puedan aparecer fenómenos que cambien sus propiedades modales y comportamiento dinámico (por envejecimiento de los materiales, modificación de la masa no estructural, etc.) el AEM-TMD siga teniendo el máximo rendimiento en la reducción de vibraciones y oscilaciones.

La frecuencia se va a variar mediante un doble conjunto imán-electroimán cuyo punto de trabajo se controlará mediante la tensión aplicada desde el sistema de control asociado.

Para modificar el amortiguamiento se usará un dispositivo similar a un freno electromagnético, consistente en una placa metálica no ferro-magnética a la que se aplicará el campo magnético generado un par de electroimanes cuya intensidad se controla (de nuevo desde el sistema de control asociado) para modificar el campo aplicado y por ende la fuerza de frenado.

El trabajo está organizado de la siguiente forma: tras esta introducción, se plantean los objetivos para seguidamente mostrar la evolución del desarrollo del dispositivo propuesto. Se finalizará con las conclusiones derivadas del trabajo realizado.

\section{OBJETIVOS}

Los objetivos particulares planteados son los siguientes:

- Exponer los fundamentos teóricos y matemáticos de los principios físicos que se van a usar.

- Diseñar dispositivos capaces de responder con los principios propuestos.

- Fabricar el dispositivo ideado: AEM-TMD.

- Modelar el conjunto AEM-TMD para su aplicación en un lazo de control.

\section{DISEÑO PROPUESTO}

\subsection{Prototipo propuesto}

El punto de partida va a ser un TMD tipo ménsula (voladizo horizontal) consistente en una pletina de aluminio ( $30 \mathrm{~mm}$ de ancho, $440 \mathrm{~mm}$ de largo y $2 \mathrm{~mm}$ de espesor), empotrada en un extremo y con una placa (también de aluminio) en el otro a modo de masa principal (ver modelo en Fig. 1 y prototipo en Fig. 14). El amortiguamiento original del conjunto se ajustará situando un imán en las proximidades de la placa de tal manera que el movimiento relativo entre ambos induzca corrientes de Foucault que disipan energía proporcional a la velocidad relativa y por tanto generan amortiguamiento viscoso fácilmente modelable [Wikipedia]. 


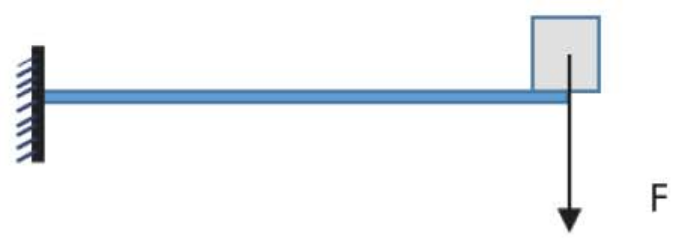

Figura 1. Ménsula

Con el fin de evaluar experimentalmente la rigidez del prototipo (mediante la relación de Hooke), se aplican tres cargas (F) conocidas al extremo libre y mediante un sensor de desplazamiento tipo láser se mide la deformada estática. Los resultados se muestran en la Tabla 1. Para la configuración indicada la rigidez a flexión resulta ser de $61.617 \mathrm{~N} / \mathrm{m}$, siendo el coeficiente de regresión entre los tres valores tomados de 0.9992, como se indica en la Fig. 2.

Tabla 1. Datos para determinación de la rigidez del voladizo.

\begin{tabular}{cc}
\hline DISTANCIA(m) & FUERZA(N) \\
\hline$-0,00324$ & 0,1962 \\
$-0,00628$ & 0,3934 \\
$-0,00965$ & 0,5915 \\
\hline
\end{tabular}

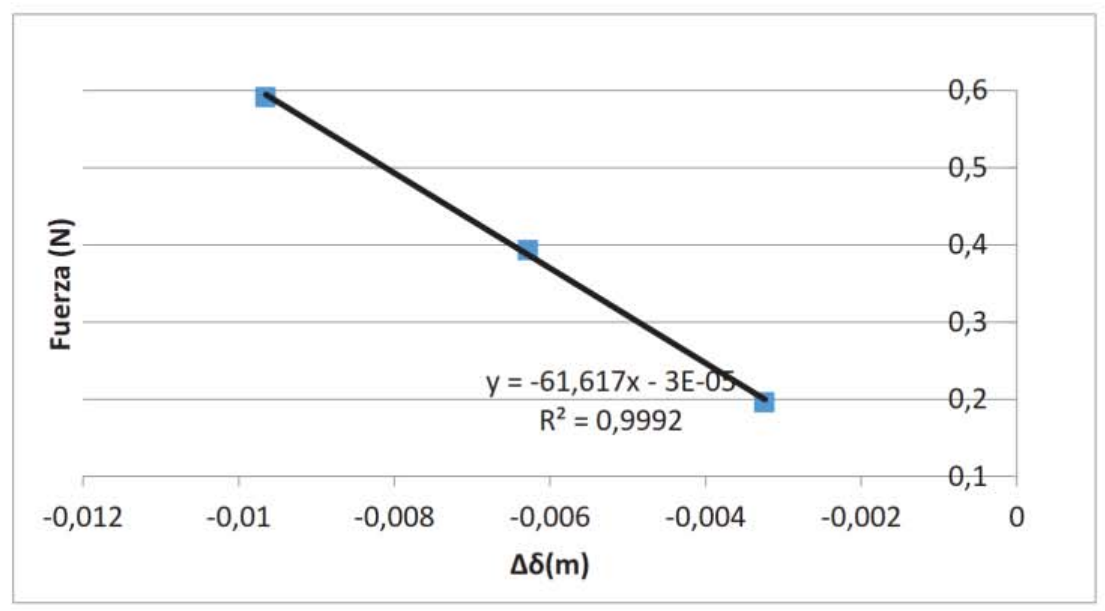

Figura 2. Cálculo de la rigidez

Para el cálculo experimental de la frecuencia y amortiguamiento se utiliza la respuesta temporal del sistema a un pequeño impulso. Para ello, se desplaza una cierta distancia el extremo libre de la ménsula y se libera. Con el láser se registran las oscilaciones. La medición de las frecuencias de dichas señales y el decaimiento exponencial permite determinar los parámetros buscados. De los cálculos se obtienen una frecuencia de $3.513 \mathrm{~Hz}$ y, sin ningún imán en las cercanías de la placa, un coeficiente de amortiguamiento de 0.001. Con la instalación del sistema de rigidez, bobinas e imanes, 
Adjustable TMD (in stiffness and damping) using magnets and coils

Fourth International Conference on Mechanical Models in Structural Engineering Madrid (Spain). 29 nov-01 dec 2017.

y amortiguamiento mínimo, se consigue un sintonizado adecuado de constante de rigidez $3.5332 \mathrm{~Hz}$ y un coeficiente de amortiguamiento 0.053 "base", Fig. 3.

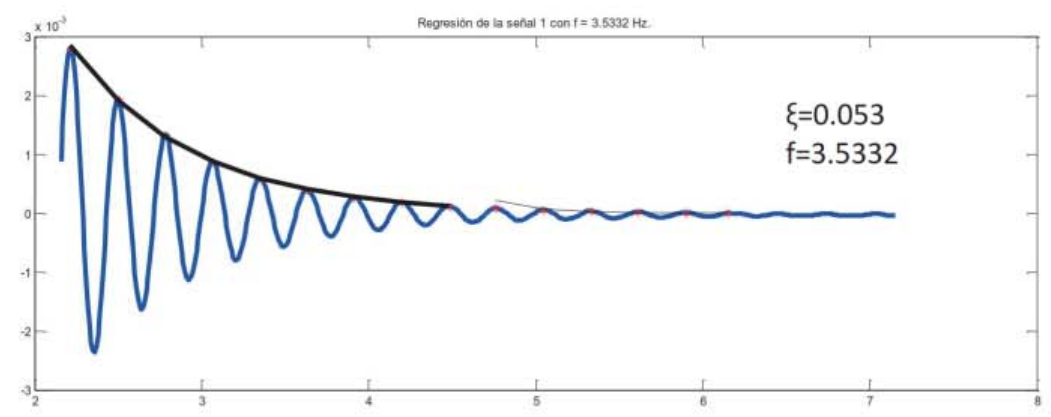

Figura 3. Decaimiento exponencial de la señal para un sintonizado adecuado

\subsection{Ajuste del amortiguamiento mediante bobinas tipo "Iapa"}

El fenómeno físico de las corrientes de Foucault (corrientes parásitas también conocida como "corrientes torbellino", o eddy current en inglés), descubierto por el francés Léon Foucault en 1851, se usará para aumentar el amortiguamiento por encima del 0.053 establecido como "base". Cuanto más fuerte sea el campo magnético aplicado, o mayor la conductividad del conductor, o mayor la velocidad relativa de movimiento, mayores serán las corrientes de Foucault y los campos opositores generados [Wikipedia].

En la placa metálica, al moverse dentro de un campo magnético, se generan corrientes que provocan una fuerza que se opone al movimiento, comportándose la misma como un amortiguamiento viscoso según la Eq.(1).

$f_{\text {frenado }}=C v$

donde la constante de proporcionalidad C depende del campo magnético del imán y de otros factores como la superficie, la conductividad del material y su espesor. También depende de $\sigma 1$ y $\alpha 2$, parámetros que se mencionan en [1].

$C=\sigma \delta B^{2} S\left(\alpha_{1}+\alpha_{2}\right)$

En el caso bajo estudio, el valor de B depende del imán permanente instalado en las cercanías de la placa y de la tensión aplicada en las bobinas correspondientes, denominadas "lapas" (ver Fig.6 y Fig. 7. Como se observa en Eq. (1) (2), el valor de la fuerza de frenado es directamente proporcional a la velocidad de movimiento relativo y depende de la inducción del campo magnético (B) elevada al cuadrado, por eso se espera experimentalmente que el amortiguamiento tenga forma parabólica.

En la Fig. 4 se puede ver el primer prototipo montado. Incluye ménsula, placa y bobina correspondiente, aunque dispuestos de distinta forma a la definitiva mostrada en la Fig. 14. 


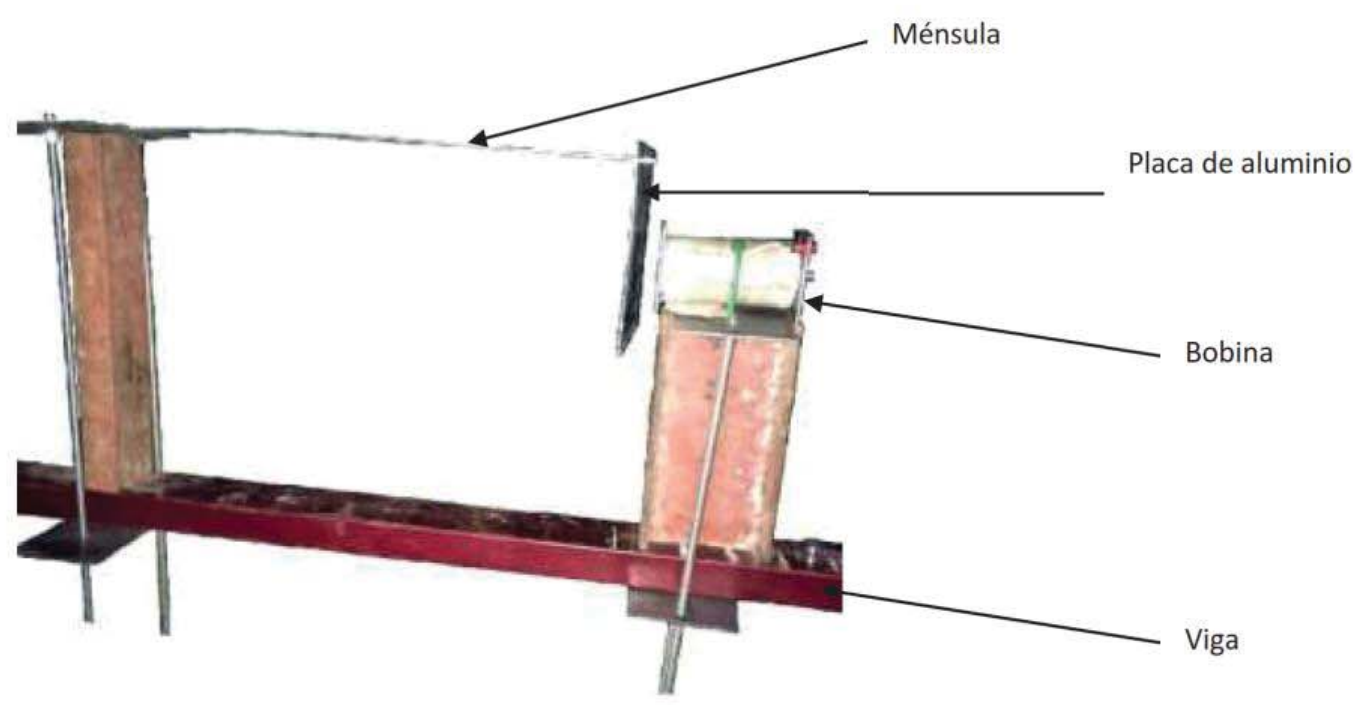

Figura 4. Versión 01 del AEM-TMD

Esta primera versión resultó ser poco práctica. La separación entre la bobina y la placa no se mantenía constante al moverse libremente el conjunto afectando negativamente al efecto del campo magnético sobre la placa. Adicionalmente la bobina resultaba muy pesada y con un alto consumo de corriente.

Placa de aluminio

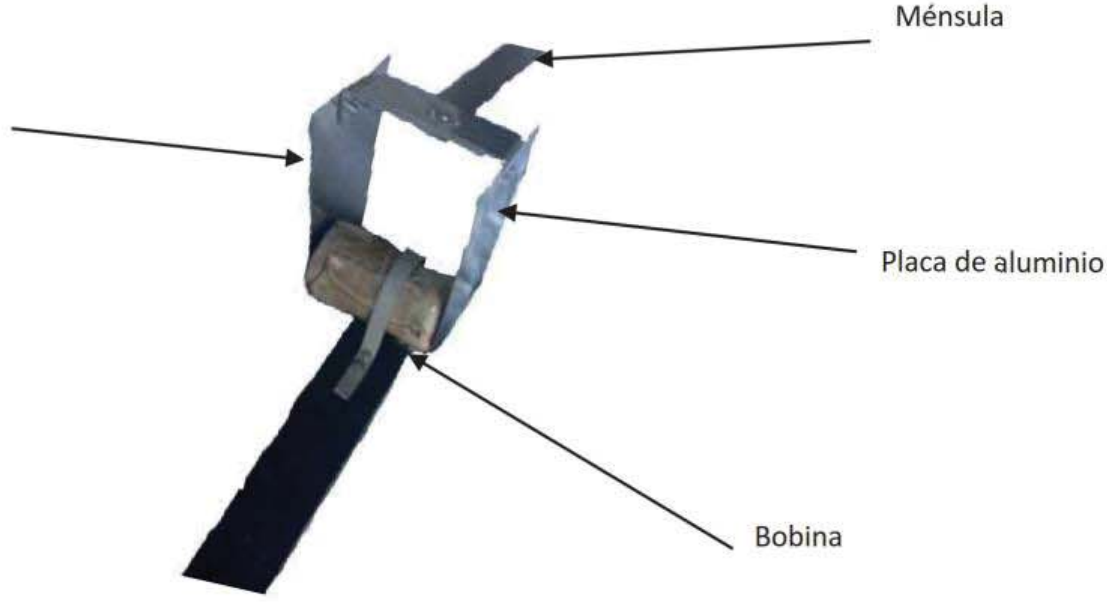

Figura 5. Versión 02 AEM-TMD

Con el fin de eliminar el problema de la falta de paralelismo del movimiento relativo placa bobina, se cambia el diseño inicial por el de la Fig. 5 en donde puede verse como en lugar de una placa se usan dos situadas a ambos lados de los polos de la bobina. El sistema mejora pero sigue siendo muy pesado y consumiendo mucha corriente. 
Adjustable TMD (in stiffness and damping) using magnets and coils

Fourth International Conference on Mechanical Models in Structural Engineering

Madrid (Spain). 29 nov-01 dec 2017.

Con el fin de solventar el problema de peso de la bobina y su alto consumo se recurre a electroimanes tipo lapa eléctrica mostrados en la Fig. 6, que con su disposición geométrica logran cerrar el campo electromagnético y ser más eficientes. Se disponen 2, como se muestra en la Fig. 7, logrando de esta manera un prototipo suficientemente funcional.

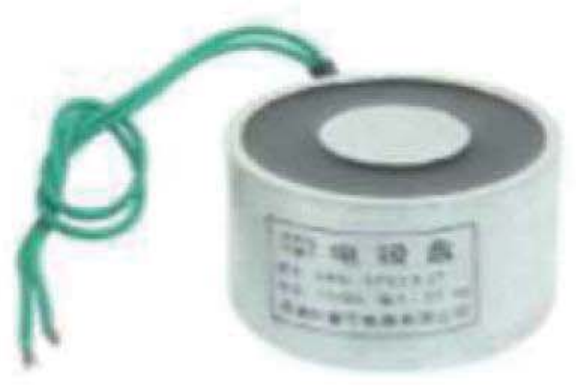

Figura 6. Bobina lapa para el control del amortiguamiento (Soline Sucked Elecric Lifting Magnet Electromagnet) amazon

Placa de aluminio

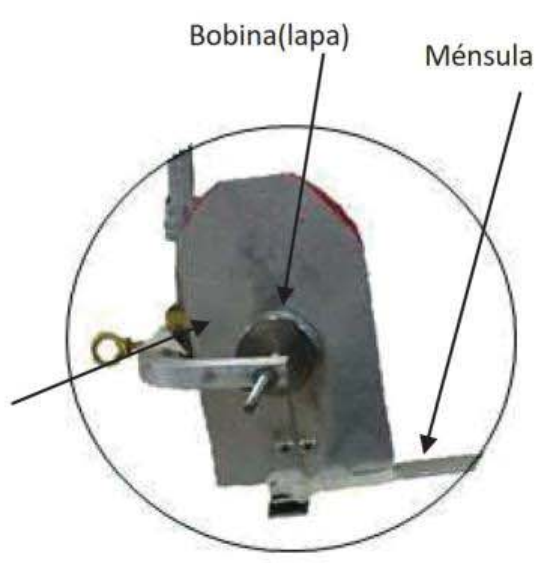

Placa de aluminio

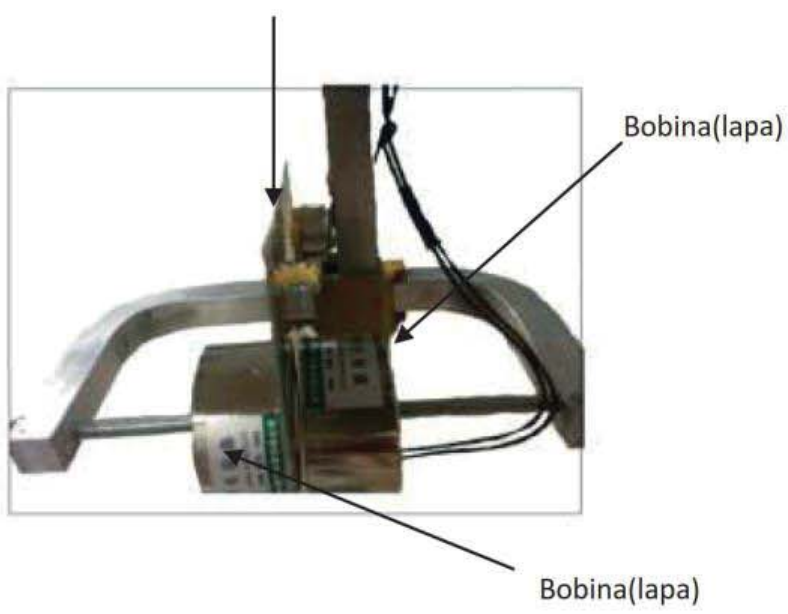

Figura 7. Versión 03 AEM-TMD

Sobre esta solución se realizaron pruebas para su caracterización. Se toman valores de tensión desde 0 hasta $+24 \mathrm{~V}$, obteniéndose los resultados mostrados en la Tabla 2 y en la Fig. 8 . Se ve cómo se pasa 
Hernández Ovidio ${ }^{1}$, Poncela Alfonso ${ }^{2}$, López, Pablo ${ }^{3}$ and, Ibán Norberto ${ }^{2}$

de 0.053 a 0.094 , consiguiendo un incremento del amortiguamiento del $77.35 \%$. En la propia Fig. 8 se muestra el ajuste cuadrático resultante.

Tabla 2. Medición de amortiguamiento de las lapas

\begin{tabular}{cc|cc}
\hline $\begin{array}{l}\text { Bobinas } \\
\text { (Vcc) }\end{array}$ & Amortiguamiento & $\begin{array}{l}\text { Bobinas } \\
\text { (Vcc) }\end{array}$ & Amortiguamiento \\
\hline 0 & 0,053 & 13 & 0,068 \\
1 & 0,053 & 14 & 0,07 \\
2 & 0,053 & 15 & 0,072 \\
3 & 0,053 & 16 & 0,075 \\
4 & 0,054 & 17 & 0,077 \\
5 & 0,056 & 18 & 0,079 \\
6 & 0,056 & 19 & 0,081 \\
7 & 0,059 & 20 & 0,085 \\
8 & 0,059 & 21 & 0,087 \\
9 & 0,061 & 22 & 0,089 \\
10 & 0,062 & 23 & 0,091 \\
11 & 0,063 & 24 & 0,094 \\
12 & 0,067 & &
\end{tabular}

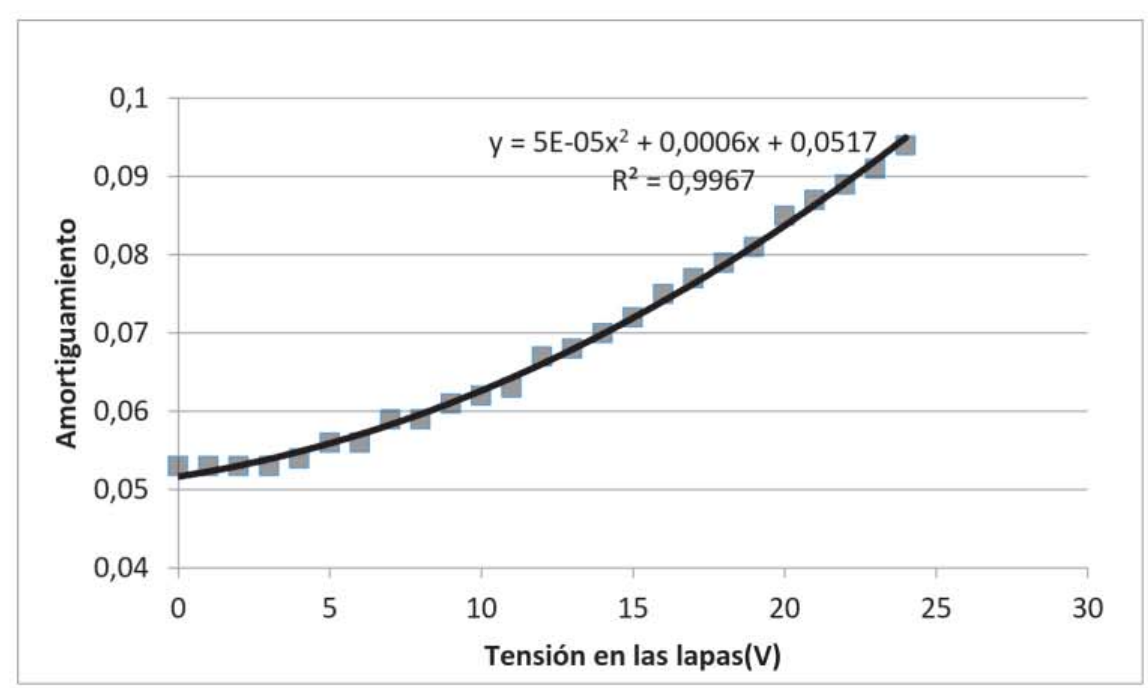

Figura 8. Amortiguamiento vs tensión en las lapas 


\section{CMMOST 2017}

4th INTERNATIONAL CONFERENCE ON

MECHANICAL MODELS IN

\section{STRUCTURAL ENGINEERING}

Madrid, SPAIN

29 Nov - 1 Dec

Technical University of Madrid

ETSI de Caminos, Canales y Puertos

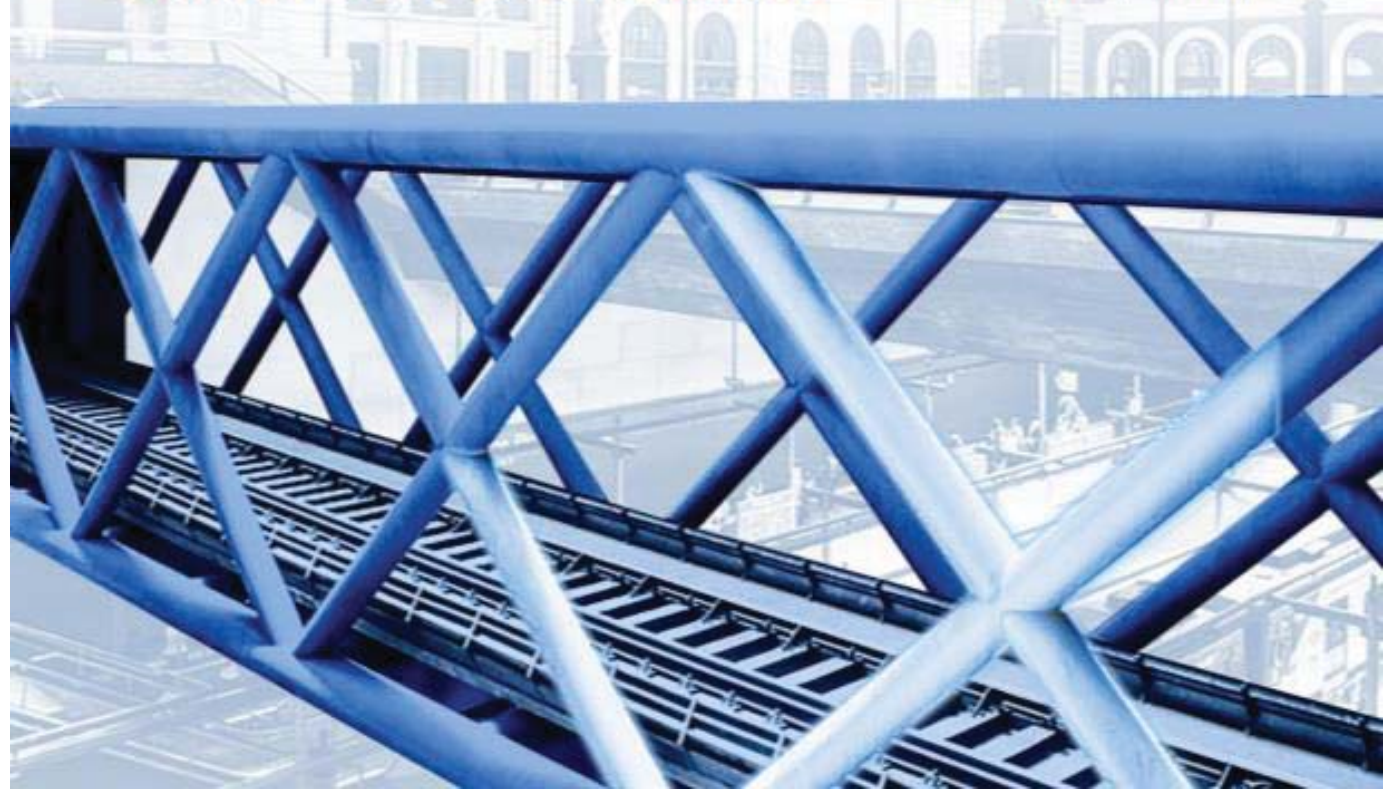

Norberto Ibán Lorenzana; Álvaro Magdaleno González; Mariano Cacho Pérez; Iván Muñoz Díaz.

\begin{tabular}{c|c|c|c|} 
Aportaciones: & Experimentación & Procesado & Edición \\
\hline \multirow{2}{*}{} & Instrumentación & Matlab & Tablas \\
& Registros & Excel & Gráficas \\
& & Calibrado & Imágenes \\
& & ANSYS & Defensa \\
\cline { 2 - 4 }
\end{tabular}




\title{
OPTIMAL LOCATION OF TMD ON ALIVELY FOOTBRIDGE
}

\author{
Norberto Ibán ${ }^{1}$, Álvaro Magdaleno ${ }^{2}$, Mariano Cacho², Iván M. Díaz ${ }^{2}$ \\ ${ }^{1}$ Centro Tecnológico CARTIF, Valladolid (SPAIN). noriba@cartif.es \\ 2ITAP, EII. Universidad de Valladolid. (SPAIN). alvaro.magdaleno@uva.es, cacho@eii.uva.es \\ ${ }^{3}$ ETSICCP, Universidad Politécnica de Madrid, Madrid (SPAIN), ivan@upm.es
}

Palabras Clave: Elementos finitos; Actualización de Modelos; Amortiguador de Masa Sintonizado; Diseño Óptimo; Respuestas Temporales

autor: noriba@cartif.es (Norberto Ibán)

\section{RESUMEN}

Las estructuras sometidas a excitaciones inducidas por las acciones humanas pueden producir efectos vibratorios que generen grandes aceleraciones y en general problemas de serviciabilidad. El control de las vibraciones mediante sistemas pasivos, semiactivos y activos han sido propuestos como posibles soluciones para reducir el nivel vibratorio en estructuras como puedan ser los puentes, mástiles de aerogeneradores o estructuras esbeltas, entre otros [1]. Se sabe que los amortiguadores de masa sintonizada (AMS o TMD, Tuned mass damper) atenúa la respuesta de la vibración de una estructura incrementando su amortiguación mediante la aplicación de fuerzas inerciales que generan una respuesta al movimiento dado por la estructura [2]. Recientemente, se han propuesto diferentes implementaciones de TMD para mejorar su eficiencia. En el caso de estructuras con frecuencias naturales espacialmente distribuidas los diseños y la ubicación de los TMDs pueden no ser tan obvios al no ser adecuado aplicar la teoría de Den Hartog [3] debido a los efectos de acoplamiento entre los diferentes modos de la estructura y el del propio TMD [4]. Por ello se recomienda calibrar el modelo y estimar sobre él la verdadera actuación del TMD. El objetivo de este trabajo es analizar si una estrategia basada en el análisis de las FRFs, sobre un modelo computacional actualizado es adecuado para evaluar la adecuación de un TMD o por el contrario los fenómenos transitorios debidos a las típicas solicitaciones presentes en estas estructuras, acciones humanas, deben ser consideradas para su optimización a tenor de los resultados de las respuestas dinámicas evaluadas en términos de aceleraciones.

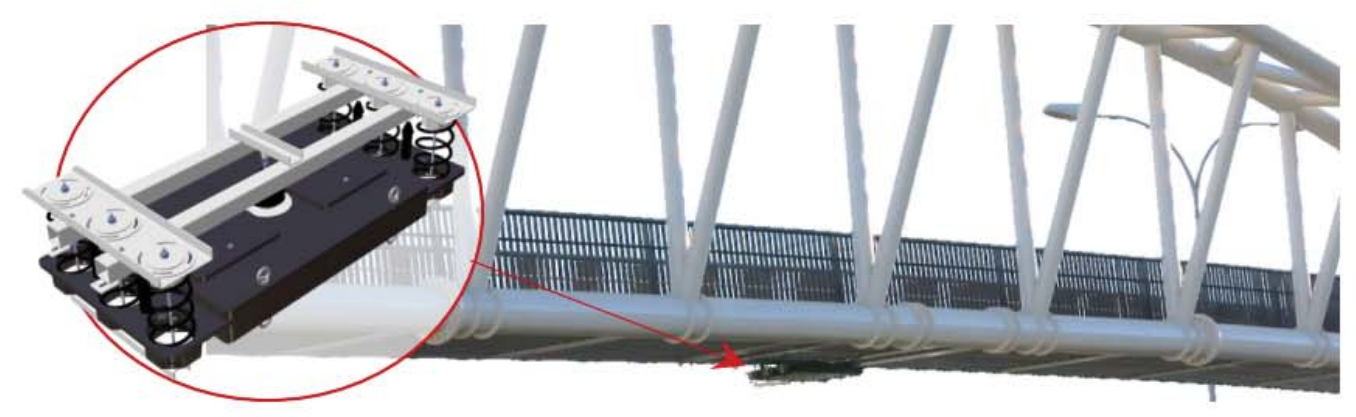

Figura 1. Acoplamiento real de TMD-pasarela peatonal 


\section{INTRODUCION}

Aunque en el pasado, en el sector de la ingeniería civil venía siendo habitual el uso de modelos aproximados para estimar la respuesta dinámica de las estructuras de tipo puente, hoy en día es habitual modelar la estructura utilizando las actuales capacidades CAE. El uso de modelos discretos y simples ha demostrado ser insuficientes para el adecuado modelado de estructuras esbeltas, ya que no pueden representar algunos efectos relacionados con los modos de vibración cuando estos están estrechamente espaciados y que frecuentemente ocurren en la práctica. Además, las pasarelas modernas son cada vez más esbeltas y propensas a oscilar bajo la acción de los peatones, por lo que necesidad de considerar las vibraciones y su control en la fase de diseño es primordial.

Conocer los métodos FE y las capacidades para realizar un modelado preciso y que se ajuste a un comportamiento estructural real, capaz a su vez de convertirse en un software asequible, guiaría, sin vacilar, a los profesionales de la ingeniería civil. Sin embargo, en lo que respecta al diseño estructural, hay una falta de experiencia en modelado de FE, particularmente en lo que respecta a su estado modal, no siendo raro que el modelo no coincida con la estructura real. La forma de avanzar en el desarrollo de estas competencias es vincular las pruebas modales y el análisis FE con la actualización de los modelos de las estructuras y extraer unas directrices generales de diseño. Un procedimiento para la toma de medidas experimentales y la actualización de los modelos de elementos finitos fueron descritos en trabajos anteriores así como el estudio y las propuestas de los dispositivos de mitigación sobre ese modelo numérico calibrado. También se estudió su ubicación óptima mediante estrategias basadas en FRFs (funciones de respuesta de frecuencia) sobre modelos simplificados. Destacar la dificultad que entraña estas estrategias, pues no solo es una tarea tediosa (se deben considerar varias FRF a lo largo de la pasarela), sino también su limitación, ya que el cruce de peatones es un efecto transitorio y las curvas FRF no incluyen la respuesta transitoria, solo el estacionario bajo carga armónica siendo esto una de las principales deficiencias de los modelos existentes, pues no consideran los cambios en las propiedades dinámicas del sistema debidos a la presencia y tránsito de los peatones.

Por ello en este trabajo se lleva a cabo una comparativa entre estrategias basadas en FRFs con las respuestas de varias simulaciones, en las que entran en consideración dispositivos de mitigación en diferentes ubicaciones para diferentes escenarios.

\section{DESCRIPCION DE LA PASARELA}

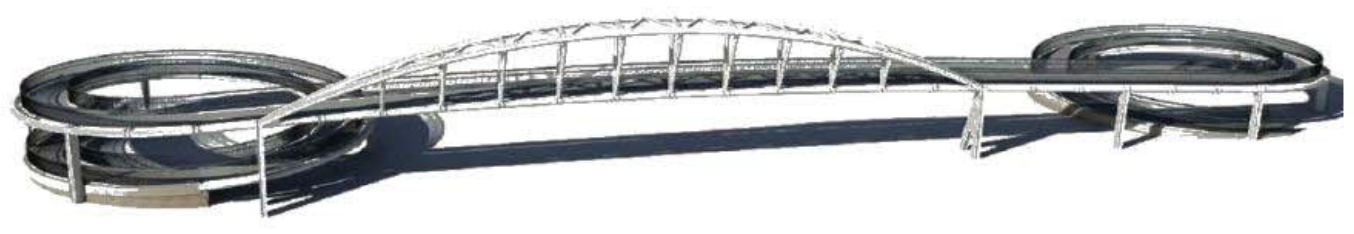

Figura 2. Pasarela bajo estudio

En este trabajo la estructura en cuestión es la pasarela peatonal de acceso al Estadio Balear sobre la Vía de cintura Ma-20 de Manacor (Palma de Mallorca). El vano central dispone de un arco construido a base de dos tubos de acero de diámetro $500 \mathrm{~mm}$ montados en celosía con 9 montantes de diámetro $200 \mathrm{~mm}$. El arco está formado por dos tubos, uno alineado sobre la vertical que da inercia al sistema y 
otro ligeramente desviado para contrarrestar el momento producido por el tablero en voladizo. El tablero montado sobre las ménsulas está construido a base de hormigón armado con chapa colaborante. En la anterior conferencia de IOMAC se presentó el procedimiento para actualizar esta pasarela para que los resultados computacionales coincidan con las mediciones desde un punto de vista estático, modal y dinámico. Las dos primeras frecuencias son $2.098 \mathrm{~Hz}$ y $2.505 \mathrm{~Hz}$, ambos en el rango propenso a ser excitada por un peatón caminando. El amortiguamiento estructural (tipo Rayleigh) se fijó en $0,32 \%$.

\section{MODELO DE ELEMENTOS FINITOS}

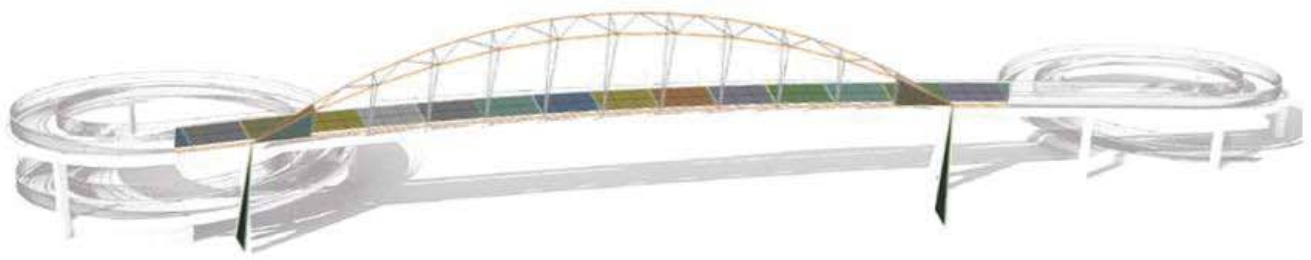

Figura 3. Modelo numérico de EF de la pasarela

Como primer paso se generó un modelo de elementos finitos de la estructura en cuestión mediante el software comercial ANSYS usando más de 620 elementos tipo BEAM188 para las barras tubulares de acero y 455 elementos SHELL181 para la cubierta de hormigón. Se consideraron varios tipos de sección transversal para el esqueleto de acero según las dimensiones comentadas en el anterior punto, pero para la cubierta se utilizó un elemento de espesor constante $(200 \mathrm{~mm})$. Aunque los pasamanos de la pasarela se muestran rígidamente unidos a la cubierta, se ha considerado excluirlos del modelado computacional por su baja o prácticamente nula participación estructural. Sin embargo su masa si ha sido considerada sobre el peso de la cubierta. Los parámetros modales (frecuencias naturales, formas modales y amortiguamientos modales) fueron extraídos tras el proceso de actualización del modelo.

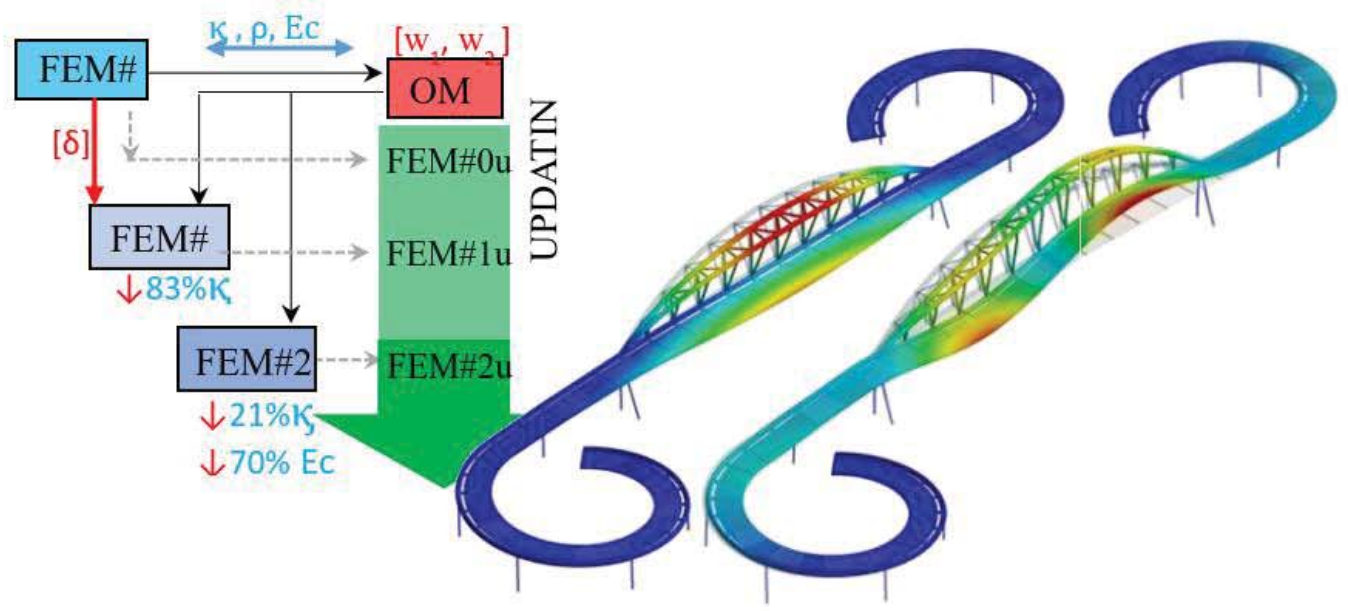

Figura 4. Primeras dos deformadas modales del modelo actualizado 
Una vez calibrado el modelo numérico (de manera estática y modal), ambos modelos deben responder de manera similar cuando son excitados por cualquier fuerza dinámica. Después de comprobar que esto es cierto (figura 5), usando para ello una fuerza tipo aplicada sobre el centro del vano, se acopla el TMD. El objetivo de esta fuerza tipo era la de obtener un registro de la respuesta con la que comparar y corresponde a una fuerza armónica a 2.098 usando un shaker. En la figura 5 se representa dicha fuerza y el registro de la respuesta donde, en el primer tramo (hasta el segundo 32) aparece la respuesta forzada y en el segundo la caída libre.

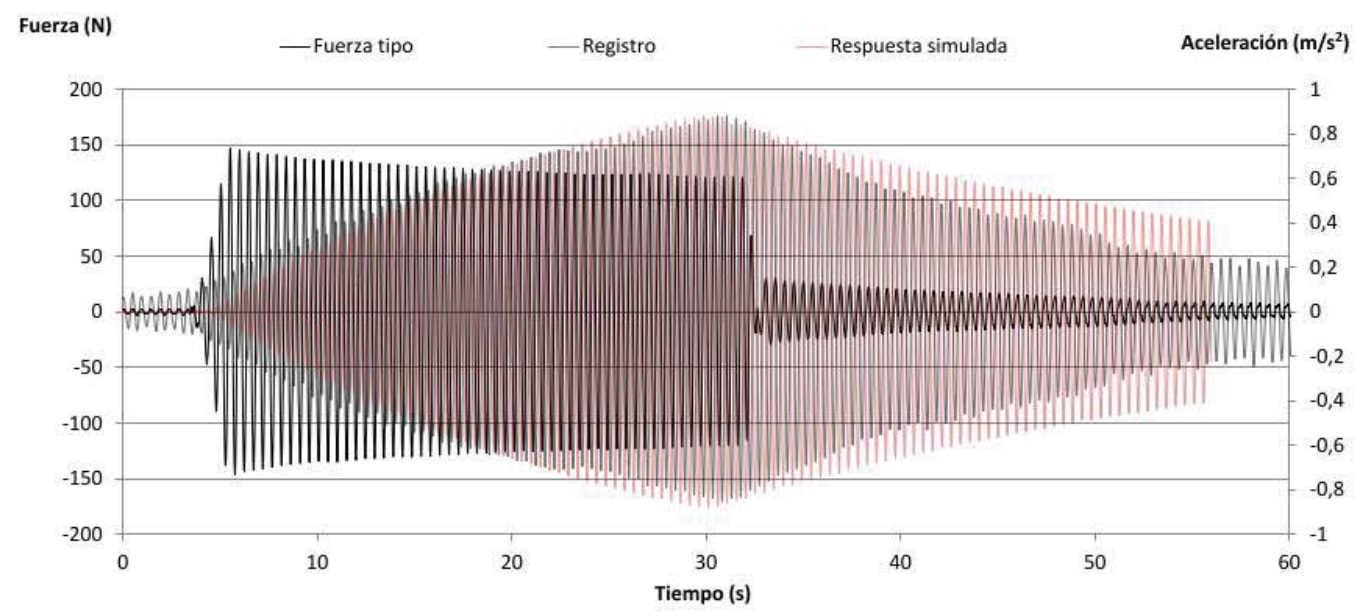

Figura 5. Respuesta en el punto medio del vano del modelo y su comparativa en la realidad

Con la estructura perfectamente modelada y ajustada con la realidad el propósito ahora es modelar al peatón. Para ello destacar que la principal diferencia entre la masa móvil con velocidad (propuesta en el modelo de interacción peatón-estructura) y la dada por una carga constante móvil es que la carga aplicada sobre la estructura debido a la masa suspendida es variable con el tiempo y la ubicación. La Figura 6 muestra el modelo adoptado haciendo uso de los diferentes elementos de la biblioteca de Ansys así como de su forma de contacto.

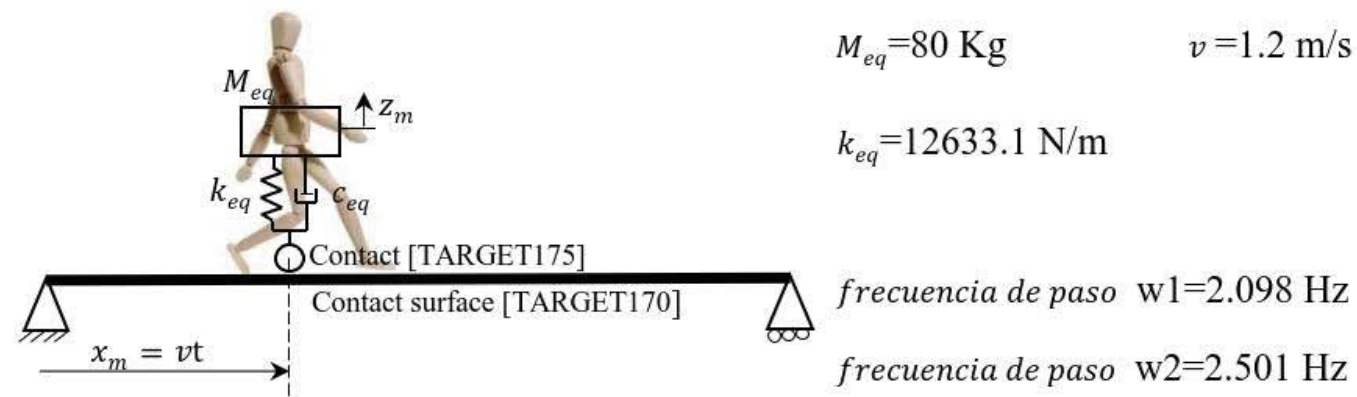

Figura 6. Modelo de interacción peatón-estructura propuesto 


\section{ESTRATEGIAS BASADAS EN FUNCIONES DE RESPUESTA EN FRECUENCIA}

Tratando de predecir la ubicación óptima del dispositivo atenuador sin considerar los fenómenos transitorios, se obtiene las FRFs (funciones de respuesta en frecuencia) para los diferentes escenarios. Los escenarios varían en función del dispositivo amortiguador empleado así como de su ubicación (A-B-C-D-E-F). Para todos los dispositivos amortiguadores (TMD) se emplea una tonelada de masa móvil inercial (que es el $2 \%$ de la masa total del modelo actualizado de la pasarela). Aunque el TMD puede sintonizarse para cualquiera de los modos se considera comenzar el estudio centrándose en el caso de que el TMD esté siempre sintonizado para la primera frecuencia resonante (w1). Para lograr este enfoque el TMD tendrá diferentes sintonizados (cuyos parámetros han sido resueltos en base a la estrategia comentada en el apartado anterior y mediante una rutina de Matlab evaluada para cada escenario, es decir su frecuencia y amortiguamiento irán en función de su posición y su objetivo). Fijaremos la atención en las posiciones $F$ ( $1 / 2$ del vano central) y C (posición 3/4) por la experiencia adquirida.

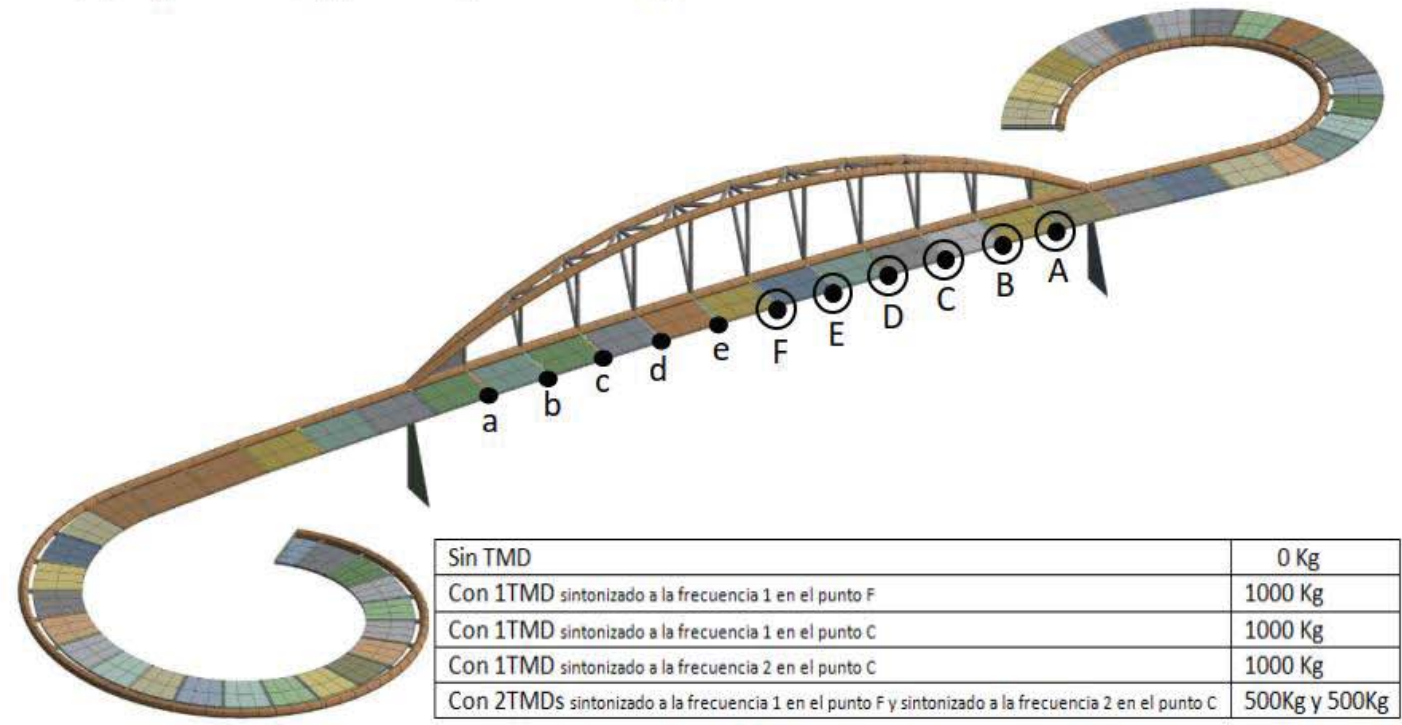

Figura 7. Posibles localizaciones para el TMD

La simulación de este problema proporciona los resultados de la figura 8 donde se puede apreciar las FRFs para el punto de análisis (P) cuando la fuerza de excitación se localiza en ese mismo punto (P) para los diferentes escenarios de estudio (sin TMD, conTMD). Destacar que entre los escenarios en los que se simula el acoplamiento del TMD este estará localizado en alguna de las dos posiciones siguientes, $\mathrm{F}$ o C, atacando siempre en la minimización del modo uno. Así la notación será FRF [P, TMDw1_FoC].

Atendiendo ahora a lo que denominamos factor de amplificación (FA) y obtenido como el valor FRF en la frecuencia w1 para los diferentes casos de estudio analizaremos mediante el valor sumatorio de estos (factor de amplificación acumulado) la educabilidad del acoplamiento mediante su comparación con los resultados que obtengamos usando estrategias basadas en respuestas transitorias de las aceleraciones en el punto medio de la pasarela. 


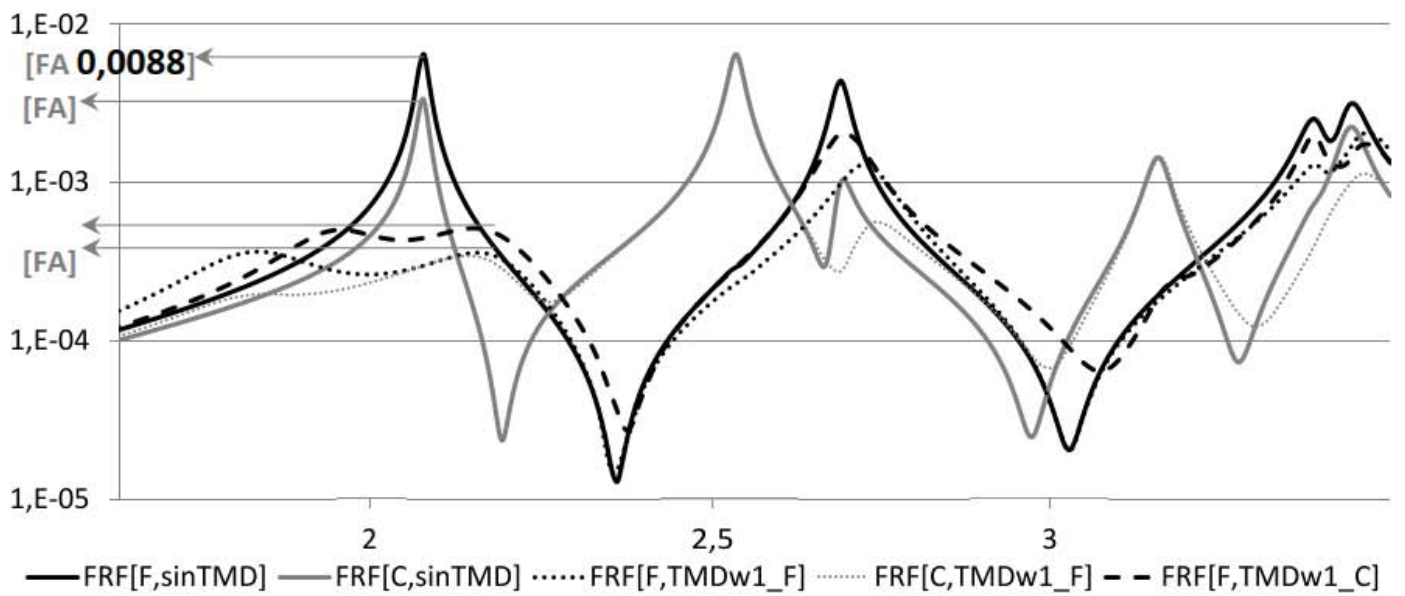

Figura 8. FRFs para los casos sin TMD y con TMD ubicado en el centro del vano (punto F)

Hacer notar que en la obtención del factor de amplificación acumulado deriva de considerar la suma de los factores de amplificación para cada uno de los puntos como consecuencia de que un peatón al andar por toda la estructura pasa por cada uno de los puntos A, B, C, D, E, F, e, d, c, b, a obteniendo para cada uno de ellos, la respuesta estacionaria significativa (aunque realmente no habrá llegada al estacionario), y ser de esta forma representativo para todo el vano.

Tabla 1. Factores de amplificación ante una fuerza actuante en el punto $F$ para cada uno de los puntos a evaluar

\section{Factor de Amplificación [FA]}

\begin{tabular}{|c|c|c|c|c|c|c|c|c|c|c|c|c|}
\hline & a & $b$ & c & $d$ & e & $\mathbf{F}$ & E & D & $\mathrm{C}$ & B & A & $\sin T M D$ \\
\hline w1 & $\ldots$ & $\ldots$ & $\ldots$ & $\ldots$ & $\ldots$ & 0,0088 & 0,0085 & 0,0076 & 0,0063 & 0,0049 & 0,0034 & 0,0701 \\
\hline w2 & $\ldots$ & $\ldots$ & $\ldots$ & $\ldots$ & $\ldots$ & 0,0003 & 0,0003 & 0,0004 & 0,0005 & 0,0004 & 0,0003 & 0,0041 \\
\hline w3 & $\ldots$ & $\ldots$ & $\ldots$ & $\ldots$ & $\ldots$ & 0,0054 & 0,0048 & 0,0037 & 0,0025 & 0,0014 & 0,0008 & 0,0319 \\
\hline
\end{tabular}

con TMDw1_F

\begin{tabular}{rrrrrrrrrrrrrr}
\hline w1 & $\ldots$ & $\ldots$ & $\ldots$ & $\ldots$ & $\ldots$ & $\mathbf{0 , 0 0 0 4}$ & 0,0004 & 0,0004 & 0,0003 & 0,0003 & 0,0002 & $\mathbf{0 , 0 0 4}$ \\
\hline w2 & $\ldots$ & $\ldots$ & $\ldots$ & $\ldots$ & $\ldots$ & 0,0002 & 0,0002 & 0,0003 & 0,0004 & 0,0003 & 0,0002 & & 0,003 \\
\hline w3 & $\ldots$ & $\ldots$ & $\ldots$ & $\ldots$ & $\ldots$ & 0,0014 & 0,0013 & 0,0011 & 0,0008 & 0,0006 & 0,0004 & 0,010
\end{tabular}




\begin{tabular}{|c|c|c|c|c|c|c|c|c|c|c|c|c|}
\hline & \multicolumn{11}{|c|}{ Factor de Amplificación [FA] } & \multirow{2}{*}{$\begin{array}{l}\text { FA acumulado } \\
\text { con TMDw1_C }\end{array}$} \\
\hline & a & $b$ & c & d & e & $\mathbf{F}$ & $\mathrm{E}$ & D & C & B & A & \\
\hline w1 & $\ldots$ & $\ldots$ & $\ldots$ & $\ldots$ & $\ldots$ & 0,0005 & 0,0005 & 0,0005 & 0,0005 & 0,0004 & 0,0002 & 0,005 \\
\hline w2 & $\ldots$ & $\ldots$ & $\cdots$ & $\ldots$ & $\ldots$ & 0,0003 & 0,0002 & 0,0001 & 0,0001 & 0,0001 & 0,0001 & 0,002 \\
\hline w3 & $\ldots$ & $\ldots$ & $\ldots$ & $\ldots$ & $\ldots$ & 0,0023 & 0,0022 & 0,0018 & 0,0012 & 0,0008 & 0,0005 & 0,015 \\
\hline
\end{tabular}

\begin{tabular}{|c|c|c|c|c|c|c|c|c|c|c|c|c|}
\hline & \multicolumn{11}{|c|}{ Factor de Amplificación [FA] } & \multirow{2}{*}{$\begin{array}{l}\text { FA acumulado } \\
\text { con TMDw2_C }\end{array}$} \\
\hline & a & $b$ & c & $d$ & e & $\mathbf{F}$ & $E$ & $\mathrm{D}$ & $\mathrm{C}$ & B & A & \\
\hline w1 & $\ldots$ & $\cdots$ & $\cdots$ & $\cdots$ & ... & 0,0013 & 0,0014 & 0,0014 & 0,0013 & 0,0010 & 0,0007 & 0,013 \\
\hline w2 & $\ldots$ & $\ldots$ & $\ldots$ & $\ldots$ & $\ldots$ & 0,0003 & 0,0002 & 0,0002 & 0,0002 & 0,0002 & 0,0001 & 0,002 \\
\hline w3 & ... & $\cdots$ & $\cdots$ & $\cdots$ & $\cdots$ & 0,0019 & 0,0015 & 0,0011 & 0,0007 & 0,0005 & 0,0003 & 0,010 \\
\hline
\end{tabular}

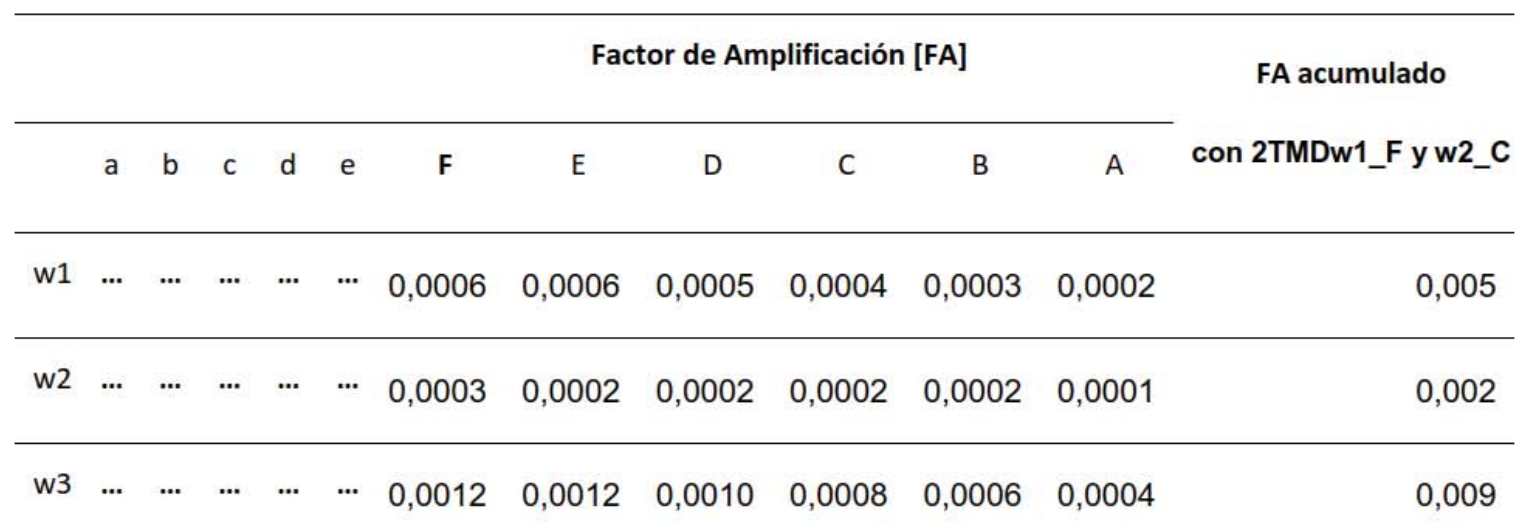

Estos resultados analizados cuando la fuerza es considerada sobre el punto $\mathrm{F}$ pueden ser, de igual modo, analizados para los diferentes puntos restantes obteniendo los factores de amplificación acumulados para los diferentes escenarios siendo estos resultados los mostrados en la siguiente tabla. 
Tabla 2. Factores de amplificación acumulada para todos los puntos de análisis

\begin{tabular}{|c|c|c|c|c|c|c|}
\hline & & & Facto & amplificacić & Imulados [FA & \\
\hline & & sinTMD & TMDw1enF & TMDw1enC & TMDw2enc & 2TMDw1Fw2C \\
\hline & w1 & 0,070 & 0,004 & 0,005 & 0,013 & 0,005 \\
\hline $\mathrm{F}$ & w2 & 0,004 & 0,003 & 0,002 & 0,002 & 0,002 \\
\hline & w3 & 0,032 & 0,010 & 0,015 & 0,010 & 0,009 \\
\hline & w1 & 0,067 & 0,003 & 0,000 & 0,000 & 0,000 \\
\hline $\mathrm{E}$ & w2 & 0,038 & 0,037 & 0,000 & 0,000 & 0,000 \\
\hline & w3 & 0,046 & 0,038 & 0,002 & 0,002 & 0,002 \\
\hline & w1 & 0,060 & 0,003 & 0,005 & 0,014 & 0,004 \\
\hline D & w2 & 0,061 & 0,061 & 0,004 & 0,002 & 0,003 \\
\hline & w3 & 0,065 & 0,061 & 0,013 & 0,007 & 0,009 \\
\hline & w1 & 0,050 & 0,003 & 0,005 & 0,013 & 0,004 \\
\hline C & w2 & 0,070 & 0,063 & 0,004 & 0,003 & 0,003 \\
\hline & w3 & 0,072 & 0,061 & 0,010 & 0,005 & 0,007 \\
\hline & w1 & 0,038 & 0,003 & 0,004 & 0,010 & 0,003 \\
\hline B & w2 & 0,061 & 0,061 & 0,004 & 0,002 & 0,003 \\
\hline & w3 & 0,062 & 0,061 & 0,008 & 0,004 & 0,005 \\
\hline & w1 & 0,027 & 0,002 & 0,003 & 0,007 & 0,002 \\
\hline A & w2 & 0,042 & 0,042 & 0,003 & 0,002 & 0,002 \\
\hline & w3 & 0,043 & 0,042 & 0,005 & 0,003 & 0,004 \\
\hline
\end{tabular}

Analizando estos valores se aprecia como el escenario donde el TMD se dispone en la posición central del vano (F) se ve reducido en un $93.84 \%$ mientras la fuerza de excitación oscila a la frecuencia w1 sobre ese mismo punto mientras que sería un $92.18 \%$ cuando la fuerza de excitación oscila a la frecuencia w1 sobre el punto F cuando el TMD se ubica en C.

De este modo y con los valores obtenidos para los diferentes escenarios podemos representar el diagrama de barras de la Figura 9 . Este gráfico representa no solo los diferentes factores de amplificación cuando la fuerza de excitación coincide con la localización del punto a evaluar sino que podemos usarlos para llevar a cabo una evaluación más completa donde la localización de la excitación entra en consideración. Aunque los valores del factor de amplificación extraídos no incluyen la respuesta transitoria, hecho por el cual necesitamos comprobar la influencia de la carga transitoria que será analizada en el siguiente apartado, sí podrían establecer nuevas medidas de evaluación.

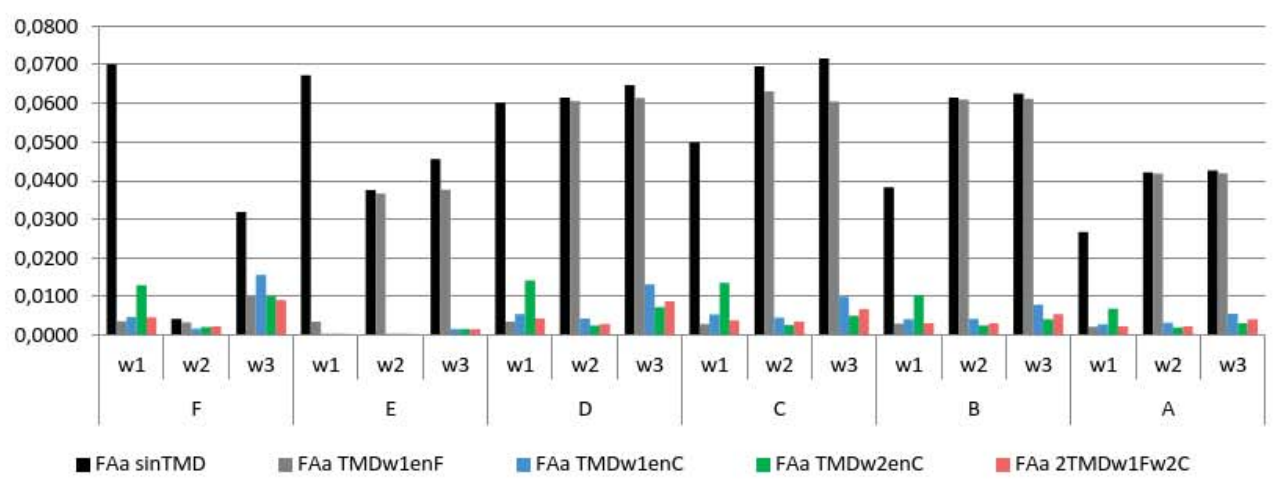

Figura 9. Factores de amplificación acumulada

Centrando la atención únicamente en lo que ocurre en el punto medio (F) el TMD estaría mejor ubicado en el punto central que en el punto $\mathrm{C}$ para cuando la frecuencia de excitación es la propia 
del modo 1. Con esta estrategia basada en FRFs y a raíz del diagrama mostrado podemos analizar las reducciones que tiene lugar en cada uno de los escenarios respecto del escenario de partida (sin_TMD) considerando diferentes hipótesis de evaluación y contemplando de esta manera no solo la reducción que acarrea un TMD en una ubicación concreta para atacar un modo concreto, sino estudiando la respuesta frente a otras posibles frecuencias propias de los otros modos analizados.

De este modo y ante los resultados que se muestran en la Tabla 3 se observa que la adopción de dos TMDs ubicados en los puntos F y C sintonizados cada uno a una frecuencia es la mejor opción cuando prevemos que la pasarela puede verse excitada ante más de una frecuencia o para el caso de excitarla en su modo 3. También ve que si la única posibilidad de excitación fuese la dada a la primera frecuencia la ubicación de un TMD sintonizado para atacar este modo en la posición F es ligeramente mejor que la combinación de los dos TMDs y algo similar ocurre ante la posibilidad de un peatón que anda a la frecuencia 2, donde un TMD ubicado en C sintonizado para atajar esta frecuencia 2 reduce su nivel vibratorio ligeramente más que la opción de los dos TMDs Tabla 9.

Tabla 3. Porcentajes de reducción en términos de FAa

\begin{tabular}{ccccc}
\hline & 1TMDw1_F & 1TMDw1_C & 1TMDw2_C & 2TMDsw1_Fy w2_C \\
\hline w1 & 93,84 & 92,18 & 77,25 & 93,79 \\
\hline w2 & 10,42 & 88,06 & 88,57 & 87,26 \\
\hline w3 & 18,44 & 81,51 & 88,4 & $\mathbf{8 7 , 9}$ \\
\hline w1w2 & 52,84 & 93,11 & 87,87 & $\mathbf{9 6 , 3 8}$ \\
\hline
\end{tabular}

Estos resultados serán comparados con las respuestas de la pasarela para diferentes escenarios, con el fin de extraer algunas conclusiones interesantes cuando el modelo incluye el efecto de los cambios en las propiedades dinámicas de la pasarela debido a la presencia del peatón.

\section{ESTRATEGIAS BASADAS EN EL ANALISIS DE LOS REGISTROS TEMPORALES}

Para la comprensión de la respuesta acoplada, se realizan varias simulaciones elegidas convenientemente, pues el coste temporal de la simulación es elevado, la más lógica (TMD localizado justo en el centro del tramo principal y sintonizado a la primera frecuencia) frente a otras. Se comparan las respuestas de la pasarela para diferentes escenarios, con el fin de extraer algunas conclusiones interesantes cuando el modelo incluye el efecto de los cambios en las propiedades dinámicas de la pasarela debido a la presencia del peatón.

El escenario considerado parte de que el peatón comienza su paso con origen a 6.6 metros de distancia del comienzo del vano y finaliza a 9.9 metros tras el fin del vano. Se mencionó anteriormente que el vano central consta de 40 metros. Todas las respuestas estudiadas en este apartado han sido obtenidas para un punto ubicado en la posición media del vano coincidente con el punto F) tal como se representa en la Figura 10 . Se parte de un tránsito de una persona $(80 \mathrm{Kg})$ que materializo la acción peatonal de andar a 125 bpm, registro con el cual se desea comparar la respuesta del modelo. El tiempo dedicado a cruzar los $56.5 \mathrm{~m}$ de vano fue estimado en unos 47 segundos, por tanto, se consideró la velocidad de tránsito como $1.2 \mathrm{~m} / \mathrm{s}$. 
Se realizan numerosas simulaciones elegidas convenientemente sobre los escenarios más relevantes a estudiar, pues el coste computacional de la simulación es elevado. Como punto de partida la Figura 10 muestra las respuestas, en aceleraciones, en el punto medio del vano referidas a aquellos escenarios donde la estructura no presenta acoplado ningún TMD y el tránsito del peatón viene definido por las diferentes frecuencias de paso coincidentes con las tres primeras frecuencias propias de la estructura frente a el registro real obtenido del tránsito peatonal real (línea roja) dado a la frecuencia de paso que escita el primer modo de la estructura.

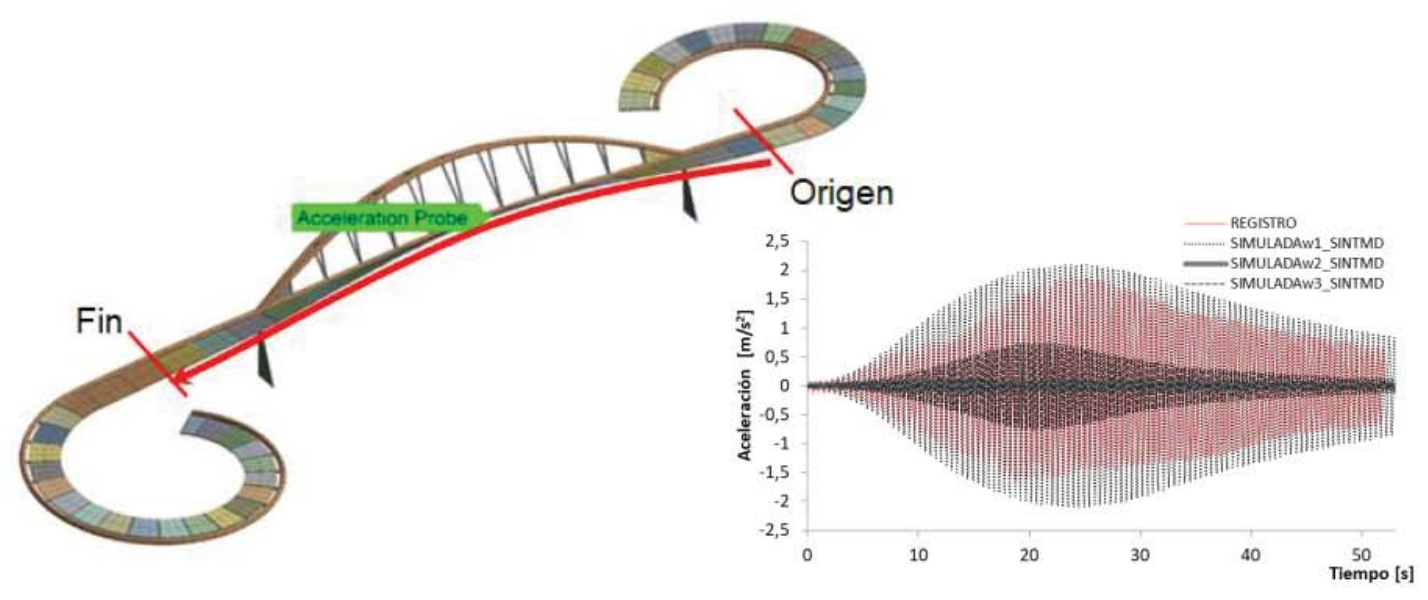

Figura 10. Trayectoria del peatón y respuestas del punto medio del modelo y del registro real

De estos primeros registros se puede comentar que la respuesta obtenida por simulación es ligeramente superior a la registrada por los equipos de medida cuando tenía lugar el tránsito del peatón. En este sentido y a modo de justificar esta circunstancia, se debe hacer notar que raramente puede una persona establecer una frecuencia de paso prefijada sin desviarse de ella y mucho menos con el ritmo asumido desde el primer momento. En este sentido no es de extrañar que por simulación, la excitación sea numéricamente perfecta y como consecuencia pueda resonar mejor, obteniéndose una mayor amplitud en términos de aceleraciones. Además en la simulación el peatón se considera que transita por la línea extrema donde estaría ubicada la barandilla, mientras que en la realidad el peatón camina por una zona más centrada. Otros escenarios, con frecuencias de paso para resonar en modo dos y tres han respondido tal como se ve en la Figura 10. En este caso se observa como un peatón que transita a la frecuencia del modo tres de la estructura imprime a esta un mayor nivel vibratorio que la dada para el caso de caminar excitando el modo dos.

Seguidamente se analizarán las respuestas simuladas para los diferentes escenarios de interés donde para cada uno de estos escenarios la frecuencia del paso del peatón son las tres primeras frecuencias de la estructura. El análisis está basado en los típicos indicadores de medida de aceleraciones como son los valores pico o máximos, el RMS (valores cuadráticos medios) u otros más apropiados, donde se considera la transitoriedad de los pasos, como pueden ser el MTVV o VDV (vibration dose value). 


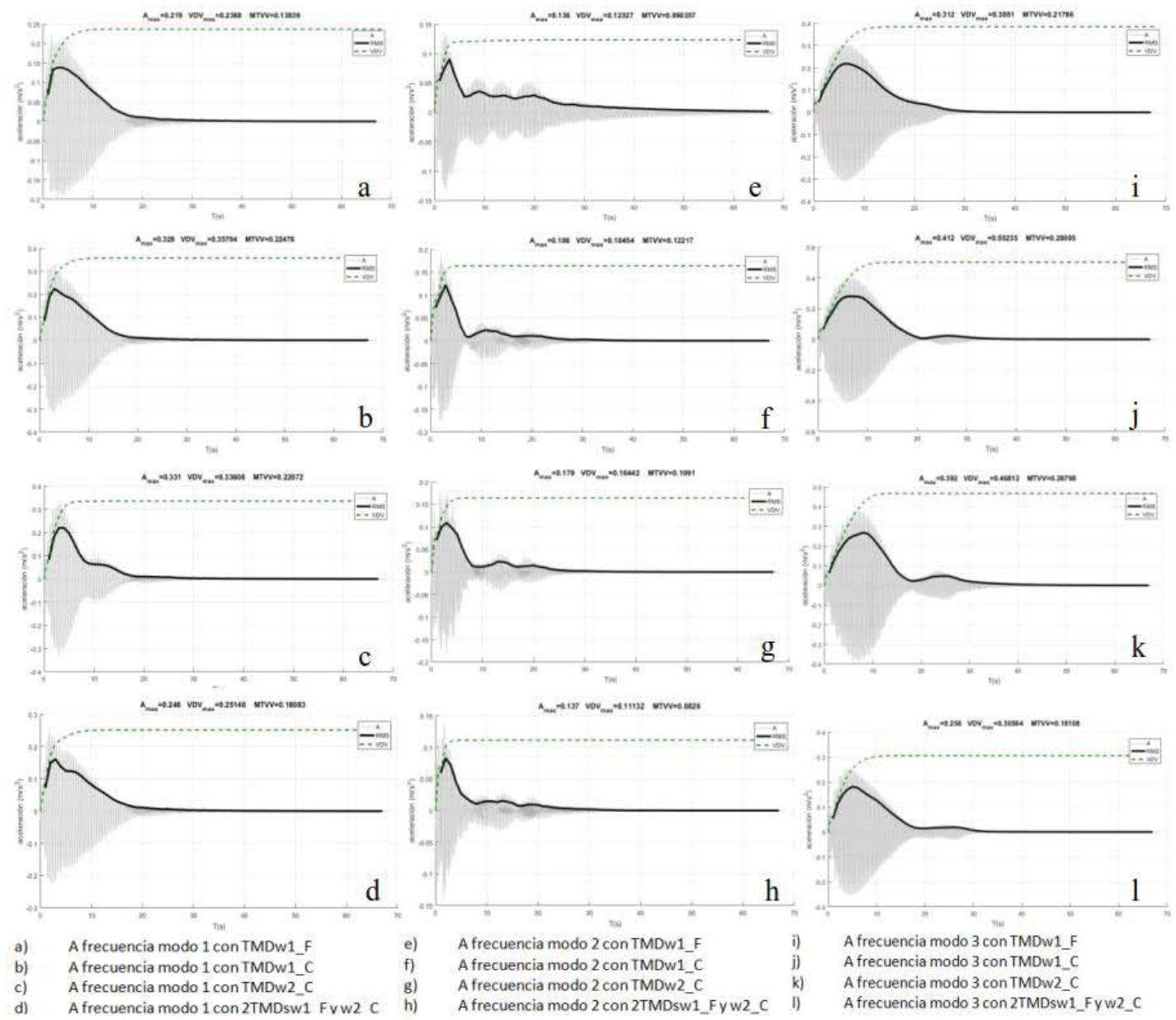

Figura 11. Respuesta temporal de aceleraciones en el centro del vano de la pasarela ante un peatón caminando.

Tabla 4. Transito del peatón coincidente con la primera frecuencia de la pasarela

\begin{tabular}{|c|c|c|c|c|c|c|c|c|c|}
\hline \multirow{3}{*}{ INDICADORES } & $\begin{array}{l}\sin \\
\text { TMD }\end{array}$ & \multicolumn{2}{|c|}{ 1TMD[1000kg] } & \multicolumn{2}{|c|}{ 1TMD[1000kg] } & \multicolumn{2}{|c|}{ 1TMD [1000kg] } & \multicolumn{2}{|c|}{ 2TMDs [500kg]x2 } \\
\hline & - & \multicolumn{2}{|c|}{$\begin{array}{l}\text { Sintonizado al } \\
\text { modo1 }\end{array}$} & \multicolumn{2}{|c|}{$\begin{array}{l}\text { Sintonizado al } \\
\text { modo1 }\end{array}$} & \multicolumn{2}{|c|}{$\begin{array}{l}\text { Sintonizado al } \\
\text { modo2 }\end{array}$} & \multicolumn{2}{|c|}{$\begin{array}{c}\text { Sintonizado al } \\
\text { modo1 y al modo2 }\end{array}$} \\
\hline & - & \multicolumn{2}{|c|}{ Ubicación F } & \multicolumn{2}{|c|}{ Ubicación C } & \multicolumn{2}{|c|}{ Ubicación C } & \multicolumn{2}{|c|}{ Ubicación F y C } \\
\hline Pick & 2.102 & 0.219 & $\begin{array}{c}\text { Reducción } \\
89.58 \%\end{array}$ & 0.328 & $\begin{array}{c}\text { Reducción } \\
84.4 \%\end{array}$ & 0.331 & $\begin{array}{l}\text { Reducción } \\
84.26 \%\end{array}$ & 0.246 & $\begin{array}{c}\text { Reducción } \\
88.30 \%\end{array}$ \\
\hline VDV & 3.413 & 0.236 & $\begin{array}{c}\text { Reducción } \\
93.06 \%\end{array}$ & 0.357 & $\begin{array}{c}\text { Reducción } \\
89.51 \%\end{array}$ & 0.336 & $\begin{array}{c}\text { Reducción } \\
90.15 \%\end{array}$ & 0.251 & $\begin{array}{c}\text { Reducción } \\
92.63 \%\end{array}$ \\
\hline MTVV & 1.515 & 0.138 & $\begin{array}{c}\text { Reducción } \\
90.87 \%\end{array}$ & 0.225 & $\begin{array}{c}\text { Reducción } \\
85.17 \%\end{array}$ & 0.221 & $\begin{array}{c}\text { Reducción } \\
85.44 \%\end{array}$ & 0.161 & $\begin{array}{c}\text { Reducción } \\
89.39 \%\end{array}$ \\
\hline
\end{tabular}


Tabla 5. Transito del peatón coincidente con la segunda frecuencia de la pasarela

\begin{tabular}{|c|c|c|c|c|c|c|c|c|c|}
\hline \multirow{3}{*}{ INDICADORES } & $\begin{array}{l}\sin \\
\text { TMD }\end{array}$ & \multicolumn{2}{|c|}{ 1TMD[1000kg] } & \multicolumn{2}{|c|}{ 1TMD[1000kg] } & \multicolumn{2}{|c|}{ 1TMD [1000kg] } & \multicolumn{2}{|c|}{ 2TMDs [500kg]x2 } \\
\hline & - & \multicolumn{2}{|c|}{$\begin{array}{l}\text { Sintonizado al } \\
\text { modo1 }\end{array}$} & \multicolumn{2}{|c|}{$\begin{array}{l}\text { Sintonizado al } \\
\text { modo1 }\end{array}$} & \multicolumn{2}{|c|}{$\begin{array}{l}\text { Sintonizado al } \\
\text { modo2 }\end{array}$} & \multicolumn{2}{|c|}{$\begin{array}{c}\text { Sintonizado al } \\
\text { modo1 y al modo2 }\end{array}$} \\
\hline & - & \multicolumn{2}{|c|}{ Ubicación F } & \multicolumn{2}{|c|}{ Ubicación C } & \multicolumn{2}{|c|}{ Ubicación C } & \multicolumn{2}{|c|}{ Ubicación F y C } \\
\hline Pick & 0.111 & 0.136 & $\begin{array}{c}\text { Ampliación } \\
22.49 \%\end{array}$ & 0.186 & $\begin{array}{c}\text { Ampliación } \\
67,52 \%\end{array}$ & 0.179 & $\begin{array}{c}\text { Ampliación } \\
61,22 \%\end{array}$ & 0.137 & $\begin{array}{c}\text { Ampliación } \\
23,39 \%\end{array}$ \\
\hline VDV & 0.118 & 0.123 & $\begin{array}{c}\text { Ampliación } \\
3.75 \%\end{array}$ & 0.164 & $\begin{array}{c}\text { Ampliación } \\
38,49 \%\end{array}$ & 0.164 & $\begin{array}{c}\text { Ampliación } \\
38,39 \%\end{array}$ & 0.111 & $\begin{array}{c}\text { Reducción } \\
6,30 \%\end{array}$ \\
\hline MTVV & 0.068 & 0.090 & $\begin{array}{c}\text { Ampliación } \\
31.98 \%\end{array}$ & 0.122 & $\begin{array}{c}\text { Ampliación } \\
78,45 \%\end{array}$ & 0.109 & $\begin{array}{c}\text { Ampliación } \\
59,36 \%\end{array}$ & 0.082 & $\begin{array}{c}\text { Ampliación } \\
20,83 \%\end{array}$ \\
\hline
\end{tabular}

Tabla 6. Transito del peatón coincidente con la tercera frecuencia de la pasarela

\begin{tabular}{|c|c|c|c|c|c|c|c|c|c|}
\hline \multirow{3}{*}{ INDICADORES } & $\begin{array}{c}\sin \\
\text { TMD }\end{array}$ & \multicolumn{2}{|c|}{$1 \mathrm{TMD}[1000 \mathrm{~kg}]$} & \multicolumn{2}{|c|}{ 1TMD[1000kg] } & \multicolumn{2}{|c|}{ 1TMD [1000kg] } & \multicolumn{2}{|c|}{ 2TMDs [500kg]x2 } \\
\hline & - & \multicolumn{2}{|c|}{$\begin{array}{l}\text { Sintonizado al } \\
\text { modo1 }\end{array}$} & \multicolumn{2}{|c|}{$\begin{array}{l}\text { Sintonizado al } \\
\text { modo1 }\end{array}$} & \multicolumn{2}{|c|}{$\begin{array}{l}\text { Sintonizado al } \\
\text { modo2 }\end{array}$} & \multicolumn{2}{|c|}{$\begin{array}{c}\text { Sintonizado al } \\
\text { modo1 y al modo2 }\end{array}$} \\
\hline & - & \multicolumn{2}{|c|}{ Ubicación F } & \multicolumn{2}{|c|}{ Ubicación C } & \multicolumn{2}{|c|}{ Ubicación C } & \multicolumn{2}{|c|}{ Ubicación F y C } \\
\hline Pick & 0.75 & 0.312 & $\begin{array}{c}\text { Reducción } \\
58.40 \%\end{array}$ & 0.412 & $\begin{array}{c}\text { Reducción } \\
45,07 \%\end{array}$ & 0.392 & $\begin{array}{c}\text { Reducción } \\
47,73 \%\end{array}$ & 0.258 & $\begin{array}{c}\text { Reducción } \\
65.60 \%\end{array}$ \\
\hline VDV & 1.037 & 0.385 & $\begin{array}{c}\text { Reducción } \\
62.89 \%\end{array}$ & 0.502 & $\begin{array}{c}\text { Reducción } \\
51,59 \%\end{array}$ & 0.468 & $\begin{array}{c}\text { Reducción } \\
54,88 \%\end{array}$ & 0.305 & $\begin{array}{c}\text { Reducción } \\
70.54 \%\end{array}$ \\
\hline MTVV & 0.529 & 0.218 & $\begin{array}{c}\text { Reducción } \\
58.89 \%\end{array}$ & 0.280 & $\begin{array}{c}\text { Reducción } \\
47,15 \%\end{array}$ & 0.268 & $\begin{array}{c}\text { Reducción } \\
49,44 \%\end{array}$ & 0.181 & $\begin{array}{c}\text { Reducción } \\
65.83 \%\end{array}$ \\
\hline
\end{tabular}

Hacer notar, ante los resultados que, si bien el efecto de los diferentes TMDs sobre las respuestas simuladas tienden a dar indicadores que advierten de un perjuicio vibratorio (no reduce sino que amplifica los indicadores de la respuesta), es este hecho claramente explicable si analizamos conjuntamente las gráficas referidas a estas situaciones. Así en la siguiente Figura 12 se visualiza cómo un par de segundos antes de que el peatón comience a transitar por lo que sería el vano de 40 metros (entraría en esta situación aproximadamente sobre el segundo 7) es en cómputo general a partir del cual la repercusión de los diferentes casos de TMD es clara y destacable en términos de reducción frente a la situación sin TMD (representada con linea negra).

Indicando así que los valores analizados en esos primeros 5 segundos de respuesta, cuando el peatón transita unos 6 metros desde su punto de inicio hasta prácticamente el primer apoyo, son en cierta medida destacables, porque advierten una situación como la que se indica la Figura 12 donde una persona pueda estar cruzando la pasarela lentamente, tan lento como para considerarlo un caso estático, mientras que una persona caminando, aun fuera del vano, excita la pasarela en su modo dos. 


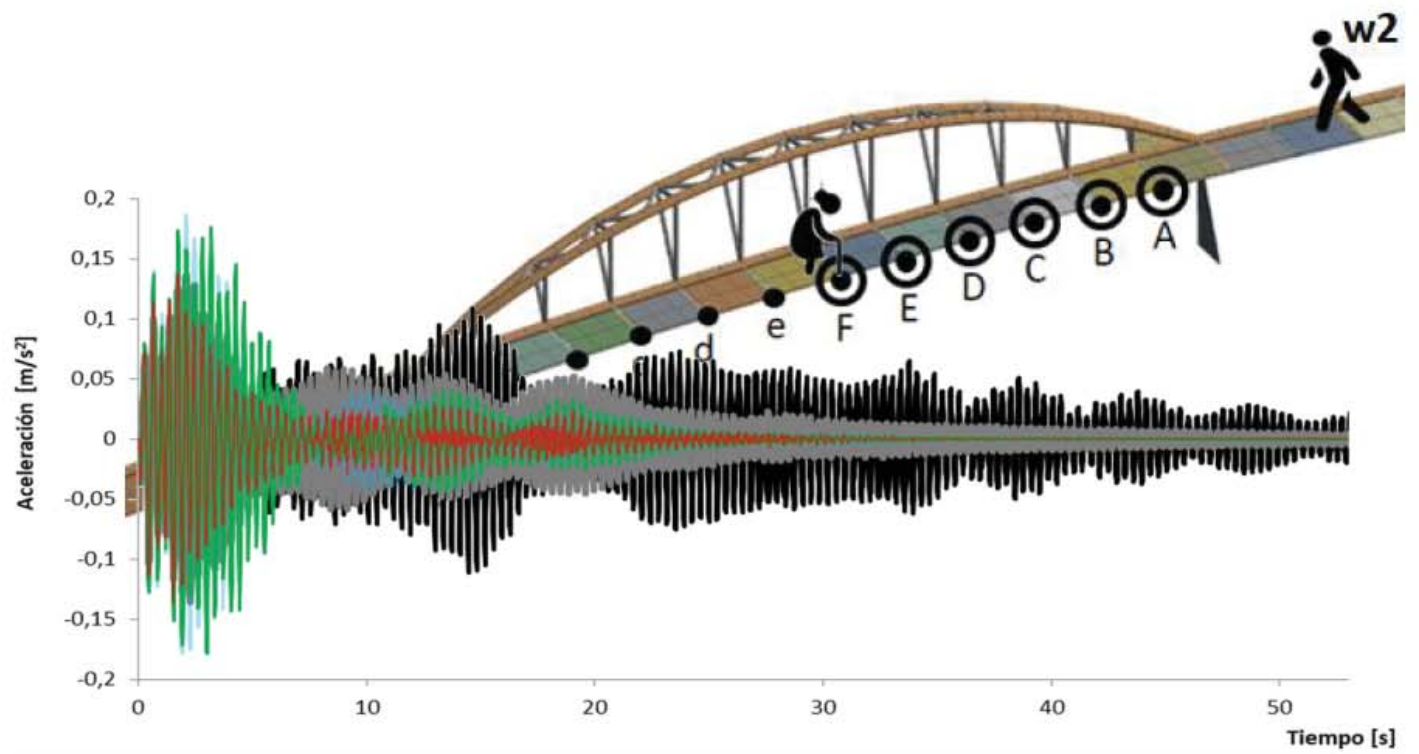

Figura 12. Análisis de las respuestas ante tránsitos coincidentes con la frecuencia dos de la pasarela

\section{CONCLUSIONES}

Los resultados para cualquiera de las estrategias muestran tendencias similares aunque difieren ligeramente del valor de reducción estimado. En la siguiente tabla se recopila los principales valores del estudio.

Tabla 3. Comparativa de estrategias

\begin{tabular}{|c|c|c|c|c|c|c|c|c|}
\hline \multirow{4}{*}{ FRECUENCIAS } & \multicolumn{2}{|c|}{ 1TMD[1000kg] } & \multicolumn{2}{|c|}{ 1TMD[1000kg] } & \multicolumn{2}{|c|}{ 1TMD [1000kg] } & \multicolumn{2}{|c|}{ 2TMDs [500kg]x2 } \\
\hline & \multicolumn{2}{|c|}{$\begin{array}{l}\text { Sintonizado al } \\
\text { modo1 }\end{array}$} & \multicolumn{2}{|c|}{$\begin{array}{l}\text { Sintonizado al } \\
\text { modo1 }\end{array}$} & \multicolumn{2}{|c|}{$\begin{array}{l}\text { Sintonizado al } \\
\text { modo2 }\end{array}$} & \multicolumn{2}{|c|}{$\begin{array}{c}\text { Sintonizado al } \\
\text { modo1 y al modo2 }\end{array}$} \\
\hline & \multicolumn{2}{|c|}{ Ubicación F } & \multicolumn{2}{|c|}{ Ubicación C } & \multicolumn{2}{|c|}{ Ubicación C } & \multicolumn{2}{|c|}{ Ubicación F y C } \\
\hline & $\sum F A a$ & VDV & $\sum \mathrm{FAa}$ & VDV & $\sum \mathrm{FAa}$ & VDV & $\sum \mathrm{FAa}$ & VDV \\
\hline w1 & $\begin{array}{c}\text { Reducción } \\
93.84 \%\end{array}$ & $\begin{array}{c}\text { Reducción } \\
93.06 \%\end{array}$ & $\begin{array}{c}\text { Reducción } \\
92.18 \%\end{array}$ & $\begin{array}{c}\text { Reducción } \\
89.51 \%\end{array}$ & $\begin{array}{c}\text { Reducción } \\
77.25 \%\end{array}$ & $\begin{array}{c}\text { Reducción } \\
90.15 \%\end{array}$ & $\begin{array}{c}\text { Reducción } \\
93.79 \%\end{array}$ & $\begin{array}{c}\text { Reducción } \\
92.63 \%\end{array}$ \\
\hline w2 & $\begin{array}{c}\text { Reducción } \\
10.42 \%\end{array}$ & $\begin{array}{c}\text { Ampliación } \\
3.75 \%\end{array}$ & $\begin{array}{c}\text { Reducción } \\
88.06 \%\end{array}$ & $\begin{array}{c}\text { Ampliación } \\
38.49 \%\end{array}$ & $\begin{array}{c}\text { Reducción } \\
88.57 \%\end{array}$ & $\begin{array}{c}\text { Ampliación } \\
38.39 \%\end{array}$ & $\begin{array}{c}\text { Reducción } \\
87.26 \%\end{array}$ & $\begin{array}{c}\text { Ampliación } \\
70.54 \%\end{array}$ \\
\hline w3 & $\begin{array}{c}\text { Reducción } \\
18.44 \%\end{array}$ & $\begin{array}{c}\text { Reducción } \\
62.89 \%\end{array}$ & $\begin{array}{c}\text { Reducción } \\
81.51 \%\end{array}$ & $\begin{array}{c}\text { Reducción } \\
51,59 \%\end{array}$ & $\begin{array}{c}\text { Reducción } \\
88.40 \%\end{array}$ & $\begin{array}{c}\text { Reducción } \\
54.88 \%\end{array}$ & $\begin{array}{c}\text { Reducción } \\
87.90 \%\end{array}$ & $\begin{array}{c}\text { Reducción } \\
70.54 \%\end{array}$ \\
\hline w1 w2 & $\begin{array}{c}\text { Reducción } \\
52.84 \%\end{array}$ & $\begin{array}{c}\text { Reducción } \\
29.77 \%\end{array}$ & $\begin{array}{c}\text { Reducción } \\
93.11 \%\end{array}$ & $\begin{array}{c}\text { Reducción } \\
17.01 \%\end{array}$ & $\begin{array}{c}\text { Reducción } \\
87.87 \%\end{array}$ & $\begin{array}{c}\text { Reducción } \\
17.25 \%\end{array}$ & $\begin{array}{c}\text { Reducción } \\
96.38 \%\end{array}$ & $\begin{array}{c}\text { Reducción } \\
32.98 \%\end{array}$ \\
\hline w1 w2 w3 & $\begin{array}{c}\text { Reducción } \\
40.82 \%\end{array}$ & $\begin{array}{c}\text { Reducción } \\
50.73 \%\end{array}$ & $\begin{array}{c}\text { Reducción } \\
89.34 \%\end{array}$ & $\begin{array}{c}\text { Reducción } \\
34.20 \%\end{array}$ & $\begin{array}{c}\text { Reducción } \\
88.46 \%\end{array}$ & $\begin{array}{c}\text { Reducción } \\
49.44 \%\end{array}$ & $\begin{array}{c}\text { Reducción } \\
92.29 \%\end{array}$ & $\begin{array}{c}\text { Reducción } \\
65.83 \%\end{array}$ \\
\hline
\end{tabular}


Excepto para el caso donde la frecuencia de tránsito se acopla con la primera de la pasarela, el resto muestran flagrantes diferencias. Entendiendo que los resultados extraídos mediante el uso de las respuestas temporales es en principio mucho más fiel a la realidad dinámica de la estructura entre otras cosas porque, si nos basamos en las funciones de respuesta en frecuencia se estaría contemplando que la respuesta habría alcanzado su máximo, circunstancia que en la mayoría de las ocasiones seguramente no suceda para cuando un peatón transita una pasarela. Dicho esto, podría entenderse que a la frecuencia de excitación coincidente con la primera de la estructura den resultados tan semejantes para ambas estrategias porque la respuesta calculada en el análisis transitorio sea muy cercana a la que alcanzaría ese máximo teórico.

Destacar, por tanto, que este trabajo remarca la necesidad de unificar criterios a la hora de definir la actuación de un TMD, en términos de reducción de la aceleración, y no solo por ser fiel a la realidad sino porque esta ambigüedad o la ausencia de este conocimiento podría derivar en la instalación de un TMD donde no sea apropiado para las circunstancias que envuelven el problema. Esto se pone de manifiesto si centramos el problema en actuar sobre el modo dos de la pasarela cuando un peatón transita resonando a esta frecuencia. Una estrategia, la basada en las funciones de respuesta en frecuencia, aconsejaría su instalación en el punto $\mathrm{C}$ sintonizada a la frecuencia del modo 2, pues su reducción es la máxima obtenida (88.57\%). Esto concretamente está del lado de la lógica, pero fijémonos que, en términos de aceleraciones máximas las respuestas transitorias obtenidas describen una ubicación inadecuada.

Tras esta evaluación y a fin de evitar para cualquier posibilidad (tres frecuencias principales) de tránsito peatonal problemas vibratorios, la mejor opción sería acoplar dos dispositivos de $500 \mathrm{~kg}$ cada uno, ubicados en las posiciones $\mathrm{F}$ y $\mathrm{C}$ sintonizado cada uno de ellos a las frecuencias del modo uno y del modo dos respectivamente, lo que no es tan obvio es predecir su eficacia, en nuestro caso en términos de VDV podríamos indicar una disminución del $65.83 \%$. Ahora bien si la posibilidad es acoplar un único TMD este debe ubicarse en el punto $F$ (mitad del vano) sintonizado a la frecuencia principal del modo uno, obteniendo una reducción del $50.73 \%$.

Estos resultados ponen de manifiesto la necesidad de realizar estudios transitorios que aseguren la respuesta dinámica del problema, a pesar del coste computacional que requiere. Otras posibilidades de análisis basadas en simplificaciones pueden resultar poco útiles si las condiciones del problema son tales que desvirtúan la realidad del escenario.

Puede que En el análisis basado en las funciones de respuesta en frecuencia se ha considerado estudiar lo que sucede en toda la pasarela, discretizando está en una serie de puntos de estudio, sin embargo esto no ha sido considerado en el análisis transitorio, el cual ha sido contemplado como puntual (centrándose en la percepción del punto central del vano, F).

\section{AGREDECIMIENTOS}

Los autores desean agradecer a D. Javier Henche (Grahen Ingenieros S.L.) y D. Víctor Darder (Melchor Mascaró) por darnos la oportunidad de trabajar con ellos. Asimismo, los autores agradecen la financiación parcial del Ministerio de Economía y Competitividad a través del proyecto BIA201571942-REDT. 


\section{REFERENCIAS}

[1] Housner GW, Bergman, LA, Caughey TK, Chassiakos AG, Claus RO, Masri SF, Skelton RE, SoongTT, SpencerBF, Yao JTP. Structural control: Past, present, and future. Journal of Engineering Mechanics-ASCE 1997; 127:887-971.

[2] SymansMD, Constantinou MC. Semi-active control systems for seismic protection of structures: a state-of-the-art review. Engineering Structures 1999;21:469-487.

[3] Den Hartog J P. Mechanical Vibrations, 4th edition, McGraw-Hill, New York, 1956.

[4] Abé M, Igusa T. Tuned Mass Dampers for structures with closely spaced natural frequencies. Earthquake Enginnering and Structural Dynamics 1995; 24: 247-261.

[5] Zarate B. A., Caicedo J. M., "Finite element model updating: multiple alternatives," Engineering Structures, vol. 30, no. 12, pp. 3724-3730, 2008. 
DYNAMIC CHARACTERIZATION AND SERVICEABILITY ASSESSMENT OF A TIMBER FOOTBRIDGE

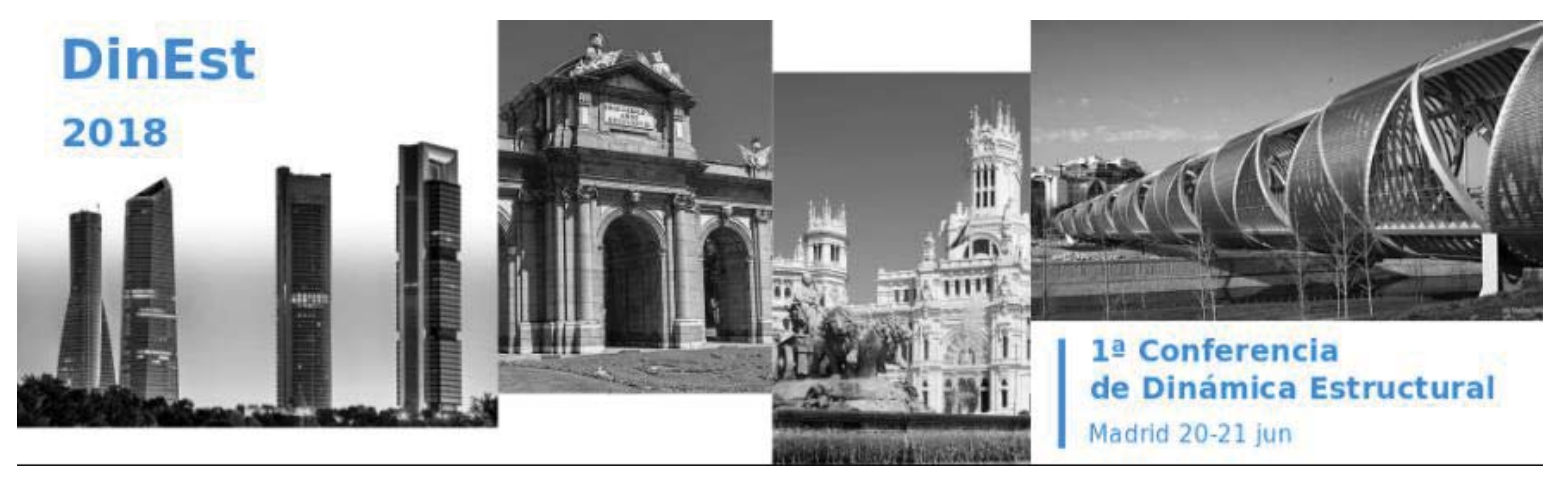

Álvaro Magdaleno González; Norberto Ibán Lorenzana; Infantino, V.; Antolín Lorenzana Ibán. Aportación: colaboracion en montajes y adquisicion de datos.

\begin{tabular}{c|c|c|c|} 
Aportaciones: & Experimentación & Procesado & Edición \\
\hline & $\begin{array}{c}\text { Instrumentación } \\
\text { Registros }\end{array}$ & Matlab & Tablas \\
& Excel & $\begin{array}{c}\text { Gráficas } \\
\text { Imágenes }\end{array}$ \\
\cline { 2 - 4 }
\end{tabular}




\title{
DYNAMIC CHARACTERIZATION AND SERCIVEABILITY ASSESSMENT OF A TIMBER FOOTBRIDGE
}

\author{
Á. Magdaleno ${ }^{1 *}$, N. Ibán ${ }^{2}$, V. Infantino ${ }^{3}$ and A. Lorenzana ${ }^{1}$ \\ ${ }^{1}$ ITAP. Escuela de Ingenierías Industriales \\ Universidad de Valladolid \\ 47011 Valladolid, Spain \\ ${ }^{2}$ Centro Tecnológico CARTIF \\ Parque Tecnológico de Boecillo \\ 47151 Boecillo, Spain \\ ${ }^{3}$ DICEAM \\ Università degli Studi Meditteranea di Reggio Calabria \\ 89124 Reggio Calabria, Italy
}

\begin{abstract}
This paper shows the experimental and numerical methodology used for the modal characterization and serviceability assessment applied to a timber pedestrian walkway. The footbridge is a 103 meters long and 2 meters wide structure consisting on 4 prefabricated modules designed by Media Madera, mounted between the two abutments at the ends and three intermediate supports. It crosses the Duero River at Pesquera, Valladolid, with, from right to left, four spans of $12,50,18$ and $23 \mathrm{~m}$. It is part of the Senda del Duero, a natural trail (GR14) of $37.5 \mathrm{~km}$ concluded in 2013. With applied research motivation, an experimental campaign was carried out in January 2018. Usefull data has been collected to calibrate the computational model of the structure. Also serviceability dynamic tests were carried out to quantify the vibrations induced by pedestrian crossing.
\end{abstract}

Key words: Timber footbridge, Model updating, Serviceability assessment

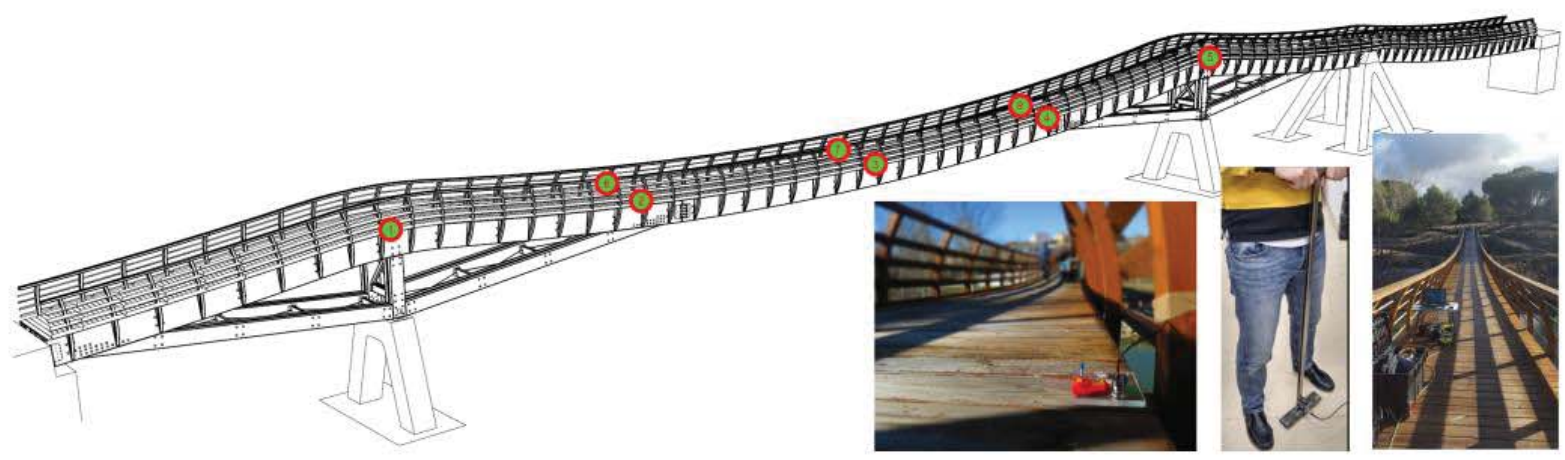

Figure 1: Experimental layout and details of datalogger, accelerometer and pogo

\footnotetext{
${ }^{*}$ Corresponding Author. E-mail: alvaro.magdaleno@uva.es ; ORCID: 0000-0002-5606-1545
} 
Á. Magdaleno, N. Ibán, V. Infantino and A. Lorenzana

\section{INTRODUCTION}

Some well-known structural dynamic drawbacks can take place in low damped slender footbridges when they are crossed by pedestrians. Depending on the pace, either walking or running, semiperiodic ground reaction forces are applied and, in case of resonance, mechanical response may exceed some desirable limits, both regarding to the ultimate stress behaviour and serviceability points of view. In the first case, structural integrity can be compromised and in the second, users can experience uncomfortable sensations that could affect their own pace and even give rise to certain interaction phenomena [3].

From the assessment point of view, in the design stage, the comfortability of a footbridge can be estimated following some procedures described in standards and design guides. Thus, for example, the EAE 2011 in its article 38.3.2 establishes, for vertical movements, the convenience of carrying out additional dynamic checks when the span exceeds $50 \mathrm{~m}$ and the natural frequencies lay in the rank between $1.25 \mathrm{~Hz}$ and $4.6 \mathrm{~Hz}$. It is desirable that the acceleration (in some points of the structure) under the intended use will not exceed $2.5 \mathrm{~m} / \mathrm{s}^{2}$. For the case study, preliminary estimate for the first vertical bending mode is $3.13 \mathrm{~Hz}$. As the structure is longer than $50 \mathrm{~m}$, additional dynamic studies are convenient, as described below.

\section{EXPERIMENTAL SET-UP}

In order to register the response of the structure and to identify its vibration modes, natural frequencies and modal damping ratios, eight uniaxial accelerometers (MMF-KS76C.100, sensitivity $100 \mathrm{mV} / \mathrm{g}$ ) are placed in the vertical direction at points 1 to 8 of the central span shown in Figure 1. The eight locations have been distributed along the span so the first and second bending and torsional modes can be properly identificated. All the recordings are synchronously registered at 1024 samples per second by means of a data logger (SIRIUS-HD 16xSTGS) located at the position 4. In this place there is also a pogo instrumented with a load cell at its lower end whose force sig- nal has been recorded synchronously along with the accelerometer signals. Details in Figure 1 show part of the described layout: the data logger, one accelerometer and the pogo. The intention is to excite the structure in a controlled way by jumping on the pogo. As the point of excitation (4) does not match to any node of vibration for the predicted (by simulation) $1^{\text {st }}$ and $2^{\text {nd }}$ bending and torsional modes, a good modal identification is expected. Note that one average person jumping on the pogo has a significant body weigh in comparison with the mass of the lightweight footbridge and therefore the structure can be effectively excited. Figure 2 shows, for one of the tests, the recordings of the accelerometers located at points 3 and 4 and also the pogo force.

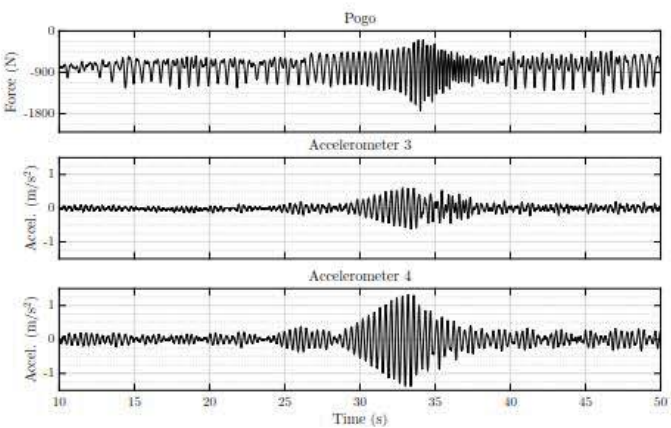

Figure 2: Recorded signals from the pogo and the accelerometers 2 and 3

\section{MODAL IDENTIFICATION}

Taking the pogo force at point 4 as input and the response at the 8 monitorized points as outputs, eight frequency response functions (FRF) can be evaluated. The Dewesoft software [https://www.dewesoft.com/] allows, for each peak, to visualize the corresponding modal shape. After the interpretation of these shapes, it is concluded that the peak at $2.67 \mathrm{~Hz}$ accounts for the first bending mode, the peak at $3.55 \mathrm{~Hz}$ corresponds to the first torsion mode and the peaks at $4.28 \mathrm{~Hz}$ and $5.7 \mathrm{~Hz}$ are for the second bending and torsion modes, respectively. According to the EAE 2011 standard, only the first three ones are under $4.6 \mathrm{~Hz}$ and, thus, they are likely to be excited by pedestrian activities (walking or running). 
However, from the point of view of the statistical distribution of human steps and the intended use of the pedestrian walkway (occasional trekking), the mode of greatest interest is the first one and the following sections will focus on it. For an accurate identification of this mode of interest, several tests were carried out jumping on the pogo in point 3 . Figure 3 shows the auto FRF where up to 4 peaks are clearly identified in the displayed range (between $1.5 \mathrm{~Hz}$ and $8.0 \mathrm{~Hz}$ ).

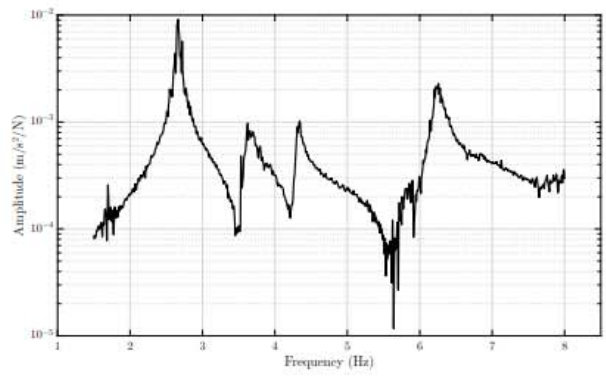

Figure 3: Auto-FRF at point 3

\section{FIRST MODE PARAMETERS}

From the dynamic point of view, it is desirable to know the mass $M$, the stiffness $K$ and the damping $C$ of an equivalent one-degree-of-freedom (1DOF) system, whose equation of motion is stated in Eq. 1. From the auto FRF shown in Figure 3, a least-square adjustment procedure can be carried out in the neighbourhood of the first peak in order to fit the accelerance expression of the simplified model (Eq. 2 [2]). In doing that, the simplified one-degree-of-freedom system should respond close to the original structure when excited by forces with frequencies in that range. This statement is usually right when the modes of the structure are apart enough, as in the footbridge under study (see Figure 3). Figure 4(a) shows the best adjustment $(\mathrm{R}=0.9919)$ in the range $2.2 \mathrm{~Hz}$ to $3.2 \mathrm{~Hz}$, resulting in a mass, a stiffness and a damping values of $M=7890 \mathrm{Kg}, K=2.21 \mathrm{MN} / \mathrm{m}$ and $C=2261 \mathrm{Ns} / \mathrm{m}$ respectively. With these values, the resulting modal damping ratio of $\xi=0.86 \%$.

$$
M \ddot{x}+C \dot{x}+K q=F
$$

$$
A(\omega)=\frac{\omega^{2}}{\sqrt{(K-M \omega)^{2}+(C \omega)^{2}}}
$$

Figure 4(b) shows in blue the excitation force (recorded via pogo) and in red the response (via accelerometer) at point 3 . Also shows in green the numerical response of the equivalent 1DOF system when undergoing the same excitation (blue force). As green and red curves are almost identical, in fact both systems are equivalent ones.

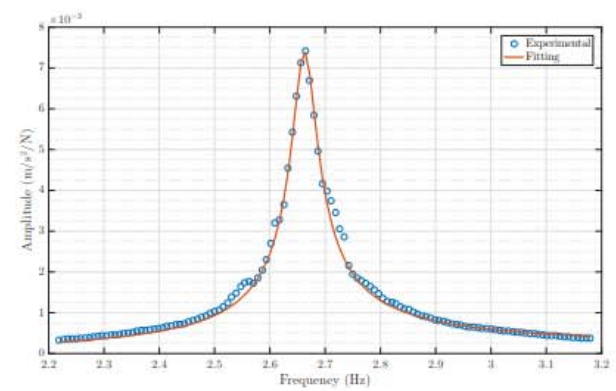

(a)

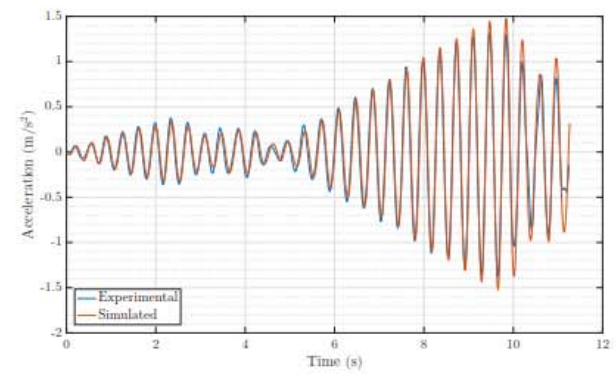

(b)

Figure 4: First mode identification

\section{SIMULATED RESPONSE UNDER STANDARD PEDESTRIAN LOAD- ING MODEL}

The former results can be used, among other applications, to calibrate the preliminary computational model (FEM) and to estimate the dynamic response when some loading pattern is applied to the structure.

Following the Eurocode 1, in its Annex A, for a pedestrian of $70 \mathrm{~kg}$ of mass the force to be considered would be simplified as $F(t)=280 \sin (2 \pi f \alpha t)$ 
[N], with $f$ the pace rate of the pedestrian which, in the worst case, equals to the natural frequency $(f=2.67 \mathrm{~Hz})$. The parameter $\alpha$ accounts for he physical impossibility for the pace to be exactly the natural frequency of the structure. Considering this loading case (with $\alpha=1$ ) during the transit time considered (15 seconds, assuming $12 \mathrm{~m} / \mathrm{s}$ speed) Figure 5(a) shows the estimated response for a round trip in which it is assumed a first crossing starting at $5 \mathrm{~s}$ and ending at $20 \mathrm{~s}$, followed by a second crossing starting at $30 \mathrm{~s}$ and ending at $45 \mathrm{~s}$.
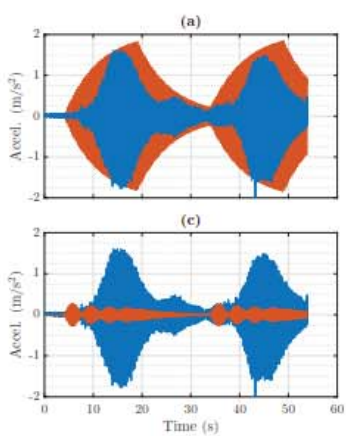

Figure 5: Comparison...

This response could sobre-estimate the real response for two reasons. On the one hand, by taking $\alpha=1$, a total coordination between the pedestrian and the structure is assumed. On the other hand, from the very first moment it is assumed that all the force acts in the center of the span. Bearing in mind this, some authors [1] recommend to modulate the amplitude of the force by the modal shape, to take into account the effect of the moving force. Assuming, for the first bending mode, a sinusoidal modal shape, the force to be considered would be $F(t)=280 \sin (\pi t / T) \sin (2 \pi f \alpha t)$, where $T$ is the transit time. In this case, the corresponding response $(\alpha=1)$ is shown in Figure 5(b).

For comparison reasons, the best registered experimental test has been selected. It corresponds to a single $70 \mathrm{~kg}$ runner (at $160 \mathrm{bpm}$, guided by a metronome). The experimental response at point 3 is the one shown in grey in Figures 5(a) and (b). A good matching with $5 \mathrm{~b}$ is noticeable.

To take into account the impossibility of coordination, the Eurocode 1 recommends $\alpha=0.9$. In this case, for a not modulated force, the response is shown in Figure 5(b) and, for the modulated one, in Figure 5(c). Clearly $\alpha=0.9$ under-estimate the real response obtainable by a well-trained runner. This consideration must be taken into account in the case of vandalism loading.

\section{CONCLUSIONS}

Through the studies presented, it is remarkable that with a portable equipment and a simple dynamic testings, valuable data can be obtained for a good dynamic characterization of lightweight infrastructures. The 1dof model reduction may be adequate for estimating the response to pedestrian crossings, provided that the loading model is realistic enough. With this aim, it is always convenient to compare the numerical models with real cases so that the parameters can be adjusted in the best possible way. The adjustments can depend on the structure under study. Once the model is calibrated, simulations can provide good estimations regarding serviceability.

\section{ACKNOWLEDGMENTS}

Authors wish to acknowledge the financial support of the MINECO (Spanish Government, Project BIA2014-59321) and the MECD (Spanish Government, FPU Grant). Also the technical support provided by Media Madera Ingenieros Consultores S.L. is acknowledged.

\section{REFERENCES}

[1] J. De Sebastián, I. M. Díaz, C. M. Casado, A. V. Poncela, and A. Lorenzana. Evaluación de la predicción de aceleraciones debidas al tránsito peatonal en una pasarela en servicio. Informes de la Construcción, 65(531):335-348, sep 2013.

[2] N.M.M. Maia and J.M.M. Silva. Theoretical and Experimental Modal Analysis. Engineering dynamics series. Research Studies Press, 1997.

[3] E. Shahabpoor, A. Pavic, V. Racic, and S. Zivanovic. Effect of group walking traffic on dynamic properties of pedestrian structures. Journal of Sound and Vibration, 387:207-225, jan 2017. 
